UNIVERSIDADE DE SÃO PAULO FACULDADE DE FILOSOFIA, LETRAS E CIÊNCIAS HUMANAS DEPARTAMENTO DE GEOGRAFIA PROGRAMA DE PÓS-GRADUAÇÃO EM GEOGRAFIAHUMANA

Antonio Marcos Roseira

\title{
NOVA ORDEM SUL-AMERICANA REORGANIZAÇÃO GEOPOLÍTICA DO ESPAÇO MUNDIAL E PROJEÇÃO INTERNACIONAL DO BRASIL
}


Antonio Marcos Roseira

\title{
NOVA ORDEM SUL-AMERICANA REORGANIZAÇÃO GEOPOLÍTICA DO ESPAÇO MUNDIAL E PROJEÇÃO INTERNACIONAL DO BRASIL
}

\author{
Tese apresentada ao Programa de Pós- \\ Graduação em Geografia Humana do \\ Departamento de Geografia, da Faculdade de \\ Filosofia, Letras e Ciências Humanas da \\ Universidade de São Paulo, como Requisito \\ Parcial para Obtenção do Título de Doutor em \\ Geografia Humana.
}

Orientador: Prof. Dr. Wanderley Messias da Costa.

São Paulo, 2011 
AUTORIZO A REPRODUÇÃO E DIVULGAÇÃO TOTAL OU PARCIAL DESTE TRABALHO, POR QUALQUER MEIO CONVENCIONAL OU ELETRÔNICO, PARA FINS DE ESTUDO E PESQUISA, DESDE QUE CITADA A FONTE. 


\section{FOLHA DE APROVAÇÃO}

Antonio Marcos Roseira

Nova Ordem Sul-Americana: Reorganização Geopolítica do Espaço Mundial e Projeção Internacional do Brasil

Aprovado em:

Banca Examinadora

Prof. Dr.(a)

Instituição: Assinatura

Prof. Dr.(a)

Instituição:

Assinatura

Prof. Dr.(a)

Instituição:

Assinatura

Prof. Dr.(a)

Instituição:

Assinatura

Prof. Dr.(a)

Instituição:

Assinatura 
$\stackrel{\grave{A}}{\text { Maria Roseira e Augusto Marques Gouveia }}$ (In Memoriam) 
O construir existe entre um projeto ou uma visão determinada e os materiais que escolhemos.

Substitui-se uma ordem inicial por outra, quaisquer que sejam os objetos que ordenamos.

Paul Valéry 
Este trabalho encerra um longo período da minha vida, marcado pela dedicação exclusiva à pós-graduação e à pesquisa em Geografia Humana. A conclusão desta tese somente tornou-se possível com a colaboração de amigos e familiares e com o suporte de instituições de ensino e fomento do Estado de São Paulo e do Brasil.

Agradeço aos funcionários da Biblioteca Florestan Fernandes, da Faculdade de Filosofia, Letras e Ciências Humanas (FFLCH), e da Biblioteca da Faculdade de Administração, Economia e Contabilidade (FEA), cuja colaboração foi indispensável nesses últimos anos.

A todos os funcionários do Departamento de Geografia. Especialmente à Jurema, Rosângela e Ana.

Aos professores da banca de qualificação, Mônica Arroyo e Ricardo Mendes. O exame rigoroso foi fundamental para o desenvolvimento final da pesquisa.

Aos colegas do Laboratório de Geografia Política e Planejamento Territorial e Ambiental (LABOPLAN) pela eterna disposição de auxílio, e por ter me acolhido como praticamente um dos seus. Especialmente à Ana Elisa Pereira pela prestatividade, espírito de colaboração e boas conversas.

Aos amigos feitos para o resto da vida, e que apesar de distantes do cotidiano, mantém uma firme presença nos campo das idéias e dos valores. Refiro-me especialmente a Pedro Mezgravis, Herodes B. Cavalcanti e Eliza Pinto de Almeida.

À Terezinha Serafim Gomes, pela agradável presença de espírito, amizade, e companheirismo. As nossas conversas são fontes de inspiração.

Ao Zé Fonseca, muitíssimo obrigado pelo apoio num momento determinante. $O$ agradecimento se estende para muito além da correção ortográfica. Sua ajuda comprovou a famosa máxima: os amigos de nossos amigos são nossos amigos! Esses agradecimentos se estendem ao Mateus Sampaio, que aceitou o trabalho cartográfico nos últimos dias.

Nesse momento é preciso lembrar-se daqueles com quem caminhamos em momentos decisivos. Devo muito à Elisa Pinheiro Freitas, uma mulher cuja 
tenacidade e empenho na busca por um lugar ao sol resultarão em muitas conquistas.

Sou profundamente grato a Branca Couto e Aline Lima Santos por esses dez anos de companheirismo. Que nossas diferenças e semelhanças nos mantenham sempre unidos. No momento mais delicado, quando a ampulheta do tempo se mostrava invencível, em vocês duas eu encontrei amparo.

Carinhosamente a Elisângela e ao Renato. Nossos encontros e conversas são momentos de muita alegria.

Ao Loildo, amigo dileto e irmão. A ele eu devo muito das minhas escolhas.

Agradeço especialmente a Osvaldo Moyano Marin, cuja generosidade e disposição para ajudar em momentos delicados permitiram que esse trabalho chegasse ao final. Paciência, paz interior, humildade, tranqüilidade e inteligência revelam um ser superior.

Sou eternamente grato à Zueleide Casagrande de Paula e à Rosa Ester Rossini, mulheres que mudaram minha vida.

Carinhosamente ao Pr. Dr. Wanderley Messias da Costa, meu orientador. Minha admiração e respeito só têm crescido durante todos esses anos. Sua cultura, erudição e conhecimento tornam a pesquisa em Geografia Política um prazeroso desafio. 
Esta pesquisa trata da relação entre Brasil e América do Sul, bem como das políticas de projeção regional e mundial envolvendo o país e seus vizinhos. O fio condutor é uma abordagem geopolítica que busca o entendimento dos principais fatores que constituem a ordem regional sul-americana. Estabeleceu-se uma periodização em duas grandes conjunturas regionais. A primeira, que se constitui com o início da Guerra Fria e perdura até 1991, é caracterizada pelo equilíbrio de poder e pelas rivalidades geopolíticas intra-regionais. Internamente é assinalada pela polarização do continente em torno de Brasil e Argentina e suas geopolíticas expansionistas. Externamente, foi definida pela projeção internacional brasileira a partir da dependência aos Estados Unidos e seus principais aliados. A segunda se refere a uma nova ordem sul-americana a partir de 1991, com a assinatura do Tratado de Assunção. A criação do Mercosul estabelece um cenário marcado pela diminuição das rivalidades, e ampliação da integração política, econômica e territorial. Essa conjuntura tem dois principais períodos. O primeiro, que se estende de 1991 até 2002, caracteriza-se por uma perspectiva mercantilista de ampliação da cooperação regional. Termina com a diminuição do intercâmbio comercial iniciada com as crises internacionais do final dos anos 1990. O segundo ocorre com a aproximação política entre os países a partir de 2003, sendo distinguido pela recuperação da economia. Na última década, essa ordem regional passou por grandes transformações devido a retomada do crescimento econômico e por novas ambições internacionais. Em conjunto, esses fatores acompanham uma tendência de re-inserção internacional da América do Sul.

Palavras-chave: Brasil, América do Sul, Integração Regional, Geopolítica. 
The present research deals with the relation between Brazil and South America, as well as with the policies of regional and world projection involving the country and its neighbors in the continent. The guiding principle of this study is a geopolitical approach which aims at the understanding of the main factors that constitute the South American regional order. A periodization in two great regional conjunctures was established. The first, which is formed with the beginning of the Cold War and remains until 1991, is characterized by the power balance and by the intra-regional geopolitical rivalries. Internally, this period was marked mainly by the polarization of the entire continent around Brazil and Argentina and their expansionist geopolitics. Externally, it was defined by the international projection of Brazil from a relation of dependence on The United States and their main allies. The second refers to a new South American order since 1991, with the signature of the Asuncion Treaty. The creation of Mercosul starts a scenario marked by the decrease of rivalries, and the enlargement of the territorial, commercial and political integration. This order has two main periods. The first which extends from 1991 to 2002 is defined by a mercantilist perspective of increase of the regional cooperation. It ends with the diminishing of the commercial interchange after the international crises at the end of the 1990's. The second begins with the political approximation between countries since 2003, and extends throughout the 2000's decade, being distinguished by the recuperation of the economy. In the last decade, this regional order went through great transformations due to the economic recuperation and new international ambitions. As a whole, these factors follow a tendency of international reinsertion of South America.

Keywords: Brazil, South America, Regional Integration, Geopolitics. 


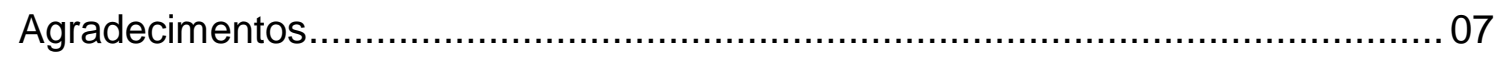

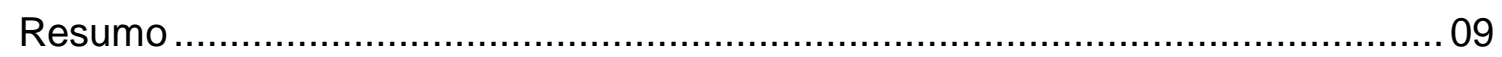

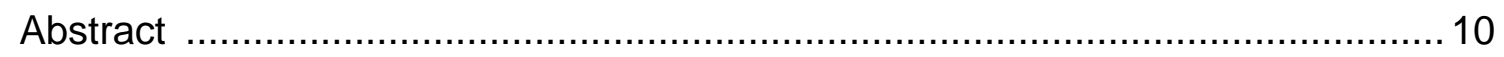

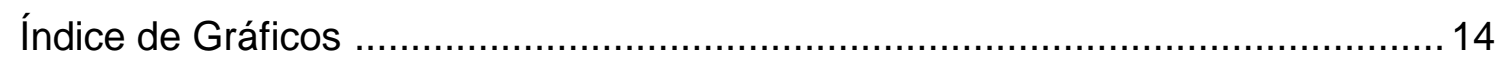

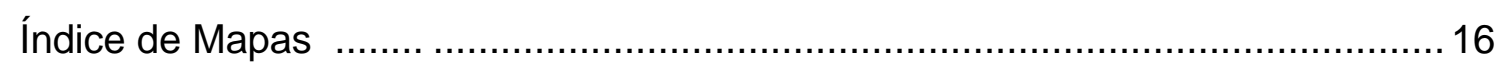

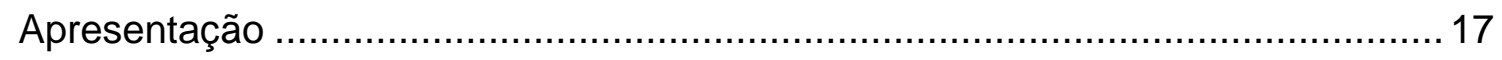

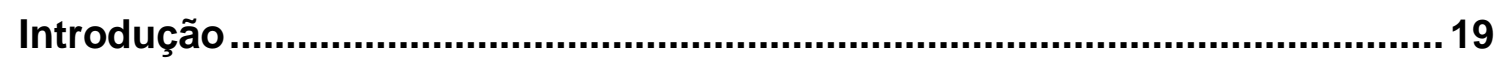

\section{PARTE 1 GEOPOLÍTICA SUL-AMERICANA DO BRASIL NA GUERRA FRIA}

CAPÍTULO 1. O Brasil e a América do Sul no Contexto da Guerra Fria .......... 28

1.1. O Brasil, o seu Continente e as Ordens Geopolíticas .............................. 28

1.1.1. Abordagem do Contexto internacional ................................................. 31

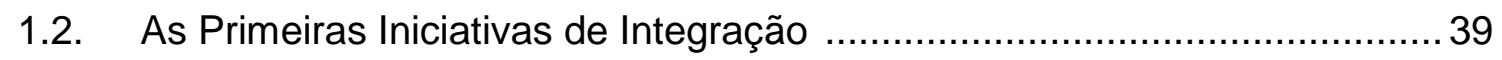

1.3. A América do Sul na Geoestratégia Norte-Americana ............................. 43

CAPÍTULO 2. Concepções Sobre a Projeção Internacional do Brasil ............ 52

2.1. Ascensão Regional do Brasil ................................................................ 52

2.2. O Containment e o Territorialismo Sul-Americano ........................................ 56

2.3. Origens e Características dos Discursos Geopolíticos Continentais do Brasil

2.4. Visualização do Espaço Mundial e Concepções da Projeção Mundial do Brasil 
Capitulo 3. Colapso da Geopolítica Militar e Origens da Integração Regional 78

3.1. Inter-Relação entre as Conjunturas Regional e Mundial 78

3.2. Rivalidades Geopolíticas e Fragmentação do Continente 83

3.3. A Importância dos Buffer States na Rivalidade entre Brasil e Argentina 92 3.4. A Economia Geopolítica e os Limites da Projeção Internacional do Brasil. 99

INTERMEZZO. Apontamentos de Transição à Nova Geopolítica Continental 110

\section{PARTE 2 \\ OS FUNDAMENTOS DA INTEGRAÇÃO SUL-AMERICANA}

CAPITULO 4. Espaços de Integração e a Nova Ordem Geopolítica 119

4.1. Integração Regional no Contexto de Reorganização do Espaço Mundial ...119

4.2. Elementos Preliminares da Nova Ordem Geopolítica Mundial 128

4.3. Legitimação da Nova Ordem Geopolítica e a América do Sul 137

Capítulo 5. Constituição da Nova Ordem Regional Sul-Americana 149

5.1. Fundamentos da Região Geopolítica e a Ordem Contemporânea 149

5.2. Mercosul, o "Núcleo Duro" da Integração Continental 157

5.3. Fundamentos da Nova Ordem Regional 165

Capitulo 6. Transformações Econômicas e Territoriais 175

6.1. Economia Geopolítica Regional Contemporânea 175

6.2. Fundamentos das Novas Relações Territoriais 188

6.3. Reordenação Territorial Sul-Americana 197 
INTERMEZZO. Apontamentos de Transição a (Re) Inserção Mundial da América do Sul

\section{PARTE 3 \\ OS DESAFIOS REGIONAIS E GLOBAIS À INTEGRAÇÃO SUL- AMERICANA}

Capitulo 7. Assimetrias Econômicas e Conflitos Geopolíticos

7.1. Instabilidades Econômicas e Assimetrias Regionais: Aspectos Preliminares

7.2. Assimetrias Econômicas: um Novo Hegemon Regional? ............................ 229

7.3. Fricções Territoriais e o Retorno da Geopolítica ....................................... 241

CAPITULO 8. Desafios Globais a Nova Ordem Sul-Americana ....................257

8.1. Soberania Globalista e a Nova Ordem Sul-Americana ..............................257

8.2. Rupturas na Economia Geopolítica: O Lugar da América do Sul no Mundo I 274

8.3. Reorganização do Espaço Mundial: O Lugar da América do Sul no Mundo II. 292

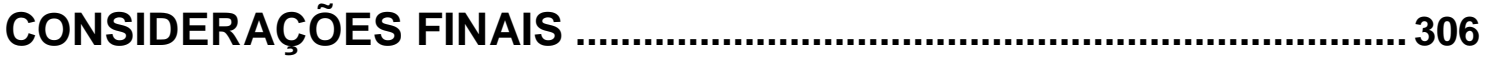

América do Sul, um Constructo Geopolítico para o Futuro .............................307

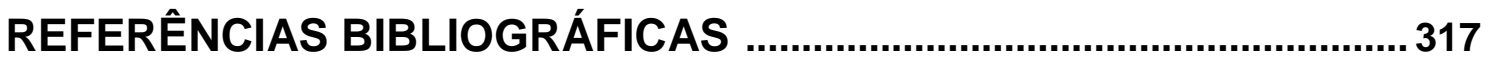




\section{ÍNDICE DE GRÁFICOS}

[GRÁFICO 1] Crescimento do PIB: Argentina, Brasil, Chile, Colômbia e Venezuela (1962-1979)

[GRÁFICO 2] Crescimento do PIB: Argentina, Brasil, Chile, Colômbia e Venezuela (1980-1989) 102

[GRÁFICO 3] Média Anual de Crescimento do PIB: Argentina, Brasil, Chile, Colômbia e Venezuela (1970-1989) 102

[GRÁFICO 4] Crescimento da Dívida Externa: Argentina, Brasil, Chile, Colômbia, Venezuela (1970-1989) 104

[GRÁFICO 5] Relação Dívida Externa - PIB: Brasil, Argentina, Chile, Venezuela e Colômbia (1970-1989) 104

[GRÁFICO 6] Intercâmbio Comercial Brasil - Mercosul (1989-2010). 184

[GRÁFICO 7] Intercâmbio Comercial Brasil - Mercosul: Variação Percentual (1989-2010) 184

[GRÁFICO 8] Intercâmbio Comercial Brasil - Argentina (1989-2010). 185

[GRÁFICO 9] Intercâmbio Comercial Brasil - Chile (1989-2010) 185

[GRÁFICO 10] Intercâmbio Comercial Brasil - Bolívia (1989-2010). 186

[GRÁFICO 11] Intercâmbio Comercial Brasil - Colômbia, Venezuela e Equador (1989-2010) 186

[GRÁFICO 12] Intercâmbio Comercial Brasil - América do Sul (1989-2010) 187

[GRÁFICO 13] Intercâmbio Comercial Brasil - América do Sul: Variação Percentual (1989-2010)

[GRÁFICO 14] Crescimento do PIB: Argentina, Brasil, Chile, Colômbia e Venezuela (1990-2010) 224

[GRÁFICO 15] Média Anual de Crescimento do PIB: Argentina, Brasil, Chile, Colômbia e Venezuela (1990-2010)... .224 
[GRÁFICO 16] Intercâmbio Comercial Brasil - Paraguai (1989-2010). 231

[GRÁFICO 17] Intercâmbio Comercial Brasil - Uruguai (1989-2010). 232

[GRÁFICO 18] Exportações Brasileiras para a América do Sul: Produtos Industrializados e Básicos (1989-2010) 233

[GRÁFICO 19] Exportações Brasileiras ao G8: Produtos Industrializados e Básicos (1989-2010). 233

[GRÁFICO 20] Evolução dos Gastos Militares na América do Sul (2001-2010).. 252

[GRÁFICO 21] Entrada de Investimentos Estrangeiros Diretos (1980-2010)

[GRÁFICO 22] Estoque de Investimento Estrangeiro Direto: Saída (1990 / 2000 / 2010). 284

[GRÁFICO 23] Estoque de Investimento Estrangeiro Direto: Entrada(1990 / 2000/ 2010). 284

[GRÁFICO 24] Intercâmbio Comercial Brasileiro com a China (19902010) 286

[GRÁFICO 25] Intercâmbio Comercial Brasileiro: China e Blocos Econômicos (1989-2010) 286

[GRÁFICO 26] Exportações Brasileiras à China (1989-2010) 287

[GRÁFICO 27] Crescimento do PIB: Bolívia, Equador, Guiana, Paraguai, Peru, Suriname e Uruguai (2001-2010) 288

[GRÁFICO 28] Intercâmbio Comercial Brasil - União Européia (1989-2010) 


\section{ÍNDICE DE MAPAS}

[MAPA 1] América do Sul: Macro-Áreas 90

[MAPA 2] Eixos de Integração e Desenvolvimento da IIRSA 201

[MAPA 3] Articulações Territoriais dos Eixos de Integração e Desenvolvimento 203

[MAPA 4] Redes Geográficas Sul-Americanas 206

[MAPA 5] América do Sul: Produto Interno Bruto - PIB (2008) 230

[MAPA 6] Conflitos na América do Sul. 243

[MAPA 7] Rede Territorial da Bolívia 249

[MAPA 8] América do Sul: Gastos com Defesa (2008 253 
Este estudo examina a relação entre Brasil e América do Sul a partir das conjunturas regionais estabelecidas do início da Guerra Fria até o período contemporâneo. A tese está dividida em: Parte 1, "Geopolítica Sul-Americana do Brasil na Guerra Fria"; Parte 2, "Os Fundamentos da Integração Sul-Americana"; Parte 3, "Os Desafios Regionais e Globais à Integração Sul-Americana".

A introdução discute os aspectos relacionados à metodologia empregada, assim como a relação da pesquisa com estudos atuais sobre a América do Sul. Faz-se uma discussão introdutória sobre as transformações em andamento no campo da Geografia Política e como estas são incorporadas pelo trabalho.

A Parte 1, dividida em três capítulos, dedica-se ao exame da política sulamericana durante a Guerra Fria e do equilíbrio de poder em torno de Brasil e Argentina. A discussão é conduzida considerando o papel dos Estados Unidos na ascensão regional do Brasil. Avalia-se o modelo militar de projeção internacional do país bem como os seus limites perante às transformações globais desde os anos 1970.

A Parte 2, dividida em três capítulos, analisa a emergência de uma nova ordem regional sul-americana segundo o imperativo da cooperação regional fundado com a assinatura do Tratado de Assunção (1991) e a constituição do Mercosul. Procura-se compreender o novo modelo de política continental bem como seus efeitos nas relações políticas, econômicas e territoriais entre os países da região. Os principais acordos regionais, a ampliação geográfica da integração fundada no Cone Sul, a evolução nas relações comerciais, e as transformações das conexões territoriais são examinados à luz da emergência da nova ordem sulamericana.

A Parte 3, dividida em dois capítulos, busca traçar os principais desafios regionais e globais da nova ordem continental. As fricções internas, os conflitos geopolíticos, os desafios econômicos e os limites e alcances do atual modelo de projeção internacional são os temas centrais que orientam as análises que 
perpassam os dois capítulos. São consideradas as recentes transformações globais e as possibilidades e desafios frente à emergência de um eixo de desenvolvimento representado pelas maiores economias emergentes.

As considerações finais apresentam uma síntese dos temas que desafiam a atual ordem sul-americana e suas maiores lideranças. Simultaneamente, são elaborados alguns apontamentos acerca das prioridades estratégicas do Brasil e de todo continente perante as transformações geopolíticas globais. 


\section{INTRODUÇÃO}

\section{O RETORNO DA GEOPOLÍTICA E A AMÉRICA DO SUL}

The primary function of the geopolitical process is to analyse, if necessary, the links between the external and internal components of a concrete localized situation.

Michel Foucher

Ao longo do século $X X$, as mais influentes análises geopolíticas da relação entre Brasil e América do Sul foram concebidas por militares com uma visão de projeção continental baseada no equilíbrio regional de poder. Essa tendência, que foi predominante dos anos 1920 até o início dos 1980, foi substituída nas últimas décadas por novas abordagens envolvendo a inter-relação entre as escalas nacional e continental. O interesse pela América do Sul rompeu os círculos militares, estando presente em policy makers, diplomatas, empresários e pesquisadores das principais universidades do país. Grande parte dos trabalhos contemporâneos, empreendidos por diferentes abordagens e disciplinas, foram catalisados pela regionalização retomada no início da década de 1990 com a criação do Mercosul.

Conseqüência da formação territorial, os interesses brasileiros em relação à América do Sul passaram a se concentrar no Cone Sul. Esse caminho retoma, 
por outros meios e concepções, a diretiva da diplomacia conduzida pelo Barão do Rio Branco no início do século XX, ao buscar cooperação política entre os países dessa região. A assinatura do Tratado do ABC em 1915 tem origem na linha de ação instituída por Rio Branco entre 1909 e 1912, baseada na idéia de que um alto nível de diálogo diplomático entre os países vizinhos era necessário para garantir a paz (CONDURU, 1998, p. 65). As políticas de integração iniciadas no final dos anos 1980 refletiam, por outro lado, intenções de diminuir as rivalidades continentais e fortalecer a região perante um mundo em profundas transformações geopolíticas.

As iniciativas do começo do século $X X$ deflagraram uma era de experiências de aproximação regional, malograda com a ascensão das ditaduras militares nos anos 1960. Apesar dos primeiros esforços de cooperação regional a partir de 1915, o realismo político, a geopolítica territorialista, e o alinhamento subordinado do Brasil às potências mundiais marcaram sua política sul-americana até o inicio dos anos 1980.

Até esse período, as preocupações do Brasil com a América do Sul estavam impregnadas de discursos geopolíticos forjados na Europa e nos Estados Unidos. A contenção das fronteiras, os conflitos diplomáticos e tensões geopolíticas generalizadas eram forças que definiam o entendimento acerca do continente.

A geografia brasileira clássica nunca se ocupou de modo exaustivo do entendimento do entorno regional do Brasil. Primeiro, porque o campo da Geografia Política começa a se desenvolver nas universidades brasileiras apenas na década de 1980. Até então, as relações entre conhecimento geográfico e política externa estavam subordinadas aos interesses da elite militar (e seus ideólogos) que comandava o país. No século $X X$ os militares arraigaram concepções da América do Sul segundo um viés territorialista voltado à legitimação da projeção continental. O território, as fronteiras, os transportes, os recursos e a população foram submetidos a discursos organicistas e expansionistas.

O enfraquecimento dessa concepção ocorre com o retorno da geopolítica aos meios acadêmicos. Esse processo foi liderado por geógrafos determinados a resgatar a disciplina invertendo os principais preceitos que definiam os estudos em torno da relação entre sociedade, território e poder. A geopolítica, como técnica de 
controle do espaço e da sociedade, passou a ser substituída por exames críticos e abordagens que buscavam compreender mecanismos de poder em torno do espaço geográfico empreendidos por atores estatais e não estatais. Concepções de poder estadocêntricas e unidimensionais deram lugar a perspectivas multidimensionais como propõe Bertha Becker em "A Geografia e o Resgate da Geopolítica" (1988).

Essa concepção é parte de uma renovação teórica mais ampla, desencadeada com a publicação em 1976 na França da obra clássica de Yves Lacoste, "A Geografia, Isso Serve Antes de Mais Nada para Fazer a Guerra". É preciso reconhecer que geógrafos norte-americanos como Isaiah Bowman (1935) e Richard Hartshorne (1950) já tinham se ocupado da crítica à instrumentalização do conhecimento geográfico pela geopolítica de Estados totalitários. Mas a crítica lacostiana atinge o âmago de todo conhecimento geográfico, e não somente os discursos estabelecidos pela Geopolitik que prevaleceu na primeira metade do século $X X$.

A relação entre conhecimento geográfico e poder se desdobra entre a Geografia dos estados maiores, praticada pelos Estados e grandes corporações, e a dos professores, responsável por discursos sobre o espaço geográfico e os lugares. O geógrafo francês estabelece uma perspectiva, que consiste em inverter a lógica dos discursos geopolíticos tradicionais e direcioná-los contra o estado maior.

No início dos anos 1980, "Por Uma Geografia do Poder" de Claude Raffestin representa a primeira busca efetiva de fundar uma nova base epistemológica a Geografia Política. Essa disciplina, na forma como inaugurada por Ratzel, tem sua legitimidade atrelada ao Estado (FARINELLI, 2000). Raffestin contrapõe o "Poder" do Estado ao "poder" exercido territorialmente por atores não estatais. O seu alvo é a "prisão metodológica" da Geografia Política, isto é, a delimitação da abordagem aos temas da população, da morfologia territorial e dos recursos.

A cisão operada por Raffestin está na descentralização da abordagem política em Geografia, revelando a multidimensionalidade nas relações entre o poder - entendido a partir de uma perspectiva relacional foucaultiana - e o território. Em grande medida, seu trabalho reflete transformações do capitalismo, com a ampliação dos fluxos transnacionais, a emergência das multinacionais como 
atores globais, e a consolidação de novos atores e escalas políticas e econômicas que desarranjam o cenário estadocêntrico que condicionava toda Geografia Política.

Um terceiro processo de transformação da Geografia Política ocorre nos Estados Unidos e Inglaterra a partir do final da década de 1980 e início da de 1990. Autores como John Agnew, Simon Dalby, Klaus Dodds, Gearóid Ó Tuathail, dentre outros, têm promovido um resgate dessa disciplina, procurando fundamentá-la como um campo de análise das conjunturas geopolíticas (regionais e globais) a partir de discursos e práticas que abrangem uma diversidade de atores estatais e não estatais. Esses teóricos integram a Escola de Geopolítica Crítica (Critical Geopolitics), caracterizada por estudos sobre a transformação no modo de relação entre poder político e econômico, e território na era da globalização.

Essa escola assimila tanto a tendência crítica estabelecida a partir da década de 1970, quanto as novas concepções centradas na globalização que consolidou os fluxos transnacionais, colocando em cheque conceitos tradicionais da Geografia Política. O território, a soberania e as relações internacionais são reexaminados a partir de conexão entre a abordagem geopolítica e a economia política internacional.

O marco nesse resgate da Geopolítica é Mastering Space (1995) de John Agnew \& Stuart Corbridge. Nesse trabalho, a disciplina é entendida como divisão do espaço global por instituições (Estados, firmas, movimentos sociais, organizações internacionais, forças armadas, grupos terroristas) em territórios e esferas de influência política e econômica (Op. Cit., p. 01-10). Através dessa divisão, a economia política internacional seria regulada materialmente e representada intelectualmente como uma ordem natural de áreas desenvolvidas e subdesenvolvidas, amigas e inimigas etc. (Op. Cit.). A geopolítica está implícita tanto na prática quando nos escritos sobre todos os tipos de relações internacionais. Agnew \& Corbridge constroem uma teoria geral da geopolítica, considerando-a simultaneamente enquanto prática e discurso, isto é, como uma ordem mundial material e um entendimento discursivo normativo (Ó TUATHAIL, 1998, p. 18).

Assim como Agnew \& Corbridge (1995) e Agnew (1998), Gearóid Ó Tuathail (1997) e John Ó Loughlin (2000) têm se empenhado no resgate da 
Geopolítica como campo de estudos das relações internacionais. A análise da política internacional é retomada mediante revisão crítica de conceitos que monopolizavam a compreensão da relação entre sociedade e território até as transformações econômicas e tecnológicas desencadeadas nas últimas décadas. Os fluxos transnacionais e as novas coletividades globais tornadas possíveis com os meios informacionais estão, segundo Timothy Luke (1998, p. 274), debilitando princípios como nacionalidade, territorialidade e soberania. Para Agnew \& Corbridge (1995) e Agnew (1998; 2008) surgem novas escalas de poder e soberania.

O retorno da Geopolítica nessa sua nova configuração teórica está relacionado às transformações da globalização em escala mundial e regional, que impactam a economia política internacional, assim como os fatores que determinam as relações interestatais. Os conflitos tornam-se menos centralizados nas relações entre Estados, e cada vez mais difusos e flexíveis através da atuação de forças não estatais como movimentos políticos internacionais organizações terroristas, crimes transfronteiriços etc. Da mesma forma, a nova escala política representada pela emergência dos blocos regionais nas duas últimas décadas institui um cenário internacional muito distinto daqueles em que floresceram os discursos territorialistas.

Esses fatores são determinantes para a compreensão da condição internacional do Brasil e da América do Sul. O resgate da Geopolítica no Brasil abriu caminho para ampliação dos estudos de cenários trazidos pela integração regional. Exames sobre a integração territorial, as interações espaciais fronteiriças etc., tem definido o escopo dessa disciplina. As pesquisas têm investigado a relação entre Brasil e América do Sul a partir de uma abordagem inversa daquela que caracterizou as análises empreendidas pela geopolítica militar no Brasil.

O presente trabalho visa examinar as configurações internas e externas da América do Sul a partir de uma perspectiva que tem como foco a geopolítica internacional do Brasil. A projeção continental e mundial do país vem sendo buscada desde a ordem bipolar até o período atual, que é caracterizado por iniciativas de integração regional. À consecução desse objetivo, busca-se incorporar as transformações da Geografia Política nas últimas décadas, evitando, todavia, incorrer no erro de descartar o arcabouço teórico tradicional. Apesar dos avanços trazidos pela revisão crítica, conceitos e categorias da Geopolítica 
Clássica continuam essenciais à compreensão dos processos que impulsionam as relações internacionais contemporâneas.

Tanto as teorias tradicionais quanto as contemporâneas estão associadas a conjunturas maiores que definem a relação da sociedade com o espaço geográfico. Contudo, não há substituição linear de uma vertente por outra. Durante o predomínio da geopolítica territorialista existiam importantes forças transnacionais; ainda que não constituíssem o âmago das estratégias direcionadas ao território e o poder. Da mesma forma, as transformações tornadas possíveis com a globalização não eliminam tendências tradicionais. A principal mudança está na perda do monopólio que dispunha o Estado no comando das relações internacionais.

A posição interna e externa da América do Sul está condicionada a diferentes conjunturas internacionais. As mais antigas, que predominaram até os anos 1980, são caracterizadas pelo territorialismo como força determinante das relações regionais e globais. As mais recentes estão assentadas na emergência da transnacionalização dos fenômenos políticos e econômicos, seja através do multilateralismo que predominou na década de 1990 ou do neorealismo a partir de 2001.

Esse estudo se insere no amplo debate atual sobre a integração sulamericana. Apesar disso, não objetiva examinar exclusivamente o continente a partir da formação do Mercosul e Unasul. Ainda que essas duas iniciativas ocupem grande parte da investigação, a pesquisa tem como escopo essencial o entendimento da nova ordem regional sul-americana a partir de uma periodização que busca destacar dois processos opostos e complementares. O primeiro se refere às dinâmicas geopolíticas estadocêntricas (globais e regionais) que definiram a relação do Brasil com o restante da América do Sul. A partir disso, examina-se a situação geopolítica interna e externa do continente. O segundo está atrelado à ruptura empreendida no final dos anos 1980, estabelecendo a base daquilo que chamamos de nova ordem sul-americana. A análise dessa ordem é guiada pelo imperativo da cooperação e da integração regional consolidado a partir da década de 1990. Em conjunto, o período precedente e o atual permitem uma visão maior das diferentes geopolíticas voltadas à projeção do Brasil e da América do Sul. 
A nova ordem sul-americana se relaciona com duas escalas distintas, mas indissociáveis. A primeira é interna, definida por dinâmicas políticas e econômicas específicas. A segunda é externa, posta por transformações da conjuntura internacional que impactam diretamente contextos locais. A condição internacional do continente está atrelada a organização do espaço mundial, entendido enquanto conjunto constituído por diferentes escalas geográficas de poder político e econômico: áreas subnacionais, Estados, blocos regionais etc.

É necessário considerar que a escala é a medida que confere visibilidade ao fenômeno (CASTRO, 1995, p. 123). Mas o fenômeno em torno da geopolítica sul-americana não é, de modo algum, monotemático. Como ensina Hartshorne (1950), a singularidade da Geografia Política está na capacidade de proporcionar análises de conjunturas. Para tanto, faz-se necessário a articulação e integração dos diversos temas que em conjunto conferem uma determinada característica geográfica.

Grosso modo, é possível diferenciar quatro abordagens de estudos sobre a América do Sul. A primeira é territorialista: estuda a região a partir da Geopolítica Tradicional. Uma vertente do realismo, essa linha privilegia os recursos naturais, a força militar, os conflitos e o equilíbrio de poder etc. A segunda define-se pelo institucionalismo: foca as instituições multilaterais (Mercosul, Unasul, e os diversos mecanismos políticos, jurídicos e diplomáticos) para análise do continente e suas diferentes áreas. A terceira é geoeconômica: examina o espaço a partir da economia e da integração comercial. A quarta é geográfico-política e regional: esforça-se para apreender diferentes dimensões da escala continental e as intersecções com a global. Inspirada na abordagem multidimensional, integra aspectos das três anteriores.

A partir dessas considerações, a presente pesquisa se divide em três planos: a) uma análise da política regional e da projeção continental do Brasil a partir do equilíbrio de poder; b) um exame dos fundamentos e das estruturas que integram a nova ordem regional; c) uma investigação sobre os limites e alcances do processo contemporâneo de inserção mundial do Brasil e da América do Sul.

Da maneira como foi estruturado, esse trabalho concebe a ordem regional de duas formas. Na primeira, a ordem é entendida apenas como conjuntura regional, isto é, uma situação geográfica marcada tanto pela presença ou pela ausência de um sistema institucional de relações interestatais ou transnacionais. 
Mesmo na ausência de um conteúdo normativo, é possível falar em ordem regional condicionada ao territorialismo, equilíbrio regional de poder, contenção fronteiriça etc.

Na segunda, a ordem é definida a partir de um conteúdo normativo, isto é, por um arranjo institucional que busca regular as interações políticas, econômicas e territoriais. O período dominado pelo equilíbrio de poder, apesar de não constituir uma ordem no sentido normativo, forma uma conjuntura singular aos países da região. A nova ordem sul-americana, ao contrário, é a primeira que constitui um arranjo institucional capaz de transformar as relações políticas, econômicas e territoriais.

Por fim, é preciso destacar que esse estudo faz parte do esforço empreendido em diversos países, de devolver à Geografia Política sua vocação inicial. Trata-se de um campo de análise das relações internacionais que surgiu no final do século XIX quando disciplinas mainstream estavam aprisionadas em contextos regionais. Significa resgatar os estudos da geopolítica como parte indissociável das relações políticas e econômicas que fazem funcionar a ordem mundial. 
PARTE 1

GEOPOLÍTICA SUL-AMERICANA DO BRASIL NA GUERRA FRIA 


\section{CAPÍTULO 1}

\section{O Brasil e a América do Sul no Contexto da Guerra Fria}

Historicamente, e até nossos dias, a ordem internacional tem sido sempre territorial, consagrando um acordo entre soberanias, e compartimentalizando o espaço.

Raymond Aron

\subsection{O Brasil, o seu Continente e as Ordens Geopolíticas}

Definir a América do Sul em termos geopolíticos é uma tarefa bastante complexa. Não existe um continente sul-americano stricto sensu, visto que a área é oficialmente uma subdivisão das Américas. Enquanto "espaço homogêneo", a América do Sul não se distingue apenas por suas florestas, cadeias orográficas, bacias hidrográficas e diversidade cultural; fatores examinados detalhadamente por Isaiah Bowman (1915). Além da condição de gigantesca massa contínua dotada de características físicas e humanas singulares, há importantes aspectos históricos e políticos que dão especificidade ao continente no contexto internacional.

A partir desses fatores, o presente estudo pretende examinar as condições internacionais da América do Sul guiando-se por duas hipóteses principais. Primeiro, a ascensão dos Estados Unidos como grande potência internacional na segunda metade do século XIX trouxe conseqüências para todo o continente americano. Mas apesar do caráter continental da Doutrina Monroe, o 
país se consolidou essencialmente como uma potência dominante na América Central após a Guerra Hispano-Americana (1898). Ainda que ao longo do século XX, a Inglaterra visse erodir lentamente o seu poder na América do Sul com a ascensão da nova potência, os Estados Unidos não foram capazes de projetar nesse continente um poder imperial na mesma dimensão daquele imposto sobre a América Central. A América do Sul é mais periférica aos interesses norteamericanos (KELLY, 1997).

Segundo, apesar de Colômbia e Venezuela terem sido mais expostas ao domínio americano no Caribe, há, como observa Sérgio Danese (2001, pp. 49-71), uma história comum aos países sul-americanos influenciada, em parte pela geografia. Após a onda de independência que transformou o continente no século $\mathrm{XIX}$, as tensões territoriais resultaram em conflitos armados, desencadeando um modelo de relações políticas fundamentado essencialmente no equilíbrio regional de poder. À medida que seus países estabeleceram inter-relações geográficas, políticas, econômicas e culturais singulares ao longo da história, a América do Sul se consolidou como região caracterizada por uma especificidade no contexto internacional.

A influência dos conflitos territoriais na política sul-americana é anterior aos processos de independência. Essa questão se destaca, desde o século XVI, como a razão fundamental das rivalidades políticas internas. Ainda que Portugal empreendesse uma ocupação voltada primeiramente para a costa atlântica (PRADO Jr., 1970), a sua expansão a oeste estabeleceu um padrão de conflito que se estenderia até meados do século XX. Em cinco séculos, as políticas territoriais luso-brasileiras, base da articulação interna e projeção externa do Brasil (COSTA, 1999, p. 25), destacam-se como ponte da interação política do país com seus vizinhos. Esse modelo de relação envolvendo o Brasil e as demais nações sul-americanas funcionava como força centrífuga às relações políticas no continente.

Simultaneamente, as rivalidades regionais faziam com que os interesses diplomáticos estivessem voltados para a Europa. Apesar da América do Sul ser uma circunstância inexorável aos seus países, tal condição não se refletia diretamente nas prioridades externas do Brasil. Durante todo o período imperial, a diplomacia do país, voltada à Europa, abordava a América como uma unidade 
homogênea, sem pesar a importância de suas variações subcontinentais à política externa. $^{1}$

Para melhor compreensão dessas características, é necessário considerar as diferentes conjunturas internacionais que predominaram do século XIX ao XX. As relações internas e a "posição" externa do continente estão condicionadas a geopolítica das relações internacionais. Esta nasce com as grandes descobertas, que influenciaram a cosmografia e a cartografia do século XV (AGNEW, 1998).

As grandes navegações "desconstruíram" as representações mundiais geográfico-cristã. No século XVIII, o alargamento do mundo se completou, evidenciando a totalidade das massas continentais da América e Oceania. Halford Mackinder (1904; 1935; 1942) não se refere à outra coisa quando chama atenção para a interdependência política planetária, após o fim do ciclo das grandes descobertas e a modernização dos meios de transporte na segunda metade do século XIX. Por um lado, essa modernização permitiu a "existência" de um "espaço mundial". Mas, por outro, a conseqüente expansão das redes territoriais contribuiu para a intensificação dos atritos geopolíticos entre os grandes impérios coloniais europeus. $^{2}$

Enquanto disciplina acadêmica, a geopolítica passa a existir somente na virada do século XIX para o XX, período em que ganha um discurso "científico". Entretanto, ela existe como dimensão da política mundial desde a expansão do modelo civilizacional europeu. Fatores relacionados a território e "poder" são inerentes tanto as relações interestatais, quanto aquelas envolvendo atores nãoestatais.

\footnotetext{
1 "No período imperial, o Brasil, ao conservar o princípio dinástico como fonte de legitimação, diferenciou-se decisivamente de seus vizinhos americanos, que passaram a representar para o império o "outro" irreconciliável. Na metafórica ruptura entre a América e a Europa, o Brasil colocava-se ideologicamente ao lado das potências européias. A chave para permitir essa operação ideológica foi o conceito de "civilização." Durante o Império, o Brasil construiu sua auto-imagem a partir da percepção de uma suposta superioridade em termos de civilização - que seu regime político representava, ao aproximá-lo das monarquias européias. Ainda que atrasado, escravista e distante, essa "monarquia tropical" sentia-se acima de seus vizinhos, que entendia anárquicos e selvagens [...]. Essa percepção foi refletida no discurso diplomático. Nos Relatórios da Secretaria de Estado dos Negócios Estrangeiros (RSNE), durante todo o Império, está sempre presente a dicotomia entre as relações com os países da Europa e com os demais países americanos. São constantes as referências, por exemplo, às "potências da América e da Europa" (RSNE, 1832, p. 11 e p. 21; 1833, p. 12; 1834, p.16), aos "governos da Europa e América" (RSNE, 1835, p. 5; 1845, p. 8), aos "Estados da Europa e América" (RSNE, 1837, p. 4), às "nações da Europa e da América" (RSNE, 1855, p. 4) e às "ligações brasileiras na Europa e América" (RSNE, 1870, p. 28). O continente americano é, nesses Relatórios, tratado como unidade. São esparsas e pouco consistentes as eventuais referências às partes que o compõem." Luis Cláudio Villafañe G. Santos, 2005, p. 2.

${ }^{2}$ A principal tese da geopolítica clássica a esse respeito encontra-se em The Geographical Pivot of History (Mackinder, 1904) que destaca o fim da era das grandes descobertas - a chamada Era Colombiana - ampliando as possibilidades de novos atritos por domínio de territórios entre as grandes potências. A modernização dos meios de comunicação e transporte proporciona novas formas de controle do espaço-tempo, fazendo com que atritos que eram apenas regionais se tornarem mundiais.
} 
Todos os discursos geopolíticos são em sua essência determinados pelas características da modernidade. Segundo Agnew (1998.), os estudos de relações internacionais são de modo geral, estruturados segundo três hipóteses: os Estados têm um poder exclusivo sobre seu território; as questões domésticas e internacionais constituem-se em campos essencialmente separados; os limites de um Estado definem os limites de uma sociedade. ${ }^{3}$ Para Agnew (1994; 1998; 2008a; 2008b; 2008c), o pensamento social está preso a uma armadilha territorial. Predomina um paradigma onde o mundo é interpretado por uma divisão em blocos de espaço.

\subsubsection{Abordagem do Contexto internacional}

A condição geopolítica sul-americana é determinada por sua relação inextricável com diferentes contextos histórico-geográficos mundiais. Se do descobrimento até o início do século XIX a região estava subordinada ao poder da Espanha e Portugal no contexto internacional, com os processos de independência os países sul-americanos se tornam parte de uma nova conjuntura. O século XIX foi caracterizado pela aceleração na expansão do capital, resultando na globalização da economia-mundo capitalista (ARRIGHI, 2008, p. 165). Neste período, todas as regiões tornaram-se parte de uma ordem política e econômica comandada pela Grã-Bretanha, que reorganizou a relação espaço-tempo em escala global.

Com a ascensão da Grã-Bretanha como a maior potência mundial, o poder geopolítico global passou a pressupor a hegemonia sobre as condições históricas e sociais, e, por conseguinte, sobre a espacialidade das relações internacionais. A modernidade se define a partir da Revolução Industrial, como uma contínua transformação da experiência do espaço-tempo (BERMAN, 1986; HARVEY, 1989). Uma potência, ao comandar transformações políticas, econômicas e tecnológicas, reorganiza as relações sociais (valores, sistemas de

\footnotetext{
${ }^{3}$ Em relação à primeira hipótese, Agnew (Op. Cit.) ressalta que a soberania foi deslocada na passagem da Idade Media para a Idade Moderna, da figura do soberano para o Estado territorial. A soberania é o poder do Estado e da sociedade hierarquicamente organizados, sobre uma determinada área, o território nacional. A defesa e a segurança da sociedade em um território é o objetivo principal de um Estado. Em relação à segunda hipótese, Agnew (Op. Cit.) entende que há na política uma divisão entre uma esfera interna e outra externa. Na interna prevalece o debate e os conflitos políticos enquanto que na externa predomina de maneira mais direta a imposição pelo poder do mais forte. A terceira hipótese expressa o Estado territorial como container da sociedade. Desde Westfalia, a idéia de modernidade está conectada ao invólucro do Estado territorial.
} 
produção, divisão do trabalho etc.) e espaciais (fluidez material e informacional, topologia das redes de produção e distribuição, hierarquia dos lugares etc.) em todas as regiões.

O alcance dessas transformações não está circunscrito ao invólucro territorial do Estado soberano, sendo necessariamente "transnacional". Estabelece-se um arranjo político e econômico mundial, resultado de uma configuração espaço-temporal. As potências hegemônicas reorganizam o espaçotempo (e por conseguinte as relações internacionais) a partir dos seus interesses políticos, econômicos e culturais. Em sua totalidade, o arranjo internacional engendrado a partir do poder de uma potência mundial, constitui uma Ordem Geopolítica.

\begin{abstract}
Em nosso uso "ordem" se refere a regras rotinizadas, instituições, atividades e estratégias através das quais a economia política internacional opera em diferentes períodos históricos. O termo qualificador "geopolítico" chama atenção para os elementos geopolíticos de uma ordem mundial. Este não é um traço "especial" ou "extra" de uma ordem abstrata. Antes, é intrínseco a ela. Ordens têm necessariamente características geográficas. Estas incluem o grau relativo de centralidade da territorialidade do estado em relação a atividades sociais e econômicas, a natureza da hierarquia dos estados (dominada por um estado apenas ou um números deles, o grau de igualdade do estado), o âmbito espacial das atividades de diferentes estados e outros atores como as organizações internacionais e comércios, a conexividade ou desconexividade entre vários atores, os efeitos condicionantes de tecnologias informacionais e militares sobre a interação espacial, e o ranqueamento de regiões mundiais e estados particulares pelos estados dominantes em termos de "ameaças" à sua "segurança" militar e econômica. (AGNEW \& CORBRIDGE, 1995, p. 15) [Tradução livre a partir do original do autor].
\end{abstract}

$\mathrm{Na}$ interdependência entre a escala continental e global, os aspectos geográficos (tradicionais ou contemporâneos) estão além de uma mera condição metafórica. Ao contrário, destacam-se como constituintes da economia política internacional. Esse conceito, largamente utilizado por Agnew \& Corbridge (1995) e Agnew (1998), reflete uma busca pela compreensão da indissociabilidade entre economia e política nas diferentes ordens internacionais. Assim, nas teorias geopolíticas surgidas nos anos 1980, esse conceito é empregado num esforço visando romper a dicotomia na análise das ordens internacionais - econômica e política.

As potências hegemônicas, como mostra Aglietta (1982) no caso britânico e americano, estabelecem um sistema internacional de regulação econômica. Passam a existir instituições (nacionais e internacionais) e procedimentos 
tacitamente reconhecidos pelos Estados capitalistas líderes, que regulam 0 comércio, as finanças, a moeda etc. As relações econômicas mundiais estão associadas a um modo de regulação em consonância com o poder político de uma hegemonia. Por outro lado, esta concepção de poder torna o Estado dependente da expansão internacional das redes de produção e distribuição das grandes empresas.

A partir dessa premissa, a economia política internacional possui uma dimensão geopolítica. Existe uma indissociabilidade entre os discursos geopolíticos - que engendram regras, normas, valores etc. - e as práticas econômicas da ordem internacional. Como resultado, configura-se uma "economia geopolítica", que pode ser definida como um híbrido formado pela geopolítica e a economia política (AGNEW \& CORBRIDGE, 1988). Ao envolver idéias e práticas de uma ordem internacional (Ó TUATHAIL, 1998, p. 18), a economia geopolítica abrange desde o modo de regulação até fatores geográficos tradicionais, como recursos naturais, população, circulação territorial etc. Dessa forma, não impacta apenas nos fatores tradicionais de produção, ou seja, terra, trabalho e capital. Tem reflexos na inovação tecnológica, na economia de serviços, nos fluxos financeiros etc.

A economia geopolítica está relacionada com a espacialidade indissociável das relações econômicas. De forma mais ampla, esta espacialidade, associada ao modo de regulação, aos valores, as crenças e as diversas normas que regem as relações internacionais, é um dos fatores estruturantes da ordem geopolítica.

Em Agnew \& Corbridge (1995) e Agnew (1998) a ordem geopolítica é uma conjuntura onde a geografia, a política e a economia são componentes inseparáveis. A economia geopolítica é organizada de acordo com os interesses de uma potência mundial e seus aliados. Este poder é garantido através do monopólio da moeda internacional, do comando sobre o modo de regulação, da liderança sobre a liquidez mundial e, em casos de fricções e conflitos, pelo uso da força bélica.

A partir dessas observações preliminares é possível traçar três fundamentos da economia geopolítica. Primeiro, constitui-se muitas vezes, tal qual demonstra Giovanni Arrighi (2008), uma afluência entre as políticas do Estado e os interesses das redes de produção e distribuição do capital. A organização de um 
mercado nacional foi uma das bases de consolidação dos Estados modernos (POLANYI, 2001). Esta interdependência transcende a escala nacional, pois desde as grandes navegações, o poder internacional de um país não pode ser desassociado dos fluxos mercadológicos organizados em consonância com os interesses de sua elite econômica. Segundo, o desenvolvimento econômico é um fator entrelaçado a políticas territoriais. O planejamento regional, os circuitos espaciais de inovação tecnológica, a fluidez territorial da produção etc., são aspectos dessa condição. Terceiro, as relações econômicas contribuem para a hierarquia internacional dos Estados. A capacidade financeira e comercial molda a topologia das redes de poder internacional de um país, permitindo a imposição dos seus interesses políticos e econômicos sobre outras nações numa determinada ordem geopolítica.

Agnew \& Corbridge (1995) dividem historicamente as relações internacionais em quatro ordens. A Ordem Geopolítica Britânica (1815-1875) foi marcada pelo Concerto da Europa no plano regional e pela hegemonia da GrãBretanha na escala global. A Ordem Geopolítica da Rivalidade Inter-Imperial (1875-1945) caracterizou-se pela ascensão de potências como Alemanha, Estados Unidos e Japão. A Ordem Geopolítica da Guerra Fria (1945-1990) foi comandada por duas superpotências: Estados Unidos e União Soviética. A Ordem Geopolítica do Pós Guerra Fria (1990-?) é identificada por meio da emergência de três forças globais - o livre-mercado, o choque de civilizações e a unipolaridade dos Estados Unidos. $^{4}$

A independência dos países sul-americanos está ligada ao surgimento da primeira ordem geopolítica mundial. A independência do Brasil fez parte de uma estratégia britânica para controlar a América do Sul pelo livre comércio (BECKER \& EGLER, 1992, p. 53). Os interesses do capitalismo industrial entraram em contradição com o pacto colonial “... baseado no monopólio metropolitano sobre o comércio..." (Op. Cit.). Com os processos de independência, o continente foi inserido na ordem geopolítica por meio de uma divisão internacional do trabalho que Aglietta (1982, p. 09) caracteriza como vertical. Diferente da hegemonia norte-

\footnotetext{
${ }^{4}$ Agnew (Op. Cit.) concebe esta ordem apenas como hipótese que é traçada a partir das três tendências predominantes de análise das relações internacionais. Em nosso trabalho, serão seguidas estritamente apenas as concepções sobre as três primeiras ordens geopolíticas. A quarta ordem será interpretada seguindo as proposições do geógrafo britânico somente enquanto periodização. Dessa forma, as suas características principais serão levantadas de acordo com as necessidades do tema da pesquisa. Por fim, a análise dos fatores que envolvem esse período será realizada apenas na segunda parte do trabalho.
} 
americana, que estimulou uma divisão internacional do trabalho horizontal (com a competitividade industrial e tecnológica), a Grã-Bretanha incorporou a América do Sul em sua ordem forçando a especialização em atividades econômicas primárioexportadoras.

Para a América do Sul, o surgimento de novas potências mundiais a partir de 1875 significou outras possibilidades políticas e econômicas. Na ordem multipolar, os Estados Unidos e a Alemanha se tornaram junto à Inglaterra, os principais parceiros comerciais dos países sul-americanos. Esta tendência se fortaleceu ainda mais com a política bilateral alemã, que colocou o país como principal parceiro comercial do Brasil na década de $1930 .^{5}$ Mas as relações da América do Sul com os EUA, que vinham se consolidando desde o final do século XIX, ganharam ainda mais força com o final dessa ordem geopolítica e a derrota da Alemanha.

$\mathrm{Na}$ Ordem Geopolítica da Guerra Fria, Brasil e Argentina modificaram sua inserção internacional. John Kennedy e Richard Nixon transformam os interesses norte-americanos em relação a todos os países do Cone Sul. Segundo Bertha Becker \& Claudio Egler (1992), o crescimento econômico do Brasil nesse período o projeta como uma importante potência regional na economia-mundo. $O$ anticomunismo foi o meio predominante de aproximação do país com as maiores potências.

Uma ordem é vinculada a discursos produzidos em todos os âmbitos sociais. A problemática geopolítica é necessariamente discursiva, pois se estabelece ao mesmo tempo como interpretação e "política" do espaço (Ó TUATHAIL \& AGNEW, 1992; Ó TUATHAIL, 1996). Ao tomar como referência principal autores clássicos da disciplina, Gearóid Ò Tuathail (Op. Cit.) defende que o discurso não antecede ou sucede, mas está simultaneamente entrelaçado a "visualização" do espaço geográfico. Como é, a uma só vez, linguagem e prática,

\footnotetext{
${ }^{5}$ Segundo Moniz Bandeira (2006, p. 102), a Alemanha instaurou um conjunto de políticas bilaterais para romper as barreiras econômicas e o sistema de comércio desfavorável imposto pelas potências da Tríplice Aliança, vencedoras da Primeira Guerra Mundial. A política bilateral visava tirar a Alemanha do sistema multilateral imposto pelos Estados Unidos que a colocou em condições desfavorável devido ao ônus da perda da Primeira Grande Guerra. Sem divisas internacionais, o país instalou por meio dos acordos um sistema de compensação, baseado na exportação de manufaturas e importação de matérias primas e produtos alimentícios de primeira necessidade. A política de relações bilaterais posta em prática pela Alemanha revigorou a posição do país no cenário internacional e o fez ameaçar a condição de primeira potência econômica dos Estados Unidos e suas influências nas várias regiões do mundo. A política alemã foi capaz de ameaçar até mesmo a posição conquistada pelos americanos na América Latina com a Doutrina Monroe. As relações comerciais do país com o Brasil atingiram um montante muito mais elevado durante a década de 1930, superando até mesmo o comércio brasileiro com os Estados Unidos. A participação da Alemanha nas importações brasileiras saltou de 14,02\% em 1934 para $25 \%$ em 1938. No mesmo período as importações brasileiras dos Estados Unidos subiram de $23,67 \%$ para $24,02 \%$, e as importações da Grã-Bretanha caíram de $17,14 \%$ para $10,04 \%$ (Op. Ci.).
} 
ele não está limitado ao indivíduo, mas abrange todo espaço social (MÜLLER, 2008). É indissociável do exercício da hegemonia, estando presente nos valores e práticas sociais. Dessa forma, os discursos sobre o território e o poder surgidos entre o final do século XIX e o início do XX são sistematizações acadêmicas que revelam e pertencem a um contexto geopolítico maior. As práticas espaciais presentes na ordem internacional são firmadas concomitantemente ao discurso geopolítico.

Segundo Michel Foucher (2000, p. 163) os discursos geopolíticos acadêmicos são percepções, racionalizações e representações ex post facto. Estão, portanto, impregnados por concepções geopolíticas mais amplas e por ideologias imbricadas em todo espaço social. Os discursos produzidos por escolas da Geografia e das Ciências Sociais diferenciam-se principalmente pela ambição ao statecraft, isto é, à arte de governo. Por trás das insistentes referências ao caráter científico de suas abordagens está também a pretensão de se destacar como técnica e suporte as políticas de Estado. Essas "construções teóricas" refletem a forma como a economia política internacional é incorporada e interpretada.

O termo discurso geopolítico se refere aqui a como a geografia da economia política internacional tem sido "escrita e lida" nas práticas de políticas internacionais e econômicas durante os diferentes períodos da ordem geopolítica. Escrita porque diz respeito ao modo como as representações geográficas são incorporadas às práticas das elites políticas. Lida porque alude às formas como essas representações são comunicadas. Antes de fazer uma apreciação dessas representações de espaço em cada período, é importante descrever o modo pelo qual o termo "discurso" está sendo usado. Não temos em mente a idéia típica de "textualidade, através da qual um grupo de textos ou documentos é escrutinado, tampouco o que o termo possa dizer sobre práticas ou comportamento, mas sua peculiaridade, estilo ou aspecto "performativo". Antes, o que pretendemos, o que poderia se chamar "discursividade" em geral, está relacionado a um contexto (...) O que é escrito ou dito pela elite política se dá como resultado de adoções inconscientes de regras de vivência, falas e pensamentos que estão implícitos em textos, discursos ou documentos que são produzidos. Mas as regras são também constituídas desta forma como "agentes epistemológicos" ou indicadores para as pessoas em geral de como deveriam viver, pensar e falar. $O$ aspecto criador de um consenso de hegemonia no sentido gramsciano corresponde essencialmente a este significado de discurso. Mas os discursos geopolíticos são apenas uma parte do tecido complexo de discursos (econômico, institucional) que formam cada hegemonia intrínseca às três ordens geopolíticas (Agnew \& Corbridge, 1995, pp. 46-47) [Tradução livre a partir do original do autor] 
Os autores denominam os discursos que caracterizaram a Ordem Geopolítica Britânica de geopolíticas civilizacionais. Como centro do mundo, os europeus têm como arcabouço de sua hegemonia a concepção de superioridade civilizacional. O continente organizava-se a partir da herança das grandes civilizações, estruturando seu poder em torno da consolidação dos Estados territoriais.

A economia política internacional era o meio de poder da Inglaterra que, como conseqüência da Revolução Industrial, tinha cada vez mais interesses em colônias ou áreas de influência como a América do Sul. A concepção de superioridade civilizacional apoiava-se ainda nos valores estabelecidos pelo cristianismo, sendo os processos de intervenção uma "providência divina" (AGNEW, 1998). No caso brasileiro, deve-se reiterar que a independência em 1922, e sua consolidação como império mercantil estavam subordinadas a ascensão da Inglaterra no comando da economia-mundo (BECKER \& EGLER, 1992).

$\mathrm{Na}$ Ordem Geopolítica da Rivalidade Inter-Imperial, prevaleceram as geopolíticas naturalizadas. Nestas, houve a construção de um discurso acadêmico sobre a superioridade européia em relação ao restante do mundo. A religião foi substituída pela crença no cientificismo "puro". A geopolítica acadêmica surge e se desenvolve segundo concepções epistemológicas fundadas em teorias das ciências naturais. Mesclando o naturalismo às filosofias de Hegel e Fichte, esta geopolítica desenvolveu uma concepção de Estado enquanto um organismo territorial.

A partir das proposições teórico-metodológicas da geografia alemã, Mackinder realizou o primeiro "diagnóstico geopolítico" da organização espacial do poder mundial. O texto The Geographical Pivot of History (1904) foi a primeira formalização geopolítica a delinear as principais dinâmicas mundiais (RETAILLÉ, 2000 , pp. 35-51). Nele, propunha um modelo geográfico onde a América do Sul embora lembrada pelo vasto potencial de desenvolvimento futuro - aparece sem relevância e distante do centro geoestratégico global. ${ }^{6}$ Apesar de ser influenciado pela ascensão da Rússia e da Alemanha, e de ser elaborado na "Era dos

\footnotetext{
${ }^{6}$ Geoestratégia envolve a aplicação do raciocínio geográfico na condução da guerra e/ou no estabelecimento de um esquema de defesa nacional (FOUCHER, 2000, p. 165). Em muitos casos - como aqueles que envolvem alianças e coalizões entre vários países, esse esquema pode ser também multinacional, com alcance continental ou transcontinental. No que tange aos blocos regionais, esse conceito adquire maior dimensão, como discutiremos de forma mais apropriada na segunda parte da tese.
} 
Impérios", o modelo geopolítico de Mackinder já antevia diversos aspectos da política internacional que ser tornariam preponderantes após a Segunda Guerra Mundial.

Segundo Leslie Hepple (2004), Mackinder, ao considerar o continente sulamericano sob a esfera de influência norte-americana no final do século XIX, entendia que essa situação poderia ser desafiada com a consolidação da Alemanha como uma potência mundial. De fato, segundo Luiz Alberto Moniz Bandeira (2006), a Alemanha promoveu uma investida comercial na América do Sul na década de 1930, chegando a ameaçar a primazia econômica dos Estados Unidos e Inglaterra na região. Com a eclosão da guerra, os países do Cone Sul foram os últimos em todo o continente a migrarem de forma definitiva do campo hegemônico britânico para o americano, consolidando, assim, a supremacia dos Estados Unidos na região.

A mudança hegemônica ocorrida no continente - que se deu primeiramente entre os países da porção setentrional sul-americana, passando posteriormente pela vertente pacífica até chegar ao Cone Sul (MELLO, 1997) - é uma manifestação regional de uma transição de alcance global. Assim como no restante do mundo, esse processo se torna completo na América do Sul após o final da Segunda Guerra Mundial e o início da era bipolar que resultou na oposição entre dois discursos.

A Ordem Geopolítica da Guerra Fria foi marcada pelo que Agnew \& Corbridge (1995) e Agnew (1998) definem como geopolíticas ideológicas (19451990). Nesse caso, de uma forma mais radicalizada do que em relação às ordens anteriores, grande parte das fricções entre os dois modelos deu-se no campo discursivo. O conceito de ideologia aqui empregado se refere a um amálgama de idéias, símbolos e estratégias postas por um confronto de ideários entre os dois lados. Ao consolidarem sua hegemonia em todo continente sul-americano durante a Guerra Fria, os Estados Unidos foram cruciais na transformação da política regional.

Esses discursos foram fundamentais no delineamento da política externa e no alinhamento dos países da região com as potências ocidentais. A primeira iniciativa visando o estreitamento das relações interestatais na América do Sul ocorreu no início do século XX, após décadas de acirramento das rivalidades 
(especialmente no Cone Sul) que resultaram em grandes guerras no final do século XIX.

As primeiras iniciativas de cooperação entre o Brasil e os demais países do Cone Sul, embrionárias para todo o processo futuro de integração regional no continente, deu-se numa era de transição da hegemonia inglesa para a americana. Esse fato resultou em características bastante específicas para as políticas regionais.

A ascensão do pan-americanismo como o mais importante valor a nortear a política em todo continente, expressava mais a transformação dos Estados Unidos em nova potência mundial, do que uma tendência de cooperação multilateral. Nesse caso, contribui à relação Brasil - Estados Unidos, a resistência da elite política nacional em se empenhar no fortalecimento dos laços regionais sul-americanos.

\subsection{As Primeiras Iniciativas de Integração}

A América do Sul somente passa a ser introduzida no discurso oficial da política externa brasileira com a proclamação da república. ${ }^{7}$ Segundo Santos (2005, p. 4), nos primeiros vinte e cinco anos da era republicana, a diplomacia estabeleceu uma "divisão" do continente em duas áreas: a América do Norte, comandada pelos Estados Unidos, e a América do Sul, onde Brasil, Argentina e Chile dispunham de autonomia relativa. ${ }^{8}$ Nesse período, havia uma concepção de América do Sul restrita ao Cone Sul. Essa limitação estava em conformidade com os interesses da diplomacia comandada por Rio Branco, que visava o estabelecimento do Tratado do ABC entre Argentina, Brasil e Chile (Op. Cit.). ${ }^{9}$ Durante toda Republica Velha, a política externa brasileira “... seguiu as linhas

\footnotetext{
7 "A proclamação da república representou a reversão imediata do distanciamento em relação ao americanismo. A delegação brasileira à Conferência de Washington de 1889-1889 teve sua chefia mudada e foi orientada a dar um "espírito americano" às instruções que haviam sido preparadas ainda pela diplomacia imperial. Após tentar, sem sucesso, negociar uma "aliança ofensiva e defensiva" com os Estados Unidos, o Brasil acabou por contentar-se com um acordo comercial, firmado em janeiro de 1891. Com a República, o discurso da chancelaria brasileira passou, ainda que timidamente, a incorporar as expressões como "América Latina", "América do Norte", "América Central e América do Sul."' Luis Cláudio Villafañe G. Santos, 2005, pp. 34.

8 "Vale lembrar que esse subsistema sul-americano não englobava, na prática, o que hoje entendemos como América do Sul. A disputa de limites entre a Venezuela e a Guiana inglesa, a secessão do Panamá (que Roosevelt resumiu com a frase: "eu tomei o Panamá") e todos os outros assuntos dos países situados ao norte da América do Sul eram tratados como questões da área de influência abertamente imperial dos Estados Unidos." Op. Cit., p. 4.

9 "O Barão de Rio Branco, à frente da pasta das relações exteriores, procurou equilíbrio em dois eixos de atuação: uma aliança tácita com o parceiro hegemônico da região, os Estados Unidos da América, para em seguida buscar a conformação de um espaço de paz e relações privilegiadas com seus parceiros sul-americanos. De fato, com Rio Branco, o continente sulamericano tem sua importância colocada sobre novas bases na diplomacia brasileira [...]." Thiago Gehre Galvão, 2009 , p. 64.
} 
delineadas por Rio Branco: voltada por um lado, para os Estados Unidos na forma de "aliança não escrita," e, por outro, dotada de uma ativa política "sulamericana"..." (Op. Cit., p. 08).

Essas primeiras tendências rumo a América do Sul foram importantes para introduzir o continente enquanto região de atuação da diplomacia brasileira. Da mesma forma, a diretriz estabelecida pelo Barão de Rio Branco, de uma aliança entre as principais forças do Cone Sul, foi retomada nas últimas décadas do século $X X$ enquanto base da regionalização no continente. $A$ concepção de regionalização aqui empregada se difere daquela utilizada por teóricos, cujo entendimento do conceito repousa exclusivamente na interação econômica em uma área internacional que acontece sem a atuação direta dos Estados. ${ }^{10} \mathrm{~A}$ partir de uma perspectiva oposta, a regionalização é um modelo político de relação interestatal, visando o alargamento ou a criação de um processo de coesão regional.

Assim como em outras áreas do globo, na América do Sul esse modelo de política internacional engloba o aprofundamento das interações econômicas e territoriais. A ampliação dessas interações é manifestação imanente de um novo modelo de política regional. A fase embrionária da regionalização como inaugurada por Rio Branco, ganha o primeiro impulso somente décadas mais tarde. Ainda que não tenha ocupado oficialmente espaço em negociações multilaterais, a primeira tentativa de formalizar uma política regional entre os três países deu-se na década de 1940, durante os governos Juan Perón e Getúlio Vargas (MONIZ BANDEIRA, 1992). A retomada do Pacto do ABC, principalmente para o presidente Perón e a sua aversão a hegemonia norte-americana, significou

\footnotetext{
10 "Regionalização diz respeito ao crescimento da integração da sociedade em uma região e aos processos muitas vezes não dirigidos de interação social. A isto, os primeiros estudiosos do regionalismo descreviam como integração informal e alguns analistas contemporâneos se referem como "regionalismo suave" (soft regionalism). O termo atribui um peso especial a processos econômicos autônomos que conduzem a níveis mais elevados de interdependência econômica em determinadas áreas geográficas do que entre essas áreas e o resto do mundo. Ainda que muitas vezes não sejam afetadas pelas políticas estatais, as forças propulsoras mais importantes da regionalização econômica provem dos mercados, do comércio privado e dos fluxos de investimento e das políticas e decisões empresariais. São de particular importância o aumento do comércio entre empresas, o número crescente de incorporações e aquisições internacionais e a emergência de redes cada vez mais densas de alianças estratégicas entre empresas [...]. Regionalização também envolve a circulação de pessoas, o desenvolvimento de múltiplos canais e complexas redes sociais, por meio dos quais idéias, atitudes políticas e maneiras de pensar se espalham de uma área para outra, criando sociedades civis regionais transnacionais. Conseqüentemente, a regionalização é com freqüência conceituada em termos de "complexos", "fluxos", "redes" ou "mosaicos". Três pontos devem ser destacados: (1) os processos envolvidos na regionalização são, pelos menos em princípio, mensuráveis - embora, como a obra de Deutsch sugere, o que se mede e o que se infere dos dados coletados permaneçam questões profundamente problemáticas; (2) a regionalização não se baseia em políticas concretas de Estados ou de grupos de Estados nem pressupõe qualquer impacto particular nas relações entre os Estados da região; e (3) os padrões de regionalização não coincidem necessariamente com as fronteiras dos Estados. Migração, mercados e redes sociais podem levar ao aumento da interação e interconectividade que vinculam alguns dos Estados existentes e criam novas regiões entre fronteiras. A essência desse "regionalismo transnacional" pode ser econômica, como nos pólos de desenvolvimento transfronteiriço, de corredores industriais ou de redes cada vez mais densas unindo os principais centros industriais, ou pode ser construída com base em elevados níveis de interpenetração humana, como acontece atualmente entre a Califórnia e o México." Andrew Hurrell, 1995, pp. 26-27.
} 
a primeira tentativa sistemática de maior autonomia frente aos Estados Unidos e Europa.

Devido à falta de entusiasmo de Vargas, e, principalmente, pela resistência existente em setores conservadores da política brasileira a qualquer proposta que não fosse pan-americanista, essa expectativa de construção de uma política continental fundamentada na cooperação regional não se concretizou em acordo formal (Op. Cit.). Todavia, essa tendência tornou-se recorrente no Cone Sul e no diálogo diplomático entre Brasil, Chile e Argentina, visando a cooperação política que perdurou até o início da década de 1960. Até a queda de João Goulart, prevaleceu propostas de cooperação política, liderada pelas principais forças do Cone Sul.

Portanto, desde a diplomacia liderada por Rio Branco, passando pelo governo Vargas até o golpe militar, a América do Sul foi paulatinamente se tornando uma região essencial para a diplomacia brasileira. O modelo americano de primazia na América Latina torna a aproximação entre os países sulamericanos uma alternativa em termos de política internacional. Nesse sentido, as forças que impulsionaram os países sul-americanos à relações políticas preferencialmente exógenas ao continente, lentamente se arrefeceram. 0 estreitamento dos laços políticos e econômicos se tornaria meio de fortalecimento regional frente a condição de subordinação perante as potências mundiais. Essa percepção se tornou o principal aspecto para a construção dos primeiros discursos de cooperação.

Além da diplomacia, há uma geografia implícita na aproximação política entre os países. Se a história diplomática fornece o embasamento das relações interestatais, caracterizando o continente como região dotada de especificidade política, aspectos geográficos tradicionais como posição e circulação estão subjacentes ao processo. Histórica e geograficamente, as relações interestatais sul-americanas se diferem daquelas que seus países mantêm com outras nações e regiões. $^{11}$

Em princípio, isso ocorre porque existe uma agenda em comum, posta por uma geografia que se manifesta por questões vitais. Temas como localização,

11 “... [O] conceito de América do Sul, como uma categoria atualizada das relações internacionais, se vincula à consolidação da entidade geográfica com uma dinâmica própria na sociedade internacional. Com isso, a América do Sul acopla-se aos debates sobre regionalização e globalização. Por um lado, a contigüidade geográfica é elemento determinante para impulsionar a cooperação internacional na área de infra-estrutura de integração e em contraposição ao ideológico latino-americano emerge a noção de um espaço sul-americano integrado." Thiago Gehre Galvão, 2009, p. 65. 
circulação natural e artificial, fronteiras e recursos naturais foram centrais não apenas durante os períodos de formação territorial. O lento processo de aproximação no século XX entre os países mantém esses tópicos como cruciais na cena sul-americana.

Contudo, o alargamento da agenda sul-americana desde Rio Branco, permitiu o estreitamento das relações políticas entre os países sem resultar diretamente em projetos sólidos. É inegável que, apesar de a América do Sul passar a existir diplomaticamente para os seus próprios países - principalmente para as três grandes forças do Cone Sul - durante décadas essa interação política pouco contribuiu para uma regionalização efetiva e para o fortalecimento internacional. De 1945 em diante, embora haja uma aproximação regional, a América do Sul não se projeta com identidade política própria na comunidade internacional.

Numa concepção que se tornou mainstream entre as grandes potências ao logo do século $X X$, os países de origem ibérica foram meramente definidos como latino-americanos. A América Latina enquanto expressão geográfica ganha força no século $X X$, principalmente pelo fato de agrupar um conjunto de países que comungam de condições políticas, econômicas e sociais relativamente semelhantes. ${ }^{12}$

As generalizações contidas nessa visão exógena a respeito do que seria a América latina têm implicações não apenas para a identidade de seus países, mas, sobretudo, para o lugar que ocupam no cenário político internacional. Do mesmo modo que as heranças deixadas pelas concepções geopolíticas de tradição anglo-americana, a percepção internacional de uma área hispanoportuguesa pobre e subordinada aos Estados Unidos será crucial para a definição de um lugar específico para seus países nas alianças ocidentais durante a Guerra Fria.

\footnotetext{
12 "A América Latina como abstração geográfica desenvolveu-se e ganhou força com o passar do tempo, chegando a caracterizar linhas de estudos nas principais universidades estadunidenses e vertentes de política externa direcionadas para uma região como se essa fosse um só país. Entretanto, as similitudes no que concerne a um passado histórico colonial e a necessidade de superação do subdesenvolvimento simplificam demasiadamente a complexidade dos países que compartilham, dentro de uma área de dimensões vastas, elementos culturais próprios e, conseqüentemente, interesses nacionais distintos. De fato, a evolução latino-americana, como uma região historicamente fragmentada no quadro da divisão internacional do trabalho, o processo de industrialização tardio, bem como a forma particular de dependência que se estabeleceu entre os países da região e os Estados Unidos catalisaram a construção mental de uma realidade histórica: a diferenciação entre duas Américas, uma anglo-saxã integrada à economia mundial; e outra, com origens ibéricas relegadas a periferia desse sistema." Thiago Gehre Galvão, 2009, pp. 64-65.
} 


\subsection{A América do Sul na Geoestratégia Norte-Americana}

A posição internacional dos países sul-americanos apresenta singularidades que os diferenciam não somente em relação a outras áreas do continente americano, mas também no que se refere a outras regiões do globo. Desde a era da diplomacia comandada pelo Barão de Rio Branco, as relações internacionais do Brasil passaram a ser orientadas em direção aos Estados Unidos. $^{13}$

Contudo, esse movimento de aproximação entre os dois maiores países do continente nem sempre se refletirá num alargamento progressivo da projeção internacional do Brasil ou dos demais países da América do Sul. A partir de 1945, com o novo impulso internacionalista da política norte-americana - traçado por Franklin D. Roosevelt nas duas décadas anteriores - o Brasil e a América do Sul perdem relevância para os Estados Unidos. Isso ocorre como uma conseqüência direta do surgimento de novas áreas de valor geoestratégico global para a nova potência mundial.

Após o fim da Segunda Guerra Mundial, algumas regiões periféricas do globo, até então de pouca relevância diplomática, adquiriram importância vital nos desdobramentos da política internacional. Entre 1945 e 1991, diversas áreas do Leste Asiático, que eram exclusivamente dependentes da industrialização japonesa (ARRIGHI, 2008, p. 345), tornaram-se foco de um imenso esforço político, econômico e militar, por parte dos Estados Unidos. O Japão e o seu entorno adquiriram importância estratégica para a política de segurança nacional dos Estados Unidos, à medida que essa área passou a ser entendida como fundamental para as políticas de contenção ao comunismo soviético (GADDIS, 2005b).

De forma muito semelhante à Europa Ocidental, foram adotadas duas medidas cardinais visando conter a expansão da União Soviética no Leste Asiático. Por um lado, os Estados Unidos se encarregaram de promover uma forte

\footnotetext{
13 "A diplomacia de Rio Branco, paradigmática para o período, estruturou o discurso sobre o americanismo e a América do Sul para atender seus três principais objetivos: a definição das fronteiras, o aumento do prestígio internacional do país e a afirmação da liderança brasileira na América do Sul [...]. Para a consecução desses objetivos, de modo bastante realista, Rio Branco optou pela política de "aliança não escrita" com os Estados Unidos. O Barão deslocou o eixo da política externa brasileira em direção a Washington, com gestos simbólicos, como a elevação das respectivas delegações ao status de embaixadas e a realização da Terceira Conferência Americana no Rio de Janeiro; e políticas concretas como o reconhecimento da soberania do Panamá, a aprovação tácita do Corolário Roosevelt, a indiferença ante as intervenções estadunidenses na América Central e no Caribe, o repúdio a Doutrina Drago, etc." Luis Cláudio Villafañe G. Santos, 2005, p. 04.
} 
militarização da região com a instalação de bases militares, principalmente no Japão; ${ }^{14}$ simultaneamente estabelecendo uma barreira bélica aos soviéticos e ampliando sua posição estratégica. Por outro lado, após o início da Guerra da Coréia em 1950, houve um esforço político e econômico, que resultou na transferência de dezenas de bilhões de dólares ao Japão e Coréia do Sul (ARRIGHI, 2008); um processo que sustentou a influência norte-americana. Mesmo com o fim da Guerra Fria, os dois países ainda se destacam junto à Austrália, como as maiores âncoras da hegemonia norte-americana em toda a região do Pacífico Asiático (BISLEY, 2007).

O empenho político e financeiro dos Estados Unidos no Leste Asiático e na Europa Ocidental contrasta com a irrelevância da América do Sul em sua política de segurança nacional. Os Estados Unidos, ao atribuir como prioridade estratégica e econômica a reconstrução européia, e obter por meio do Plano Marshall uma forma de saída para seus produtos, relegou toda América Latina a segundo plano (RAPOPORT \& SPIGUEL, 2009). Em março / abril de 1948, durante a Conferência Interamericana em Bogotá, as reclamações latinoamericanas devido a falta de apoio financeiro através de assistência governamental dos Estados Unidos chocou-se com a estratégia de Washington. Em seu discurso em Bogotá, o Secretário de Estado George Marshall alegou que a recuperação européia traria a solução aos problemas dos países latinos americanos (Op. Cit.). A região seria beneficiada pelo Plano Marshall com suas exportações agrícolas ao velho continente financiadas por dólares americanos (Op. Cit.).

Com Truman, houve um distanciamento entre os Estados Unidos e o Cone Sul. Isso se refletiu especialmente nas relações do país com a Argentina, principal economia da região. A industrialização nacionalista de Perón conflitava com os interesses norte-americanos (Op. Cit.). Apesar dos atritos entre os propósitos do governo Truman e a industrialização das principais economias sulamericanas, os Estados Unidos abriram espaço para a exportação agrícola desses

\footnotetext{
14 Deve-se destacar que embora os EUA tenham forçado uma militarização da área com a instalação de bases militares, impuseram ao Japão uma "constituição pacífica". Os desdobramentos dessa imposição ao Japão perduram até o período contemporâneo. A esse respeito, Michael T. Seigel (2007), afirma que, apesar da constituição ter um caráter pacifista, o Japão possui uma das mais poderosas forças armadas do mundo. Em 2004 o seu orçamento militar ultrapassou 49 bilhões de dólares (Op. Cit.). Desde o inicio dos anos 2000, tem sido discutido entre os principais partidos do país a mudança da constituição para permitir o uso de força em questões externas de acordo com alguns princípios. Seigel (Op. Cit.) afirma que a busca pela mudança do Artigo $9^{\circ}$ da Constituição jap onesa ocorre com o aumento do poder militar da China e da Coréia do Norte. Os japoneses partem do pressuposto de que a mudança na constituição, permitindo tanto maior participação nos conflitos internacionais quanto em guerras "preventivas" contra ameaças regionais, como a Coréia do Norte, assegurará a segurança coletiva.
} 
países para a Europa. Segundo Rapoport \& Spiegel (Op. Cit.) a economia americana não seria capaz de prover sozinha a demanda européia por alimentos. A consolidação da supremacia continental dos Estados Unidos com o fim da guerra não exigia mudanças radicais na relação com os países da América Central e da América do Sul.

A essa perspectiva de projeção continental dos Estados Unidos, soma-se outro fator que, embora de natureza essencialmente geográfica, foi primordial para toda política de segurança nacional do país. No alvorecer da Guerra Fria, destacava-se para importantes analistas norte-americanos, uma dimensão geopolítica no conflito que se anunciava com a União Soviética. Fatores como fronteira, população, recursos naturais, posição e dimensão territorial eram elementos norteadores da política de segurança nacional. George Frost Kennan, o mais influente policy maker americano na primeira década da Guerra Fria, foi um dos nomes a defender, já nos anos 1940, uma abordagem de explícito caráter geopolítico.

No que diz respeito à política internacional, o Plano Marshall, como o programa de assistência econômica que direcionou a reconstrução e a recuperação européia, foi diretamente influenciado pelas concepções de Kennan. Diplomata americano em Moscou no início da ordem bipolar, Kennan exerceu influência em toda estratégia norte-americana da Guerra Fria. Isso se deu, sobretudo através de idéias expostas em dois textos: The Long Telegram (1945) e The Source of Soviet Conduct (1947). Crítico da abordagem americana frente a URSS, Kennan foi um dos primeiros analistas a perceber o internacionalismo do projeto comunista, alegando que este não se completaria nos limites do império soviético. Como na política externa norte-americana, havia no projeto da União Soviética uma ambição global.

Dessa forma, os objetivos últimos da política internacional soviética não visavam o equilíbrio de poder e a coexistência entre dois modelos políticoeconômicos. O projeto comunista pressupunha necessariamente a derrocada completa do capitalismo em escala planetária, o que legitimaria a urgência com que as autoridades americanas deveriam conduzir o containment. Numa perspectiva geoestratégica, George Kennan estabeleceu as bases de todo o modo de enfrentamento feito pelos Estados Unidos à ameaça comunista. Embora em seus textos exista uma perspectiva sociológica sofisticada acerca de um modelo 
de enfrentamento ao comunismo soviético, Kennan estabelece um forte apelo geopolítico.

O containment, enquanto definição norteadora da grande estratégia norteamericana durante a Guerra Fria significou diversas frentes, envolvendo meios territoriais, militares, econômicos e culturais para impedir o avanço do comunismo e do império soviético. Ainda que tenha assimilado, de Harry Truman a Ronald Reagan, diferentes roupagens, o seu desenho básico inaugurado por Kennan foi responsável por estabelecer em linhas gerais, a forma geográfica pela qual os norte-americanos ditariam uma política de equilíbrio de poder por todo período da Guerra Fria.

Aos Estados Unidos, caberia proteger principalmente as áreas consideradas vitais para a sua segurança nacional. George Kennan elencava um conjunto vasto de países e regiões, incluindo América do Sul, costa ocidental da África, Mediterrâneo e Oriente Médio. No entanto, defendia a importância da proteção de países que formavam junto com a URSS os cinco centros industriais do mundo.

Além dos Estados Unidos, a Alemanha, Europa Central, Grã-Bretanha e Japão formariam as áreas privilegiadas pelo containment na segunda metade do século XX. Assim, duas regiões seriam economicamente privilegiadas pela estratégia norte-americana: a Europa Ocidental e o Leste Asiático. A América do Sul se tornou ainda mais periférica para os principais interesses dos Estados Unidos. Por uma impossibilidade de extensão planetária do apoio financeiro do país, essa tendência adotada nas administrações Truman e Eisenhower se manteve com novos contornos durantes os governos de John Kennedy, Richard Nixon e Gerald Ford.

A condição periférica sul-americana na Guerra Fria é endógena a própria tradição geopolítica anglo-americana, consolidada desde o final do século XIX, e com vasta influência entre 1945 e 1990. Há mais de cem anos, quando Mackinder publicou The Geographical Pivot of History, iniciava-se uma discussão que ecoaria por todo século XX. As suas principais teses, expostas primeiramente nesse artigo e aprofundadas posteriormente em Democratic Ideals and Reality (1919) exerceram grande influência sobre teóricos da Geopolítica e Relações Internacionais. 
A postura pragmática de Mackinder impõe um "realismo geográfico"15 $\mathrm{com}$ implicações sobre a política externa das grandes potências em diferentes momentos do século XX. Assim como o clássico conceito ratzeliano lebensraum, que antes e durante a Segunda Guerra Mundial destacou-se como pedra angular para o expansionismo de algumas potências européias, a oposição mackinderiana entre poder marítimo e um poder terrestre prevaleceu como poderoso paradigma para a geoestratégia norte-americana durante quase toda a segunda metade do século. Foi Mackinder quem conformou a geopolítica como hoje a conhecemos (CAIRO, 2008, p. 223).

Analistas e homens de Estado que se inspiraram no geógrafo inglês levaram profundamente a sério o conceito de poder terrestre. O próprio Mackinder ao apresentar sua teoria na Royal Geographical Society ${ }^{16}$ pela primeira vez, dois meses antes da publicação na Geographical Journal, o fazia como um alerta aos homens de Estado sobre a possibilidade de emergência de um novo poder capaz de fazer frente à hegemonia das grandes potências ocidentais, mas propriamente aos Estados Unidos e a Inglaterra. De acordo com John Lewis Gaddis (2005b, p.56), no pós-1945, rapidamente se desenvolveu nos Estados Unidos uma linha de raciocínio reminiscente da geopolítica mackinderiana e suas ponderações acerca da ameaça soviética de exercer, a partir do pivô geográfico da história, ${ }^{17}$ domínio

\footnotetext{
15 "O pragmatismo de Mackinder, por ele entendido como realismo, caracteriza-se por uma tentativa permanente de aliar à análise política do equilíbrio de poder do quadro internacional os elementos empíricos (para ele concretos) fornecidos pelos estudos correntes produzidos pela geografia. Dessa associação peculiar, entende o autor, surgiria a geografia política. Por conta disso, critica o que interpreta como ingenuidade ou "limitação da visão nacional e internacional" presentes na elite e cidadãos em geral, que tendiam a pensar nos conflitos mundiais segundo as molduras clássicas dos regimes democráticoliberais, ou seja, a idéia de que a civilização ocidental comportar-se ia mediante regras, aspirações e motivações de certo modo similares para todos. Para Mackinder, este teria sido o equívoco quase fatal para os ingleses e demais "povos livres", que teimavam em não reconhecer a fragilidade do equilíbrio mundial e o avanço de Estados-nações sob regimes "despóticos" dispostos e preparados para a guerra de expansão na Europa e no mundo." Wanderley Messias da Costa, 2008, pp. 77-78.

${ }^{16}$ Ver a respeito Gearóid Ó Tuathail $(1992 ; 1996)$ e sua descrição da Royal Geographical Society como uma instituição que reúne profissionais da Geografia e apoiadores desse campo do conhecimento na Grã-Bretanha. Fundada em 1830, muito antes da institucionalização do ensino da disciplina nas universidades do país, a RGS se caracterizava em principio como um clube de viajantes formado apenas por homens, sendo proibida a entrada e participação de mulheres como membros até 1915. Ó Tuathail defende que a RGS tinha uma lógica imperial, à medida que havia certa relação entre o conhecimento geográfico produzido pelos membros da instituição e o imperialismo britânico. A RGS foi responsável pela campanha para a adoção da Geografia nas universidades e nas escolas britânicas. Em 1884 a instituição produziu um relatório sobre o ensino da disciplina no continente e as implicações para o Império Britânico. O relatório foi lançado em 1886, tornando-se base para a campanha da entidade.

17 O pivô geográfico foi definido por Mackinder em duas oportunidades principais: primeiro em The Geographical Pivot of History (1904) e posteriormente em Democratic Ideals and Reality (1919). Em linhas gerais, caracteriza-se como um vasto sistema de bacias hidrográficas, planícies, pântanos e estepes. A maior parte do solo, por caracterizar-se como uma grande estepe, manteve uma esparsa, mas considerável população de nômades que se movimentavam por meio do cavalo ou do camelo. Essa área possui em torno de 21.000.000 de quilômetros quadrados e foi, segundo Mackinder, a grande responsável pela coesão política na Europa durante a Idade Média. O continente europeu era acossado ao norte pelas levas de bárbaros escandinavos e à leste por hordas de mongóis e nômades que ameaçavam o mundo cristão. As cruzadas foram um movimento de coesão continental na Europa, diminuindo as grandes guerras internas e ao mesmo tempo permitindo uma autoridade católica sobre o continente. O Império Mongol ameaçava a oeste o continente europeu, e ao sul países como a China e a Índia. Mackinder afirma que a revolução da navegação e a descoberta da passagem de Boa Esperança permitiram que os povos europeus avançassem sobre regiões ao redor do continente asiático, enfraquecendo os povos do pivô geográfico. Os navios europeus alcançam as bordas da Eurásia, fazendo uma grande oposição entre as civilizações do camelo e cavalo com a dos navios. A constituição de bases insulares do "anel exterior" formado por Japão, América do Norte, África do Sul, Austrália forma o alicerce da civilização européia fora do velho continente sem a sombra representada pela ameaça das
} 
sobre toda a massa continental euroasiática territorialmente monopolizada pela Rússia.

Mackinder procurava uma fórmula que expressasse aspectos da causa geográfica na história universal (VENIER, 2004, pp.330-336). O "Pivô Geográfico da História" pode ser entendido também como uma reflexão provocativa em política internacional que visava demonstrar a relevância estratégica da Geografia na condução de políticas estatais (statecraft) internacionais (Op. Cit.). Na Era Eduardiana, Mackinder buscava prever as possíveis ameaças futuras ao Império Britânico (Op. Cit.). A principal delas era considerada o poder terrestre, que por meio da expansão das estradas de ferro russas dava "coesão" territorial a grande massa continental. A ascensão da Rússia na era pós-colombiana (desencadeada com o fim do ciclo das grandes descobertas) ameaçava a efetividade do poder marítimo da Grã-Bretanha e a civilização ocidental como um todo (WALTON, 2005, pp. 223-235).

A partir da década de 1940, Nicholas Spykman, holandês radicado nos Estados Unidos, cientista político e professor da Universidade de Yale, destaca-se com a proposição do conceito de rimland, uma espécie de oposto complementar ao heartland. ${ }^{18}$ Toda a região que abrange o rimland se tornou central ao containment. Havia dois modelos de definição desse espaço (GADDIS, 2005b). O primeiro, defendido pela Doutrina Truman e pelo artigo " $X$ " de Kennan, afirmava que os Estados Unidos deveriam considerar toda área de igual importância. Mas, logo após a publicação do artigo de Kennan, já se desenvolvia outra linha que advogava a defesa de regiões específicas do rimland, denominadas de strongpoints. Acabou prevalecendo essa segunda concepção, pois os Estados Unidos não possuíam recursos para apoiar cada um dos países da Ásia contra o comunismo.

\footnotetext{
"civilizações bárbaras". O geógrafo afirma ainda que o mesmo século que vê a consolidação do mundo conquistado pelos europeus assiste a unificação territorial efetuada com grande sucesso pela Rússia. A construção de estradas de ferro no século XIX substitui os cavalos e os camelos e faz com que, de Moscou a Sibéria, todo o território seja controlado por um Estado central.

18 "Tendo como base o modelo de Mackinder, Spykman minimiza o interesse no controle do coração continental. Para ele o anel continental (Rimland) é a área chave - que corresponde, grosso modo, ao cinturão interior de Mackinder -, cujo controle permitiria um domínio global do planeta [...]. Uma tarefa da potência marítima seria, portanto, o controle de um anel continental euroasiático unificado. A potência marítima, nas proximidades da Segunda Guerra Mundial, já não era mais a Grã-Bretanha. Assim, quanto Spykman (1944) defendia a intervenção dos Estados Unidos nas terras periféricas da Eurásia, ele está afirmando claramente que se produziu uma transição geopolítica - ou se está produzindo. E o que ocorre com a América Latina, no modelo de Spykman? A região não está nesse anel continental, e, portanto, não é peça fundamental da estratégia de domínio global do autor. Isso se reflete na escassa atenção que Spykman presta a América Latina." Heriberto Cairo, 2008, p. 225.
} 
Portanto, se para a linha reminiscente da geopolítica mackinderiana o containment era necessariamente global $^{19}$, em principio o esforço anticomunista americano guiou-se pelos strongpoints definidos pelos centros industriais e militares destacados por Kennan. Se a América do Sul fora considerada pelo presidente John Kennedy como a área mais sensível e perigosa no mundo para o avanço dos ideais comunistas no início dos anos 1960 (MONIZ BANDEIRA, 2006), as iniciativas americanas à região eram irrelevantes nos primeiros anos da Guerra Fria.

Durante os governos de Truman e Eisenhower, o lugar do continente no containment americano não estava além da condição de região mais distante do centro estratégico do mundo, como esboçado pelos mapas de Mackinder. Mais do que estar geograficamente distante dos primeiros movimentos soviéticos de expansão geopolítica, nenhum dos países da região se caracterizava como centro industrial ou militar de relevância. Além de ser um espaço político de pouca importância no plano internacional, a América do Sul caracterizava-se como palco de disputas entre os Estados Unidos e a Inglaterra. Até a eclosão da Revolução Cubana a partir de 1959 e da crise dos mísseis em 1962, o continente despertava pouco interesse não apenas para a geoestratégia, mas para todo o conjunto das políticas americanas. A América do Sul começa adquirir maior relevância como área chave na Guerra Fria no momento em que a União Soviética rompe o cinturão euroasiático, cerne do containment empreendido pela administração Eisenhower.

A observação de George Kennan acerca das limitações da dissuasão militar como meio de containment se mostraram precisas. Em regiões do Terceiro Mundo, como na América Latina, os movimentos revolucionários foram um meio eficaz de expansão do comunismo, sem envolver necessariamente desgaste político e militar da URSS. Esses movimentos desnudaram problemas estruturais

\footnotetext{
${ }^{19}$ Mackinder se destaca entre os primeiros analistas da política internacional que perceberam a radical mudança entre o final do século XIX e início do século XX. A dinâmica da política internacional deixa de ter um caráter apenas regional para alcançar projeções de fato, mundiais. Além de toda perspicácia no levantamento da conjuntura regional euro-asiática, alguns aspectos da teoria do geógrafo inglês passam praticamente ignorados por muitos dos comentadores de sua obra. Mackinder chama a atenção no início do texto para uma nova condição geográfica da humanidade, tão relevante a ponto de mudar toda a dinâmica das relações políticas entre as nações e colocar o mundo em outra condição. Dentro do contexto onde o Império Britânico era planetário, não chega a causar estranheza, embora inovador para a época, o fato de Mackinder transcender o continente europeu, palco privilegiado da política internacional, e propor uma teoria a partir de uma unidade mundo. A unidade geopolítica planetária, que apareceria no contexto das geopolíticas ideológicas da Guerra Fria como efeito dominó ou como grande chessboard, possui na visão geográfica de Mackinder a condição de um organismo político e econômico mundial, onde um acontecimento em um dado lugar poderia ecoar em todo o globo, metaforizado por ele como a estrutura fechada de um grande edifício ou navio. O espaço mundial com todas as suas escalas, já aparece em sua obra como um sistema político fechado e interdependente.
} 
da grande estratégia norte-americana, criticada pela excessiva dependência da dissuasão nuclear e retaliação massiva durante o governo Eisenhower (GADDIS, 2005b, p. 174).

$\mathrm{Na}$ tentativa de sobrepujar a URSS, esse modelo estratégico se caracterizou pela dissuasão nuclear em regiões adjacentes ao império comunista. ${ }^{20}$ Um segundo problema do containment centrado na Europa e na Ásia, como exemplifica a vertente posta em prática pelo governo Eisenhower, era a incapacidade de resposta aos movimentos revolucionários no Terceiro Mundo (Op. Cit.).

Conforme se concentrava economicamente na Europa Ocidental e alguns países do Leste Asiático, e com a falência do modelo de dissuasão militar do governo Eisenhower, a hegemonia norte-americana foi ameaçada pelo avanço do comunismo em diversos continentes. Apesar da incapacidade de impedir o avanço de movimentos comunistas em países do Terceiro Mundo, deve-se reconhecer que Eisenhower e Dulles foram responsáveis por implementar em diversos países uma forma de contraposição a esse regime político. Além de não confrontar a concepção do presidente sobre a ação dos Estados Unidos em outros países, o método de financiamento de forças locais se tornava economicamente mais viável (Op. Cit.).

Kennan $(1945 ; 1947)$ foi o primeiro a alertar que o comunismo soviético agia não apenas militarmente, mas principalmente por meios econômicos, sociais e institucionais. O internacionalismo soviético tentava romper o que entendia como encirclement exercido pelos países capitalistas. Como defendia Kennan, o cercamento funcionava não apenas como meio de legitimação do expansionismo soviético, mas também do próprio totalitarismo aplicado domesticamente pela URSS.

Os países economicamente periféricos ao containment tornaram-se os principais objetivos do comunismo. Em áreas do chamado Terceiro Mundo havia largas possibilidades de expansão do comunismo. Contrariando os preceitos do equilíbrio de poder e suas alianças políticas e militares, havia um universalismo no

\footnotetext{
${ }^{20}$ Segundo Gaddis (2005b), o poder nuclear ganha uma função central na política anticomunista de Eisenhower e John Foster Dulles, seu secretário de Estado. A política externa passou a defender a força nuclear como um meio que permitisse simultaneamente a ampliação do poder norte-americano e a contenção dos gastos. No containment levado a cabo por Truman, o orçamento militar teve um crescimento vertiginoso devido à utilização maciça dos meios militares tradicionais. Eisenhower e Dulles buscavam a construção de um poderoso meio de retaliação que não implicava necessariamente a ampliação maciça dos gastos. Buscavam meios de alcançar máxima proteção com custos toleráveis. Dulles faz um discurso em 1954 no Council of Foreign Relations, explicitando as diferenças com a administração Truman e os novos aspectos da política de segurança nacional.
} 


\author{
comunismo soviético tão radical quanto no idealismo americano. ${ }^{21}$ Para uma \\ análise geopolítica da América do Sul na Ordem Geopolítica da Guerra Fria, faz-se \\ necessário descrever as principais forças na sua relação com o Brasil e o cenário \\ internacional.
}

\footnotetext{
${ }^{21}$ Segundo Gaddis (2005b) George Kennan acreditava na predominância de duas tendências na política externa norteamericana: universalista e particularista. A universalista, na tradição americana, é herdeira tanto da concepção wilsoniana de sistema internacional institucionalmente ordenado, quanto da perspectiva de One-World expresso no internacionalismo de Roosevelt. A Liga das Nações (e posteriormente a ONU) faz parte dessa tendência como instituições cuja função basilar é introduzir harmonia no sistema internacional. Kennan não considerava o universalismo adequado aos Estados Unidos, pois entendia que o mundo era uma diversidade, não cabendo aos americanos moldá-la a sua imagem e semelhança. Nesse sentido, a postura particularista se fundamenta no fato de que a sede de poder ainda é o aspecto dominante em política internacional, não podendo ser contida, exceto por contraposição, negando, portanto a possibilidade de existência de uma ordem legalmente e institucionalmente constituída. Essa ordem apenas pode existir baseada em um pequeno grupo de países e não em um formalismo abstrato de uma lei universal internacional ou organização mundial. Kennan considerava o particularismo, a opcão adequada aos Estados Unidos, pois acreditava que o universalismo levaria os americanos a um compromisso que não considerava viável, isto é, a eliminação do conflito armado da vida internacional. Portanto, Kennan não acreditava em harmonia, mas em um delicado equilíbrio de poder para garantir a segurança de um Estado (ou grupo de Estados) no sistema internacional.
} 


\title{
Concepções Sobre a Projeção Internacional do Brasil
}

\author{
The axis of history begins in Moscow, \\ goes to Bonn, crosses over to \\ Washington, and then goes on to Tokyo. \\ What occurs in the southern world is not \\ important. It is not worth the time. \\ Henry Kissinger
}

\subsection{Ascensão Regional do Brasil}

Em sua história de conflitos, da descolonização até o final dos anos 1980, não surgiu no interior da América do Sul nenhuma força geopolítica capaz de exercer dominação ou hegemonia sobre seus vizinhos. Ainda assim, a rápida emergência do Brasil como uma potência regional entre 1964 e 1985, faz com que o entendimento da condição do continente na Ordem Geopolítica da Guerra Fria passe pela relação entre o país e os Estados Unidos. O Golpe Militar de 1964 causou uma transformação profunda na concepção de projeção internacional do Brasil.

Isso permite caracterizar a política externa brasileira em dois momentos nessa ordem geopolítica. No primeiro, de 1945 a 1964, a política internacional do país estava estruturada essencialmente a partir de um posicionamento panamericanista. Nesse contexto, tanto o continente americano quanto a escala sulamericana se destacavam como áreas privilegiadas de atuação. O segundo momento, de 1964 a 1985, embora sofra variações no que se refere ao alinhamento aos Estados Unidos, foi marcado por um pragmatismo político onde 
os "interesses nacionais" são as principais forças norteadoras da política internacional.

No ano de 1966, durante o governo de Castelo Branco, o Brasil abandona a doutrina de fronteiras ideológicas depois da grande repercussão negativa do envio de tropas para auxiliar dos Estados Unidos na ocupação da república dominicana (MONIZ BANDEIRA, 1992). Em 1974, o governo Geisel reforça a postura pragmática e abandona o alinhamento automático com os Estados Unidos (Op. Cit.). Embora mantenha o discurso panamericanista, predomina uma forte concepção de projeção continental, buscando firmar o país com principal potência sul-americana. Rompe-se com a política de inspiração regionalista fundada na cooperação e inaugura-se o realismo geográfico, onde políticas territoriais fundadas no espaço nacional estão na base da expansão do poder em escala continental.

A projeção continental do Brasil, fator fundamental para as novas concepções acerca de sua ascensão internacional, relaciona-se com transformações da economia geopolítica internacional. Estas transformações são impulsionadas pelos interesses das redes de produção e distribuição das empresas e por fatores relacionados às redes de poder das grandes potências mundiais. Num contexto de aproximação entre os interesses dos Estados Unidos e de suas principais corporações, destaca-se a desconcentração da produção industrial.

Esse fator ganha destaque nas décadas de 1960 e 1970, sendo esta última marcada por um crescimento industrial em regiões periféricas da economia mundial. Apesar da crise econômica da década de 1970, alguns fatores sustentaram o crescimento de regiões periféricas, transformando-as em semiperiferias da economia-mundo, subordinadas à hegemonia norte-americana (BECKER \& EGLER, 1992). Conforme demonstra Arrighi (2008), no sistema monetário estabelecido em Bretton Woods, os Estados Unidos alcançaram 0 monopólio (virtual) da liquidez mundial, pelo montante de ouro de suas reservas internacionais e pela procura crescente por dólares. ${ }^{22}$ A partir de então, o país se

\footnotetext{
22 Arrighi (Op. Cit., p.287) defende que esse sistema monetário fora mais que um conjunto técnico visando estabilizar a paridade entre moedas nacionais selecionadas e ancorar o conjunto dessa paridade aos custos de produção, via padrão de troca entre o dólar americano e o ouro. Se fosse apenas isso, o novo sistema monetário teria apenas restaurado o padrão ouro do final do século XIX e início do século XX, com o Dólar e o FED substituindo a libra e o Banco da Inglaterra. No sistema monetário estabelecido em Bretton Woods, a "produção" do dinheiro mundial era controlada por uma rede de organizações governamentais, motivadas por considerações de bem-estar, segurança e poder. O dinheiro mundial se tornou um produto das atividades estatais.
} 
tornava a principal fonte de expansão do capital nas periferias da economia mundial.

Com o caminho estabelecido pelo Plano Marshall, essa expansão destacou-se como um dos sustentáculos do containment americano em escala global. A partir do governo de Juscelino Kubitschek, o Brasil tornou-se o principal destino sul-americano do capital proveniente dos Estados Unidos e da Europa Ocidental. O país destaca-se como modelo do papel exercido pelas grandes corporações multinacionais no suporte a hegemonia norte-americana em áreas periféricas. ${ }^{23}$ Enquanto o "keynesianismo militar" foi responsável pela injeção de liquidez na economia mundial entre 1950 e 1973, a desconcentração industrial ampliou os limites geográficos da economia mundial nas décadas seguintes. ${ }^{24} \mathrm{O}$ crédito oferecido por bancos europeus e americanos, associado à desconcentração industrial impôs um novo marco na expansão do capitalismo mundial. $^{25}$

A esse respeito, Saskia Sassen (2001) analisa as economias dos países do Primeiro Mundo, transformadas com a emigração de indústrias para regiões pobres. Nas economias centrais, as atividades econômicas tornaram-se mais centradas no setor terciário, enquanto que regiões periféricas se industrializaram velozmente. As flutuações no valo do dólar a partir de 1971 foram fundamentais

\footnotetext{
${ }^{23}$ Arrighi (2008, pp. 250-251) define as corporações transnacionais que emergem no final do século XIX e início do século XX como business organizations que se especializavam numa linha de negócios em múltiplos territórios e jurisdições. Se comparadas as Joint Stock Chartered Companies holandesas e britânicas, as grandes corporações transnacionais americanas, além de serem muito maiores, têm solapado progressivamente a centralidade do sistema interestatal como lócus principal do poder mundial.

${ }^{24}$ Arrighi (Op. Cit.) associa a "Era de Ouro" do capitalismo, entre a Guerra da Coréia e o Acordo de Paz de Paris - que virtualmente pôs fim a Guerra do Vietnã - com os investimentos militares americanos. Dean Acheson, Secretário de Estado na Administração Truman, afirmou que o início da Guerra da Coréia os salvara. Esse conflito permitiu aos Estados Unidos resolverem o problema mundial de liquidez. O discurso anticomunista de Truman convenceu o Congresso Americano sobre a necessidade de ampliar o orçamento militar do país. Segundo Arrighi (Op. Cit. pp. 306-307) o suporte militar aos países aliados e os gastos militares diretos no exterior, ao crescerem muito nos períodos entre 1950-1958 e 1964-1973, proporcionaram à economia mundial a liquidez necessária a sua expansão. Mais que isso, o cume da hegemonia norte-americana, diferentemente da britânica, se deu por um controle do mercado. Houve nesse processo, uma substituição do mercado como a base da expansão do capitalismo. Em outras palavras, na "Era de Ouro", houve um controle do mercado por meio da regulação do sistema monetário internacional, ao mesmo tempo em que o Estado, ao alavancar os investimentos militares, era o indutor da liquidez mundial.

${ }_{25}$ A esse respeito ver Arrighi (Op. Cit.), que apresenta uma investigação detalhada sobre a influência do mercado de Eurodólares para a quebra do Sistema de Bretton Woods. O autor analisa a importância do Eurodólar na "independência" do mercado no mecanismo interbancário de produção de dinheiro, e o enfraquecimento do Estado no que tange ao comando do sistema financeiro internacional. Arrighi lembra que o mercado de Eurodólares formara-se no final dos anos 1950 e início dos anos 1960 a partir de necessidades financeiras dos países comunistas. Para financiar suas relações comerciais com as nações ocidentais, esses países necessitavam de reservas em dólares. Porém, estas reservas eram depositadas em Londres para fugir do risco de congelamento caso fossem colocadas em bancos americanos. O fato de as grandes corporações americanas passarem a investir em Eurodólares - para fugir das taxações financeiras impostas as movimentações dentro dos Estados Unidos - permitiu que esse mercado experimentasse um crescimento incontrolável, se tornando nos final da década de 1960 a maior fonte de moeda do mundo. A crise do petróleo só faz agudizar essa realidade. Os excedentes proporcionados pela alta dessa commodity, ao serem depositados no mercado de Eurodólares, vão baratear e ampliar ainda mais a oferta da moeda americana. Quando a incapacidade do Banco Central Americano (FED) de preservar o modo de produção e regulação do dinheiro mundial leva a quebra do sistema de Bretton Woods, o dólar barato no mercado internacional adquire um papel muito importante para os países pobres. A moeda americana passa a ser utilizada por muitos países do Terceiro Mundo para equilibrar suas finanças que estavam ameaçadas pelas flutuações cambiais impostas pelo novo sistema monetário internacional.
} 
para que muitas transnacionais americanas, visando conter os custos trazidos pela variação cambial, instalassem-se em mercados do Terceiro Mundo (ARRIGHI, 2008). Assim como o containment dos Estados Unidos, os interesses corporativos foram um dos maiores pilares da transformação da economia geopolítica internacional.

O Brasil se torna favorecido por esse contexto. Os anos 1970 significaram para a Argentina e o Chile um período de desaceleração no crescimento econômico. Segundo dados do Banco Mundial (2010), os dois países, cuja economia se expandiu numa média de $4,5 \%$ na década de 1960 , experimentam respectivamente um crescimento de $3 \%$ e a $2,2 \%$ anos 1970 . O Brasil, por outro lado, tem uma média de crescimento de $6,0 \%$ na década de 1960 , e de $8,6 \%$ na seguinte. Em 1965 o PIB argentino de US\$29,0 bilhões correspondia a 35,5\% do sul-americano. Em 1970 essa fatia cai para 26,8\% e em 1980 para somente 16,0\%. O PIB brasileiro, que correspondia respectivamente a $26,6 \%$ e $36,8 \%$ em 1965 e 1970, passa a representar $47,7 \%$ do PIB sul-americano de US\$ 476,3 bilhões em 1980. Como evidencia a curva do Gráfico 1, do início da década de 1960 até o final da de 1970, o Brasil se torna rapidamente a maior economia do continente.

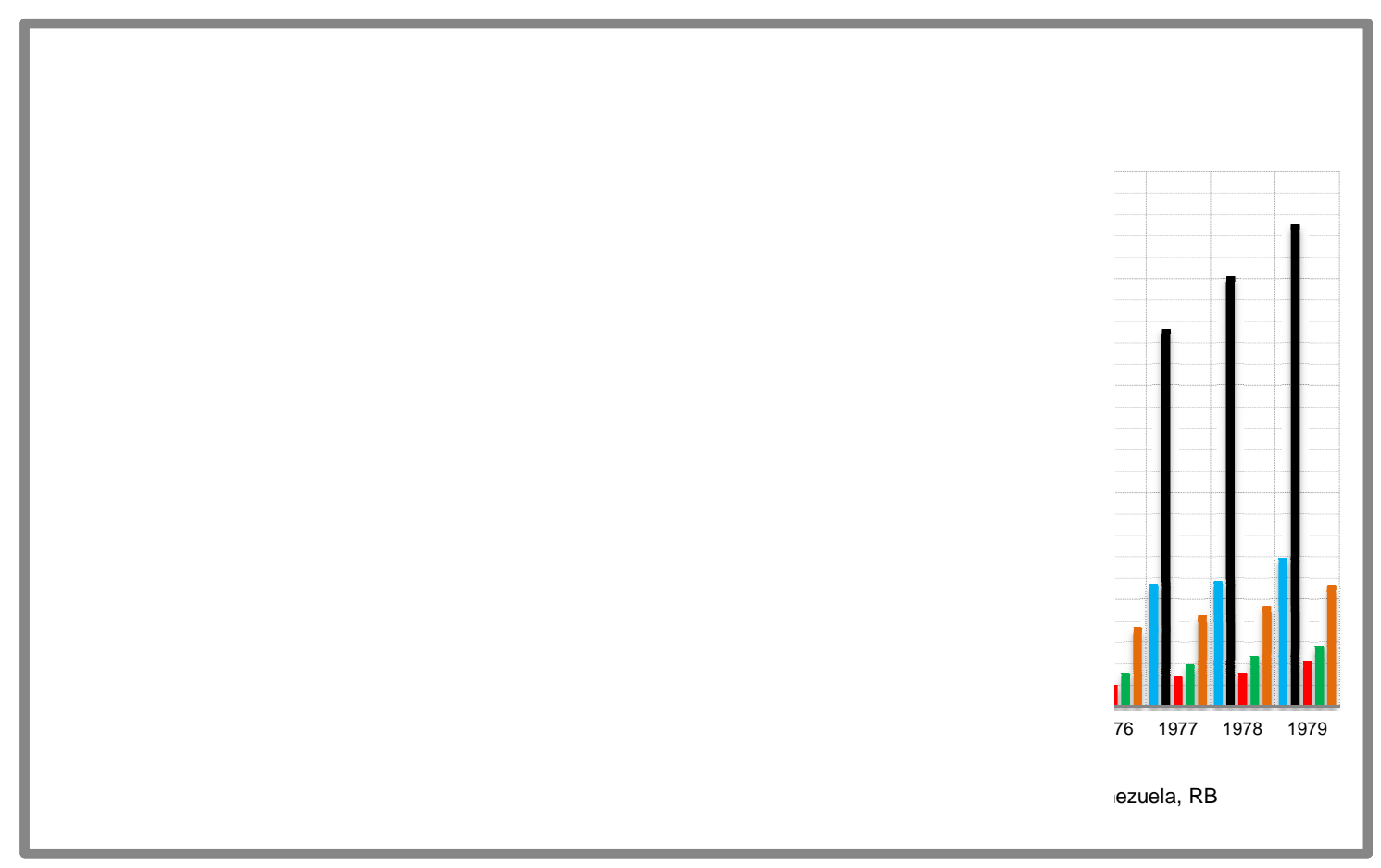


Portanto, entre o início da década de 1960 e o final da de 1970, há uma confluência de forças externas e internas que fazem com que o Brasil se torne um país chave ao containment conduzido pelos Estados Unidos. A economia geopolítica internacional está imbricada em um contexto geoestratégico mais complexo. Com os militares no governo, o Estado passou a articular explicitamente a modernização que envolvia a indústria, a ciência e a tecnologia, à geopolítica territorialista. Ancorado em questões geográficas tradicionais, passou a predominar a crença de que o Brasil se tornaria inevitavelmente uma potência mundial. Essa geopolítica coincidiu com uma grande transformação geoestratégica global.

Com a Revolução Cubana, a América Latina ganha um papel mais relevante na política de segurança nacional dos Estados Unidos. Enquanto nas administrações de Harry Truman e Dwight Eisenhower esta política privilegiava fundamentalmente a Europa e o Pacífico Asiático, a partir do governo John Kennedy se destaca a ampliação da geoestratégia anticomunista. ${ }^{26}$ Com a administração Kennedy, a flexibilização do containment (GADDIS, 2005b) caracteriza-se como a sua renovação frente os desafios postos pela expansão geográfica do comunismo e a superação da barreira nuclear ao redor da União Soviética imposta por Eisenhower. Na esteira do pan-americanismo, o Brasil toma a dianteira no processo de reinserção da América do Sul nos interesses americanos.

\subsection{O Containment e o Territorialismo Sul-Americano}

$\mathrm{Na}$ Ordem Geopolítica da Guerra Fria, o primeiro modelo de transformação da política regional foi a Operação Pan-Americana (OPA) proposta por Juscelino Kubistchek em 1958, portanto antes mesmo do início da revolução

\footnotetext{
${ }^{26}$ Mesmo com a relevância de outras regiões, o core do containment ao comunismo permanece nas áreas estabelecidas por George Kennan, pelo National Security Concil (NSC) e pelo Plano Marshall. Durante a administração Reagan há um retorno a uma postura mais inflexível da política externa dos Estados Unidos em relação ao bloco comunista. Ronald Reagan promoveu esse retorno (que muitos analistas chamaram de Segunda Guerra Fria) a partir da crença de que as necessidades de contenção ao comunismo soviético havia pouco mudado em mais de quarenta anos. Num relatório, ao congresso americano (e publicado posteriormente em 1988), o então presidente defende que os fatos da geografia são permanentes. Retomando a tese mackinderiana, assegura que os interesses norte-americanos estariam em risco se um Estado (ou grupo de Estados inimigos) dominasse o hertland formado pela massa terrestre euroasiática. Segundo Reagan, todas as administrações americanas precedentes endossaram o conceito de que os Estados Unidos e seus aliados deveriam impedir a União Soviética de dominar as grandes concentrações de poder industrial e a capacidade humana na Europa Ocidental e no Leste Asiático. Portanto, Reagan promove - sustentado por um discurso anticomunista extremamente agressivo - o retorno às teses de Mackinder e Kennan.
} 
cubana. A OPA pode ser definida como uma proposta de flexibilização do combate ao comunismo, à medida que o seu princípio reside na concepção de que toda América Latina não estaria segura perante a ameaça comunista enquanto não fossem resolvidas os graves problemas sociais. Grosso modo, a OPA fora uma forma de reivindicar maior participação da região nos recursos financeiros dos Estados Unidos que eram direcionados quase que exclusivamente para a Europa e Sudeste Asiático. Essa forma de enfrentamento ao comunismo soviético se tornou, de certa maneira, consenso até mesmo nos Estados Unidos. A Aliança Para o Progresso inaugurada por John Kennedy no início da década de 1960 injetou 20 bilhões de dólares num período de 10 anos em toda América Latina (GADDIS, 2005b, p. 223), tornando-se poderoso meio de descentralização e flexibilização do containment. ${ }^{27}$

A intenção de Kubistchek de asseverar a unidade pan-americana como um meio de desenvolvimento econômico não foi somente manifestação de sincronia política com os Estados Unidos. Para além dessa manifestação de proximidade, a OPA inaugura durante a Guerra Fria um modelo americano de hegemonia na América do Sul que perduraria por décadas. Segundo Moniz Bandeira (2006) a América do Sul era tida por Kennedy como a área mais perigosa do mundo em relação ao avanço do comunismo. Num contexto de crescimento da esquerda no Cone Sul, os Estados Unidos adotaram um perigoso pragmatismo político.

A militarização da política na América do Sul, embora tenha se tornado o meio mais eficiente de containment, contrastava com a defesa democrática dos Estados Unidos a partir da Segunda Guerra Mundial. Ironicamente, o universalismo em nome da democracia presente na política externa norteamericana, levou o país a mergulhar num intenso realismo onde a autocracia foi aceita e legitimada em várias regiões do globo. Entre as décadas de 1960 e 1970, a América do Sul, que se tornou terreno fértil para a implantação dessa política externa de base realista, torna-se uma "síntese" da Guerra Fria. Por um lado, com o alinhamento automático aos Estados Unidos, destaca-se na condição de área de expansão do capitalismo internacional. Por outro, caracteriza-se também como

\footnotetext{
27 "Kennedy, havia muito tempo, entendia que o avanço da União Soviética e da China não se processaria por meio de ação bélica convencional, ou nuclear, mas através da guerra de guerrilha e que por mais poderoso que fosse o poderio estratégico dos Estados Unidos ele poderia ser corroído "by forces of subversion, infiltration, intimidation, indirect or non-overt aggression, internal revolution, diplomatic blackmail, guerrilla warfare", ameaças que, finalmente, só poderiam ser superadas por meio da reforma social e política, capacitando as vítimas em potencial a se defenderem." Luiz Alberto Moniz Bandeira, 2005, p. 250.
} 
uma região de forte resistência ao capitalismo conduzido pela modernização conservadora, ${ }^{28}$ com a proliferação de guerrilhas e movimentos de insurgência esquerdistas. A América do Sul, como continente bastante suscetível ao avanço do comunismo soviético, virou ao avesso a geopolítica mackinderiana implícita no containment.

Deve-se considerar que na ordem geopolítica da Guerra Fria, os golpes militares que derrubaram grande parte dos governos na América Latina não derivaram apenas no alinhamento automático com os Estados Unidos. Ao mesmo tempo em que os Estados Unidos consolidaram sua hegemonia na América Latina, houve uma reorganização das relações interestatais, principalmente entre os países sul-americanos. Aqui, a militarização da política não desemboca apenas em um modelo de relação entre seus países. Resultou num novo paradigma de política internacional, marcado pelo pragmatismo nacionalista, que em muitos casos era discrepante dos interesses norte-americanos na região e no mundo. No contexto regional, o esforço de aproximação política dá lugar ao expansionismo e ao retorno do equilíbrio de poder como principio da política interestatal (KELLY, 1997).

Logo após a Segunda Guerra, a tendência de diálogo visando à cooperação com as primeiras aproximações entre Brasil e Argentina durante os governos Juan Perón e Getúlio Vargas, foi um meio de fortalecimento regional que passava pelo rompimento dos conflitos territoriais vigentes desde a descolonização. Com os governos militares, essa tendência de aproximação política que prevalece até a década de 1960, abre espaço para a velha geopolítica, carregada de realismo e de uma visão territorialista de poder em política internacional.

Esse entendimento, assentado nos fatores geográficos, estará presente em praticamente todos os países sul-americanos. Questões fronteiriças e territoriais, fatores tão caros a política em todo continente entre o século XIX e as primeiras décadas do século $X X$, ganham novos contornos e adquirem grande

\footnotetext{
${ }^{28}$ Becker \& Egler (1992, p. 78) definem modernização conservadora como via de desenvolvimento e industrialização que teve inicio no primeiro Governo Vargas, e que se estende por outros períodos da história brasileira, como durante o regime militar. $\mathrm{Na}$ modernização conservadora, o governo controla a política e o planejamento econômico por meio do intervencionismo, sem prejuízo do poder dos grupos dominantes tradicionais. O Estado avança na modernização dos meios de produção em todo território nacional, sem, entretanto desafiar a estrutura de poder vigente, bem como as causas da pobreza, da concentração de renda e dos diversos problemas sociais. O regime militar é um clássico exemplo de modernização conservadora, fazendo avançar de maneira muito veloz (e sob o planejamento estatal) os diversos setores da economia. Entretanto, sob o mesmo regime, ampliou-se a concentração de renda, o latifúndio, a miséria nas grandes metrópoles, a diminuição do valor real dos salários etc.
} 
força balizadora nas relações políticas. A despeito de todo o empenho desde a década de 1940 para romper com as rivalidades fronteiriças que caracterizavam relações interestatais, o territorialismo emerge, durante os governos militares entre as décadas de 1960 e 1980, como a principal força política na América do Sul. ${ }^{29}$ Especialmente entre os países do Cone Sul nas décadas de predomínio das ditaduras militares, as prioridades da política internacional pautavam-se pelo expansionismo.

Assim como nas grandes potências da Ordem Geopolítica da Rivalidade Inter-Imperial, o territorialismo sul-americano destacava-se por seu discurso cientificista, presente primeiramente nos clássicos fundadores do pensamento geopolítico, como Friedrich Ratzel $(1987 ; 1990)^{30}$ e Halford J. Mackinder (1887; 1935). ${ }^{31}$ Para compreender a tendência geopolítica majoritária na América do Sul, - principalmente em sua porção meridional - torna-se fundamental atentar para um dos preceitos fundamentais da geopolítica clássica inaugurados por Mackinder. ${ }^{32}$

\footnotetext{
29 Giovanni Arrighi (2008) faz uma diferenciação entre dois paradigmas de projeção de poder em política internacional, bastante útil para a compreensão do que implicou em termos de política regional a ascensão de regimes militares na América do Sul. Arrighi destaca dois modelos opostos na busca pela primazia entre as grandes potências: territorialismo e capitalismo. Segundo Arrighi (Op. Cit. p. 23) no modelo territorialista, o controle sobre o território e a população é o grande objetivo para a ampliação do poder, enquanto que o domínio sobre o capital móvel destaca-se apenas como meio para alcançar esse fim. No modelo capitalista, ao contrário, o controle sobre o capital móvel destaca-se como o objetivo final enquanto que o controle sobre o território e população, o meio. Numa perspectiva distinta, o historiador Paul Kennedy (1989) destaca o aspecto territorial como o centro da ascensão e queda das grandes potências nos diversos continentes. Arrighi lembra que desde a Holanda, passando pela França, Inglaterra e Estados Unidos, há sempre uma síntese entre as lógicas capitalista e territorialista. Em The Great Transformation (2001), Karl Polanyi afirma que a Alemanha foi extremamente territorialista, mas pelo fato de ter chegado tarde, necessitando como a Inglaterra, de territórios para ampliar o seu capitalismo. Tão importante quanto isso, devemos levar em consideração que os Estados Unidos, embora não fossem colonialistas, foram extremamente territorialistas para dentro, visando assegurar a expansão do território nacional. Para Giovanni Arrighi (2008, p. 60), os americanos produziram uma perfeita harmonia entre territorialismo e capitalismo. Assim como no caso inglês, a expansão comercial mundial americana não se sustentaria sem uma vasta base territorial interna, e o controle de um sistema planetário de circulação territorial. Cabe ressaltar que uma parte significativa desse territorialismo era composta por aquilo que Alfred Mahan, em The Influence of Sea Power Upon History, 1660-1783 (1987) denominara de poder marítimo, isto é, um poder comercial e político assentado no poder naval e no domínio de rotas comerciais oceânicas, estreitos de passagem, áreas estratégicas etc.

30 Para não confundir o contexto de publicação do texto e o contexto de surgimento da teoria do autor, faz-se necessário algumas observações sobre as edições das obras de Friedrich Ratzel que servem de base para a análise. Diferentemente de Halford J. Mackinder, que tivemos acesso completo as versões originais de seus principais textos, as obras Friedrich Ratzel aqui referidas são uma edição em língua francesa e outra em língua portuguesa. A edição de La Géographie Politique: les concepts fondamentaus (1987) consiste numa tradução resumida de Politische Geographie, obra publicada originalmente pelo geógrafo alemão em 1897. Ratzel (1990) trata-se de uma coletânea de textos, que abarcam os principais temas tratados pelo geógrafo alemão.

${ }^{31}$ Não seria exagero afirmar que essa idéia de ciência como verdade norteadora, estava distante do radicalismo anticomunista que predominou na geopolítica, da década de 1940 em diante. Como defende em On the Scope and Methods of Geography (1887), a velha geografia - praticada em forma de enciclopédia e compêndios acerca dos lugares, muito comum na Inglaterra até a segunda metade do século XIX - era irracional, pois não buscava traçar relações causais. Muito menos ambiciosa, se contentava em proporcionar um conjunto de dados isolados. Os primeiros escritos de Mackinder, como o texto supracitado, foram menos conhecidos que o artigo da Geographical Journal. E o tema principal era justamente o método da ciência geográfica.

32 No empenho pela adoção do ensino de Geografia nas universidades e escolas britânicas, em suas palestras na Royal Geographical Society, e em seus artigos publicados em importantes revistas acadêmicas, Mackinder criou um poderoso arcabouço geopolítico. O discurso geopolítico de Mackinder é bastante amplo, envolvendo desde o sistema educacional até a política internacional. Havia, por exemplo, uma geopolítica explícita em sua defesa pela adoção da geografia como disciplina escolar e universitária. Esta linha analítica se encontra presente em artigos como Geography as a Pivotal Subject in Education (1921) e Progress of Geography in the Field and in the Study During the Reign of his Majesty King George The Fifth (1935). Mackinder entendia que a adoção da Geografia pelo sistema educacional britânico seria a base de uma nova compreensão do mundo a partir da "visualização" do espaço em escala planetária, derivando numa elite mais bem preparada para a expansão
} 
Para Mackinder, a projeção de poder em escala internacional depende da capacidade de visualização do espaço mundial (Ó TUATHAIL, 1996). O poder do Estado está estreitamente relacionado a um entendimento sobre a organização geográfica das forças políticas e econômicas globais. Visualizar significa interpretar a configuração planetária das forças geopolíticas. Na concepção do geógrafo inglês, a elite política de um país deve ler geograficamente o mundo, e dessa forma, constituir políticas nacionais e internacionais de poder. Visualizar é estabelecer discursos e interpretações, isto é, imagens sobre os lugares e o mundo.

Governos militares do continente, fundamentados em temas geográficos, direcionavam as políticas interna e externa de seus países a partir de concepções disseminadas por essa geopolítica. Sobretudo no Cone Sul, as doutrinas geopolíticas exerceram função de statecraft, tornando-se influentes visões sobre a participação dos países da região nos contextos internacionais. Acrescenta-se que geopolíticos como Golbery do Couto e Silva no Brasil, Enrique Guglialmelli na Argentina e Augusto Pinochet Ugarte no Chile, além de teorizarem a condição de seus respectivos países no contexto internacional, tornaram-se influentes policy makers.

No Brasil, mesmo antes da fundação da Escola Superior de Guerra (ESG) em 1949, existia uma crescente produção em geopolítica, levada a cabo por geógrafos, cientistas políticos, e principalmente militares. Embora não possua formação original em nenhuma dessas áreas, Everardo Backheuser destaca-se como um dos mais relevantes geopolíticos da escola brasileira. ${ }^{33}$ Segundo Cabral (2007, p. 14), Backheuser foi responsável por introduzir no Brasil durante a década de 1920, o pensamento geopolítico de Kjellén. Embora algumas ressalvas devam ser feitas a esse respeito, Backheuser é considerado um dos responsáveis pela disseminação da visão instrumental do conhecimento geográfico entre os

\footnotetext{
do poder em escala internacional. Essa mesma concepção geopolítica estava subjacente em textos metodológicos como em On The Scope and Methods of Geography (1887), e explícita em análises da política internacional, como as realizadas em The Geographical Pivot of History (1904), Democratic Ideals and Reality (1942), e The Round World and the Winning of the Peace (1943).

33 "Os analistas, em geral, concordam que um dos mais destacados pioneiros na área foi E. Backheuser, autor de vários ensaios no gênero, sendo que os principais foram reunidos em dois trabalhos [A Estrutura Política do Brasil, 1926; Estrutura Geopolítica. O Espaço, 1933]. Geólogo de formação e professor da Escola Politécnica do Rio de Janeiro, foi a partir dessa especialidade que ele concluiu ter chegado à geografia física, e desta à antropogeografia e à geografia política." Wanderley Messias da Costa, 1992, p. 187.
} 
geopolíticos militares brasileiros, nos moldes da geografia aplicada pelo teórico sueco. ${ }^{34}$

\title{
2.3. Origens e Características dos Discursos Geopolíticos Continentais do Brasil
}

\author{
Desde o período em que George Kennan comandou o Policy Planning
} Staff, os diferentes modelos de containment colocados em prática pelos Estados Unidos reservavam um lugar para a América do Sul no bloco ocidental. Ainda que esse lugar tenha sido, com maior ou menor grau, caracteristicamente periférico para os interesses da maior potência mundial, certamente é definidor da forma de interpretar a condição do continente na Ordem Geopolítica da Guerra Fria. Nesse caso, deve-se levar em consideração o argumento de Gaddis (2005b), para quem a grande estratégia norte-americana é perpassada por uma geopolítica de matriz mackinderiana e, nesse sentido, não tem reflexos apenas na forma como os governos do país interpretam a América do Sul. Tão importante quanto é o fato de que o constructo mackinderiano se constitui em uma das influências majoritárias das teorias geopolíticas sul-americanas e suas perspectivas quanto à projeção internacional.

Ocorre que, enquanto no que se refere a constituição de uma sistema de circulação territorial - entendida como o movimento dos seres e das coisas (RAFFESTIN, 1993) - a geopolítica militar brasileira guarda intensa relação com Halford Mackinder, em relação ao seu discurso sobre o Estado, o território e as fronteiras, sua matriz direta está na geopolitik inaugurada por Kjellén. ${ }^{35}$ Espaço,

\footnotetext{
${ }^{34}$ Devido as influências do modelo posto por Kjellén sobre estudiosos europeus da geopolítica, torna-se, em certo sentido, uma tarefa bastante complexa definir com precisão a filiação teórico-metodológica de determinados autores. O organicismo estreito de Kjellén foi levado às últimas conseqüências com o geógrafo-general Karl Haushofer e a Escola Geopolítica de Munique. Certamente, a geopolítica alemã, que estava em alta nas décadas de 1930 e 1940, exerceu influência em Backheuser. Como coloca Costa, (Op. Cit. P. 190) "... seria mais adequado identificar a fonte de suas inspirações não em Ratzel ou Kjellén, mas diretamente em Haushofer e seu grupo, o que é razoável, pois ele foi o único brasileiro que teve um artigo publicado na tão controvertida Revista de Geopolítica alemã." Se por um lado reconhecemos a ligação de Backheuser com a geopolítica alemã, por outro, continuaremos ressaltando sua ligação com Kjellén, considerando que em seus ensaios, fora o introdutor direto dos conceitos do teórico sueco. Conforme a geopolítica alemã entra em decadência no pós - Segunda Guerra, sendo publicamente execrada na Europa e Estados Unidos como mostra Ó Tuathail (1996), geopolíticos brasileiros como Golbery Couto e Silva e Meira Mattos, ao condenarem o pensamento produzido pela Escola de Munique, demonstram uma ligação direta com pensamento de Kjellén.

${ }^{35}$ Conforme análise de André-Louis Sanguin (1977) a Geopolitik é uma vertente voltada às necessidades expansionistas de países da Europa Central, principalmente a Alemanha. A Geopolítica, na forma como inaugurada e desenvolvida por Kjellén se expressa como Geopolitik, pois potencializa o determinismo e o organicismo presente na obra de Ratzel, os associando com uma realpolitik voltada ao expansionismo alemão do final do século XIX. Esse engajamento da geopolítica ganha mais força após o Tratado de Versalhes, que estabeleceu as perdas territoriais alemãs após o fim da Primeira Guerra Mundial. A
} 
posição e organismo, três idéias-força sobre as quais está edificado o pensamento de Ratzel, adquirem uma roupagem determinista com a geopolitik, que passa a intoxicar a Geografia Política até o final da Segunda Guerra Mundial (SANGUIN, 1977).

Karl Wittfogel (1992), numa devastadora crítica "antigeopolítica", lembra que na Alemanha dos anos 1920, os escritos geopolíticos brotavam repentinamente como cogumelos depois de uma chuva de verão. Mas esse desastre epistemológico, ao contrário do que defende Wittfogel, não tem em todos os sentidos, uma relação coesa com o pensamento de Ratzel. A Geopolitik inaugurada por Kjellén torna-se ponte entre o pensamento do geógrafo alemão e o expansionismo germânico no entre Guerras. Mas de certa forma, essa ponte subverte sua origem visando alterar seu destino. Ironicamente, pela forma como se apropriou da Geografia, o destino alcançado pela Geopolitik está mais no passado instrumental da geografia do que no futuro político e epistemológico traçado por Ratzel.

Kjéllen visa construir, em diálogo com a Geografia, um campo de estudo exclusivamente político sobre a relação entre Estado, sociedade e território. Da forma como foi estabelecida por Ratzel, e apesar de ponderações acerca da necessidade de aperfeiçoamento metodológico, essa relação é reconhecida mesmo por Paul Vidal de La Blache (1898), seu principal crítico, como um campo promissor para o conhecimento geográfico. Segundo Franco Farinelli (2000), Ratzel propõe uma Geografia do Estado em oposição a Erdkunde, isto é, a geografia de legitimação epistemológica pura fundada por Carl Ritter e Alexandre von Humboldt. ${ }^{36}$

Farinelli (Op. Cit.) se opõe a muitos dos críticos de Ratzel que o acusaram instrumentalizar o conhecimento geográfico em benefício de uma Alemanha em

Geopolitik passa a ganhar nas décadas seguintes uma roupagem nazista e ultra-expansionista com Haushofer e a Escola de Munique.

${ }^{36}$ Para análises mais aprofundadas sobre a Erdkunde, além de Franco Farinelli em Friedrich Ratzel and the Nature of (Political) Geography (2000), ver ainda Richard Hartshorne em The Nature of Geography (1939). Segundo Hartshorne, com Ritter e von Humboldt, fundadores da Geografia Moderna, essa disciplina passa a desenvolver uma visão teleológica do universo e do planeta.O geógrafo americano argumenta que o homem é a razão metodológica de Ritter, e o centro de todo processo de análise geográfica. O estabelecimento da geografia como "ciência moderna", que se dá inicialmente com Immanuel Kant, ocupa o período entre 1750 e 1850. Na esteira de Kant - que ministrou um curso de Geografia durante 48 semestres (entre 1756 e 1796), período que Hartshorne define como pré-clássico - Ritter e von Humboldt fundam a Geografia Clássica, deslocando esse campo do conhecimento da instrumentalização política para o saber científico. A Erdkunde, como praticada por Ritter e von Humboldt, entendia o método regional como única forma de representar cientificamente uma totalidade expressa pela relação homem-natureza. Em linhas gerais, Farinelli argumenta que com a geografia de legitimação epistemológica - ou geografia pura - há uma sofisticação desse conhecimento, buscando estudar e compreender a Terra em sua relação com toda humanidade. Esse tipo de conhecimento não era mais chamado de Geografia, mas de Erdkunde, que pode ser traduzido como "conhecimento sobre a Terra." Enquanto que a Geografia medieval era legitimada pelo poder vigente, a geografia pura era legitimada pela ciência e pelo conhecimento "em si." A antiga legitimação estatal foi substituída pela legitimação epistemológica. 
ascensão. O geógrafo italiano defende que a Geografia do Estado, diferentemente da geografia estatal praticada na Idade Média, buscava trazer a política para o centro da análise geográfica. ${ }^{37}$ A geopolitik nos moldes propostos por Kjellén, ao transformar o modelo ratzeliano num simples instrumento expansionista, abandona a legitimação epistemológica, e retoma, de certa forma, a antiga tradição de geografia estatal. Apesar de se declarar "científica", a legitimação dessa tradição torna-se meramente instrumental. Essa vertente encontra solo fértil na América do Sul, especialmente nas décadas de 1960 e 1970, em revistas especializadas da região. ${ }^{38}$

Com algumas ressalvas, há no caso sul-americano uma interação entre a geopolítica mackinderiana subjacente ao containment americano e o expansionismo organicista da Geopolitik. ${ }^{39}$ Em termos de concepção de Estado e território, os geopolíticos brasileiros analisam a condição do país na Ordem Geopolítica da Guerra Fria segundo a tradição da geografia estatal retomada por Kjellén. Por outro lado, a forma como, dentro dessa tradição, interpretaram o lugar do Brasil e do continente no contexto internacional da Guerra Fria, descendeu diretamente da tradição geopolítica mackinderiana presente nos Estados Unidos e na Europa.

Como já destacado, essa tradição se define pela concepção política do espaço mundial bem como pelo lugar que os Estados Unidos e a Europa estabeleceram para o continente sul-americano na Ordem Geopolítica da Guerra Fria. Por serem suas políticas internacionais impregnadas por essa perspectiva, é

\footnotetext{
${ }^{37}$ Para Farinelli (2000), a geografia de Ratzel se torna ideológica à medida que a interpretação dos geógrafos franceses (e indiretamente dos alemães) substituiu em Ratzel o objeto pela função da Geografia. Em Ratzel, pondera Farinelli, o objeto da Geografia é o Estado e sua função, isto é, o seu sentido, é a política. Seus críticos, ao inverterem essa ordem, fazem com que o Estado deixe de ser o objeto, para se tornar a função última da geografia proposta pelo geógrafo alemão. Ratzel busca trazer a política de volta para a Geografia inspirando-se em Herder e Ritter e não no evolucionismo e na tradição positivista como alegam muitos dos seus críticos. Nesse sentido, Ratzel foi o último representante da Erdkunde, pois percebeu que era impossível alterar sua função política sem a destruir. A Geografia Política de Ratzel era a negação de uma legitimação epistemológica pura, ao mesmo tempo em que buscava legitimar em base científica a existência do Estado. Apesar das ressalvas de Farinelli quanto às críticas ao pensamento de Ratzel, devemos ser cautelosos para não subvalorizar as influências do momento político da Alemanha. Segundo Costa (1992) o contexto histórico da Alemanha influencia sobremaneira a Geografia Política de Ratzel, que demonstrava preocupações com a unificação alemã iniciado por Otto von Bismarck. Costa (Op. Cit.) salienta que como membro da Liga Pangermanista, Ratzel avaliava como "mal concluído" esse processo de unificação.

${ }^{38}$ Leslie Hepple (2004, p. 360) chama atenção para o fato de que um texto militar chileno já citava Ratzel em 1905, Storni, almirante argentino, já citava Mahan em 1915, e Everardo Backheuser já publicava na Zeitschrift für Geopolitik, a bíblia da geopolítica expansionista alemã, em meados da década de 1920. Hepple destaca ainda o papel dos periódicos Geopolítica, Geosur, Estratégia e Revista Chilena de Geopolítica, importantes para a disseminação de idéias em todo o continente, principalmente de 1960 em diante.

${ }^{39}$ Importantes geopolíticos brasileiros como Golbery do Couto e Silva, Carlos de Meira Mattos, dentre outros, a rechaçam de forma contundente em seus escritos. Como mostra Ó Tuathail (1996, pp. 111-140), a geopolitik alemã, se tornou símbolo nos países europeus e nos Estados Unidos como instrumental a serviço do nazismo na Segunda Guerra. Ao mesmo tempo em que os geopolíticos brasileiros buscam se aproximar da geopolitik de Kjellén, procuram deixar bastante claro que a geopolítica por eles produzida não era germanófila. Essa postura tinha vários objetivos, dentre eles, ressaltar os laços brasileiros com os países vencedores da Segunda Grande Guerra e rechaçar qualquer tendência teórica nazista num país multicultural como o Brasil.
} 
necessário entender como os militares brasileiros apreenderam a posição da América do Sul. Nesse caso, deve-se considerar que a proposição de modelos de projeção internacional no continente - principalmente em países como Brasil, Argentina e Chile - estava subordinada ao arcabouço ratzeliano, a "geografia estatal" de Kjellén e ao modelo mackinderiano de "visualização" do espaço mundial.

$\mathrm{Na}$ América do Sul, foi Mário Travassos o introdutor do modelo mackinderiano de análise política. Em sua obra clássica, Projeção Continental do Brasil (1935), Travassos analisou aquilo que considerava como principal meio de proeminência do Brasil em seu continente. Nesse intuito, apresentou o mais importante e influente esquema continental de comunicações territoriais. ${ }^{40}$ Sua imaginação geopolítica alcançou larga influência no desenvolvimento da disciplina em diversos países do continente. Travassos publicou seus trabalhos num período em que o territorialismo predominava na política sul-americana. Embora isso valha especialmente para Projeção Continental do Brasil, o alcance analítico de sua obra não se resume ao modelo expansionista que reverberou por décadas na América do Sul.

Para Mário Travassos (1935) a projeção continental do Brasil passava por um sistema de circulação territorial conectando grandes áreas da América do Sul. Em sua obra, o Brasil caracteriza-se por seu grande território que, devido sua posição, é o único capaz de promover o vertebramento em escala sul-americana. A partir do Brasil, a Bacia Amazônica poderia ser conectada a Bacia Platina, aproveitando-se a capacidade de navegação das duas maiores redes hidrográficas do continente. Da mesma forma, o Oceano Atlântico deveria ser interligado ao Oceano Pacífico, principalmente via estradas de ferro. Controlando a maior parte da Bacia Amazônica, com uma posição privilegiada na Bacia Platina, e, sendo o principal país Atlântico, a conexão com o Pacífico projetaria o Brasil como potência bi-oceânica.

\footnotetext{
${ }^{40}$ Cada um a sua maneira, Everardo Backheuser e Mário Travassos refletem as heranças dos pais fundadores do pensamento geopolítico. Travassos tem uma ligação mais estreita com os discursos estabelecidos por Alfred Mahan e Halford Mackinder. De forma muito semelhante, Mackinder e Mahan (sobretudo em The Influence of Sea Power Upon History) privilegiaram o estudo da circulação terrestre e marítima como o meio de análise da política internacional. Backheuser foi o principal introdutor de um modelo analítico, cuja matriz se encontra em Ratzel e Kjellén. A partir de Ratzel, Backheuser introduz os conceitos clássicos do pensamento geopolítico. De Kjellén, herdou um organicismo mais estreito, que se tornaria referência em toda América do Sul. Evidentemente, todos os principais clássicos dessa disciplina na Europa e Estados Unidos exerceram influência, com maior ou menor grau, sobre os dois fundadores da escola brasileira. Mas, as influências de Mahan e Mackinder em Travassos, e de Ratzel e Kjellén sobre Backheuser foram mais estreitas, determinando a estrutura analítica de suas abordagens.
} 
O modelo de integração territorial proposto por Travassos era uma resposta ao protagonismo geopolítico argentino. Segundo Travassos, a proeminência argentina na Bacia do Prata se concretizara por meio da construção de uma rede ferroviária, o que ressaltava o homem como fator geográfico de primeira grandeza. Já na década de 1930, a Argentina estava ligada via rede ferroviária a três capitais sul-americanas: a Santiago por meio de uma via férrea que interligava a riqueza andina com o Atlântico; a Assunção, que por sua vez conectava em seu percurso Córdoba, Salto e Posadas; e a La Paz, por meio da soldagem em Tupiza da via argentina com as linhas bolivianas. Travassos destaca ainda os reflexos do caráter continental da ligação Buenos Aires - La Paz, que multiplicava os contatos com o Pacífico, por meio das ligações com os portos de Val Paraíso, Antofagasta e Mejillones (Chile) e de Mollendo (Peru). Para Travassos, essas ligações funcionavam como verdadeiras bombas aspirantes, levando para a altiplanície as "... riquezas dos vales longitudinais da vertente ocidental andina..." (Op. Cit. p. 35). Segundo o autor, a conexão entre Buenos Aires e La Paz coloca os antagonismos geográficos do Amazonas e Prata em favor da Argentina.

De fato, o vertebramento territorial proposto pelo general Travassos se tornou um modelo brasileiro para as interações físicas continentais durante os períodos autoritários recentes da história sul-americana. Todavia, mesmo no atual processo de integração regional, aspectos cardinais desse vertebramento - como as interconexões Oceano Atlântico / Oceano Pacífico e Bacia do Prata / Bacia Amazônica - são componentes inseparáveis para as políticas de cooperação em andamento.

$\mathrm{Na}$ década de 1930, Travassos chama atenção para a necessidade de interação entre um sistema de comunicação territorial natural e outro artificial. $O$ militar foi o mais importante analista a propor no século XX um sistema de circulação continental. Sua concepção de projeção continental foi referência para políticas territoriais brasileiras da década de $1950 \mathrm{em}$ diante. Pelo fato de sua obra exercer muita influência na ESG, suas concepções tornaram-se grandes referências para geopolitólogos e advogados do regime militar e do processo de modernização conservadora empreendida pelos militares a que se refere Becker \& Egler (1992). 
Em grande medida, o discurso da projeção continental do Brasil é uma aplicação sul-americana da concepção de poder terrestre e marítimo, introduzidos por Mackinder. ${ }^{41}$ Mas, ao contrário de alguns analistas militares que estabeleceram esquemas voltados explicitamente para a posição global do Brasil, e ainda que sua obra objetivasse a pensar o futuro do país como potência internacional (CABRAL, 2007), Travassos instituiu uma geopolítica mackinderiana voltada principalmente para o contexto sul-americano. Ainda que a predomínio continental seja base definidora de uma expansão planetária, não é questão central nos seus estudos uma análise explícita da projeção mundial do Brasil. Mas a preocupação com a condição mundial do país pode ser inferida de sua teoria, cuja base mackinderiana pressupõe uma interação/integração entre as múltiplas escalas do espaço político internacional.

Os discursos geopolíticos mainstream, ao trilharem o caminho aberto por Travassos e Backheuser, apesar de focados primeiramente em fatores geográficos, ${ }^{42}$ estavam voltados para outros meios de projeção de poder. Alguns autores importantes da geopolítica brasileira consideravam, dentre uma diversidade de outros aspectos, o desenvolvimento econômico e científico, respectivamente estratégicos. ${ }^{43}$ No projeto geopolítico para a modernidade empreendido principalmente pelos militares, foi acrescido ao tradicionalismo territorialista da geopolítica clássica, a valorização do "vetor científico-tecnológico moderno para o controle do espaço-tempo" como componente central da política de Estado. ${ }^{44} \mathrm{O}$ projeto geopolítico para a modernidade pautado no vetor científico-

\footnotetext{
${ }^{41}$ Em Democratic Ideals and Reality (1942) Halford Mackinder aprofunda a discussão sobre o poder terrestre, que fora introduzido em The Geographical Pivot of History (1904). Da mesma forma que no artigo que 1904, o livro, cuja primeira edição é de 1919, analisa o poder terrestre como um sistema de vertebramento e integração de um território continental através de uma região pivô. Porém, nessa obra Mackinder aprofunda concepções que em seus primeiros textos estavam apenas subentendidas. Dessa forma, detalha algumas de suas principais formulações, permitindo compreender que o desenvolvimento dos meios de comunicação e transporte estava "encolhendo" espaços geográficos, fazendo com que grandes continentes ganhassem aspectos de insularidade. Essa espécie de compressão espaço-temporal causada pela modernização dos meios de transporte resultaria em poder terrestre. O país que viesse a comandar esse poder continental se tornaria uma potência marítima.

${ }^{42}$ A esse respeito, ver principalmente Raffestin (1993), Agnew \& Corbridge (1995) e Agnew (1998). De modo geral, os autores constroem uma crítica à geografia tradicional e a sua incapacidade de captar as distintas formas de manifestação de poder na relação entre sociedade e território. Acusam o pensamento produzido ao longo da história dessa disciplina, de ser excessivamente centrado no Estado. A crítica que Agnew e Corbridge (Op. Cit.) fazem ao pensamento clássico é bastante salutar para a compreensão da geopolítica sul-americana. Em geral, esta era excessivamente concentrada naquilo que os autores definem como "fatores estáticos" do território. E isso, num período onde a informação, a fluidez e os novos horizontes postos pela ciência desafiavam a "velha" geografia como baluarte do poder na relação entre sociedade e território. Embora alguns autores da geopolítica brasileira estivessem atentos a novos vetores econômicos, científicos e tecnológicos, sua produção era dominada pelo territorialismo que marcou as grandes potências européias, especialmente até a Segunda Grande Guerra.

${ }^{43}$ Para Meira Mattos (1975, p. 70), a “... superfície do território, natureza das fronteiras, quantidade de população, ausência ou presença de matérias-primas, desenvolvimento econômico e tecnológico, capacidade financeira, homogeneidade étnica, grau de integração social, estabilidade política e coesão nacional..." são questões primordiais para que um país alcance a condição de potência.

44 "As premissas do projeto geopolítico não foram determinadas pela geografia do país nem se resumiram a apropriação física do território. O marco do novo projeto foi a intencionalidade do domínio do vetor científico-tecnológico moderno para o controle
} 
tecnológico, já era parte do Plano de Metas do governo Kubitschek (BECKER \& EGLER, 1992, p. 125).

Apesar da importância cada vez maior das relações comerciais nas políticas interestatais no pós-guerra, os discursos geopolíticos clássicos conservaram o prestígio enquanto statecraft. Não há como negar que o comprometimento de Mackinder em promover a geografia ao status de statecraft da política internacional foi bem sucedido. ${ }^{45}$ Como muito bem evidencia 0 containment americano, as correntes tradicionais da geopolítica funcionaram como um suporte amplamente empregado durante o século $X X$ de sustentação às decisões de política internacional. A geopolítica mackinderiana, proposta a partir do princípio da visualização do espaço, foi alçada à condição de statecraft especialmente em escala global, porém, com relevante adesão em contextos regionais.

Alguns discursos geopolíticos militares sul-americanos ganharam notoriedade na segunda metade do século $\mathrm{XX}$, com leituras territorialistas da política internacional. ${ }^{46}$ Geopolíticos brasileiros como Lysias Rodrigues, Golbery do Couto e Silva, Meira Mattos e Terezinha de Castro, distinguiam-se especialmente por conceber um "lugar" para Brasil e a América do Sul na Ordem Internacional da Guerra Fria. Isso significa dizer que, de maneira mais ou menos semelhante, buscaram dar mais proeminência a condição do Brasil no mundo ocidental. De

do tempo e do espaço, entendidos pelas Forças Armadas como condição para a constituição do Estado-Nação na nova era mundial, e para a modernização acelerada da sociedade e do espaço nacional necessária para alcançar o crescimento econômico e projeção internacional." Bertha Becker e Cláudio Egler, 1992, p. 124-125.

${ }^{45}$ A esse respeito, ver Gearóid Ó Tuathail (1992; 1996), R. Mayhew (2000) e Pascal Venier (2004). Os autores apresentam uma discussão sobre o empenho de Mackinder visando projetar a Geografia à condição de statecraft, e às influências do contexto europeu e mundial sobre sua teoria. Statecraft, um conceito destacado por Ó Tuathail (1992), significa arte ou capacidade de governo. Para Ó Tuathail (Op. Cit.) o comprometimento de Mackinder com o imperialismo britânico do final do século XIX determinou todo seu esforço para projetar a Geografia como statecraft. Mackinder era um crente na ciência como forma de revelação de uma lógica e uma "ordem natural" subjacente à sociedade. A abordagem mackinderiana, denominada por alguns comentadores de New Geography, busca dar uma nova função a Geografia em um mundo "completo" e em integração. Ela não seria meramente descritiva, devendo proporcionar a população um olhar sobre todo o planeta. Essa concepção, como demonstra grande parte dos analistas de sua teoria, não se separa da política. A sua geografia seria um guia da política. Mayhew (2000) coloca em dúvida essa pretensão e pergunta: não teria a política se tornado o guia da New Geography proposta por Mackinder? Segundo Mayhew (Op. Cit.) a posição político-partidária de Mackinder - que pertenceu ao Partido Conservador britânico e foi membro do parlamento - guiava sua Geografia. Para Venier (2000), The Geographical Pivot of History deve ser visto como reflexão provocativa, que visava demonstrar a relevância da Geografia na condução de políticas internacionais.

46 John Chield (1979) e Phillip Kelly (1997) fazem um inventário dos principais teóricos sul-americanos da geopolítica. Kelly (Op. Cit.) enfatiza a influência que alcançaram em setores da academia, e o papel que alguns deles tiveram como homens de Estado. Destaca dentre outros: Carlos de Meira Mattos, Golbery do Couto e Silva e Terezinha de Castro do Brasil; Enrique Guglialmelli, José Felipe Marine e Nicolas Boscovich da Argentina; Bernardo Quagliotti de Bellis do Uruguai; Julia Vilella Arrélaga do Paraguai; Alípio Valencia Veja da Bolívia; Augusto Pinochet Ugarte, Ramón Canhas Montalva e Emilio Meneses Ciuffardi do Chile. De modo geral, os geopolíticos do Cone Sul apresentavam por meio de seus escritos, um diálogo com seus pares, refutando, concordando ou assimilando criticamente a produção dos países vizinhos. Como evidenciado pelos dois analistas, todos mantinham a geopolítica clássica como modelo. Seus discursos geopolíticos, carregados de um forte territorialismo, preservavam em plena segunda metade do século XX, aspectos centrais de um pensamento geopolítico que havia predominado num mundo de décadas atrás. Apesar de alguns autores dessas diferentes escolas sul-americanas incorporarem, implícita ou explicitamente, o vetor científico-tecnológico, suas análises eram predominantemente pautadas em relações políticas balizadas pelo colonialismo, por um expansionismo agressivo, e principalmente por uma ordem internacional estadocêntrica. 
forma muito parecida, todos estes analistas construíram um discurso geopolítico acerca da posição do Brasil no containment americano e no Ocidente de modo geral.

Ao refletir um projeto forjado por setores da sociedade civil e militar, essas abordagens promoviam um diálogo com o discurso mackinderiano, expresso tanto nos escritos clássicos, como nos diferentes modelos de containment adotados desde George Kennan e George Marshall. Ainda que os intelectuais militares não sejam responsáveis stricto sensu pelo projeto geopolítico da modernidade, há inúmeros exemplos da proximidade entre geopolítica e Estado. A atuação de policy makers provenientes desse meio é fartamente documentada por estudiosos no continente.

Everardo Backheuser foi o introdutor da crença de que as políticas de fronteira devem ser atribuição do governo federal. A Marcha para Oeste, com a necessidade de ocupação dos espaços vazios, foi o primeiro movimento da modernização onde a política do território precedeu o território da política (BECKER \& EGLER, 1992). O Governo Vargas foi o primeiro a pensar políticas de fronteiras nos moldes preconizados por Backheuser. Ainda que essa influência não se inicie com o golpe militar, esses ideólogos ganham relevância nas décadas de 1960 e 1970.

Sobretudo os discursos geopolíticos nacionais e argentinos (especialmente com Enrique Guglialmelli e Nicolas Boscovich), da segunda metade do século XX possuem uma abordagem sobre geografia e poder em estreita relação com aquelas desenvolvidas pelos teóricos da primeira metade do século XX no Brasil. Mas, concernente à relação entre posição e circulação, a abordagem desses geopolíticos era surpreendentemente mais estreita que a de Travassos.

Há na abordagem travassiana uma sofisticação posta pela interação entre geografia, técnica e comunicação territorial, que, com exceção de Golbery do Couto e Silva, raras vezes encontra lugar no discurso geopolítico tradicional desenvolvido no continente. Meira Mattos, por exemplo, embora valorizasse os "sistemas de comunicações territoriais", focava demasiadamente na posição geográfica.

A circulação territorial destaca-se não somente como um dos componentes basilares do discurso geopolítico, mas como ponte entra a "velha" e 
a "nova geografia". Posto de forma mais específica, é um conceito central à medida que permite a conexão entre o conhecimento geopolítico clássico e a organização contemporânea do meio geográfico, fundamentalmente marcado pela fluidez material e informacional. Em Meira Mattos (2001), a integração do território, a interiorização dos meios de transporte e comunicação, a criação de uma indústria aeronáutica nacional e a expansão do transporte aéreo são exemplos da relação entre o impositivo geopolítico da circulação territorial e do vetor tecnológico moderno.

Por outro lado, destaca-se no conjunto de sua produção teórica uma fixação comum pelo "estático". A obsessão pela posição brasileira no Atlântico Sul, pela dimensão territorial do país e pelas características de sua população evidencia não apenas a advocacia de um "pan-americanismo sem restrições". Meira Mattos elabora a defesa da participação do Brasil no "Ocidente Cristão" baseado, sobretudo, na categoria mais privilegiada de seu discurso: a posição geográfica. Nesse caso, o vetor científico tecnológico subordina-se ao "status quo territorial". 47

\subsection{Visualização do Espaço Mundial e Concepções da Projeção Mundial do Brasil}

Ainda que os discursos produzidos por Meira Mattos e vários outros teóricos brasileiros da geopolítica na segunda metade do século XX tenham se destacado no "diagnóstico" da posição internacional do país, nenhum deles teve a sofisticação e o alcance do realizado por Golbery do Couto e Silva. O mais influente dos geopolíticos brasileiros da segunda metade do século XX produziu a mais completa síntese elaborada por essa disciplina no país. Em Geopolítica do Brasil (1967), Golbery do Couto e Silva amalgama o discurso geopolítico clássico ao containment em andamento durante a Guerra Fria e ao projeto brasileiro para a modernidade. Sua obra foi a primeira a propor de modo sistemático no Brasil uma

\footnotetext{
${ }^{47}$ Segundo Phillip Kelly (1982) cinco temas geopolíticos perpassam os escritos de Meira Mattos. a) Os fatores geopolíticos como fundamentais para o desenvolvimento do Brasil. Em seu pensamento, destacam-se como fatores geopolíticos, integração e planejamento político, espaço e posição territorial, recursos naturais e tecnologia, e coesão e vitalidade da população. b) A posição geográfica coloca o Brasil como aliado natural dos Estados Unidos; c) A segurança do Brasil está ligada à Bacia do Atlântico Sul; d) O pensamento geopolítico carece de planejamento e do desenvolvimento regional da Amazônia; e) Desenvolvimento, poder e segurança estão intimamente ligados, e quando projetados além da esfera continental, proporcionarão o destino nacional do Brasil: o status de grande potência.
} 
síntese entre o arcabouço dos discursos geopolíticos clássicos e o vetor científicotecnológico.

Chefe da Casa Civil em dois dos cinco governos militares, Golbery do Couto e Silva pôde por em prática várias de suas concepções geopolíticas sobre o Brasil (KELLY, 1997). Entre os aspectos estruturantes do seu discurso está a proposta de "visualização" do espaço mundial, baseada nos esquemas de Mackinder e Spykman. Suas análises se orientam pelo realismo político e pela defesa do Brasil como o parceiro privilegiado dos Estados Unidos. Há uma variedade de temas abrangendo desde a consolidação territorial do país até o poder continental. Em conjunto, refletem sua perspectiva de projeção interna e externa do Brasil.

Dentre os temas mais comuns - que no seu entender são questões fundamentais da geopolítica brasileira - estão: integração nacional e valorização espacial, expansionismo para o interior e projeção pacífica no exterior, geopolítica de contenção ao longo das linhas de fronteiras e participação na defesa do mundo Ocidental. Junto a esses temas, a "visualização" do espaço mundial estava subordinada a inserção da América do Sul no contexto da Guerra Fria. Assim como em toda escola geopolítica brasileira, Golbery do Couto e Silva privilegia o alinhamento automático com os EUA num mundo dividido em dois grandes pólos de poder. ${ }^{48}$

Característica comum entre ideólogos do regime militar, a defesa desse alinhamento era posta via exaltação dos fatores geográficos. Golbery do Couto e Silva (Op. Cit. p. 51) ressalta um conjunto de dados naturais como elementos a garantir a aliança estratégica com os norte-americanos. Além de uma economia não competitiva e da tradição de amizade, o geopolítico destaca a posição do Nordeste e a desembocadura do amazonas, considerados de extremo valor geoestratégico no contexto da Guerra Fria. Golbery do Couto e Silva ainda enfatiza o manganês e as areias monazíticas como recursos naturais fundamentais na relação com os Estados Unidos.

A sua geopolítica estabelece nas condições naturais os "trunfos do poder" do Brasil e as condições de uma importante aliança estratégica com a maior

\footnotetext{
${ }^{48}$ Golbery do Couto e Silva (1967, pp. 19-22) se inspira na geopolítica ratzeliana para defender a posição do Brasil no mundo. Defende que estamos na "era da história continental" apregoada por Ratzel. A projecão continental do Brasil na América do Sul seria o meio fundamental para o país se destacar como potência na era da história continental. Golbery do Couto e Silva defende a posição do Brasil como "Estado-barão" rodeado por "Estados vassalos", fator que lhe asseguraria a projeção internacional.
} 
potência mundial. O ideólogo do regime militar defende que a importância do Brasil no contexto global é assegurada por sua posição geográfica, com grande presença no Atlântico Sul. À medida que a América do Sul é a chave do controle da circulação nesse oceano, um regime comunista aliado da União Soviética no continente representaria ameaça a todo Ocidente. Portanto, são nos elementos estáticos do território que se encontram os trunfos da inserção internacional do Brasil. Daí a defesa da manutenção do status quo territorial contra qualquer revisionismo.

A defesa do alinhamento automático com os Estados Unidos orientava sua compartimentalização do espaço mundial através da teoria dos hemiciclos. Os hemiciclos são expressões cartográficas de uma visão do espaço mundial a partir da periferia. Apesar de mimetizarem em muitos aspectos concepções oriundas dos países centrais, representam uma aspiração internacional ao buscar situar um país periférico no centro geoestratégico mundial. Golbery do Couto e Silva (Op. Cit. pp. 79-81) situa a América do Sul no mundo através de uma representação azimutal, onde o globo aparece dividido por dois vastos hemiciclos, sendo um interior e outro exterior.

No "Hemiciclo Interior", que abrange um raio médio de $10.000 \mathrm{~km}$, aparece a América do Sul no centro do mundo, circundada pela América do Norte, África e Antártica. O geopolítico salienta que no interior desse hemiciclo não há ameaça ao Brasil, e destaca como causa dessa condição, dentre outros fatores, o panamericanismo e a ausência de potencial de agressão. Quando evoca o ideal panamericanista como garantia de proteção da América do Sul frente a União Soviética, Golbery do Couto e Silva (Op. Cit. p. 192) está em sintonia com a escola geopolítica brasileira e com as principais tendências da política externa inaugurada em 1964.

Por sua vez, o "Hemiciclo Exterior" - que abrange grande parte da massa euroasiática, Pacífico Asiático, Austrália, Nova Zelândia etc. - aparece como perigo aos países sul-americanos. Golbery do Couto e Silva (Op. Cit.) argumenta que é no interior dessa área que saíram grandes ameaças ao Ocidente, como a Alemanha de Guilherme II, o Reich de Hitler, o Império Nipônico de Hirohito, além do eixo Moscou-Pequim. Este hemiciclo, pela influência direta no seu discurso, é o que fundamenta sua visualização do espaço mundial. É em relação a esta área, berço do comunismo soviético, que a América do Sul deve estruturar sua política 
de segurança. Enquanto as três grandes massas terrestres que compõem o "Hemiciclo Interior" não estiverem sob o controle de uma potência agressora, a América do Sul está imune a ações de forças mais diretas. "O "Hemiciclo Interior" baliza, portanto, de fato, a fronteira decisiva da segurança sul-americana" (Op. Cit. p. 83).

Com a teoria dos hemiciclos, Golbery do Couto e Silva inverte a visualização do espaço mundial, produzida principalmente pela geopolítica anglosaxã. Como coloca em Geopolítica do Brasil (Op. Cit., p. 32) o diálogo que mantém com a geopolítica clássica dá-se via Spykman. O holandês foi o primeiro o apontar, ainda na Segunda Guerra Mundial, uma concepção de containment em consonância com os interesses americanos. ${ }^{49}$ Se Spykman (1942) inverte a fórmula mackinderiana colocando no centro mundial o rimland, o geopolítico brasileiro inverte as duas fórmulas clássicas pondo a América do Sul no centro do containment.

Mas é necessário cautela quanto ao real alcance da geopolítica de Golbery do Couto e Silva. Historicamente, o alinhamento com os Estados Unidos não deve ser tomado como significado puro de subordinação internacional. Esse raciocínio levou a teses equivocadas, como a desenvolvida por Schilling (1981), que afirma a existência de um subimperialismo brasileiro a partir da década de $1960 .^{50}$

No que se refere a tendência de alinhamento do Brasil com os Estados Unidos, cabem importantes ressalvas. É necessário ter cuidado para avaliar a relação entre as duas nações nas décadas de 1960 e 1970. Não existia no país sul-americano a busca por uma aliança a qualquer custo. No governo Médice, havia por parte do Brasil uma recusa em aceitar incondicionalmente uma posição submissa frente aos interesses dos Estados Unidos. Os militares já consideravam o país um membro maduro da comunidade das nações. Como mostra Matias

\footnotetext{
49 Além do seu famoso estudo sobre os desafios da projeção mundial dos Estados Unidos, Spykman tem dois artigos Geography and Foreign Policy I (1938a) e Geography and Foreign Policy II (1938b) - onde expõem suas concepções sobre a influência do meio natural na política internacional. Sua posição (cuja maior síntese se encontra na teoria do rimland) tem forte influência de um determinismo mais estreito, que migrou da Geografia para a Ciência Política por meio da interpretação de Kjellén.

${ }^{50}$ A tese do subimperialismo brasileiro exposta em Paulo Schilling é bastante distinta do seu significado original, desenvolvido em Subdesarollo Y Revolución (1970) de Ruy Mauro Marini. Em Marini, como destaca Leonel Itaussu Mello (1997), a tese do subimperialismo estava centrada fundamentalmente em questões econômicas, como a transferência de indústrias, capital e tecnologia dos países centrais para o Brasil. Schilling (Op. Cit.) se concentra em questões geopolíticas para defender sua versão do subimperialismo. Destaca, sobretudo, questões que passam pela posição geográfica, recursos naturais, uso estratégico de bacias hidrográficas e usinas hidroelétricas etc. De igual relevância, afirma que o auxílio a golpes de Estado no Chile e Bolívia foi uma forma utilizada pelo Brasil para se colocar como uma potência subimperialista aliada dos Estados Unidos.
} 
Spektor (2008, p. 50) o governo Médice impôs dificuldades ao objetivo abertamente defendido por Henry Kissinger (ainda como Assessor de Segurança Nacional da Casa Branca) de delegar poder e influência para o Brasil. Nesse sentido, havia uma resistência a Doutrina Nixon, e sua prerrogativa de que os aliados passariam a ter a responsabilidade de se defenderem do comunismo. Como destaca Spektor (Op. Cit.) o Brasil não estava disposto a arcar sozinho com os custos de enfrentar a Guerra Fria na região.

Spektor (Op. Cit.) destaca ainda outro aspecto que era temido pelo Brasil. Para o Governo Médice esse alinhamento explícito poderia prejudicar a relação do país com seus vizinhos, que passariam a se sentir ameaçados. A esse respeito, deve-se ressaltar que o pragmatismo político do Governo Geisel na década de 1970 enfraquecia ainda mais o valor de uma aliança com os norte-americanos. Interesses nacionalistas passaram, muitas vezes, a se sobrepor a aspectos do alinhamento automático com os Estados Unidos. Nesse governo, as diferenças entre os dois países tornam-se ainda maiores. Spektor (Op. Cit.) argumenta que Geisel e Azeredo da Silveira, seu ministro das relações exteriores, forçaram uma importante guinada na política externa, onde o pragmatismo político era exercido por meio de uma visão ecumênica. Dessa forma, o país expandiria seus laços políticos independentemente de credo, filiação ideológica ou etnia. A partir desse momento, o anticomunismo não poderia ser o único guia da diplomacia levada a cabo pelo Itamaraty e Palácio do Planalto. Relações com o Oriente Médio, África Negra e China passaram a ser entendidas como fundamentais para os interesses do país.

Embora a consolidação da nova direção da política externa brasileira na década de 1970 revele os limites da perspectiva de Golbery do Couto e Silva, sua "inversão" é a primeira definição do escopo geográfico da projeção internacional do Brasil. Apesar de sua concepção estar relacionada à política externa conduzida na primeira década do regime militar, perde força com o pragmatismo adotado por Geisel e Azeredo da Silveira. Isso corrobora com o entendimento de que a influência do seu discurso geopolítico na diplomacia brasileira fora bem menor do que comumente argumentado. Foi justamente o governo em que foi chefe da Casa Civil, que mudou a política externa numa linha bastante ousada para a geopolítica militar. 
A expectativa de aproximação com Pequim, que compunha com Moscou o eixo de poder do "Hemiciclo Exterior", era o mais evidente sinal das limitações da escola geopolítica brasileira. Mas isso não impediu Golbery do Couto e Silva de colocar com certa precisão - a partir do que definia como os três campos da geopolítica nacional: o interno, o continental e o mundial - a arena internacional do Brasil. Nesse campo, o país ocuparia uma posição de liderança na América do Sul, no Atlântico Sul e na África Ocidental. Apesar da limitação do "Hemiciclo Interior" à atuação internacional do Brasil, há inegavelmente em seu discurso uma perspectiva de inserção do país enquanto ator relevante na ordem internacional bipolar.

Também nesse sentido, sua obra apresentou uma síntese entre o pensamento geopolítico clássico e os novos imperativos colocados pelo vetor científico-tecnológico em escala mundial. É dessa forma que visa ampliar o alcance do discurso geopolítico para além da dimensão puramente territorial. Para Golbery do Couto e Silva (Op. Cit. p.166) a geopolítica atua no domínio estratégico e não-estratégico.

Assim como Meira Mattos (2004) que destaca o transbordamento do campo estratégico para o planejamento empresarial e científico, Golbery do Couto e Silva vê o domínio não-estratégico no campo do progresso e desenvolvimento. Daí sua concepção de "Poder Nacional" como forma integrada dos meios políticos, psicossociais, econômicos e militares. Esse desdobramento do planejamento rompe o ambiente militar, alcançando as instituições civis. A ação do Estado é condicionada a "Estratégia de Segurança Nacional." Os militares exerciam um poder que passava pelo plano governamental e institucional. A planificação abrangia o território, a economia e o conjunto das instituições (BECKER \& EGLER, 1992).

$\mathrm{Na}$ proposta de Golbery do Couto e Silva (Op. Cit.), a "Estratégia Nacional" impõe-se como um grande arcabouço, compreendendo as estratégias política, psicossocial, econômica e militar. Em conjunto, compõem o que denomina de Poder Nacional. A força de coesão de todo esse processo é o nacionalismo, o maior de todos os valores. De certa forma, Golbery do Couto e Silva o entende como força gravitacional, isto é, um poder natural exercido sobre todos os homens. Em seu discurso, a ideologia da unidade nacional é um "absoluto em si mesmo" (Op. Cit. p. 99). 
O exame do modelo defendido pelo discurso geopolítico brasileiro torna imprescindível revisitar a filiação teórica de Golbery do Couto e Silva. Esse processo não se faz necessário apenas para compreensão da sua abordagem. Quando se trata de geopolítica não estamos lindando apenas com os discursos, mas também com imagens (FOUCHER, 2000, p. 163). Nesse sentido, retomar a filiação teórica de Golbery do Couto e Silva significa, sobretudo, avançar no entendimento da "imagem geopolítica" do Brasil, forjada pelos militares a partir dessa disciplina.

Apesar de Golbery do Couto e Silva criticar o endeusamento do Estado à custa do indivíduo, o regime autoritário em que se destacava enquanto policy maker se sustentava por uma posição oposta. Ao trilhar a tradição geopolítica anglo-saxã, onde Mahan, Mackinder e Spykman são raízes ideológicas, Golbery do Couto e Silva opta por uma vertente não muito distinta da natureza autoritária do Estado alemão até o final da Primeira Guerra Mundial. ${ }^{51}$ Mackinder, apesar de alertar a elite política do seu país acerca da ameaça representada pelo modelo autoritário germânico, nutria por este, forte admiração. O geógrafo inglês apreciava e temia a capacidade de desenvolvimento territorial, econômico, bélico e social da emergente potência. Embora não defendesse a mudança do liberalismo inglês para um modelo autoritário, certamente ansiava por mais poder disciplinador do Estado.

Ironicamente, seu entusiasmo pelo modelo monárquico inglês, territorialmente menos centralizado, o tornava crítico do Estado centralizado. Mesmo que o modelo de Estado não devesse ser excessivamente centralizado, a elite política deveria ser capaz de impor a questão nacional acima de todos os demais valores. O alvo de sua crítica não era o paradigma de poder fundado na economia política, mas o laissez-faire. Mackinder (1942) entende que a Inglaterra carece justamente daquilo que não falta à Alemanha: o organizer. Tendo como figura ideal Otto von Bismarck, para Mackinder o organizer era um disciplinador,

\footnotetext{
51 Muitos críticos do pensamento clássico dessa disciplina acabam dando tratamento indistinto às diferentes escolas dessa disciplina, o que acaba se revelando num grave equívoco teórico. O pensamento de Halford Mackinder não pode ser associado indiscriminadamente à escola geopolítica de Munique, de fortes conexões com o regime nazista, embora tenha exercido, de forma explícita sobre o primeiro e implícita sobre o segundo, inegável influência. Importantes analistas buscam na filosofia política os meios para compreensão do pensamento do geógrafo inglês. Para Wanderley Messias da Costa (1992) o pensamento de Mackinder guia-se pelo que denomina de "realismo geográfico." Importantes aspectos do discurso de Mackinder encontram explicação em sua filiação hobbesiana, base de sua análise acerca da política internacional. Ó Tuathail (1992; 1996) destaca, por outro lado, como força norteadora do pensamento de Mackinder, o "romantismo" de tendência monarquista.
} 
impondo por meio da forte presença do Estado, novos valores políticos, sociais e culturais.

Há um conjunto de temas em comum na geopolítica brasileira formulada pelos egressos da ESG. A inter-relação entre capitalismo, americanismo (ocidentalismo) e projeção sul-americana do Brasil é um aspecto estruturante do discurso geopolítico nacional. Isso the confere uma característica bastante particular no conjunto dos discursos produzidos no interior dessa disciplina, tanto na Europa quanto nos Estados Unidos. Por sua origem, seus temas centrais e o momento histórico em que ganhou relevância, esse discurso se define por meio de uma geopolítica essencialmente militar. Isso significa admitir que o conteúdo geoestratégico seja mais territorialista do que aquele elaborado no hemisfério norte.

O alcance da geopolítica nesse período irá transcender os discursos de projeção internacional e planejamento territorial. É com essa visão que Meira Mattos (1975) defende a mudança do paradigma de Defesa Nacional pela Doutrina de Segurança Nacional feita pelos militares na década de 1960. Castelo Branco, na condição de um dos principais mentores dessa doutrina, salienta que a Defesa Nacional está circunscrita aos aspectos militares e às possibilidades de agressão externa.

Por outro lado, o conceito de Segurança Nacional abarca a defesa global de todas as instituições do Estado, incorporando aspectos psicossociais na busca pela estabilidade política. Dessa forma, essa concepção leva em consideração a agressão interna, pela infiltração daquilo que os militares entendiam como subversão ideológica. Destacam-se nesse caso principalmente os movimentos sociais, as guerrilhas e os partidos de orientação esquerdista. Esse aspecto se enquadra com precisão nas proposições trazidas pelo containment americano desde a formulação inaugural de George Kennan (1945). A Doutrina de Segurança Nacional é fundamentalmente um meio de disciplinarização de todo o espaço nacional.

O crescimento econômico, como parte integrante da Doutrina de Segurança Nacional, funcionava como importante meio de legitimação interna do regime. À medida que a expansão do PIB durante os governos militares alçou o Brasil à condição de uma das maiores economias mundiais, forneceu ao país maior envergadura em sua inserção internacional. Sob os auspícios dos militares, 
o projeto geopolítico da modernidade caracterizou-se como uma via singular de projeção internacional. Tal como analisou Mackinder (1942) em relação ao modelo prussiano, o planejamento econômico e territorial centralizado levado a cabo pelo regime militar no Brasil estabelece o Estado nacional como unidade básica do poder. 


\section{Colapso da Geopolítica Militar e Origens da Integração Regional} bridge.

Franklin D. Roosevelt

\subsection{Inter-Relação entre as Conjunturas Regional e Mundial}

Embora os militares defendessem o padrão geoestratégico angloamericano, o nacionalismo enquanto "absoluto em si mesmo" reforçava uma concepção germânica de poder nacional. ${ }^{52}$ Mesmo que durante os governos militares tenha havido forte expansão do PIB e desenvolvimento de setores industriais e tecnológicos estratégicos, esse modelo enfrentou graves limitações com o fim da "era de ouro" da economia mundial. O crescimento econômico centralizado, socialmente excludente e altamente condicionado ao financiamento internacional não foi o único fator de limitação do modelo geopolítico militar brasileiro.

\footnotetext{
52 Na forma como está sendo empregado, o termo "concepção germânica" não tem relação com "via prussiana". Partindo da discussão feita por Mackinder em Democratic Ideals and Reality (1942), esse termo está circunscrito aos aspectos geopolíticos do planejamento estatal, em que economia, território, além de outras estâncias da sociedade, estão subordinados a um modelo de Estado centralizador e disciplinador. Mackinder (Op. Cit.) faz a diferenciação entre o modelo inglês e o germânico, exatamente no sentido de ressaltar as potencialidades geopolíticas de uma visão nacionalista e disciplinadora adotada pela Alemanha.
} 
As condições do alinhamento automático com os Estados Unidos e a geopolítica regional sul-americana tornaram-se empecilhos para 0 desenvolvimento de toda região. Tal qual analisado no capítulo anterior, junto à consolidação de novos centros mundiais do capitalismo, a crise econômica mundial desencadeada a partir de 1973, fez com que alguns países do continente reavaliassem a relação com os Estados Unidos. As transformações da economia geopolítica internacional, ao estabelecer um ambiente favorável ao crescimento de outras regiões, tornaram possível a reavaliação da relação com os norteamericanos.

Mas na virada dos anos 1970 para os anos 1980 houve nova reorganização da economia geopolítica internacional, que resultou na crise da dívida e na hiperinflação aos países sul-americanos. Essas transformações, que tiveram importante influência para a mudança da política regional no continente, estilhaçaram, sobretudo, os fundamentos da geopolítica de projeção mundial do Brasil.

Alguns autores destacam fatores gerais que levaram esses países a uma crise econômica profunda. A recessão econômica dos anos 1980 forçou a queda dos preços das matérias-primas e reduziu as exportações (BECKER \& EGLER, 1992, p. 237). Isto causou graves problemas para a balança externa de toda América Latina, fazendo com que seus países mergulhassem num profundo problema de déficits. Essa situação, que comprometeu por décadas a condição financeira na região, não é somente resultado de uma situação econômica desfavorável.

A influência das grandes corporações e a explosão da oferta de dólar barato permitiu, como demonstra Arrighi (2008), o retorno do mercado autoregulado e a reorganização da economia geopolítica em outras bases. O dólar abundante e a economia internacional favorável até meados dos anos 1970 evoluíram para uma conjuntura extremamente negativa. Nos anos 1980, a crise da dívida e a hiperinflação se tornaram uma expressão cruel da falência do modelo geopolítico militar.

A restrição monetária posta em curso por Paul Volcker (presidente do Federal Reserve - FED) no final do governo Carter fez o que o poder militar norteamericano não seria capaz de fazer: por os países pobres de joelhos (Op. Cit.). Colocando de forma mais específica, as políticas de restrição a oferta do dólar 
elevou seu valor, agudizou a crise, e diminuiu a demanda pelas commodities produzidas pelos países sul-americanos. A crise enfrentada na América do Sul na década de 1980 é resultado da geopolítica conservadora, que remonta ao territorialismo que predominou na política internacional até o final da Segunda Guerra Mundial.

A visão anacrônica não se evidencia apenas pelo territorialismo, mas, também, pela defesa incondicional de um modelo de aliança com os Estados Unidos que não contribuía, por exemplo, para o rompimento de deficiências tecnológicas em setores estratégicos. Ao se referir à idéia de "Terceira Posição" defendida por Perón na Argentina, Golbery do Couto e Silva alertava para o crescimento da oposição aos Estados Unidos entre os vizinhos hispanoamericanos. $^{53}$

Golbery do Couto e Silva apelava aos discursos que destacavam a longa tradição de amizade entre Estados Unidos e Brasil e o caráter não competitivo de suas economias. Embora não fosse prudente ao governo brasileiro uma posição antiamericanista, o alinhamento automático aos Estados Unidos também fragilizava a condição internacional de toda América do Sul. Uma soma de fatores resultou numa conjuntura que passou a representar sérias limitações aos países sul-americanos. O equilíbrio de poder, a busca por relações preferenciais com os Estados Unidos, as geopolíticas de contenção e o modelo econômico altamente dependente do financiamento externo resultaram em efeitos devastadores para os países.

Embora o Brasil fosse inegavelmente a grande âncora americana na América do Sul, a relação entre os dois países também passou por grandes tensões. Durante a década de 1970, à medida que o Brasil consolidava o crescimento econômico e ampliava suas pretensões regionais e globais, também se colocava como desafio aos Estados Unidos. A partir do governo Carter, as diferenças entre os dois países tornaram-se ainda mais visíveis. A tolerância em relação ao regime militar demonstrada pelas administrações Nixon e Ford, perdeu espaço com o discurso em defesa dos direitos humanos do governo seguinte. Talvez, um dos episódios mais emblemáticos dessa condição seja o acordo com a

\footnotetext{
${ }^{53}$ Nos dois momentos em que Perón governou a Argentina, se posicionava contra o alinhamento da região com os Estados Unidos e defendia a "Terceira Posição". Segundo Schilling (1981), o presidente argentino era defensor de uma aliança política entre os países do Cone Sul, que por sua vez não deveriam manter alinhamento incondicional com os Estados Unidos ou com a União Soviética.
} 
Alemanha para transferência de tecnologia e construção de usinas nucleares no Brasil.

Pelo temor de disseminação de armas nucleares, o tratado entre Brasil e Alemanha alarmou a opinião pública mundial, tendo nos Estados Unidos os maiores opositores. A famosa justificativa de Roosevelt a respeito da aliança com os soviéticos durante a guerra nos serve como sinal: o pragmatismo político americano permite "caminhar com o diabo", mas apenas até a superação de uma conjuntura desfavorável. Embora a oposição as ditaduras militares fosse uma diretriz do governo Carter, essa postura apenas se tornou possível com a détente iniciada no final dos anos 1960 e o arrefecimento da ameaça comunista no continente.

Mas o distanciamento entre os dois países também aconteceu por outros fatores. A liderança econômica incontestável dos Estados Unidos e o caráter conservador da modernização posta em marcha nos principais países do Cone Sul fizeram com que, até meados da década de 1970, a região seguisse seu receituário. De 1974 em diante, essa postura perde força no Brasil, em prol de um pragmatismo que refletia duas grandes tendências no cenário internacional. A crise de hegemonia dos Estados Unidos e a consolidação de outros centros do capitalismo mundial.

Essa segunda tendência se destaca pela ascensão do Leste Asiático liderado pelo Japão, e da Europa Ocidental com o processo de integração regional. As principais nações da Europa Ocidental retomam, através de outro paradigma, sua relevância geopolítica mundial. Junto ao Japão, representa novas possibilidades de alianças a países periféricos aos interesses dos Estados Unidos. $^{54}$

\footnotetext{
${ }^{54}$ Matias Spektor (2008, pp. 71-73) defende que o ideário ativista na política externa brasileira não surgiu repentinamente em 1973. Lembra-nos que havia vinte anos que essa postura se manifestava com os ideais de "universalização", "ecumenismo", "diversificação das parcerias" etc. Spektor (Op. Cit.) salienta que embora não houvesse grupos ou estadistas atrelados a um projeto dessa natureza, existiam importantes vozes no Itamaraty, como o embaixador (nos Estados Unidos) João Augusto de Araújo Castro e Azeredo da Silveira, cujas cartas e correspondências trocadas entre si demonstravam essa posição. Na visão desses diplomatas, um país com as dimensões do Brasil deveria abandonar a política externa introspectiva. Moniz Bandeira (1992) faz ponderacõos semelhantes. Defende que antes de 1974, o Brasil já adotava uma política externa pragmática, abandonando o alinhamento automático com os Estados Unidos. Nesse sentido, lembra que em 1966, ainda durante o governo de Castelo Branco, o Brasil abdica da doutrina das fronteiras ideológicas. Essa postura, que se estende durante o governo de Costa e Silva, ocorre principalmente devido à grande repercussão negativa do envio de tropas para auxiliar os americanos na ocupação da República Dominicana. Moniz Bandeira (Op. Cit.) defende que Costa e Silva resgata uma política externa soberana, muito próxima daquela praticada nos governos de Jânio Quadros e João Goulart. O autor vai mais além, afirmando que os militares abandonam o alinhamento subalterno por vislumbrarem um destino manifesto, imposto ao Brasil por sua geografia. Apesar dos fatores elencados por Moniz Bandeira, nenhum desses governos alterou de forma tão radical o quadro da relação com os Estados Unidos quanto Geisel e Azeredo da Silveira, que desafiaram o modelo vigente em diversas frentes da política exterior.
} 
Esse período significa também uma inflexão na relação do Brasil com a Argentina. Recordamos com Hélio Jaguaribe (2005) que historicamente a relação entre as duas nações oscilou entre momentos de cooperação e rivalidade. Desde as sucessivas tentativas portuguesas de ultrapassar os limites territoriais do Brasil, impostos pelo Tratado de Madri, as relações com a Argentina experimentaram inúmeros atritos.

Todavia, com a proposta do Tratado do ABC entre Chile, Brasil e Argentina, posta por Rio Branco no inicio do século $X X$ - assim como as aproximações entre os três países nas décadas de 1940 e 1950 inspiradas nessa iniciativa - os esforços de cooperação entre os dois países ganham importante impulso. ${ }^{55}$

Mesmo no início do regime militar existiam iniciativas para a ampliação das relações Brasil - Argentina. Nesse período, os dois países mantiveram diálogos buscando estreitar as relações comerciais em setores estratégicos para a América do Sul. Roberto Campos, quando ministro do planejamento de Castelo Branco, propôs ao governo argentino a formação de uma união aduaneira que se estenderia aos demais países da região (MONIZ BANDEIRA, 1992). Esse acordo envolveria exclusivamente os setores siderúrgicos, petroquímicos e agrícolas dos países signatários.

Nessa mesma época, o Brasil se dispunha junto à Argentina, Bolívia, Paraguai e Uruguai, a construção de uma siderúrgica multinacional em Corumbá para o aproveitamento das jazidas de ferro de El Mutum na Bolívia (Op. Cit.). Ainda se destaca como iniciativa do gênero, a proposta argentina de integração territorial na Bacia do Prata, feita durante o governo de Arturo Umberto Illia (19631966). As possibilidades de ampliação da integração física entre Uruguai, Paraguai, Brasil e Argentina esbarrariam, dentre outros fatores, em interesses geoestratégicos.

A contenda envolvendo o aproveitamento do potencial energético do rio Paraná acabou se destacando como um dos principais pontos de atritos entre os países. Se comparado a Argentina, o Brasil era menos dependente do potencial hidroelétrico do Rio Paraná, tendo à sua disposição o potencial da Bacia Amazônica (SCHILLING, 1981). Além disso, a construção de uma grande

\footnotetext{
${ }^{55}$ As políticas brasileiras de aproximação com a Argentina foram até os governos de Jânio Quadros e João Goulart. Quadros, no seu curto governo, e Arturo Frondizi, presidente argentino entre 1958 e 1962, visavam estreitar relações através de acordos comerciais.
} 
barragem no rio Paraná comprometeria a navegação em um eixo tradicional de vertebramento do território, e afetaria interesses fundamentais da economia argentina. $^{56}$

\subsection{Rivalidades Geopolíticas e Fragmentação do Continente}

A rivalidade regional não se impõe apenas pela questão geoestratégica. $A$ influência mútua de três fatores definiu a política continental do Brasil durante as décadas de 1960 e 1970. Há uma convergência entre o discurso geopolítico militar brasileiro, a diplomacia do país nesse período, e a concepção de fronteiras ideológicas.

Em conjunto, geram efeitos em toda política sul-americana. Impulsiona os processos de contenção em detrimento da cooperação, intensificando as rivalidades. Os discursos geopolíticos contribuíram para a imagem expansionista do Brasil, ao mesmo tempo em que sua diplomacia se destacava por uma abordagem internacionalista que freqüentemente ignorava seus vizinhos. Na maior parte do século $\mathrm{XX}$, quando o contexto regional aparece na argumentação internacionalista do país "... o faz apenas de forma tangencial e indireta" (SPEKTOR, 2010, p. 34).

A doutrina das fronteiras ideológicas acabou impondo barreiras às relações dos países sul-americanos. Ao relativizar a soberania nacional em favor do anticomunismo, a doutrina possibilitava um viés autoritário na relação de Brasil e Argentina com os demais países. A assinatura do Acordo de Cartágena em 1966, entre Chile, Bolívia, Venezuela, Peru e Equador, para criação do Pacto Andino foi um movimento de cooperação regional que representava também uma divisão do continente por blocos como forma de equilibrar as relações com as duas principais potências sul-americanas. A criação desse bloco econômico resultava numa importante fratura da Associação Latino Americana de Livre Comércio $(\mathrm{ALALC}){ }^{57}$

\footnotetext{
${ }^{56}$ Segundo Paulo Schilling (1981), a exploração argentina dos minérios de ferro e manganês da reserva boliviana de Mutum era um fator fundamental para o desenvolvimento industrial do país. Entre as décadas de 1960 e 1970 , essa exploração era altamente dependente da navegabilidade dos rios da Bacia do Prata. Entretanto, Wanderley Messias da Costa (1999, p. 37) destaca outro aspecto, lembrando que Itaipu desempenhou importante papel na perenização das relações do Brasil com o Paraguai.

${ }^{57}$ Muitos países oscilavam na relação entre Brasil e Argentina, devido à fragilidades frente às duas potências regionais. Criouse a percepção de que as alianças levariam ao fortalecimento contra essas fragilidades. Quagliotti de Bellis, influente geopolítico uruguaio e um dos primeiros a ter essa percepção, propunha uma aliança estratégica entre Uruguai, Paraguai e
} 
Não é por outro motivo que Golbery do Couto e Silva (1967, p. 75) adverte sobre a ameaça posta pela constituição de blocos regionais políticos ou apenas econômicos. A partir do realismo geográfico, entendia que este novo ente político poderia comprometer a paz. Argumentamos anteriormente com Kelly (1997), que historicamente as alianças - bilaterais ou multilaterais - levaram o continente sulamericano a um equilíbrio regional de poder. No entanto, a influência de potências externas e a fragmentação interna não foram exclusivamente impostas por esse aspecto.

É necessário levar em consideração que a situação da América do Sul na ordem internacional está indissociavelmente atrelada a sua condição de mais antiga periferia do capitalismo. O Brasil, dentro de uma das áreas mais influenciadas pelo poder imperial dos Estados Unidos - que como destaca Hardt \& Negri (2005), foi marcado pela descentralização da produção industrial - teve uma das mais meteóricas ascensões econômicas do século $X X$. O rápido crescimento foi, em parte, sustentado por relações prioritárias com o centro mundial do capitalismo. O modo como os Estados Unidos consolidaram sua hegemonia mundial, fundada em grande parte no poder transnacional de suas corporações (ARRIGHI, 2008), foi determinante para o enfraquecimento da política regional sulamericana.

A desconcentração industrial (SASSEN, 2001) reforçou ainda mais a tendência dominante entre os países sul-americanos, de relações preferenciais com os países ricos. ${ }^{58}$ Haroldo Ramanzini Júnior \& Haroldo Vigevani (2010, p. 47), são bastante enfáticos a esse respeito, entendendo o retrocesso da integração como reflexo desse padrão de relação. A divisão internacional do trabalho, num "sistema mundo" pensado a partir da separação centro / periferia, privilegiou a América Latina no debate desenvolvimentista nas décadas de 1960 e 1970 (GALVÃO, 2009, p. 65).

A tendência de relações preferenciais com os países ricos, dominante em todo continente, reforçou o acirramento dos interesses nacionais em detrimento da

Bolívia (URUPABOL) como fortalecimento frente às principais forças do continente. Entendia que o enfraquecimento dos países de língua hispânica pelo processo de balcanização é um meio pelo qual Argentina e Brasil se impunham na América do Sul.

58 Há uma diferença imposta pelo uso do conceito de "desconcentração industrial" em relação à "descentralização das atividades industriais". Quando Hardt \& Negri (2005) utilizam "descentralização" estão se referindo a um processo geral, onde os Estados Unidos exportaram suas plantas industriais para o Terceiro Mundo como forma de exercício de hegemonia. Embora se preocupem com questões econômicas, os autores têm uma premissa essencialmente política. Saskia Sassen (2001), ao utilizar "desconcentração industrial", enfatiza o caráter geográfico de uma mudança econômica global. Enquanto essa transformação amplia o alcance geográfico da produção industrial, mantém o comando dessas atividades concentrado nos países ricos. 
política regional. Impediu, dessa forma, um projeto de integração de facto, à medida que para alcançá-lo, deve haver “... concessões recíprocas, onde quem detém mais poder teria que se dispor a concessões maiores..." (RAMANZINI Jr.\& VIGEVANI, 2010, p. 47). Enquanto os Estados Unidos estabeleciam um conjunto de alianças com as principais regiões industrializadas do hemisfério norte, os países sul-americanos formavam um conjunto desarticulado de países do Terceiro Mundo.

A divisão do espaço mundial em primeiro, segundo e terceiro mundos na Ordem Geopolítica da Guerra Fria (AGNEW \& CORBRIDGE, 1995), não permite compreender somente a situação internacional dos países sul-americanos. A despeito do Movimento dos Países Não Alinhados, as nações terceiro-mundistas não foram capazes de articular alianças que alterassem a ordem internacional, por uma questão de dependência política, econômica e tecnológica. ${ }^{59}$ Essa questão é recorrente em todo continente, pois as relações prioritárias com os países desenvolvidos, a falta de complementaridade econômica e as dificuldades derivadas da pobreza, impedem a concretização de alianças regionais amplas (RAMANZINI Jr. \& VIGEVANI 2010, p. 47). Falta aos países sul-americanos, força política e econômica, fator que contribuiu para perpetuar o status de espaço de subordinação.

Os sul-americanos reforçaram a condição de continente fragmentado nas décadas de 1960 e 1970. A reivindicação de suporte econômico americano à América Latina lançada por Kubistchek por meio da OPA tinha a importante prerrogativa de propor a cooperação entre a maior potência mundial e o continente latino-americano, como forma de desenvolvimento regional no auge da Guerra Fria.

Ainda que a análise elaborada por Gaddis (2005b) permita inferir que esse princípio estivesse limitado pelo containment dos Estados Unidos, direcionado especialmente a Europa e o Leste Asiático, a OPA pressupunha semelhanças nas condições econômicas, políticas e sociais dos países latino-americanos. De acordo com Santos (2005, p. 13) essa identificação da diplomacia brasileira com os países

\footnotetext{
59 Os países do Terceiro Mundo não foram capazes de estabelecer um nível de cooperação que permitisse alavancar o desenvolvimento. Como observa Agnew \& Corbridge (1995), o Terceiro Mundo permaneceu até o fim da ordem bipolar, como espaço de disputa entre o Primeiro e o Segundo Mundo. Todavia, esses países tiveram durante as últimas décadas da Guerra Fria, a ONU como um espaço de luta política frente às grandes potências. Spektor (2008, pp. 122-123) destaca a vitória dos países terceiro-mundistas na aprovação de uma resolução, cujo esboço fora discutido em 17 de outubro de 1975 no Comitê Social, Humanitário e Cultural da Assembléia Geral da UNU, que igualava o sionismo a "... uma forma de racismo e discriminação racial”.
} 
em desenvolvimento ganha ainda mais peso durante os governos Quadros e Goulart. $^{60}$

A ALALC, formada pelo Tratado de Montevidéu em 18 de fevereiro de 1960, é bastante simbólica no que tange ao abrandamento da investida integracionista no continente. Enquanto em seu princípio a ALALC ilustra a tendência de cooperação em âmbito latino-americano, o seu posterior fracasso remete às limitações dos regimes autoritários em relação à cooperação. Porém, seria demasiadamente imprudente relacionar o fracasso da integração sulamericana nas décadas de 1960 e 1970 apenas ao territorialismo militar, esquecendo-se de que se trata de uma questão conjuntural. Seguindo a tendência de cooperação entre as duas principais potências sul-americanas nos primeiros anos do regime militar brasileiro, têm-se a assinatura do Tratado da Bacia do Prata em 1969.

Embora o acordo estivesse em consonância com a proposta de integração física da região feita pelo governo de Umberto Illia, a assinatura se deu sob ditaduras militares do Brasil (governo Costa e Silva) e da Argentina (governo Onganía). Assinado inicialmente por Uruguai, Paraguai, Bolívia, Brasil e Argentina, esse acordo acabou se convertendo num importante background dos projetos futuros.

É dele decorrente a primeira investida sistemática de integração territorial no Cone Sul, assim como o surgimento do Fundo Financeiro para 0 Desenvolvimento dos Países da Bacia do Prata (FONPLATA). Cabe destacar que desde sua fundação, esse organismo multilateral tem focado no financiamento de projetos de integração e desenvolvimento regional. ${ }^{61}$ Entretanto, a partir de meados da década de 1970, esse tipo de cooperação se torna precária pela crise econômica mundial e a deterioração das condições financeiras dos cinco países signatários. Lavando em consideração a importância do equilíbrio de poder, o territorialismo militar se destaca apenas como outro dado relevante dessa equação.

\footnotetext{
60 Segundo Santos (2005) se desenvolveu nesses dois governos uma "política externa independente", onde o Brasil se identifica com os países em desenvolvimento e o seu discurso diplomático foca em questões do debate Norte-Sul. A "política externa independente" não se restringiu a América Latina, incorporando países da África e Ásia e, advogando em favor da descolonização etc.

61 O FONPLATA foi criado com a função de garantir apoio técnico e financeiro a estudos, projetos, obras etc., visando o desenvolvimento e a integração física entre os países que compõe a Bacia do Prata. Esses projetos envolvem recursos hídricos, eletrificação, interconexões viárias, ferroviárias, fluviais, aéreas, e projetos de habitação popular, de telecomunicações, etc.
} 
Todavia, a concepção de projeção continental do Brasil expressa pelo discurso geopolítico, ao influenciar o acirramento das políticas de equilíbrio de poder das décadas de 1960 e 1970, acabava funcionando como contrapeso às iniciativas de cooperação. A ascensão dos militares não reforçou apenas 0 equilíbrio regional de poder em torno de Brasil e Argentina. Embora o alinhamento dos demais países junto às duas principais forças do continente seja o caso mais significativo de equilíbrio de poder, o Pacto Andino é, como argumentado nos parágrafos anteriores, emblemático a esse respeito. Destaca-se nesse caso, o papel contraproducente da doutrina das fronteiras ideológicas, que atingiu valor supranacional com os militares no poder. As possibilidades de intervenção estimularam o alinhamento entre países sul-americanos fora do Cone Sul como forma de contrabalancear as vantagens geopolíticas dessa região. A postura diplomática do Brasil, distanciada em relação aos países fora da porção meridional, não era dissonante da fragmentação do continente. Spektor (2010, p. 25) destaca que até 1981, nenhum chefe de Estado brasileiro havia visitado o Peru ou a Colômbia.

A ameaça transnacional representada pela doutrina das fronteiras ideológicas, e a assimetria econômica, política e territorial entre Brasil e Argentina de um lado, e os demais países de outro, recrudesceu tendências fragmentárias históricas. Esse arranjo era predominante pela influência hegemônica americana na porção setentrional do continente, constante durante todo século XX. Saraiva \& Ruiz (2009, p. 157) chamam atenção para o fato de que a Venezuela, como país de múltipla identidade - andina, caribenha, e mesmo amazônica - manteve até o final do século $X X$, interesses prioritários em relação à Cuenca do Caribe. Contribuía ainda a esse respeito, a forma brasileira, argentina e chilena de circunscrever suas políticas sul-americanas ao Cone Sul, desde o início do século passado.

A concepção de continente sul-americano restrita somente a essa área, originária das primeiras décadas da fundação da República no Brasil (SANTOS, 2005, p. 4), permaneceu predominante na diplomacia do país durante a primeira década do regime militar. Afora a iniciativa do Pacto Andino e do Tratado de Cooperação Amazônica (TCA) firmado em 1978, as ações buscando uma política regional autônoma eram fundamentalmente resultado de relações interestatais na porção meridional sul-americana. Embora a partir da década de 1950 houvesse 
importantes impulsos rumo à integração de áreas fronteiriças, o continente manteve a condição de espaço fragmentado até as últimas décadas do século passado.

Isso remete à importantes questões relacionadas à interdependência entre articulação de um espaço regional e os interesses políticos. Na Geografia, o espaço é compreendido de modo inseparável da ciência e técnica desde o final do século XIX. Durante o século $X X$, as análises de áreas geográficas segundo 0 movimento e a fluidez posta por diferentes sistemas técnicos ganha, aos poucos, importância. É no auge dessa tendência, que Étienne Juillard (1965, pp. 224-236), adverte que o espaço não pode ser concebido somente "como uma justaposição de áreas mais ou menos extensas, mas como o campo de ação de fluxos de toda ordem..."

Richard Hartshorne $(1939,1950 ; 1959)$ demonstra que a "homogeneidade de uma área" está necessariamente relacionada à sua interconectividade interna. ${ }^{62}$ A integração regional é dada por sistemas técnicos, permitindo aquilo que Preston James (1967, p. 03) define como “... interconexão entre coisas e acontecimentos de origens diferentes". O aprofundamento das interações políticas, econômicas e sociais no contexto da globalização torna a fluidez material e informacional uma condição ainda mais determinante aos espaços regionais. A fluidez tem sido um aspecto importante para o estudo regional desde a década de 1930. Mas, seja através do funcionalismo de Hartshorne (1939, 1950; 1959), dos "tipos ideais" de rede urbana de Harris \& Ullman (1945) ou na geografia francesa das décadas de 1960 e 1970, a escala subnacional se destacou na condição de foco privilegiado para o entendimento da circulação no interior da região. Todavia, com a globalização, a formação dos blocos econômicos impôs uma reordenação da circulação, trazendo uma forte característica de extroversão aos espaços nacionais.

Além do mais, a integração européia tem demonstrado que a região possui também um sentido geopolítico. Mas trata-se, ao contrário, de um sentido "inverso", onde as forças centrípetas nacionais são, em determinadas questões, suplantadas por forças centrífugas que reordenam as redes territoriais em favor de

\footnotetext{
62 Homogeneidade tem uma conotação específica em geografia regional, pois não significa ausência de variações históricas, geográficas e culturais. Como ensina Derwent Whittlesey $(1960$, p. 13) a homogeneidade se refere a um conjunto de relações que dá coesão a uma área. Portanto, trata-se de um conjunto de variáveis (naturais ou artificiais) e forças (visíveis ou invisíveis) que moldam um determinado espaço, dando-lhe nesses termos certa homogeneidade, isto é, características em comum.
} 
relações continentais. A regionalização, como a construção de um espaço político, econômico e social integrado, estabelece-se como um paradigma da política internacional.

Enquanto na política européia do pós-guerra a região passa a ter uma conotação de cooperação, na América do Sul prevalece a desarticulação entre suas diversas áreas. $\mathrm{O}$ territorialismo, pedra angular das relações continentais, impede a regionalização e a conseqüente transformação das relações interestatais através da cooperação. Ao invés de uma região geopolítica de base integrativa e cooperacional, destaca-se a divisão da América do Sul em várias áreas desarticuladas.

Como demonstra o Mapa 1 (p. 90), essa segregação imprime ao continente uma divisão (que prevaleceu até os anos 1980) em quatro macro-áreas: amazônica, andina, meridional e oriental. O território da maioria dos países faz parte de mais de uma macro-área. Porém, a escassez de infra-estruturas de circulação territorial fez com que em quase todo século $X X$, elas fossem majoritariamente segregadas dos demais espaços sul-americanos. Na porção meridional, esta segregação era posta, principalmente, por políticas do Brasil, Argentina e Chile fundadas na manutenção do status quo fronteiriço (COSTA, 1999, p. 30).

A macro-área Amazônica compreende a Região Norte, Mato Grosso e Maranhão no Brasil, centro-norte da Bolívia, vertente oriental do Peru e Equador, departamentos do Amazonas, Caquetá, Guainía, Guaviare, Putumayo e Vaupés na Colômbia (ocupando $42 \%$ de todo território do país), Região Zuliana da Venezuela, Guiana, Suriname e Guiana Francesa. Esta macro-área era caracterizada até os anos 1970 por um grande vazio demográfico, ausência quase completa de infra-estruturas de transporte e comunicação e pela sua desarticulação com outras regiões dos países que a compõem. Esta condição é dada pelo fato de as nações andinas setentrionais terem suas relações políticas voltadas para o Caribe ou para o Pacífico. Historicamente, os países setentrionais mantiveram relações direcionadas a Cuenca do Caribe e aos Estados Unidos. A área não foi foco, apesar da assinatura do TCA de cooperação multilateral importante. ${ }^{63}$

${ }^{63}$ Faz parte do TCA um grupo de oito países amazônicos: Venezuela, Suriname, Guiana, Colômbia, Equador, Peru, Brasil e Bolívia. Assinado em Brasília durante o governo Geisel, esse tratado visa estabelecer cooperação em diversas áreas como 


\section{MAPA 1 \\ América do Sul: Macro-Áreas}

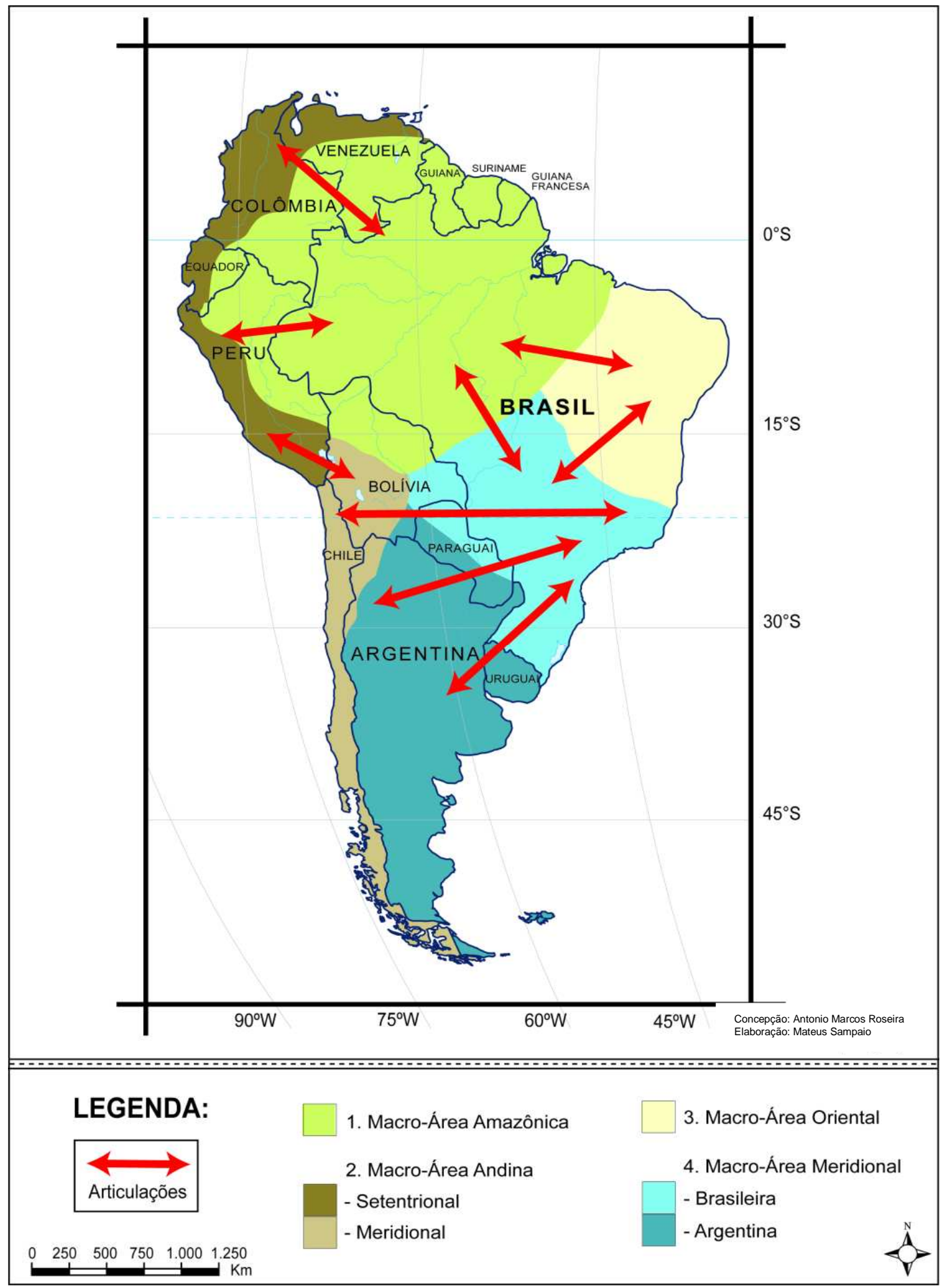

pesquisa científica, infra-estrutura, comércio, recursos naturais, e comunicação. Em 1995 foi criada a Organização do Tratado de Cooperação Amazônica, uma instituição multilateral formada pelos signatários que busca por em pratica os objetivos do TCA. 
A macro-área Andina é formada pelo Chile, regiões andinas da Bolívia, Peru, Equador, Colômbia e Venezuela. Este espaço foi o primeiro a criar um bloco econômico no continente, o Pacto Andino - atualmente Comunidade Andina de Nações (CAN). Pode ser dividida em Andina Meridional e Andina Setentrional. A primeira envolve toda região andina Boliviana até o extremo sul do Chile. Apesar dos atritos geopolíticos e da segregação geográfica, tanto Chile quanto Bolívia mantiveram relações com o restante do Cone Sul, fator que contribuiu para a aproximação desses países com o Mercosul nos anos 1990. A segunda (formada pela zona andina do Peru até a Venezuela) é uma zona mais voltada para o Pacífico, o Caribe e os Estados Unidos, com relações escassas com o interior do continente

Nessa região, Bolívia e Peru têm a importante posição de territórios intermediários entre as porções setentrionais e meridionais do continente. De modo geral, esta área se manteve bastante desconectada do interior do continente também devido a barreira representada pelo maciço andino. Por esse fator, as tensões fronteiriças internas (Chile- Bolívia, Peru-Equador, Colômbia-Venezuela) não impediram os seus países de manterem até os anos 1980, relações mais sólidas entre si - em detrimento de maior aproximação com o interior sulamericano. Esta tendência não se aplica apenas as relações bilaterais ChileBolívia.

A macro-área Oriental é composta pelo Nordeste brasileiro, porção oriental do Tocantins e áreas setentrionais de Minas Gerais. A região possui característica geográfica bastante singular. Se por um lado, é uma imensa península brasileira de projeção em direção ao Atlântico, por outro, é a única área brasileira apenas indiretamente conectada aos países hispânicos. A predominância dos grandes centros urbanos na costa atlântica, o baixo desenvolvimento do vetor tecno-industrial e a concentração de pobreza contribuem para o isolamento.

A macro-área Meridional abrange de leste a oeste, desde a vertente atlântica (do Rio de Janeiro até o Sul da Argentina) até regiões da vertente oriental das Cordilheiras dos Andes. De norte a Sul envolve o território boliviano (ao sul das cidades de Santa Cruz e Cochabamba), Mato Grosso Sul, São Paulo e centro sul de Minas, Espírito Santo, Rio de Janeiro até os limites austrais do território argentino. A área é definida pelo alcance do vetor tecno-industrial, cujos núcleos 
principais estão nos grandes eixos formados por Rio de Janeiro - São Paulo Campinas, no Brasil e Córdoba - Rosário - Buenos Aires, na Argentina. Dadas essas características, é dividida em duas zonas: Meridional Argentina e Meridional Brasileira.

A primeira é definida pelas forças centrípetas exercidas pelo vetor tecnoindustrial do país platino, que alcança o extremo sul do continente, Uruguai, Paraguai e Bolívia. Isso se tornou possível graças à conexão territorial com os dois países a partir da construção de ramais ferroviários que os mantiveram dependentes do Porto de Buenos Aires. A segunda demonstra o alcance do vetor tecno-industrial brasileiro, que se projeta para além do território nacional. A partir da década de 1950, as políticas de integração nacional, sobretudo aquelas que se deram no Sul e Sudeste, permitiram a projeção desse vetor ao Paraguai e Bolívia, relativizando, dessa forma, a histórica hegemonia argentina sobre a Bacia do Prata.

A macro-área Meridional é a mais importante em termos de política continental. As suas relações internas definiram, pari passo a hegemonia norteamericana, o modelo geopolítico sul-americano. O equilíbrio regional de poder é a melhor síntese da inserção sul-americana na Guerra Fria. Torna-se, assim, necessário examinar a forma como Argentina e Brasil estruturaram suas políticas continentais e o papel do Paraguai, Uruguai e Bolívia nas geopolíticas de contenção.

\subsection{A Importância dos Buffer States na Rivalidade entre Brasil e Argentina}

Parte da infra-estrutura de circulação territorial entre os países do Cone Sul provém de tensões geopolíticas. Importantes investimentos feitos pelo Brasil na segunda metade do século XX, visando conexão territorial com Uruguai, Paraguai e Bolívia, estavam no bojo de "ações neutralizantes" como as recomendadas por Travassos (1935). Problemas enfrentados por esses países os que mais sofrem com as assimetrias econômicas e territoriais no interior do Cone Sul - estão associados a questões territorialistas. A classificação do Uruguai como Estado tampão feita pela geopolítica militar, uma alusão à sua condição de 
"áreas de amortecimento" entre Brasil e Argentina, sinaliza a importância dada pelas principais forças do Cone Sul a países tidos como vitais para o equilíbrio de poder. ${ }^{64}$

Mesmo assim, nas décadas de 1960 e 1970 a ameaça representada pelo Uruguai tinha mais proximidade com aspectos da doutrina de fronteiras ideológicas do que com a condição de buffer state, mais relevante durante o século XIX, período em que predominou a fase mais aguda do territorialismo sul-americano e os conflitos bélicos. As possibilidades de vitória da esquerda no país aumentavam as preocupações do regime militar brasileiro que tinha posto em ação a Doutrina de Segurança Nacional e a política externa das fronteiras ideológicas (MELLO, 1997, p.195). A construção, por parte do Ministério de Obras Públicas do Brasil, de rodovias nacionais que convergem para as cidades-limítrofes com o Uruguai foi uma forma de vivificação da fronteira; um processo comparável ao adotado em relação ao Paraguai, examinado dentre outros, por Marlene Xavier dos Santos (1995).

A condição boliviana e paraguaia de prisioneiro geopolítico, cuja posição mediterrânea sem saída ao mar contribuiu para as relações pendulares que historicamente mantiveram com Brasil e Argentina, são aspectos da velha geopolítica que ganham força a partir da década de 1950. Com as exportações e importações dependentes de portos marítimos vizinhos, a situação dessas duas nações tornou-se a mais significativa para o equilíbrio de poder regional no decorrer do século XX. Nesse sentido, a satelitização do Paraguai empreendida pelo Brasil, começa efetivamente com a abertura da Ponte Internacional da Amizade em 1965 durante o governo de Castelo Branco (ROSEIRA, 2006, p. 6061). A inauguração da BR-277 em 1969, outro elemento central de vivificação da fronteira (SANTOS, 1995), é parte intrínseca da atração política do Paraguai empreendida pelos militares brasileiros. Essa auto-estrada de natureza geoestratégica, ao se conectar com o sistema viário paraguaio via Ciudad Del Este, compõe a chamada "Rodovia do Atlântico". Dessa forma, permite ao país

\footnotetext{
${ }^{64}$ No discurso geopolítico, a condição de Estado tampão é dada por sua posição entre duas potências antagônicas ou regiões dominadas por potências externas. Em inglês a expressão buffer state é precisa, à medida que este "tipo geográfico" funciona como uma área de amortecimento das tensões entre forças geopolíticas opostas. A influência da Inglaterra na condição de buffer state do Uruguai - por meio da arbitragem por ela desempenhada nas negociações de paz da Guerra da Cisplatina (1826-1828), em que o Brasil saia derrotado pelas forças uruguaias apoiadas pela Argentina - refletia uma política usual entre os grandes impérios coloniais europeus durante o XIX. Segundo Eric Hobsbawm (1988, p. 89) algumas áreas do globo escaparam da colonização simplesmente porque as potências rivais não entraram em acordo quanto a uma fórmula de divisão. Hobsbown (Op. Cit.) destaca como dois exemplos importantes do final do século XIX, o Afeganistão, que separava a GrãBretanha e a Rússia, e o antigo Sião (hoje Tailândia), que dividia as zonas de controle britânico e francês na no Sudeste Asiático.
} 
vizinho acesso ao porto de Paranaguá, transformado em área livre para seu comércio exterior.

A respeito desse processo de satelitização, Roseira (2006, pp. 67-77) ressalta a importância da construção da Hidroelétrica de Itaipu. A edificação, entre 1975 a 1982, da hidroelétrica na Tríplice Fronteira entre Brasil, Paraguai e Argentina, contribuiu para a reversão da vantagem geoestratégica argentina. ${ }^{65}$ Foz do Iguaçu, apenas uma pequena cidade nas franjas do oeste paranaense, se converteu junto a Ciudad Del Este, no mais importante pólo transfronteiriço da América do Sul.

Ao examinar esse modelo de influência sobre o Paraguai, Mello (1997, pp. 181-190) chama atenção para os efeitos da presença dos brasiguaios na porção oriental do país. A chamada "invasão pacífica" é considerada pelo autor, componente da influência brasileira, visto que os mais de 400 mil emigrantes que atravessaram a fronteira, não tiveram somente papel na ocupação de uma região de vazio demográfico. Os Brasiguaios foram importantes na vivificação da zona de fronteira em favor do Brasil. A polarização de áreas tributárias pela concentração de serviços, um tipo clássico de lugar central analisado por Chauncy Harris \& Edward Ullman (1941, p. 07-17), permitiu a Foz do Iguaçu, exercer força gravitacional não apenas sobre o oeste paranaense, mas em grande parte do leste paraguaio. ${ }^{66}$

\footnotetext{
${ }^{65}$ Em Lysias Rodrigues (1947) essa região é destacada junto a outras duas áreas sul-americanas, como um ponto de atrito (Punctum Dolens) de alcance continental. O primeiro dos Puncti Dolens destacado por Rodrigues é justamente o do Iguaçu, localizado na região das quedas d'água, e considerado área crítica devido ao choque das duas maiores forças antagônicas da região: Brasil e Argentina. O segundo é o Punctum Dolens Boliviano, localizado no denominado "triângulo estratégico" formado por Cochabamba, Santa Cruz de La Sierra e Sucre. A condição de área de atrito pode ser resumida tanto pelas concepções de Mário Travassos (1935) - para quem o triângulo é um hertland sul-americano - quanto pelas de Golbery do Couto e Silva (1967), que o entende como parte de uma área de soldadura continental. O triângulo estratégico boliviano é tido pelos geopolíticos como área de ligação das bacias Platina e Amazônica, e das vertentes do Atlântico e do Pacífico. A dependência boliviana do sistema fluvial platino, como coloca Mello (1997), e as políticas argentinas (e posteriormente brasileiras) de integração territorial com a Bolívia, transformam a região em uma importante área de atrito. O terceiro ponto de tensão está localizado na tríplice fronteira entre Brasil, Peru e Colômbia. Denominado de Punctum Dolens de Letícia (cidade colombiana, que junto à Tabatinga no lado brasileiro polariza a fronteira), destaca-se como área vital para a conexão das vertentes do Atlântico e do Pacífico, e como um nó de transportes de relevância continental. Essa condição é garantida principalmente pela integração natural proporcionada pela Bacia do Amazonas que fornece acesso ao Oceano Atlântico para os países andinos. Esta situação conjuntura territorial é fundamental para as pretensões hegemônicas do Brasil no continente (Op. Cit.). Mas dentre todos os Punctum Dolens, o do Iguaçu se distingue por ser - como assevera Golbery do Couto e Silva (1967) - o centro de tensão máxima do continente. Os atritos entre Brasil e Argentina em torno do aproveitamento hidroelétrico das águas do rio Paraná e as políticas acerca do acesso paraguaio ao Atlântico, exercem força centrífuga com conseqüências a toda América do Sul.

${ }^{66}$ Ribeiro (2001) e Roseira (2006) detalham os aspectos nacionais e regionais subjacentes à questão dos brasiguaios. Ribeiro (Op. Cit.) traz à tona a presença de brasileiros no leste paraguaio como componente central das interações espaciais na fronteira. Segundo Roseira (Op. Cit., p. 79) a "aproximação entre os dois países, por meio de acordos bilaterais, além de proporcionar a construção da Ponte da Amizade, a utilização conjunta do Porto de Paranaguá e a construção de Itaipu, influenciou as políticas de terras do Paraguai." Ribeiro (Op. Cit. p. 49) salienta que a contrapartida paraguaia, foi a mudança da Lei de Terras de 1940, excluindo o texto que proibia a venda de propriedades rurais nas zonas de fronteira a estrangeiros. Independente de ser ou não parte de uma política deliberada, esse fenômeno amplia a influência brasileira no Paraguai. $O$ idioma, a moeda estrangeira e a cultura de forma geral, contribuíram para abrasileirar o lado oeste do rio Paraná. Esse fator foi fundamental para a ampliação da importância de Foz do Iguaçu, uma cidade, que para empregarmos novamente uma tese de Harris \& Ullman (1941), é simultaneamente um fator de influência e um produto do entorno regional. Como a população do Oeste Paranaense, os brasiguaios nos Departamentos paraguaios limítrofes com o Brasil utilizavam uma série de serviços em
} 
As políticas territoriais brasileira exerceram papel semelhante em relação à Bolívia. Desde a década de 1930, teóricos militares têm explicitado o papel chave do país andino no equilíbrio regional de poder em torno das duas principais potências sul-americanas. Esse papel não se exerce somente pela perda da saída ao mar decorrente da Guerra do Pacífico (1879-1883), fato que transformou a Bolívia no segundo prisioneiro geopolítico sul-americano. ${ }^{67} \mathrm{O}$ seu território, localizado no centro geográfico do continente, ao conectar três regiões sulamericanas - Meridional, Andina e Amazônica - faz do país um carrefour continental.

A esse respeito, Travassos (1935) foi o primeiro geopolítico a construir um discurso, que reverberaria em todo o século $X X$, sobre o valor continental do "triângulo econômico" formado por Cochabamba, Santa Cruz de la Sierra e Sucre. O autor defende em seu clássico trabalho que essa área é estratégica para a ligação das bacias Amazônica e Platina, e das vertentes continentais Atlântica e Pacífica. ${ }^{68}$ Num caminho semelhante, Lewis A. Tambs (1978) compara o triângulo boliviano à Bacia do Caribe, pois ambas as áreas são fundamentais à economia continental ao propiciar a conexão entre as vertentes dos Oceanos Atlântico e Pacífico. ${ }^{69}$

Os Convênios de Cochabamba assinados durante o governo Médice reforçaram a importância dessa área como objeto das políticas brasileiras de satelitização da Bolívia. O acordo objetivava estabelecer cooperação entre os dois países em áreas sensíveis a região, como energia, siderurgia e transporte. Em sentido mais amplo, visava cooperar econômica e financeiramente com o governo de Banzer. Mas, como mostra Paulo Schilling (1981), muitos dos compromissos assumidos pelo Brasil com a Bolívia não foram tirados do papel por incapacidade

Foz do Iguaçu. Concomitantemente, o crescimento da cidade amplia a oferta, permitindo a essa população o uso de serviços como de saúde.

${ }^{67}$ A Bolívia está entre os países que mais sofreram perdas territoriais na América do Sul. Além do acesso Pacífico, o país foi privado de uma vasta porção ao norte, quando o Brasil adquiriu, em termos estabelecido pelo Tratado de Petrópolis (1930), o controle do território do Acre. A busca por acesso ao Atlântico levou o país a Guerra do Chaco (1932-1935) contra o Paraguaio. Apesar da derrota, o acordo de paz garantiu à Bolívia um porto no rio Paraguai, que serve de acesso aos portos uruguaios do Atlântico.

${ }_{68}$ Travassos (1935) constrói esse argumento alegando que Santa Cruz de la Sierra é atraída pela Bacia Amazônica pelo rio Grande, importante formador do rio Mamoré. Cochabamba, por outro lado, está conectada a rede ferroviária platina, o que reforça em sua concepção, o homem como um fator geográfico de primeira grandeza. Para Travassos há uma vantagem em favor do Brasil, pois entende que a atração da Bacia Amazônica sobre Santa Cruz é mais importante do que a ligação de Cochabamba à rede ferroviária platina, pelo fato de a cidade oriental se constituir num verdadeiro centro de gravidade do planalto.

${ }^{69}$ Lewis Tambs (1978) se fundamenta na geografia do "triângulo", conferindo-Ihe a condição estratégica de heartland sulamericano. Dessa forma, lembra que os Andes são quebrados por corredores montanhosos no maciço boliviano. Tambs (Op. Cit.) lembra que a passagem de Santa Rosa guia do Pacífico ao Altiplano e a Puerta del Monte termina nas planícies mesocontinentais. Nessa região se origina os tributários da Bacia Amazônica a Nordeste, e os tributários da Bacia do Prata a Sudeste. 
financeira do governo Médice. O regime militar brasileiro não financiou a usina siderúrgica para a exploração das jazidas de Mutum. O GASBOL só começou a ser construído em 1997, durante do governo Fernando Henrique Cardoso; a usina petroquímica prevista no acordo apenas foi construída na década de 1990 pela Petrobrás.

Apesar dos limites da cooperação entre os dois países, houve um esforço de sustentação de Banzer no poder por parte do governo Médice. Após o golpe militar que colocou os militares no poder, os Estados Unidos responderam com o envio de US\$ 2 milhões, seguidos de mais duas parcelas de US\$20 milhões e US\$ 25 milhões (SPEKTOR, 2008, p. 54). Em 1971, os americanos aprovaram um programa de ajuda militar a Bolívia, enviando "US\$ 7 milhões, caminhões blindados de transporte pessoal, um avião C-57 e, possivelmente, seis jatos A37B, dois transportadores C-130 e equipamentos para cinco batalhões móveis de infantaria." (Op. Cit.).

A participação no golpe que pôs Hugo Banzer no poder, e a subseqüente aproximação com a Bolívia, uma política em conformidade com a Doutrina das Fronteiras Ideológicas, foram um dos aspectos mais importantes no equilíbrio regional de poder. Ainda que grande parte da cooperação prevista pelos convênios tenha levado décadas para sair do papel, o fortalecimento das relações bilaterais sob os governos Médice e Banzer resultou em políticas indispensáveis para a projeção continental do Brasil. A partir da intensificação dessas relações, 0 equilíbrio regional de poder, que há décadas resultava em políticas territoriais em solo boliviano, começa definitivamente a ser alterado em favor do Brasil. ${ }^{70}$ Ironicamente, as políticas territoriais postas em andamento por Argentina, Bolívia e Brasil, resultaram na materialização do triângulo estratégico ao longo do século $X X^{71}$

\footnotetext{
70"A atuação brasileira em território boliviano foi ferrenha. O governo brasileiro construiu a ligação rodoviária conectando a Plataforma Central de Reserva brasileira à Corumbá no Mato Grosso do Sul, permitindo assim a ligação até Santa Cruz de La Sierra. Posteriormente o governo revolucionário boliviano construiu a auto-estrada ligando Santa Cruz à Cochabamba, o que dava acesso do Porto de Santos até os portos chilenos do Pacifico. Em relação à conexão ferroviária, o governo brasileiro em 1957, terminou a obra da Ferrovia Noroeste ligando Bauru à Corumbá na divisa da Bolívia. Além disso, com os recursos previstos no Tratado de Petrópolis, os governos brasileiro e boliviano decidiram investir na construção da ferrovia ligando Corumbá à Santa Cruz de La Sierra. Naturalmente, por pressão argentina e pelas dificuldades de se romper os contrafortes andinos entre Cochabamba e Santa Cruz, construiu-se um ramal ligando Santa Cruz até Yacuíba (Departamento de Tarija) e daí até o norte argentino. [...] Assim não foi por acaso que a malha ferroviária oriental boliviana se integra, ainda hoje, à ocidental apenas em território argentino." Matheus H. Pfrimer \& Antonio M. Roseira, 2009, pp. 10-11.

${ }^{71}$ Segundo Pfrimer \& Roseira (2009) e Pfrimer (2011) houve uma intersecção entre discursos geopolíticos sul-americanos e as práticas de diferentes atores em relação ao triângulo formado por Santa Cruz de la Sierra, Sucre e Cochabamba. Atuando de modo indissociável, os discursos e as políticas territoriais foram responsáveis por transformar essa área em um lugar estratégico à escala continental. Mas os autores propõem uma modificação em relação à conformação original do triângulo, que se completava ao Sul em Sucre. A análise das redes territoriais bolivianas no período de integração regional do MERCOSUL evidencia que o novo triângulo é constituído pelas cidades de Santa Cruz, Cochabamba e Tarija. "Essa área
} 
As políticas territoriais brasileiras contribuíram para reforçar a condição da tríplice fronteira Brasil-Paraguai-Argentina e do triângulo boliviano como centros de tensão da política continental durante as décadas de 1960 e 1970. O discurso geopolítico foi determinante à materialização dessas áreas enquanto Puncti Dolens de escala continental. O discurso, ao envolver simultaneamente interpretação e prática, permite a incorporação por parte das elites políticas, das representações geográficas, que são por sua vez, materializadas no espaço. A imagem geopolítica de que fala Michel Foucher (2000), sendo derivada do discurso, é concomitantemente representação e ação em todo território sul-americano. $\mathrm{Na}$ porção meridional, o grupo de países formado por Uruguai, Paraguai e Bolívia, destaca-se como áreas nevrálgicas continentais, para onde confluíam as tensões derivadas principalmente do militarismo expansionista das duas principais forças regionais.

Duas tendências antagônicas da política continental funcionavam como forças centrífugas e centrípetas no que tange o estreitamento das interações multilaterais. Ainda que de modos distintos, essas duas tendências eram importantes para a organização do território no Cone Sul. Como exemplo de forças de cooperação, o Tratado da Bacia do Prata foi crucial para muitos avanços na integração física contemporânea. Por outro lado, os acordos bilaterais decorrentes do equilíbrio de poder, mesmo funcionando como forças centrífugas ao multilateralismo no continente, foram importantes para avanços no vertebramento territorial.

Essa lógica se torna explícita inclusive nos acordos entre Brasil e Bolívia visando a interligação das vertentes Atlântica e Pacífica. O ramal conectando Corumbá a Santa Cruz, cuja construção fora estabelecido pelos Acordos de Roboré firmado entre os dois países em 1958, funciona como infra-estrutura base para os projetos contemporâneos envolvendo a conexão bioceânica entre os portos de Santos no Brasil e Arica no Chile. A concretização de uma linha férrea de Santa Cruz até Arica, passando por Cochabamba e La Paz, ao mesmo tempo em que reforça a integração entre as regiões andina e oriental da Bolívia, transforma a antiga integração de Santos a Santa Cruz num corredor

densa com o formato triangular é constituída por eixos técnicos que integram a rede urbana de origem colonial, ainda vigente no altiplano (Oruro - Potosí - Tarija), e a rede urbana tributária do corredor econômico boliviano (La Paz - Cochabamba Santa Cruz) à nova rede urbana que se origina das relações entre Santa Cruz e Tarija. Envoltos e bem articulados aos pólos urbanos principais (Santa Cruz, Cochabamba, Tarija) há ainda centros secundários importantes como Potosí, Oruro, Sucre e Yacuíba..." Matheus Pfrimer \& Antonio Marcos Roseira, 2009, p. 14. 
transcontinental. De fato, além das disjunções proporcionadas por sistemas ferroviários divergentes erigidos na América do Sul - com analisa Pedro Camargo (1999), um processo marcado pela adoção de diferentes padrões de bitolas - há sérias limitações impostas pela rivalidade regional cultivada durante grande parte do século $X X^{72}$

O discurso geopolítico militar brasileiro, como bem expressa Golbery do Couto e Silva (1967) com uma compreensão de "guerra total" herdada de Ludendorff, tinha uma poderosa pretensão ubíqua. A geopolítica deveria estar presente em todos os setores da sociedade. Mas como não poderia deixar de ser, é justamente nas políticas territoriais que esse discurso revela o seu grau de penetração entre os policy makers. A esse respeito, Richard Hartshorne (1950, pp. 95-130) e Jean Gottmann (1975, pp. 29-47) evidenciam uma relação funcionalista intrínseca entre o espaço geográfico e o modelo político de um determinado Estado. No Cone Sul, as políticas territoriais são resultado direto das tensões geopolíticas.

Nesse caso, poucas coisas são tão explícitas na identificação de um modelo de política regional de um país quanto seu sistema de transporte. Já no início do século XX, Camille Vallaux apontava a estrutura geral de circulação de um país como reveladora da natureza da projeção externa de um Estado, “... ora sinalizando enlaces voltados para cooperação, ora envolvidas com políticas de poder e de hegemonia em contextos de rivalidades regionais." (COSTA, 1999, p. 30). Os enlaces territoriais erigidos no Cone Sul durante quase todo século $X X$ revela o telurismo sobrejacente ao discurso geopolítico militar, que ao funcionar com uma força centrífuga sobre a política regional, limitou a visão dos países sobre o seu entorno.

\footnotetext{
72 Dentre os limites postos pelo equilíbrio de poder, está a não concretização dos ramais ligando Santa Cruz à Cochabamba. A conexão ferroviária entre Santos e Santa Cruz de la Sierra, tem como um dos mais importantes ramais a ferrovia que liga Bauru no Estado de São Paulo à Corumbá na divisa do Mato Grosso com a Bolívia. Este ramal era operado pela antiga companhia Estrada de Ferro Noroeste do Brasil (NOB), estando em consonância com projetos de infra-estrutura estabelecido pelo antigo Tratado de Petrópolis, firmado em 1903. O tratado, no intuito de fornecer via rio Amazonas uma saída ao Atlântico para a Bolívia, estabeleceu o compromisso de construção da Estrada de Ferro Madeira-Mamoré. Segundo Pfrimer \& Roseira (2009), devido às pressões argentinas e as dificuldades de romper os contrafortes andinos entre Santa Cruz e Cochabamba, foi construído em território boliviano, o ramal ligando Santa Cruz até Yacuíba, e daí até o norte argentino. A respeito da segregação da rede ferroviária continental, o estudo de Pedro de Camargo (1999) é revelador. O autor detecta em relação às redes ferroviárias sul-americanas, quatro disjunções em regiões de fronteira: uma entre Paraguai e Brasil, outra entre Bolívia e Peru e duas entre Argentina e Chile. Camargo revela ainda, uma variação de cinco tipos de bitolas adotados pelos países do continente.
} 


\subsection{A Economia Geopolítica e os Limites da Projeção Internacional do Brasil}

A fragmentação geográfica da América do Sul revela, além do caráter da projeção externa dos seus países, aspectos da economia geopolítica. A condição das infra-estruturas territoriais de circulação é ilustrativa a esse respeito. $O$ caráter da circulação (nacional ou continental) é determinado também pelo poder de investimento dos Estados. No continente, a incapacidade de reorganizar a fluidez material e informacional tem relações com a pequena envergadura econômica dos seus países. Essa situação é, de fato, agravada pela crise econômica dos anos 1970.

O Tratado da Bacia do Prata é simbólico a respeito das mudanças na política interestatal no Cone Sul. Apesar das tensões e desconfianças mútuas, a lógica que impulsiona a organização do território passa por modificações conforme se alteravam os preceitos da diplomacia. $O$ enfraquecimento do alinhamento automático contribui para a reorganização da política externa brasileira nas escalas regional e mundial. Mas esse tratado, resultado de interesses interestatais emergentes, sofre o impacto direto das transformações da economia geopolítica mundial.

O engajamento de Geisel e Azeredo da Silveira no redirecionamento da diplomacia brasileira é revelador sobre o esgotamento das concepções geopolíticas militares. O seu significado é ainda mais importante se for levado em consideração a intersecção entre os efeitos geopolíticos da détente e da crise econômica mundial. O período de relações privilegiadas do regime militar com o Governo Nixon esgotou-se com a saída de Kissinger do Departamento de Estado em 1977. Mas a própria aproximação entre EUA e URSS iniciada no final da década de 1960 reduziu as tensões globais na década de 1970 e contribuiu para o distanciamento da Administração Carter em relação aos governos autoritários sulamericanos. $^{73}$

Entretanto, Geisel e Azeredo da Silveira quebram o molde da política externa a partir de 1974 (SPEKTOR, 2008). A substituição do alinhamento automático no final do governo Nixon pelo maior envolvimento com o Terceiro

\footnotetext{
73 Segundo Parboni (1986), a aproximação comercial entre Estados Unidos e União Soviética começa em 1969 com o Export Administration Act. Considerado uma conseqüência natural da détente, o acordo foi assinado por Nixon com o intuito de facilitar o comércio com os países socialistas. Porém, a "intromissão" do Congresso Americano, condicionando o aprofundamento das relações comerciais com a União Soviética ao fim das restrições que o país impunha a migração de judeus fez a cooperação fracassar.
} 
Mundo demonstra a transformação da identidade internacional do país. A adoção de uma política externa pragmática não é apenas conseqüência do amadurecimento da diplomacia brasileira. É uma reação direta às transformações da ordem geopolítica mundial.

Os primeiros sinais da deterioração da hegemonia norte-americana nos anos 1970 (portanto quase vinte anos antes da queda do império soviético) ao serem acompanhados pela consolidação de novos centros do capitalismo, abriram importantes janelas ao país, que havia se convertido rapidamente em uma nova potência regional. No início do governo, Geisel e Azeredo da Silveira propuseram mecanismos de consulta diplomática ao Japão, à Grã-Bretanha, à França e à Itália, com o intuito de incutir na comunidade internacional a idéia de que o país era digno de tratamento especial (Op. Cit.). Apesar do fracasso inicial dessa operação, com Londres manifestando que as relações com o Brasil não justificavam um arranjo especial, o cenário mudou após Paris aceitar a proposta de Brasília.

O país passou a desfrutar de prestígio internacional, e os convites para visitas a França, Inglaterra, Japão e Alemanha demonstravam que a Europa e a maior potência asiática começavam a perceber a nova condição do país sulamericano (Op. Cit. p. 95). O acordo nuclear com a Alemanha nasce desse contexto. Geisel e Silveira relativizaram muitos aspectos da relação com os Estados Unidos visando um lugar especial para o Brasil na política externa norteamericana.

Se a colaboração entre os governos Geisel e Nixon fracassa com o não engajamento brasileiro na agenda internacional desenhada por Kissinger, a eleição de Carter faz a relação entre os dois países atingir um dos seus momentos mais delicados. Os direitos humanos e o acordo nuclear com a Alemanha foram os temas mais sensíveis ao novo governo, dificultando essa relação. Além das pressões sobre a Alemanha, o governo norte-americano usou a rivalidade regional por meio da ameaça de um acordo nuclear com a Argentina para minar as pretensões brasileiras.

As pressões sobre os direitos humanos, freando as relações perigosas encorajadas por Kissinger, solapavam a legitimidade de um regime que teve forte apoio americano desde o início da década de 1960. Assim, os limites da geopolítica militar são escancarados. $O$ autoritarismo, os novos rumos da política 
externa nacional e o crescimento econômico dependente do financiamento externo, não poderiam ser sustentados sem a intermediação da maior potência mundial.

O monopólio da moeda internacional tornou possível aos Estados Unidos reorganizarem a econômica geopolítica mundial. Dentre os principais efeitos dessa mudança aos países sul-americanos, destaca-se uma crise econômica que enfraqueceu ainda mais as ditaduras militares perante o novo posicionamento da política externa norte-americana. Um dos fatores que mais debilitaram as economias da região foi a queda do preço internacional das commodities, $40 \%$ entre 1980 e 1988.

$\mathrm{Na}$ América Latina, o pagamento da dívida que representava $1 / 3$ das exportações em 1977, passou a corresponder 2/3 em 1982 (ARRIGHI, 2008, p. 334). A elevação dos juros e a desregulamentação do mercado financeiro (com a conseqüente atração de short-term funds) funcionaram como poderosa força gravitacional, atraindo capitais de todo o mundo e comprometendo investimentos em diversas regiões (PARBONI, 1986, pp. 05-18). Os países sul-americanos, cujo crescimento econômico era sustentado pelo valor das commodities, foram severamente afetados por essas políticas econômicas ortodoxas (PAULANI, 2009, p. 31).

Os Gráficos 2 e 3 (p. 102) evidenciam que o ritmo de crescimento das principais economias do continente foi afetado pelas transformações da economia geopolítica no início dos anos 1970. A recessão mundial da década seguinte agravou ainda mais esta situação. A economia brasileira, a única realmente privilegiada pelas transformações dos anos 1970, sofreu um grande revés na década de 1980. Segundo dados disponibilizados pelo Banco Mundial (WorldBank Databank, 2011), a média anual de crescimento do PIB, que foi de $6,0 \%$ na década de 1960 , subiu para $8,6 \%$ na de 1970 , mas caiu abruptamente para 3,0\% na seguinte.

A média anual de crescimento da economia argentina, de 4,5\% na década de 1960, caiu para 3\% na seguinte. A situação tornou-se mais problemática a partir de 1980, com expansão nula do PIB. A Venezuela, com dados disponíveis a partir de 1975, cresceu numa média anual de 3,6\% até 1979. Essa média cai vertiginosamente para $0,2 \%$ nos anos 1980. O Chile é o único país com crescimento na década de 1980 superior ao da anterior. A sua média anual de 
crescimento, que foi de $4,5 \%$ na década de 1960 , caiu para 2,2\% na década de 1970, mas subiu para 5,5\% na de 1980. A Colômbia acompanha a tendência registrada pelo Brasil. A média anual de crescimento de 5,1\% na década de 1960, sobe para $5,6 \%$ na década de 1970 , caindo significativamente para $3,9 \%$ na seguinte.
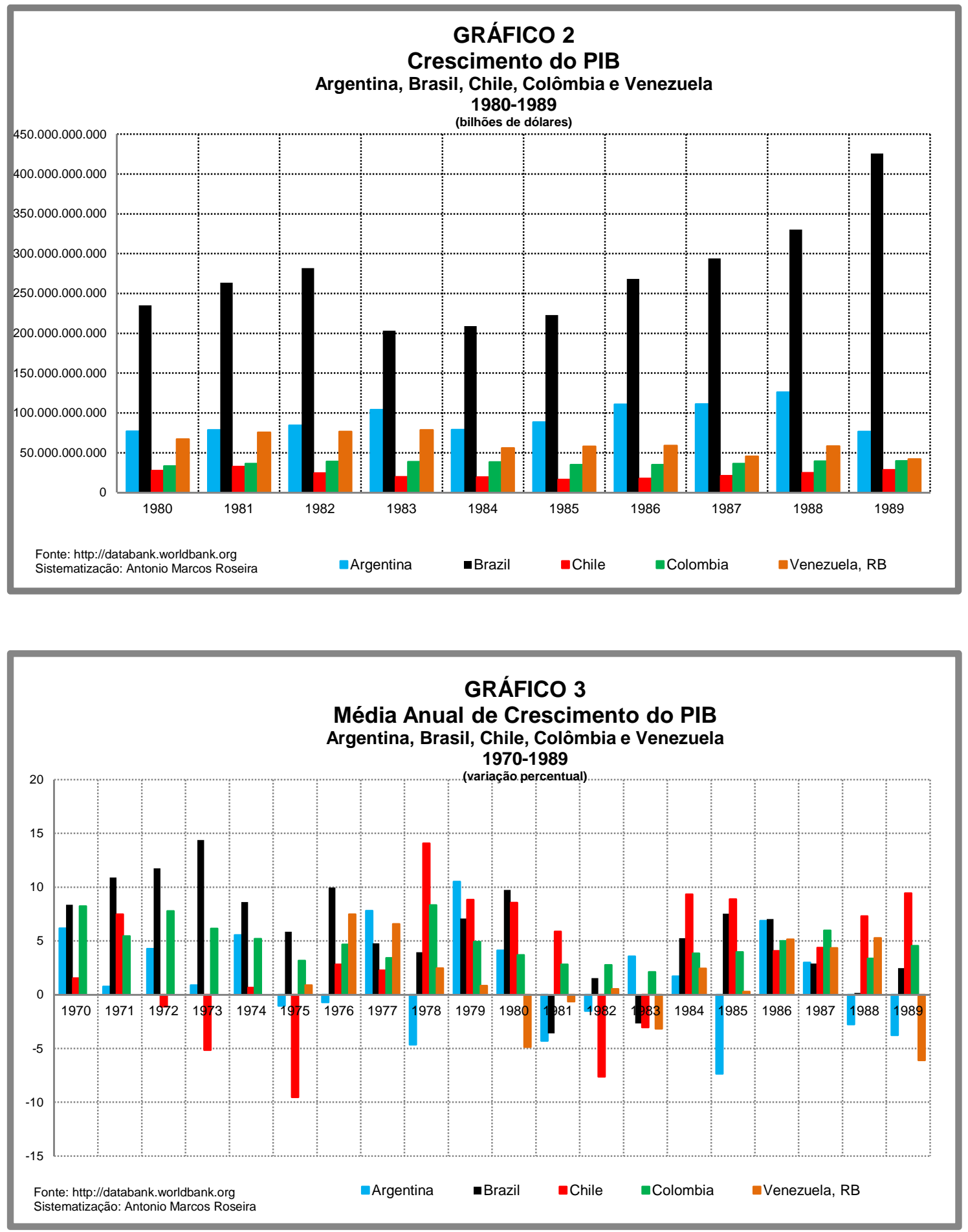
O crescimento chileno nos anos 1980 está relacionado a uma recuperação do país frente às crises políticas enfrentadas durante a década de 1970. Na Argentina, o chamado Pacto Social proposto pelos governos de Héctor José Cámpora (1973-1976) e Juan Perón (1973-1974), tentando alcançar a distribuição de renda e o pleno emprego, desmoronou com o conflito interno desencadeado pela crise mundial (RAPOPORT, 2009, p. 38). A instabilidade política - com a atuação de movimentos guerrilheiros de esquerda e forças paramilitares de direita, a morte de Perón, e o governo débil de Isabel Perón (1974-1976) - marcou um período de crise inflacionária, abrindo caminho para um novo golpe militar (Op. Cit. pp. 38-39).

O caso chileno é bastante singular a esse respeito, pois o golpe militar abriu caminho para uma reforma econômica radical. Antes dos governos de Ronald Reagan e Margareth Thatcher e há 15 anos do Consenso de Washington, o regime militar promoveu um conjunto de reformas de mercado (TOMASSINI, 2009, p. 114). No primeiro decênio, o custo dessas reformas foi o desemprego de $30 \%$ e um impressionante aumento da pobreza, que alcançou $50 \%$ da população chilena (Op. Cit.). Assim, os anos 1980 foram um período de recuperação da economia.

Os dados comparativos sobre o crescimento das principais economias sulamericanas evidenciam que o Brasil foi, de fato, o país mais privilegiado pela oferta de dólar na década de 1970. O modelo de crescimento baseado no papel central do Estado na década de 1960 foi reforçado pela abundante oferta internacional de dólar. Se o aumento do petróleo e a recessão mundial prejudicavam a economia brasileira, o dólar barato postergou a crise para os anos 1980. Toda América do Sul foi afetada pela crise da dívida, que impediu investimento e paralisou a economia dos seus países. Além dos limites do desenvolvimentismo, esta crise simboliza a falência total do modelo geopolítico militar.

Os Gráficos 4 e 5 (p. 104) demonstram o crescimento da dívida externa após as medidas de valorização do dólar no primeiro mandato de Reagan. A dívida argentina, 19\% do PIB em 1970, passa para 36\% em 1980 e 93\% em 1989. A brasileira, 14\% do PIB em 1970, passa para 36\% em 1980 e alcança o pico de 53\% em 1984. A chilena representava 35\% do PIB em 1970, 46\% em 1980 e $142 \%$ em 1985. A colombiana era $32 \%$ do PIB em 1970, 21\% em 1980 e 45\% em 
1989. A dívida venezuelana saltou de 11\% do PIB em 1970, para 44\% em 1980 e $81 \%$ em 1989.
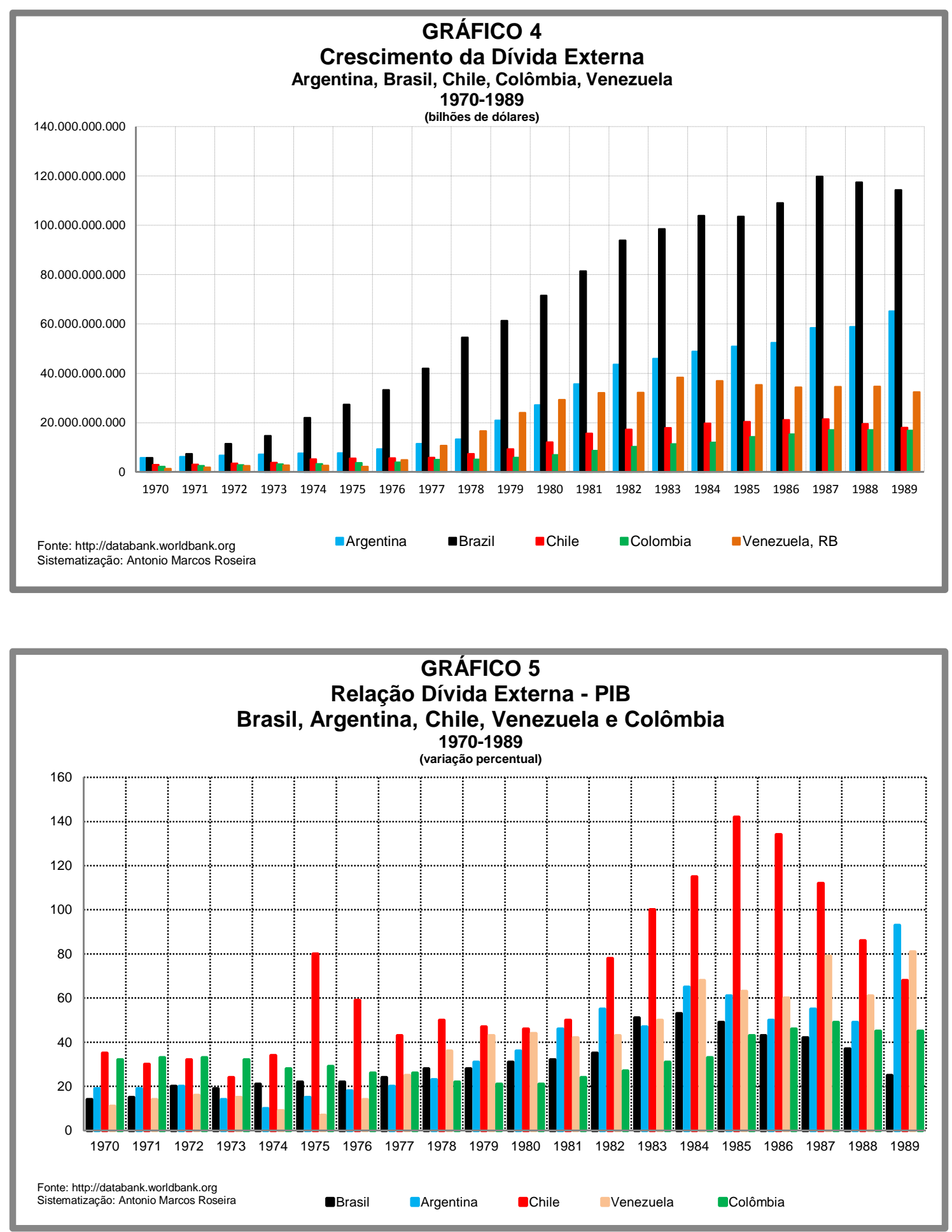

A reação americana a crise dos anos 1970 é um movimento deliberado visando sustentar a liderança econômica (PARBONI, 1986). As políticas de 
desvalorização do dólar durante os governos Nixon e Carter somente podem ser explicadas como uma reação ao declínio relativo do país, vis-à-vis a Europa Ocidental e o Japão. A elevação dos juros e do dólar no último ano do governo democrata, processo que perdurou durante o primeiro mandato de Reagan, reorganiza toda a economia internacional. O controle da inflação com a elevação dos juros, associado ao processo de desregulamentação financeira marcou a reemergência do livre-mercado. Segundo Arrighi (2008, p. 72), os Estados Unidos estimularam a reorganização da economia internacional sob as bases do mercado auto-regulado. $^{74}$

Enquanto a desvalorização do dólar permite a recuperação industrial dos Estados Unidos até o início dos anos 1980, a política econômica ortodoxa de Reagan está na base da auto-regulação do mercado financeiro, cujos primeiros sinais se evidenciavam na explosão dos depósitos em Eurodólares na década de 1970. Mas a recuperação da produção industrial esvaneceu com a ascensão da reaganomics. ${ }^{75}$ As praças financeiras das maiores economias capitalistas passam a atrair capitais de todo mundo. Apesar da livre circulação, os fluxos financeiros "desterritorializados" concentram-se nas principais cidades globais (SASSEN, 2001).

Ao gravitar em torno dos centros financeiros, o capital descola-se da economia real, com efeitos devastadores em longo prazo. Os países sulamericanos, castigados pela dívida, estavam à margem do fluxo internacional de capital, que se deslocava para a ciranda financeira. A desregulamentação faz o regime de acumulação ser dominado pela valorização financeira (CHESNAIS, 1997).

Porém, a nova economia geopolítica não se resume as transformações financeiras. Com a globalização, o valor das tecnologias informacionais alcança outro patamar. Numa sociedade dominada pelo conhecimento, “... as vantagens comparativas estáticas ou ricardianas, baseadas em recursos naturais, perdem importância relativa e ganham destaque as vantagens construídas e criadas, cuja base está exatamente na capacidade diferenciada de gerar conhecimento e inovação (DINIZ, SANTOS \& CROCCO, 2006, p. 87). As novas condições do

\footnotetext{
${ }^{74} \mathrm{~A}$ esse respeito cabem algumas ressalvas, pois o mercado auto-regulado apenas existiu efetivamente com a hegemonia britânica. Segundo Arrighi (Op. Cit.), as medidas de liberalizacão do comércio adotadas pelos Estados Unidos foram bastante limitadas. Mas, a desregulamentação promovida por Reagan fez do mercado financeiro a esfera onde o laissez-faire se tornou hegemônico.

${ }^{75} \mathrm{O}$ termo faz referência à ascensão da economia neoliberal nos Estados Unidos nos anos 1980.
} 
poder econômico estão assentadas na inovação e no desenvolvimento de tecnologias informacionais.

Muitos estudiosos detectam um big bang informacional na economia americana a partir do início dos anos 1970, quando o engenheiro da Intel, Ted Hoff, criou o primeiro microprocessador. Manuel Castells (1999) analisa de maneira minuciosa como "esse computador dentro de um chip", tornou possível a criação dos primeiros personal computers - o Altair, o Apple I, o Apple II, e o PC da IBM - permitindo uma revolução informacional sem paralelos. A inovação tecnológica sofisticou os sistemas de produção e permitiu a expansão de novos setores econômicos que se tornaram estratégicos aos Estados Unidos. O gasto crescente em armamentos durante os anos 1980, justificado pela radicalização do discurso anticomunista de Ronald Reagan, tinha fortes motivos econômicos. As centenas de bilhões de dólares injetados no Pentágono beneficiavam diretamente setores de alta-tecnologia como os de telecomunicações, computação e o aeroespacial.

Ainda que a operação em torno do dólar comandada por Paul Volcker tenha se tornado possível pelo fim do regime de Bretton Woods, há outros fatores importantes que permitiram o seu êxito. Entretanto, essa política não seria possível sem a existência de um mercado continental doméstico, com um território dotado de extensas reservas de recursos naturais. Embora estes sejam aspectos constituintes do poder norte-americano, o desenvolvimento científico e tecnológico se coloca como um dos grandes imperativos da hegemonia global exercida pelo país. O rompimento de uma nova fronteira expressa pela revolução microeletrônica permitiu, sob a sua égide, a aceleração de setores estratégicos como a física, a engenharia genética etc.

Essa relação entre ciência, tecnologia e geopolítica não é, de modo algum, nova. Textos geopolíticos fundadores pressupõem novos mecanismos de poder territorial trazidos pelas revoluções dos transportes e comunicação no século XIX. Mas com a globalização, o domínio do vetor científico-tecnológico se tornou uma condição determinante para projeção internacional de qualquer país. No período atual a geopolítica está impregnada de tecnologia que reforça a multidimensionalidade do poder que passa pelo Estado, assim como por atores não-estatais. 
Se de um modo a ascensão do capitalismo financeiro tem efeitos negativos à economia industrial tradicional, de outro, contribuiu para a Belle Époque do desenvolvimento tecnológico. Com as possibilidades de cessão de patentes financiadas com fundo público e formação de joint venture entre o setor coorporativo e universitário, houve um cruzamento entre as instituições científicas americanas e as finanças globais (LIMA, 2008, p. 42). Isso contribuiu para o crescimento das chamadas firmas inovadoras, fazendo com que a revolução eletrônica das décadas precedentes ampliasse as fronteiras da expansão do capital. Associados aos investimentos em tecnologia militar e o surgimento da micro-eletrônica, a conexão entre a inovação e as finanças alteraram a economia geopolítica.

Mas, a capilarização do vetor científico-tecnológico em territórios nacionais ou áreas supranacionais não exige somente crescimento econômico. A territorialização desse vetor depende do nível de renda, do acesso a informação e do modelo de educação. Não é por outro motivo que o expansionismo fundado principalmente no território perde terreno na Europa, Estados Unidos e Japão. O desenvolvimento social trazido pelo acelerado crescimento dos países industrializados no Pós Segunda Guerra Mundial, tornou possível a disseminação do conhecimento, da informação, da tecnologia e do consumo. Ainda que a geopolítica clássica estivesse fortemente incrustada na Guerra Fria, a crescente cooperação entre os países capitalistas industrializados desemboca num novo modelo de relações interestatais. Mesmo sendo a formação da União Européia estimulada pelo containment americano, esse modelo de integração se estabeleceu como grande paradigma da regionalização e cooperação internacional no mundo contemporâneo. Se os regimes militares sul-americanos viam o mundo pelas lentes do "realismo geográfico", a Europa Ocidental apostava quase tudo no idealismo.

Nos países industrializados, a velha geopolítica perde relevância na segunda metade do século $X X$, enquanto seu rationale se mantém hegemônico no Cone Sul até o início dos anos 1980. Nessa região, duas grandes crises locais na segunda metade da década de 1970 reforçam as tendências territorialistas tradicionais.

As tensões entre Brasil e Argentina sobre o aproveitamento hidroelétrico do rio Paraná, e a grave crise entre Argentina e Chile a respeito do controle do 
Canal de Beagle, reflete a importância do controle de áreas estratégicas e ao uso dos recursos naturais nas relações entre esses países no limiar dos anos 1980. Outro agravante, a reaproximação da Argentina com os Estados Unidos por meio de um acordo militar durante o governo Reagan (MONIZ BANDEIRA, 1992), funciona como legitimação de um regime autoritário sul-americano, justamente num período em que crise mundial desnudava os limites do modelo geopolítico militar.

A esse respeito, a Guerra das Malvinas em 1982 escancarou os limites das relações políticas entre qualquer país sul-americano e os Estados Unidos. Por hierarquia de interesses, a parceria anglo-americana está acima do panamericanismo, que nas últimas décadas do século $X X$ já não era tão expressivo. Por outro lado, a derrota argentina não contribuiu apenas para enfraquecimento do regime militar, tornando-se evento emblemático ao imperativo da regionalização. Mas, quando o equilíbrio de poder perde a primazia, a crise econômica compromete os investimentos em integração física e os avanços propostos pelo Tratado da Bacia do Prata - único mecanismo de integração até o surgimento do Mercosul. .

A partir da década de 1970 a crise mundial incidiu de forma desigual sobre a América Latina, fragmentando e a dividindo em duas parcelas (BECKER \& EGLER, 1992, p. 248). O México, um dos principais exemplos de crescimento atrelado ao crédito internacional, passou a apostar numa regionalização dependente da maior potência mundial. Os Estados Unidos ampliaram o poder econômico sobre o país e a América Central, ao passo que o continente europeu se destacava como um dos principais investidores e maior parceiro comercial do Brasil (Op. Cit.).

Apesar de a recessão econômica ter comprometido o rápido crescimento econômico brasileiro, não impediu a diversificação das suas relações econômicas e a sua projeção como importante ator na economia geopolítica internacional. As sólidas relações econômicas mantidas com a Europa - no momento em que o Caribe, a América Central e México estreitaram a preferência pelos Estados Unidos - contribuíram para a projeção global do seu comércio. Segundo Castro \& Cardoso (1995, p. 116) o processo de integração regional iniciado no Cone Sul permite duas importantes direções. Além da ampliação das relações comerciais 
com a Europa, abrem-se novas possibilidades com os países do leste e sudeste asiático.

Apesar de a crise econômica internacional malograr as ambições brasileiras, não impediu a primeira experiência multilateral realmente expressiva entre os países do Cone Sul. Essa área, como vislumbrara o Barão do Rio Branco no início do século XX, tornou-se o embrião de uma política regional autônoma, mesmo que internacionalmente os seus países orbitassem em torno dos Estados Unidos.

A cooperação e a integração regional evidenciam novos elementos do poder na política internacional. Jacques Lévy (2000, pp. 01-06) chama atenção para o fato de que a Realpolitik não pode ser compreendida sem Idealpolitik. Segundo Denis Retaillé (2000, pp. 48-49) o retorno da geopolítica na França se deu pela luta contra o imperialismo. Do mesmo modo que essa retomada esteve ligada a uma mudança nas dinâmicas do poder na Ordem Geopolítica da Guerra Fria, os inúmeros modelos de integração regional em andamento em todo mundo são concomitantemente derivação e meio na transformação da natureza do poder político em escala global. A arquitetura política internacional erigida sob comando dos Estados Unidos, ao mesmo tempo em que permitiu a consolidação de sua hegemonia mundial, tornou possível a solidificação de novos modelos de relações interestatais.

O idealismo americano, ao se tornar como defende Henry Kissinger (1994), o meio de organização de um sistema institucional global, resultou num paradigma imanente à política internacional, presente em todas as suas escalas espaciais. Através do Mercosul, a constituição de uma arquitetura política no Cone Sul abre espaço para uma concepção geopolítica contemporânea na região, atrelado a um poder de natureza branda, dependente do comércio, da capacidade tecnológica e indústria, e do aparelhamento institucional das relações internacionais. 


\title{
Apontamentos de Transição à Nova Geopolítica Continental
}

\author{
Certamente o Estado não é a única \\ unidade de poder, embora seja uma \\ delas. E, certamente, o poder não é \\ determinado pela configuração das terras \\ e mares e pela geografia dos lugares e, \\ sim, por motivações e decisões humanas \\ e pelas relações sociais \\ Bertha Becker
}

A célebre fórmula do Estado como o "monopólio legítimo da violência" (WEBER, 1999, pp. 525-529 \& 2000, p. 143;) encontra certa limitação analítica frente uma ordem política internacional institucionalmente legitimada, como vislumbrava o presidente americano Woodrow Wilson no início do século XX. Se o Estado enquanto Leviatã centralizado na figura do monarca perdeu a primazia para um ente político cuja autoridade se manifesta até os limites do território nacional, a arquitetura internacional erigida pelos Estados Unidos após a Segunda Guerra Mundial aponta para o limiar de uma nova era na relação entre soberania e poder político.

John Agnew (2008, pp. 06-07) sugere que além da soberania de jure há uma soberania de facto, quando o poder, não sendo reduzido aos limites do Estado territorial, é apreendido em circulação. Há uma soberania efetiva para além das fronteiras nacionais, manifestada por meio de novas formas de exercício da autoridade, expressas em questões tão díspares quanto o comércio, a moeda, os direitos humanos, o planejamento econômico, o meio-ambiente e os recursos naturais. Há séculos, o uso do território já não se restringe ao poder exclusivo do 
Estado. De certa forma, o Estado territorial é um "tipo ideal" cujo processo analítico passa ao largo de questões que não estão exatamente circunscritas às fronteiras nacionais. Desde sua origem, o Estado westfaliano não corresponde plenamente aos fatos políticos, econômicos e sociais, como faz crer a geopolítica tradicional. Segundo Arrighi (2008), historicamente, as grandes hegemonias foram caracterizadas por transcender a autoridade territorial de outros Estados. As ordens geopolíticas globais são essencialmente uma forma de poder transnacional que se sobrepõem à soberania do Estado sobre seu povo, sua economia e seu território. Na globalização, essa lógica é cada vez mais institucionalizada, estilhaçando a primazia da velha concepção de soberania predominante no pensamento social.

As transformações em escala mundial que culminaram com um empoderamento de instituições e regimes políticos e econômicos em detrimento do Estado tiveram importantes efeitos sobre todos os países sul-americanos. As novas relações interestatais delineadas no continente a partir dos anos 1980 são uma reação ao enfraquecimento do Estado e da sociedade como um todo frente à emergência de novos modelos políticos. Destaca-se que nesse modelo, o fortalecimento da sociedade não passa apenas pelo Estado, mas também por instituições supranacionais. Assim sendo, a transição da política continental fundada no equilíbrio de poder para a cooperação balizada pelos processos de integração significa especificamente a consolidação de três tendências na América do Sul.

Primeiro, a transição do equilíbrio de poder para a cooperação resulta na formação de uma região geopolítica. É verdade, como coloca Roberto Lobato Correia (1990), que a região tem sua origem no reger romano. Nosso objeto induz a uma análise do comando de um grupo de Estados sobre uma área. Porém, os objetivos dessa pesquisa fazem lembrar que a noção de região se tornou mais complexa que sua acepção original, voltada fundamentalmente para a questão fiscal, administrativa e militar como destacava Michel Foucault (2000, p. 157). Muito além de seu significado etimológico, a região é uma confluência de forças que se revelam em sua estrutura interna, assim como em suas articulações externas.

A região (como interconexão espacial) envolve interações materiais e imateriais, passando por uma sinergia física e social. Assim sendo, espaço 
geográfico não é organizado somente por infra-estruturas físicas, mas por ideais e valores. Na década de 1960, iniciativas de regionalização já eram importantes instrumentos sul-americanos de cooperação. Mas a constituição do Mercosul representa um passo à frente. A busca por coesão política e econômica se transformou no principal fundamento de projeção internacional para seus Estados Partes e Associados, havendo uma completa transformação diplomática de suas prioridades

Segundo, a integração representa um esforço por substituição da supremacia das grandes potências pela soberania regional. As nações sulamericanas, incapazes de constituir um sistema político multilateral, não possuíam os meios de contrabalancear o poder exercido pelas potências mundiais em seu próprio continente. Num primeiro momento, as rivalidades locais associadas à dependência externa fizeram com que a política continental fosse determinada pelos interesses exógenos. O entendimento de que a condição sul-americana no cenário mundial está imbricada a uma ordem geopolítica pressupõe que a atuação de grandes potências no continente não está circunscrita à concepção de poder enquanto dominação. Limitar o conceito de hegemonia à dominação exercida por um Estado sobre outros é privilegiar como critica Agnew (1998, p. 57) o poder coercivo nas relações internacionais. Ao contrário, hegemonia pressupõe a ampliação do poder de dominação pela liderança intelectual e moral (ARRIGHI, 2008).

Comandar uma determinada região, seja ela nacional ou multinacional, exige o exercício da soberania. Essa concepção leva a outras questões igualmente importantes a esse estudo. Ao longo da história, os discursos geopolíticos privilegiaram o território, ressaltando suas relações intrínsecas com o Estado e o poder. Não é por outro motivo que a tessitura territorial, como ensina Raffestin (1993), expõe também uma imagem do poder estatal. Se tradicionalmente, o território é associado à soberania sobre um espaço e ao expansionismo dos Estados e dos impérios, o conceito de região remete primeiramente à administração e ao aménagement. Isso não permite ignorar que região é poder mesmo sob uma forma branda. A organização do território pressupõe a consolidação do poder sobre diferentes regiões, seja ele em sua forma autoritária ou democrática. 
A substituição da geografia estatal pela Erdkunde no século XVIII, fez com que o método regional - principalmente com Alexandre von Humboldt, Carl Ritter e Alfred Hettner, como demonstra Hartshorne (1939) na mais influente investigação sobre o pensamento geográfico - estivesse mais associado à legitimidade científica do que ao poder do Estado. Também no século $\mathrm{XX}$, com a vertente lablachiana, passando pela proposta hartshorniana até chegar às correntes pragmáticas, essa abordagem esteve muito atrelada a uma busca por legitimidade científica.

Em razão do seu tradicional emprego em abordagens relacionadas aos estudos ambientais e físico-naturais, e também aos aspectos de administração e gestão de macro-divisões, províncias e demais escalas sócio-espaciais nacionais, o conceito de região está pouco associado ao poder coercitivo, pelo menos em sua forma mais explícita. Com a propagação dos espaços internacionais de integração na segunda metade do século $X X$, nota-se a emergência de espaços internacionais moldados pelo soft power. A concepção de "poder brando" se assenta, sobretudo, na capacidade de moldar a vontade de outros (NYE Jr. 2008, p. 29).

O que torna os blocos regionais tão atrativos no cenário internacional contemporâneo? Associada às vantagens comerciais, destaca-se uma poderosa força de cooperação, fundada em valores e na habilidade de estabelecer a agenda de escolhas políticas. Na base do idealismo político internacional, esse poder brando se destaca como um dos componentes do regionalismo político contemporâneo.

Apesar das mudanças de paradigma, é necessário cautela para qualquer correlação entre o empenho sul-americano por autonomia e a emergência de uma soberania regional de base cooperacional. Com exceção da experiência européia, que alcançou um nível sem precedentes de compartilhamento das esferas políticas, econômicas e sociais entre Estados, não é possível fazer essa relação com nenhum modelo de integração contemporâneo. Por outro lado, a integração no Cone Sul significa uma mudança de paradigma, fazendo emergir o que Agnew (2008a, p. 131) denomina de regime soberano integrativo. Esse regime, que tem como melhor síntese a União Européia, implica na coexistência de diferentes níveis de governos e alcance transnacional de políticas, antes delimitadas às fronteiras nacionais. 
Se na primeira década a formação do Mercosul resultou na ampliação da interdependência entre seus membros, os últimos anos foram marcados por uma aproximação de cunho mais político. Mesmo que a integração econômica não tenha ultrapassado o nível de união aduaneira, tornou possível um alinhamento entre seus Estados, cujo principal efeito reside no fortalecimento da autoridade sobre uma área multinacional. Isso se materializa por um sistema regional de governança.

Terceiro, o processo contemporâneo de integração marca a preponderância regional do Brasil. Para potências emergentes como Brasil, Índia, Rússia e China, a preponderância regional é um elemento de ampliação de poder no cenário internacional (HURRELL, 2006). Em relação ao Brasil, essa tendência, explícita desde a última década do século $X X$, define a importante transição do equilíbrio de poder para a cooperação regional. A nova política sul-americana brasileira reflete a intersecção de diferentes tendências nas relações internacionais. O fim da Guerra Fria recrudesceu a antiga crença econômica de que interdependência comercial impõe uma paz universal às relações internacionais.

O retorno dos discursos sobre o mercado auto-regulado ao centro do debate político e econômico mundial nas últimas décadas teve poderosos efeitos sobre o delineamento do projeto de integração do Mercosul. O crescimento econômico dos Estados Unidos na década de 1990, condicionado à explosão de uma nova onda tecnológica e a financeirização da economia mundial seduziu não apenas ideólogos do mercado, mas principalmente homens de Estado de todo mundo. A teoria neoclássica, que ganhou força no pensamento econômico nos anos 1960, transformou-se numa ideologia contra o Estado (BRESSER-PEREIRA, 2009, p. 16).

Nesse contexto, a proliferação dos acordos regionais em todo o mundo, um fenômeno comandado pelos Estados nacionais, converteu-se na principal ferramenta para a liberalização comercial. É por esse motivo que a maioria dos blocos econômicos, ao contrário da União Européia, se constitui apenas em zonas de livre comércio. Para muitos setores da economia nacional, esse nível de integração funciona como forma de acesso aos mercados locais, sem, por outro lado, comprometer importantes interesses comerciais com países extra-bloco. Essa tem sido uma importante característica a impedir que os países do Cone Sul 
alcancem o aprofundamento da integração prevista pelo Tratado de Assunção (1991). Na década de 1990, a fidelidade brasileira ao bloco ocidental cedeu lugar a uma afinidade econômico-doutrinária, marcando uma aproximação com os Estados Unidos e uma indefinição quanto a sua atuação internacional (SOUTO MAIOR, 2006, p. 42).

Há importantes conexões entre essa postura internacional do Brasil e a ascensão dos novos discursos econômicos. Em princípio, existe uma clara delimitação da integração regional à esfera comercial. É verdade que em seus primeiros anos, o MERCOSUL foi muito importante à interdependência econômica entre seus membros, realidade esta que não pode ser subtraída de um projeto político.

Mas por outro lado, a prevalência da visão primordialmente mercantilista atenuava a importância desse bloco econômico para a política internacional dos seus Estados Partes. Apesar das indefinições sobre a atuação internacional, a proeminência econômica não impediu a sua consolidação como principal potência da América do Sul. Se a forma clássica do containment americano e a geopolítica militar sucumbiram aos novos tempos, a projeção comercial brasileira em seu continente foi o aspecto central da sua proeminência regional. Na primeira década do século $\mathrm{XXI}$, a perspectiva mercantilista, bastante enfraquecida pelas crises econômicas locais, cede lugar a um posicionamento político mais agressivo, onde a integração se torna uma das bases das pretensões brasileiras no contexto internacional.

A ausência de grandes ambições da política internacional do Brasil nos anos 1990 era resultado do colapso econômico da década de 1980 e conseqüência direta da dependência econômico-doutrinária perante às grandes potências e às instituições globais. Nos anos 1970, a ambiciosa política internacional de Geisel não foi apenas resultado de uma nova postura, mas conseqüência da nova condição brasileira de potência econômica emergente. Duas décadas mais tarde, a preponderância regional do Brasil estava em conformidade com a subordinação das economias de todo o continente às instituições como o FMI e Banco Mundial. O modelo econômico adotado pelas principais forças econômicas do Cone Sul, resultando no empoderamento do mercado financeiro e das instituições transnacionais, fez com que a limitação de 
suas relações internacionais restringisse também as potencialidades políticas da integração.

Associado à elevação do valor das commodities, o crescimento econômico mundial a partir de 2001 amplia a importância global do Brasil. É esse processo que possibilita uma política externa ambiciosa e o paralelo com o projeto empreendido por Geisel e Azeredo da Silveira nos anos 1970. Embora as semelhanças entre os dois momentos se restrinjam ao pragmatismo e à diversificação das alianças, ambos são marcados pela crença de que a diplomacia deve estar à frente das relações econômicas, criando meios ao desenvolvimento nacional.

É justamente na escala sul-americana que aparecem as maiores diferenças entre as duas abordagens diplomáticas. A política de integração muda a orientação mercantilista, investe numa aliança política continental, e se transforma numa das plataformas da projeção internacional do Brasil. Se nesse período se estabeleceu maior aproximação entre Argentina e Brasil, não houve grande evolução nos aspectos econômicos intrabloco, como a observada na década de 1990. Segundo Vigevani \& Ramanzini Junior (2010, pp. 45-63), o crescimento da China e do Sudeste Asiático, liderando a economia mundial entre 2001 e 2008, direcionou grande parte dos interesses comerciais dos países do Mercosul para a Ásia.

Isso não significa uma completa separação entre os interesses econômicos dos Estados Partes e Associados do bloco econômico. Como lembra Vigevani \& Ramanzini Junior (Op. Cit.), na Cúpula dos Chefes de Estados das Américas em Mar Del Plata (2005), foi confirmado o adiamento sine die da Área de Livre Comércio das Américas (ALCA). Esse é um evento extremamente simbólico, indo de encontro aos três apontamentos aqui esboçados. A resistência frente a ALCA verificada na maioria dos setores econômicos e sociais dos países do continente reflete uma crescente "consciência regional", isto é, o fortalecimento da crença de que o desenvolvimento passa, sobretudo, pela intensificação das relações sul-americanas. Essa resistência indica ainda que o surgimento dos novos pólos econômicos mundiais resulta, como aconteceu durante as décadas de 1960 e 1970, em novas possibilidades de expansão das relações políticas e comerciais. 
Há outro aspecto fundamental para a relação desses países com as principais potências mundiais. A posição marginal da América do Sul ao containment e, de forma geral, aos interesses das grandes potências explicita a necessidade de buscar novas alianças - com os países da própria região e de outros continentes. Assim, impôs-se uma necessidade urgente de reavaliação do posicionamento histórico que não mais refletia as condições internacionais na virada do século XX para o XXI. Se a primeira proposta efetiva de regionalização no Cone Sul não foi outra coisa senão um reexame da importância da região pelos seus próprios países, não é surpresa a resistência à proposta de livre comércio dos Estados Unidos.

Esse processo é resultado de uma nova conjuntura geopolítica, captada por amplos segmentos da sociedade. Além disso, a retomada do crescimento econômico brasileiro nos últimos anos reforçou a sua importância para o continente. Nos anos seguintes a crise financeira de 2008, a economia brasileira se tornou uma importante âncora das relações comerciais para a maioria dos países.

Os três apontamentos são proposições de uma nova conjuntura geopolítica. Torna-se necessário, nesse caso, compreender as transformações das relações internacionais nas últimas décadas - em escala regional e global - para entender os limites e alcances da nova geopolítica continental do Brasil, bem como da situação internacional da América do Sul. O aprofundamento analítico das relações entre o Brasil, o seu continente e o espaço global, implica escrutínio das dimensões que compõem a integração regional. É preciso averiguar e compreender até que ponto os processos de integração transcendem a retórica diplomática e se realizam nas dimensões materiais e sociais. Portanto, faz-se necessário compreender em que medida o regionalismo político se converte em regionalização. 
PARTE 2

OS FUNDAMENTOS DA INTEGRAÇÃO SULAMERICANA 


\title{
Espaços de Integração e a Nova Ordem Geopolítica
}

\author{
Hoje, quando vivemos uma dialética do \\ mundo concreto, evoluímos da noção, \\ tornada antiga, de Estado Territorial para \\ a noção pós-moderna de \\ transnacionalização do território \\ Milton Santos
}

\subsection{Integração Regional no Contexto de Reorganização do Espaço Mundial}

O Estado vem perdendo nas últimas décadas a condição de arena privilegiada da análise social. Em razão das transformações na produção, no consumo e no desenvolvimento tecnológico, a economia, as ciências sociais, e a geografia têm se debruçado sobre escalas espaciais de crescente importância. $O$ surgimento de outros espaços centrais a ordem mundial traz importantes elementos para a economia geopolítica. Essa tendência, que ganhou força com a transformação dos sistemas de produção, a partir da década de 1970 como examina Harvey (1989), Storper (1996), Castells (1999a, 1999b; 1999c) e Arrighi (2008a), reordena fluxos mercadológicos, políticas territoriais e hierarquia dos lugares.

Até os anos 1970, a economia geopolítica era conseqüência da supremacia do Estado sobre a economia e o território. A partir desse período, os movimentos de liberdade civil, a revolução informacional, as transformações dos 
sistemas empresariais de gestão e produção e a desregulamentação dos mercados contribuíram para mudanças no conjunto das forças que definem as relações internacionais. Os aglomerados industriais de alta tecnologia, que passaram a ganhar mais proeminência nos Estados Unidos e na Europa Ocidental nesse período, tornaram-se escalas espaciais centrais na hierarquia econômica, comandando a inovação da produção e novos modelos de gestão. O Estado, ao prover o modo de regulação, infra-estruturas e recursos financeiros, cria as condições para o crescimento de novos setores e regiões. Mas esses espaços não seriam possíveis sem a capacidade local de gerar inovação em gestão ou em tecnologia.

Ao fomentar o desenvolvimento tecnológico, o planejamento do território e políticas industriais, o Estado continua um ator decisivo na economia geopolítica internacional. O livre-mercado entendido como ausência de Estado, tornou-se uma das expressões mais banais e mal empregadas nas ciências humanas. Faz supor que os governos se tornaram completamente ausentes no desenvolvimento econômico, social e territorial. O Estado é o mais importante ator para o desenvolvimento regional e nacional. Ocorre que, o desenvolvimento não é garantido apenas pela macroeconomia. As experiências pós-fordistas das últimas décadas demonstram a valorização da microeconomia. Essa constatação não tem relação com o fim do Estado, mas com a complexificação das estratégias econômicas.

O Estado, não tendo o poder de definir exclusivamente suas políticas de desenvolvimento, tornou-se uma rede que articula diversas instituições nacionais, regionais e globais (CASTELLS, 2001). O "Estado-rede" articula no plano interno uma infinidade de instituições não estatais. O resultado mais conhecido é justamente a consolidação dos novos espaços de concentração do poder econômico, que reorganizam a economia geopolítica. Mas a consonância entre interesses empresariais e estatais não está relacionada à lógica que prevaleceu na ordem geopolítica precedente, onde as grandes corporações estavam subordinadas a um ambiente regulatório comandado pelo Estado. A desregulamentação tornou as empresas internacionais e o mercado financeiro em forças econômicas capazes de rivalizar com o Estado na condução dos interesses da sociedade. 
Essas transformações geram uma nova espacialidade da economia geopolítica. O mercado financeiro opera por meio de uma fluidez planetária, comandada a partir das grandes praças financeiras, sediadas nas cidades globais. As corporações no topo da economia mundial estabelecem o seu comando nessas mesmas cidades. Porém, a concepção de seus produtos se encontra enraizada em regiões de inovação tecnológica enquanto que sua produção é muitas vezes delegada para áreas de países em desenvolvimento na América Latina, Sudeste Asiático etc.

A partir da década de 1970, houve uma redescoberta da região, por um grupo de economistas políticos, cientistas sociais e geógrafos (STORPER, 1996). Nas antigas abordagens, a região era considerada mera derivação de processos político-econômicos mais profundos. Com a globalização, há uma renascença regional marcada pela organização da economia mundial num mosaico interativo de regiões (BENKO, 1993; STORPER \& SCOTT, 1995; SCOTT, 1996; STORPER, 1996).

As novas estruturas espaciais de produção se distinguem, sobretudo, através da concentração de conhecimentos, know how, tecnologias, inovação etc. (PORTER, 1993; 1999). Assim, a prosperidade da sociedade não está associada exclusivamente à condições macroeconômicas gerais, mas também à capacidade do Estado em induzir o surgimento e o sucesso de clusters produtivos, isto é, áreas que polarizam e comandam as novas formas de gestão e produção na economia contemporânea. A região se torna um motor da vida social (STORPER, 1996).

Devido ao alto nível de especialização, as regiões formadas por aglomerados industriais lideram diversos segmentos da produção em diferentes continentes. O poder econômico de um Estado está cada vez mais associado à existência de aglomerados industriais em setores agrícolas, industriais ou de prestação de serviços. Mas são os clusters de alta tecnologia que demonstram o modelo de liderança econômica dos países desenvolvidos no capitalismo contemporâneo. Estes clusters - farmacêuticos, aeroespaciais, eletrônicos, dentre outros - são constituídos principalmente nos países desenvolvidos, e quando em regiões em desenvolvimento, são formados geralmente por empresas estrangeiras. 
Os aglomerados Industriais, ainda que transformem o mundo num imenso caleidoscópio regional, são áreas diretamente influenciadas pelas grandes corporações, pelos Estados e também instituições subnacionais e supranacionais. Isso resulta do fato de que o comando das relações políticas e econômicas mundiais está em quatro escalas geográficas principais. A fluidez territorial, os aglomerados industriais e as políticas econômicas estão relacionados ao poder dos Estados, dos blocos regionais, das cidades-regiões globais (sede das grandes corporações nacionais e mundiais) e também de importantes instituições supranacionais.

Scott, Agnew, Soja \& Storper (1999, pp. 11-31), ao examinarem o arranjo geográfico mundial, dividem a ordem espacial, hierarquizando-a em quatro níveis interpenetrantes. O primeiro é posto pelo espaço transnacional global de fluxos financeiros, políticos, populacionais e culturais, comandado por instituições mundiais como FMI, Banco Mundial, OMC etc. O segundo é formado pelos blocos econômicos (Mercosul, UE, NAFTA, APEC, ASEAN, CARICOM, SACU, União do Magrebe Árabe etc. $)^{76}$ que funcionam como catalisadores de amplas alianças multilaterais frente às transformações impostas pela ordem geopolítica internacional. Os Estados soberanos são o terceiro ponto dessa hierarquia. Embora tenham relativamente perdido poder para as novas escalas políticas e econômicas, preservam a maior capacidade de comando na ordem internacional. As cidades-regiões globais são a última escala geográfica de concentração de poder.

Segundo Scott, Agnew, Soja \& Storper (Op. Cit.), existem mais de trezentas cidades-regiões no mundo com população acima de um milhão de habitantes e em torno de vinte com população superior a dez milhões. Conforme a globalização se intensifica, aumenta o crescimento das aglomerações urbanas ao redor do mundo. As cidades-regiões globais concentram as finanças, a produção e consumo de massa, tornando-se importantes nódulos globais de poder econômico e político. Mas no contexto de enfraquecimento do Estado e das políticas públicas, estas cidades são também o lugar da pobreza e da exclusão social (FAINSTEIN, 1999).

\footnotetext{
${ }^{76}$ Mercado Comum do Sul (Mercosul), União Européia (EU), Tratado Norte-Americano de Livre-Comércio (NAFTA), Cooperacão Econômica da Ásia e do Pacífico (APEC), Associação de Nações do Sudeste Asiático (ASEAN), Comunidade do Caribe (CARICOM), União Aduaneira da África Austral (SACU) e União do Magrebe Árabe, são apenas alguns dos inúmeros arranjos regionais do mundo contemporâneo. Em outros momentos desse estudo, alguns outros blocos são destacados, bem como suas relações com as relações internacionais contemporâneas.
} 
A ênfase dada ao aspecto regional dessas cidades ocorre pela circunstância onde um aglomerado de metrópoles e cidades formam uma vasta área que se destaca como uma região urbanizada e industrializada. As cidadesregiões são novos motores da economia global, pois se caracterizam pela concentração de conhecimento, habilidades, mão-de-obra especializada, tecnologias, fornecedores e oportunidades de negócio, que permitem uma alta concentração de produtividade. Essas áreas, embora produzam principalmente para os seus países, têm grande parte de suas atividades voltadas para mercados globais.

Há importantes diferenças entre o conceito de cidade região global e o de cidade global. A cidade-região global não se define apenas pela produção de serviços globais, mas principalmente pela concentração de indústrias voltadas para o mercado nacional (SASSEN, 1999). Dessa maneira, como os propósitos são muitos distintos daqueles da cidade produtora de serviços, as infra-estruturas também o são. Na perspectiva da análise da cidade-região global, privilegiam-se as estradas, as ferrovias, o transporte público e construções que não têm as mesmas funções das infra-estruturas da cidade global - telemática, satélite, fibra ótica etc.

Saskia Sassen (Op. Cit.) faz algumas comparações entre os dois conceitos, principalmente questionando o paradigma da centralidade. Assim como Peter Hall (1999), lembra que as cidades-regiões globais são em sua estrutura, policêntricas. Forma-se uma rede de diversos centros com poder de comando e organização do espaço urbano. Este conceito foca especialmente na formação de uma região que é responsável por uma morfologia espacial específica (CAMAGNI, 1999). Uma de suas bases é Megalopolis (1962) de Jean Gottmann, trabalho pioneiro no estudo da morfologia e funcionalidade da área urbanizada da costa leste americana, que se inicia em Boston, passa por Nova York e termina em Washington.

As cidades globais estão voltadas a uma nova geografia de centralidade. Nessa perspectiva, são interpretadas como nós, que interagem numa rede global. Se a cidade-região global está ligada em grande parte ao nacional, esse não é o caso da cidade global. Esta concentra serviços financeiros e os tornam disponíveis em escala mundial. Possuem, portanto, uma dupla natureza geográfica, dada pela dispersão (circulação) e pela concentração. As "cidades globais" são os centros de 
localização de atividades econômicas nacionais e internacionais que se desenvolvem independentemente de seu meio geográfico local ou regional imediato (BENKO,1993, pp. 58-59). A desregulamentação forçou a perda do controle desses fluxos, simultaneamente concentrados nesses nós e em circulação transnacional.

As relações políticas e econômicas não seriam reorganizadas apenas pelo fortalecimento de outras escalas geográficas. A emergência de países, até então sem poder político e econômico para fazer frente às potencias tradicionais, reafirma a importância dos Estados como centro de poder na política internacional. O crescimento de novas áreas implica num alargamento do espaço mundial. Nicholas Spykman (1944) já prenunciava que o desenvolvimento de áreas do rimland euroasiático - China, Índia, Sudeste Asiático etc. - resultaria em nova força global.

Os blocos regionais se constituem em um amálgama continental, articulando diferentes escalas políticas e econômicas. Os Estados, as cidadesregiões globais, as áreas de especialização produtiva e as zonas de integração fronteiriças formam um conjunto espacial integrado por um sistema de fluidez territorial. Enquanto a globalização exerce força centrifuga sobre as mais diversas escalas geográficas, fazendo com que os fluxos materiais e informacionais se dirijam para outros continentes, a regionalização força a um centripetismo continental. Embora também seja uma força de extroversão a ordem territorial clássica, o faz em favor da cooperação entre Estados em condições geopolíticas análogas.

A lógica da "fragmentação" do território nacional, principalmente entre países pobres ou em desenvolvimento, opera em conformidade com as forças centrífugas da globalização e tendem a fazer com que o território nacional seja "estilhaçado". Sem a ação do Estado nacional, as novas escalas regionais podem funcionar apenas em prol dos interesses corporativos, sejam eles nacionais ou globais.

É nessa conjuntura espacialmente complexa que o valor estratégico dado ao Cone Sul nos últimos vinte anos pela diplomacia brasileira tem sinalizado para a formação de uma região geopolítica. Diferente do expansionismo brasileiro e argentino que prevaleceram entre as décadas de 1960 e 1970, a configuração do Cone Sul como o núcleo de uma região geopolítica continental parte do princípio 
de que a construção de novo ente político se coloca como mecanismo de transformação da inserção internacional dos Estados Partes e Associados do Mercosul.

Nesse sentido, Saul Bernard Cohen (2003, pp. 01-33) defende que na conjuntura de multipolarização das relações internacionais, o Cone Sul pode alcançar maior poder de participação na agenda política e econômica mundial. Sob a ótica política, a integração regional significa a consolidação das novas alianças multilaterais. Numa perspectiva estritamente econômica, permite a articulação continental de novas escalas subnacionais, como as cidades-regiões globais e os clusters. A constituição de uma área política e economicamente coesa no Cone Sul está em consonância com desdobramentos da ordem geopolítica contemporânea.

A concepção de preponderância regional como meio de projeção internacional (HURRELL, 2006) não invalida o argumento de que a nova geopolítica continental está fundada na idealpolitik. Se a integração sul-americana (a partir do Cone Sul) é para o Brasil um meio de reivindicação de mais poder na ordem geopolítica internacional, deve-se considerar o caráter "consensual" dessa posição. Há em certo sentido, uma delegação por parte das nações vizinhas, que apesar das rivalidades históricas, dos atritos presentes, e das discordâncias políticas, entendem que o país congrega os principais elementos para a liderança interna e representatividade externa (Op. Cit.). Essa característica, que não está presente apenas na integração forjada no Cone Sul, corrobora com o caráter mais político do que propriamente econômico dos blocos regionais em formação em todo o mundo.

A multiplicação, a partir do exemplo europeu de integração, de acordos regionais de diferentes naturezas como a APEC na Ásia-Pacífico, ASEAN no Sudeste Asiático, NAFTA na América do Norte, a COMESA na África etc., demonstra que a formação de regiões geopolíticas se tornou um dos novos fundamentos das relações internacionais. Sendo entendidos pelos Estados como pressupostos para a coesão interna e projeção externa, os acordos regionais possuem importantes aspectos em comum. Ainda que os acordos visem níveis de aproximação e integração distintos, a transformação da base territorial está entre os elementos indissociáveis de todas as iniciativas do gênero. Como a maioria dos 
projetos de integração, o Mercosul envolve a transformação da geopolítica continental.

Portanto, a regionalização envolve indissociavelmente política, economia e território. A política, através de acordos, protocolos e tratados, permite a mudança efetiva da relação entre Estados que durante décadas foram antagonistas na busca por projeção externa. O território se destaca como a base geográfica e um dos principais vetores da integração. Ao mesmo tempo em que proporciona as condições físico-naturais, o território se torna um dos objetivos centrais da política. A transformação da base geográfica é fator determinante para a coesão de uma região transnacional. A economia, por outro lado, destaca-se como principal meio de legitimação do processo, visto que o discurso do crescimento econômico e da melhoria das condições de vida da população é a justificativa da integração com maior penetração perante a opinião pública e a população.

A mudança de paradigma da política internacional no Cone Sul está acompanhada de uma transformação no entendimento do território pelo Estado. Essa transformação impulsionada pelas necessidades de integração regional está implícita no próprio Tratado de Assunção (1991). O arranjo reticular do território é imanente ao controle do espaço da nação e a capilaridade do poder institucional do Estado (RAFFESTIN, 1993). Nas últimas décadas, a rede territorial atravessa a escala nacional, e evidencia seu papel estruturante para os projetos de integração entre antigos rivais. A diferença fundamental do planejamento contemporâneo do território está na coexistência entre forças de introversão e extroversão, isto é, no entrelaçamento e na interdependência entre os interesses nacionais e transnacionais.

Nesse contexto, o território nacional, ao compor uma malha transnacional vetorizada por forças externas, é não mais "moldado" exclusivamente por forças internas. Aspectos discutidos nos parágrafos acima - como a especialização dos lugares, a concentração da produção e consumo, e a circulação material e informacional - forçam a transformação dos preceitos que regem a organização territorial do Estado. Até mesmo o ordenamento do território nacional está sujeito aos fluxos internacionais de capitais, bens, serviços e informações (COSTA, 2005a, pp. 55-59). 
No limiar do século XXI, muitos analistas se debruçaram em estudos sobre a relação entre as redes e o território. Essa perspectiva, apesar das novas conjunturas e terminologias, não é inteiramente nova. Richard Hartshorne no período entre 1940 e 1950, e Jean Gottmann nas duas décadas seguintes já evidenciavam o funcionamento em rede do território. ${ }^{77} \mathrm{Na}$ década de 1970, o geógrafo francês salienta a existência de dois padrões para o uso do território: alguns Estados são isolacionistas, enquanto outros são preferencialmente "expansionistas" no que se refere às suas relações territoriais (GOTTMANN, 1975)..$^{78}$

O modelo "expansionista" está na base da globalização. A conexidade do território-rede está no cerne de inúmeros estudos sobre a globalização e a sociedade contemporânea. Nas relações internacionais, essa perspectiva reticular não se restringe a "Estados cosmopolitas". De fato, a globalização se caracteriza como resultado de forças hegemônicas, sendo seus componentes intrínsecos as mais modernas redes de comunicação e transporte, como evidencia Manuel Castells (1999a). Entretanto, não são somente as principais potências que estão mergulhadas nos fluxos globalizados. Castells (1999b; 1999c) adverte que as redes transnacionais também conectam todos os movimentos dissonantes da globalização. Dessa forma, o "quarto mundo" e a exclusão social estão em simbiose global.

Todos os lugares da América do Sul, sem exceção, estão subordinados a ordem geopolítica contemporânea. A "Guerra ao Terror", as tempestades financeiras (cada vez mais constantes desde a quebra da bolsa de Nova York em 1987), a crise ambiental e a economia geopolítica; todos esses fatores têm impactos diretos ou indiretos sobre todo continente. Todavia, os efeitos dessa ordem geopolítica são perversos, sobretudo, para áreas pobres. Em espaços periféricos, “... a globalização não faz senão edulcorar uma nova forma de exploração e imperialismo, ou seja, a ditadura do mercado mundial." (BECK, 2003. p. 10).

\footnotetext{
77 Para Hartshorne (Op. Cit.) a morfologia do território reflete a própria organização social. O centro, a periferia e as fronteiras são organizados de acordo com os princípios da própria organização do Estado. Nesse sentido, apresenta uma concepção que denomina de Estado-área, evidenciando uma relação imanente entre Estado e território. Jean Gottmann (1975), demonstrando o caráter intrínseco da relação entre o Estado e o seu espaço de domínio, lança luz sobre o uso do território. Tanto em Hartshorne quanto em Gottmann, a morfologia confere tessitura e funcionalidade de acordo com o modelo de relações políticas.

${ }^{8} \mathrm{O}$ conceito de expansão expresso por Gottmann (Op. Cit.) não tem somente relação com o imperialismo. O autor se refere, antes de tudo, à criação de um sistema de relações políticas e econômicas. Nesse sentido, a expansão não envolve necessariamente o aumento do poder coercivo, mas a busca de suporte político e econômico através de uma rede de relações externas.
} 
O espaço continental de integração, ao exercer força de coesão sobre as diversas áreas sul-americanas, funciona como um containment à tendência de dispersão imposta pelas escalas (interpenetrantes) que compõem a ordem geopolítica. Por outro lado, a valorização da especialização econômica regional e a constituição de uma fluidez territorial seletiva tendem a excluir ainda mais os lugares que não se estabeleceram nos grandes circuitos nacionais e globais da economia.

O relativo enfraquecimento dos Estados nacionais, a constituição de um caleidoscópio global de áreas de especialização produtiva e a divisão do espaço mundial em quatro escalas interpenetrantes é o dado maior da organização espacial da ordem geopolítica contemporânea. Nas regiões periféricas, os blocos regionais e os Estados nacionais são os entes políticos capazes de articular, em favor da sociedade, as demais escalas geográficas que integram espaço mundial. Caso contrário, os interesses hegemônicos das potências que comandam a ordem geopolítica atual tendem a se sobrepor e subordinar ainda mais as áreas periféricas.

\subsection{Elementos Preliminares da Nova Ordem Geopolítica Mundial}

Conforme previamente discutido, os acontecimentos que contribuíram para integração regional no Cone Sul são anteriores ao fim da bipolaridade. 0 Mercosul é resultado de experiências gestadas na antiga ordem geopolítica mundial, que se tornaram rapidamente hegemônicas nas relações internacionais na década de 1990. As forças que alcançaram a preponderância nessa década se desenvolveram no interior da ordem bipolar, expressando-se não apenas através de inúmeros projetos de integração regional, mas também pelo surgimento de novos centros econômicos de relevância mundial. A regionalização proposta pelos quatro países que assinaram o Tratado de Assunção se tornou determinante para o enfraquecimento do alinhamento automático com os Estados Unidos no Cone Sul.

Semelhante aos blocos regionais, as instituições globais são responsáveis pela maior transformação na ordem internacional após o fim do ancien régime. As 
relações internacionais são conduzidas ou intermediadas por instituições como FMI, BIRD, OMC, além dos diversos organismos internacionais que compõem a Organização das Nações Unidas (ONU). Hoje, o espaço mundial não é apenas resultado das relações interestatais. É conseqüência de uma complexidade de fluxos materiais e informacionais, em parte induzidos pelo Estado e corporações transnacionais e, em parte "ordenados" por instituições multilaterais e supranacionais.

Em que medida essa transformação foi gestada na Ordem Geopolítica da Guerra Fria? A constituição de um "império planetário" através da institucionalização da política internacional tem como um dos fundamentos, a antiga proposta da Liga das Nações (HARDT \& NEGRI, 2005; 2009). A primeira tentativa de criação de uma governança mundial representada pela Liga é a mais importante contribuição americana para a política internacional; que segundo Kissinger (1994) se deu por meio da postura visionária do presidente Woodrow Wilson.

A famosa concepção de arsenal of democracy do presidente Franklin D. Roosevelt (uma herança do idealismo wilsoniano) como contraposição ao manpower mackinderiano, encontrou a sua mais perfeita tradução com a formação da ONU. Desde então, valores considerados universais como a democracia e os direitos humanos passaram a transcender paulatinamente o invólucro dos Estados nacionais hegemônicos, e se tornaram fatores norteadores da ação transnacional das instituições supranacionais e da política internacional como um todo. Desde então, a idealpolitik ganhou força a ponto de se contrapor à supremacia da realpolitik. $^{79}$

Mesmo com todo o esforço de transnacionalização da política, a existência efetiva de um espaço global fluído acima de todas as fronteiras e poderes nacionais nunca passou de um delírio coletivo que aprisionou teóricos de diversas

\footnotetext{
${ }^{79}$ Uma importante análise a esse respeito se encontra em Diplomacy (1994) de Henry Kissinger. No capítulo intitulado The Hinge (pp.29-77), Kissinger pormenoriza a origem de dois paradigmas da política externa norte-americana. O primeiro, cujo principal expoente é Theodore Roosevelt, se fundamenta no equilíbrio de poder. O outro, protagonizado por Woodrow Wilson, é uma nova visão da política internacional, onde a realpolitik é suplantada pelo idealismo. Com o enfraquecimento da Europa e ascensão de novas potências, os dois presidentes foram responsáveis por quebrar o isolacionismo do país. Estabeleceram um modelo de aderência internacional dos Estados Unidos, transformando-se em fundadores da política externa norte-americana. Diferente dos "pais fundadores" que pregavam a superioridade moral do país em relação à Europa, a premissa de Theodore Roosevelt era de que os Estados Unidos se constituíam num poder como qualquer outro, não sendo uma encarnação da virtude. Woodrow Wilson possuía uma concepção - a partir da sabedoria convencional americana estabelecida pelos "pais fundadores" - de que as democracias não guerreiam entre si. Entendia que a paz era dependente de instituições democráticas. $\mathrm{Na}$ esteira de George Washington, Woodrow Wilson visava diferenciar moralmente o comportamento do país em relação às outras potências. O engajamento na política internacional estaria orientado por sua fé moral. A criação de instituições mundiais de caráter democrático para a condução das relações internacionais visava transcender os valores americanos para a escala global.
} 
áreas e matizes em todo o mundo. $O$ desejo quase carnal dos economistas neoclássicos, de um espaço global liso e aberto a todos os fluxos financeiros e comerciais resultou num poderoso assalto teórico ao Estado. Este perigoso movimento foi comandado por uma coalizão de rentistas e brilhantes profissionais financeiros que usou o neoliberalismo para se enriquecer (BRESSER-PEREIRA, 2009, p. 15).

O mecanismo de desimbricação entre economia e sociedade, operado pelo "moinho satânico" do mercado não se completa porque leva toda civilização à beira do abismo (POLANYI, 2001). A própria tendência de liberalização do comércio mundial reiniciada com a consolidação da hegemonia mundial americana é reveladora da complexidade da substituição do Estado pelas forças do mercado. As instituições supranacionais mundiais têm sua ação restringida pela força dos Estados, mais interessados na escala nacional do que em uma "civilização global". 80

Não se deve ignorar que a institucionalização cada vez maior das relações internacionais permite o surgimento de um Leviatã planetário que não pode ser considerado o simples resultado da vitória de uma vertente econômica. James $\mathrm{N}$. Rosenau (2000, p.11-43) entende que ordenação da política internacional contemporânea é posta por um sistema de governança estabelecido pela interação de atores estatais e não estatais. Se os fluxos materiais e informacionais impõem a livre circulação, diversas instituições políticas (de diferentes propósitos e alcances) forçam a estratificação e o controle da circulação. Tomando emprestado um conceito chave em Gilles Deleuze (1996), a formação de um aparelho institucional em uma sociedade se reflete no "estriamento do território", seja ele nacional ou transnacional.

\footnotetext{
${ }^{80}$ Nos últimas décadas, o trabalho clássico de Karl Polanyi, The Great Transformation (publicado originalmente no ano de 1944) tem adquirido proeminência nas discussões econômicas. A crítica à hegemonia dos economistas neoclássicos no aparelho de Estado nas últimas décadas, assim como os constantes ataques ao discurso neoliberal após as crises recorrentes que assolam a economia internacional desde o crash da Bolsa de Nova York em 1987, tem no filósofo húngaro a maior referência. Polanyi concebeu um monumental exame crítico do pensamento econômico como resposta à emergente "escola austríaca" liderada por Ludwig von Misses. Diferente dessa escola, Polanyi não acreditava que a liberdade do indivíduo passava pela liberdade econômica e a auto-regulação do mercado. Apesar de considerar o mercado uma das grandes invenções sociais, as relações econômicas e comerciais não deveriam suplantar os interesses da sociedade. Em sua concepção, o mercado auto-regulado se transforma num "moinho satânico", destruidor dos valores sociais e até mesmo da natureza. Mais que isso, ao não reconhecer Estados, fronteiras, natureza, crenças, tradições, e exterminando o capital social, a auto-regulação significa para o próprio mercado, um mecanismo de autodestruição. Polanyi escrutiniza o pensamento econômico desde Adam Smith e David Ricardo até chegar à grande crise econômica da primeira metade do século XX, para explicitar os efeitos negativos do mercado auto-regulado sobre o "capital social" e o conjunto da sociedade. Como lembra Joseph Stiglitz (2001), Polanyi entende o mercado como componente indissociável de uma economia mais ampla, e esta, como parte de uma sociedade ainda mais ampla. A economia de mercado não é um fim em si mesmo, mas um meio para fins mais fundamentais.
} 
Independentemente de serem as relações internacionais fundadas na realpolitik ou na idealpolitik, o poder em suas mais distintas manifestações, implica na busca pelo controle de toda forma de circulação. Até mesmo a ausência de regulação efetiva dos fluxos financeiros globais compõe um modo de regulação específico.

Ainda que a OMC funcione como mecanismo de liberalização comercial, e instituições como ONU se impõem como forças supranacionais homogeneizantes, formas tradicionais ou novas de organização espacial da política reafirmam o caráter assimétrico do poder. O que seria o Mercosul senão uma manifestação dessa assimetria? Como descreve Celso Amorim (1999, p. 06), a integração no Cone Sul foi também uma forma de proteção frente à abertura comercial internacional que se impunha aos países do continente no começo da década de 1990. A evolução da tendência de regionalização - expressa de forma concreta pela primeira vez com o Acordo de Cooperação Econômica n 14 entre Brasil e Argentina (1990), um passo decisivo para a integração multilateral que seria proposta pelo Tratado de Assunção - resultou da necessidade de cooperação frente à ameaça representada pela proposta de George Bush para criação da ALCA.

O estabelecimento da união aduaneira com a criação da Tarifa Externa Comum (TEC) em 1994 resultou numa maior interdependência no interior do bloco. Mais que um mecanismo de aprofundamento das relações comerciais, a TEC significou um passo decisivo para o estabelecimento da região geopolítica. A tarifa possui esse alcance, ao possibilitar a articulação efetiva de um espaço regional frente aos interesses hegemônicos que movem a globalização. No que tange ao continente americano, funciona como a mais importante defesa contra a investida dos Estados Unidos visando a criação da área de livre comércio sob seus auspícios.

O Tratado de Assunção ambiciona, com as propostas de união aduaneira e mercado comum, não apenas a constituição de uma área buffer ao poder econômico das potências. Almeja da mesma forma, a constituição de uma autoridade regional. Isso nos leva a noção de soberania proposta por John Agnew (2005; 2006; 2008).

A soberania regional proposta pela integração estabelecida por este Tratado deve ser compreendida como uma "autoridade em rede" que coexiste 
simultaneamente com redes de soberania; sejam elas tradicionais ou contemporâneas.

Rompendo com geopolítica estadocêntrica, Agnew (2008, pp. 130-132), defende a coexistência de quatro regimes soberanos na política internacional contemporânea. São denominados de clássico, imperialista, integrativo e globalista. O regime clássico é o modelo westfaliano de soberania do Estado territorial. Envolve o emprego do exercício do poder no interior do território nacional. Esse regime é ameaçado tanto por forças internas quanto externas. Os movimentos separatistas, a falta de legitimidades do sistema político e carências de integração territorial são exemplos de fatores internos que ameaçam a soberania do Estado.

Da mesma forma, há forças externas, representadas por potências imperialistas, ou mesmo instituições globais que limitam o poder de um determinado Estado dentro do seu próprio território. O regime imperialista é o oposto do clássico, sendo formado por forças externas que se sobrepõem ao poder local. Envolve, sobretudo, o poder hierárquico da política internacional. 0 poder despótico está sempre em mãos externas, podendo ser o FMI ou um Estado distante. Nesse regime, a autoridade central é ameaçada por diversos fatores, como dependência e manipulação externa, corrupção, má administração, e conflitos sociais.

O regime soberano integrativo implica a coexistência entre diferentes níveis de governos, que passam por diferentes áreas subnacionais e supranacionais. Esses níveis envolvem desde a escala continental da UE, até o território nacional e regiões subnacionais (Estados, províncias e municípios). Já o regime globalista, existe através do poder global de um Estado, que arrola diversos países em seu sistema político mundial. De natureza hegemônica, esse regime se sustenta enquanto um mix de coerção e consenso, fazendo com que os demais Estados sejam absorvidos por suas redes transnacionais. Nesse caso, o exercício do poder depende de um processo de legitimação, constituído como analisa Norberto Bobbio (1986), por meio de um sistema político que possua respaldo na sociedade. Como mostram o caso inglês no século XIX e o americano a partir de 1945, a soberania globalista depende de mecanismos "desterritorializados" de poder. 
A proposição do conceito de soberania integrativa tem, em muitos sentidos, correlações com aquilo que Manuel Castells (2001, pp. 147-169) define como soberania compartilhada. Essa tendência se expressa com mais clareza no projeto europeu de regionalização, um dos mais importantes tipos de autoridade sócio-espacial. Partindo dessa concepção, o Mercosul pode ser considerado tanto uma reação ao regime imperialista exercido pelos Estados Unidos em toda América Latina, como uma forma de inserção competitiva na globalização, em parte também derivada do regime globalista da maior potência mundial (AGNEW, 2008a, p. 131)

A Ordem Geopolítica Pós-Guerra Fria se diferencia pela influência mútua entre distintas manifestações de atritos e conflitos. As relações internacionais não são estadocêntricas, nem mercadocêntricas. Agnew (1998, pp. 115-126) destaca três tendências predominantes na definição e análise dos conflitos internacionais: (a) o regime de acesso ao mercado e sua oposição; (b) o choque de civilizações; (c) do Estado-centrismo e a unipolaridade dos Estados Unidos. Essas três linhas são hegemônicas nas principais correntes contemporâneas de análise da política internacional.

$\mathrm{Na}$ primeira conjuntura, a transnacionalização cada vez maior da economia, o avanço do livre-mercado, associados aos elementos da geopolítica tradicional, funcionam como uma fonte permanente de conflitos que perpassa toda política internacional. A segunda, onde a mais perfeita expressão se encontra na concepção de "choque de civilizações" popularizada por Samuel P. Huntington (1993; 1996), enfoca na intensificação dos conflitos entre diferentes civilizações como meio de análise das relações internacionais. Há um sério problema em relação à identificação das culturas, pois não é possível a definição exata de uma civilização, ou mesmo a diferenciação de civilizações (AGNEW, 1998). A globalização funciona através de forças opostas, pois simultaneamente enfraquece e recrudesce as diferenças culturais. Muitas das ameaças externas, grosseiramente reduzidas a uma determinada cultura, são resultados da necessidade de criação de uma nova identidade para as ações geopolíticas americanas (AGNEW, 1998)

Analistas da terceira corrente enfocam o aumento do poder imperial dos Estados Unidos. Essa tendência se tornou predominante após os atentados de 11 de Setembro de 2001. Com o governo de George W. Bush, a política externa 
norte-americana passou a ser caracterizada pelo hiper-realismo, com forte impacto sobre a soberania westfaliana (COSTA, 2005, pp. 72-87). O regime soberano globalista norte-americano, tornado de fato mundial com débâcle do comunismo, sofre constantes perdas de legitimidade devido à imposição de um poder militar planetário.

O caráter transnacional do hiper-realismo se sustenta em uma concepção de segurança que é simultaneamente nacional e global. Mustapha Kemal Pasha (2007) afirma que o 11 de Setembro intensificou a tendência de um mundo pós Westfalia. Enquanto a globalização dissolve as bases do mundo westfaliano de uma forma mais consensual, o 11 de Setembro legitima o surgimento de um estado de emergência que justifica ações transterritoriais de um "império ameaçador".

Para Pasha (Op. Cit.) a ação do império transforma tempo em espaço, criando áreas modernas e áreas não civilizadas. Nesse caso, as zonas de cultura islâmicas espalhadas pela África e Ásia estariam entre as áreas que deveriam ser subordinadas à razão ocidental. O mundo westfaliano é ameaçado por um império que criou um Estado de emergência, pondo em xeque a soberania dos Estados nacionais.

Segundo Costa (2005), os neorealistas, muitos por trás da política externa do país, entendem que pela primeira vez desde o fim da Guerra Fria, os Estados Unidos têm uma estratégia para assegurar o seu poder sobre todas as demais nações do mundo, deixando de lado o multilateralismo. Várias ações americanas têm destacado um unilateralismo irrestrito. Além da "guerra ao terror", a resistência contra reivindicações por mudanças no Conselho de Segurança da ONU, a oposição ao Protocolo de Kyoto e a manutenção de prisões que desrespeitam os direitos humanos evidenciam a clara resistência do país a própria tradição wilsoniana.

O caráter "desterritorializado" do terrorismo justificaria o sobrepujamento das fronteiras e da soberania nacional. ${ }^{81} \mathrm{~A}$ hegemonia norte-americana carece do

\footnotetext{
${ }^{81} \mathrm{O}$ termo desterritorializado faz referência apenas à fluidez transfronteiriça das ameaças à segurança interna dos países. Mesmo se privilegiarmos a perspectiva tradicional de território, reduzido a noção de espaço do Estado, não é possível falar em ameaças desterritorializadas. Primeiro, as organizações terroristas operam territorializadas em determinadas regiões, sejam elas pobres ou ricas. Segundo, no que tange as relações internacionais, o foco não pode ser exclusivamente na fluidez das redes terroristas, visto que estas organizações operam em determinadas regiões com o apoio de Estados. Por fim, em Geografia Política, as discussões sobre a desterritorialização correm o risco de cair numa armadilha tautológica. A desterritorialização, reterritorialização e multiterritorialidade, como trabalhados por Rogério Haesbaert (2004), são importantes à compreensão das condições antropológicas do ser na chamada pós-modernidade. Mas para o entendimento dos processos geopolíticos, tradicionais ou contemporâneos, essa linha tende a conduzir a equívocos, como a sobrevalorização de processos
} 
mix de coerção e consenso que a definiu até o final da década de 1990 (AGNEW, 1998, p. 125). Aspectos centrais da soberania globalista se transformam numa condição geral da ordem geopolítica, transcendendo muitas vezes os interesses do hegemon. Os Estados Unidos são o país - sobretudo a partir do governo Bush que menos aderiram aos tratados de não proliferação e de diminuição do arsenal nuclear (HAMEL-GREEN, 2007). São contra a entrada do G-4 (Brasil, Alemanha, Japão e Índia) no Conselho de Segurança, a mudança da Comissão de Direitos Humanos para Conselho de Direitos Humanos e a formação da Comissão de Paz (YAMADA, 2007).

Potências médias têm nos valores morais e na governança, um nicho de atuação na política internacional (PATIENCE, 2007). Deficiências em hard power impele muitas potências regionais e nações mais pobres a encontrarem espaço de representatividade em instituições multilaterais; regionais ou globais. Historicamente, este tem sido o caso brasileiro. A participação em arenas multilaterais é uma característica constante da política externa brasileira desde 0 final do século XIX (SOARES DE LIMA \& HIRST, 2006, p. 25). Com a criação da ONU, e sem poder econômico e militar para forçar sua posição no cenário internacional, o país enfatiza atividades diplomáticas por meio dessa instituição, tida como uma das poucas áreas onde pode exercer influência (PUNTIGLIANO, 2008, p. 35).

As potências médias da Europa e do Pacífico Asiático estão propensas a atuarem em questões relacionadas aos direitos humanos e ao meio ambiente. Países em desenvolvimento têm priorizado, sobretudo, arenas de negociação multilateral para fortalecerem seus interesses em temas-chave ao desenvolvimento: barreiras comerciais, protecionismo e subsídios agrícolas dos países ricos.

O Brasil, como principal potência regional sul-americana, possui maior capacidade de liderar negociações multilaterais com países desenvolvidos. Enquanto hegemon regional, o país conduz seus interesses globais segundo prioridades da política continental. Mas essa questão pode ser posta de forma inversa.

"pós-modernos" numa ordem onde o hard power e a relação entre Estado, economia, território e poder (ainda) é preponderante. 
O Itamaraty tem usado a condição de líder regional para legitimar a ambição por maior poder em instituições e arenas internacionais. Em certo sentido, a famosa frase de Nixon, “... para onde for o Brasil, também irá o resto do continente latino-americano" (SPEKTOR, 2008, p. 60) não é equivocada. No contexto das rivalidades geopolíticas, a ambição internacional do Brasil causava tensões em todo continente. O imperativo da cooperação nos anos 1980 trouxe uma mudança fundamental. A liderança regional brasileira não se tornou fator de desestabilização interna porque passou a estar condicionada a agenda externa do continente.

Existe uma diferença crucial entre a preponderância regional brasileira contemporânea e a projeção continental na Ordem Geopolítica da Guerra Fria. Quando o chanceler Azeredo da Silveira interpretava que o enfraquecimento da Argentina na década de 1970 poria fim ao equilíbrio de poder, fazendo com que os países mais fracos fossem a reboque do Brasil (Op. Cit., 2008, p. 66), expressava a subordinação da América do Sul aos interesses do país. O esforço para se sobrepor ao continente predominou na diplomacia brasileira dessa ordem geopolítica.

Com as políticas de integração, a diplomacia brasileira utiliza as relações preferenciais com seus "sócios naturais" em prol de sua política mundial (BERNALMEZA, 2008). Todavia, como conseqüência da ordem geopolítica contemporânea, esta tendência possui sentido oposto da projeção continental que predominou durante as rivalidades. Com as transformações da economia geopolítica e o fortalecimento da idealpolitik, a projeção internacional brasileira só faz sentido num contexto de fortalecimento de toda América do Sul. Esta tendência dominou todos os governos democráticos, ganhando ainda mais importância com a administração Lula.

A crise de 2008 e a substituição do G8 pelo G20 são sinais de mudanças significativas no Interior da Ordem Geopolítica Pós-Guerra Fria. No limiar do século XXI, a regionalização era uma forma de resistência aos efeitos negativos da hegemonia global exercida pelos Estados Unidos. Nos últimos anos, esse processo adquiriu outros significados. A tendência predominante de multipolarização do cenário internacional confere às políticas sul-americanas de integração uma posição relevante à transformação da ordem geopolítica contemporânea. 
Entretanto, os principais fundamentos da Ordem Geopolítica Pós-Guerra Fria não perderam importância, mesmo com a ascensão de novas potências. A legitimação dessa ordem depende da força persuasiva que se manifesta pela cultura, pelos valores políticos, pelo ordenamento institucional, e pela economia geopolítica. Essa conjuntura molda a organização de todos os espaços de integração.

\subsection{Legitimação da Nova Ordem Geopolítica e a América do Sul.}

As políticas de integração regional estão subordinadas à Ordem Geopolítica Pós - Guerra Fria. O fato de a integração ser reduzida, no mais das vezes, a uma ótica mercantilista, não deve obscurecer o seu impulso fundador de autonomia regional. Sob o mercado, a cultura ou as relações interestatais, a integração é uma tentativa de redefinir o lugar da América do Sul na política internacional.

A tendência predominante nas relações internacionais de conceber os países latino-americanos enquanto parte de uma civilização homogênea não pode ser ignorada no exame das políticas de cooperação. Esta concepção reflete aspectos que perpassam as relações envolvendo o Estado, a sociedade e o território.

Seria um grave erro ignorar que os problemas de dominação e de dependência econômica e política dão características comuns aos países latinoamericanos, dos menores aos maiores como nota Manuel Correia de Andrade (1989). Mas, devem-se ser destacadas três diferenças. Primeiro, a América do Sul não tem uma presença militar americana tão maciça como a América Central e Caribe (COSTA, 2009). As mais de vinte áreas e territórios com bases ou núcleos de apoio às forças armadas dos Estados Unidos (Op. Cit.) refletem o domínio do país, consolidado desde a derrota espanhola na Guerra Hispano-Americana de 1898.

Segundo, a adesão do México ao NAFTA, e a posição de aliado incondicional dos Estados Unidos (SANTOS, 2007), ao resultar na ampliação do poder político e econômico americano sobre o país e toda América Central (BECKER \& EGLER, 1992) permite diferenciar dois grandes projetos geopolíticos 
na América Latina. O primeiro, comandado pelos Estados Unidos, aposta na continuidade de sua hegemonia histórica na região. O segundo, comandado pelo Brasil, investe na reversão desse processo por meio da política de autonomia regional.

Terceiro, as diferenças internas têm sido ignoradas em favor de uma imagem reducionista, conseqüência de representações hegemônicas do mundo. Colocado de outra maneira, a América Latina foi absorvida por discursos geopolíticos centrais. Uma abordagem construída exclusivamente a partir da dependência não serve somente como legitimação das forças históricas internas de resistência. A América Latina possui uma imagem geopolítica que também funciona como meio de legitimação de imposições oriundas das principais potências.

É preciso considerar que uma situação histórica, de competição imperial ou guerra, leva ao estabelecimento de um modelo auto-explanatório, que funciona como base para representação do mundo (RETAILLÉ, 2000, pp. 42-43). Aos discursos geopolíticos contemporâneo, toda riqueza representada pela diversidade cultural latino-americana tem sido majoritariamente subordinada a concepções ultra-realista presentes em autores como Samuel Huntington (1993; 1996) e Thomas Barnett (2004) que interpretam toda a região enquanto risco à ordem mundial. ${ }^{82}$

Esse raciocínio não é exclusividade dos últimos governos republicanos. Bill Clinton, em discurso na Assembléia Geral da ONU (1997), coloca os Estados "fora da lei" como a principal ameaça à ordem internacional. O presidente democrata estava ressaltando transformações do mundo Pós-Guerra Fria que já havia destacado em seu Discurso Inaugural de 1993, quando declarou que não

\footnotetext{
${ }^{82}$ Ao defender a globalização como o estágio mais avançado da civilização, Barnett não pressupõe que os problemas a ela relacionados advêm de suas contradições, mas da recusa de países e regiões em nela se inserirem. Para Barnett, as redes e os fluxos globais levaram prosperidade e desenvolvimento para muitas áreas do globo e somente aquelas que se recusam à modernização não são capazes de experimentar esses avanços. Essas idéias foram expostas pela primeira vez no artigo intitulado The Pentagon's New Map: It Explains Why We're Going to War and Why We'll Keep Going to War, publicado em 2004 na Squire, conservadora revista americana. Nele, o autor faz uma defesa veemente do governo Bush e sua disposição de entrar novamente em guerra contra o regime de Saddam Hussein. O aspecto mais marcante do artigo é a proposta de diferenciação do globo em duas áreas de características opostas. O CORE (centro) é descrito como um conjunto de áreas dispersas, formado por países que dominam os fluxos financeiros, e que são principalmente caracterizados pela predominância de governos estáveis, padrão de vida em ascensão, segurança coletiva e ainda (como ressalta o autor), pela existência de mais mortes por suicídio que por assassinato. Essas áreas são formadas principalmente pela América do Norte, União Européia, Rússia, Japão, partes da América do Sul, Austrália, Nova Zelândia e África do Sul, e economias emergentes da Ásia (principalmente China e Índia). Para Barnett, o GAP (fenda) poderia ser todo o resto do planeta, mas prefere nomear o anel caribenho, virtualmente toda a África, Cáucaso, Ásia Central, Oriente Médio e Sudeste Asiático. Barnett destaca ainda os casos de países inseridos em regiões que não compreendem suas características políticas: Israel está isolado no GAP e a Coréia do Norte encontra-se à deriva no CORE. O autor faz uma lista dos países com os quais os Estados Unidos terão que cooperar para impedir que a rede terrorista alcance o CORE. Esses países são chamados por ele de Seam States (Estados de junção), estando nessa categoria México, Brasil, África do Sul, Marrocos, Argélia, Grécia, Paquistão, Tailândia, Malásia, Filipinas e Indonésia.
} 
existia mais divisão clara entre o que era externo e o que era interno. Políticos e policy makers norte-americanos entendem que a ameaça à segurança nacional se desloca da União Soviética para "Estados fora da lei" e regiões menos desenvolvidas. A contenção mackinderiana de Reagan dá lugar a uma abordagem transnacional.

A publicação do "The Clash of Civilizations" por Huntington na Foreign Affairs em 1993 teve um impacto semelhante ao ocorrido com o aparecimento do texto de Mackinder na Geographical Journal, quase noventa anos antes. Não coincidentemente, se a visualização do espaço mundial mackinderiana derivava da percepção do surgimento de novas potências rivais ao império britânico, o "choque de civilizações" reflete o ultraconservadorismo de setores americanos, que na ausência das tradicionais ameaças estatais, vê na própria diversidade cultural do mundo (escancarada pela globalização), o grande desafio à política de segurança nacional.

A imagem geopolítica se define concomitantemente como representação de mundo e políticas espaciais (AGNEW \& CORBRIDGE, 1995; AGNEW, 1998; FOUCHER, 2000). Como uma forma de hegemonia, a imagem reflete a hierarquia imanente à ordem geopolítica, ao mesmo tempo em que impõe novos meios geográficos de exercícios de poder. O choque de civilizações, o regime do livremercado e o poder imperial dos Estados Unidos envolvem abordagens das relações internacionais muito distintas. Ainda assim, não se deve perder de vista o fato de que todas elas estão igualmente imbricadas na mesma ordem geopolítica mundial.

O que está em questão não é refutar a América Latina, cujas condições políticas, econômicas, sociais e culturais trazem um inegável grau de homogeneidade e interdependência. Num mundo onde a diversidade cultural se tornou uma condição predominante, esse continente tem muito a contribuir para o exercício da tolerância e para o desenvolvimento de um novo modelo civilizacional. Mas, o seu interior é também caracterizado pela existência de áreas com dinâmicas singulares. Ignorar esse aspecto denota a incapacidade de pensar estrategicamente as políticas de território e poder, por trás de visões simplificadoras.

O fato de a maioria dos países sul-americanos ter optado por um caminho muito distinto daquele trilhado pelo México e América Central é o componente 
fundamental do esforço de transformação da imagem de todo continente. Para compreensão desse processo é preciso examinar os diferentes contextos internacionais.

A América do Sul está subordinada a dois momentos da Ordem Geopolítica da Guerra Fria. O primeiro momento, de 1990 a 2001 se caracteriza pelo protagonismo do multilateralismo, enquanto o segundo, de 2001 até o presente, se destaca como o ápice do uso da força como recurso de poder pelos Estados Unidos. Entre 1990 e 2001, os fluxos econômicos e políticos transnacionais, as soberanias supranacionais, e a consolidação de uma governança internacional fazem parte de uma conjuntura internacional baseada, sobretudo, na idealpolitik. A legitimação da hegemonia mundial ocorre mais pelo poder persuasivo dos ideais políticos e valores civilizacionais e menos pelo uso da força.

O multilateralismo que domina esse período se transforma no mais importante meio de regionalização da América do Sul. As iniciativas de cooperação mimetizam muitos dos principais aspectos que compõem a ordem global. Isso está refletido, por exemplo, no caráter multidimensional da integração sul-americana, onde pequenas e grandes empresas, comunidades locais e escalas subnacionais (Estados, municípios e zonas de fronteiras) se tornam agentes importantes à política regional. Setores governamentais não tradicionais às relações internacionais e segmentos da sociedade civil também conduzem a regionalização. Isso é possível por meio de transformações impostas pela ordem geopolítica contemporânea que reorganiza as relações entre milhares de atores estatais e não estatais.

No período de 1990 e 2001, as interações políticas, econômicas e sociais globais alcançam novo patamar, com a intensificação das relações entre atores estatais e não estatais. Forjou-se uma estrutura de governança internacional que implicava participação no jogo do poder de inúmeros atores não estatais (HOLZSCHEITER, 2005). A globalização econômica enfraquece a tradicional capacidade do Estado em impor a sua própria vontade, pois passa a depender da articulação com uma rede de instituições não estatais (CASTELLS, 2001, pp. 147169).

O governo Clinton retoma discursos democráticos que havia marcado o internacionalismo dos presidentes democratas Woodrow Wilson e Franklin D. 
Roosevelt. Junto à estrutura institucional forjada nas décadas de 1940 e 1950, o modelo hegemônico norte-americano na década de 1990 torna possível a participação de setores da sociedade civil nas relações internacionais. Apesar de ter se tornado popular nos anos 1990, essa transformação tem suas origens em décadas anteriores.

Após os anos 1950, a intensificação dos fluxos intra-regionais proporcionada pelas zonas de livre comércio, uniões aduaneiras e mercados comuns, já promovia uma ampliação do escopo da política internacional. Além das instituições estatais tradicionais, esta passa a abranger as grandes empresas, as finanças, os espaços subnacionais etc. Ainda sob a Guerra Fria, essas transformações contribuíam para a consolidação de um espaço transnacional planetário. São os fluxos de informação, os transportes, o movimento do dinheiro e instrumentos de crédito, e a circulação de pessoas (NYE \& KEOHANE, 1971a) que tornam possível o alargamento do espaço transnacional nas décadas de 1960 e 1970.

Nos últimos anos, o impacto de atores e "coalizões internacionais" sobre as políticas estatais tem sido ainda mais importante para as relações internacionais. A coexistência e interação entre atores estatais e não estatais no cenário mundial passa a definir grande parte da dinâmica desse campo (RISSEKAPPEN, 1995). Os atores não-estatais modificam as relações políticas mundiais por meio da transnacionalização que engloba desde ONGs (JORDAN \& VAN TUIJL, 2000) até movimentos sociais em áreas como América Latina (SIKKINK, 2002).

As interações internacionais proporcionadas por estas transformações ganharam ainda mais visibilidade com a importância do idealismo para a diplomacia americana nos anos 1990. É com a transformação do idealismo wilsoniano em principal vertente da política dos Estados Unidos e a valorização da dimensão consensual do poder que o "arsenal da democracia" se torna, de fato, força geopolítica global. Discursos sobre uma arena global democrática - ainda que não erigida a partir da democracia representativa - se transforma em força legitimadora da atuação transnacional de instituições supranacionais e instituições não estatais. Nesse contexto, estudiosos propõem uma revisão de conceitos clássicos. 
Sidney Tarrow (2005) propõe um reexame do conceito de internacionalização, que esteve por muito tempo atrelado a uma definição exclusiva de relação interestatal. A partir das transformações recentes impostas pela globalização, Sidney Tarrow entende esse processo, a partir da inter-relação de três tendências principais: a) ampliação da inter-relação entre Estados, funcionários governamentais e atores não estatais; b) crescimento das conexões verticais entre o sub-nacional, nacional e internacional; c) aumento de uma estrutura formal e informal que encoraja os movimentos de ativismo transnacional e facilita a formação de uma rede de atores não estatais, estatais e supranacionais.

Autores como John Keane (2001), defendem que o protagonismo cada vez maior de atores não-estatais torna possível a existência de uma "sociedade civil global", que altera normas e leis internacionais e nacionais. Segundo Keane (Op. Cit.) a estrutura da "sociedade civil global" seria composta por um conjunto organizações e instituições, caracterizada por relações verticais e horizontais. Esta estrutura mundial constitui o que Jacques Lévy (1993) denominou de rede-mundo. Os grupos transnacionais exercem pressão, influenciando o comportamento dos Estados, as negociações intergovernamentais e as agencias internacionais (RUGGIE, 2004).

Para Robert Cox (1999), a hegemonia contemporânea se constitui por meio de várias camadas com diferentes autoridades. Partindo desse pressuposto, a sociedade civil internacional é uma gama mundial de organizações com diferentes formas de ação, contra ou a favor do Estado e o mercado. A sociedade civil global é uma arena de conflitos e não a simples defesa das forças hegemônicas. Deve-se lembrar que a transnacionalização é importante ferramenta até para movimentos sociais, cujos efeitos territoriais revelam um componente geopolítico (SLATER, 2000). Esse é o caso de importantes movimentos sociais latino-americanos que tiveram na articulação com movimento de defesa dos direitos humanos localizados principalmente na Europa e Estados Unidos, um mecanismo de fortalecimento local.

Mas a valorização do discurso dos direitos humanos também faz parte do fenômeno da globalização (ALVES, 2004, p. 12). Como destaca Ronnie Lipschutz (2005), a sociedade civil global existe enquanto relação dialética entre um modo em desenvolvimento de uma governança global e um sistema de mercado mundial 
regulado pelo Estado e instituições Internacionais. Mas se a sociedade civil global é uma arena de potencialidades que não se resume aos interesses das principais forças hegemônicas, não se deve esquecer que sua existência está condicionada à materialização da soberania globalista norte-americana na Ordem Geopolítica da Guerra Fria.

O crescimento da dependência da soberania estatal em relação a consensos internos e externos forjados no âmbito da sociedade civil (KALDOR, 2003) tem fortalecido uma espécie de novo evolucionismo social. A democracia representativa é ameaçada por uma espécie de "democracia por articulação" (CHANDLER, 2003), onde organizações não governamentais, entrelaçadas ao arcabouço geopolítico das grandes potências, ecoam mundialmente novos valores e uma "consciência moral". A atuação dessas organizações ocorre pelo exercício de uma "autoridade moral", que funciona como recurso de poder (HAAL, 2003, p. 597).

Predomina entre correntes transnacionalistas a idéia de que a sociedade civil internacional seria apenas um desdobramento lógico das novas transformações políticas, econômicas e sociais das últimas décadas, ignorando seu caráter geopolítico. De fato, essas mudanças não estão mecanicamente subordinadas ao poder norte-americano, mas sua existência é uma condição inextricável de interesses que movem a ordem geopolítica contemporânea. São os Estados mais poderosos que estabelecem as regras do sistema internacional (KRASNER,1995). Em muitos caos, os Estados menos poderosos são transformados naquilo que Otávio lanni (1993) denominou de província da sociedade global.

A efetividade da soberania globalista depende da consolidação de uma capilaridade institucional e territorial mundial $E$ isso somente é possível pela articulação entre os Estados e os atores não estatais. Nesse caso, como nota David Held, Anthony MCGREW, David Goldblatt, \& Jonathan Perraton (1999), são as instituições supranacionais as grandes responsáveis pelo enfraquecimento da soberania westfaliana nas últimas décadas. As instituições supranacionais conduzem o sistema de governança global, pois além de serem manifestações diretas da soberania globalista, são capazes de articular os atores estatais e não estatais. 
Esse entendimento não significa que a política internacional esteja totalmente submetida à vontade americana. Recorda-se nesse caso que a própria ONU, acabou se transformando num importante espaço de demonstração de força política para muitos países em desenvolvimento. Esses países, que se constituem em maioria, possuem capacidade de fazer valer seus interesses em diversas questões - ainda que o núcleo duro formado pelo Conselho de Segurança mantenha na mão das grandes potências o poder de decisão sobre questões mais sensíveis como a guerra e a intervenção, isto é, o monopólio da força. A referência a um sistema internacional subordinado aos interesses dos Estados Unidos pressupõe que todas as suas engrenagens foram erigidas a partir do alcance do poder mundial desse país. Certamente, mesmo que o país não possua no futuro a condição de única superpotência mundial, muitos dos aspectos que dão sustentação a esse sistema internacional perdurarão, transcendendo a sua era hegemônica.

Esse cenário, onde a hegemonia mundial estava perfeitamente ancorada no mix de consenso e coerção, desmorona no início da década de 2000. Na América do Sul, essa falência está condicionada a dois fatores principais. A crise do modelo neoliberal trouxe uma forte descrença nas instituições multilaterais e no sistema de governança internacional, que passou a ser vista como altamente favorável aos países ricos. Isso resultou num reordenamento político continental, onde governos de esquerda ou centro-esquerda buscaram se afastar dos Estados Unidos.

Por outro lado, passam a predominar a partir de 2001 o neorealismo e a dimensão coerciva da hegemonia norte-americana. O governo de George W. Bush investe contra o multilateralismo e busca marcar nova posição frente às ameaças globais, tidas como reminiscências bárbaras e retrógradas frente às potencias ocidentais desenvolvidas.

Os maiores interesses geoestratégicos do limiar desse século foram travestidos de interesses humanistas, visando à reconstrução de regiões representadas pelo atraso, pobreza, corrupção etc. Entretanto, a primeira década desse século apenas tornou claro o que já era iminente em décadas atrás. Há uma única superpotência, cujos interesses e presença alcançam todas as regiões do planeta. 
Todavia, consolidam-se, como aspecto central da transição, novas potências regionais que, ao alargarem sua influência continental, estabelecem-se cada vez mais como um desafio ao poder imperial dos Estados Unidos. Nesse período, o discurso sobre a necessidade de modernização, democratização, e superação do atraso funciona como ferramenta para que setores ultraconservadores reafirmem a presença do país em áreas sensíveis à ascensão de novas potências.

Ressalta-se, entretanto, que essa lógica não se aplica somente num dos principais palcos geoestratégicos do mundo, com o acirramento da competição entre americanos, russos e chineses em torno do Golfo Pérsico e Bacia do Cáspio, um caso detalhadamente examinado por Michael Klare (2005, pp. 146-179). Embora de forma mais branda, esta se caracteriza também como uma questão sul-americana. Como a consolidação de uma aliança local, o Mercosul funciona enquanto o mais importante meio de containment aos interesses dos Estados Unidos.

A política de fortalecimento regional relacionada à integração no Cone Sul tem resultados diferençados nos dois períodos da Ordem Geopolítica Pós-Guerra Fria. Em termos de transformação das relações sul-americanas, a fase mercantilista do Mercosul que predominou durante toda década de 1990, e a fase do alinhamento diplomático que prevalece desde o início da década de 2000, têm efeitos igualmente importantes. Não são simplesmente resultados de diferentes orientações ideológicas, mas conseqüências da transformação da ordem geopolítica.

Em mais de vinte anos de integração, o Mercosul teve dois meios de legitimação. Embora a integração tenha nascido numa conjuntura de crise profunda, sua proposta inicial tinha elementos do desenvolvimentismo, que havia encontrado seu limite desde o final dos anos 1970. Mas, as condições da segunda metade dos anos 1980 não impossibilitaram apenas a atuação do Estado eu seu próprio território.

A crise solapou a capacidade de investimento em importantes aspectos da regionalização, como infra-estruturas relacionadas à integração energética e territorial. A incapacidade de investimentos, aliada às transformações econômicas do período, fez com quem o destrave do comércio intra-regional se tornasse 
prioritário. As elites regionais perseguiam a tendência predominante em outros continentes.

Nesse período, o comércio intra-regional crescia mais rapidamente na América no Norte, Ásia e Oceania do que o próprio comércio global (ARAÚJO Jr., 2010, p. 33). A fase mercantilista da integração, muito importante para a ampliação das relações comerciais intra-regional, representou a descoberta de um novo mundo para as elites empresariais do Cone Sul. Subordinadas à Ordem Geopolítica Pós-Guerra Fria, o mercantilismo era sustentado pelo entendimento de que o subdesenvolvimento, a pobreza, a exclusão social etc., seriam superados por meio da emulação das novas práticas econômicas internacionais. A consolidação de uma nova concepção econômica na região não foi apenas o meio de combater os excessos de uma sociedade estadocêntrica. A falácia mercadocêntrica que predominava em toda economia (OFFE, 2001, pp. 119-145) se tornou o cânone da política regional, onde a integração foi reduzida ao comércio.

A direção mercantilista não está limitada apenas aos primeiros dez anos do Mercosul. A valorização do alinhamento diplomático com a ascensão de governos de esquerda ou centro-esquerda não superou muitas limitações impostas pela integração mercantilista. Esse paradigma é marcado pela integração de baixa densidade (RAMANZINI Jr. \& VIGEVANI 2010, pp. 45-63). A prioridade é a cooperação e não na integração, que exige um maior aprofundamento da regionalização. As relações historicamente consolidadas com os países desenvolvidos e a falta de complementaridade econômica entre os Estados Partes e Associados são importantes empecilhos para o não aprofundamento desse processo (Op. Cit.).

Nem mesmo a aproximação política e diplomática com a ascensão de governos de orientações ideológicas semelhantes no Cone Sul, foi capaz de superar o protagonismo do mercantilismo. Não obstante a ampliação das relações políticas, o mercantilismo tem predominado por força dos interesses internos dos principais membros do Mercosul. A inexeqüível proposta de criação de um mercado comum em quatro anos, posta pelo Tratado de Assunção, é agravada pelos interesses que buscam manter a autonomia dos países da região referente às relações comerciais com novas áreas internacionais de forte ascensão econômica. 
Nesse contexto, o Mercosul funciona como um vórtice de alinhamento entre seus membros em torno de temas internacionais. Por outro lado, a integração de baixa intensidade (e aberta) visa manter as possibilidades comerciais trazidas por regiões de economias em expansão. O mercantilismo e o alinhamento diplomático são fórmulas encontradas pelos Estados Partes para inserção na Ordem Geopolítica Pós-Guerra Fria. As diferentes legitimações da regionalização são respostas à hegemonia e à soberania imperial americana no continente.

Celso Amorim (2009, pp. 05-26), pontua que o alcance do Mercosul está cunhado no próprio nome. O Mercado Comum do Sul anseia a escala continental da integração, congregando todos os países da América do Sul. ${ }^{83} 0$ estabelecimento da união aduaneira pela Tarifa Externa Comum (TEC) em 1995 entre os quatro signatários do Tratado de Assunção foi uma forma de fortalecimento perante a ALCA e simultaneamente um meio de posicionamento multilateral perante a abertura econômica da década de noventa (Op. Cit.). Esse processo, espelho da demanda local frente à emergência da nova ordem geopolítica, guarda semelhanças e diferenças com outros projetos de regionalizações.

Faz-se necessário ressaltar que inúmeros fatores distinguem as regionalizações contemporâneas das clássicas divisões geopolíticas do espaço mundial, muito comuns no decorrer do século XX. O fim da bipolaridade força a uma sofisticação das abordagens concernentes às diversas iniciativas de regionalização em andamento em todos os continentes. No entanto, ainda que se leve em consideração suas graves limitações, as formulações presentes nas primeiras teorias geopolíticas ainda possuem relevância aos estudos da reorganização regional das relações internacionais. Pressupõe-se destarte, que fatores como território, população e recursos naturais são componentes fundamentais das políticas regionais contemporâneas, conquanto a partir de outras pressuposições.

Também nesse caso, as mudanças globais resultam na interação entre diversas forças, sejam elas contemporâneas ou antigas. Análises da conjuntura internacional fundadas exclusivamente em uma variável tendem a se arrefecer

83 "O MERCOSUL é o "Mercado Comum do Sul", até para deixar essa abertura para outros países. A própria mídia brasileira, e até analistas que estudam esse assunto, dizem que é o "Mercado do Cone Sul", o que não é nem nunca foi. Até porque, o Brasil não se resume ao Cone Sul." Celso Amorim, 2009, p. 11. 
frente à multidimensionalidade da geopolítica destacada por Bertha Becker (1988, pp. 99-125).

Como já argumentado, a multidimensionalidade dos arranjos regionais se expressa através da convergência de múltiplos vetores de coesão, com destaque para a política e a economia. Por conseguinte, os aspectos geoestratégicos e mesmo civilizacionais - embora muito diferente da forma estabelecida por Huntington (1993; 1996) - são apenas um dos vetores dentre aqueles presentes na estruturação dessas regiões. Logo, o estabelecimento dessa nova arena da política internacional se destaca como uma importante escala de intermediação entre o global e o local. 


\title{
CAPÍTULO 5
}

\section{Constituição da Nova Ordem Regional Sul-Americana}

\author{
The assumption has long been that states \\ monopolize power that they then distribute \\ or use to fulfill their desires. In fact, what if \\ states are no more than coordinating \\ devices to connect and integrate networks \\ of power into discrete territories? \\ John Agnew
}

\subsection{Fundamentos da Região Geopolítica e a Ordem Contemporânea}

No que se refere ao contexto mundial, torna-se necessário ponderar sobre as heranças da ordem geopolítica precedente, que também foi marcada por importantes investidas bilaterais e multilaterais dos Estados Unidos. O governo norte-americano despendeu grande esforço para firmar acordos bilaterais em várias regiões de regime capitalista no início da década de 1980 (CASTRO \& CARDOSO, 1995).

Os Estados Unidos assinaram acordos de livre comércio em vários continentes, destacando-se principalmente aqueles com Israel em 1985 e com o Canadá em 1989 - este último sendo protótipo do futuro NAFTA. A esse respeito, é igualmente importante o empenho para o estreitamento das relações com países de industrialização recente como o México, Coréia do Sul, e Austrália (Op. Cit.). O 
conjunto dessas iniciativas evidencia a nova face do containment ao comunismo soviético. $^{84}$

Somente com o fim da bipolaridade que essa tendência derivaria na formação de regiões geopolíticas. Não estando subordinada ao containment americano, a regionalização é peça-chave na ascensão de novas potências mundiais. Enquanto que durante a Guerra Fria, os acordos bilaterais e multilaterais de livre comércio estavam relacionados direta ou indiretamente ao containment, a partir do início dos anos 1990 passam a ter relação com a busca por maior autonomia e poder regional. Isso significa que a lógica que rege a formação de regiões multinacionais passou a ser a de constituição de um espaço geopolítico continental.

Dado esse fator, faz-se necessário aprofundar a discussão sobre o conceito de região geopolítica. Como conseqüência da multidimensionalidade geopolítica que compõe a conjuntura interna (regional) e externa (global), este conceito é tributário de um cruzamento de referências. Devido à natureza política, os processos que configuram as atuais regiões multinacionais não podem ser apreendidos apenas por concepções pautadas exclusivamente nas relações econômicas e materiais. Estas, ao conduzir a uma abordagem "estrutural" de região - muito importante para o exame de processos econômicos - não privilegiam a dimensão política. Se as relações políticas são um dos sustentáculos da regionalização, deve-se atentar para as forças ideacionais que conduzem esse processo. É necessário considerar que a região multinacional não é apenas um espaço geograficamente estruturado por forças econômicas e materiais. É também uma área que existe no campo das idéias e dos valores coletivos. A dimensão estrutural coexiste com a dimensão ideacional, sendo partes de uma conjuntura maior.

Desde os anos 1960, fatores clássicos do estudo regional foram ignorados em prol de uma nova busca pela legitimidade científica. Mas muitos aspectos da

\footnotetext{
${ }^{84}$ Segundo Castro \& Cardoso (1995), estas iniciativas levaram à discussão acerca do multilateralismo e do regionalismo nos Estados Unidos. Muitos analistas entendiam que a nova arquitetura política do mundo deveria necessariamente ser erigida por meio de arranjos regionais interagindo entre si. Esses arranjos seriam comandados por órgãos multilaterais como o FMI, o BIRD e o GATT. Um mundo definido como um conjunto de regiões em interação seria a forma de defesa contra o comunismo soviético. Entretanto, Castro \& Cardoso (Op. Cit.) lembram que a mesma década de 1980 testemunha o surgimento de novos pólos de poder econômico mundial. A China começa a experimentar um grande ciclo de crescimento, tornando-se não somente independente do comunismo soviético, mas escapando da esfera de controle americana e construindo a sua própria região de influência. Nesse mesmo período, o Japão compete com os EUA como a mais importante economia do planeta. Como conseqüência, promove sua descentralização industrial para a região do Pacífico na busca de enfrentar os altos custos de produção interna e também promover a consolidação de sua esfera de influência econômica, pensada desde o final do século XIX.
} 
concepção neokantiana de região síntese ainda podem ser pertinentes ao campo da Geografia Política. ${ }^{85}$ Dentre estes, destacam-se as correlações espaciais entre os fenômenos, que podem funcionar como instrumentos para traçar conjunturas político-territoriais. As regiões multinacionais são o resultado concreto da interrelação e interdependência entre processos políticos, econômicos e territoriais numa dada área.

A linha neokantiana de estudo regional (baseada na ideografia, isto é, nas relações entre fenômenos em um determinado espaço) ${ }^{86}$ perde a primazia com a publicação do artigo de Fred K. Schaeffer, Exceptionalism in Geography: a Methodological Examination (1953), que prega o abandono do método descritivo e advoga a necessidade de buscar as "leis" que regem e ordenam o espaço geográfico. A partir de Schaeffer, a New Geography promoveu a busca pela legitimidade científica através da dedução de leis gerais, e de métodos de classificação como expõem David Grigg (1973), negando a metodologia precedente. $^{87}$

A concepção de região síntese resgatada por Hartshorne (1939; 1960), e predominante em boa parte do século $X X$, cai em ostracismo com a preeminência do Positivismo Lógico. ${ }^{88}$ Com a ascensão da New Geography e a valorização dos modelos lógico-matemáticos, destaca-se o entendimento de uma ordem intrínseca ao espaço (LENCIONI, 1999). Tal qual a Geografia Ativa (majoritária na França), a New Geography entende o espaço a partir dos aspectos estruturais. Na Geografia Ativa, o espaço regional é interpretado a partir das redes urbanas, onde a cidade exerce como demonstra Michel Rochefort (1967), a função de comando. Na New

\footnotetext{
85 É preciso prudência a esse respeito, pois os geógrafos neokantianos consideravam a região como uma síntese entre os fatores humanos e naturais. Entendiam que o método regional era o meio ideal de romper com a dicotomia entre os aspectos humanos e físicos. A idéia de região síntese aqui retomada se refere exclusivamente aos aspectos políticos, econômicos e sociais.

${ }^{86}$ A partir da crítica da visão da região como organismo ou unidade concreta, esta passou a ser pensada corograficamente como um arranjo seguindo a perspectiva do idealismo transcendental kantiano, qual seja de considerar as coisas enquanto representações e não coisas em si. Se tempo e espaço em Kant seriam formas sensíveis da nossa intuição, todos os velhos axiomas geográficos acerca da região baseados no naturalismo partiam do erro de tomar nossa interpretação do mundo como realidade em si.

${ }^{87}$ A New Geography, também conhecida como Geografia Teorética-Quantitativa, foi uma corrente da Geografia, cujos estudos foram pautados por deduções de leis gerais e pela utilização de modelos lógico-matemáticos. Foi responsável pelo rompimento com a metodologia ideográfica que prevaleceu na Geografia até meados dos anos 1960. Fundamentada no positivismo lógico, questionava o subjetivismo e a intuição que prevaleceu em toda geografia neokantista. Valorizava a razão, que deveria predominar por meio de procedimentos comuns às ciências exatas, como a descrição "objetiva" do objetivo e a dedução de leis gerais.

${ }^{88} \mathrm{O}$ método regional da geografia neokantiana está subordinado às concepções de espaço absoluto. Com base na filosofia kantiana, este se caracteriza como uma categoria da existência como destaca Martins (2007, p. 37), funcionando como receptáculo da materialidade (CORRÊA, 1995, p. 18). Nessa linha, o espaço está (como o tempo) relacionado às formas sensíveis da nossa intuição. Em Geografia Política, entre as primeiras teorias a romper com esse pressuposto, está o estudo de Camille Vallaux, que critica a concepção ratzeliana de "espaço abstrato", propondo o conceito de "espaço concreto", que segundo Costa (1992) é definido como uma dimensão determinada que se apresenta em suas singularidades concretas, humanas e físicas.
} 
Geography se destacam dois modelos: as regiões homogêneas e as funcionais ou polarizadas. $^{89}$

Estas concepções mudaram completamente a metodologia do estudo regional. Tanto para os geógrafos marxistas, onde muitas vezes este estudo estava relacionado à divisão territorial do trabalho (LENCIONI, 1999) quanto para a nova geografia econômica americana centrada no exame da concentração geográfica da indústria e da tecnológica, a região é entendida segundo aspectos estruturais. A contribuição da New Geography, não completamente transformada pelas novas correntes da geografia, está no entendimento da região como espaço estruturado.

A região geopolítica não significa a desvalorização de concepções estruturais que predominam desde os anos 1960. Não há como entender uma região ignorando o aspecto estrutural e as relações materiais que lhes dão coesão. A dimensão ideacional é um complemento importante para essa classe de região, pois permite incluir o campo dos valores políticos na análise. A região não é apenas o resultado concreto de forças econômicas e materiais, mas um entendimento no campo dos valores e das idéias que reflete características da ordem geopolítica.

Deve-se entender que a região geopolítica é uma "representação" que induz a políticas econômicas e territoriais, que por sua vez revelam a sua interrelação com a ordem global. Internamente, é uma área organizada a partir de concepções predominantes nas relações políticas e econômicas que conduzem a cooperação entre um grupo de países. É, portanto, uma manifestação geográfica das novas relações internacionais. Deste modo, mesmo a "unidade concreta" que se manifesta pela articulação de um espaço regional a partir das interações físicas está intimamente relacionada a representações da ordem internacional. A região geopolítica é um constructo espacial que faz interagir forças ideacionais e materiais.

Há, portanto, uma interdependência entre o plano ideacional e a dimensão material posta pelo espaço geográfico. As regiões geopolíticas são entidades

\footnotetext{
89 "As primeiras (regiões homogêneas) partem da idéia de que ao selecionarmos variáveis verdadeiramente estruturantes do espaço, os intervalos nas freqüências e na magnitude dessas variáveis, estatisticamente mensurados, definem espaços mais ou menos homogêneos - regiões isonômicas, isto é, divisões do espaço que correspondem a verdadeiros níveis hierárquicos e significativos da diferenciação espacial. [...] Quanto às regiões funcionais, a estruturação do espaço não é vista sob o caráter da uniformidade espacial, mas sim de múltiplas relações que circulam e dão forma a um espaço que é internamente diferenciado. Grande parte desta perspectiva surge com a valorização do papel da cidade como centro de organização espacial." Paulo Cesar da Costa Gomes, 1995, pp. 63-64.
} 
ideais ao resultarem de uma concepção de poder e organização do espaço mundial. Por outro lado, torna-se uma entidade concreta na medida que existe um imbricamento entre essas concepções e as políticas territoriais voltadas à integração. A região é uma entidade ideal (HARTSHORNE, 1939; 1960), mas também uma área concreta, articulada por forças materiais. Na sociedade em rede (CASTELLS, 1999a; 1999d) a região possui um caráter de fluidez material e informacional.

As iniciativas atuais de regionalização por meio dos "blocos econômicos" estão conectadas à interpretações da nova ordem geopolítica, presentes simultaneamente na academia, nos governos e na sociedade civil como um todo. O regionalismo como tendência política é um fenômeno relevante da segunda metade do século XX (HURRELL, 1995). Malgrado longa existência dessa tendência política, a região geopolítica é um dado específico da Ordem Geopolítica Pós-Guerra Fria.

O sentido contemporâneo da região como particularidade de intermediação entre o global e o local (LENCIONI, 1999), não está alijado da política, tanto na perspectiva do território nacional quanto transnacional. É desnecessário temer como Paulo Cesar da Costa Gomes (1995, p. 73), que a concepção de região a partir dos blocos econômicos comprometeria um dado essencial sobre o conceito, isto é, “... o fundamento político de controle e gestão de um território".

É uma preocupação equivocada à medida que não se deve circunscrever a regionalização aos blocos econômicos. Como analisaremos mais adiante, os blocos apenas compõem uma espécie de núcleo duro de um processo de regionalização que é muito mais amplo. A cultura, os valores e as crenças imbuídas no conjunto da sociedade se tornam uma base essencial da regionalização. Diferente da crença de que concepções do senso comum impregnadas na idéia de bloco econômico comprometeria a própria cientificidade do conceito de região (GOMES, Op. Cit.), entendemos que o espaço banal é uma dimensão imprescindível à formação de áreas multinacionais na ordem geopolítica atual. $^{90}$

\footnotetext{
90 Para Milton Santos (2000) o espaço banal é o espaço de todos. É o espaço das instituições, empresas, pessoas e das vivências. Essa concepção é bastante profícua para entendermos o alcance da regionalização na globalização. A concepção de bloco econômico como região, predominante nos meios de comunicação e na sociedade em geral, não deve ser desprezada e entendida somente como uma forma menor de interpretação desse conceito. De fato, a integração regional não deve ser circunscrita à idéia de bloco econômico. Entretanto, se a região geopolítica é inseparável do aspecto ideacional, é da
} 
Todavia, ainda que a região geopolítica dependa de relações que transcorram em todos os âmbitos sociais, seus propósitos sãos estabelecidos pelas elites políticas. É por esse motivo que essa classe de região envolve uma concepção geoestratégica. Mas nesse caso, a geoestratégia não está circunscrita à guerra ou à defesa nacional como destaca Foucher (2000, p. 165). Com a preponderância da idealpolitik, a geoestratégia amplia seu alcance inicial, atrelando-se a novos meios de projeção internacional na ordem geopolítica contemporânea.

A partir dessa consideração, é necessário entender que as elites políticas locais não são responsáveis apenas pela articulação de um espaço regional frente à ascensão de uma nova ordem geopolítica. Os novos direcionamentos da política interestatal em toda América do Sul são responsáveis pela transformação das relações internacionais, embora de forma menos incisiva se comparado a outros continentes.

Mas se os países do Cone Sul alcançaram nas últimas décadas maior influência na agenda internacional (COHEN, 2003, pp. 01-33), isso não se deu somente através da cooperação. A integração de baixa densidade que predomina no Cone Sul (RAMANZINI Jr. \& VIGEVANI, 2010, pp. 45-63), permite a coexistência de forças tradicionais e contemporâneas. Logo, o Estado continua como o ator hegemônico, tendo na regionalização um meio de imposição de seus interesses internacionais. É nesse sentido que a integração está em conformidade com a reorganização do poder no mundo. Brasil e Argentina, países lideres desse processo no Cone Sul, não são exceções. Também Índia, China e Rússia têm na escala regional uma importante plataforma da política internacional (HURREL, 2006).

Os acordos comerciais (bilaterais e multilaterais) que funcionaram como peça-chave à reorganização do containment americano no final da ordem geopolítica precedente, acabaram se transformando no meio fundamental de enfraquecimento do poder imperial do país em várias áreas do globo. Dessa forma, torna-se possível uma análise do declínio relativo do poder dos Estados Unidos, à medida que a ascensão das novas potências resulta na diminuição de

mesma forma dependente do espaço banal, ou seja, do espaço de todos. As necessidades de desenvolvimento econômico e social exigem do processo de integração a inserção de todas as instâncias sociais. Ainda que em princípio esse projeto exprima interesses das elites e dirigentes locais, sua existência efetiva depende do conjunto da sociedade. A regionalização resulta na transformação das relações econômicas, da cultura e da identidade, fenômenos que se manifestariam no espaço de todos. 
espaços de subordinação, e força uma retração de sua superextensão imperial em todo mundo.

A importância da região geopolítica é perceptível através de dois meios complementares. O primeiro se estabelece com o estreitamento das relações política e comercial intra-regional, enquanto o segundo se define com a ampliação dessas relações no plano inter-regional. Apesar da ampliação da coesão regional ser possível apenas a partir da transformação das relações locais, seu objetivo final envolve também a reestruturação das relações dos países com outras áreas do globo.

Assim como China, Rússia e Índia, o Brasil se constitui em um "Estado pivô" em sua região, pois seu crescimento econômico e sua relevância política tornam-se base importante para o fortalecimento de seus vizinhos. Como o crescimento chinês, cada vez mais ancorado numa via pacífica de projeção no Pacífico Asiático (MUZAFFAR, 2007), a economia brasileira é um importante pilar na afirmação da idealpolitik como paradigma da política continental. Ao fortalecer as relações comerciais intra-regionais, o crescimento econômico brasileiro tem sido o fator central ao enfraquecimento da influência norte-americana na América do Sul.

Ainda que seja através do estudo do estreitamento das relações políticas e comerciais entre os diversos espaços de integração no mundo a forma ideal de compreender a importância da região geopolítica no cenário internacional, o Estado nacional ocupa conjuntamente o centro do debate. Em comum, China, Índia, Brasil e Rússia acreditam no direito de maior influência nos assuntos mundiais (HURRELL, 2006, p. 02). Um dos fundamentos do fortalecimento dessa crença é a liderança que exercem nos fluxos comerciais intra-regionais no limiar do século XXI.

É notável, por exemplo, a transformação do posicionamento chinês nas suas relações com os demais países do Pacífico Asiático. Essa mudança é conseqüência do fortalecimento do entendimento da existência de uma interdependência entre as relações políticas e econômicas. O aumento da cooperação política, impulsionada também pela importância econômica do país para o seu continente, resulta por sua vez no maior estreitamento do comércio 
regional. ${ }^{91}$ Em 2010 foi estabelecido o acordo de livre comércio entre a China e a ASEAN, passo central para o fortalecimento das relações comerciais entre os países da região.

Deve-se às relações comerciais com os países asiáticos o crescimento de países como Peru, Chile e Brasil na primeira década desse século, um processo atrelado ao preço internacional das commodities. A articulação de um acordo de livre comércio entre a União Européia e o Mercosul corrobora a importância desse espaço.

Portanto, região geopolítica é também um mecanismo de expansão das relações comerciais. $\mathrm{Na}$ ordem atual se vislumbra no horizonte uma transformação, onde o enfraquecimento relativo do eurocentrismo e do americentrismo $^{92}$ faz nascer uma nova configuração espacial do poder mundial. A condição atual do Cone Sul não é apenas resultado de um posicionamento político com origens na parceria Brasil - Argentina em meados da década de 1980. É também conseqüência do rápido desenvolvimento no mundo de outros países e regiões. ${ }^{93}$

Quando o surgimento de novas potências mundiais na segunda metade do século XIX alterou a política internacional, o fez por meio de um realismo geográfico que resultava no compartimentação do espaço mundial. Às novas potências que despontam nesse período, a regionalização não é estritamente um mecanismo de compartimentação. É, sobretudo, um meio de articulação territorial que mira justamente na integração com o mundo global. Por essas razões, a região multinacional é um espaço geoestratégico de reordenamento da política internacional.

\footnotetext{
91 A China tem reconhecido amplamente o peso da diplomacia baseada na cooperação multilateral na nova ordem mundial (FOOT, 2006, pp. 77-94). A Shanghai Cooperation (SCO), uma organização multilateral firmada entre o país, a Rússia, o Cazaquistão, o Uzbequistão, o Quirquistão e o Tajiquistão, estabelece uma agenda antiterrorista. Visa ainda, a instituição de uma área de cooperação econômica.

92 Richard Peet (2005, pp. 936-943) cunha esse termo levando em consideração o alcance político, econômico e cultural do poder norte-americano no mundo. O geógrafo destaca a perversidade do americentrismo, dando-lhe a alcunha de a mais perniciosa ideologia que o mundo já conheceu. No sentido aqui empregado, o americentrismo consiste numa tendência sob a qual os países estabelecem a sua visão geopolítica e sua conduta internacional. No que se refere aos discursos geopolíticos brasileiros, o americentrismo encontra sua maior expressão nas análises do general Golbery, examinadas na primeira parte desse trabalho.

${ }_{93}$ Argumentamos nesse trabalho que o Brasil já adotava na década de 1970 uma postura abertamente pragmática, visando tirar proveito do surgimento dos novos pólos econômicos mundiais. Mas a ascensão do Japão e a recuperação da Europa Ocidental foram apenas um preâmbulo frente à profunda reconfiguração (ainda que somente em gestação) das forças econômicas e políticas na Ordem Geopolítica Pós-Guerra Fria. No atual período, a ruptura com as relações centradas nos Estados Unidos é muito mais ampla, se considerarmos o escopo e os interesses das novas forças políticas e econômicas em ascensão.
} 


\subsection{Mercosul, o “Núcleo Duro" da Integração Continental}

A relação entre blocos econômicos e integração é muitas vezes interpretada de forma equivocada por teóricos das ciências econômicas e sociais. As zonas de cooperação não estão delimitadas pela formação dos blocos, embora tenham neles o âmago de sua organização. Mesmo que a multipolarização em curso possua relações estreitas com esses novos entes políticos, as áreas de regionalização são mais amplas e complexas. Hoje, somente o mais antigo dos processos de integração em curso, o da União Européia, é um espaço consolidado. Somente este pode ser tomado estritamente como sinônimo de região geopolítica.

Porém, mesmo esta que, é caracteristicamente o espaço internacional de integração mais consolidado no mundo, exige a esse respeito, algumas observações. A União Européia, com suas origens no Tratado de Roma (1957), cujos Estados signatários foram Alemanha Ocidental, França, Bélgica, Países Baixos, Luxemburgo e Itália, caracteriza-se desde meados da década de 1970, pelo constante alargamento. Formada atualmente por vinte e sete Estadosmembros e com mais seis candidatos (Albânia, Islândia, Croácia, Macedônia, Turquia e Montenegro), esse bloco rompeu os limites da Europa Ocidental, penetrando na Europa Oriental, Bálcãs e na Península Escandinava. Alguns aspectos permitem entendê-la como uma região consolidada. Historicamente, desenvolveu-se entre seus países uma ampla integração territorial, a partir de uma densa rede de transporte e comunicação, que põem em interação suas economias, culturas e políticas. A União Européia é a única iniciativa no mundo que atingiu o último estágio da integração, que consiste na união econômica e monetária.

A maioria dos processos em andamento são apenas propostas de livrecomércio, união aduaneira ou mercado comum. O Estágio proposto e atingido pela União Européia permite a sua atuação supranacional, por meio de diversas instituições políticas e econômicas. Essa área de integração é uma rede transterritorial e transnacional, marcada por um complexo processo de compartilhamento do poder, que entrelaça regiões subnacionais, o Estado nacional e quase todo o continente. A moeda, a política agrícola, a política econômica, dentre outros fatores, consolidam um espaço regional de fato coeso. A União 
Européia é o arquétipo do regime soberano integrativo (AGNEW, 2008a, pp. 130132).

O Mercosul e a ASEAN representam dois exemplos emblemáticos de formação de região geopolítica. São, em vários aspectos, distintos do arquétipo estabelecido pela União Européia. A integração na Ásia Oriental é um pressuposto à consolidação dessa área como o terceiro grande espaço econômico mundial. $A$ ASEAN + 3 é um importante recurso de ampliação das relações políticas e intensificação das trocas comerciais. Consiste no núcleo duro da formação de um espaço continental e, diferente de seus propósitos de alinhamento anticomunista no final da década de 1960, visa uma agenda regional autônoma. ${ }^{94} \mathrm{Na}$ atual ordem geopolítica, o imperativo da cooperação capitaneada por essa iniciativa é fundamental, sobretudo para a coexistência pacífica entre China, Coréia do Sul e Japão (CAMILLERI, 2007). Somada aos fatores positivos da inevitável força de extroversão exercida pela APEC, a ASEAN+3 resulta em um núcleo de adensamento das relações políticas, econômicas e culturais, cujo alcance é mais amplo que a simples soma das áreas de seus Estados Partes. ${ }^{95}$ Nas últimas décadas, destaca-se o desenvolvimento de várias zonas multinacionais de integração, centrais à mudança das relações internas e externas em todo Pacífico Asiático.

Ainda que se trate de áreas de características econômicas, políticas, culturais e diplomáticas muito distintas, o paralelo entre o Pacífico Asiático e a América do Sul é pertinente devido o papel semelhante que a integração exerce na transformação das suas geopolíticas internas e externas. Mas diferente do Cone Sul, a integração comandada pela ASEAN se baseia mais no regionalismo aberto,

\footnotetext{
${ }^{94}$ A criação da ASEAN em 1967 aconteceu com o apoio americano (MUZAFFAR, 2007). Estabelecida por Indonésia, Malásia, Cingapura, Tailândia e Filipinas, como um espaço de cooperação, esse bloco atendia aos interesses anticomunistas das elites da região, com forte inclinação para relações com os Estados Unidos. Com a transformação em Área de Livre Comércio em 1992, a ASEAN funciona como plataforma de desenvolvimento econômico, atraindo novos membros como Vietnã, Laos, Myanmar, Camboja. Com a Coréia do Sul, China e Japão, foram estabelecidos acordos de cooperação, resultando na ASEAN+3.

${ }_{95}$ Para a compreensão dos diferentes propósitos da APEC e ASEAN, é necessário diferenciar duas grandes zonas de integração. O Pacífico Asiático é uma área que agrupa países do extremo oriente da Ásia, enquanto a Ásia-Pacífico é um espaço transcontinental, que abarca as áreas banhadas pelo Pacífico (MICHAEL \& MARSHALL, 2007). O Pacífico Asiático, mais do que uma área profícua para o surgimento de arranjos regionais, tem se mostrado espaço de integração inter-blocos. $O$ Acordo Comercial sobre Relações Econômicas entre Austrália e Nova Zelândia (ANZCERTA) - bloco responsável pela ampliação das relações comerciais entre os esses dois países - tem funcionado, por exemplo, como mecanismo de ligação com a ASEAN. Por sua vez, a APEC é um instrumento em estruturação, de liberalização comercial para a Ásia-Pacífico. Como o maior espaço econômico do mundo, envolve outras regiões além da Ásia e Oceania. Entre os 21 Estados Partes que a compõem, a maioria deles na Ásia, estão os países da América do Norte, e dois da América do Sul (Chile e Peru). Devido à condição de "fábrica do mundo" do Sudeste Asiático, a APEC é uma importante força de extroversão econômica, pois fortalece o comércio com outros continentes. Portanto, por se tratar de uma região altamente dependente do comércio global, o encaixe entre os dois blocos regionais é fundamental. A ASEAN amplia a interdependência política e econômica no Pacífico Asiático e a APEC permite a ampliação das relações da região com toda Ásia-Pacífico. Muitas críticas ao Mercosul se espelham nesse modelo.
} 
pois a condição de área de livre comércio permite o adensamento das relações econômicas internas e externas. Se por um lado, a união aduaneira inibe uma maior abertura comercial dos membros plenos do Mercosul com países extrabloco, por outro, é responsável pela interdependência intra-bloco. A condição de núcleo duro da integração sul-americana resulta da interdependência possibilitada pela união aduaneira.

A despeito do fato de que muitos críticos como Araújo Jr. (2009, p. 34) interpretam a TEC como o maior empecilho à ampliação do comércio mundial brasileiro, sua importância extrapola a coesão política e econômica entre as nações do Cone Sul. O grau de interdependência permitido pela condição de união aduaneira transformou o Mercosul em poderosa força magnética sobre o restante do continente. Num contínuo processo de alargamento do bloco, Brasil, Argentina, Paraguai e Uruguai têm assinado Acordos de Complementação Econômica (ACE) com a maioria dos países sul-americanos desde $1996 .{ }^{96}$ Os primeiros países a firmarem acordo de livre comércio com o Mercosul foram Chile e Bolívia, em 1996. Outros ACE foram assinados posteriormente com o Peru (2003), CAN (2003), Equador, Colômbia e Venezuela (2004), alcançando todas as regiões da América do Sul.

O empenho diplomático de criação da zona de livre comércio entre a CAN e o Mercosul corrobora a condição do "bloco meridional" como núcleo duro da integração continental. Tal como evidenciava o ACE com a Bolívia em 1996, o interesse das nações andinas no aprofundamento de suas relações comerciais com os países do Mercosul é inevitavelmente um fator de enfraquecimento da CAN no âmbito continental. Nesse caso, a projeção continental do "bloco meridional" se dá através de duas maneiras, ambas igualmente importantes para América do Sul. O ingresso (em andamento) da Venezuela como membro pleno não deve ser desprezado, pois projeta o Mercosul até a Bacia do Caribe. A constituição de uma área sul-americana de livre comércio, por outro lado, é vital ao aprofundamento da cooperação como paradigma das relações entre as nações da região.

As políticas de coesão regional ultrapassam o Cone Sul, fortalecendo toda escala continental frente a projetos externos. A criação da União das Nações Sul-

${ }^{96}$ O ACE é um mecanismo de liberalização comercial entre dois ou mais países. Trata-se de um processo de liberalização gradual do comércio bilateral ou multilateral, cujo objetivo final é a formação de uma Área de Livre Comércio. 
Americanas (Unasul) em 2008, reforça esse movimento, sendo o mais importante projeto de contenção aos Estados Unidos empreendido na América do Sul. A Unasul não significa apenas a formalização do livre comércio, mas a ampliação do escopo geográfico da cooperação iniciada com a assinatura do Tratado de Assunção.

O discurso economicista que tem se tornado bastante popular ao caracterizar a TEC como entrave ao crescimento do comércio internacional brasileiro com países extrabloco, representa um retrocesso do aprofundamento da política continental iniciado na década de 1980. Essa concepção, que reduz todo escopo das relações internacionais às trocas comerciais, decorre do cambaleante fundamento posto pelos economistas neoliberais de que as prerrogativas do desenvolvimento estão no livre-mercado. Sem a existência da TEC, não há o estreitamento da interdependência política entre os membros do Mercosul. Sem a criação da união aduaneira, as economias da região não teriam alcançado o nível contemporâneo de integração. ${ }^{97} \mathrm{Na}$ maioria das vezes, os vários setores críticos à tarifa externa comum usam como referência países de características econômicas muito distintas daquelas apresentadas pelo Brasil e os seus parceiros do Cone Sul. $^{98}$

Não se trata de ignorar os obstáculos ao comércio extrabloco com a criação da união aduaneira. Todavia, o fortalecimento do comércio intrabloco e a conseqüente interdependência entre os Estados Partes é uma derivação direta da criação da TEC que não pode ser negligenciada. Além da importância regional desses dois fatores, outro aspecto deve ser levado em consideração no escopo da análise sobre a integração sul-americana. Se a regionalização contida no Tratado de Assunção pressupõe uma integração mais profunda que uma mera liberalização comercial, o "entrave" posto pela TEC deve ser compensado por um esforço multilateral de ampliação das relações comerciais com os Estados extrablocos. No caso sul-americano, é justamente esse o papel representado pela Unasul.

\footnotetext{
97 Antes do Tratado de Assunção, o empresariado brasileiro questionava a necessidade de criação da União Aduaneira, preferindo negociar com as grandes potências sem a tarifa externa comum. Anos depois da assinatura desse tratado, o empresariado demonstrava receios frente a qualquer iniciativa de ampliação do Mercosul que o descaracterizasse, pois o bloco havia se tornado importante fonte de receita (AMORIM, 2009).

${ }_{98}$ Muitas vozes críticas a TEC e a condição de União Aduaneira do Mercosul no meio acadêmico, político e jornalístico usam constantemente como exemplo o caso do comércio chinês. Entretanto, é necessário considerar que as vantagens competitivas chinesas são o baixo valor da mão-de-obra, a poderosa política estatal de investimentos em infra-estruturas e uma estratégia nacional de absorção de tecnologia, além de uma moeda altamente desvalorizada, fundamental para o baixo preço de seus produtos no mercado internacional.
} 
O empenho que culminou com a criação da Unasul tem a extraordinária prerrogativa de promover a ampliação no comércio continental, um processo restrito ao Cone Sul desde o impulso inicial com os acordos Brasil-Argentina na década de 1980. Os mecanismos de liberalização comercial permitiram que em apenas seis anos, as trocas entre os países sul-americanos aumentassem em mais de 600\% (AMORIM, 2009). Mas, se o veio comercial não é o único fundamento da integração, é preciso compreender o escopo da Unasul nessa ordem geopolítica, onde a fluidez territorial e a economia geopolítica são cada vez mais decisivas. Cumpre aferir as variáveis da integração posta por essa nova instituição.

Seria possível advogar a existência de uma região geopolítica sulamericana a partir da criação do novo bloco em 2008? Os acordos costurados a partir do Mercosul possuem força para expandir sua dimensão estratégica para todo continente? O Tratado Constitutivo da Unasul assinado pelos doze países sulamericanos em 2008 cria uma institucionalidade jurídica ausente na antiga Comunidade Sul-Americana de Nações (CASA) - formada em 2004 com a área de livre comércio entre Mercosul e CAN. O tratado possui algumas variáveis complementares: comércio, infra-estrutura, energia e defesa (Op. Cit.). Esta última foi incorporada sete meses após a criação da Unasul, com a instituição do Conselho de Defesa Sul-Americano (CDS). Esse órgão visa a coordenação multilateral no campo da defesa e segurança, um dos mais espinhosos na América do Sul.

O CDS permite a ampliação do processo de interdependência em construção no continente para campo da defesa e segurança. O estabelecimento de um sistema multilateral relacionado a essa área não é propriamente reação às possíveis ameaças representadas por potências externas. Busca primeiro, impedir situações como a ocorrida entre Colômbia e Equador em 2008, que culminou com o rompimento das relações entre os dois países (DREGER, 2009, p. 61). Embora diálogos entre brasileiros e argentinos visando um sistema coletivo de defesa sejam comuns desde os anos 1990 (OLIVEIRA, 2009, p. 80), não houve avanços efetivos nessa área. A intensificação da tendência de cooperação entre os Estados Partes do Mercosul, cujos atritos remanescentes não se comparam às fortes tensões entre Colômbia e Equador, Colômbia e Venezuela, e muito menos aos 
conflitos armados como a Guerra Peru-Equador (1995), não conferiu prioridade a essa temática.

São justamente as tensões entre os países setentrionais que estimulam uma política de soluções de controvérsias nessa área. A criação do CDS estabelece um estágio até recentemente distante para as relações entre os seus integrantes. Ainda que fatores a impulsionar a cooperação na área de defesa e segurança sejam majoritariamente internos, a criação da CDS é o primeiro passo para um sistema de cooperação mais aprofundado frente às ameaças externas. Assim como em outros continentes, o crescimento econômico reforça interesses em áreas estratégicas, como recursos naturais, energia, circulação marítima etc. $A$ nova conjuntura econômica continental tende a exigir da agenda de defesa de muitos países sul-americanos, maior investimento em poder de dissuasão à forças externas.

Um avanço inegável em matéria de defesa e segurança e influenciado pelos conflitos e tensões diplomáticas entre os países supracitados, o CDS é uma das bases da expansão institucional e geográfica da cooperação inaugurada pelo Mercosul. Mesmo considerando que sua criação seja resultado de um esforço multilateral, deve-se à crescente liderança regional brasileira, a articulação de um acordo sobre um tema tão complexo. A Política de Defesa Nacional brasileira aprovada em 2005 destaca a importância de aprofundar os laços com os países sul-americanos, com prioridade atribuída à segurança regional (COSTA, 2009, pp. 01-23).

Apesar das sérias tensões em outras áreas do continente, como a centenária questão boliviana de acesso ao Pacífico, o principal laboratório do CDS é a região setentrional. Os conflitos nessa área são o maior desafio às ações visando à estabilização das crises políticas e militares. O êxito dessa agenda é dependente, sobretudo, do arrefecimento das graves tensões entre Colômbia e Venezuela. Após a eleição de Juan Manoel Santos, interesses comerciais mútuos têm contribuído para a melhoria de suas relações. Contudo, as FARCS e a presença militar americana ostensiva em solo colombiano ainda são poderosas forças de fricção a desafiar não apenas o CDS, mas toda política atual de integração.

Entretanto, as variáveis que perpassam a construção de uma região geopolítica sul-americana não se restringem aos temas de defesa e segurança. $O$ 
sucesso na ratificação de acordos de livre comércio entre o Mercosul e países extra-bloco desde os anos 1990, assevera a disseminação geográfica do processo de coesão regional no Cone Sul. Embora a integração continental tenha na convergência entre Brasil e Argentina uma influência significativa (FERRER, 2000, pp. 05-17), somente a maior potência sul-americana possui condições econômicas, políticas e geográficas para liderá-la. Mas, o Brasil não se torna por meio de sua projeção continental, um "Estado-barão" rodeado por Estados vassalos como gostaria Golbery do Couto e Silva (1967, pp. 19-22). No entanto, o fato da legitimidade do processo de integração estar na cooperação em detrimento de qualquer anseio expansionista, não impede o inegável protagonismo regional do Brasil. Como anteriormente argumentado, esse protagonismo está atrelado à interdependência.

As geopolíticas contemporâneas e clássicas confere dupla sustentação à preponderância brasileira. A primeira é a economia, cujo tamanho e sofisticação não tem paralelo com seus vizinhos. A segunda é a geografia, com a integração entre as bacias Amazônica e Platina, e as vertentes do Atlântico e Pacifico. Tal qual uma imensa "área de soldadura", o território brasileiro permite o transbordamento da idealpolitik predominante no Cone Sul até os países setentrionais. A continentalidade do país é fundamental à transformação das relações interestatais em todas as áreas sul-americanas, ao enfraquecimento das influências de potências externas, e, por conseguinte, à consolidação da região geopolítica.

Com o programa Brasil em Ação lançado em 1996, o governo Fernando Henrique Cardoso (1995-2002) estabelece um marco nas políticas de integração nacional. Ainda hoje, as conexões inter-regionais preservam aspectos daquilo que Golbery do Couto e Silva (1967, pp. 42-45) denominou de "Brasil Arquipélago". Com os novos conteúdos da economia mundial, o modelo de planejamento instituído na década de 1990 propõe pela primeira vez de modo sistemático, a articulação do território nacional à incipiente malha de transporte sul-americana. $O$ novo marco fez a primazia do desenvolvimento regional ser substituída pelos Eixos Nacionais de Integração e Desenvolvimento (PORTO, 2006, pp. 84-85). A inovação trazida ao planejamento do território fundamenta-se na necessidade de articulação das regiões produtivas com o continente e a economia política 
internacional. $^{99}$ Os EID tornaram-se a principal base para o lançamento da Iniciativa para a Integração da Infra-estrutura Regional Sul-Americana (IIRSA) em 2000, o mais importante empreendimento multilateral na área de transporte na América do Sul.

"A justificativa dos EID se fundamenta em necessidades internas e externas da retomada dos investimentos produtivos e da redefinição do papel do Estado" (BECKER, 1999, p. 36). Com a falência do modelo militar, a centralidade exercida pelo Estado no planejamento do território foi relativizada pela ascensão de interesses corporativos. Num ambiente de abertura econômica e ascensão do mercado como agente central na política nacional, esses interesses definiram as prioridades dos investimentos em todos os modais de transporte. Os investimentos no setor ferroviário, por exemplo, tinham como objetivo promover uma fluidez corporativa, exemplificada pelo escoamento da soja produzida nos fronts agrícolas do Cerrado (CASTILHO, 2007, pp. 33-43; VENCOVSKY \& CASTILHO, 2007, pp. 119-134).

A Geografia Política tomada como “... base de uma tecnologia espacial do poder do Estado" (BECKER, 1995, p. 283) não é suficiente para a compreensão das questões do nosso tempo. A crescente importância de atores não estatais tem influência direta sobre as políticas territoriais. Há uma nova racionalidade onde a logística associada à transformações trazidas pela revolução científico-tecnológica se destaca como a base da nova Geopolítica (Op. Cit., p 286). A nova organização do território, concebida através de uma fluidez seletiva, subordina-se aos interesses de poderosos atores corporativos nacionais, continentais e também mundiais.

A expansão das relações comerciais globais e o vertiginoso aumento da interdependência econômica entre os Estados Partes e Associados do Mercosul tiveram por esse motivo, influência vital nos parâmetros contemporâneos da logística territorial. Áreas de maior concentração da produção e consumo, o Sul e o Sudeste exercem força centrípeta sobre todo o Cone Sul, além das demais regiões brasileiras, dos países setentrionais e da vertente do Pacífico. É em torno

\footnotetext{
${ }^{99}$ Segundo Porto (2006, p. 94), os EID e os seus corredores foram definidos de acordo com a dinamicidade econômica das regiões. Nos últimos anos, houve uma transformação da taxa de participação das regiões no PIB nacional. No bojo dessa mudança, destaca-se o aumento da participação do Centro-Oeste devido ao crescimento da sua economia agrícola, justificando o fato de a região participar de quase todos os corredores. Por outro lado, Porto (Op. Cit., p. 101) afirma que há um modelo concêntrico para os investimentos, onde o Sudeste aparece enquanto uma "rótula" e o Nordeste como a área mais periférica. Como conseqüência, a região aparece desarticulada dos principais EID. Porém, alguns importantes projetos compõem os eixos de integração da Nordeste, destacando-se as rodovias BR-116 e BR-101, e as ferrovias São Francisco e Transnordestina.
} 
dessa vasta área, denominada de região concentrada por Milton Santos \& Maria Laura Silveira (2001), que se articula a maioria dos corredores que compõem os EID. ${ }^{100}$

O vetor tecno-industrial é base da articulação do Brasil com a economia mundo (BECKER, 1997, pp. 11-14). Instalado em grandes cidades da região concentrada, esse vetor está interligado com inúmeras áreas de características semelhantes em todo globo. No caso sul-americano é o eixo formado por Rio São Paulo - Córdoba - Rosário - Buenos Aires que se constitui na região de maior desenvolvimento (FERRER, 2000, p. 06). Por conseguinte, é esta área que comanda as trocas comerciais intra e inter-regionais. "As forças centrípetas da geografia são mais intensas quanto maior é o nível de desenvolvimento tecnológico e industrial” (Op. Cit.). A concentração do vetor tecno-industrial em áreas mais desenvolvidas da Argentina, Brasil e Chile é o principal fator que confere à regionalização do Mercosul a qualidade de núcleo duro da integração sul-americana.

\subsection{Fundamentos da Nova Ordem Regional}

Apesar das crises constantes desde a assinatura do Tratado de Assunção, temas importantes da política interna e externa foram tratados pelos Estados Partes segundo os interesses que envolvem o Mercosul. A condição de núcleo duro da integração continental está posta até mesmo nos ideais que levaram a criação do bloco econômico. Pode ser encontrada na "experiência estratégica" inaugurada por Sarney e Alfonsín, que envolvia a criação de um entorno regional necessário a realização de objetivos conjuntos (PENÃ, 2001, p. 07). Os interesses iniciais que sustentaram os primeiros movimentos da regionalização foram explicitados através de uma agenda multitemática. O Mercosul exerce força centrípeta sobre a América do Sul por um conjunto de macro-vetores, que em

\footnotetext{
${ }^{100}$ A partir dos estudos para os Eixos Nacionais de Integração e Desenvolvimento, Edgard Porto (2006) enumera os principais corredores projetados para o território brasileiro: 1) Corredor Rio Grande: baseado nos fluxos agrícolas entre Brasil, Uruguai e Argentina, com exportações pelos portos de Porto Alegre e Rio Grande; 2) Corredor Paraná / Santa Catarina: visa interligar a produção de graneis agrícolas entre a região Sul e Centro-Oeste, com exportações pelos portos de Paranaguá e São Francisco. 3) Corredor São Paulo: privilegia o escoamento da produção industrial, da produção de fertilizantes, granéis sólidos do Estado de São Paulo e parte dos Estados do Centro-Oeste pelo porto de Santos. 4) Corredor Centro-Leste: tem em vista atender a exportação de grãos do Espírito Santo, Minas Gerais e Estados do Centro-Oeste pelo porto de Tubarão em Vitória. 5) Corredor Nordeste: propiciará o consumo de produtos industrializados produzidos no Sudeste e de farelos produzidos no oeste da Bahia, Maranhão e Piauí. A partir de 2020, visa-se integrar esses cinco principais corredores aos corredores da Amazônia pela utilização da Hidrovia Madeira-Amazonas.
} 
interação estabelecem a forma da política regional inaugurada no final dos anos 1980.

A criação de uma área sul-americana de livre comércio e o ingresso da Venezuela como membro pleno não corrobora somente para a liderança do Mercosul no bojo da integração continental. Em conjunto, os ACEs, o CDS e a expansão geográfica da TEC até a zona setentrional sul-americana consolidam o rompimento do entorno espacial onde estava circunscrito o modelo atual da política regional. Esses mecanismos de cooperação passam a alcançar quase a totalidade da América do Sul, continentalizando a nova concepção de relações internacionais.

Mas se coexistem na globalização as forças antagônicas representadas pelo idealismo e realismo (LAFER \& FONSECA, 1994; LAFER, 2000), a regionalização implica na interação entre essas tendências da ordem geopolítica presente.

A regionalização produz uma síntese entre realismo e idealismo, à medida que modifica a arquitetura das relações internas e funda novas concepções de projeção internacional às nações sul-americanas. No contexto continental, os dois paradigmas majoritários da política internacional contemporânea somente podem ser apreendidos pela confluência de diversos temas da integração. As tendências realistas ainda se manifestam em questões como defesa e segurança, recursos naturais e fronteiras. As idealistas são mais visíveis em novos arranjos políticos, em acordos multilaterais e no aumento da interdependência comercial entre os países. Mas esses temas são essencialmente transversais, e estão presentes tanto numa abordagem quanto noutra. Porém, alguns têm influência mais destacada como força de desagregação, ao passo que outros são pilares da integração.

Considerando que o realismo se sustenta basicamente em "encontros de poder" (FONSECA, 1994, p. 87), sua capilaridade transnacional depende do uso da força. As forças idealistas demonstram por sua vez uma extraordinária influência no ordenamento das relações internacionais contemporâneas em todas as escalas. Pelo fato de a ordem geopolítica não significar necessariamente um mundo baseado no consenso e cooperação (AGNEW \& CORBRIDGE, 1995, pp. 15-16), o modo realista tem predominado, sobretudo, contra atores estatais e não estatais, cujo comportamento político é considerado uma ameaça à soberania 
globalista. De modo geral, o realismo é predominante em questões geopolíticas clássicas.

Na América do Sul, a influência da idealpolitik tem características que a diferenciam daquela exercida em escala global ou mesmo em espaços de integração mais consolidados, como é o caso da União Européia. Nesses espaços, as forças idealistas não se fazem presentes, como discutimos anteriormente, apenas pelo mercado e instituições supranacionais. O desenvolvimento de uma arena democrática internacional, mesmo que por articulação e não por representação como nota Chandler (2003), torna possível a participação de múltiplos setores da sociedade civil na regionalização. Na América do Sul, os fluxos intra-regionais são bastante diferentes dos que predominam nos espaços que comandam a globalização.

A integração conduzida pelo Mercosul ampliou a participação de atores estatais não tradicionais no campo da política externa, como Estados e municípios. Da mesma forma, ampliou o crescente protagonismo de atores não estatais tradicionais, como as empresas. Mas não é possível aplicar o raciocínio transnacionalista que predomina na escala européia e global para o Cone Sul. O aprofundamento da integração européia fez com que a sociedade civil fosse integrante ativa do processo. A participação deste segmento é somente possível a partir do aprofundamento da integração, que exige o envolvimento de diversos setores não estatais. A criação do mercado comum é somente a primeira etapa desse processo.

A União Européia é bastante significativa a esse respeito. O que é definido como "cidadania da União" confere ao cidadão europeu dentre diversos direitos, o de residir em qualquer Estado membro, o de votar e ser eleito em seu país para o Parlamento Europeu, e o de ter assistência e proteção diplomática em países terceiros (WANDERLEY, 2002, p. 68). Destaca-se também na União Européia a atuação do Comitê Econômico e Social “... constituído de 222 representantes de grupos de trabalhadores, patronato e interesses diversos - profissões liberais, agricultura, cooperativas, câmaras de comércio e associações de consumidores." (Op. Cit.). A soberania integrativa do bloco significa também a capacidade de estender a legitimidade da autoridade regional a partir de direitos civis fundamentais. 
No caso do Mercosul, o problema reside justamente no predomínio do modelo de integração de baixa densidade que demonstra Ramanzini jr. \& Vigevani (2010). A inclusão dos diversos segmentos da sociedade civil como acontece no exemplo europeu, exige o estabelecimento de uma estrutura institucional supranacional. Ainda que sem a mesma penetração social do sistema político tradicional, o aprofundamento da integração depende de um ordenamento institucional regional, cuja efetividade está na criação de práticas políticas e sociais continentais.

As primeiras atenções às questões sociais aparecem no Mercosul com a criação pelo Protocolo de Ouro Preto (1994) do Foro Consultivo EconômicoSocial. Este órgão atua sob recomendação do Grupo Mercado Comum, possuindo um poder meramente consultivo. Visa cooperar com o desenvolvimento econômico e social através da análise do impacto social da integração, proposições de políticas sociais e outros aspectos que contribuam para o progresso econômico e social. O Foro é um canal à disposição de empresários e trabalhadores (ACCIOLY, 1999, p. 125)

A criação em 1998, da Declaração Sociolaboral, como um instrumento que busca garantir um conjunto restrito de direitos individuais e estabelecer mecanismos de negociações coletivas e um espaço de solução de conflitos entre segmentos sociais ou países (WANDERLEY, 20002, p. 68) é um avanço relacionado às questões sociais, a maior fragilidade do modelo estabelecido em 1991. ${ }^{101}$

Do ponto de vista institucional e político o Mercosul se aproxima mais do modelo europeu do que das demais propostas de regionalização em outros continentes. Tem, por exemplo, uma tendência comunitária maior que o NAFTA, uma iniciativa totalmente livre-cambista (ALMEIDA, 2003). Essa tendência pode ser observada principalmente com a estrutura jurídico-institucional do Mercosul. Foi, em certo sentido, estabelecido um direito comunitário pelo bloco, entendido como o conjunto normativo que visa reger a relação dos Estados Partes, unidos

\footnotetext{
101 "A Declaração propõe a definição de um espaço social nas discussões do Bloco, um conjunto de garantias e o reconhecimento das Convenções da OIT como fonte jurídica. Propugnam-se como princípios irrenunciáveis a democracia política e o respeito irrestrito aos direitos civis e políticos. Centralmente, a Carta contém uma percepção do processo de integração como uma possibilidade histórica para melhorar as condições de vida das sociedades nacionais, um apelo aos governos para propor uma eficaz intervenção dos Estados que garanta os direitos dos trabalhadores. A posição perante a livre circulação da mão-de-obra é a de garantir no Bloco igualdade de direitos, condições de trabalho, condições dignas de vida, moradia, educação e saúde. Na perspectiva dos direitos coletivos, propõe a liberdade sindical, a negociação coletiva, o direito à greve, o direito a permanente informação e consulta dos outros órgãos do Mercosul." Op. Cit.
} 
em uma federação e submetidos a órgãos de caráter supranacional (MÜLLER, 2003).

Há, de fato, o estabelecimento de uma estrutura supranacional para regular as relações entre os Estados no âmbito do Mercosul. Todavia, no âmbito do bloco, as empresas, os trabalhadores e todos os demais setores da sociedade estão subordinados ao direito internacional e nacional. Sob a perspectiva jurídica, ainda que existam as fontes do direito no interior do Mercosul (BASSO, 2000), não houve (ainda) o estabelecimento de uma estrutura jurídica supranacional como no caso europeu. O Mercosul possui um desenho institucional intergovernamental, onde os órgãos são formados por representantes do poder executivo e legislativo dos Estados membros, em um sistema de tomada de decisão por consenso (HOFFMANN, COUTINHO \& KFURI, 2008). ${ }^{102}$ As crises internas, a valorização dos interesses nacionais sobre o regional, e o predomínio da "integração de baixa densidade" impedem o maior aprofundamento da estrutura institucional supranacional.

Como conseqüência da natureza multilateral da regionalização, o Mercosul estabelece diferentes intersecções entre as estruturas que conduzem o processo de integração e as instituições internacionais da ordem geopolítica contemporânea. Portanto, a constituição de uma nova ordem regional está apoiada na síntese realizada, a partir do modo de regulação predominante nas escalas nacional e global. A estrutura jurídico-institucional fundada pelo Mercosul (ACCIOLY, 1999) é bastante ilustrativa no entendimento dessa questão. As fontes do direito no interior do bloco envolvem os princípios do direito internacional, as decisões dos seus tribunais arbitrais, a jurisprudência dos tribunais nacionais etc. (BASSO, 2000).

A inter-relação entre instituições que compõem o sistema política nacional e a ordem internacional é um dos aspectos definidores do alcance da

\footnotetext{
102 Segundo Hoffmann, Coutinho \& Kfuri, (2008), o Tratado de Assunção previa dois órgãos para o Mercosul: Conselho do Mercado Comum (CMC) e Grupo Mercado Comum (GMC). O CMC é um órgão supervisor formado por ministros da economia e das relações exteriores, além da participação dos presidentes em pelo menos uma reunião anual. É responsável pela condução política e tomada de decisão para constituição do Mercado Comum. O GMC é um órgão executivo formado por ministros da economia e relações exteriores e presidentes de Banco Central com a tarefa de zelar pelo cumprimento do Tratado, tomar providências quanto ao cumprimento das decisões do Conselho, propor medidas concretas para ampliação do programa de liberalização comercial, etc. Por determinação do Tratado de Assunção, o Protocolo de Ouro Preto (1994) ampliou a estrutura institucional do bloco, com a criação de mais quatro órgãos: Comissão de Comércio do Mercosul (CCM), Comissão Parlamentar Conjunta (CPC), Foro Consultivo Econômico-Social (FCES) e a Secretaria Administrativa do Mercosul (SAM). A CCM tem a tarefa de auxiliar o GMC visando o funcionamento da União Aduaneira, as políticas comerciais comuns, e o comércio intra-Mercosul e inter-regional. A CPC é formada por um número igual de parlamentares dos Estados membros, com intuito de acelerar "... procedimentos internos correspondentes aos Estados Partes para a pronta entrada em vigor das normas emanadas do Mercosul..." (Op. Cit. p. 105). O FCES é subordinado ao GMC, sendo um órgão de representação de setores econômicos e sociais. A SAM, com sede permanente em Montevidéu, é um órgão de apoio operacional, organizando reuniões, publicando decisões etc.
} 
regionalização liderada pelo Mercosul. Contudo, a estrutura institucional é apenas parte de uma ordem regional maior. O retorno à discussão sobre o conceito de ordem se faz necessário perante a imprescindibilidade de avançar no entendimento de características endógenas a qualquer processo de regionalização.

Em que sentido é possível conceber uma ordem regional? Qualquer entendimento relativo a uma ordem que fundamente a região geopolítica deve levar em consideração a condição dessa área enquanto um meio ordenamento das relações políticas, econômicas e sociais, altamente condicionado ao arranjo hegemônico global. Portanto, falar em ordem regional significa entender a existência de um sistema multilateral dotado de instituições, normas e procedimentos que disciplinam e organizam as relações entre todos os envolvidos na integração. A região, entendida como intermediação entre o global e o local (LENCIONI, 1999), significa uma mimetização de aspectos centrais da ordem mundial, cujo objetivo consiste na tentativa da transformação das correlações de forças.

A regionalização é conduzida por "estruturas de integração", entendidas como as principais forças que comandam, organizam e sustentam a nova ordem regional. Através de um novo paradigma político, as estruturas de integração são os meios pelos quais o processo de regionalização é colocado em andamento. Dessa forma, são tanto forças materializadas e visíveis em infra-estruturas físicas e relações comerciais quanto "forças invisíveis" manifestadas por meio de valores que norteiam a política e a diplomacia. Assim como as demais, as forças invisíveis moldam a morfologia e a funcionalidade de uma área (HARTSHORNE, 1950, pp. 95-130).

As estruturas de integração não são idênticas em todas as iniciativas em andamento no mundo, variando conforme as especificidades dos diversos blocos econômicos. Isso não impede que muitas delas estejam semelhantemente presentes na Ásia, Europa, América do Norte, América do Sul e África. Política, economia, e território, por exemplo, são estruturas presentes na maioria das regionalizações em curso. Muitos teóricos destacam defesa e segurança, energia, e meio ambiente, como aspectos condutores da integração sul-americana. Todos os temas aqui colocados são igualmente importantes para a integração sulamericana. Mas política, econômica e território são estruturas de integração 
porque se constituem em macro-vetores sob os quais estão subordinados todos os demais temas.

O nível de desenvolvimento de questões relacionadas à política, economia e território depende dos objetivos que orientam a gênese de um bloco regional. Quanto mais aprofundada uma proposta de integração, maior será o desenvolvimento das estruturas de integração. O inverso também é verdadeiro, pois a baixa densidade da cooperação está associada a uma aliança estratégica construída em torno de uma agenda pouco diversificada. No caso da União Européia, o inédito nível de interdependência entre seus membros está exemplarmente exposto no fato de que até a moeda; um baluarte da soberania clássica, não é mais monopólio de um único Estado. Em relação à APEC, que não visa além de uma zona transcontinental de livre comércio, os temas estão centrados em mecanismos de liberalização dos fluxos comerciais entre os seus 21 membros. $^{103}$

Uma particularidade geográfica faz com que o ordenamento regional sulamericano seja caracterizado, diferente de outras importantes integrações no mundo, como numa iniciativa multilateral majoritariamente dependente da agenda de uma única nação. ${ }^{104}$ A posição de "rótula" continental exercida pelo território do Brasil, somada à supremacia política e econômica, subordina diferentes agendas de integração aos interesses continentais e mundiais do país. A influência brasileira, legitimada também pelo discurso de interdependência, coloca imposições metodológicas para a análise das estruturas de integração. A mais importante delas é exatamente o fato acima considerado de que qualquer dimensão importante da integração se desenvolve paralelamente aos interesses brasileiros.

Para Sergio Danese (2001, pp. 49-71), existem quatro dimensões de integração do Brasil com a América do Sul, sendo todas imanentes aos esforços

\footnotetext{
103 A APEC é uma gigantesca "região descontínua" com características que a torna diferente dos demais blocos econômicos. Não se encaixa entre as demais iniciativas, pois tem entre seus membros países com interesses muito diferenciados. Não se enquadra na categoria de região geopolítica porque não existem interesses em torno de uma agenda mais ampla. A única força de coesão que mantém no mesmo bloco econômico diversos países politicamente tão dispares é o interesse de ampliar o comércio.

${ }^{104}$ Nem mesmo a posição americana no NAFTA poder ser comparada à situação brasileira na América do Sul, embora ambos os países sejam a força sob a qual se organiza a integração em suas respectivas áreas. Mas, se os Estados Unidos lideram uma área de livre comércio num espaço com apenas três países, o Brasil é o articulador de uma zona de livre comércio com doze países. O Brasil tem sido também o principal pilar da união aduaneira que vai da Patagônia à Bacia do Caribe. Exceto Rússia e China, nenhuma nação no mundo tem tantos vizinhos limítrofes quanto o Brasil. As fronteiras que o país possui com dez de seus doze vizinhos contribuíram para que desenvolvessem relações, em maior ou menor grau, com todas as regiões sul-americanas. Poucos países foram forçados a desenvolver uma agenda continental de relações bilaterais e multilaterais tão vasta.
} 
de cooperação conduzidos pelo país. A integração física, baseada na construção de um sistema multimodal de transportes, é prioritária desde os primeiros encontros presidenciais entre o Brasil e seus parceiros. Com o lançamento da IIRSA, pela primeira vez esse tema foi alvo de uma política multilateral sistematizada.

A economia, por seu turno, é a área onde o país tem alcançado os resultados mais expressivos na integração com seus vizinhos. A ampliação das trocas comerciais se tornou o carro-chefe da cooperação interestatal devido sua atuação significativa como força de coesão entre os parceiros. De modo semelhante aos investimentos em integração física, a agenda em torno da questão energética adquire relevância acentuada conforme avança a ampliação das relações comerciais. Se integração e energia são dois conceitos unidos (LÓPEZSUÁREZ, et al., 2010, pp. 49-60), a retomada do crescimento econômico entre a maioria dos países sul-americanos, aliada à crescente interdependência comercial no continente, ressalta ainda mais a importância de políticas de integração nessa área. Os interesses em energia são diversificados, e envolvem o petróleo argentino e venezuelano, o gás natural boliviano, argentino e peruano, a energia elétrica do Paraguai, Argentina e Venezuela, e o carvão colombiano (DANESE, 2001).

Danese (Op. Cit.) destaca a política como a grande impulsionadora da integração do Brasil com a América do Sul. A política não é apenas um pilar central desse processo, mas a responsável pelo desenvolvimento das outras três dimensões. A transformação do paradigma político, revelada na "experiência estratégica" de que fala Peña (2001, p. 07), está na origem da aproximação do Brasil com o seu continente, desde os primeiros diálogos envolvendo a criação do Mercosul. É uma determinada concepção política que comanda as agendas de cooperação energética, econômica, militar, ambiental ou qualquer outra áreachave.

O diplomata brasileiro aborda metodologicamente as quatro dimensões enquanto realidades indissociáveis no processo de integração. A interação e influência mútua exercida entre elas constituem um arcabouço geral para as relações entre os países sul-americanos. Essa concepção multidimensional enfatiza alguns dos temas privilegiados pelas principais iniciativas (bilaterais e multilaterais) desde o final dos anos 1980. A interinfluência entre as dimensões 
transforma a conjuntura das relações continentais, permitindo a nova ordem regional.

Contudo, política e economia possuem maior alcance se comparadas aos demais temas. As dimensões da integração são iniciativas paralelas que ocorrem num mesmo espaço, mas em diferentes perspectivas, como podem ser observadas em relação à energia, transportes etc. Política e economia formam junto ao território as três estruturas de integração visto que através delas são ordenadas as demais agendas da regionalização. Na condição de macro-vetores da nova conjuntura, são acima de tudo, concepções maiores que organizam e definem os temas da cooperação sul-americana. Formam a razão de ser da nova ordem regional.

Território não é terra ou superfície, mas um espaço delimitado por relações de poder (RAFFESTIN, 1993; SOUZA, 1995). Abrange desde os recursos naturais até a população, evocando, como pioneiramente notaram Hartshorne (1933) e Bowman (1946), sentimentos individuais e coletivos. O território é a arena de desdobramento de uma conjuntura política, ou como assinala Armando Corrêa da Silva (1993, p. 259), é o domínio de um evento. De tal forma, é espaço revestido da dimensão política (CORRÊA, 1993, p. 251). Em qualquer escala, os fenômenos políticos possuem dimensão territorial. Dos teóricos modernos aos pósmodernos, esse conceito tem sido privilegiado pelas abordagens políticas em Geografia.

Todavia, destaca-se nos últimos anos, um re-exame desse conceito chave, cada vez menos centrado no Estado nacional. Há uma releitura do território frente à globalização, pois a fluidez informacional constitui um meio privilegiado à emergência de uma diversidade de atores não estatais. Impregnado de conteúdos multidimensionais e transnacionais, o território fundamenta as políticas de integração nas áreas de transporte, comunicação e energia. Semelhantemente, as demais estruturas de integração são concepções que ordenam os temas da cooperação.

O novo paradigma da política regional é o alicerce dos acordos diplomáticos em diferentes áreas. Da mesma forma, os tratados de livre comércio, o estabelecimento de uma tarifa externa comum e todas as políticas comerciais, revelam concepções econômicas preponderantes na América do Sul desde o final dos anos 1980. Nesse mundo em mutação, lideres políticos, oficiais de governo, 
especialistas e conselheiros em política internacional, uma "comunidade" que Agnew \& Corbridge (1995, p. 48) denominam political élites, ainda monopolizam o statecraft. 


\section{CAPÍTULO 6}

\section{Transformações Econômicas e Territoriais}

A articulação do Brasil à economia-mundo corresponde a novas estratégias econômicas e políticas que remodelam o território como condição para o seu pleno desenvolvimento através de vários tipos de rede com velocidade diferenciada.

Bertha K. Becker

\subsection{Economia Geopolítica Regional Contemporânea}

"O poder econômico, como evidenciado nos escritos de Adolf A. Berle, é o "poder sem glória". Embora exercido por indivíduos, resulta do controle de uma organização. Possui uma estrutura coletiva e se apóia em uma rede de conexões materiais" (GOTTMANN, 1973, p. 53) [Tradução livre a partir do original do autor]. Embora esse poder não esteja exatamente subordinado ao Estado como entendiam os teóricos da geopolítica tradicional, as redes comerciais de produção e distribuição estão na base de consolidação dos Estados modernos como mostra Polanyi (2001). Mesmo com a ascensão dos mercados na década de 1970, o paradigma geopolítico trazido pela Inglaterra no século XIX e aprofundado no XX pelos Estados Unidos, encontra-se imbricado na regionalização sul-americana. Também aqui há uma síntese entre capitalismo e territorialismo. A ampliação do poder dos países sul-americanos passa também pela expansão de suas redes empresariais.

Este entendimento não pressupõe que todas as forças geopolíticas estejam subordinadas ao Estado. Trata-se, sobretudo, de interesses que 
convergem em determinados temas e aspectos das agendas política nacional e internacional. Também não se trata, obviamente, da economia nacional com um todo, mas de atores econômicos hegemônicos, cuja força não é somente capaz de influenciar seus Estados, mas de interferir na dinâmica da economia geopolítica global. A fusão da sociedade com o Estado territorial não é necessariamente uma ilusão intelectual, mas sim o tratamento dessa escala política como uma unidade racional hegeliana (AGNEW \& CORBRIDGE, 1995, p. 94). A crença no Estado nacional como o container absoluto de toda vida social entra em declínio junto com a exclusividade da territorialidade estatal. Em muitos aspectos, existe na economia geopolítica uma poderosa confluência de interesses de setores estatais e empresariais.

Este juízo não significa pressupor que os interesses internacionais dos Estados estejam subordinados às corporações. A complexidade da ordem geopolítica está na interdependência entre os interesses transnacionais das empresas e princípios que orientam a projeção internacional de um Estado. Mesmo estando a expansão das corporações vinculada às políticas de Estado, nem por isso, governos e empresas possuem os mesmos interesses. Governos são organizações orientadas pelo poder, que usam a guerra, a força de polícia e procedimentos jurídicos, reforçados pela força de atração dos sentimentos morais, como meios característicos de alcançar seus objetivos, fazendo existir um sistema de lei e alianças (ARRIGHI, 2008, p. 86). Os empreendimentos comerciais, em contraste, são organizações orientadas pelo lucro. Têm como atividades a compra e venda, fazendo existir sistemas de produção e distribuição (Op. Cit.). Deve-se considerar que as empresas (e outros atores não estatais como ONGs) têm interesses mais localizados, alcançando muitas vezes a escala regional ou local (CASTRO, 2005).

Além dessas diferenças, as grandes corporações possuem poderosa força centrífuga, quebrando laços que unem os cidadãos sob a hegemonia do Estado nacional (Op. Cit.). Para os sul-americanos, as multinacionais se tornaram sinônimos do poder norte-americano, ainda que seja em sua forma branda. Nas primeiras décadas de sua hegemonia, os Estados Unidos adotaram 0 protecionismo, preservaram seu mercado interno, e se tornaram terreno fértil para o desenvolvimento de mega companhias. Estas por sua vez, romperam o protecionismo em diversos outros países por meio dos Investimentos Estrangeiros 
Diretos (IED), tornando-se braços da hegemonia do seu país (Op. Cit. p. 303). Também os europeus e japoneses, consolidaram seu poder internacional nas décadas de 1960 e 1970 com as multinacionais. Como as americanas, as grandes corporações européias e japonesas se tornaram multinacionais de alcance mundial.

Argumentamos na Parte 1 que a desconcentração industrial e a expansão do crédito internacional contribuíram de forma decisiva ao crescimento econômico de países-chave. O desenvolvimento industrial proporcionou o fortalecimento de potências emergentes, que em conseqüência ampliaram a supremacia sobre seu entorno regional. Somada às demais formas de IED, as multinacionais eram os agentes principais dessa hierarquia. O capitalismo de corporações (ARRIGHI, 2008) permitiu na ordem precedente uma hierarquia geopolítica estruturada conforme as estratégias americanas de contenção. Estabeleceu-se o exercício do poder das principais potências mundiais sobre as regionais, e destas sobre as pequenas economias que formavam o seu entorno. Entretanto, a divisão internacional do trabalho horizontal estabelecida pela hegemonia norte-americana - singularizada principalmente pela competitividade industrial com a Europa e o Japão - tornou-se, ironicamente, o meio fundamental na transformação da hierarquia que caracterizava as relações econômicas mundiais (AGLIETTA, 1982, p. 21).

A despeito da recuperação européia e do acelerado desenvolvimento japonês nos anos 1960 e 1970 minarem a superioridade tecnológica norteamericana, a revolução informacional, a financeirização da economia, e a débâcle do comunismo soviético reorganizaram a hierarquia internacional em vantagem dos Estados Unidos. Visto dos anos 1980, o futuro estava sujeito à preponderância norte-americana ou ao surgimento de um sistema de economias regionais que substituiria a hierarquia dominante (Op. Cit. p. 41). Os três fatores acima mencionados contribuíram decisivamente para tornar a primeira década da ordem geopolítica contemporânea em um dos períodos mais importantes da hegemonia dos Estados Unidos.

Os efeitos da desregulamentação financeira, da abertura dos mercados, e do aumento da fluidez territorial para a América do Sul foram distintos nos anos 1980 e 1990. Com a paridade entre o dólar e moedas locais, as economias outrora protegidas pelas fronteiras e favorecidas pela imigração de multinacionais 
encontram outro desafio. Após o período de hiperinflação, os países sulamericanos enfrentaram a debilitação de setores econômicos estratégicos. Nos anos 1990, a crise atingiu setores industriais forjados no auge do desenvolvimentismo

Numa conjuntura de forte crescimento industrial do Sudeste Asiático, os interesses cada vez mais complexos das multinacionais não coincidem exatamente com as necessidades econômicas dos países sul-americanos. A velha hierarquia entre as potências mundiais, regionais e pequenos países perdeu sentido com o fim da Guerra Fria, a revolução informacional, e as transformações na forma organizacional das redes empresariais. Na ordem geopolítica precedente, as empresas multinacionais constituíam redes de produção e distribuição em diversos países e regiões. Com a globalização, essa lógica sofre uma transformação profunda. As maiores multinacionais estão inseridas numa diversidade de redes não subordinadas ao seu domínio (CASTELLS, 1999a, pp. 250-259). A desintegração vertical e a terceirização da produção ${ }^{105}$, uma reação à competitividade da economia global, tornou muitas corporações desprovidas de fábricas.

$\mathrm{Na}$ sociedade informacional, nem sempre as firmas donas das grandes marcas são as proprietárias das fábricas. Muitas multinacionais do setor de alta tecnologia não possuem sequer uma única fábrica, sendo suas mercadorias produzidas por processos terceirizados. Por dependerem de redes externas a sua administração, a função que essas empresas ocupam na economia geopolítica atual é completamente distinta da que exerceram durante o período da Guerra Fria. Com a explosão dos IED na década de 1990, as multinacionais tornam-se poderosos atores transnacionais (GILPIN, 1971, pp. 398-419; WELLS Jr, 1971, pp. 447-464). No Pós-Guerra Fria, as multinacionais do setor de alta tecnologia são atores transnacionais distintos das corporações da ordem geopolítica precedente. Elas centralizam atividades de P\&D nos países desenvolvidos, enquanto a fabricação de seus produtos tecnológicos é majoritariamente terceirizada em áreas periféricas.

\footnotetext{
105 Desintegração vertical e terceirização estão relacionados a uma complexificação dos sistemas de produção, que pertencem cada vez menos às grandes corporações globais. Esses termos significam a organização de uma rede de fornecedores de bens, serviços e materiais que compõe o produto. A empresa é detentora da marca e do produto final, mas não comanda a produção.
} 
As principais economias desenvolvidas se apóiam numa "geopolítica informacional". A associação cada vez mais estreita entre ciência e sistemas de produção divide o mundo entre os países que lideram as patentes e a inovação tecnológica e aqueles que possuem mão-de-obra barata (e qualificada) para a montagem do produto. A Europa, o Japão e os Estados Unidos possuem formas de fomentar o desenvolvimento tecnológico (PORTER, 1993; STORPER, 1996, CASTELLS, 1999a). Suas mercadorias, produzidas majoritariamente na "fábrica do mundo" que se tornou a China e o Sudeste Asiático, penetram através da diminuição das barreiras comerciais da globalização, todas as regiões menos desenvolvidas. Essa transformação não significa que a importância geopolítica das grandes corporações tenha deixando de existir. A América do Sul continua uma área de acentuada atuação de grandes corporações mundiais. A constituição de uma união aduaneira tende a atrair empresas extrabloco na busca de maiores vantagens comerciais. O que muda é o contexto da economia geopolítica internacional.

À exceção de raros setores, as potências regionais sul-americanas se tornam cada vez mais fornecedoras de commodities enquanto absorvem produtos tecnológicos concebidos na Europa, Estados Unidos, Japão e Coréia e produzidos na China e outros países do Sudeste Asiático. Esses fatores são fundamentais para a compreensão do contexto sul-americano. Constitui-se uma hierarquia do comércio regional, onde Brasil e Argentina lideram a exportação de produtos industrializados. A "experiência estratégica" que impulsionou o Mercosul denota o estabelecimento de um espaço transnacional de cooperação, cuja finalidade é favorecer o desenvolvimento de setores da indústria, comércio e agricultura dos Estados Partes. Há um containment delimitado inicialmente pelo entorno regional do Mercosul não restringível às relações políticas dos seus membros. O bloco, como meio de fortalecimento das relações comerciais regionais, é uma experiência bem sucedida.

$\mathrm{Na}$ Brasil, a confluência de interesses do governo com setores industriais estava na base de toda modernização conservadora que predominou no país desde a década de 1930. Mas, a economia geopolítica atual impôs necessidades que forçaram a diversificação dos interesses econômicos nacionais. A expansão das redes de poder do país esta relacionada à expansão continental do comércio e das empresas. 
América do Sul tem se mostrado a principal área de expansão das atividades das empresas brasileiras. Multinacionais brasileiras do setor de energia, indústria automotiva, construção civil, siderurgia etc., têm atuado em todas as regiões do continente. Com o apoio do governo federal, essas empresas se tornaram braços da geopolítica brasileira. Por outro lado, o aumento das relações comerciais intrabloco corrobora com a importância da América do Sul para todos os seus países. Apesar das assimetrias no desenvolvimento econômico e industrial, a interdependência comercial é um pilar do desenvolvimento sulamericano.

A interdependência entre interesses do Estado e das empresas no campo das relações internacionais estava no cerne dos primeiros movimentos sistemáticos de cooperação regional iniciados por Sarney e Alfonsín. Mas essa tendência nunca se tornou tão explícita como na última década. Nenhum estadista brasileiro encarnou tão bem a função de intermediador dos interesses empresariais nacionais no exterior quanto o presidente Luiz Inácio Lula da Silva. Essa postura governamental comum nas últimas décadas - que fez Milton Santos associar de forma irônica o cargo de presidente da república a um simples caixeiro viajante $^{106}$ - revela o crescimento da interdependência entre as duas esferas no Brasil. Dado o domínio dos interesses corporativos em detrimento dos demais setores da sociedade, a crítica de Milton Santos é certamente uma das mais importantes.

Mas, o predomínio de fatores mercantis é também resultado de transformações da economia política na aurora da ordem contemporânea. A crise da dívida e a posterior supremacia do neoliberalismo em todo continente, comprometeu a capacidade de investimento dos países, que estimularam cortes de gastos, gerando um circulo vicioso de juros elevados, dívida pública, recessão e desemprego. O discurso do livre-mercado impunha uma nova concepção sobre o papel do Estado nos países pobres, inaugurando uma tendência que até a crise de 2008 era defendida por setores da sociedade como um avanço "natural" do mundo moderno.

\footnotetext{
106 "Eu sou um geógrafo, então, eu creio que o território nacional - e todos países têm um território, salvo decisão em contrário cria essa comunidade, e nenhum país funciona sem esse território, e esse território é a área na qual o Estado exerce, digamos assim, a sua força, o seu poder, sobretudo hoje, porque o chamado mundo não têm como se impor sobre os territórios. Não existe esta capacidade do chamado mundo de dizer o que se vai fazer dentro de cada país. Ao contrário, os Estados é que são, quando quererem, fiéis coadjuvantes do chamado mundo. É a razão pela qual os presidentes se tornaram caixeiros viajantes de empresas, e com freqüência caixeiros viajantes de empresas não nacionais". Milton Santos (Entrevista no Programa Roda Vida da TV Cultura em 30 de março de 1997)
} 
Apesar de nações em desenvolvimento serem extremamente dependentes de investimentos e políticas estatais tradicionais, esse discurso se tornou parte indissociável da integração no Cone Sul durante quase toda década de 1990. A busca pela abertura comercial irrestrita que predominou a partir de 1991 não estava presente na cooperação bilateral inaugurada pelo Programa de Integração e Cooperação Econômica (PICE), assinado por Sarney e Alfonsín em 1986 (RUIZ, 2007, pp. 187-209). A proposta original inaugurada pelos dois presidentes estava mais próxima do desenvolvimentismo que predominara até aquele período. ${ }^{107}$ Mas, apesar de ajustado ao Consenso de Washington, as relações comerciais dos anos 1990 tiveram importância crucial para a alteração da ordem regional.

O Mercosul tornou-se a principal plataforma para a internacionalização das economias locais. Nas últimas décadas, o bloco constituiu-se em um dos principais parceiros comerciais do Brasil. Pela condição de maior economia sulamericana, o aumento das importações e exportações do Brasil é um importante termômetro para averiguar o alcance da integração. O intercâmbio comercial do país com os demais membros pelos do Mercosul teve uma forte elevação entre o final dos anos 1980 e o final da primeira década desse século (GRÁFICO 6 p. 184). Com exceção do Brasil, todos os Estados Partes do Mercosul, tiveram nos parceiros do Bloco o principal foco do intercâmbio comercial durante a década de 1990 (KUWAHARA, 1999). Segundo dados do Ministério do Desenvolvimento, Indústria e Comércio Exterior (MDIC-DEPLA, 2011), o comércio brasileiro com Mercosul expandiu 998,2\% em 22 anos, saltando de US\$ 3.5 bilhões em 1989 para US\$ 39.2 bilhões em 2010.

O comércio com a Argentina (Gráfico 8, p. 185), tornado um dos seus mais importantes parceiros, salta de US\$ 1.9 bilhão em 1989 para US\$ 32.9 bilhões em 2010. Na década de 1990 também houve um forte aumento do comércio corrente brasileiro com Chile e Bolívia, as primeiras nações a assinarem ACE com o Mercosul na década de 1990. As transações entre Brasil e Chile (Gráfico 9, p. 185) saltam de US\$ 1.2 bilhão em 1989 para US\$ 8.3 bilhões em

\footnotetext{
107 O PICE foi um programa distinto da integração aberta dos anos 1990 (RUIZ, 2007, p. 198). Visava uma integração paulatina por setores industriais, onde a "... complementação dinâmica constituía o próprio núcleo da integração" (Op. Cit.). Os acordos de complementação industrial se assemelhavam mais ao modelo cepalista de uma integração gradual e seletiva, diferente da abertura neoliberal (Op. Cit.). O PICE produziu fortes resultados em matéria comercial, aonde a Argentina se tornou o maior parceiro do Brasil, superando os Estados Unidos. O aumento do intercâmbio não se restringiu ao setor agrícola, avançando sobre o industrial. Com o tempo, o programa sofreu mudanças significativas. Mas no início, seu núcleo era o Protocolo 2, sobre bens de capital e a complementação industrial e tecnológica. Havia no PICE acordos envolvendo seis das sete indústrias mais dinâmicas (Op. Cit. p. 190).
} 
2010. No mesmo período, as transações registradas entre Brasil e Bolívia (Gráfico 10, p. 186) sobem de US\$ 255 milhões para US\$ 3.3 bilhões. Em 22 anos, o comércio corrente brasileiro com os cinco países do Cone Sul passa de US\$ 5 bilhões para US\$ 51bilhões, um aumento de 913\%. É importante destacar que essa evolução é superior a experimentada pelo conjunto das transações mundiais brasileiras, que no mesmo período teve um aumento de $628 \%$, saltando de US\$ 52 bilhões para US\$ 383 bilhões.

A assinatura do ACE 59, a aproximação com a CAN, e a criação da CASA fez com que o comércio continental brasileiro tenha experimentado crescimento vertiginoso. Entre 1989 e 2003, o comércio brasileiro com Equador, Colômbia e Venezuela - os signatários do ACE 59 - passa de US\$ 878 milhões para US\$2.1 bilhões, uma evolução de 140\% (Gráfico 11, p. 186). Após a assinatura desse acordo em dezembro de 2003, o comércio tem uma evolução mais expressiva. Entre 2004 e 2010, o intercâmbio passa de US $\$ 3.4$ bilhões para US $\$ 8.9$ bilhões um aumento de $162 \%$.

A ampliação do livre comércio para o conjunto das nações sul-americanas foi fundamental para a interdependência econômica do Brasil com o restante da América do Sul. As transações comerciais entre o país e seus vizinhos sofrem um forte acréscimo de 907\% em 22 anos, e passam de US\$ 6.2 bilhões em 1989 para US\$ 63 bilhões em 2010 (Gráfico 12, p. 187). O aumento se intensifica principalmente partir de 2003, ano da aproximação do Mercosul com a CAN. As transações brasileiras com a América do Sul significam em 1989, 11,8\% do total da sua balança comercial. Com a criação da zona continental de livre comércio, essa fatia saltou para 16,4\%. Esse aumento ocorre em favor do Brasil. Em 1989, a América do Sul era destino de 8,98 \% das exportações brasileiras, enquanto que em 2010 essa participação saltou para 18,41\%. Por outro lado, a participação da América do Sul nas importações do país caiu de 17,35 \% em 1989, para 14,24\% em 2010.

Se observarmos as séries históricas sobre a evolução percentual do intercâmbio Brasileiro com o Mercosul (Gráfico 7, p. 184) e com toda América do Sul (Gráfico 13, p. 187) é possível notar que participação do continente no total do comércio Brasileiro, apesar da inegável evolução descrita acima, permanece estável. Isso ocorre em razão do aumento vertiginoso do comércio mundial nas ultimas décadas. Sem a criação do Mercosul e da Unasul, a tendência seria o 
aumento das relações comerciais com outros continentes, comprometendo o fortalecimento regional.

Nesse contexto, os interesses corporativos ou estatais não determinam isoladamente a nova ordem regional sul-americana. A interdependência continental é estabelecida através da confluência entre as necessidades impostas pelas redes econômicas e os interesses que regem o poder do Estado. Muito embora os interesses empresariais de lucro constantemente divirjam das imposições das redes de poder do Estado, há uma sinergia geopolítica entre essas duas esferas.

Por um lado, esse fato demonstra que o Estado não deve ser reificado, como fez a geopolítica clássica. Por outro, evidencia que a projeção internacional não está reduzida aos interesses de grupos econômicos. Esta é uma das condições da multidimensionalidade da geopolítica destacada por Becker (1983; 1988).

A nova economia geopolítica continental resulta de uma transformação geográfica dos interesses econômicos do Estado. Entre 1950-70, a região subnacional foi a escala espacial privilegiada por uma estratégia de unificação dos mercados e do poder político nos territórios nacionais (BECKER, 1983, p. 09). A contradição entre Estado e Empresa tem raízes na reconstrução do capitalismo na década de 1970, com o desenvolvimento de tecnologias de produção e transporte (Op. Cit., p. 10.).

A nova fluidez, ao libertar as empresas das "amarras" do território nacional e estabelecê-las como importantes atores internacionais, fortaleceu a crença na substituição dos Estados por um mercado planetário desterritorializado. Entretanto, cientistas sociais, historiadores, economistas e geógrafos de diversas correntes têm demonstrado nas últimas décadas, que apesar de novas roupagens, a imbricação entre Estados e interesses corporativos continua na base da ordem internacional.

Desde o início da década de 1970, a transformação geográfica do interesse político-econômico dos Estados se manifesta primeiramente no planejamento dessas escalas regionais. Com os anos 1990 e a rápida consolidação dos blocos econômicos ao redor do mundo, há um aprofundamento dessa tendência. 

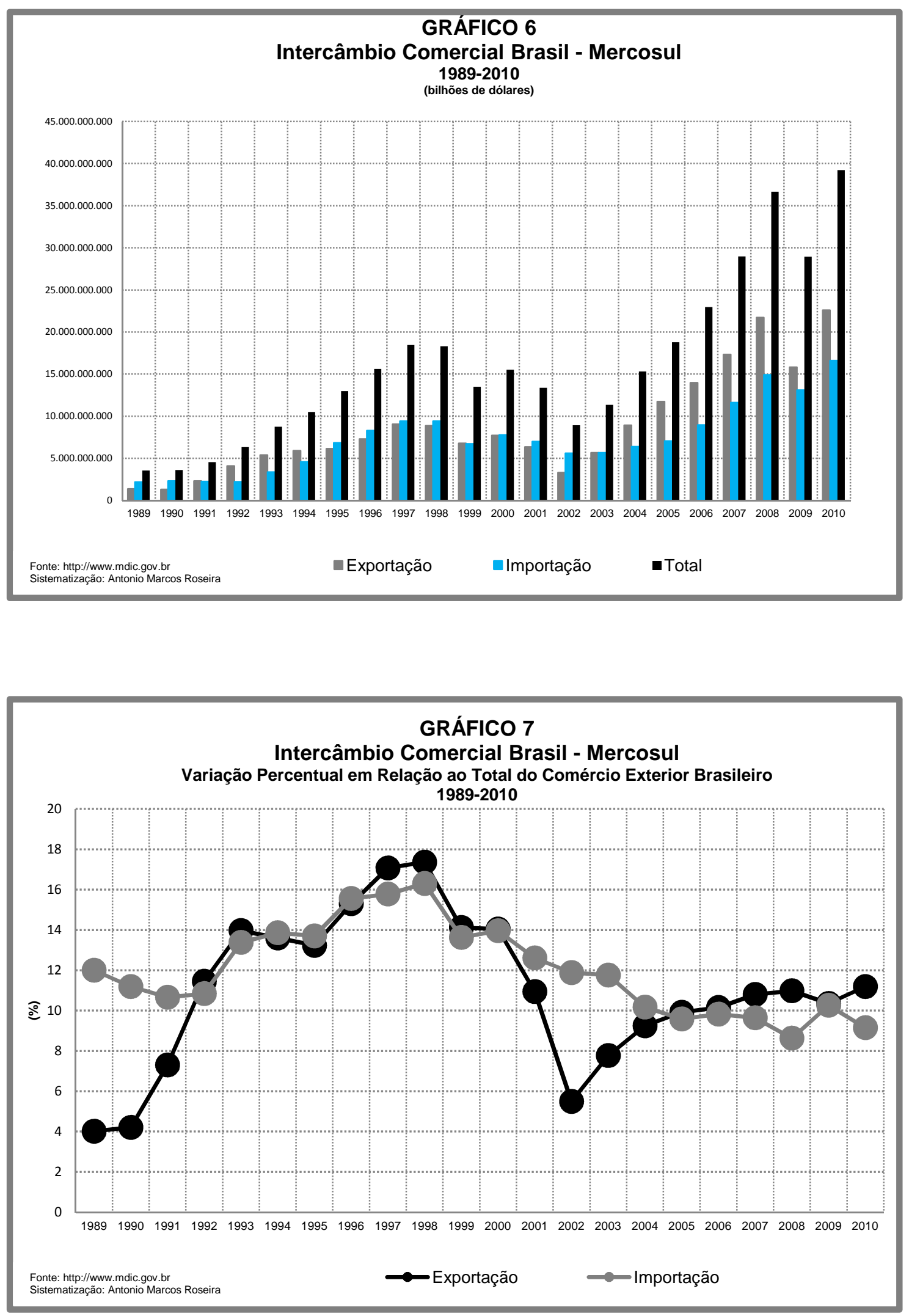

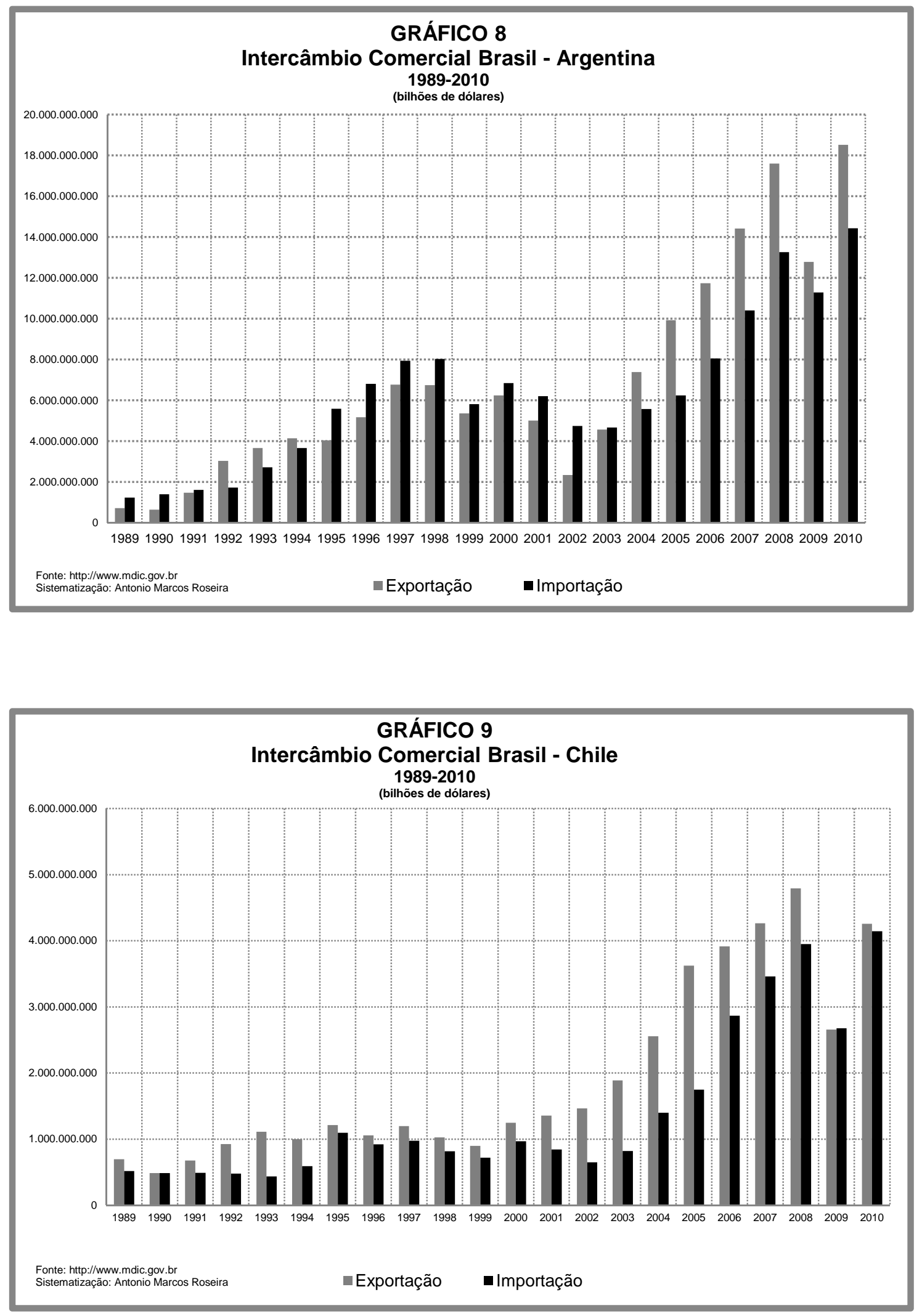

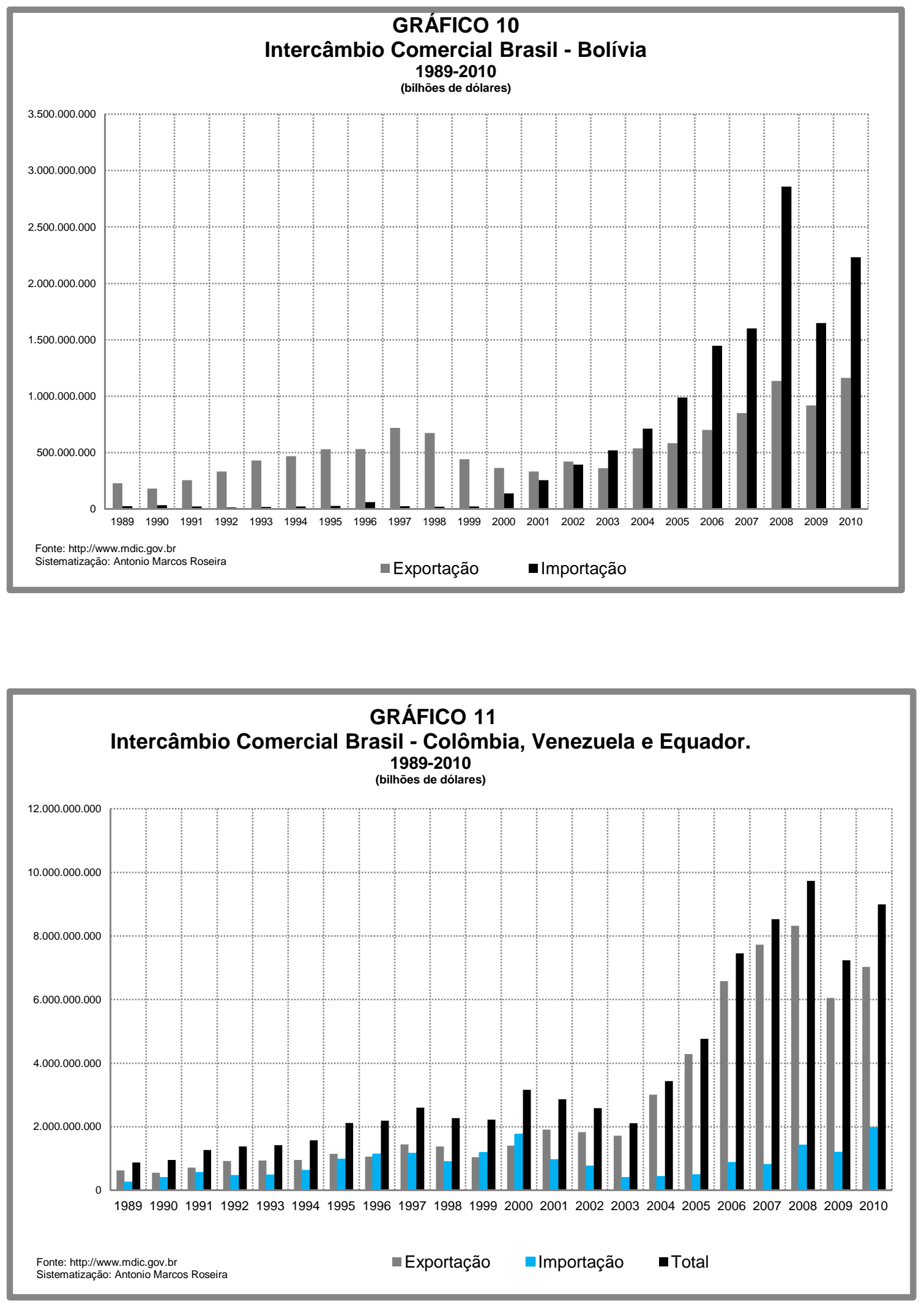

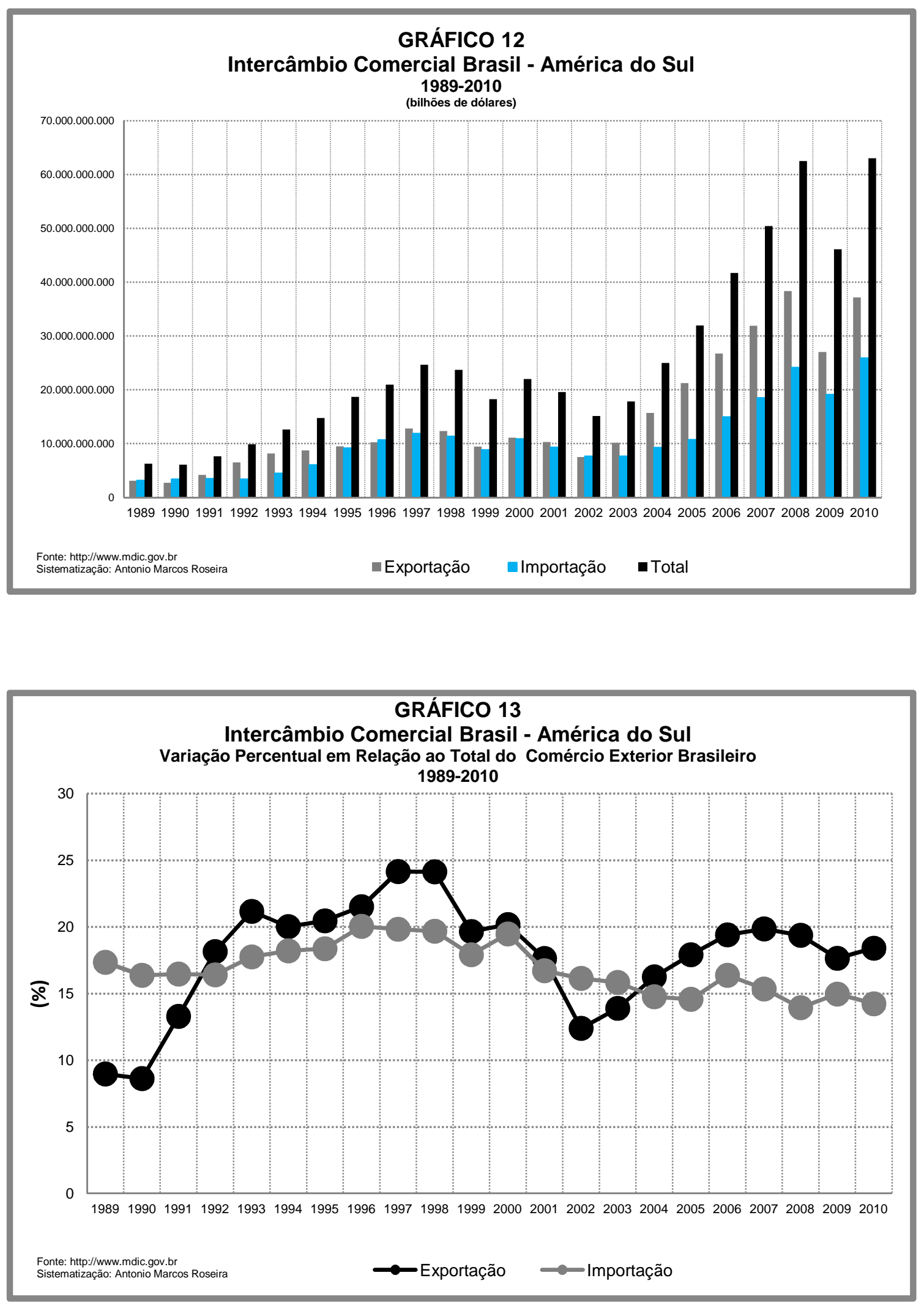


\subsection{Fundamentos das Novas Relações Territoriais}

A reordenação dos fluxos econômicos é inseparável da reorganização do território. Assim como as demais estruturas de integração, o território não é apenas um reflexo dessas mudanças. Muito mais que isso, está no cerne das transformações nas relações interestatais. As novas interações territoriais são um dado estruturador da ordem geopolítica contemporânea. Em conformidade com o atual momento da política sul-americana, as relações econômicas contribuem para a reconfiguração dos fluxos regionais e mundiais, consolidando uma nova ordem territorial.

Como uma derivação da ordem regional, a ordem territorial está no campo daquilo que Hartshorne (1935b, p. 953) denominou de paisagem cultural. O Estado produz um efeito paisagem, evidenciado por um conjunto de infra-estruturas institucionais e territoriais que expõe a capilaridade do seu poder político e cultural (Op. Cit.).

O hibrido entre Geografia Regional e Geografia Política proposto por Hartshorne (1935a, p.804) permite, com ressalvas, transmutar essa premissa originalmente restrita às subdivisões do espaço nacional, para as áreas multinacionais. Um espaço regional integrado, ao abranger a edificação de um conjunto de infra-estruturas territoriais, resulta na transformação da paisagem cultural; ainda que com alcance inferior ao registrado no espaço de soberania do Estado-nação. A nova ordem se expressa pela transformação dos sistemas técnicos e logísticos, que constituem um cenário geográfico de transnacionalização do território.

O território é um importante pilar da regionalização, estando relacionado aos seus aspectos empíricos; dirigidos e não dirigidos. ${ }^{108} \mathrm{O}$ desenvolvimento de uma rede de fluxos materiais e informacionais não envolve exclusivamente questões econômicas, mas também ambientais e culturais. Como a regional, a ordem territorial é estabelecida através de uma síntese multidimensional. Derivação de um modelo político, o ordenamento do território está subordinado a

\footnotetext{
108 Segundo Hurrell (1995, p. 26), ao envolver a integração de uma sociedade em uma região através do aumento das interações políticas e econômicas, a regionalização significa também processos não dirigidos, isto é, fatores "espontâneos" que não estão diretamente subordinados às políticas oficiais de integração multinacional. Nesse caso, podemos destacar como exemplo, o caso das regiões fronteiriças, que como já havia demonstrado Hartshorne (1933, p. 195-228) em um clássico estudo, possui uma dinâmica que muitas vezes não está circunscrita aos limites oficiais do território nacional. Existe, sobretudo nas fronteiras meridionais sul-americanas, um desenvolvimento histórico de interações espaciais, inicialmente desacoplado das políticas oficiais.
} 
uma perspectiva de espaço e poder. Enquanto a ordem regional é o desenvolvimento de todas as estruturas e dimensões da integração, a reordenação do território implica a readaptação do meio geográfico à cooperação multilateral. $\mathrm{A}$ continentalidade exige novas técnicas de transporte e de gerência (GEIGER, 1993, p. 239).

A exploração de recursos naturais, as estratégias de desenvolvimento regional (subnacional), e o ordenamento do território, são resultados de decisões políticas e expressões de um momento histórico. Porém, trata-se de um processo de imbricação e influência mútua. Na ordem geopolítica contemporânea, ergue-se uma tecnologia territorial que supera o significado precedente do espaço geográfico e impõe novas práticas político-sociais para as nações sulamericanas. $^{109}$

A proliferação das experiências de integração transforma o significado do território. Como observa Jean Gottmann (1973, p. 141) o agrupamento dos seis países que originalmente formavam a Comunidade Economia Européia (CEE), forçou uma importante transformação do exercício da soberania. O surgimento da soberania regional no continente europeu vem acompanhado de uma organização integrativa do território. Por conseguinte, a consolidação de uma entidade política regional implica no estabelecimento de um território transnacional, isto é, em rede continental.

$\mathrm{Na}$ sociedade em rede, "o poder dos fluxos é mais importante que os fluxos de poder" (CASTELLS, 1999a, p. 565). Se o movimento tangível e intangível através das fronteiras estatais redefine os fluxos tradicionais de poder (NYE \& KEOHANE, 1971a; 1971b), a questão territorial está no centro do grande debate a respeito da transformação das relações internacionais. O território transnacional uma manifestação espacial da sociedade na Era da Informação ${ }^{110}$ - é uma das

\footnotetext{
109 “... um novo espaço de fluxos, de vetores, calcado na comunicação e na velocidade acelerada tende a superar os espaços dos lugares, as fronteiras e os Estados. As sociedades territorialmente localizadas perdem autonomia em face dos atores da escala mundial que agem segundo uma lógica global em grande parte por ela ignorada e não controlada, em unidades que por seu tamanho e transnacionalidade permanecem acima das pressões sociais e controles políticos, e cujas comunicações e decisões se pautam em informações e instruções recebidas segundo a posição de cada local na rede de trocas e não segundo os valores sociais e culturais das localidades. [...] Uma nova dialética se estabelece entre os espaços de fluxos gerenciais, do poder, e o espaço do significado histórico, da experiência, que tende a dissolução. [...] No entanto, o espaço e a sociedade não são apenas expressão de processos econômicos e tecnológicos que, na verdade, são resultados de decisões políticas e estratégias organizacionais." Bertha Becker, 1988, p. 102.

${ }_{110} \mathrm{O}$ conceito de Era da Informação é empregado segundo Castells (1999a, 1999b \& 1999c). De acordo com o sociólogo, a revolução eletrônica na década de 1970 permitiu a perestroyka do capitalismo e o surgimento da sociedade informacional. A invenção do microprocessador tornou possível o surgimento dos computadores pessoais, da internet e a revolução de todos os sistemas de comunicação. A sociedade em rede, com as transformações políticas, econômicas e sociais aceleradas pelas tecnologias informacionais, faz interagir praticamente todas as sociedades e lugares. Na era da informação, a produção industrial passou a ser cada vez mais dependente de conhecimento e informação. Uma combinação de fatores tecnológicos,
} 
condições definidoras da globalização e da integração regional. A evolução da ordem territorial estatal para a ordem transnacional em rede é uma conseqüência da indissociabilidade entre o modelo político-social e a organização do meio geográfico.

Mas a transnacionalização não encerra a temática das redes na ciência geográfica. Qualquer soberania, seja ela clássica, imperialista, integrativa ou global, exige o arranjo reticular do território. A capilaridade da autoridade passa pelo forjamento de uma rede territorial não delimitada por uma noção euclidiana abstrata. Portanto, a questão do território-rede não se resume à linhas e pontos que integram a superfície terrestre. A diferença entre a rede morfofuncional pensada através da noção euclidiana (e privilegiada pela Geografia tradicional) e o território-rede é que este último está correlacionado de forma direta com atores políticos não estatais. Não é, portanto, uma arena exclusiva dos interesses do Estado.

O território-rede é uma das condições do poder do Estado. A sua transnacionalização significa o transbordamento da escala nacional, tornando-se continental e global. Esta é uma condição posta pelas transformações do capitalismo mundial na década de 1970, que como nota Aldomar Rückert (2005, p. 31) alterou o modelo de planejamento estatal em todo mundo periférico. A substituição do Estado desenvolvimentista pelo modelo liberal no Brasil resultou em novo modelo de planejamento. A redefinição do papel do Estado finda com o planejamento centralizado e vincula o ordenamento do território à geopolítica contemporânea. ${ }^{111}$

Na Primeira Parte lançamos o argumento de que Mário Travassos (1935) replica na América do Sul a concepção mackinderiana de articulação em rede do

institucionais e culturais fez surgir uma indústria da inovação, subordinando nessa era, o capital à economia informacional global.

111 "O processo de globalização já em curso nos anos 80 , as transformações do sistema capitalista como um todo, a falência do planejamento centralizado e o fim dos padrões tecnológicos vigentes desde o pós-guerra, associados ao ideário políticoeconômico liberal, passam a fornecer as grandes linhas em que passam a se inspirar as ações que visam às reestruturações econômicas e territoriais. A década de 1990 e a crise dos Estados Desenvolvimentistas periféricos representam, portanto, rupturas de paradigmas socioeconômicos e políticos com significados e alcances tão ou mais profundos do que a própria constituição dos Estados Nacionais sul-americanos, no século XIX. [...] A crise do nacional desenvolvimentismo e do planejamento centralizado; as redefinições da geopolítica clássica que perde seus sentidos originais; a tendência às economias flexíveis e à "flexibilização dos lugares", pela alta mobilização do capital e a inserção subordinada dos territórios nacionais periféricos no processo de globalização financeira e de mercados, e a emergência dos processos políticos descentralizantes na fase do processo de redemocratização conduzem os Estados do Sul, como um todo e especialmente aos latino-americanos, como o Brasil, a reatualizar suas políticas externas e internas e a requalificar suas opções e necessidades de ordenamento territorial e de desenvolvimento. [...] Estes processos acima mencionados localizam-se em cenários globais progressivamente mais complexos os quais imprimem severas incertezas a esses países. Nesses cenários, reconhece-se a necessidade de se analisarem as diferenciações territoriais emergentes - os novos significados que adquirem os usos políticos do território e suas novas formas e conteúdos territoriais - em momento histórico tão pleno de rupturas de paradigmas e de mudanças de padrões políticos de desenvolvimento". Aldomar A. Rückert, 2005, p. 32. 
território nacional com 0 continente. Com as rivalidades geopolíticas predominantes no Cone Sul, as diversas estratégias de contenção - decorrentes das políticas de projeção de Brasil e Argentina - impossibilitaram a consolidação de uma rede territorial sul-americana. O continente sul-americano foi caracterizado pela segregação interna, tornando-se fragmentado e marcado por ilhas de integração. As fortes rivalidades geopolíticas internas e as barreiras naturais, técnicas e também financeiras o destacavam como um imenso "continente arquipélago".

Mas tanto na ordem geopolítica precedente quanto na contemporânea, as políticas sul-americanas de integração física passam de forma majoritária pelo território brasileiro. A posição de rótula faz do Brasil uma "área de soldadura" continental. Soma-se a isso o fato de que a integração projetada pela IRSA tem como modelo organizacional os EID lançados pelo governo Fernando Henrique Cardoso. Prevalece na América do Sul o modelo travassiano de circulação territorial. Apesar das transformações impostas pela ordem geopolítica atual, a integração multimodal proposta por Travassos (Op. Cit.) é capital aos EID e à IIRSA.

Esse padrão continua presente nos investimentos em infra-estruturas de transporte do Programa de Aceleração do Crescimento (PAC) do governo Lula. ${ }^{112}$ O PAC - que não é um plano de Estado, mas de governo (COSTA \& PADULA, 2009, p. 10) - mantém concepções prévias de integração continental do Brasil. Mas o modelo de circulação territorial pensado pelos militares sofre importantes alterações em tempos de regionalização. A substituição do realismo geográfico expresso na contenção fronteiriça pela cooperação do território-rede transnacional está assentada sobre as transformações econômicas e políticas da ordem geopolítica.

Argumentamos também na Primeira Parte que o conceito de circulação é ponte entre a "velha" e a "nova" geopolítica. Isso não permite apenas a relação entre os discursos geopolíticos tradicionais e a configuração atual do espaço

\footnotetext{
112 “O PAC prevê investimentos de $\mathrm{R} \$ 58,3$ bilhões para o setor de infra-estrutura logística de 2007 a 2010 , sendo $\mathrm{R} \$ 13,4$ bilhões para 2007. A princípio, destes recursos, a parcela correspondente diretamente a desembolsos do Estado equivale a $11,7 \%$, sendo o restante proveniente de empresas estatais e do setor privado - neste último caso, dependem das avaliações sobre a taxa de juros e taxa interna de retorno dos investimentos (TIR), além de 10 avanços em marcos regulatórios favoráveis a lógica de investimento privado. Para a execução dos investimentos do PAC, estão previstos R $\$ 34$ bilhões do Orçamento Geral da União e o financiamento do BNDES de R\$17 bilhões. No geral, o PAC privilegia a participação do investimento privado na infra-estrutura logística, e depende demasiadamente dos investimentos privados para o seu sucesso, que não fica garantido. Essa dependência leva a necessidade de adoção de outras medidas, como redução de impostos, juros e spreads bancários." Darc Costa \& Raphael Padula, 2009, p. 10.
} 
continental. Nesse sentido, torna-se necessário aprofundar a discussão, pois todas as eras geopolíticas pressupõem um sistema de circulação territorial em conformidade com os imperativos que dirigem a ordem e a economia geopolítica internacional.

De posse de uma concepção geométrica do espaço geográfico que predominou até os anos 1970, cientistas sociais, economistas e geógrafos de diferentes tendências, desenvolveram uma abordagem morfofuncional. $\mathrm{Na}$ geografia, esta compreensão foi determinante em estudos sobre circulação territorial, e esteve muitas vezes subordinada aos discursos geopolíticos tradicionais, sejam eles europeus, americanos, ou mesmo sul-americanos. ${ }^{113}$ Ellen Semple (1911) e Jean Gottmann (1975), a despeito de pertencerem a diferentes períodos e vertentes analíticas opostas, são dois teóricos paradigmáticos no emprego do conceito de uso do território a partir de um entendimento morfofuncional $^{114}$

Esta posição é uma clara decorrência das características predominantes na relação entre poder e espaço até os anos 1970. Afora potências que estabeleceram uma síntese entre territorialismo e capitalismo, o uso do território esteve majoritariamente subordinado aos interesses do Estado nacional. $\mathrm{Na}$ América do Sul, esta relação morfofuncional fora durante a maior parte do século passado, conseqüência de tendências expansionistas. Mas o território foi transformado com o enfraquecimento do monopólio Estado, que o moldava e definia os lugares (SANTOS, 1993, p. 15). A perspectiva morfofuncional perde sua raison d'être conforme o Estado deixa de ser o único ator territorial relevante. $\mathrm{A}$ organização do espaço nacional não emana exclusivamente do poder estatal. A concepção de planejamento trazida por transformações econômicas da década de 1970 (RUCKERT, 2005) passa a fortalecer a atuação territorial de atores não estatais.

No Brasil, Bertha Becker (1983) está entre as primeiras analistas a observar os novos usos do território a partir de atores não estatais; uma condição

\footnotetext{
113 Segundo Raffestin (1993), é predominante na Geografia Política a tríade população, território e autoridade a partir da preocupação com a morfologia do Território. Categorias como circulação, dimensão, forma e posição pressupõe uma visão geométrica do território.

${ }^{114} \mathrm{Na}$ escola determinista, o uso do território estava associado à capacidade de crescimento e expansão dos Estados. Semple (Op. Cit. p. 181) afirma que o crescimento era uma lei das sociedades humanas e se manifestava na expansão dos grupos sociais e na apropriação de áreas geográficas maiores. A protrusão das fronteiras resultava principalmente em novas formas de utilização econômica do solo. Distante do determinismo organicista de Semple, Gottmann (1972, p. 29- 47.) associa o uso do território à organização política dos Estados. Países que privilegiam relações econômicas com o mundo internacional tendem a organizar o seu território a partir da conexão com espaços externos. Outros Estados organizam o território a partir de interesses internos.
} 
que abrange desde os movimentos reivindicatórios até as grandes empresas nacionais ou multinacionais. A relação entre o Estado e seu espaço é alterada com as mudanças tecnológicas e econômicas da década de $1970 .{ }^{115}$ Como destaca Aldomar Rückert (2010) as transformações na relação entre Estado e território no Brasil estão relacionadas com o processo de reforma do Estado levado a cabo nos anos 1990.

A substituição do desenvolvimentismo pelo neoliberalismo, ao impor novas concepções de planejamento, ampliou em muitos países periféricos a importância dos atores privados nas políticas de ordenamento territorial. O contexto da integração acirrou esta tendência, tornando o planejamento dependente dos interesses comerciais das grandes empresas sul-americanas. "Com 0 esgotamento do Estado Desenvolvimentista na década de 1980, o planejamento deu lugar - ao menos conceitual - à concepção de "gestão do território"” (RÜCKERT, 2005, p. 19)

Com a economia política internacional assinalada pelo acirramento das desigualdades sociais, Milton Santos desloca a discussão do conceito em si para o uso do território. ${ }^{116}$ De tal modo, a investigação da relação entre sociedade e território no Brasil se faz através do exame de atuação de forças econômicas, nacionais ou globais, que a seu ver, relegam ao Estado uma posição coadjuvante. ${ }^{117}$

Milton Santos \& Maria Laura Silveira (2001) investigam, dentre outros temas, a fluidez do território nacional a partir da hegemonia das forças do mercado. Com a globalização, o enfraquecimento do Estado nacional perante as forças econômicas fez com que os interesses coorporativos se tornassem determinantes na ordenação dos fluxos materiais e informacionais no território brasileiro.

\footnotetext{
115 "A reavaliação do papel do espaço e a reconstituição de sua potência social e política é uma exigência vinculada à nova realidade política após 1970, em que explodem as contradições decorrentes do modelo de industrialização calcado na tecnologia intensiva de capital. Conflitos entre forças internacionais e nacionais, entre grupos sociais que compõem a formação social e entre segmentos do próprio Estado, ressaltam a importância da instância política e demonstram que o aparelho governamental não é o instrumento único do poder. [...] Face à multidimensionalidade do poder, o espaço reassume sua força e recupera-se a noção de território. Trata-se pois agora de uma geopolítica de relações multidimensionais do poder em diferentes níveis espaciais". Bertha Becker, 1983, pp. 06-07.

116 "Ele [o território] só se torna um conceito utilizável para a análise social quando o consideramos a partir do seu uso, a partir do momento em que o pensamos juntamente com aqueles atores que dele se utilizam. A globalização amplia a importância desse conceito. Em parte, por causa da competitividade, cujo exercício, levando a uma busca desesperada de uma maior produtividade, depende de condições oferecidas nos lugares da produção, nos lugares da circulação, nos lugares do consumo". Milton Santos in: Odete Seabra, Monica Carvalho \& José Corrêa Leite, 2000, p. 22.

117 "... há um uso privilegiado do território em função das forças hegemônicas. Estas, por meio de suas ordens, comandam verticalmente o território e a vida social, relegando o Estado a uma posição de coadjuvante ou de testemunha, sempre que ele se retira, como no caso brasileiro, do processo de ordenação do uso do território". Op. Cit. p. 23.
} 
Para os autores, a reordenação dos fluxos territoriais no Brasil visa atender principalmente interesses corporativos. Contudo, esta tendência, pertinente a qualquer análise da América do Sul, não encerra o debate. Trata-se novamente, da seara geopolítica de imbricação entre as redes econômicas de produção e distribuição e as redes do poder internacional do Estado. A influência coorporativa na nova fluidez sul-americana é indissociável da atual economia geopolítica.

As políticas de integração territorial colocadas em andamento nos anos 1990 não se resumem a uma política de governo. Fazem parte de uma política de Estado em conformidade com os novos interesses brasileiros na Ordem Geopolítica Pós-Guerra Fria. O governo Fernando Henrique Cardoso, ao estabelecer a política dos EID não instituiu apenas a articulação da malha territorial nacional com o continente. Os EID ao se tornarem a base cardinal de organização da IIRSA, consolidaram o modelo contemporâneo de integração territorial na América do Sul. À medida que o atual modelo de ordenamento territorial está associado à economia geopolítica, é necessário fazer ressalvas acerca do alcance desse conceito.

O desenvolvimento de novos fronts agrícolas impôs outras necessidades de mobilidade no território brasileiro (CASTILHO, 2004). Essa transformação está associada à mudança do sistema produtivo baseado no complexo agroindustrial para a organização em rede da produção agrícola. ${ }^{118}$ Mas não é somente o desenvolvimento de fronts agrícolas nas regiões Norte e Centro-Oeste que modifica o ordenamento logístico do território nacional. Com o aumento acentuado do preço internacional das commodities na última década, a exploração das jazidas minerais, sobretudo na Região Norte, força o desenvolvimento de sistemas

\footnotetext{
118 Segundo Ricardo Castilho (Op. Cit.), entre as décadas de 1960 e 1970 predominou um modelo denominado de complexo agroindustrial. Nessas décadas, o Estado era o grande gestor dos processos produtivos, pois a produção de soja estava ligada a uma modernização conservadora (créditos agrícolas, insumos e distribuição de terras) onde o grande interesse do Estado, além da ampliação da produção, estava no controle geopolítico de suas áreas periféricas. Nas décadas de 1980 e 1990 passou a predominar o que o autor denomina de organização em rede, onde o capital privado (credito, circulação, armazenamento, distribuição, comercialização) e novas redes coorporativas estão inseridos numa nova racionalidade. Nessa nova dinâmica, grandes empresas como a Cargill, a Bungee, o grupo Maggi, e a ADM proporcionam o acesso a novos mercados e impõe aos produtores o controle da cadeia produtiva. Castilho (Op. Cit.) afirma ainda que o complexo agroindustrial nas antigas áreas produtoras (Região Sul) - dentro da concepção de Estado gerenciador e gestor - se destacava empresas como Ceval, Cargill, Sadia e Perdigão. Nos novos fronts agrícolas, existe uma radical diferença em relação ao tamanho da propriedade agrícola e ao uso de novas tecnologias. Esses novos fronts - Mato Grosso, Mato Grosso do Sul, sul de Goiás (Jataí), Bahia (Barreiras) e Maranhão (Balsas) - se tornaram os maiores responsáveis pelo aumento da produção de soja no território brasileiro, que no período entre 1990 e 2000 experimentou um crescimento na ordem de 65\%. As maiores regiões produtoras, o Centro-Oeste e o Sul, são isoladamente as grandes regiões de destaque na produção nacional de soja. De 1990 a 2000 a Região Sul experimentou um crescimento de $8,6 \%$ no volume produzido e um decréscimo de 1,3\% na área plantada. No mesmo período, o Centro-Oeste testemunhou um aumento de $140 \%$ no seu volume produzido frente a uma expansão de $45,1 \%$ da área plantada.
} 
logísticos, em espaços historicamente carentes de infra-estruturas de transporte e comunicação.

Os recursos naturais têm exercido certo protagonismo no desenvolvimento de infra-estruturas territoriais na América do Sul. Destacam-se as conexões entre as vertentes do Atlântico e do Pacífico, que conectam as áreas econômicas no interior do continente que possuem as maiores demandas por recursos naturais. Claude Raffestin (1993) chama atenção para o fato de que os recursos naturais não existem em si, mas somente por meio das funções que exercem na sociedade em um dado momento histórico. Entre os países sul-americanos, a sua importância para o expansionismo geopolítico cede lugar para a cooperação regional.

Os recursos naturais se tornaram centrais para a integração continental. A conexão entre grandes regiões de consumo e áreas ricas em minérios ou hidrocarbonetos é um dos grandes desafios da regionalização. Envolve desde a necessidade de gigantescos aportes financeiros até o nacionalismo inerente a qualquer temática territorial. Tanto no que tange às relações entre Estados quanto aquelas envolvendo regiões subnacionais, ainda é predominante as disparidades econômicas entre as áreas ricas em recursos naturais e os grandes centros de consumo.

A ampliação dos sistemas logísticos nas regiões Centro-Oeste e Norte do Brasil está associada em primeiro lugar à necessidade de integração dos novos fronts agrícolas e áreas de exploração de jazidas minerais com os grandes mercados mundiais. No setor energético, este processo está atrelado principalmente ao crescimento das maiores regiões de consumo no Brasil, Argentina e Chile. Por esse motivo, destaca-se principalmente no Cone Sul, área responsável pelas primeiras iniciativas do gênero, como a construção do Yabog em 1972, um gasoduto entre Argentina e Bolívia (LÓPEZ-SUÁREZ, et. al., 2010, p.51).

Apesar de os interesses em energia envolverem também países como Bolívia, Peru Equador, Colômbia e Venezuela, a ampliação das infra-estruturas desse setor obedece aos interesses envolvendo os espaços de concentração do vetor tecno-industrial. A integração energética, em alinhamento com fatores determinantes ao adensamento dos fluxos materiais e informacionais sul- 
americanos, corrobora com a condição de núcleo duro da regionalização exercida pelo Mercosul.

Grosso modo, é possível diferenciar duas vastas áreas de articulação física do Brasil com a América do Sul. Com maior desenvolvimento econômico, o Sul e o Sudeste constituem uma rede territorial com maior equilíbrio entre as forças de introversão e extroversão. Entre 1930 e 1980, o Estado estabeleceu um sistema de circulação, cujos objetivos centrais também abarcavam a integração dos mercados internos. A constituição de grandes espaços de consumo transformou-se em força de introversão que moldou a circulação primeiramente para dentro.

Apenas com a abertura econômica que as forças de extroversão do mercado mundial foram capazes de reorientar a rede, dando-Ihe também um sentido externo. Isso não significa que o território era no passado completamente fechado e que no presente se tornou totalmente aberto. Ao contrário, trata-se de duas tendências de ordenamento do território que predominam em períodos distintos.

O enfraquecimento do Estado e as políticas de desmonte da máquina estatal fazem com que a globalização afete desigualmente as diversas regiões do país (BECKER, 1997, pp. 05). O adensamento desigual dos fluxos econômicos (PORTO, 2006) contribuiu para uma lógica oposta de integração territorial no Centro-Oeste, Norte e Nordeste. Nas últimas décadas, o adensamento dos fluxos materiais e informacionais nessas regiões estão subordinados às forças de extroversão.

Ao avançar sobre regiões de menor poder econômico, os novos fronts agrícolas e de extração mineral imprimem aos sistemas logísticos uma orientação predominantemente exógena, invertendo a lógica da coesão territorial. Com o predomínio da integração mercantil, o Nordeste aparece desarticulado dos principais eixos nacionais de integração e dessa forma, dos grandes corredores da IIRSA.

Isso não significa que o Nordeste esteja alijado da expansão da produção agrícola, que pode ser notada com os novos fronts sojícolas em Barreiras na Bahia e Balsas no Maranhão (CASTILHO, 2004) ou mesmo com a especialização produtivas em fruticultura no Médio São Francisco (ELIAS, 2006). A Transnordestina, uma das obras mais importantes em construção pelo PAC, 
objetiva justamente o escoamento da produção agrícola do cerrado nordestino. Mas apesar dos investimentos em infra-estruturas desse programa ter destinado 0 segundo maior recurso ao Nordeste, atrás somente do Sudeste (COSTA \& VALENTE Jr, 2011, p. 02), tem prevalecido a tendência de déficit na integração da região com outras áreas do Brasil e da América do Sul. O PAC dá atenção especial aos eixos Mercosul-Chile e Capricórnio (ARAÚJO Jr., 2010, p. 41), responsáveis pela integração dos eixos economicamente mais desenvolvidos no Cone Sul.

Mas apesar das limitações, a integração territorial sul-americana rompeu com a compartimentação que predominou durante a ordem geopolítica precedente. Ainda que não tenha sido completamente superada a condição de "continente arquipélago", dois fatores sustentam a nova ordem territorial. O primeiro é a intensificação da integração física entre as diferentes regiões sulamericanas. O segundo é o ordenamento da fluidez territorial segundo as forças exercidas pelos mercados extracontinentais. Em conjunto, reorganizam na América do Sul aquilo que Raffestin (1993) denomina de tessitura territorial. Em ambos os fatores, a nova ordem territorial é em grande parte dependente da liderança política, do poder econômico e também da preponderância geográfica do Brasil.

\subsection{Reordenação Territorial Sul-Americana}

A ascensão da política regional fundada na cooperação, ao reorganizar os sistemas logísticos na América do Sul, supera a segregação espacial que predominou na Ordem Geopolítica da Guerra Fria. Durante este período, as comunicações territoriais revelavam as compartimentações internas de todo espaço sul-americano e representavam "linhas de força" do equilíbrio regional de poder.

Umas das grandes lições da geopolítica clássica é que o alcance de um sistema político está relacionado também com a sua capilaridade territorial. Não é por outro motivo que Raffestin (Op. Cit.) argumentou que o território revela a imagem do poder. Os processos de reforma do Estado e a ascensão dos interesses corporativos transformam a velha forma de captar, via território, o 
alcance do poder. Autores como Hartshorne (1950) e Gottmann (1972) demonstravam que na sociedade moderna essa imagem era necessariamente estatal. Por mais que esses geógrafos superassem o determinismo geográfico presente em Ratzel (1987) ou Semple (1911), caiam no determinismo do Estado nacional.

Da forma como trabalhada pelos geógrafos nas últimas décadas, a noção de uso do território contribui para o exame da fluidez material e informacional sulamericana. O continente demonstra perfeitamente as transformações captadas por Becker (1983) e Santos \& Silveira (2001), pois os sistemas logísticos nacionais e continentais são pensados tanto por meio das políticas de poder dos Estados quanto através de interesses coorporativos de produção e distribuição. A ruptura da segregação espacial sul-americana expõe a dupla tendência de aproximação política entre os Estados e de integração mercadológica entre as diferentes regiões.

O que a integração territorial tem revelado nas últimas duas décadas é exatamente a consonância entre essas duas tendências. Ainda que pese os efeitos negativos de uma ordenação logística pautada pelo mercantilismo, a imagem atual do território demonstra uma inegável superação da disposição segregativa precedente. Organizadas a partir dos interesses estatais, corporativos e regionais, as novas linhas de força demarcam no território a tendência de cooperação.

A inversão do raciocínio geopolítico está na inversão da própria condição do poder. A valorização do poder dos fluxos sobre os fluxos do poder (CASTELLS, 1999a) é nítida quando se observa a reorganização da circulação territorial. Com a regionalização, o poder dos fluxos materiais e informacionais moldam o território continental de um modo que a geopolítica unidimensional do Estado seria incapaz alcançar.

Mas qualquer imagem territorial demonstra uma concentração geográfica de poder. Através do imperativo da fluidez, a centralização dos fluxos se constitui em grande medida, em concentração de poder. As linhas de força representadas por sistemas logísticos expõem uma parcela da imagem do poder na América do Sul.

Em certo sentido, a circulação constitui uma nervura territorial, entendida como o conjunto das linhas de força (sistemas logísticos materiais e 
informacionais) que define a integração física sul-americana. Essas linhas formam espessamentos por onde fluem a matéria, a informação, os valores, a cultura etc. A nervura evidencia as diferentes densidades dos fluxos da rede territorial, que por sua vez, demonstra o alcance da integração. É, portanto, o conjunto dado pela capilaridade das linhas de força, revelando a imagem do poder através da fluidez territorial.

A compartimentação do espaço sul-americanos examinado na Primeira Parte resulta da ausência de uma rede territorial continental. Os sistemas logísticos eram geograficamente delimitados pelo equilíbrio regional de poder. Enquanto linhas de força, os corredores logísticos demonstravam a prioridade das relações bilaterais, principalmente entre Brasil, Argentina, Bolívia e Paraguai. Os espessamentos formados pelos corredores logísticos demonstram ainda hoje, o poder dos fluxos e expõem os interesses que ordenam a circulação na América do Sul.

As linhas de força do continente foram bastante alteradas nos últimos vinte anos (THÉRY \& MELLO, 2005, pp. 291-292). Mesmo que os tradicionais eixos de desenvolvimento formados pelos vetores tecno-industriais comandem a ampliação da integração física, é inegável a projeção dos fluxos materiais e informacionais para áreas do continente, até recentemente, relegadas pela política local.

Os déficits de integração física demonstrados pelo Nordeste, Norte e Centro-Oeste do Brasil, pela zona andina e por toda região amazônica, são desafios para a consolidação de um sistema logístico de fato continental. Apesar disso, os esforços de integração física têm permitido a constituição de uma rede territorial sul-americana. As grandes linhas de força representadas por investimentos rodoviários, ferroviários e hidroviários têm constituído canais de integração física entre as porções meridionais, septentrionais, orientais e ocidentais.

Esta transformação é permitida pela IIRSA, que proporciona uma imagem esquemática da rede sul-americana, e dos espaços internos de articulação territorial. Enquanto uma iniciativa multilateral, a IIRSA é a maior expressão territorial da atual política sul-americana. Se o território revela a imagem do poder, esta iniciativa demonstra a sua adaptação diante dos interesses de forças transnacionais representadas pelos Estados, grandes corporações multinacionais 
(locais e mundiais), e até mesmo por pequenas e médias empresas, cada vez mais inseridas na economia continental. Mesmo preservando tendências fundadas pelo modelo travassiano, a IIRSA é o grande esforço de superação da contenção fronteiriça.

Como demonstrado pelo Mapa 2 (p. 201), a IIRSA é constituída por 10 eixos de integração em transporte, comunicação e energia, abrangendo todas as grandes áreas da América do Sul. ${ }^{119}$ Até junho de 2010, havia integrado um impressionante portfólio de 524 projetos com investimento estimado em US\$ 96,1 bilhões (IIRSA, 2010a, p. 48). Do total dos projetos, 107 estão no Eixo MercosulChile, 95 na Hidrovia Paraguai-Paraná e 72 no Eixo Capricórnio. A maior parte dos corredores está na faixa industrial que se estende entre o Rio de Janeiro e Santiago.

Entre os seus principais objetivos, destacam-se a integração vertical e horizontal do continente, prioridades em parte já detectadas no estudo Integración em el Sector Transporte em el Cone Sur (1997), do Banco Interamericano de Desenvolvimento (BID). A primeira abrange diversos projetos de conexão intermodal entre as bacias hidrográficas Platina, Amazônica e do Orinoco. Almeja integrar a porção meridional e a setentrional do continente, aproveitando a vasta riqueza hídrica sul-americana - que proporciona aquilo que os geopolíticos militares denominavam de "mar interno". A segunda busca principalmente ampliar os sistemas logísticos intermodais para conectar as vertentes do Atlântico e do Pacífico.

A IIRSA prioriza, sobretudo, os corredores de acesso entre essas duas vertentes, pois percorrem os espaços de concentração do vetor tecno-industrial. Mas os investimentos hidroviários, ferroviários e rodoviários não procuram somente facilitar a integração interna, mas também o acesso aos portos do

\footnotetext{
${ }^{119}$ Os dez eixos definidos pela IIRSA são: 1) Eixo Andino: Abrange Venezuela, Colômbia, Peru, Equador e Bolívia (vetorizado por dois corredores viários: a Rodovia Pan-Americana ao longo da Cordilheira dos Andes na Venezuela, Colômbia e Equador, e ao longo do litoral no Peru; e a Rodovia Marginal da Selva, beirando a cordilheira andina na Venezuela e a Floresta Amazônica na Colômbia, Equador e Peru); 2) Eixo Andino do Sul: fronteira Chile-Argentina; 3) Eixo Capricórnio: Chile (Antofagasta), Argentina (Jujuy), Paraguai (Assunção) e Brasil (Porto Alegre); 4) Eixo Hidrovia Paraguai-Paraná: Países da Bacia Platina (Brasil, Uruguai, Paraguai e Argentina); 5) Eixo Amazonas: Colômbia, Peru, Equador e Região Norte do Brasil; 6) Eixo Escudo das Guianas: Venezuela, Guiana, Suriname e extremo norte do Brasil (Roraima, Amapá, Para e Amazonas); 7) Eixo do Sul: Sul do Chile e da Argentina; 8) Eixo Interoceânico Central: Peru (Arequipa, Moquegua, Puno e Tacna), Chile (Antofagasta), Bolívia (Beni, La Paz, Oruro, Potosí, Tarija, Cochabamba, Chuquisaca e Santa Cruz), e Brasil (Mato Grosso, Mato Grosso do Sul, Rio de Janeiro, São Paulo e Paraná); 9) Eixo Peru-Brasil-Bolívia: Peru (Tacna, Moquegua, Arequipa, Apurimac, Cusco, Madre de Dios e Puno), Bolívia (Pando, Beni e La Paz), Brasil (Acre e Rondônia); 10) Eixo Mercosul-Chile: Conecta os maiores centros industriais e comerciais entre o Chile, Argentina, Paraguai, Uruguai e Brasil, além dos principais portos desses países.
} 
Pacífico e do Atlântico, possibilitando maior eficiência no escoamento das exportações.

\section{MAPA 2 \\ Eixos de Integração e Desenvolvimento da IIRSA}

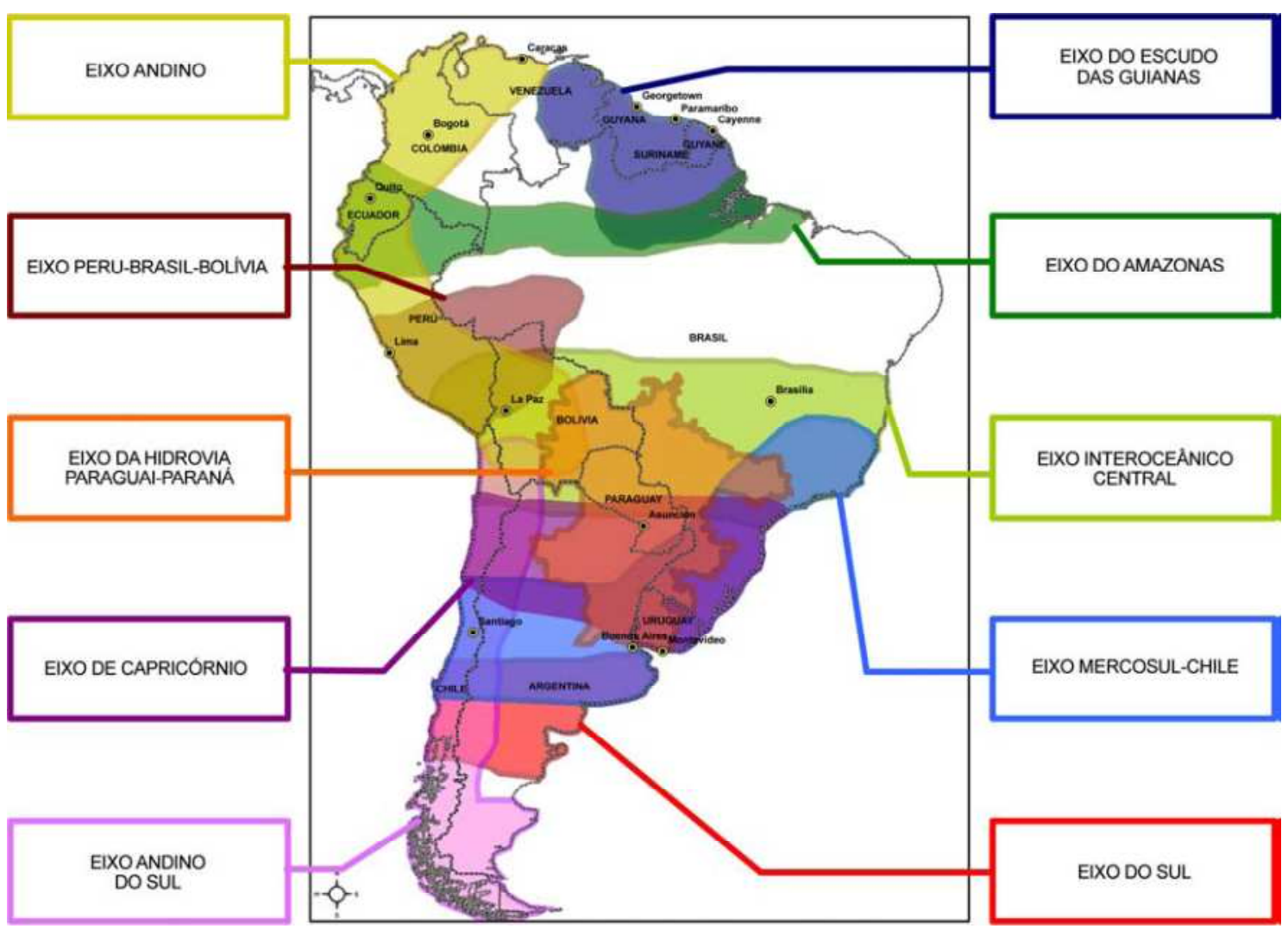

FONTE: IIRSA, 2010, p. 19.

A IIRSA é financiada por instituições multilaterais de fomento como FONDPLATA, CAF, BID, e bancos nacionais como BNDES. Pensada inicialmente como meio de combater as disparidades regionais, a sua carteira de projetos foi reduzida à "Agenda de Implementação Consensual 2005-2010", aprovada em 2004, na reunião dos presidentes da América do Sul em Cuzco (ARAÚJO Jr, 2010). Os projetos realizados até 2010 , foram abreviados para 31 , significando 15\% dos investimentos totais (Op. Cit.). A postergação da maioria dos investimentos para depois desse ano não invalida o modelo de integração física estabelecido pela IIRSA. 
Ao lado da redução das tarifas alfandegárias, esta iniciativa é capital para a ampliação das relações comerciais. A intensificação do comércio em espaços regionais tem relação com os custos de transação. A proximidade estreita laços entre setores econômicos, firmas, e entre estas e os consumidores. Esta é uma tendência que, como mostra Storper (1996), se destacou na analise de regiões subnacionais de desenvolvimento econômico ou inovação tecnológica. Entretanto, mesmo não tendo efeito semelhante na escala continental, a diminuição dos custos de transporte é decisiva para o aumento das relações comerciais sulamericanas.

A concentração econômica das áreas mais urbanizadas e industrializadas possui força centrípeta sobre todo continente. Para que as vantagens da economia de escala dadas pelas grandes aglomerações urbanas (KRUGMAN, 1980) sejam expandidas para além das fronteiras nacionais, faz-se necessário a diminuição dos custos de transportes. ${ }^{120}$ A expansão da produtividade e dos lucros está associada com a ampliação e modernização dos sistemas logísticos continentais. Sob a perspectiva das relações econômicas, os corredores sul-americanos visam diminuir os custos do comércio e aumentar a competitividade das economias locais.

Esses objetivos são vitais para a dinâmica dos fluxos intra-regionais e a constituição da rede territorial. Mesmo que os corredores estejam também atrelados à geopolítica, a prioridade mercadológica da fluidez territorial na América do Sul tem relação com a diminuição dos custos de transação entre as áreas de concentração industrial. Isso está explícito principalmente nos eixos meridionais da IIRSA.

Um eixo, um espaço que congrega um conjunto de atividades e permite a irradiação de relações sociais (ANDRADE, 1987), é uma importante força de coesão. A concentração dos investimentos em infra-estrutura logística é um indicador do nível de coesão, pois difere em todas as porções do continente. Se quanto maior a sinergia no interior de uma área, maior a densidade dos sistemas logísticos, a nervura territorial demonstra os diferentes níveis de integração. Isso

\footnotetext{
${ }^{120}$ A economia de escala mantém a relação estreita com o mercado nacional. Como analisou Paul Krugman (1980) o tamanho do mercado nacional continua determinante para a força econômica de um país. Dado a amplitude e a escala do seu mercado e a relação com a diminuição dos custos de transportes, os grandes centros urbanos continuam a principal força de atração de capital, mão-de-obra e indústrias. A redução dos custos de transporte em escala continental permite o fortalecimento da economia de escala.
} 
pode ser notado no Mapa 3, que apresenta um esquema visual da nova rede territorial.

MAPA 3

Articulações Territoriais dos Eixos de Integração e Desenvolvimento

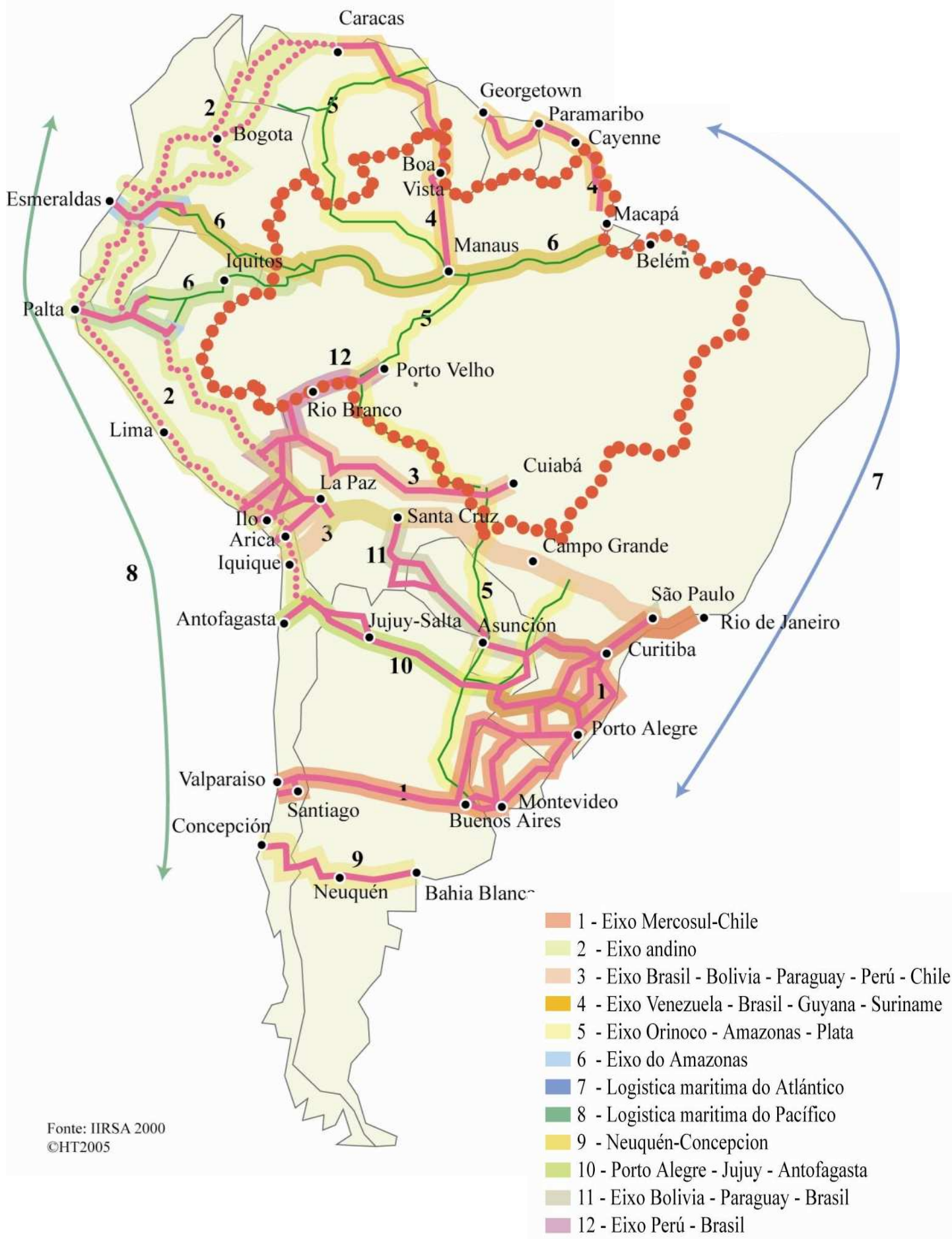


As dimensões da integração regional se desenvolvem em ritmos diferenciados (HOFFMANN, COUTINHO \& KFURI, 2008). O território revela essas disparidades no ritmo de integração de duas maneiras. Primeiro, o desenvolvimento das infra-estruturas de transporte é mais lento que a ampliação das relações comerciais. A diferença de ritmo entre o comércio e o território é agravada pela morosidade dos investimentos em infra-estruturas. Segundo, essas disparidades podem ser observadas na rede territorial, cujas diferentes densidades dos sistemas logísticos tornam possível uma compartimentação do espaço sulamericano.

A partir da articulação do território brasileiro com os demais países, a integração física esboçada nos anos 1990, torna possível uma nova divisão regional do continente. Diante desse quadro, Costa (1999, p. 35) propôs o que chamou de "perspectiva provisória de regionalização" onde divide a América do Sul em quatro áreas: articulações meridionais, orientais, ocidentais e setentrionais. Entretanto, diferente da ordem geopolítica precedente, estas áreas se caracterizam pelo considerável aumento das interconexões com o restante do continente.

As articulações meridionais e orientais abrangem áreas em que foram projetados os eixos Mercosul-Chile, Capricórnio, Sul, Andino do Sul, Hidrovia Paraguai-Paraná e Interoceânico Central. Envolvem, portanto, os espaços de articulação entre as principais redes urbanas e zonas portuárias. As articulações ocidentais correspondem ao eixo Peru-Brasil-Bolívia, à vertente oeste do Interoceânico Central, e partes do Andino (região centro-sul do Peru). São caracterizadas, sobretudo, pelos novos fronts de expansão da pecuária e agricultura. As articulações setentrionais são o espaço onde se organizam os corredores logísticos formados pelos eixos Amazonas, Andino e Escudo das Guianas. É um espaço cada vez mais atraído pelas forças de integração do Cone Sul.

A proposição da macroregionalização a partir da circulação territorial visa escapar da armadilha da velha compartimentação geomorfológica do espaço sulamericano. Este modelo de compartimentação é um dos elementos predominantes na segregação entre as quatro macro-áreas - Amazônica, Andina, Meridional e Oriental - que vigorou até a década de 1980. Era tanto uma derivação das concepções geopolíticas vigentes e do equilíbrio regional de poder, quanto 
resultado das limitações financeiras dos países para romper com as barreiras naturais.

Tal como examinado previamente, a emergência da malha territorial no continente se faz através da articulação entre diferentes redes logísticas internas. Por um lado, estas redes não rompem completamente com a divisão proporcionada pelas quatro articulações evidenciadas por Costa (Op. Cit.) no final dos anos 1990. Por outro, os novos corredores logísticos da IIRSA tornam possível a multiplicação e o adensamento das interações físicas. Com a definição e o planejamento dos novos corredores continentais, esboça-se uma integração do espaço sul-americano através do entrelaçamento e da interdependência de quatro redes geográficas (Mapa 4, p. 206) Mas isso não significa, apesar de avanços recentes, que todas as áreas façam igualmente parte das políticas multilaterais de integração física.

A rede Oriental preserva muitas das características que a definiam até os anos 1980, em relação ao conjunto da circulação territorial, pois mantém a condição de área menos articulada com as demais regiões sul-americanas. Os investimentos nos eixos de desenvolvimento no Nordeste, concentrados nas rodovias BR-116, BR-101, na hidrovia do São Francisco e na ferrovia Transnordestina (PORTO, 2006) amplia a integração com o Norte, o Centro-Oeste e o Sudeste do Brasil. Apesar da região ter uma previsão de investimento de $R \$$ 15,5 bilhões em transportes pelo PAC (COSTA \& VALENTE Jr., 2011, p. 02), não é prioritária à IIRSA. Não está contemplada por nenhum dos seus eixos de integração.

Pela importância geoestratégica que ocupa na América do Sul, a rede Setentrional é uma das maiores prioridades da IIRSA. Os investimentos em integração física têm rompido com a segregação geomorfológica que impedia a integração entre as áreas andina e amazônica. A nova região em formação abrange além de Guiana, Suriname, Guiana Francesa, Equador, Colômbia, Venezuela e o Norte do Peru, os Estados do Amazonas, Acre, Pará e Tocantins no Brasil, 
MAPA 4

Redes Geográficas Sul-Americanas

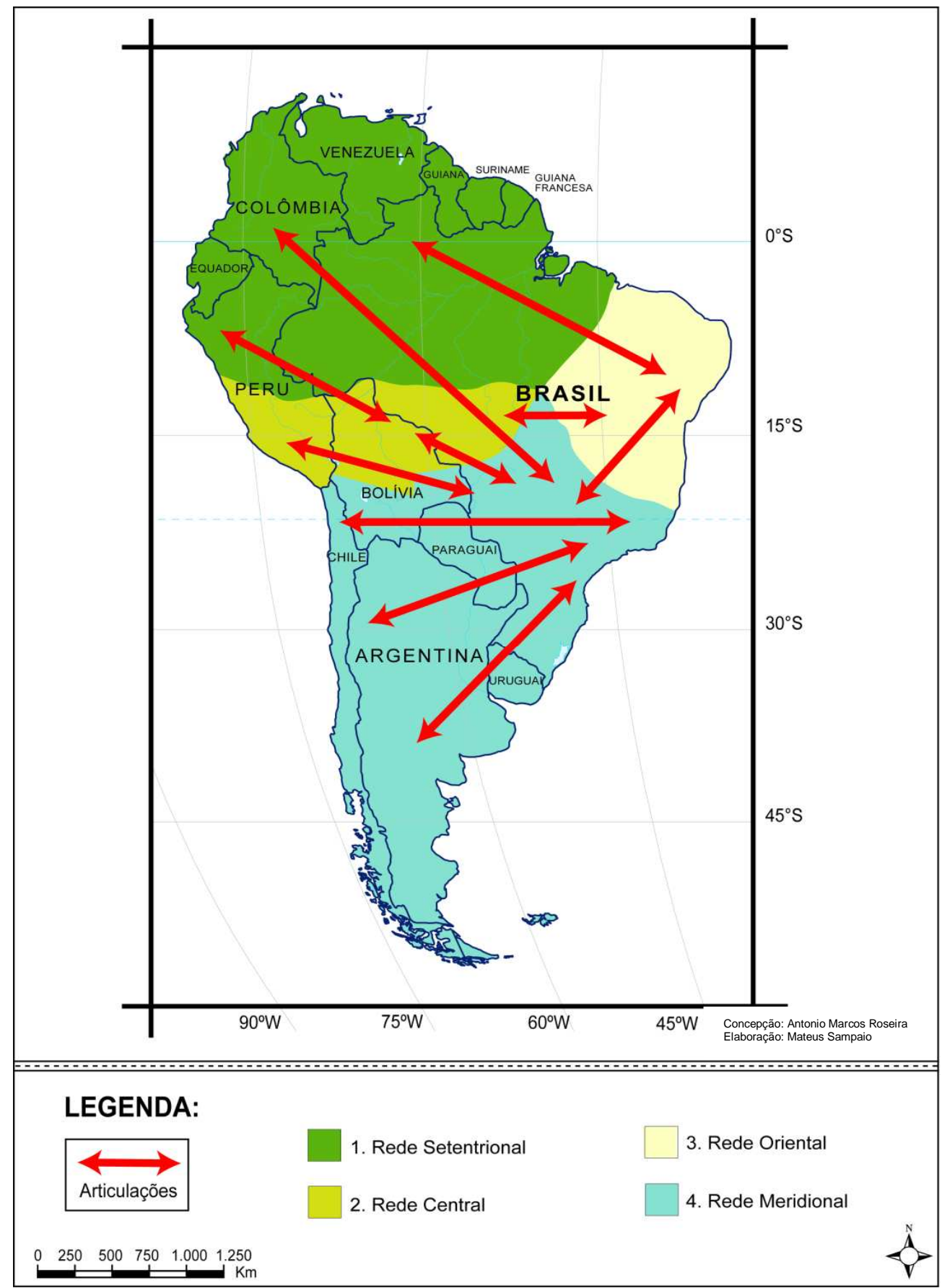

Esta área é contemplada por três eixos de integração da IIRSA: Amazonas, Escudo das Guianas e porção setentrional do Andino. Os investimentos vão desde a integração energética, passando por hidrovias, rodovias 
e ferrovias etc. ${ }^{121} \mathrm{O}$ sentido de extroversão da circulação territorial se destaca em todos os espaços dessa região, principalmente por meio da logística de escoamento dos novos fronts de exploração mineral e produção agrícola no Brasil. ${ }^{122}$

A rede Central compreende a porção Sul do Peru, Norte da Bolívia, e no Brasil, os Estados de Rondônia, Mato Grosso, e as regiões Norte de Goiás e Sul do Tocantins. A ampliação dos enlaces dos Estados do Centro-Oeste e amazônico-ocidentais com a Bolívia e Peru está rompendo as barreiras representadas pelo interflúvio ali localizado (COSTA, 1999). Esta região conecta o Acre e Rondônia ao Peru pelo Corredor Rodoviário Porto Velho - Rio Branco Assis - Puerto Maldonado - Cusco / Juliaca-Portos do Pacífico. Estes Estados são conectados à Bolívia através do Corredor (Rodoviário) Rio Branco - Cobija Riberalta - Yucumo - La Paz e pelo Corredor (Fluvial) Madeira - Madre de Dios Beni.

A rede Central se caracteriza como zona de transição entre as porções Setentrional e Meridional. No Brasil, se conecta à Setentrional por meio dos corredores Noroeste e Centro-Norte, e das rodovias Belém-Brasília e CuiabáSantarém. ${ }^{123}$ Com a Meridional, as conexões mais importantes são as rodoviárias, possibilitadas, sobretudo, através da BR-364, principal via de integração do Sudeste/Centro-Oeste/Norte, e da BR-163 que ao Sul interliga Rondonópolis a Campo Grande e esta a BR-267 de acesso a São Paulo (DINIZ, 2006, pp. 123124). Outro corredor é formado pela Ferronorte, que se estende por 504

\footnotetext{
${ }^{121}$ Entre os investimentos prioritários, destacam-se a rede de hidrovias do Amazonas, os corredores viários entre Venezuela e Colômbia, Peru e Equador, e Colômbia e Equador. Destacam-se ainda os projetos de interconexões elétricas entre Equador e Peru, Colômbia e Equador. Dentre as principais iniciativas bilaterais, chama atenção a construção do Gasoduto Transcaribenho entre Venezuela e Colômbia iniciado em 2006, confirmando a aproximação política e econômica entre os dois países. Na rede Setentrional, a cooperação tem envolvido os setores de energia, transporte, e integração fronteiriça. As redes logísticas dessa área têm sido conectadas com outras regiões sul-americanas através de vias rodoviárias (predominantes na porção andina) e ferroviárias e hidroviárias (predominantes na porção amazônica). Em relação ao Escuto das Guianas, avança as interconexões entre Venezuela e Brasil, Venezuela, Guiana e Suriname, Brasil e Guiana Francesa (IIRSA, 2010, pp.143159). Entre os maiores projetos, estão a recuperação da rodovia Caraca-Manaus e a Hidrovia do Rio Negro até a fronteira com a Venezuela.

${ }_{122}$ Castilho (2004) identifica quatro corredores que integram as novas áreas de produção agrícola aos mercados internacionais: Corredor Noroeste, Corredor Centro Norte, Rodovia Belém-Brasília, Rodovia Cuiabá-Santarém, e Ferrovia Ferronorte. O Corredor Noroeste é composto pela Rodovia Cuiabá - Porto Velho (BR-163 e BR-364), Hidrovia do Madeira (Rios Madeira e Amazonas) e o Porto de Itacoatiara (Rio Amazonas). O porto é equipado com terminais graneleiros privados, que pertencem a empresa Hermasa Logística, do grupo Maggi. O Corredor Centro-Norte é estruturado pela Hidrovia AraguaiaTocantins. Quando concluído, oferecerá duas alternativas para o transporte de granéis sólidos na região Norte. Pelo Rio Tocantins e ferrovias Norte-Sul e Carajás até o Porto de Itaqui (Maranhão); Pelo Rio Araguaia, e deste pela Ferrovia Norte-Sul. A Rodovia Belém-Brasília e Rodovia Cuiabá-Santarém conduz até o Porto Vila do Conde (Belém). A Rodovia Cuiabá-Santarém conduz até o Porto Fluvial de Santarém, nos terminais da Gargill. Pela posição estratégica no transporte de soja, estes portos vêm passando por modernização. A Ferrovia Ferronorte liga Alto Taquari (Mato Grosso), através de uma ponte ferroviária sobre o Rio Paraná (entre Mato Grosso do Sul e São Paulo), até a malha ferroviária de São Paulo e daí aos portos de Santos e Paranaguá.

${ }^{123}$ A rodovia Belém-Brasília conduz até o Porto Vila do Conde (Belém). A Rodovia Cuiabá-Santarém, em péssimas condições conduz até o Porto Fluvial de Santarém, nos terminais graneleiros da Cargill (CASTILHO, 2004). Nos últimos anos, esses portos vêm passando por uma modernização em razão de sua posição estratégica ao movimento da soja para exportação (Op. Cit.).
} 
quilômetros, entre os municípios de Alto Araguaia (Mato Grosso) e Santa Fé do Sul (São Paulo). A ferrovia segue a expansão dos fronts agrícolas (VENCOVSKY \& CASTILHO, 2007, p. 121), conectando o Centro-Oeste aos portos do Atlântico no Sudeste.

A rede Meridional é o locus de concentração dos sistemas de circulação territorial sul-americanos. Grosso modo, preserva o mesmo alcance que a caracterizava até a década de 1980. O que muda é a ampliação e a modernização dos sistemas logísticos que tem aos poucos, diluído a segregação entre as redes territoriais comandadas pelos principais vetores tecno-industriais da Argentina e do Brasil.

A divisão entre Meridional Argentina e Meridional Brasileira começa a perder relevância com os esforços de integração representados pelos corredores da IIRSA. As articulações ocidentais, orientais e meridionais detectadas por Costa (1999) continuam funcionando como redes que comandam as tendências de integração em grande parte dessa região. Da mesma forma, as articulações orientais e meridionais comandam a conexão entre os principais vetores tecnoindustriais.

Ainda assim, o adensamento da malha territorial permite conceber uma região ordenada por uma mesma tendência de interação regional. O que a diferencia das demais redes é justamente a força de introversão exercida pelos seus mercados. Enquanto a integração nas redes Setentrional e Central é comandada por forças externas, os espaços periféricos na Meridional estão (também) subordinados aos seus vetores tecno-industriais. Essa lógica define tanto a articulação do Triângulo Estratégico Boliviano ao Brasil e Argentina (PFRIMER \& ROSEIRA, 2009) quanto à integração da Patagônia do Norte à área formada por Rosário-Buenos Aires-La Plata. Mesmo que em grande parte seja comandado pelo capital internacional, como demonstra 0 caso argentino (SILVERA, 1993), esse processo é dependente da força exercida pelos grandes centros urbanos.

Essa tendência pode ser observada também na ampliação dos enlaces fronteiriços no Cone Sul. Nos últimos anos tem-se multiplicado as iniciativas de integração em áreas de fronteira no Cone Sul. Este é o caso da Tríplice Fronteira Brasil-Paraguai-Argentina (ROSEIRA, 2006), e das fronteiras entre o Rio Grande do Sul e Argentina (DIETZ, 2008) e entre o Chile e a Argentina (VELUT, 2009). As 
fronteiras com ampliação das interações espaciais, são áreas privilegiadas da regionalização.

Segundo dados da IIRSA (2010b, pp. 62-63), dos US\$14,02 bilhões em investimentos previstos para os 31 projetos da "Agenda Consensuada", US\$ 8,23 bilhões (58\%) estão concentrados nos eixos Capricórnio e Mercosul-Chile. A Hidrovia Paraguai-Paraná, a Ferrovia Transandina Central (que ligará o Chile a Argentina), os corredores que compõem a Rodovia Mercosul, além de pontes binacionais entre Brasil e Uruguai, Brasil e Argentina e Brasil e Paraguai, estão entre os projetos que visam romper de vez com a segregação espacial no Cone Sul. São projetos dessa natureza que revolucionarão os sistemas de fluxos e redefinirão a funcionalidade das fronteiras no Cone Sul (CICCOLELLA, 1993, p. 301).

Junto aos governos nacionais, as redes de cidades são outra importante força que define a integração na porção Meridional. As redes de cidades consagradas como força de regionalização na Europa (FRIEDMANN, 1999) e no Sudeste Asiático (DOUGLASS, 1999) - exercem influência na integração física sul-americana de duas formas. A primeira, posta pela Rede Mercocidades, é política.

A Rede Mercocidades constitui a mais bem sucedida, se não a única experiência de uma rede de cidades genuinamente sul-americana (KLEIMAN, 2010, p. 61). Visa fundamentalmente, favorecer e consolidar a governança territorial multinível na integração regional (ODDONE, 2010, p. 79). Essa iniciativa foi criada em 1995 na Declaração de Assunção, envolvendo 12 cidades do Brasil, Argentina, Paraguai e Uruguai (RÜCKERT, 2005). Segundo dados da Secretaria Executiva das Mercocidades (2010, p. 108), é composta por 213 cidades, abrangendo em torno de 80 milhões de cidadãos. Após ter surgido entre os membros plenos do Mercosul, a rede foi expandida para o Peru, Venezuela, Chile e Bolívia.

A Rede Mercocidades, como um espaço de cooperação multilateral independente das decisões dos governos (BINNER, 2010, p. 23), estabelece circuitos de cooperação em diversos setores, corroborando com a tendência multidimensional da integração. A concentração das mercocidades na porção Meridional demonstra que a liderança continental exercida por esse espaço, ao 
não se resumir aos interesses dos governos nacionais e envolver diferentes escalas espaciais de concentração do poder político, é fundamentalmente multinível.

A segunda influência das cidades na rede Meridional se dá economicamente. O desaparecimento da barreira alfandegária estabelece correntes de mercadorias, valorizando o papel de uma aglomeração (BOUDEVILLE, 1974, p. 14). Seus fluxos materiais e informacionais definem uma rede de autoridade e influência. Este entendimento é base da integração física da IIRSA.

Mas o papel econômico das cidades não é homogêneo. As megaaglomerações formadas pelas cidades-regiões globais, locus da concentração da produção e do consumo, exercem força gravitacional que molda o sentido geográfico dos corredores logísticos. As transformações espaciais da economia, a partir dos anos 1970 trouxeram novo papel regional às grandes aglomerações metropolitanas sul-americanas. O caso emblemático de São Paulo mostra que a desconcentração industrial foi acompanhada pela concentração e controle do capital que, continuam social e espacialmente concentrados (LENCIONI, 1993, p. 203). De um modo, grandes cidades como Belo Horizonte, Rio de Janeiro, São Paulo, Curitiba, Porto Alegre, Montevidéu, Buenos Aires, Rosário, Córdoba e Santiago comandam o consumo e as trocas comerciais. De outro, são centros de comando das redes empresariais. Nestas aglomerações metropolitanas se localizam a sedes das grandes empresas globais e regionais, e o poder econômico e financeiro da rede Meridional.

As cidades pequenas e médias por outro lado, estão se tornando cada vez mais importantes nessa área. A rede de municípios, desde os anéis urbanizados das grandes metrópoles, até as zonas de fronteira, cumpre importante papel na dinamização das relações comerciais. No século XX, a proliferação dessas cidades nas franjas ocidentais de ocupação do território brasileiro foi fator determinante para a ampliação das interações espaciais em zonas de fronteira na Bacia do Prata.

As cidades médias, favorecidas por transformações econômicas das últimas décadas são lugares que privilegiado para o desenvolvimento de clusters. A rede Meridional concentra o desenvolvimento dessas regiões de especialização produtiva. Da mesma forma, é o espaço de maior densidade da rede de cidades 
(médias e pequenas), que ao lado das grandes metrópoles, concentra a produção e o consumo.

A rede meridional é uma síntese da nova ordem regional, que envolve desde o novo paradigma político até as transformações da economia geopolítica nas últimas décadas. É o espaço por excelência onde se desenvolvem as três estruturas de integração. Em escala municipal, estadual ou nacional, a política estabeleceu um nível de cooperação, que apesar das crises, dificilmente poderá ser revertido. Os investimentos em infra-estruturas de transportes, dependentes da capacidade econômica e financeira dos países, tendem a expressar a nova ordem regional. Por outro lado, a concentração e o crescimento das relações econômicas garantem a permanência da região meridional como o núcleo duro da integração continental. 


\section{Apontamentos de Transição a (Re) Inserção Mundial da América do Sul}

A state may see the region as a means of aggregating power and fostering a regional coalition in support of its external negotiation

Andrew Hurrell

As deficiências nas políticas de integração territorial são um dos aspectos mais criticados da regionalização sul-americana. São comuns, sobretudo, entre os principais meios de comunicação, comparações entre o ritmo dos investimentos em infra-estrutura no continente, e o projeto europeu já consolidado. Mais recentemente, a imensa capacidade chinesa de ampliação e modernização dos meios de transportes é vista como corroboração da ineficiência sul-americana. Malgrado a ampliação dos investimentos, a precariedade da integração física tem sido interpretada como uma condição do atraso e da ineficiência dos governos da região.

Em muitos casos, as críticas são coerentes e consistentes, pois o fracasso na transformação da ordem territorial comprometerá, incontestavelmente, o avanço do projeto regional. Mas numa postura radicalmente oposta, as críticas mais ferrenhas têm origem em setores que pregam o malogro do atual modelo de integração continental. Os discursos relacionados à transformação da gestão e do planejamento dos sistemas logísticos estão, grosso modo, relacionados à defesa 
virulenta da ampliação do papel do mercado e de uma integração de baixa densidade.

Existem dois equívocos constantes no exame de temas relacionados à infra-estrutura na América do Sul. O primeiro, e mais grave de todos, é o discurso ostentado por defensores da ortodoxia neoliberal, que explica 0 baixo desenvolvimento da região exclusivamente a partir da existência de gargalos setoriais. A situação de atraso seria causada, sobretudo, pelo baixo investimento em logística e transporte. Governos inoperantes e incapazes de criar condições de investimentos são considerados desastres que assola todo continente. A superação desse anacronismo exige da administração pública destravar os investimentos, incentivando e flexibilizando a participação do setor privado. Nesse caso, o desafio não seria exatamente político e econômico, mas técnico ou gerencial.

O segundo equivoco está na crença expressa por um keynesianismo vulgar, de que a expansão dos gastos públicos é o único caminho para se libertar da armadilha imposta à economia pela defesa da diminuição do papel do Estado. Ao cortar gastos, o governo não alcançaria eficiência administrativa, e tampouco recuperaria a força da economia.

De certa forma, ambas as concepções têm seu quinhão na crise que assolou a América do Sul nas últimas décadas. Especialmente no Brasil, a noção de que o crescimento indefinido dos gastos públicos é a via possível do desenvolvimento econômico e social desmoronou com o colapso da geopolítica militar nos anos 1980. Do mesmo modo, a fé cega na racionalidade do mercado desabou com a melancólica decadência do neoliberalismo iniciada com as crises recentes.

A incapacidade de realizar investimentos massivos em infra-estrutura demonstra o dilema posto por um dos desafios da integração sul-americana. Ao mesmo tempo em que essa questão demanda a ampliação do papel do Estado, o seu enfrentamento não pode ocorrer à custa da expansão desenfreada da dívida pública. De tal modo, a eliminação dos gargalos de transporte e a superação da precariedade da integração física dependem da retomada do crescimento, que permite a expansão dos investimentos públicos sem comprometer a relação dívida / PIB. 
A crença, disseminada pelos arautos do mercado auto-regulado, de que a condição precária dos transportes em regiões em desenvolvimento como a América do Sul é causada pela ineficiência dos governos, reflete uma vulgarização que está subordinada às tendências impostas pela ordem geopolítica contemporânea. Esse credo é vassalo de discursos geopolíticos hegemônicos, que segundo Agnew (1998), estabelecem uma imagem aos lugares periféricos, buscando ao mesmo tempo explicar e legitimar suas condições políticas, econômicas e sociais. A fé inabalável de uma elite regional no livre-mercado expõe a hierarquização do espaço mundial comandada pela economia geopolítica mundial.

Se a ampliação dos investimentos em infra-estrutura está relacionada ao crescimento, este, por sua vez, depende de transformações da economia geopolítica em escala global. Da forma como previamente examinada, a nova ordem territorial não significa a superação plena das limitações de investimentos em infra-estruturas. É antes de tudo, uma transformação da relação entre Estado e planejamento do território, que impõe uma reorientação do sentido das redes logísticas.

Dimensão indissociável do desenvolvimento nacional e continental, o território expõe tanto as fragilidades da atual ordem regional, quanto as possibilidades de desenvolvimento da América do Sul num mundo em profundas transformações. Para além de um pessimismo cego, é preciso saber olhar para os gargalos de transportes como uma imensa demanda não atendida. No Brasil, a retomada do crescimento econômico na última década começa a romper com a estagnação em diversos setores estratégicos. A melhora econômica tem atraído grandes grupos de investidores estrangeiros, cada vez mais interessados no enorme potencial aberto pela necessidade de ampliação de infra-estruturas de transporte.

Os desafios da questão territorial sul-americana envolvem uma nova conjuntura global. Essa premissa leva a alguns apontamentos acerca da relação entre regionalização, integração territorial e (re) inserção mundial do continente. Primeiro, a retomada dos investimentos brasileiros em infra-estruturas de transporte é a viga mestra na consolidação da nova ordem territorial sulamericana. Essa assertiva pode ser interpretada de duas maneiras. De um lado, o Brasil se tornou uma força econômica cujos investimentos em infra-estruturas 
como linhas de transmissão, metro, hidroelétricas, rodovias e ferrovias, alcançam todo continente. Como um dos maiores bancos públicos do mundo, o BNDES tem realizado vultosos aportes na maioria dos países sul-americanos. De outro lado, a posição brasileira de rótula continental faz com que os principais investimentos em transporte realizados em território nacional tenham impacto sobre todo continente.

Nesse caso, a organização do território não demonstra somente a predominância de um modelo político como salienta Hartshorne (1950). Comprova o alcance geográfico da presença política e econômica do Brasil. Portanto, a nova ordem territorial sul-americana pode ser entendida como uma das expressões máximas da projeção continental do Brasil. Mas ao mesmo tempo, sua configuração revela a subordinação do continente à economia geopolítica global. $A$ extroversão cada vez maior das redes logísticas e a integração das vertentes do Atlântico e do Pacífico também demonstram a forma subordinada que prevalece na aproximação da maioria do continente às novas regiões emergentes. Esta relação tem reforçado a histórica condição primário-exportadora das economias locais.

Segundo, a ordem territorial atual compõe novos eixos globais de desenvolvimento econômico e influência política. Apesar da extroversão dos sistemas logísticos demonstrarem o risco de especialização produtiva no setor primário-exportador, contribuem para a aproximação da região com a África, Ásia do Sul e Ásia Oriental. A preponderância regional do Brasil o torna o articulador sul-americano de um eixo geopolítico junto às economias extracontinentais emergentes.

A integração das vertentes do Pacífico e do Atlântico tornou-se ainda mais premente com o crescimento da China. Os principais portos sul-americanos do Pacífico ganham importância, especialmente se considerada a tendência predominante de ampliação das relações comerciais com outras regiões asiáticas. Diante do potencial de crescimento nas próximas décadas, o intercâmbio das principais economias sul-americanas com a Índia ainda é bastante incipiente.

Terceiro, e não menos importante, a integração física é um dos fatores determinantes à ampliação da capacidade regional de atrair investimentos externos. O aumento da renda e do consumo potencializa os investimentos em transporte. Mas com maior ou menor grau, os países não superaram a exclusão de áreas e parcelas significativas da população. Embora esta também seja uma 
realidade de espaços de concentração do vetor tecno-industrial, as regiões deprimidas expõem as deficiências da integração nacional. Portanto, a capilarização dos sistemas logísticos está associada à ampliação do mercado nacional. Para tanto, esse processo não exige somente crescimento econômico, mas, sobretudo, a expansão da renda e desenvolvimento social.

Uma das principais características da economia contemporânea - a multiplicação dos IED a partir dos anos 1990 - projeta corporações as globais e regionais como forças geopolíticas. Num contexto em que predomina o enfraquecimento do Estado, os investimentos realizados pelas grandes empresas reforçam as disparidades econômicas, resultando em conflitos sociais. Em muitas economias emergentes, os governos têm demonstrado um posicionamento ativo, cooptando as corporações globais, continentais e nacionais num amplo projeto geopolítico. De modo geral, esse posicionamento contribui diretamente ao fortalecimento da indústria, da ciência, e de setores estratégicos de média e alta tecnologia.

A consolidação desse modelo depende de uma geopolítica ancorada numa concepção de desenvolvimento que abranja a totalidade do território nacional e todos os segmentos da população. Assim sendo, pressupõe a capilarização dos sistemas técnicos e informacionais para além das áreas core, alcançando a hinterlândia e as fímbrias do território nacional. Tal como observa Stiglitz (2001) a respeito da ascensão asiática, o desenvolvimento da escala nacional ou continental depende de um contrato social que garanta os direitos da população. Na Era da Informação, a influência de um país depende da geopolítica informacional, que pressupõe necessariamente ciência, tecnologia, e bem estar social.

Ainda que incipiente, a recente retomada do desenvolvimento entre os países sul-americanos reforça a posição do continente no novo mapa do mundo. $O$ crescimento das principais economias da região, com destaque ao Brasil, refletiuse em maior relevância internacional e atratividade aos investimentos externos. Esta é uma das conseqüências diretas da ampliação da renda e do mercado nacional.

A extroversão da rede territorial sul-americana manifesta a maior fragilidade da região na economia política internacional. A subordinação à economia geopolítica conduzida pelas potências hegemônicas da soberania 
globalista tem perdido ímpeto frente ao estreitamento das relações entre países emergentes. Apesar dos ganhos cada vez mais expressivos baseados na vantagem competitiva do setor primário-exportador, a retomada do crescimento sul-americano está na esteira de regiões e países que têm galgado posições cada vez mais relevantes em setores industriais de médio e alto desenvolvimento tecnológico.

Por fim, um dos maiores desafios à projeção internacional da América do Sul está posta por forças centrífugas internas. As assimetrias econômicas e territoriais estão entre os maiores desafios de aprofundamento da nova ordem regional. Por um lado, revela a incapacidade interestatal de combater as desigualdades entre os países, uma busca que legitimou as iniciativas de integração. Por outro, a crescente importância econômica e financeira do Brasil na América do Sul não impediu as recentes e perigosas fricções interestatais. Ao usar a cooperação regional como meio de legitimação de seus interesses globais, o país alimenta a desconfiança - dos menores aos maiores países. A conseqüência mais grave é justamente o fortalecimento de grandes potências externas, que segundo Hurrell (2006) vêem nas fricções internas um meio de projetar influência na região. 


\section{PARTE 3}

\section{OS DESAFIOS REGIONAIS E GLOBAIS À INTEGRAÇÃO SUL-AMERICANA}




\title{
CAPÍTULO 7
}

\section{Assimetrias Econômicas e Conflitos Geopolíticos}

\author{
Any given geographical distribution of \\ political power is bound to try to \\ perpetuate itself, although the \\ geographical substratum that originally \\ brought this distribution about may have \\ been substantially modified.
}

Jean Gottmann

\subsection{Instabilidades Econômicas e Assimetrias Regionais: Aspectos Preliminares}

Houve, no início da década de 1990, uma euforia generalizada com a assinatura do Tratado de Assunção. O otimismo que tomou conta dos países signatários era expresso por setores governamentais e empresariais, além da academia, da imprensa, a de diversos segmentos da sociedade civil. Num contexto continental ainda muito marcado pela instabilidade dos anos 1980, a integração surgia com enorme potencial frente aos graves problemas econômicos, políticos e sociais.

Nesse contexto, a tendência mercantil dominou os primeiros anos da regionalização. Brasil, Argentina, Paraguai e Uruguai eram tratados como se fossem “... territórios homogêneos, sem desigualdades internas" (ARROYO, 1993, p. 309). Valorizava-se o mercado e o potencial das trocas comerciais, ignorando as inúmeras assimetrias internas, a pobreza e a exclusão social. A integração mercantil e de "baixa densidade" prevaleceu em detrimento de uma política regional que também objetivasse o combate as desigualdades subnacionais e continentais. 
O modo como o Mercosul foi constituído em 1991 reflete tendências majoritárias da globalização, com a valorização do mercado em detrimento da sociedade. Dentre as principais críticas em relação à globalização, está o argumento de que os seus benefícios afluem a uma pequena parcela da humanidade, sendo eivada de assimetrias (AMORIM, 2003, p. 121). A preponderância mundial das cidades globais e dos clusters industriais e tecnológicos é acompanhada pelo aumento da pobreza, das crises financeiras, da falência de Estados, da criminalidade, das áreas de exclusão social etc. Os processos de globalização e fragmentação resultam numa geografia das desigualdades (SOUZA, 1993, p. 21), que se expressa em escala subnacional e continental.

Guerra, sofrimento, miséria e exploração caracterizam cada vez mais o mundo global (HARDT \& NEGRI, 2009, p. vii). A ascensão do capitalismo informacional/global se distingue pela simultaneidade do desenvolvimento e subdesenvolvimento econômico (CASTELLS, 1999c, p. 107). A globalização aumenta o número de pobres, cria uma fome generalizada, acarreta o fenômeno dos sem-teto, restaura doenças que havia desaparecido, mata a noção de solidariedade e reduz as noções de moralidade pública (SANTOS, 1997, pp. 1314).

A desregulamentação financeira dos anos 1980, a re-emergência do movimento de auto-regulação do mercado, e aquilo que Milton Santos (Op. Cit., p. 20) chama de "movimentação autônoma do dinheiro em estado puro" se sobrepõe, mais e mais, ao desenvolvimento econômico, ao bem-estar social e ao meio ambiente. A supremacia das leis de mercado, uma inovação do século XIX que Polanyi (2001, p. 82) definiu como o surgimento do "homem econômico", coloca em risco o Estado, o trabalho, a natureza e valores fundamentais da vida humana. Nos últimos anos, essa dimensão perversa encontrou sua melhor representação no mercado financeiro, que se tornou uma espécie de Leviatã aterrador e imprevisível.

Polanyi (Op. Cit., p. 172) entende que a ausência da ameaça da fome individual faz da sociedade primitiva mais humana que a economia de mercado. ${ }^{124}$

${ }^{124} \mathrm{Em}$ The Great Transformation, Polanyi (2001) demonstra que nas sociedades primitivas a fome está relacionada com problemas na capacidade (coletiva) de produção e distribuição de alimentos. Havia uma ordem nos sistemas de produção e distribuição dessas sociedades, garantida por dois princípios de comportamento associados à economia: reciprocidade e redistribuição (Op. Cit., pp. 54-55). Na Europa, até o final da Idade Média, eram outras instituições e não o mercado que prevaleciam. Os mercados se tornaram numerosos do século XVI para frente, sob o sistema mercantil, e passaram a ser a 
A referência de Polanyi ao livre-mercado sustentado pela hegemonia britânica no século XIX encontra paralelo com o movimento de auto-regulação do mercado na globalização.

Apesar de existir apenas enquanto ideologia e símbolo, e não como ator (SANTOS, 1997, p. 17), o mercado possui uma força geopolítica transnacional. Isso ocorre porque a geopolítica não é uma singularidade, mas uma pluralidade (Ó TUATHAIL \& DALBY, 1998, p. 04). Através de valores e crenças transmitidos por instituições supranacionais, pelas grandes corporações, pelos meios de comunicação, pela academia, e por diversos segmentos da sociedade, o primado do dinheiro e do mercado se sobrepõe a todas as escalas geográficas no mundo global.

Se a integração iniciada no Cone Sul é, por um lado, resultado de uma "experiência estratégica" de fortalecimento regional, por outro ela não escapa da força geopolítica do mercado. O Mercosul é uma iniciativa que nasce consubstanciada pelas "novas" concepções de desenvolvimento econômico e social que imperam na globalização. Este bloco estabelece no contexto regional a tendência predominante da economia global. A substituição do desenvolvimentismo pelo mercado representa a inserção da região na nova agenda mundial.

Passa a prevalecer uma concepção de inserção competitiva de "espaços ganhadores" que comandam a produção e o consumo na América do Sul. A partir das premissas que dirigiram as políticas de cooperação regional no início dos anos 1990, a solução para as desigualdades sociais e para as crises econômicas estaria no aprofundamento da interdependência comercial. A expansão das relações comerciais incidiria no aumento das oportunidades de emprego e no nível de renda. Ignorou-se que o aspecto social é fator determinante no processo de regionalização. A instabilidade da moeda, a pobreza, e a inconstância no nível da produção industrial fazem com que a integração seja também instável (FERRER, 2000).

principal preocupação de governo (Op. Cit. pp. 57-58). Porém não havia sinal de controle da sociedade humana pelo mercado. A regulação era forte e a concepção de auto-regulação só acontece no século XIX, com a transformação do trabalho, da terra e do dinheiro em commodities. Com a ascensão da economia de mercado na Europa, a ameaça da fome passou a ser individual, sendo ditada pela oferta de trabalho e pela capacidade (individual) de inserção no mercado de trabalho. Para Polanyi (Op. Cit., p. 172), essa transformação faz a visão hobbesiana de Estado como Leviatã ser ofuscada pela concepção ricardiana de mercado: um fluxo de vidas humanas, regulado pela quantidade de comida disponível. Com a retomada do livre-mercado nos anos 1980, há um retorno do discurso da auto-regulação como equilíbrio ideal da sociedade, da vida, do trabalho, da natureza etc. 
Como argumentamos no Capítulo 6, os anos 1990 foram marcados pela enorme expansão das relações comerciais entre os Estados Partes e associados, marcando o sucesso do regionalismo aberto. Entretanto, a curva ascendente das relações comerciais e a perspectiva otimista sobre o Mercosul sofrem forte revés com a crise econômica deflagrada no final da década de 1990. Destaca-se nesse período, a mudança do regime cambial brasileiro, que detonou a mais séria crise enfrentada pelo Mercosul desde sua fundação (MACHADO \& RIBEIRO, 1999, p. 01). Não por acaso, a estabilidade da integração no Cone Sul desmorona com a crise severa no final dos anos 1990, do modelo econômico inspirado no mercado auto-regulado. $^{125}$

Desde então, a atmosfera de otimismo se esvaneceu sob o aumento das crises bilaterais e multilaterais. O Mercosul passou a ser visto como parte do problema (PEÑA, 2001, p. 12). Enquanto a estabilidade monetária, proporcionada pelo cambio fixo ancorado ao dólar, prevaleceu entre as principais economias do Cone Sul, o comércio regional dava sinais aparentemente inesgotáveis de expansão. A deflagração da crise cambial em 1999 escancarou as graves assimetrias do modelo mercantil de regionalização. A desvalorização do Real e posteriormente do Peso criou ambiente de incerteza de facto nas operações comerciais e de jure no avanço institucional do bloco (SENHORAS \& VITTE, 2006). Nesse contexto de instabilidade da moeda, a expansão do comércio foi amortizada pela crise, que derrubou os níveis de produção e consumo em todo continente.

A crise financeira que varreu a América do Sul entre 1999 e 2003 derrubou o crescimento econômico, que, em alguns países, já era inferior ao registrado nas décadas anteriores. A vulnerabilidade externa da economia brasileira e argentina frente ao endividamento e às constantes incursões de fundos

\footnotetext{
${ }^{125}$ É preciso ter cautela a esse respeito. Apesar da força do Consenso de Washington e dos terríveis efeitos econômicos e sociais do chamado neoliberalismo na América do Sul, a idéia de livre-mercado não foi plenamente realizada. Polanyi (2001) ensina que o livre-mercado nunca se completa. Há um duplo movimento: o primeiro se caracteriza pelo esforço de autoregulação do mercado que leva sociedade à beira do abismo, e o segundo pelo processo de retomada de controle do mercado pela sociedade. Segundo Polanyi (Op. Cit.) esta é uma tendência que caracteriza a sociedade de mercado. É verdade que o filósofo escreveu no calor do New Deal, e que suas idéias refletem um momento histórico bastante específico. Deve-se considerar que as constantes crises financeiras desde o final dos anos 1980 não levaram a um processo de controle do mercado pela sociedade nos países centrais. Mas, por outro lado, houve um fortalecimento do papel do Estado em regiões periféricas que sofreram com as crises financeiras dos anos 1990. Esse é o caso dos países do Sudeste Asiático e posteriormente da América do Sul. Destaca-se o fato de que o desmonte do Estado não se realizou plenamente neste continente nos anos 1990. Países como Brasil e Argentina preservaram parte (mesmo que pequena) do seu papel de indutor do desenvolvimento (com a ação de bancos, empresas e órgãos estatais). Acresce-se que o início dos anos 2000 foi caracterizado pela retomada do papel do Estado, num contramovimento à tendência de fortalecimento do neoliberalismo em outras regiões. Assim, a concepção de mercado auto-regulado é sempre uma metáfora a um processo de fortalecimento da dimensão econômica em detrimento dos interesses do Estado e da sociedade. Da forma como ambicionado, o livre-mercado é uma utopia.
} 
especulativos voláteis (RAPOPORT, 2009, p. 47) demonstrava a força da economia geopolítica atrelada ao mercado auto-regulado. Mas, se nos anos 1980 a quebra da região estava associada ao poder norte-americano, que transformara o modo de regulação da economia internacional segundo seus interesses, o colapso dos anos 1990 foi deflagrado pela geopolítica do mercado. A exemplo do que fizera a economia geopolítica norte-americana na década de 1980, os constantes ataques especulativos a moedas de mercados emergentes ${ }^{126}$, propiciada pela desregulamentação financeira, colocaram muitos países em desenvolvimento de joelhos.

Como demonstram os gráficos 14 e 15 (p. 224), o crescimento de todas as maiores economias sul-americanas foi afetado entre 1998 e 2002, havendo uma recuperação a partir de 2004. Nos cinco anos mais agudos da crise, as economias do Brasil e da Argentina, que puxavam a expansão do comércio regional, cresceram respectivamente $2 \%$ e $-2,4 \%$. Esse processo coincide com a diminuição brusca do comércio intrabloco, conforme demonstrados nos gráficos do Capítulo 6.

Entretanto, a diminuição do comércio regional foi apenas o primeiro efeito da crise econômica que se instalou entre os países sul-americanos no final dos anos 1990. Essa tendência, revertida a partir de 2003, demonstra apenas o limiar de crises maiores entre os membros (plenos e associados) do Mercosul. Os conflitos entre Argentina e Uruguai em torno da questão das papeleras, entre Brasil e Bolívia a respeito do gás natural boliviano, e entre Brasil e Paraguai em relação ao valor do excedente de energia gerada por Itaipu são problemas que expõe os desafios da regionalização frente às assimetrias internas e os interesses nacionais.

O alargamento geográfico da integração proporcionado pela Unasul acrescenta questões ainda mais sensíveis para a agenda regional. Por um lado, a proposta da zona de livre comércio continental é, do ponto de vista institucional, menos complexa que a agenda de criação da União Aduaneira e do Mercado Comum no Cone Sul. Mas por outro, as assimetrias entre as porções meridional e

\footnotetext{
126 "A expressão "mercados emergentes" que surge no mundo das finanças, no início da década de 1990, é atribuída às praças financeiras da periferia por ficarem interligadas diretamente, em forma de rede, aos mercados dos países do centro do sistema. Assim, cidades como São Paulo, México, Buenos Aires e Santiago se somam ao grupo das tradicionais praças de Nova lorque, Londres e Tóquio, concentrando transações em ações, operações do mercado a termo e do mercado de câmbio, operações do mercado de swaps, opções e futuro. A paisagem da City londrina repete-se, parcialmente, em alguns pedaços das cidades latino-americanas, que cada vez mais albergam em seus respectivos centros sedes de bancos estrangeiros, empresas de seguros, corretoras de valores, escritórios de consultoria internacionais, além de shoppings, flats, apart hotel, escritórios comerciais em prédios inteligentes, etc." Mônica Arroyo, 2006, p. 182.
} 
setentrional, associadas à menor interdependência econômica e política destas duas áreas, expõem ainda mais os desafios e os limites contemporâneos da regionalização.
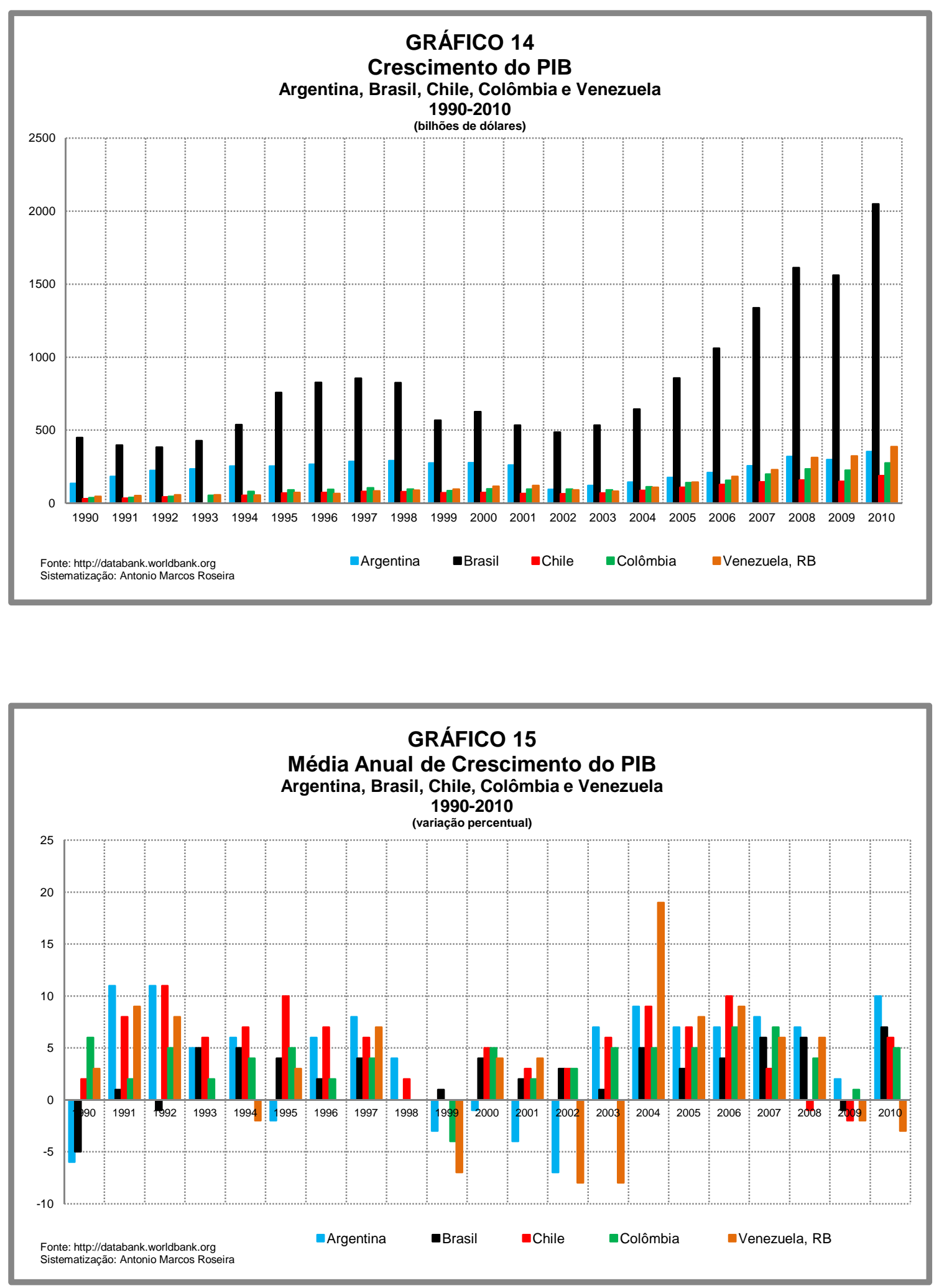
Se a densidade das linhas de força formadas pelos sistemas logísticos expõe as prioridades da integração comercial e física, o território pode ser considerado um importante indicador das assimetrias da regionalização sulamericana. Os diferentes níveis de capilaridade da rede territorial mostram que a demasiada ênfase dada às relações comerciais não diminui as desigualdades regionais.

Portanto, a densidade dos sistemas logísticos expõe claramente a primeira fragilidade da regionalização. Apesar da gravidade dos problemas supracitados, o maior desafio ainda se caracteriza pelos diferentes níveis de participação dos lugares na nova agenda política e econômica sul-americana. As interconexões físicas demonstram que as “... forças centrípetas da geografia são mais intensas quanto maior o nível de desenvolvimento tecnológico e industrial (FERRER, 2000, p. 06).

Nos primeiros anos do Mercosul, autores como Mônica Arroyo (1993) chamavam atenção para a falácia acerca do alcance geográfico da bloco. É verdade que por um lado, como entendiam teóricos do modelo da desigualdade regional, o desenvolvimento desigual de uma área é uma condição concomitante do próprio crescimento (WROBEL, 1974, pp. 01-16). Nos primeiros estágios de desenvolvimento econômico de uma nação ocorre a concentração do crescimento em uma ou algumas regiões que possuem vantagens iniciais. Mas, com o surgimento de áreas econômicas continentais, esse processo não está restrito a escala nacional.

Ainda que os interesses dos Estados e do bloco econômico em relação a região continental sejam muito distintos da perspectiva clássica do desenvolvimento das áreas nacionais, há o desafio de diminuir as desigualdades entre as diversas escalas espaciais do continente que compõem o processo de integração. Essa necessidade deveria ser premente em uma região tão desigual quanto a América do Sul, cujas assimetrias não estão circunscritas às relações interestatais, evidenciando-se nas discrepâncias do desenvolvimento de áreas subnacionais.

O agravante da integração sul-americana está no fato de a Unasul ser essencialmente uma área de livre comércio. Ainda que a constituição desse bloco seja um grande avanço à agenda regional e coesão política entre os seus membros, esse modelo de integração não é o meio ideal de combate às 
desigualdades regionais. O Mercosul, que com a entrada da Venezuela se tornou de fato continental, não visou na primeira década uma política de combate as assimetrias. $^{127}$

Portanto, há uma nítida diferença entre o Mercosul de jure e o de facto. Enquanto o primeiro alcança todas as áreas dos Estados membros, o segundo está concentrado na zona tecno-industrial que vai de Belo Horizonte a Santiago, privilegiando quase toda rede Meridional. Segundo dados do MDIC-DEPLA (2011), do total das importações brasileiras provenientes do Mercosul em 2008, 84,1\% eram feitas pelos Estados do Rio Grande do Sul, Santa Catarina, Paraná, São Paulo, Rio de Janeiro e Minas Gerais. Das exportações com destino ao bloco, $81,2 \%$ eram realizadas por Rio Grande do Sul, Paraná, São Paulo, Minas Gerais e Bahia. Em mais de vinte anos de assinatura do Tratado de Assunção, a integração de facto ainda se concentra nas regiões industrializadas do Brasil, Argentina e Chile.

No que diz respeito às assimetrias interestatais, é preocupante a situação do Uruguai e, sobretudo, do Paraguai, a economia mais frágil do Cone Sul. Nas últimas décadas, o crescimento do Uruguai tem se mostrado dependente da expansão econômica da Argentina e do comércio regional (SOSA, 2010, p. 06). Esta situação não é muito diferente para o Paraguai, que desde os anos 1950 tem o crescimento atrelado ao Brasil (KRAUER, 2009, p. 176). A expansão econômica brasileira nos anos 2000 tem um efeito regional positivo, produzindo ondas de crescimento para economias de menor volume, como as desses dois países e a da Bolívia.

Mas, a primeira lição da experiência européia para iniciativas que visam maior aprofundamento da integração é o fato de que as maiores economias devam arcar com a maior parte dos custos de combate às desigualdades regionais. A segunda, é que esse processo deve alcançar, dentre outros fatores, o desenvolvimento de regiões deprimidas, abrangendo questões como tecnologia, transportes, meio ambiente, turismo, educação e políticas sociais voltadas ao emprego.

\footnotetext{
${ }^{127}$ Esta tem sido uma das preocupações da UE, que apesar de não ter prerrogativas formais em matéria de planejamento do território - uma incumbência de cada Estado-nação (RÜCKERT, 2010, p. 21) - coordena um esforço em busca do desenvolvimento regional. A criação em 1975 do Fundo Europeu de Desenvolvimento Regional (FEDER) para financiar áreas menos desenvolvidas mostra que mesmo as regiões mais ricas dependem de uma agenda multilateral de combate as desigualdades. Na questão territorial, destaca-se o ESPON, programa para o Aménagement du Territoire adotado em 2007, com fins de apoiar a política regional com "... estudos, dados e observações das tendências de desenvolvimento ..." (RÜCKERT, 2010, p. 21).
} 
A restrição mercantilista transforma a integração numa simples mimetização da abertura econômica global em escala continental. De fato, o crescimento da interdependência comercial tem sido importante para 0 fortalecimento da América do Sul. Mas a predominância das trocas comerciais acaba por reforçar as desigualdades regionais que caracterizam o continente. Esse modelo enfraquece o Estado perante às novas escalas de concentração de poder. Se por um lado, caracteriza o Mercosul como um indiscutível sucesso na integração de "áreas ganhadoras", por outro, não privilegia o desenvolvimento de mecanismos multilaterais e supranacionais de combate a exclusão, o desemprego, e o baixo desenvolvimento industrial e tecnológico de áreas "deprimidas".

Porém, a ausência de políticas de combate as assimetrias regionais não é apenas conseqüência do predomínio da orientação mercantilista. Em grande parte, esta fragilidade reflete a condição sul-americana, pois 0 investimento é conseqüência direta da situação econômica de um Estado. Não é por acaso que as primeiras políticas concretas de combate às desigualdades surgem com a retomada do crescimento nos anos 2000. Criado em dezembro de 2004 e estabelecido em junho de 2005, o Fundo para a Convergência Estrutural do Mercosul (FOCEM) é a primeira iniciativa institucional voltada ao enfrentamento das assimetrias entre os Estados partes. Tem como objetivo o financiamento de infra-estruturas de transporte, geração e distribuição de energia, desenvolvimento tecnológico e programas sociais nos países mais pobres e em áreas deprimidas do continente.

Brasil, Argentina, Uruguai e Paraguai financiam respectivamente 70\%, $27 \%, 2 \%$ e $1 \%$ dos recursos do FOCEM. O Fundo possui orçamento anual de US\$ 100 milhões, valor que apesar de insignificante frente às demandas locais, é expressivo no que concerne aos avanços nos investimentos realizados pelos Estados. Desde a sua fundação em 2005, as receitas do Fundo já ultrapassaram a quantia de US\$ 400 milhões (CARTA DE MONTEVIDÉU, 2009, p.01). Mas o FOCEM não é a única iniciativa institucional de combate as desigualdades regionais, embora seja a mais relevante. Destacam-se o projeto de Economia 
Social e Solidária para a Integração Regional ${ }^{128}$ e o Programa de Integração Produtiva. $^{129}$

Essas iniciativas são pequenas se comparadas aos investimentos estatais das maiores economias, porém bastante expressivas se tomarmos como referência os países mais pobres. Deve-se levar em consideração o montante de recursos disponibilizados pelo FOCEM às menores economias. Ao Paraguai, com PIB de US\$ 19,4 bilhões em 2010 (WorldBank Databank, 2011), são destinados 48\% do montante de US\$ 100 milhões do Fundo. O Uruguai, cujo PIB alcançou US\$ 39,1 bilhões no mesmo ano (Op. Cit.), recebe 32\% dos recursos. Apesar disso, a ampliação da estrutura institucional, ainda que corrija deficiências da integração mercantil, é uma tendência ainda incipiente perante os desafios do Mercosul. A característica intergovernamental do bloco (HOFFMANN, COUTINHO \& KFURI, 2008) torna o desenvolvimento da região muito dependente dos Estados.

De um lado, a ampliação da estrutura institucional do Mercosul foi muito mais lenta do que previamente estabelecida pelo Tratado de Assunção, que estipulava um prazo de quatro anos para a integração alcançar o estágio de Mercado Comum. ${ }^{130}$ De outro, a América do Sul ainda é economicamente frágil e suscetível às crises internacionais. Apesar da retomada do crescimento (bastante atrelado aos preços internacionais das commodities) ter fortalecido toda região perante as últimas crises financeiras globais, as profundas assimetrias continentais exigem um volume de investimento muito além da capacidade atual dos Estados Partes.

\footnotetext{
128 "Realizou-se, em 4 de dezembro, a XVII Reunião de Ministros e Autoridades de Desenvolvimento Social (RMADS) do MERCOSUL. Participaram também representantes da Venezuela e do Chile. Foi aprovada proposta relativa ao projeto conjunto "Economia Social e Solidária para a Integração Regional". O projeto deverá ter uma duração de cinco anos e poderá solicitar recursos do FOCEM. Beneficiará um total de 15 municípios fronteiriços, já selecionados pelos quatro países. Entre os seus componentes, destaca-se a criação de Centros de Promoção de Economia Social e Solidária em Zonas de Fronteira (CPESS). Outro tema tratado na XVII RMADS foi a constituição da Comissão de Coordenação de Ministros de Assuntos Sociais do MERCOSUL (CCMAS), proposta pelo Brasil. Entre suas atribuições, caberá à CCMAS elaborar o Plano Estratégico de Ação Social do MERCOSUL." Carta de Montevidéu, 2010, p. 10.

${ }^{129}$ Criado em 2009, o Programa de Integração Produtiva PIP, operacionalizado pelo Grupo de Integração Produtiva (GIP), é um programa do Grupo Mercado Comum. Tem por objetivo contribuir para a complementaridade produtiva das empresas do Mercosul.

${ }^{130}$ Nos Propósitos, Princípios e Instrumentos (Artigo 1) está estabelecido que: "Os Estados Partes decidem constituir um Mercado Comum, que deverá estar estabelecido a 31 de dezembro de 1994, e que se denominará "Mercado Comum do Sul" (MERCOSUL). Este Mercado comum implica: A livre circulação de bens, serviços e fatores produtivos entre os países, através, entre outros, da eliminação dos direitos alfandegários e restrições não tarifárias à circulação de mercadorias e de qualquer outra medida de efeito equivalente; $O$ estabelecimento de uma tarifa externa comum e a adoção de uma política comercial comum em relação a terceiros Estados ou agrupamentos de Estados e a coordenação de posições em foros econômicocomerciais regionais e internacionais; A coordenação de políticas macroeconômicas e setoriais entre os Estados Partes - de comércio exterior, agrícola, industrial, fiscal, monetária, cambial e de capitais, de outras que se acordem -, a fim de assegurar condições adequadas de concorrência entre os Estados Partes, e; O compromisso dos Estados Partes de harmonizar suas legislações, nas áreas pertinentes, para lograr o fortalecimento do processo de integração." Tratado de Assunção (1991). In: http://www.mercosul.gov.br/tratados-e-protocolos/tratado-de-assuncao-1
} 
No que se refere a Unasul, esta situação é ainda mais incerta. Uma Zona de Livre Comércio, ao não ter como objetivo central o aprofundamento institucional, torna as desigualdades regionais uma prioridade distante para as regiões andinas e setentrionais. Além disso, a Venezuela, desde 2009 a segunda maior economia sul-americana, é um dos países que mais tem sofrido o impacto da crise mundial deflagrada em 2008. A queda no preço internacional do petróleo afetou o seu modelo de crescimento, comprometendo assim, a capacidade de investimentos. Os países andinos das redes Central e Setentrional têm suas exportações pouco diversificadas, sendo dependentes das commodities. Além da Venezuela, esse é caso de duas economias expressivas fora do Cone Sul: Peru e Colômbia.

Em suma, destacam-se três características que reforçam as assimetrias regionais sul-americanas. Primeiro, a predominância do modelo mercantilista de integração, que busca mimetizar, por meio do regionalismo aberto, as novas condições da economia mundial em escala continental. Associada ao enfraquecimento do Estado e à hegemonia do mercado auto-regulado tende a incluir áreas mais desenvolvidas e excluir as menos desenvolvidas, constituindo uma integração de facto e uma de jure. Segundo, o baixo aprofundamento da estrutura institucional do Mercosul e a condição de Zona de Livre Comércio da Unasul têm impedido uma ação supranacional no combate as desigualdades regionais. Por fim, as limitações financeiras entre os países sul-americanos têm sido a principal causa da ineficiência no enfrentamento das desigualdades regionais.

\subsection{Assimetrias Econômicas: um Novo Hegemon Regional?}

Dentre as assimetrias sul-americanas, destacam-se também as diferenças econômicas entre o Brasil e o restante do continente. Segundo dados do Banco Mundial (2010) o PIB brasileiro de US\$2,0 trilhões em 2010 corresponde a 57,7\% do PIB sul-americano de US\$ 3,5 trilhões. A retomada do crescimento ampliou a diferença em relação à economia brasileira e a do restante da América do Sul. Essa diferença, que vem se acentuando desde 2008, amplia a importância do país ao continente. Se compararmos o Mapa 5 (p.230) com os demais sobre circulação 
territorial (Capítulo 6) é possível perceber que as forças centrífugas do território e da economia transformam os demais países em satélites do Brasil. Essa "satelitização" é observada de duas formas: através dos fluxos comerciais e dos IED.

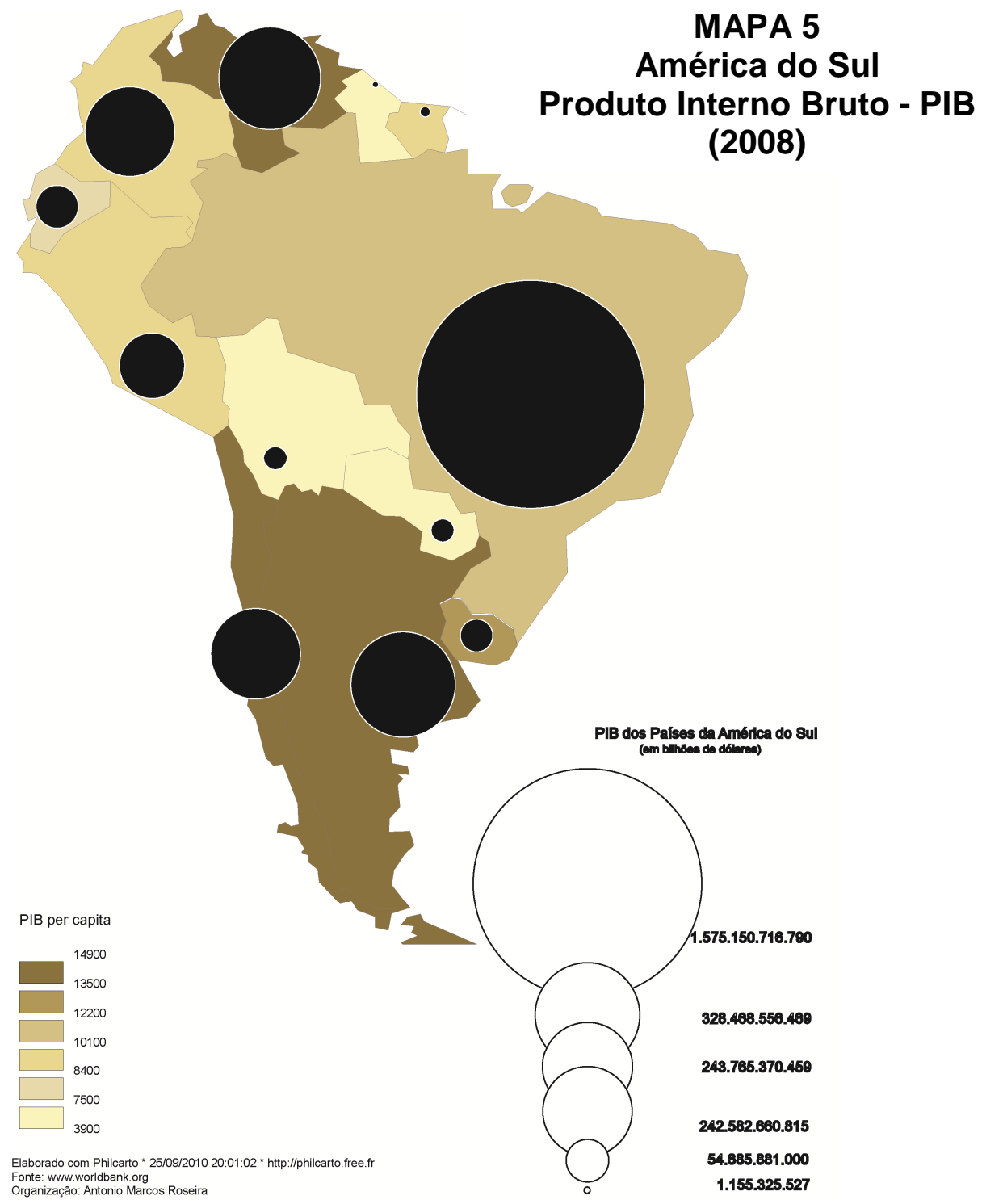

Se por um lado, o aumento do comércio regional expõe a crescente interdependência sul-americana, por outro, desnuda as assimetrias entre as maiores e as menores economias. Essa característica, própria de um continente economicamente tão desigual como a América do Sul, expressa algumas das fragilidades no aprofundamento da integração. Junto às divergências comerciais 
argentino-brasileiras, as assimetrias entre estes dois países e o restante do Cone Sul evidenciam os sérios limites do modelo de integração fundado com o Tratado de 1991.

Essa questão é agravada principalmente pelo desnível do desenvolvimento industrial e tecnológico entre os membros do Mercosul. Comercialmente, estas disparidades ficam muito claras no intercâmbio do Brasil com o Paraguai. Desde 1989, as exportações brasileiras ao país, que tem uma economia maior apenas que as da Bolívia, Guiana e Suriname, avançaram num ritmo muito superior as importações.

O Gráfico 16 demonstra o crescente desequilíbrio no intercâmbio comercial Brasil-Paraguai. De 1989 a 2010, as importações brasileiras provenientes do país foram de US\$ 358 milhões para US\$ 611 milhões, um aumento de 70\%. Nesse mesmo período, as exportações brasileiras a esse destino foram de US\$ 322 milhões para US\$ 2.5 bilhões, expandindo 688\%. Dos dez principais produtos importados do Paraguai pelo Brasil, seis são agrícolas, como arroz e trigo. Dos dez produtos brasileiros exportados ao Paraguai, todos são industrializados (MDICDEPLA, 2010).

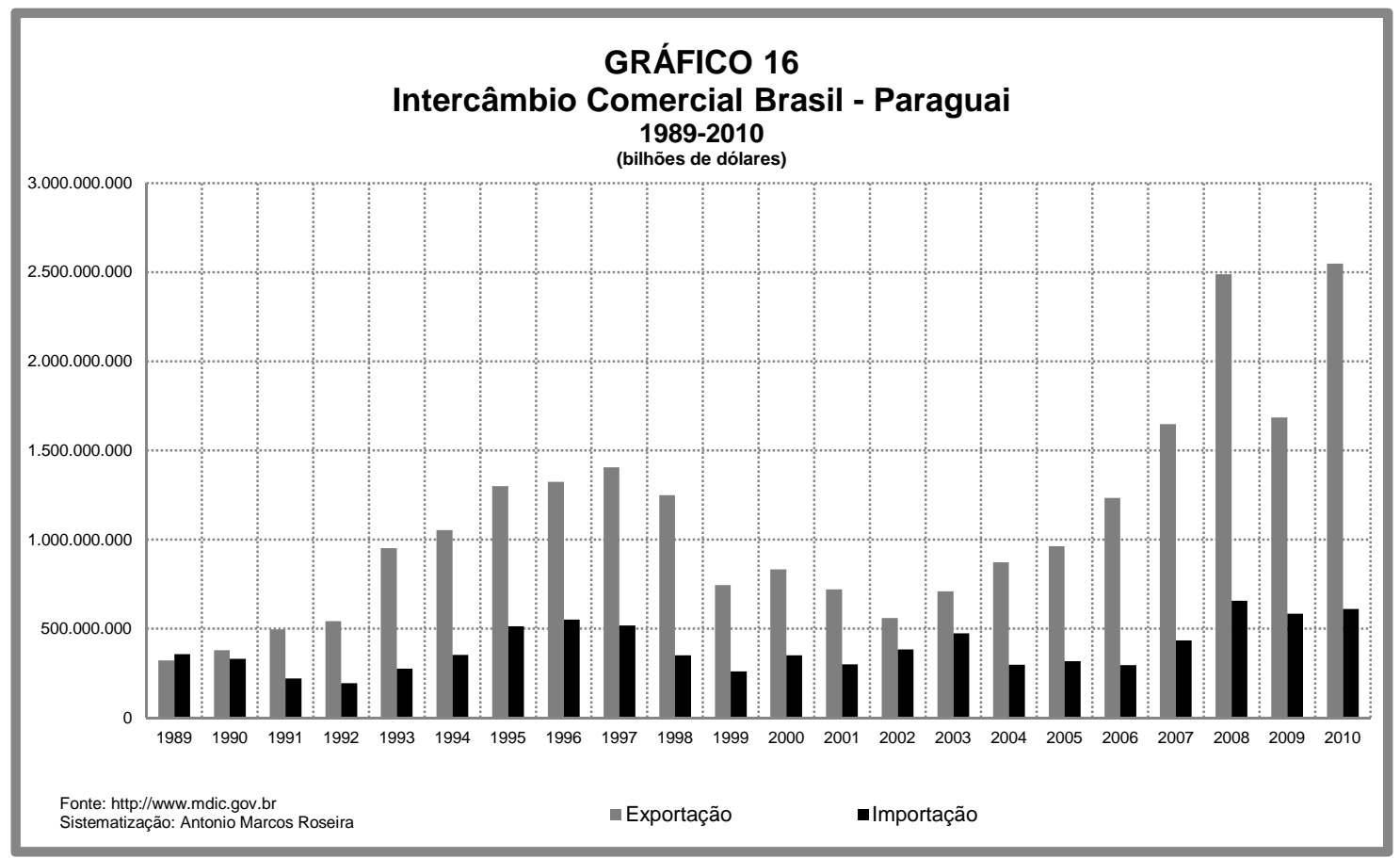

O desnível nas relações comerciais é menor entre Brasil e Uruguai. Como 
evidencia o Gráfico 17, há grande expansão tanto nas importações quanto nas exportações. Entre 1989 e 2010, as importações brasileiras provenientes do país subiram de US\$ 594 milhões para US\$ 1,5 bilhão, um aumento expressivo de 164\%. Já as exportações saltaram de US\$ 334 milhões para US\$ 1.5 bilhão, expandindo $358 \%$. Esse maior equilíbrio é evidenciado pela maior penetração dos produtos uruguaios no Brasil, e pela maior diversidade dos itens exportados pelo país platino. Ainda que muitos dos principais produtos de exportação sejam agrícolas, como trigo, há destaque para itens industrializados, como veículos automotivos.

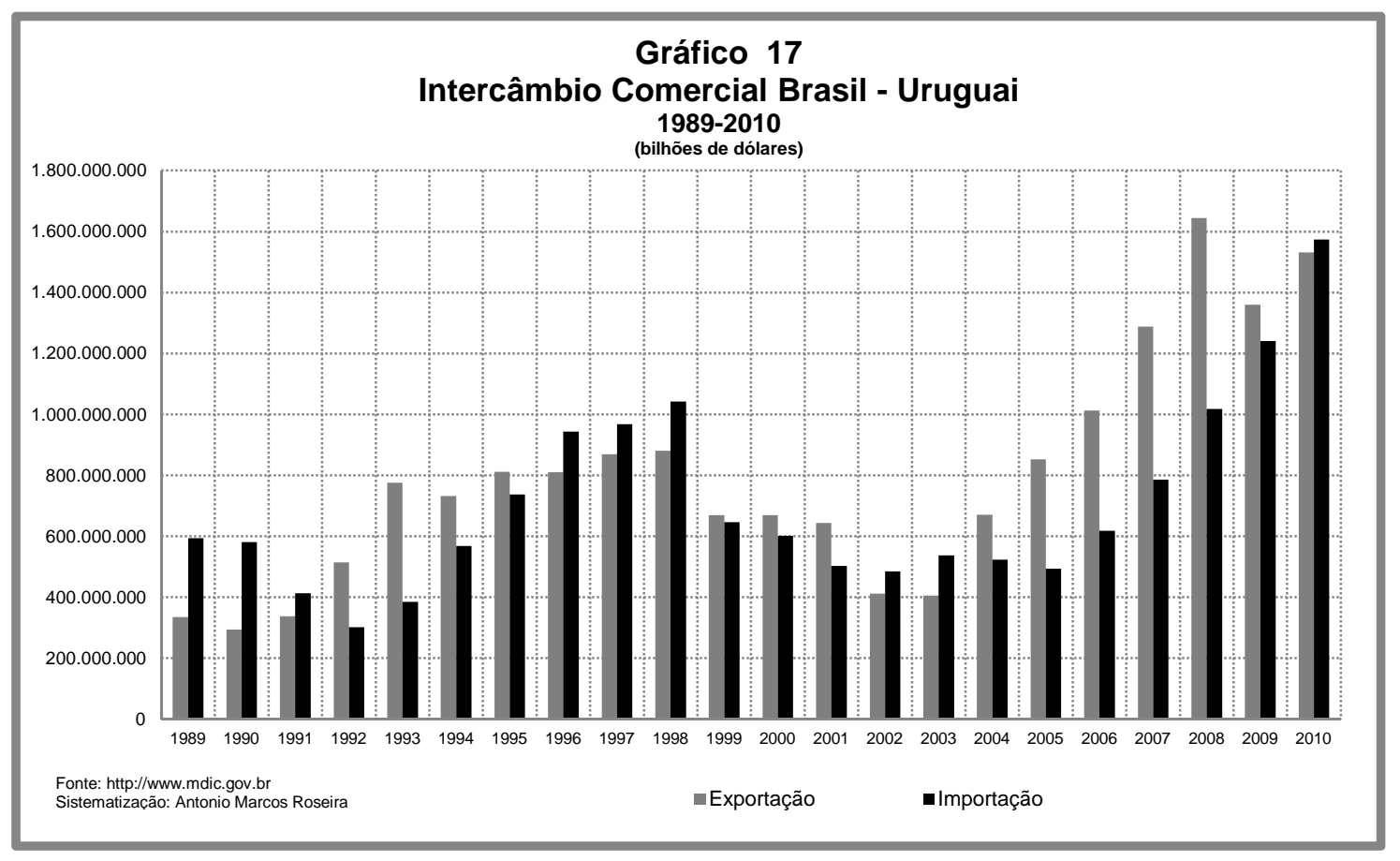

Independentemente da situação de maior ou menor equilíbrio no comércio do Brasil com seus vizinhos, o continente tornou-se fundamental as suas indústrias. $\mathrm{O}$ aspecto essencial que tem definido o intercâmbio comercial entre 0 país e a América do Sul é o caráter setorial (CARVALHO \& SENNES, 1999, p. 25). "As exportações do setor agropecuário são muito reduzidas no mercado regional, enquanto os setores de média e alta tecnologia são bastante expressivos" (Op. Cit.).

As exportações de bens industrializados a essa região, que eram de US\$ 2.8 bilhões em 1989, atingiram 32,4 bilhões em 2010, crescendo 1.058\% (Gráfico 
18). Uma comparação com o grupo dos oito países mais ricos (G-8) mostra a importância da região ao Brasil. A exportação industrial ao G8 cresceu em ritmo inferior àquelas com destino à América do Sul. Entre 1989 e 2010, houve expansão de $123,9 \%$, subindo de US $\$ 12$, 8 bilhões para US $\$ 28,8$ bilhões (Gráfico 19).
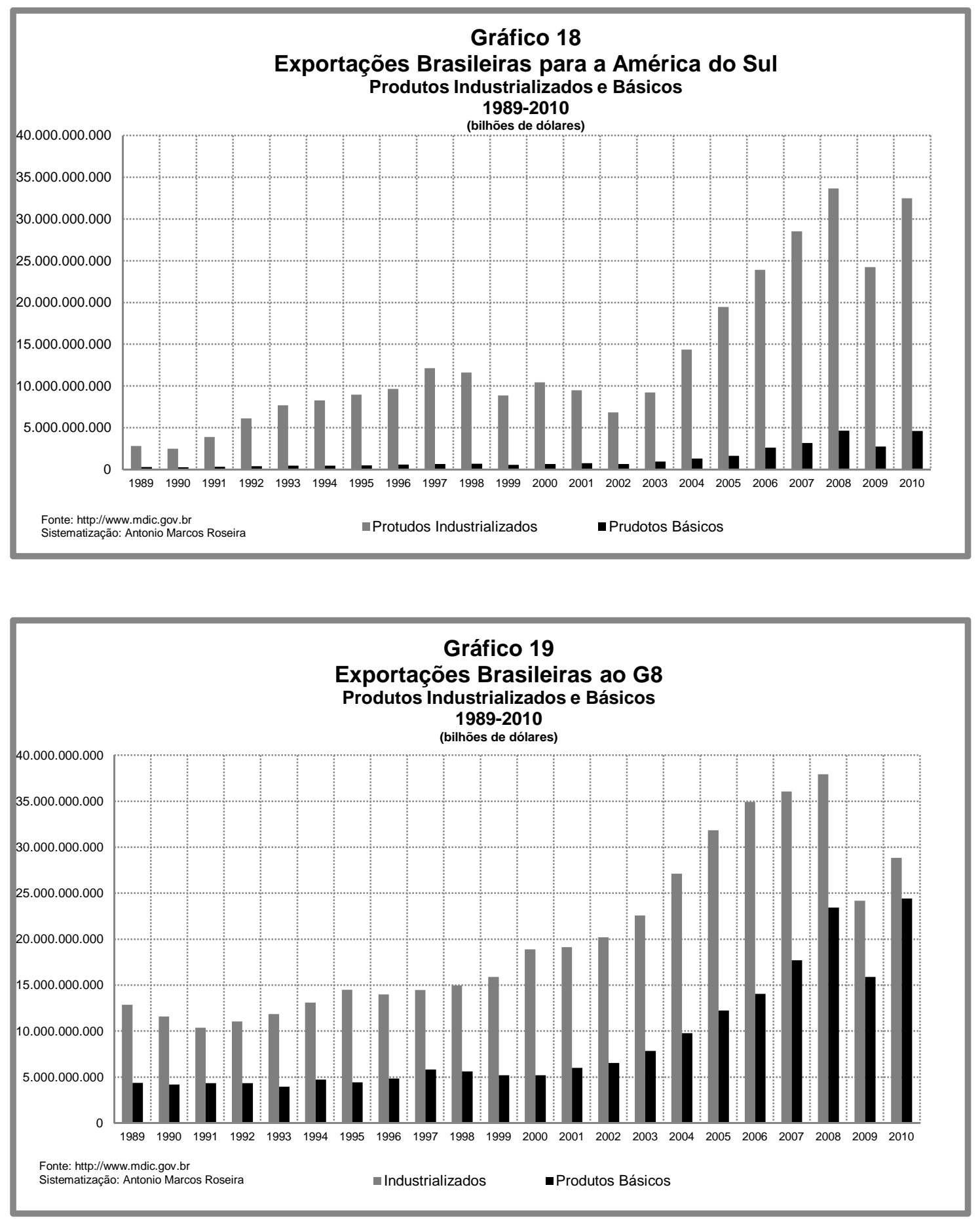
As exportações desse segmento ao continente ganham mais força justamente a partir da assinatura dos acordos que resultaram numa área sulamericana de livre comércio em 2004. Esses dados reforçam o argumento acerca da existência de uma economia geopolítica por trás da integração entre o Mercosul e o restante do continente. $\mathrm{O}$ crescimento da exportação de produtos básicos ao G8, que representava somente $25,3 \%$ das exportações a esses países em 1989, alcançou $45,6 \%$ em 2010 . Isso mostra que o país tem perdido espaço mundial no comércio de bens manufaturados. No entanto, a expansão das exportações industriais a América do Sul confirma o fortalecimento regional do Brasil nesse setor.

A superioridade comercial do Brasil tem dois efeitos para a sua relação com o continente. O primeiro é a possibilidade de crescimento dos países vizinhos, dada pelo aumento das exportações ao seu mercado interno. Se uma economia com PIB de US\$ 2 trilhões é muito significativa no contexto mundial, no âmbito regional é imprescindível para o crescimento dos demais países. A integração, ao facilitar o acesso das demais nações sul-americanas ao mercado do Brasil, faz com que em períodos de crescimento esse país exerça força centrípeta continental. O segundo fator é posto pelas assimetrias econômicas regionais, com o país dominando a exportação de produtos industrializados, principalmente para as nações menores, fator que gera constantes desgastes no modelo atual de integração.

De um lado, há os conflitos comerciais entre as duas economias mais industrializadas do continente. Desde a desvalorização do Real em 1999, é constante a adoção de medidas restritivas por parte da Argentina em relação aos produtos industrializados brasileiros, principalmente aqueles dos setores automobilístico, calçadista e de eletrodomésticos da linha branca (geladeiras, microondas, fogões etc.). Um dos últimos episódios dessa crise crônica foi a retaliação por parte do governo da presidente Dilma Rousseff, dificultando a importação de automóveis fabricados na Argentina - uma reação as barreiras estabelecidas pelo governo da presidente Cristiana Kirchner aos produtos brasileiros. $^{131}$

\footnotetext{
131 A crise entre Brasil e Argentina foi desencadeada em maio de 2011, quando o governo da presidente Dilma Rousseff dificultou a entrada de veículos argentinos (principal produto de exportação do país), aplicando um sistema de "licenças nãoautomáticas", depois de fracassarem os pedidos para a retirada de barreiras a produtos brasileiros, como calçados, auto-peças e eletrodomésticos.
} 
De outro lado, um dos marcos da crise regional é o Tratado de Investimentos e Comércio assinado entre Estados Unidos e Uruguai em 2007, criando um ambiente de incerteza quanto ao futuro do Mercosul. ${ }^{132}$ Sob o governo de George W. Bush, os Estados Unidos assinaram tratados de livre comércio com o Chile, em 2003, e Colômbia e Peru, em 2006. Com o fracasso da ALCA, esses acordos compõem uma estratégia deliberada que visa fracionar o continente, enfraquecer a integração regional e funcionar como containment à liderança do Brasil.

Nessa conjuntura, predominam na América do Sul duas tendências opostas em relação à cooperação. Diferente dos membros plenos do Mercosul, que promoveram a integração ao estágio de União Aduaneira, as principais economias da vertente do Pacífico investem no livre comércio com nações de diferentes continentes. Esses países não fecharam acordos apenas com os Estados Unidos. O Chile, uma das economias mais abertas da região, assinou tratados de livre comércio com grandes potências como China, Índia Japão e UE. O Peru assinou com China, Japão, UE e Coréia do Sul. A Colômbia firmou acordos com Canadá e Suíça.

Sem os ACEs firmados pelo Mercosul com o restante do continente, e a criação da Unasul, o Chile, a Colômbia e o Peru teriam os interesses voltados quase que exclusivamente às potências extracontinentais. É por esse motivo que a Unasul significa uma força de coesão continental, pois busca atrair para a região justamente esse grupo de países que nas últimas décadas tem se mostrado mais susceptíveis as forças de extroversão. No caso específico dos Estados Partes do Mercosul, uma celebração de acordos de livre comércio com países extracontinentais resultaria no fim da tendência de aprofundamento da regionalização.

Prevalece a tendência de arrefecimento nas disposições de aproximação isolada do Paraguai e Uruguai com os Estados Unidos ou outra potência extrabloco enquanto perdurarem os governos de esquerda nesses dois países. $O$ presidente uruguaio José Mujica afirmou em entrevista que uma das prioridades de sua administração será a integração regional. ${ }^{133}$ No entanto, o presidente defende

\footnotetext{
132 O Tratado de Investimentos e Comércio é visto pelos demais membros do Mercosul como um passo anterior ao Tratado de Livre Comércio. Uma das principais vantagens ao Uruguai foi o fim das restrições para exportação de Mirtilo ao mercado americano.

133 "Essa entrevista serve para ratificar que a posição do governo do Uruguai sobre o processo de integração regional não deverá sofrer mudanças radicais. A trajetória política e a moderação no discurso de José Mujica somada à vocação para o
} 
que o Mercosul precisa promover a integração nas áreas das ciências, tecnologias e infra-estruturas, rompendo com o predomínio do mercantilismo (FAGUNDES, 2010).

Esta é uma demanda das menores economias, para quem a regionalização só é atrativa ao promover a redução das assimetrias regionais. Portanto, a integração mercantilista, apesar de ter sido importante para ampliar a interdependência, encontra limites também no atual momento da política sulamericana

Na década passada, as fragilidades desse modelo foram atenuadas pela ampliação de investimentos brasileiros. A atuação das grandes corporações nacionais exerce contrapeso à dominação comercial do país. Com as dificuldades enfrentadas para reduzir saldos comerciais favoráveis ao Brasil, sobretudo pelas menores economias, o crescimento dos investimentos estrangeiros realizados pelas multinacionais é importante por mitigar os efeitos negativos da projeção comercial. ${ }^{134}$

Algo impensável há algumas décadas, grandes empresas brasileiras se tornaram importantes multinacionais, com espaço de atuação privilegiado na América do Sul. No mundo dominado por mega-corporações norte-americanas, européias, japonesas e coreanas, companhias nacionais têm realizado investimentos massivos em vários países sul-americanos nas últimas décadas. Como demonstra estudo da KPMG (2008, pp. 01-20), esse poderio econômico vai além das commodities minerais e agrícolas, projetando-se no setor de indústria e serviços.

Dentre as maiores companhias brasileiras com atuação na América do Sul, destacam-se a presença da Petrobras em nove países, da Camargo Correa em oito, da Gerdau em seis, da CVRD e da Votorantim em quatro e da JBS em três. ${ }^{135}$ Além dessas companhias, AmBev, Natura, Odebrecht, Multibrás, Tigre,

mercado externo do país são fortes indicativos que, a partir da posse do novo presidente, para o governo de Montevidéu, o Mercosul estará definitivamente caminhando para uma plena integração mercantil, tarifária, cultural e política." Pedro Ernesto Fagundes, 2010, pp. 52-53

134 "As dificuldades enfrentadas pelos países sul-americanos relacionam-se, em geral, às próprias deficiências de suas estruturas produtivas, com escassa diversificação e baixa produtividade no setor industrial. Nesse sentido, o investimento por parte das empresas brasileiras, especialmente as que atuam no ramo industrial, pode ser uma ferramenta poderosa para colaborar com o desenvolvimento produtivo desses países, reduzindo as assimetrias econômicas." Fernando J. Ribeiro \& Raquel Casado Lima, 2008, p. 37.

135 Segundo Carvalho \& Sennes (2009, pp. 28-29), a Petrobras atua na Argentina, Uruguai, Paraguai, Chile, Peru, Bolívia, Equador, Colômbia e Venezuela; A Camargo Correa na Argentina, Bolívia, Peru, Colômbia, Venezuela, Paraguai, Chile e Uruguai; A Gerdau na Argentina, Chile, Colômbia, Uruguai, Peru e Venezuela; A CVRD na Argentina, Chile, Peru e Colômbia; A Votorantim na Argentina, Bolívia, Peru, e Colômbia; a JBS na Argentina e Chile. 
Banco do Brasil, Itaú, Marcopolo, Tramontina e Andrade Gutiérrez têm forte atuação no continente.

Segundo relatório do Centro de Estudos de Integração e Desenvolvimento (CINDES, 2010, p. 07), o atual crescimento dos investimentos diretos das empresas brasileiras está relacionado a alguns fatores: a busca por condições estáveis de acesso a mercados; a defesa frente às mudanças cambiais; o aproveitamento de recursos naturais; e, as vantagens conferidas pelas preferências comerciais negociadas por países da região com mercados extracontinentais.

De fato, são os interesses corporativos que mais estimulam a continentalização das redes empresariais brasileiras. Mas esse processo não resulta somente do movimento "espontâneo" propiciado pela integração. Faz parte de uma política deliberada conduzida pelo Estado brasileiro. O Ministério das Relações Exteriores (MRE) “... entende que, daqui para adiante, os investimentos diretos brasileiros tendem a assumir uma posição cada vez mais importante nas relações econômicas do Brasil com seus vizinhos..." (RIBEIRO \& LIMA, 2008, p. 37).

Conforme estudo elaborado pela Confederação Nacional da Indústria (CNI, 2007) o Brasil recupera a partir de 2004, o espaço perdido no final da década de 1990, ampliando sua participação nos fluxos de investimentos internacionais. ${ }^{136}$ Em 2007 já ocupava a posição de segundo maior investidor externo entre os países em desenvolvimento (RIBEIRO \& LIMA, 2008, p. 06). De acordo com outro estudo, realizado pela Conferência das Nações Unidas sobre Comércio e Desenvolvimento (UNCTAD, 2009), o Brasil é o maior investidor estrangeiro da América do Sul. Somente no ano de 2009, o BNDES disponibilizou mais de US\$ 8 bilhões para a expansão internacional das empresas nacionais (UNCTAD, 2010, pp. 48-49).

Nos últimos anos, destacam-se os empréstimos do banco para Venezuela, Argentina, Equador, Peru, Bolívia, Uruguai e Paraguai (SOUZA, 2010, p. 13). Os créditos mais vultosos têm sido aqueles voltados para o financiamento de infra-

\footnotetext{
136 "O investimento brasileiro no exterior permaneceu flutuando entre US\$ 1 bilhão e US\$ 3 bilhões, entre 1995 e 2000 . Após a queda de 1996, houve uma recuperação entre 1997 e 1998, com investimentos dirigidos ao MERCOSUL. Esse patamar permaneceu constante em 1999, 2000 e 2002. [...] Em 2004, os fluxos do investimento no exterior registraram um crescimento excepcional, colocando o Brasil entre os cinco maiores investidores externos das economias em desenvolvimento. Em 2006 os fluxos de investimento no exterior superaram a entrada de investimento estrangeiro. Este resultado reflete a operação de compra da INCO pela Vale do Rio Doce, além da intensificação do processo de investimento no exterior por parte das grandes e médias empresas exportadores." CNI, 2007, pp. 18-19.
} 
estruturas. $^{137}$ É comum esses empréstimos estarem relacionados a atuação de firmas brasileiras, como é o caso da Odebrecht na construção de 3 linhas do metro de Caracas. O caso da atuação da empreiteira na Venezuela é apenas um dos que demonstram que o suporte do Estado não está atrelado somente as firmas estatais.

Segundo estudo da UNCTAD (2010, pp. 48-49) há mais de 900 firmas nacionais com investimentos no exterior, envolvendo desde grandes companhias como Gerdau, Embraer e Votorantim, até as médias empresas. Alegamos no Capitulo 6 que firmas nacionais, sobretudo as do setor de energia, construção civil e siderurgia, têm atuado em toda América do Sul como braços geopolíticos do Brasil. O apoio do BNDES corrobora a tese de que há uma consonância entre os interesses das redes de produção e distribuição das empresas e as redes de poder do Estado. Esta é a base da economia geopolítica empreendida pelo Brasil no continente.

Todavia, como mostra o caso das firmas brasileiras, o papel atual das corporações globais não é idêntico ao que exerceram em boa parte da Ordem Geopolítica da Guerra Fria. Principalmente com o enfraquecimento do Estado, as corporações têm um poder cada vez maior. Mesmo que exista um atrelamento entre os interesses das maiores potências e os de suas firmas globais, as redes de produção e distribuição são também resultado de demandas específicas da economia. Esse raciocínio não tem relação com o antigo esquema de "captura do Estado", que tanto marcou as teorias de leninistas e sociais-democratas (AGNEW, 1998, p. 118). ${ }^{138}$

Mantém-se a consonância geopolítica entre corporações e Estados em determinadas questões, sem esquecer que as demandas corporativas são cada vez mais complexas como demonstra Castells (1999a). A projeção continental das empresas brasileiras nem sempre está subordinada aos interesses geopolíticos do

\footnotetext{
137 "Em 2005 foram aprovadas e contratadas operações pelo BNDES, segundo o BCB (2005), no valor de US\$ 1,1 bilhões. Destacando-se na Venezuela o empréstimo de US $\$ 121$ milhões para construção da hidrelétrica La Vueltosa, US $\$ 108$ milhões para a linha 4 do metrô de Caracas, US\$ 78 milhões para a linha 3 do mesmo metrô e US\$20 milhões para a FONDAPA. Na Argentina pode-se destacar o financiamento dos Gasodutos Norte de US\$ 37 milhões e San Martin de US\$ 200 milhões. No Paraguai o empréstimo para construção da Rodovia Ruta de US\$ 77 milhões e, no Chile, para a ampliação do metrô de Santiago no valor de US\$182 milhões. Em 2007, foi disponibilizado para a CAF, também segundo dados do BCB (2007), e também pelo BNDES, recursos da ordem de US\$200 milhões, visando aprofundar a integração entre o Brasil." Ana Tereza Lopes Marra de Sousa, 2010, p. 14.

${ }^{138} \mathrm{O}$ fato de uma ordem geopolítica não estar necessariamente dependente de um hegemon (AGNEW \& CORBRIDGE, 1995), força a substituição tanto de concepcões realistas, de limitação dos conflitos internacionais aos interesses estatais, quanto de antigas abordagens marxistas que restringem a política ao capital. Nessa ordem geopolítica, marcada por um sistema de governança multi-institucional (HARDT \& NEGRI, 2009), os interesses de Estados e corporações convergem ou divergem conforme as prioridades de suas agendas.
} 
Estado brasileiro, predominando muitas vezes a busca por vantagens exclusivamente corporativas como demonstra o estudo supracitado do CINDES (2010).

A projeção continental das empresas brasileiras nem sempre funciona como força centrípeta a integração sul-americana. Muitas vezes, as firmas nacionais são associadas pelos países vizinhos a uma manobra imperialista. Essa dimensão se tornou bem conhecida com a eclosão da crise entre Brasil e Bolívia em 2006. A nacionalização do setor de hidrocarbonetos e o conseqüente cancelamento dos contratos da Petrobras, cujas atividades em solo boliviano correspondiam a 18\% do PIB do país (DUARTE, SARAIVA \& BONÉ, 2008, p. 92), evidenciam que as assimetrias podem comprometer a posição sul-americana do Brasil. ${ }^{139}$

As assimetrias entre o gigantismo da corporação brasileira e a economia de países como a Bolívia são reveladoras. O PIB boliviano de US\$18,9 bilhões em 2010 (WorldBank Databank, 2011) equivale a apenas 9,9\% do valor de marcado da Petrobras no mesmo ano, que segundo a revista Forbes (2010) é de US\$ 190,3 bilhões.

A crise entre Brasil e Equador eclodiu em 2008, quando o governo de Rafael Correa se recusou a pagar o empréstimo de US\$242,9 milhões concedidos pelo BNDES através da Odebrecht. Inicialmente, a posição equatoriana foi uma reação aos problemas estruturais registrados pela hidrelétrica de San Francisco, construída pela empresa brasileira. Apesar da superação da crise bilateral e o retorno da Odebrecht ao país em 2010, a nova propensão de atritos políticos foi consolidada. Na América do Sul, governos de esquerda têm se mostrado propensos a conflitos quando as assimetrias afetam setores e áreas estratégicas nacionais.

A ampliação da superioridade comercial e econômica confirma que o Brasil vem de fato se consolidando como hegemon sul-americano. A crise financeira internacional contemporânea e o conseqüente enfraquecimento das potências mundiais o tornam uma das principais fontes de recursos na América do

\footnotetext{
139 "Esse quadro de conflitos, inclui também a decisão do atual governo da Bolívia de forçar a abertura de uma complicada rodada de negociações em torno da revisão do contrato internacional para o preço do gás que fornece ao Brasil, um insumo do qual é forte dependente, e que tem sido utilizado principalmente nas suas atividades industriais e no seu programa de ampliação das termoelétricas." Wanderley Messias da Costa, 2009, p. 13.
} 
Sul, região onde a maioria dos países é bastante dependente de financiamento externo.

Através do BNDES, o Brasil tem pouco a pouco, ocupado o papel das grandes potências e instituições supranacionais no continente. Mas as crises com as menores economias sul-americanas revelam mais do que novas orientações trazidas por governos nacionalistas nos últimos anos. Alguns dos conflitos entre o país e os seus vizinhos têm relação direta com resquícios do realismo geográfico militar.

Em alguns aspectos, a continentalização de empresas nacionais guarda semelhança com o modelo militar de projeção econômica do país. À medida que essas companhias, sustentadas pelo financiamento do Estado brasileiro, assinam acordos que não sejam favoráveis a todas as partes envolvidas, abre caminho para o questionamento da própria liderança continental do Brasil. De certo modo, o sentido de cooperação - a base de legitimação da nova política regional - é ameaçado.

Essas situações continuarão exigindo do Brasil um grande esforço diplomático. A disposição de recrudescer uma política centrada nos interesses nacionais atenderia reivindicações de setores políticos e econômicos nacionais, mas poria em risco a integração sul-americana. Essa posição poderia trazer de volta o equilíbrio regional de poder, com os países mais fracos se aliando, de modo formal ou informal, contra o modelo de política continental liderado pelo Brasil.

A política continental fundada na idealpolitik não existe sem custo. A única forma de o Brasil manter a legitimidade, mesmo em relação a conflitos bilaterais, seria aprofundar os mecanismos institucionais de combate as assimetrias. A liderança continental e a posição de "representante regional" na arena internacional não exigem outro caminho senão o combate às disparidades. Instalase um dilema: um país de profundas desigualdades internas não resolvidas tem legitimidade perante sua população e força econômica para resolver assimetrias externas? 


\subsection{Fricções Territoriais e o Retorno da Geopolítica}

A atual ordem sul-americana não pressupõe uma mudança linear do equilíbrio regional de poder para a cooperação. Num cenário marcado pela multidimensionalidade da geopolítica, temas tradicionais acerca do Estado e o território se mantêm como uma das forças que marcam as relações interestatais. É inegável que a primazia do realismo geográfico deu lugar à integração e à cooperação continental. Mas, a geopolítica tradicional ainda perdura, especialmente em temas como fronteiras, recursos naturais, meio ambiente, saída marítima etc.

O realismo geográfico que predominou durante a ordem sul-americana precedente não resultou em nenhuma guerra intracontinental - uma situação que esteve muito próxima com o conflito entre Argentina e Chile sobre o Canal de Beagle. ${ }^{140}$ Ainda que os governos militares tenham tratado aspectos territoriais como norteadores dos interesses nacionais (internos e externos), essa direção não ultrapassou uma conjuntura geral de tensões, rivalidades e de distanciamento político.

Mas é inegável que esse período consolidou os grandes objetivos geopolíticos da maioria dos países da região. Muitos desses objetivos foram absorvidos pela nova agenda regional, manifestando-se através da orientação integracionista. A projeção continental do Brasil, da forma como pensada pelos militares, deu lugar a continentalização do poder comercial e financeiro. Mas em muitos casos, questões estritamente territoriais têm se sobreposto a agenda de cooperação. Tal qual demonstrado pelo conflito armado entre Peru e Equador em 1995, problemas dessa natureza estão presentes desde o alvorecer da nova ordem sul-americana. Mas na última década, sua importância tem sido reforçada com a vitória de governos de esquerda e centro-esquerda, e a revalorização do Estado.

\footnotetext{
${ }^{140}$ Um dos períodos mais graves na relação entre Argentina e Chile ocorreu durante o final da década de 1970, com o recrudescimento da disputa pelas ilhas de Nueva, Picton e Lennox. Estas ilhas permitem o controle do Canal de Beagle, que junto ao Estreito de Magalhães e a Passagem de Drake formam o corredor de comunicação entre os oceanos Atlântico e Pacífico. O conflito entre os dois países terminou com o Chile garantindo o seu controle sobre o canal. A vitória do país foi permitida num primeiro momento pela arbitragem realizada pela Inglaterra em 1977. Entretanto, devido às tensões que quase levaram os dois países à guerra, e também com o repúdio do governo argentino à arbitragem inglesa, a questão acabou passando pela mediação realizada pelo papa João Paulo II em 1978 que assegurou aos chilenos o controle do canal de Drake e das ilhas.
} 
Somam-se às questões territoriais, os diversos impasses relacionados ao comércio. De modo geral, é possível diferenciar as crises nas relações comerciais derivadas das assimetrias regionais - como a relação entre as maiores e as menores economias - daquelas causadas por conflitos de orientação interestatal. Estes últimos têm uma relação com a geopolítica tradicional. Por mais que sejam derivação direta do próprio modelo de abertura comercial adotado pelo Mercosul em 1991, também refletem conflitos de interesses relacionados aos Estados.

Os constantes impasses bilaterais entre Brasil e Argentina em torno do comércio são manifestações de interesses de setores econômicos dos dois países. Porém, por estarem diretamente associados à regionalização, a sua superação depende das relações multilaterais no Mercosul. Embora esses temas envolvam interesse nacional, não possuem a mesma força centrífuga das questões territoriais.

Avaliando apenas a dimensão territorial, é possível destacar os conflitos predominantes no continente. Costa (2009) os diferencia em seis categorias principais: conflitos por demarcação de fronteiras, conflitos ambientais, conflitos de controle fronteiriço, conflitos energéticos, conflitos agrários e conflitos geopolíticos. O Mapa 6 (p. 243) mostra que todos os países estão envolvidos em alguma dessas categorias.

Para Bolívia e Paraguai, os países mais afetados pelas assimetrias territoriais e econômicas no Cone Sul, o fortalecimento do Estado nos anos 2000 exerce um papel ambíguo na nova ordem regional. Por um lado, avigora a cooperação entre os países da região e a oposição a influência de forças externas. Mas por outro lado, as perdas territoriais do final do século XIX e início do XX, e a sujeição ao equilíbrio regional de poder entre 1950 e 1980 fazem da relação dos dois "prisioneiros geopolíticos" com o restante do Cone Sul, um foco de instabilidades.

Até os anos 1980, a posição de "área de amortecimento" que exerciam nas relações entre Brasil e Argentina, tornou temas como circulação territorial, aproveitamento hidroelétrico do rio Paraná e fluxos populacionais transfronteiriços, peças-chave no equilíbrio regional de poder. Decorrência direta da política de satelitização, as relações entre Brasil e Paraguai têm duas fontes principais de conflitos geopolíticos. 


\section{MAPA 6 \\ Conflitos na América do Sul}

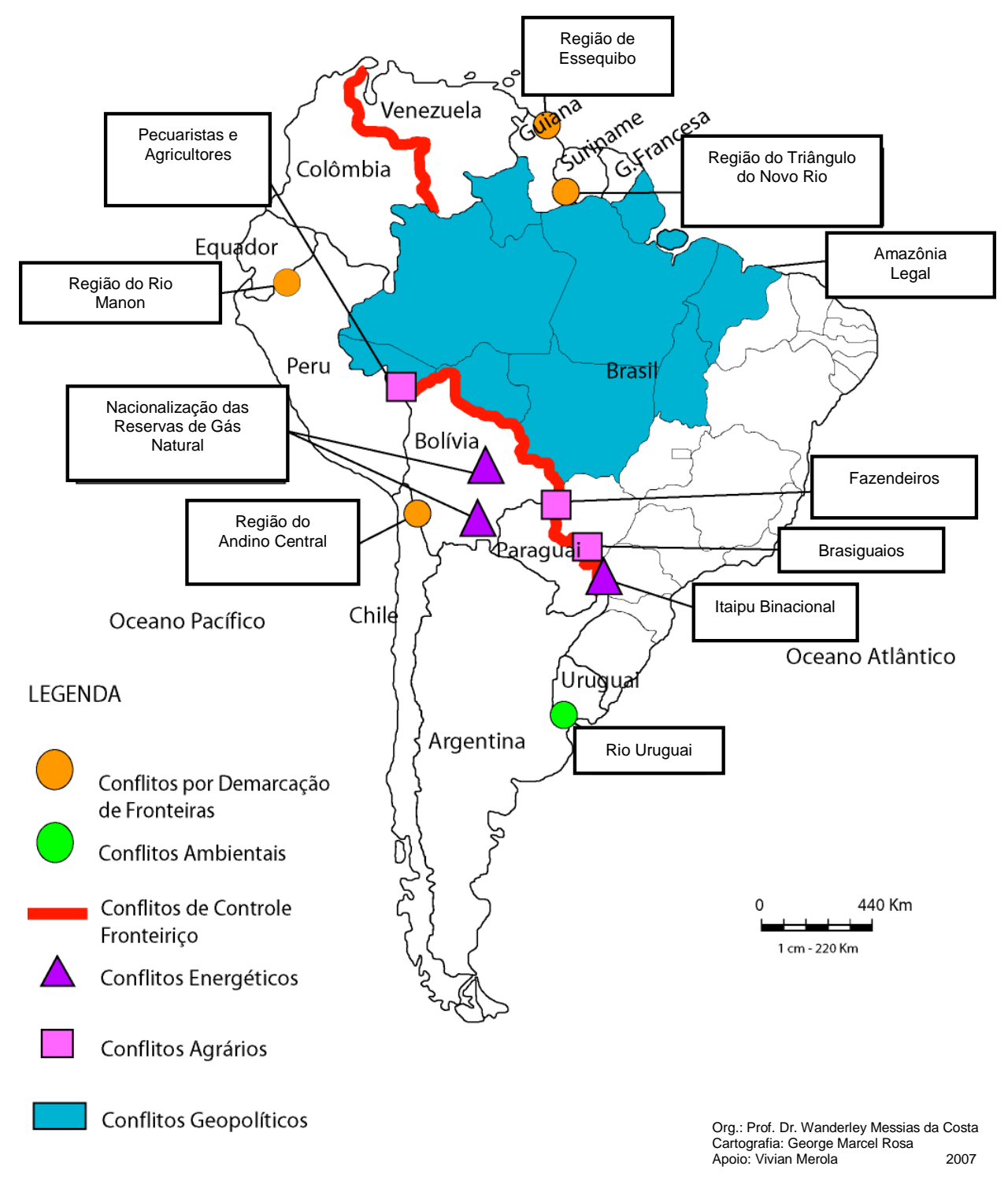

A mais grave é o conflito acerca dos royalties recebido pelo país sobre o excedente de energia produzido por Itaipu. Segundo o Tratado de Itaipu, assinado em 1973 para a construção da usina, o Paraguai tem direito a utilizar 50\% da energia gerada por Itaipu (BLANCO, 2009, p. 03). Entretanto, utiliza apenas $5 \%$, o suficiente para suprir $95 \%$ de sua demanda energética (Op. Cit.). Apesar de o país vender o excedente de energia no valor de US $\$ 45,31$ por megawatts, fica apenas com US\$2,81, sendo o restante abatido em razão da dívida adquirida com 0 
governo brasileiro para a construção da usina (Op. Cit.). A superação dessa grave assimetria foi uma das promessas da campanha presidencial de Fernando Lugo, que promoveu uma discussão nacional em torno da hidroelétrica, representado pelo slogan Itaipu, Lo Justo para Paraguai, associando os demais candidatos ao Brasil.

Desde que Lugo assumiu a presidência em agosto de 2008, a renegociação em torno do valor dos royalties entrou no centro das discussões bilaterais entre Brasil e Paraguai. As relações cordiais entre Lugo e Lula e o enorme superávit comercial do Brasil foram facilitadores para o avanço das negociações bilaterais - mesmo com a resistência de setores da oposição brasileira. ${ }^{141} \mathrm{O}$ novo acordo assinado em 2009 entre os dois países triplica o valor anual recebido pelo Paraguai, passando de US\$120 milhões para US $\$ 360$ milhões (Op. Cit.). ${ }^{142} \mathrm{O}$ aumento é significativo para um país com PIB de US\$19,4 bilhões em 2010.

A migração de agricultores brasileiros ao Paraguai, que no período militar foi importante para a vivificação da região de fronteira (RIBEIRO, 2001; ROSEIRA, 2006), tornou-se uma fonte de conflitos no leste do país. Recentemente têm aumentado as ocupações feitas por sem-terra paraguaios às propriedades de brasiguaios.

Os Brasiguaios são outra grande fragilidade geopolítica do Paraguai (KELLY, 1997). A essa "invasão pacífica" pesa o passado da política de fatos consumados do uti possidetis da diplomacia luso-brasileira como corolário da expansão indireta (MELLO, 1997, p. 189). Mesmo que o contexto de cooperação torne remota a possibilidade de uso de meios diplomáticos e territoriais que predominaram até o século XIX, a história brasileira de expansão para Oeste e a

\footnotetext{
141 Segundo o Jornal do Senado (edição de 13 de maio de 2011), o reajuste do valor dos royalties dividiu os senadores. Políticos da oposição fizeram fortes críticas à mudança do acordo entre os dois países. O senador Itamar Franco (PPS-MG) alegou que o reajuste do valor pago ao Paraguai foi definido por "fatores subjetivos e políticos", lembrando que os consumidores brasileiros seriam diretamente afetados através do aumento da tarifa de energia elétrica. Para o senador Demóstenes Torres (DEM-GO) o reajuste é fruto de um "acordo de companheiros", firmado entre os presidentes Lula e Lugo. Aloysio Nunes (PSDB-SP) exigiu uma política externa sem "companheirismo". Paulo Bauer (PSDB-SC) afirmou que a aprovação da revisão é baseada na ideologia política.

142 "Contudo o acordo não se restringiu a renegociar o regime de exploração e utilização dos recursos hidroelétricos de Itaipu. Em declaração à imprensa após a cerimônia de assinatura do acordo, Lula afirmou que "os países maiores têm obrigação de ajudar com que os países de economia menor possam dar um salto de qualidade na sua capacidade de desenvolvimento, na sua capacidade produtiva, e na competitividade das relações entre os dois países". Nesse sentido, acordou-se a construção, custeada pelo Brasil de linha de transmissão entre a SE Itaipu-MD e a SE Villa Hayes. Além disso, o presidente Lula reiterou a disposição de propor ao Congresso Nacional brasileiro "a criação de um fundo de desenvolvimento regional, a ser alimentado com recursos orçamentários, para apoiar a implementação de projetos de associação industrial e produtiva, com especial atenção aos setores em que se possa desenvolver maior uso industrial da energia no Paraguai, assim como a execução de programas de eletrificação rural". O novo acordo também apresenta projetos de integração física, além de ser oferecido ao governo paraguaio financiamentos com recursos do BNDES16 e do PROEX17 para obras de infra-estrutura." Luis Fernando Blanco, 2009, p.5
} 
característica do povoamento do oriente paraguaio tem claro potencial de instabilidade.

Apesar de fragilizado por estas questões "territoriais", a posição geográfica do Paraguai o torna em espaço fundamental para o acesso a Bacia do Prata e aos corredores de interligação ao Oceano Pacífico - vantagem geoestratégica presente nos antigos discursos geopolíticos do país (KELLY, 1997). Da mesma forma a hidroelétrica garante ao país uma condição central à integração regional (Op. Cit.).

No contexto da integração, a Bolívia ainda se mantém enquanto o país com a mais delicada condição regional. A primeira delas, relacionada aos hidrocarburos, tem sido enfrentada recentemente com o controle nacional da exploração do petróleo e gás natural. Por um lado, esta problemática é comercial, como discutimos no capítulo anterior. Mas por outro, está assentada na geopolítica tradicional, onde o controle dos recursos naturais passa pela soberania sobre 0 território.

Mas a Bolívia enfrenta outros graves problemas regionais, sendo o mais antigo a condição de "prisioneiro geopolítico" - perpetuada com as frustradas negociações visando a saída ao Pacífico. O acesso ao oceano é um grande tema nacional, havendo até mesmo comemoração ao dia do mar. ${ }^{143}$ Desde 1962 , quando houve o conflito bilateral sobre o desvio do rio Lauca ${ }^{144}$, os dois Estados não mantêm relações diplomáticas (MITRI, 2010, pp. 15-16). Esta contenda contribui para tornar sua fronteira com o Chile uma das áreas mais tensas da América do Sul.

Ironicamente, foi durante os governos de Pinochet e Banzer que mais se avançou rumo a solução do problema (Op. Cit.). Os dois governos buscaram traçar um acordo que permitisse o acesso boliviano ao Pacífico, tendo como ponto alto o encontro entre Pinochet e Banzer na cidade boliviana de Charaña no ano de 1975. Se de um lado, a geopolítica militar chilena fora marcada pela preocupação com o "cercamento" posto por Argentina, Bolívia e Peru (KELLY, 1997), de outro, o posicionamento ideológico semelhante entre governos autoritários - apoiados pelo

\footnotetext{
${ }^{143}$ A Bolívia comemora o Dia del Mar todo 23 de março. A comemoração significa uma forma de lembrar a perda da província de Antofagasta para o Chile na Guerra do Pacífico, e uma forma de discussão sobre a necessidade de recuperar o acesso ao mar.

${ }_{144}$ A Bolívia rompeu relações diplomáticas com o Chile em 1962, após os chilenos desviarem de maneira unilateral as águas do rio Lauca. Este é um rio binacional que nasce no altiplano andino no Chile e deságua no lago Coipasa no Departamento boliviano de Oruro.
} 
containment anticomunista de Kissinger e Nixon - permitiu aproximação entre os dois países, quase levando a solução da questão. O corredor que ligaria a Bolívia a Arica discutido entre os dois presidentes não prosperou por oposição do Peru. Por imposição do Tratado de Lima (1929), o Chile deve consultar o governo peruano sobre qualquer negociação para ceder terras de Arica a um terceiro país. $^{145}$

A gravidade desse tema ficou explicita novamente em 2003 com a chamada Guerra del Gas. A decisão do governo de Gonzalo Sánchez de Lozada de construir um gasoduto pra exportar o gás conectando as reservas do departamento de Tarija até o porto de Mejillones em Antofagasta - considerada a saída mais barata para a exportação - contribuiu para o desencadeamento de uma série de manifestações populares. Além das próprias condições internas de não acesso ao gás pela população mais pobre, contribuiu para os conflitos internos a decisão do governo de ligar as reservas de gás ao território chileno (PERREAUT, 2006).

A despeito de 2010 ter representado a retomada das negociações bilaterais, com os dois governos criando uma comissão para analisar o assunto, 0 Chile tem demonstrado resistência em conceder a saída marítima à Bolívia. O presidente Sebastián Piñera afirmou em junho de 2011 que a questão já está totalmente resolvida pelo Tratado de Paz e Amistad de 1904. Após as ameaças do governo boliviano de apelar ao Tribunal Internacional de Justiça, o presidente Morales anunciou em 27 de julho de 2011 que os dois países retomaram as negociações.

Essa perpetuação da condição de país cercado por terras (landlocked) fere as determinações do Tratado de 1904, que obriga o Chile a garantir compensações pela perda da Bolívia do acesso ao Pacífico. O movimento de produtos do país nos portos chilenos não é livre e as suas exportações pagam para cruzar a fronteira (BOLÍVIA, 2004). Segundo o governo boliviano, as disposições do Tratado e acordos complementares são constantemente

\footnotetext{
145 O Tratado de Lima (assinado em 03 de Junho de 1929) surgiu com a disposição de resolver as controvérsias do artigo terceiro do Tratado de Paz y Amistad. O Tratado estabelece que o Departamento de Tacna deve ficar sob a soberania do Peru e o Departamento de Arica sob a do Chile. A necessidade de consulta entre os dois países está posta no Artigo Primeiro do seu Protocolo Complementar: "Los Gobiernos del Perú y de Chile no podrán, sin previo acuerdo entre ellos, ceder a una tercera potencia la totalidad o parte de los territorios que, en conformidad al Tratado de esta misma fecha, quedan bajo sus respectivas soberanías, ni podrán, sin ese requisito, construir, a través de ellos, nuevas líneas férreas internacionales." Tratado de Lima, 1929, p.04.
} 
desconsideradas por questões administrativas, sanitárias ou de segurança (Op. Cit.).

Outro delicado assunto está nas fronteiras orientais, principalmente nos Departamento de Santa Cruz de la Sierra e Pando, devido a imigração de agricultores brasileiros. Impulsionado pelo baixo preço e pela fertilidade das terras, os milhares de agricultores que emigraram para a Bolívia desde os anos 1990 tem contribuído para a modernização da sojicultura no país. Transformaram a porção oriental do Departamento de Santa Cruz na mais importante área agropecuária do país e uma das principais do continente. Mas a presença de estrangeiros tem sido motivo de instabilidades políticas e sociais pela concentração fundiária e pelo envolvimento político. Segundo o governo Morales, os sojicultores brasileiros têm se envolvido no apoio aos movimentos autonomistas (COSTA, 2009, p. 19). Num país onde o separatismo é uma das grandes ameaças, o envolvimento de brasileiro em disputas políticas internas é um potencial de instabilidades e crises bilaterais. ${ }^{146}$

Já na área da Tríplice Fronteira Brasil-Bolívia-Peru destaca-se um fluxo migratório “... que parte principalmente de Brasiléia e Assis Brasil, no Estado do Acre, para a direção de Cobija (Bolívia) e Pucallpa/lbéria (Peru)" (Op. Cit.). Esse evento remonta em menor escala o fluxo populacional no século XIX que garantiu o controle do Acre pelo Brasil. Assim como no Leste Paraguaio, a presença de brasileiros no Departamento de Pando tem resultado em constantes conflitos agrários com a população boliviana que se sente ameaçada pelos fluxos migratórios.

Nesse contexto, ressalta-se que as áreas fronteiriças, apesar de sua inserção em redes migratórias complexas, possuem baixo nível de integração (SOUCHAUD \& CARMO, 2006, p. 16). A migração nessas áreas não é diretamente impulsionada pela integração. Está atrelada ao desenvolvimento de fronts agrícolas no Centro-Oeste e no Norte do Brasil e seu transbordamento para países vizinhos.

\footnotetext{
${ }^{146}$ Na Bolívia, existe o Movimento Nação Camba de Libertação (MNC-L), uma organização separatista que reúne políticos e parte da classe média dos Departamentos de Tarija, Beni, Pando, e principalmente Santa Cruz de la Sierra com o intuído de separar a porção oriental (e não andina) do restante do país. O MNC-L possui uma milícia armada, e conflitos com o governo central resultariam em grande desestabilização política na região, afetando diretamente o Brasil. Primeiro, porque a economia brasileira é dependente do gás boliviano, cuja produção e distribuição seriam diretamente afetados. Segundo, pelo fato de um conflito separatista ter forte potencial de envolver a Venezuela na defesa do governo de Evo Morales. O separatismo ganhou um novo e fracassado capítulo com o plebiscito promovido pelo Departamento de Santa Cruz em 2008. Não reconhecido pelo governo central e nem pela suprema corte do país, o plebiscito visava maior autonomia política, administrativa e financeira. Apesar de mais de $85 \%$ da população ter votado a favor da autonomia, a abstenção superou os $37 \%$. O presidente Evo Morales acusou o governo americano e sua embaixada na Bolívia, de conspiração em favor do movimento de autonomia.
} 
A expansão populacional brasileira na área de soldadura continental, ${ }^{147}$ um meio de garantir a soberania nacional e projeção continental (COUTO \& SILVA, 1969, p. 135), tornou-se fonte de atritos no âmbito da regionalização. Tanto nas relações com o Paraguai quanto com a Bolívia, os fluxos de brasileiros se constituem em poderosa força de pressão a ameaçar a fronteira de jure. Enquanto as políticas de integração transformam o sentido da fronteira, fluxos migratórios que ameaçam a soberania territorial dos Estados ressaltam sua dimensão tradicional. A regionalização persuade os Estados a organizar a fronteira através da porosidade, enquanto que fluxos populacionais a margem da integração exercem força oposta: levam a uma situação de resgate de atritos relacionados ao território.

A situação regional da Bolívia é vital para o avanço da integração. No passado, os grandes temas geopolíticos do país giravam em torno do cercamento posto por Peru, Chile, Argentina e Brasil (KELLY, 1997) e da condição de heartland sul-americano (TRAVASSOS, 1935; TAMBS, 1978; HEPPLE, 2004). Além de não significar a superação do "cercamento", a ordem regional contemporânea mantém a valorização da posição-chave do território boliviano, ainda que sob outra perspectiva. A esse respeito, a diferença é que o triângulo estratégico deixou de ser uma das bases do equilíbrio regional de poder para se tornar um hub logístico continental (PFRIMER \& ROSEIRA, 2009; PFRIMER, 2011). Essa mudança reflete uma nova racionalidade, a logística, que associada à revolução científico-tecnológica, está na base da nova geopolítica (BECKER, 1995, p. 86).

O atual triângulo formado pelas cidades de Santa Cruz, Cochabamba e Tarija (MAPA 7, p. 249), é o mais importante hub logístico da nova ordem territorial sul-americana. Os corredores formados por rodovias, ferrovias, gasodutos, rede elétrica, rede ótica etc., o conectam ao restante da América do Sul, especialmente ao Brasil e a Argentina, sendo uma área fundamental à materialização das interações entre a rede Meridional e a Central e entre as vertentes do Atlântico e do Pacífico.

\footnotetext{
${ }_{147}$ Área de soldadura é um conceito cunhado por Golbery do Couto e Silva (1967) para um espaço que abarca o Centro-Oeste brasileiro, a Bolívia, o Paraguai (exceto sua porção extremo-sul), o extremo oeste paranaense. Esta área é responsável pela conexão entre as bacias Platina e Amazônica.
} 


\section{MAPA 7 \\ Rede Territorial da Bolívia}
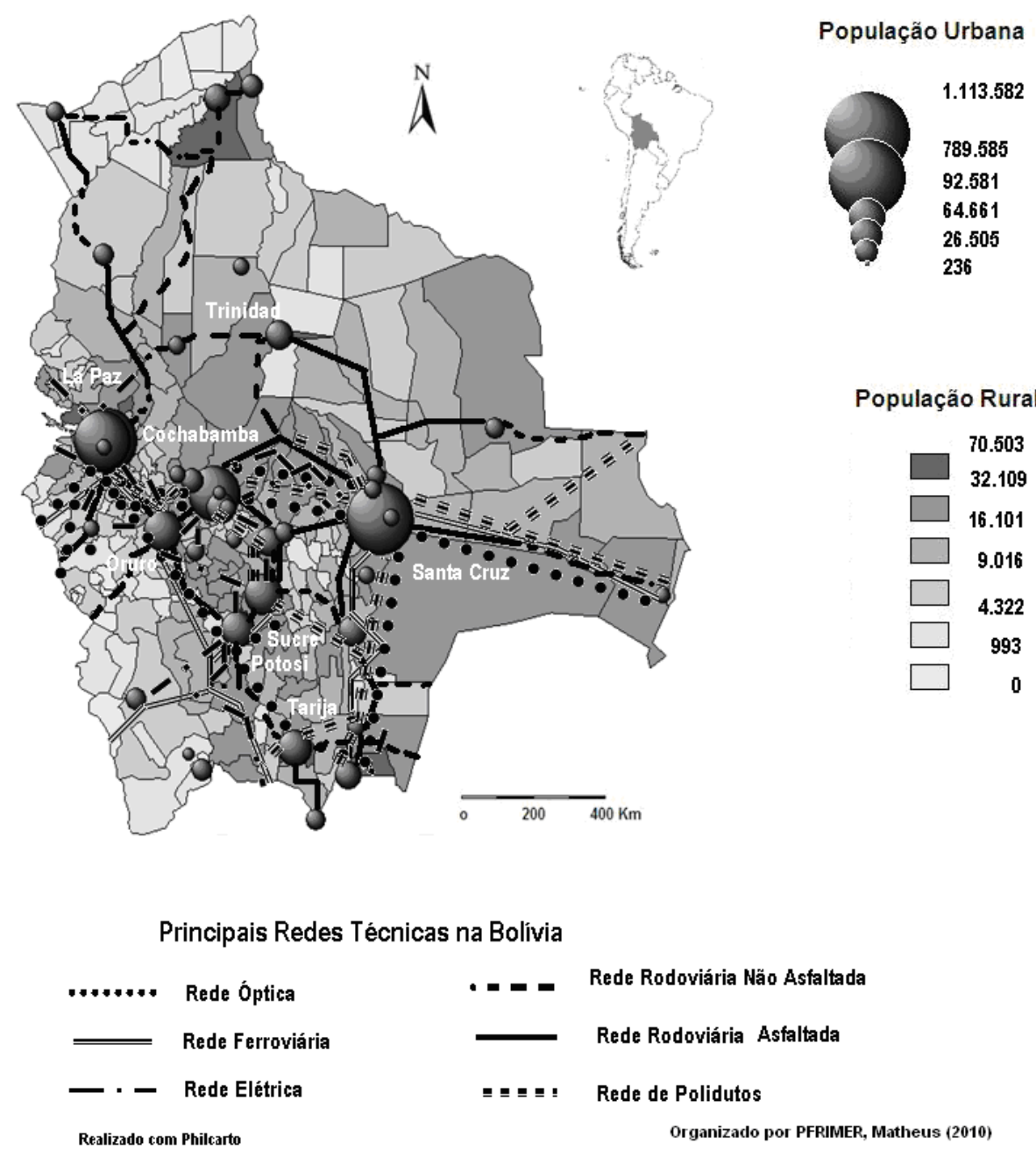

De modo ainda mais problemático que entre os países do Cone Sul, a rede Setentrional foi locus de acirramento das instabilidades geopolíticas na última década. A tendência de enfraquecimento da CAN, intensificada com a saída da Venezuela em 2006, faz parte de uma conjuntura de escalada das tensões regionais. Esse cenário tem como evento determinante a criação do Plano Colômbia em 2000, uma iniciativa do governo colombiano com apoio político, financeiro e militar norte-americano. ${ }^{148}$ A partir dessa iniciativa, as ações

\footnotetext{
148 "O plano inclui principalmente, investimentos maciços na aquisição de equipamento militar sofisticado, treinamento, atividades de inteligência, operações conjuntas a partir de instalações militares e núcleos de apoio diversos (fixos e móveis), dentre outros. Nos últimos seis anos, os gastos envolvidos pelo plano, somados os aportes financeiros dos dois países alcançaram a cifra de US\$ 7 bilhões. Essa presença e as operações militares abrangem praticamente o país inteiro, e com desdobramento no Peru (regiões de lquitos e Pucalpa) e constituem, no limite, um ativo tamponamento das fronteiras com o Equador, a Nicarágua, a Venezuela e o Brasil. O que se desenvolve nesse país, constitui, na verdade, uma guerra híbrida, na
} 
empreendidas contra o narcotráfico e guerrilhas esquerdistas - como o Exército de Libertação Nacional (ELN) e as Forças Armadas Revolucionárias Colombianas (FARC) - não afetou somente as relações entre Colômbia e Venezuela. Em alguns casos, a transfronteirização do conflito ampliou o ambiente de fricções para além da rede Setentrional.

"Países como Equador, Venezuela, Peru e Panamá, bem como o Brasil, passaram a ter problemas em suas fronteiras com a criação do Plano Colômbia." (REIS \& LEANDRO, 2010, p.03). Nesse contexto, as ações militares têm pressionado guerrilheiros e a população civil em direção a territórios vizinhos. A deflagração de uma tragédia humanitária foi uma conseqüência inevitável desse processo. O conflito colombiano foi responsável pela explosão do contingente de desalojados em solo nacional e por um fluxo de centenas de milhares de refugiados em outros países. ${ }^{149}$ As constantes transgressões fronteiriças e operações clandestinas em países vizinhos agudizam os conflitos e tensões interestatais.

Essa situação é apenas compreendida frente a novas concepções de segurança nacional surgidas na ordem geopolítica contemporânea. Enquanto até o início dos anos 1990 a política de segurança nacional dos Estados Unidos para o todo hemisfério se calcava em ameaças representadas por potências externas, hoje, o fator que galvaniza energia em Washington são as migrações descontroladas e o tráfico de drogas (HERZ, 2002, p. 93). O conflito na rede Setentrional é exemplar para o entendimento desse contexto, sobretudo por envolver guerrilhas de esquerdas classificadas como terroristas pelo governo norte-americano.

Desde a implantação, o Plano Colômbia tem enfraquecido a guerrilha e desmobilizado grupos paramilitares (RANGEL, 2009, p. 119). Segundo Rangel (Op. Cit.), a redução da presença territorial, a diminuição dos ataques a força pública, o decrescimento do número de homens armados (de 18 mil para cerca de 7 mil em 2009), a queda da capacidade operacional, e a perda de comandantes, demonstram o enfraquecimento progressivo e irreversível das FARC. Apesar

qual se misturam características de movimentação e combate convencionais de tropas regulares, com as escaramuças típicas de guerrilha na selva." Wanderley Messias da Costa, 2009, pp.20-21.

149 A tragédia dos refugiados colombianos ultrapassa o alcance regional, com parte dessa população migrando para outros continentes. Segundo dados do Alto Comissariado das Nacões Unidas para os Refugiados (ACNUR, 2011), até o início de 2011 existiam 3,5 milhões de desalojados no país e 395 mil refugiados colombianos em outras nações ao redor do mundo. A Colômbia se destaca como o país de origem do maior número de refugiados em todo continente americano (ACNUR, 2007, p. 07). 
dessas transformações recentes, a agenda de segurança dos Estados Unidos para a Colômbia continuará sendo, como já observara Rafael Duarte Villa \& Maria Del Pilar Ostos (2005, p. 22), a mais importante forma de ação americana na América do Sul.

Do ponto de vista regional, a transferência de armamentos feita pelo governo norte-americano e o caráter transfronteiriço do conflito contribuiu decisivamente para uma corrida armamentista entre Colômbia e Venezuela. $\mathrm{O}$ exército colombiano tem empregado armamentos utilizados pelos Estados Unidos nos principais palcos de guerra da atual ordem geopolítica. ${ }^{150}$ Entre 2004 e 2008, a Venezuela promoveu uma expansão dos gastos militares através de acordos de compra de armamentos com a Rússia. Segundo estudo do Center for Strategic and International Studies (CSIS, 2009, p. 03), a cooperação militar entre Rússia e Venezuela desde 2006 é uma resposta ao acordo entre Estados Unidos e Colômbia.

O ponto crítico da relação entre Venezuela e Colômbia se inicia em 2008, quando o exército colombiano invadiu o território equatoriano numa operação secreta que culminou com a morte de Raúl Reyes, o número 2 das FARC. Em outubro de 2009, o anúncio do acordo que dá acesso as tropas americanas a sete bases colombianas eleva ainda mais as tensões entre os dois países. Quando Hugo Chaves, em resposta, congela as relações entre os dois países e ordena redução no comércio bilateral, ameaça o esforço de interdependência econômica regional. A eleição de Juan Manoel Santos em junho de 2010 abriu caminho para a reaproximação iniciada em agosto do mesmo ano. Esse processo também reflete a importância das relações comerciais entre os dois países. Apesar dos recentes conflitos diplomáticos, a Venezuela é o segundo maior parceiro comercial da Colômbia.

Em escala sul-americana, os investimentos do Plano Colômbia é peça central no aumento dos gastos militares. A Colômbia foi o primeiro país a promover aumento significativo dos investimentos no setor de defesa. Em 2001 os gastos militares do país eram de US\$ 5,3 bilhões. Em 2010 esse valor sobe para US\$ 9,1

\footnotetext{
${ }^{150}$ Enquadram-se os helicópteros Apaches que se destacaram como a mais importante peça da estratégia militar americana, tanto na Guerra do Iraque quanto na Guerra do Afeganistão. Empregados com a mais sofisticada tecnologia da engenharia militar, são altamente silenciosos, além de possuírem mísseis teleguiados e sensores que captam movimentos a quilômetros de distância. Todas essas características os tornam praticamente imperceptíveis, proporcionando um altíssimo desempenho na guerra contra terroristas. A entrada desse armamento na cena sul-americana está relacionada principalmente ao fato de os americanos considerarem que a guerrilha de orientação marxista guarda muitos aspectos em comum com a atuação de grupos terroristas.
} 
bilhões, uma expansão de $71 \%$. O Gráfico 20 demonstra que o orçamento militar colombiano foi o segundo maior da América do Sul em toda década, atrás apenas do Brasil.

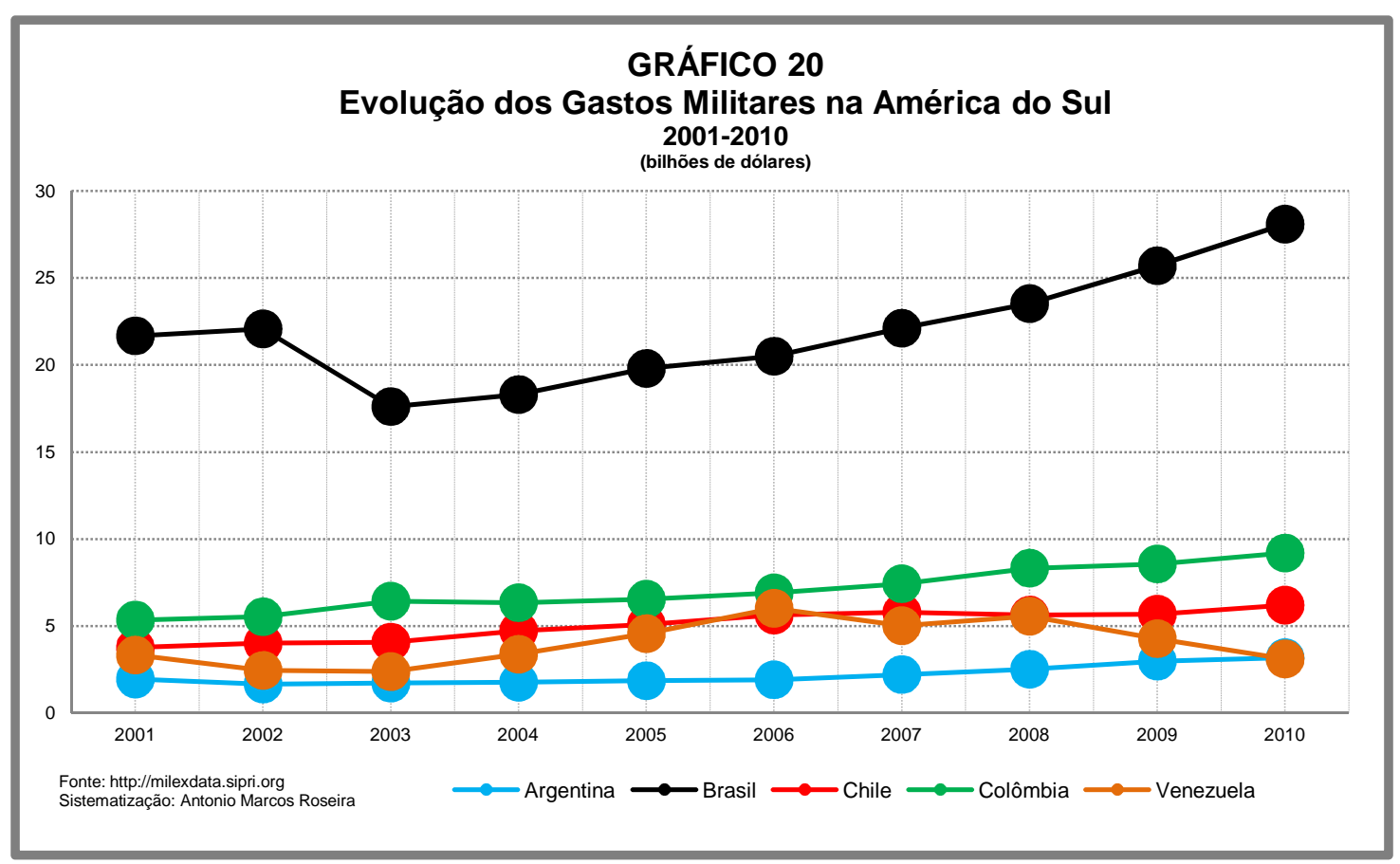

O caso da Venezuela é bastante peculiar. Os gastos militares saltam de US \$ 3,3 bilhões em 2001 para US $\$ 6,0$ bilhões em 2006, uma expansão de 80\%. Todavia, em 2008 se inicia uma rápida diminuição, com esse montante caindo para US\$ 3,1 bilhões em 2010, diminuindo 50\%. Essa tendência, embora ocorra num cenário de enfraquecimento das tensões geopolíticas com a Colômbia, é também resultado da deterioração da economia venezuelana com a crise mundial em 2008.

$\mathrm{Na}$ rede Meridional, o Chile - devido às tensões fronteiriças previamente discutidas - também promoveu considerável expansão dos gastos com defesa. $O$ orçamento militar, de US $\$ 3,7$ bilhões em 2001, alcançou US\$ 6,1 bilhões em 2010. Esta expansão de $64 \%$ coloca o país com o terceiro maior orçamento do continente.

Os gastos brasileiros com defesa também experimentam crescimento. Ao expandir apenas $29 \%$ (bem abaixo dos outros países) passa de US\$21,6 bilhões em 2001 para US $\$ 28,0$ bilhões em 2010. A partir de 2008, o crescimento dos gastos militares do Brasil (superiores a soma do orçamento da Colômbia, Chile, 
Argentina e Venezuela) responde a iniciativa de modernização das forças armadas. O Mapa 8 complementa o Gráfico 20, mostrando as diferenças de gastos militares na América do Sul e a disparidade entre o brasileiro e os dos demais países.

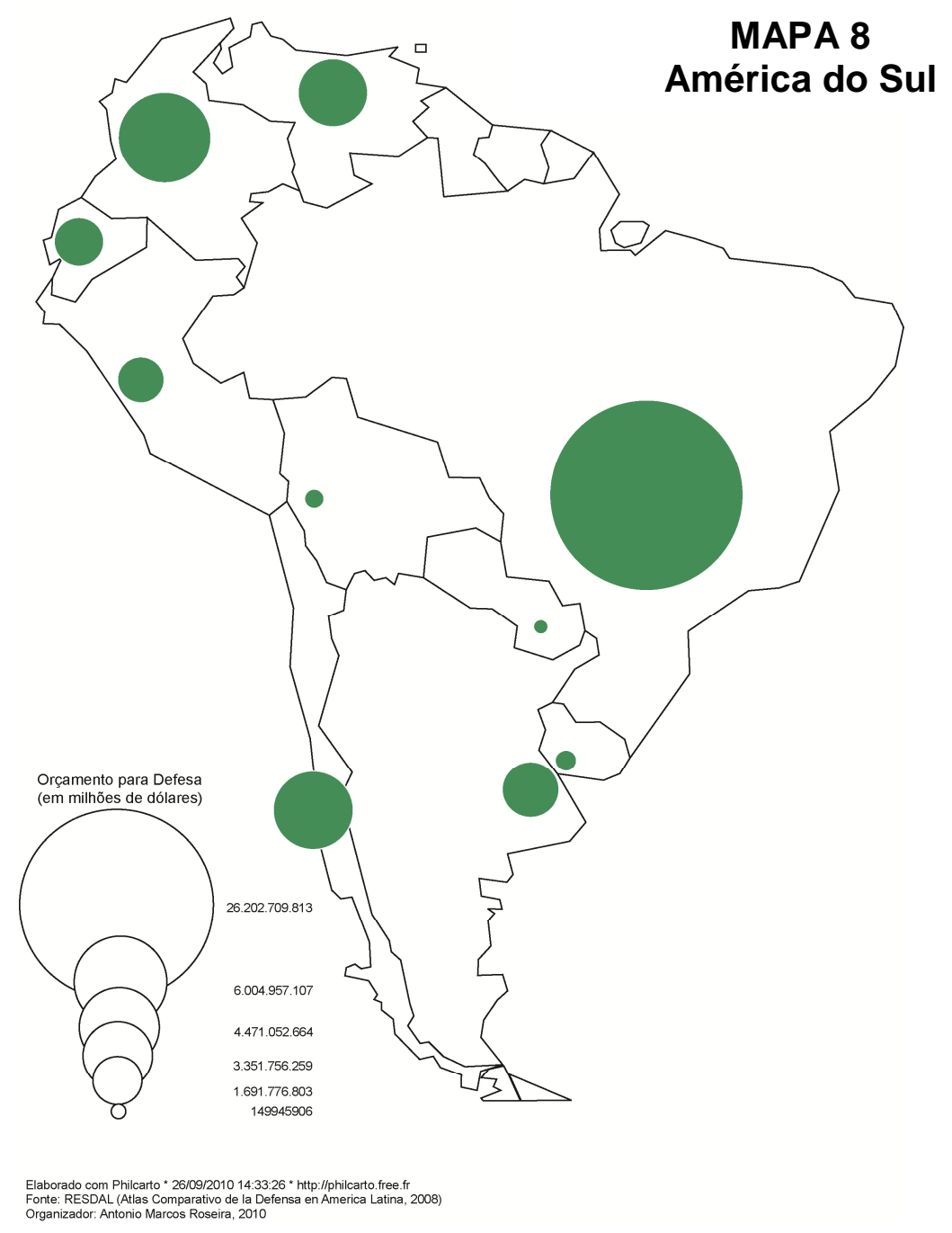

Estabelecida pela Estratégia de Defesa Nacional em 2008, a modernização das forças armadas está relacionada às necessidades prementes de ampliação da presença militar do país na Amazônia e no Atlântico Sul, e às ambições de conquistar um assento no Conselho de Segurança da ONU (SIPRI, 2009, p. 203).

Durante a década de 2000, a Argentina teve o menor gasto com defesa entre as grandes economias continentais, equiparando-se a Venezuela apenas em 2010. Apesar de o orçamento militar argentino ter crescido 62\% de 2001 a 2010, a 
elevação de US\$ 1,9 bilhão para US\$ 3,1 bilhões é discreta frente os demais países.

De um lado, o país não tem as ambições de projeção continental e nem o "fardo" da dimensão geográfica do Brasil. De outro, possui grave problema bilateral apenas com o Uruguai. Ainda que a questão em torno das Papeleras seja uma das sérias ameaças ao avanço da regionalização, não confere a gravidade de outros conflitos geopolíticos. Por outro lado, as relações do país com o Chile, uma das mais tensas e perigosas durante o equilíbrio regional de poder, tem sido marcada pela détente.

Muitas das atuais instabilidades sul-americanas são de fundamento bilateral. Diferentes da ordem continental precedente, não são provenientes do equilíbrio regional de poder. Grosso modo, os conflitos interestatais não "contaminaram" o cenário regional a ponto de fazer ruir a cooperação e a integração, e trazer de volta o realismo geográfico como fundamento da política regional. Além disso, alguns conflitos fronteiriços que foram importantes até algumas décadas atrás têm perdido a primazia nas relações continentais devido à regionalização. ${ }^{151}$ Não são, portanto, responsáveis únicos pela "corrida armamentista".

Deve-se considerar que a expansão regional dos gastos militares faz parte de um processo em andamento em todo mundo. Após o período de 1988 a 1998 quando prevaleceu, segundo estudo do SIPRI (2009), a queda do investimento mundial em defesa - ressurge a tendência de ampliação aguda dos gastos nessa área.

Além disso, muitos dos sérios problemas geopolíticos sul-americanos têm conexão com ameaças postas por potências externas, especialmente os Estados Unidos. Esse entendimento não se refere apenas à problemática relação entre Colômbia e Venezuela. Através da relação com forças externas, questões ligadas

\footnotetext{
${ }^{151}$ A Despeito das instabilidades entre Chile, Peru e Bolívia, importantes disputas territoriais, como as existentes entre Peru e Equador, Venezuela e Guiana, e Venezuela e Colômbia, vêm perdendo força. Isso ocorre pela aproximação dos países e as transformações do cenário regional. As questões entre Peru e Equador, embora não totalmente superadas, têm sido ofuscadas pela aproximação política e econômica entre os dois países nos últimos anos. Os problemas entre Venezuela e Guiana em torno da região oeste do Rio Essequibo, ainda que também não resolvidos, encontram pouco espaço na atual conjuntura regional. O auge da contestação dessa área ocorreu no período em que a Guiana era colônia britânica, tendo como um dos momentos de maior tensão quando o Congresso Nacional da Venezuela aprovou, em 1965, um novo mapa do país, onde a região em disputa passou a constar como Zona de Reclamación (SILVA, 2006). Mas essa demanda se tornou uma possibilidade bem mais distante com a independência da Guiana em 1966. À medida que a comunidade internacional reconheceu a soberania do país, legitimou as suas fronteiras (Op. Cit.). Apesar de esta questão ter adquirido nova visibilidade com o governo Chaves, a atual situação internacional da Venezuela (posta através da entrada no Mercosul e na Unasul, e com as crises políticas e diplomáticas com os Estados Unidos) não permite posição mais radical. Por fim, a reivindicação colombiana sobre o Arquipélago de Los Monjes no Golfo da Venezuela perdeu relevância frente às tensões bilaterais em torno das bases americanas, e devido aos problemas de controle fronteiriço, intensificados com o Plano Colômbia e a guerra ao narcotráfico.
} 
ao território e aos recursos afetam, sem exceção, todos os países e áreas do continente.

Poucos temas sintetizam tão bem essa condição quanto o empenho brasileiro de ampliação da presença na Amazônia e no Atlântico Sul. O fato de a Amazônia se consolidar como área de interesse mundial nas últimas décadas, estabeleceu um desafio de soberania ao Brasil e a todos os países da rede Setentrional.

Deve-se considerar que na atual ordem geopolítica, os discursos sobre o meio ambiente se tornaram baluartes da governança internacional. Como os direitos humanos, a preservação da natureza transformou-se em valor universal. Sob os auspícios das grandes potências, os discursos ambientalistas também serviram para mitigar a soberania dos países pobres sobre porções do seu próprio território. A despeito de esta via ter perdido força após 2001, ainda é uma poderosa forma de exercício de hegemonia das grandes potências sobre países periféricos.

Levando em consideração esta conjuntura, os desafios geopolíticos da Amazônia vão além do fortalecimento da Organização do Tratado de Cooperação Amazônica (OTCA). A ocupação, povoamento, progresso econômico e integração territorial a partir do modelo tradicional, de origem militar, encontram sérios limites na Era da Informação. Tal como defende Becker (2009a, p. 40), hoje é necessário basear o desenvolvimento na evolução científico-tecnológica para atribuir valor à floresta em pé, tornando-a capaz de competir com a agroindústria, a pecuária e a madeira.

Tal como salienta Becker (2009b) a redefinição das relações entre sociedade e natureza pela ciência, tecnologia e informação, traz novas possibilidades de inserção da Amazônia nas relações econômicas. Não há como escapar do discurso ambiental, que expõe necessidades incontornáveis do nosso tempo.

A soberania sobre a Amazônia passa pelo fortalecimento de modelos de desenvolvimento fundados na preservação do meio ambiente e no combate às desigualdades sociais e regionais. Somente essa perspectiva é capaz de evitar a ingerência de governos e organizações estrangeiras na ocupação e uso dos territórios e dos seus recursos, gravíssimas tendências atuais observadas por Costa (2009, p. 18). O “... aprisionamento em uma cada vez mais estratégica 
agenda ambiental internacional ou global..." (Op. Cit.) deve ser evitado colocando a preservação ambiental no espaço amazônico de fato no centro das políticas regionais.

A necessidade de projeção geopolítica sobre o Atlântico Sul requer, além da ampliação do hard power, o aprofundamento da cooperação militar iniciada pelos países com a criação do CDS. O imperativo de fortalecimento dos poderes naval e marítimo é escancarado pelas recentes descobertas de gás e petróleo, que tornam este oceano uma prioridade geoestratégica do Brasil e de toda América do Sul.

A Amazônia e o Atlântico Sul nos conduzem a outra escala geopolítica. Com exceção de alguns temas, como as tensões envolvendo Colômbia e Venezuela, as questões territoriais previamente analisadas passam por uma agenda predominantemente interna. Estas duas áreas relacionam, por outro lado, o continente aos desafios postos pela soberania globalista nesse início de século XXI. 


\title{
CAPÍTULO 8
}

\section{Desafios Globais a Nova Ordem Sul-Americana}

\author{
A reputação de poder é poder, pois ela \\ atrai a adesão daqueles que necessitam \\ de proteção. \\ Thomas Hobbes
}

The international system of the twenty-first century will be marked by a seeming contradiction: on the one hand, fragmentation; on the other, growing globalization

Henry Kissinger

\subsection{Soberania Globalista e a Nova Ordem Sul-Americana}

Durante a Ordem Geopolítica da Guerra Fria, o entendimento da condição internacional da América do Sul passa necessariamente pelo exame do containment. Desde que os Estados Unidos despontaram como a maior potência mundial, a situação internacional de todos os países sul-americanos esteve associada às concepções de governos norte-americanos sobre as ameaças no plano mundial. Entender a região no mundo passava por sua dependência dos Estados Unidos.

Esse processo não muda durante o primeiro período da atual ordem geopolítica (1990-2001), quando essa tendência se mantém através da idealpolitik. Mesmo com o Mercosul, a situação internacional da região estava subordinada à 
governança global que marcou o auge da soberania globalista dos Estados Unidos.

Setembro de 2001 significou o início daquilo que Mackinder (1919; 1942) denomina de powerful momentum e que Arrighi (2008) chama de caos sistêmico um período de ruptura de uma conjuntura internacional através de uma guerra ou de uma crise econômica e financeira profunda. ${ }^{152}$ A "Guerra ao Terror" reestruturou inteiramente a estratégia militar global americana, até então organizada segundo o padrão de conflito da Guerra Fria. Nesse contexto, é necessário entender o alcance das transformações da ordem geopolítica atual à condição da América do Sul.

A atual projeção internacional sul-americana passa por mudanças ensejadas entre o primeiro e o segundo período dessa ordem geopolítica. Essas mudanças não estão circunscritas apenas a economia e ao comércio, envolvendo também a agenda de segurança consolidada com o poder imperial dos Estados Unidos.

Ao debilitar o multilateralismo e as instituições supranacionais, o governo Bush se apóia na confiança de setores políticos conservadores na realpolitik e no uso da força como meio de afirmação do poder no cenário internacional. Se o primeiro período da ordem geopolítica atual fortaleceu a crença na paz perpétua e na vitória inexorável do modelo político e econômico ocidental como advoga Francis Fukuyama ${ }^{153}$ - o segundo resgatou a crença na natureza anárquica da arena internacional por uma via ultra-radical que Costa (2005) denomina de hiperrealista. ${ }^{154}$

\footnotetext{
${ }^{152}$ Se o conceito de Arrighi mantém relação com a economia política, o do geógrafo está circunscrito ao campo da guerra. Mackinder (1942, p. 02) define a guerra como powerful momentum ao considerar a "destruição" por ela causada um meio de transformação do curso da sociedade. Para ele (Op. Cit., p 05), certas tendências da "natureza humana" estão presentes em todas as formas de organização política, e, portanto nas relações internacionais. Estaria na existência dessa natureza a razão dos conflitos e das guerras internacionais. Reflexo dessa condição, o powerful momentum seria um processo inescapável de todas as sociedades em diferentes períodos da história. Esse conceito reflete a concepção hobbesiana realista de "todos contra todos", fortalecida na teoria das relações internacionais após a publicação de Politics Among Nations (1948) por Hans Morgenthau.

${ }^{153}$ A controvertida tese de Fukuyama sobre o "Fim da História" inverte a crença marxista sobre o fim do capitalismo, apostando numa vitória irreversível do Estado liberal. Fukuyama entende que o declínio do comunismo marca o ponto final da evolução ideológica, e que a universalização da democracia liberal é a forma definitiva de governo. Como adverte Costa (2005, p. 39), o conceito trabalhado por Fukuyama não defende o fim dos eventos, sendo empregado no sentido da filosofia da história de Hegel, que o utilizou quando se referiu a vitória do iluminismo sobre as demais formas de pensamento político ou ideológico dominantes.

${ }^{154}$ A política externa norte-americana passou a ser marcada por uma posição hiper-realista com o governo Bush (COSTA, 2005). Em contraste com o realismo clássico, o hiper-realismo questiona a inviolabilidade da soberania do Estado em nome da defesa contra uma "... força militar não-estatal que opera utilizando-se das redes globais disponíveis..." (Op. Cit.). Embora desde o Concerto da Europa a soberania globalista é uma força de restrição à soberania vestfaliana, o hiper-realismo impõe novos limites. A Estratégia de Segurança Nacional (2002) evidencia o alcance do "novo império", à medida que permite ao governo americano violar a soberania em qualquer lugar do planeta, em favor da luta contra o terror. Segundo Costa (Op. Cit.), muitos neorealistas por trás da política externa dos Estados Unidos defendem que pela primeira vez desde o fim da Guerra Fria, o país tem uma verdadeira estratégia para assegurar seu poder sobre todas as demais nações do mundo. Esse posicionamento deixa em segundo plano a agenda multilateralista dos anos 1990. Diversas iniciativas políticas e militares têm
} 
O uso da força se torna o meio predominante na busca por preservar a supremacia americana após 2001. Associado a uma posição universalista, a via militar adotada pelo governo Bush ignora o alerta dos "pais fundadores" da grande estratégia norte-americana. Um dos mais notáveis, Kennan advertia que os Estados Unidos não eram grandes e fortes o suficiente para colocar sob jugo todas as "forças hostis ou irresponsáveis" (GADDIS, 2005b, p. 27). Esta limitação, que sustentou na Guerra Fria a defesa de policy makers sobre a necessidade de preservar o equilíbrio de poder com a URSS, acabou sendo exposta nos últimos anos.

A Doutrina Bush foi delineada pela pre-emption, uma estratégia de ação militar contra qualquer Estado que esteja para lançar um ataque (Op. Cit., 2005a, p. 02). ${ }^{155}$ Se os atentados perpetrados em 11 de Setembro foram realmente possibilitados pela globalização econômica e o adensamento dos fluxos, 0 containment, como praticado na Guerra Fria, se tornou obsoleto (Op. Cit., 2005b, pp. 384-385).

À estratégia lançada pela Casa Branca em 2002, organizações terroristas, por possuírem suporte dos "Estados fora-da-lei", não são ameaças totalmente nãoestatais. ${ }^{156}$ Junto a Guerra do Afeganistão (2001-atual), a Guerra do Iraque (20032010) - que consumiu mais de US\$ 3 trilhões (STIGLITZ \& BILMES, 2008) - é o símbolo da pre-emption. O governo Bush buscou dar legitimidade às ações bélicas levadas a cabo nesses dois países acusados de serem os principais financiadores de organizações terroristas no Oriente Médio, associando os interesses norteamericanos a uma cruzada mundial em defesa de valores universais como a democracia.

A condição internacional dos países sul-americanos, até então subordinada ao poder norte-americano primordialmente através do soft power, passa a ser relacionada a conjuntura internacional definida por um novo poder

\footnotetext{
afirmado o unilateralismo do país no cenário internacional. Na década de 2000, o unilateralismo da Guerra ao Terror, a resistência contra as alterações no Conselho de Segurança, a recusa em assinar o Protocolo de Kyoto, e a permanência de prisões que violam os direitos humanos demonstram que os Estados Unidos se opuseram ao multilateralismo, sobretudo quando ameaçava seus interesses.

155 Gaddis (2005a) destaca duas estratégias: pre-emption e prevention. A segunda se difere da primeira por significar uma ação militar contra um Estado que pode, em algum momento do futuro, se transformar num risco aos Estados Unidos. Para Gaddis (Op. Cit.), o governo Bush fundiu os dois termos usando a palavra pre-emption para justificar o que acabou se revelando uma guerra preventiva contra o Iraque. A substituição de uma pela outra é um sintoma da expansão imperial americana.

${ }_{156}$ Para os Estados Unidos, a pre-emption envolve a ação multilateral quando possível e unilateral quando necessário para conter o "invisível" (Op. Cit. 2005b). A pre-emption não é inteiramente nova, pois foi também empregada durante a Guerra Fria (Op. Cit.). Todavia, após 2001 ela se torna a forma organizacional da geoestratégia mundial americana, substituindo o containment.
} 
imperial. Desta forma, a regionalização passa a ser relacionada, direta ou indiretamente, à nova estratégia norte-americana. A questão da segurança e o "novo" paradigma de conflitos internacionais, apesar de estabelecerem uma conjuntura mundial altamente coercitiva, criam um ambiente inédito a toda política continental sul-americana.

Concomitante ao cenário imposto pela Doutrina Bush, caracterizado pela centralidade do Oriente Médio e Ásia Central nos interesses externos norteamericanos, houve o fortalecimento internacional dos maiores países sulamericanos. Por um lado, isso está relacionado à economia geopolítica da última década. Por outro, não seria possível sem as transformações dos interesses globais dos Estados Unidos.

Como em outros continentes, a via bélica solapou a legitimidade do poder norte-americano na América do Sul. O caráter hiper-realista da Guerra ao Terror, com a violação dos direitos humanos, a expansão do poder militar etc., transformou o pais numa fonte de insegurança mundial. ${ }^{157}$ Os Estados Unidos, cujo poder global se assentava na concepção rooseveltiana de "arsenal da democracia", se transforma em símbolo da coerção, inflando o antiamericanismo em todo o planeta. ${ }^{158}$

Mackinder chamava atenção em Democratic Ideals and Reality (portanto, já no final da Primeira Grande Guerra) para o que denomina de "duas estradas para a tirania": a primeira é a conquista de todas as nações por uma única nação; a segunda é a perversão do "poder internacional" para a coerção de nações forada-lei (lawless nation). Em ambos os caminhos, o poder está em compasso com a coerção.

\footnotetext{
157 "Não se trata [...] de um unilateralismo qualquer como aquele exercido pelo governo Reagan, ou mais remotamente, na virada do século XIX para o século XX, como o que vigorou durante o governo de Theodore Roosevelt. Desta feita, trata-se de política imperial que incorpora alguns elementos da estratégia desenvolvida nos anos 1990, como por exemplo, uma aproximação e um entendimento explícito com as demais grandes potências, como a Rússia e a China e, ao mesmo tempo, uma política de aproximação calculada com as potências regionais emergentes, como a Índia, o Paquistão, o Brasil e a Turquia. Escorada no objetivo prioritário de combate ao terrorismo essa política torna-se um vetor estratégico que tende a tornar letra morta os compromissos anteriormente assumidos com as quase duas centenas de pequenos e médios estados do mundo, a maior parte deles composta por jovens e frágeis nações que tem a expectativa de alguma forma de apoio internacional e, portanto, de um olhar cooperativo por parte da maior potência econômica do globo. Ao contrário, o axioma radical adotado com a estratégia definida em setembro de 2002, segundo o qual "ou você está conosco, ou você está com os terroristas" é emblemático dessa nova doutrina e impõe internamente um maniqueísmo político de difícil superação e, externamente, desenha uma estreitíssima faixa de alternativas políticas para os demais estados do mundo." Wanderley Messias da Costa, 2005, p. 78.

${ }^{158}$ Essa questão tem sido base de muitos estudos sobre o poder unipolar dos Estados Unidos. No que tange ao poder militar, alegam que os Estados Unidos não têm rival no atual momento da historia. A agressividade do país é uma tentativa de barrar a projeção de possíveis concorrentes, não-territoriais e territoriais (ex. China). Para Agnew (1998) aqui está o destino dos Estados Unidos, pois a agressividade pode colocá-lo como inimigo em comum para o restante da humanidade. Um via totalmente contrária à cooperação, que como destaca Kissinger (1994) é a grande contribuição americana as relações internacionais.
} 
Num cenário dominado pelo unilateralismo, os governos "antiamericanistas" no comando das maiores economias sul-americanas se distanciaram dos Estados Unidos. Mas o afastamento e o fortalecimento político e econômico do continente não os tornaram invulneráveis aos desdobramentos da Doutrina Bush.

O continente passa a ser diretamente afetado pela reorganização geográfica do poderio bélico americano. Por um lado, o Pentágono vem diminuindo a presença militar em áreas tradicionais, como a Europa e Ásia-Pacífico. ${ }^{159}$ Por outro, a pre-emption valoriza a presença em espaços periféricos, com destaque para a Ásia Central e América Latina. ${ }^{160}$ Apesar dessa novidade, a operacionalidade da força militar americana objetiva a defesa de áreas do globo que foram centrais ao containment. ${ }^{161}$ A priorização de bases fixas na América Latina, Ásia Central e Oriente Médio provém de um modelo de projeção geopolítica em áreas periféricas, justamente as denominadas de GAP pelo ultraconservador Barnett (2004).

Grosso modo, é possível traçar três influências principais da estratégia dos Estados Unidos à ordem regional sul-americana. Primeiro, o caráter transnacional da pre-emption é uma ameaça a soberania dos países. Segundo, interesses militares americanos podem comprometer a soberania da região na Amazônia e a projeção do Brasil no Atlântico Sul. Por fim, a expansão do poder militar norte-americano no continente é uma séria ameaça a coesão política e econômica regional.

\footnotetext{
159 Costa (2005, pp. 72-87) analisa a reorganização da presença militar americana no mundo, que em conformidade com a Estratégia de Segurança Nacional de 2002, é a mais significativa desde o final da Segunda Guerra Mundial. As principais transformaç̃̃es envolvem o fechamento de bases militares na Europa (Alemanha e Itália) e na Ásia-Pacífico (Filipinas, Coréia do Sul e Japão). O que estimula o fechamento das bases européias é o estreitamento cada vez maior das relações entre Estados Unidos e Rússia. Essa aproximação política diminui os riscos de guerra com o ex-rival da Guerra Fria. Em relação à Ásia-Pacífico, os Estados Unidos observam o fortalecimento da via pacífica da política externa chinesa, com a adesão aos acordos multilaterais e ao regionalismo. O controle diplomático da questão das armas nucleares da Coréia do Norte faz diminuir eventuais ameaças a Coréia do Sul, Japão, Austrália e Nova Zelândia, tradicionais parceiros americanos na ÁsiaPacífico.

160 Segundo Costa (Op. Cit.), as áreas geográficas a se destacarem pela ampliação da presença militar americana nos anos 2000 são a Ásia Central (Afeganistão, Quirguistão e Uzbequistão) e a América Latina (Colômbia, Equador e Peru). A Ásia Central se caracterizou como prioridade para o país após os atentados de 11 de Setembro, sendo considerada uma área de concentração de grupos terroristas. Mas a criação da Organização para Cooperação de Xangai em 2001 permitiu o fortalecimento das relações entre a Ásia Central, a Rússia e China, influenciando no fechamento das bases no Uzbequistão em 2005, e no Quirguistão em 2009. Na América Latina, a ampliação da presença militar visa preservar a influência regional americana.

161 Segundo Costa (Op. Cit.) a estratégia 1-4-2-1 se define da seguinte maneira: (1) defender o próprio território; (4) deter hostilidades em quatro grandes regiões (Europa, Nordeste Asiático, Sudeste Asiático e Oriente Médio); (2) vencer duas guerras simultâneas em duas destas quatro áreas; (1) ter a capacidade de tomar a capital e instalar um governo em uma dessas duas áreas. Os Estados Unidos estão transitando de um modelo de defesa baseado em uma guerra para outro que se fundamenta na capacidade de lutar duas guerras simultaneamente, o que revela a escalada da sua agressividade e a ampliação do poderio militar. De acordo com Costa (Op. Cit.), as prioridades da estratégia global americana são a Ásia Central e o Sudeste Asiático. O desmonte de bases em diversas áreas consideradas estratégicas é também resultado de uma nova operacionalidade do poder bélico do país, que passa a ser baseado em forças móveis, facilmente deslocáveis de uma determinada região para outra.
} 
Em relação ao primeiro aspecto, deve-se considerar que fragilidades territoriais e fronteiriças sul-americanas adquirem uma relevância inédita no mundo. Conforme o controle das fronteiras se torna um dos fundamentos da Guerra ao Terror (AMOORE, 2006), áreas do continente passam a ganhar prioridade.

A valorização de espaços periféricos ao containment pela pre-emption cria uma situação incomum ao tema da segurança na América do Sul. Uma das áreas mais sensíveis à agenda antiterrorista é a Tríplice Fronteira Brasil-ParaguaiArgentina. Localizada na região polarizada pelas cidades trigêmeas de Foz do Iguaçu, Ciudad del Este e Puerto Iguazú, a Tríplice Fronteira é um área, cujo cenário geopolítico singular tem influência sobre toda América do Sul. "Todos os fatores típicos em escala global - contrabando, tráfico de drogas, de armas, lavagem de dinheiro etc. - associados à precariedade do controle da circulação na Tríplice Fronteira, indicam um cenário de insegurança regional" (ROSEIRA, 2006, p. 149).

A região é marcada pela presença de organizações criminosas, como a máfia chinesa e japonesa (BARTOLOMÉ, 2003; ABBOTT, 2005). Nos últimos anos, investigações captaram a presença de conexões terroristas de grupos como Hezbollah, Al-Qaeda, Hamas e Jihad (ABBOTT, 2005; HUDSON, 2003; BOOTE, 2009). A atuação da CIA na região é guiada por pressupostos estabelecidos pela Estratégia Nacional de Defesa de 2002, que visa eliminar as ameaças terroristas antes de chegar as fronteiras americanas (ABBOTT, 2005). Mas é preciso ressaltar que a análise de muitos autores sobre a região está condicionada ao hiper-realismo e à posição americana de expansão do seu poder imperial em todo o planeta.

Nesse sentido, a preocupação americana com a presença de atividades terroristas na Tríplice Fronteira - defendida abertamente, por exemplo, pelo diretor do FBI, Robert S. Mueller (FBI, 2003) - faz parte de um procedimento de legitimação de sua expansão imperial. Exatamente por isso, toca num aspecto delicado da segurança regional: a fragilidade frente à agenda de uma potência externa. 
De fato, a América do Sul não representa perigo a comunidade internacional, tendo, ao contrário, contribuído com missões de paz pelo mundo (ROJAS ARAVENA, 2005, pp. 53-77). Mas é inegável que existe um ambiente de insegurança regional na Tríplice Fronteira. Apesar de essa problemática fronteiriça perder relevância internacional após o arrefecimento do neoconservadorismo - um processo consolidado com a eleição de Barack Obama ${ }^{162}$ - a Tríplice Fronteira é uma síntese do caráter transnacional que envolve os temas relacionados à segurança continental. Em grande parte, essa posição na ordem regional sulamericana ocorre pelo fato de a área polarizar um núcleo logístico que integra o Nordeste Argentino, o Leste Paraguaio e o Oeste Paranaense ao resto do continente. ${ }^{163}$

\section{Com o aumento da sensibilidade dos organismos internacionais e} Estados nacionais em relação às atividades ilegais (MACHADO, 1999, p. 25), os problemas fronteiriços se destacam como um dos pontos cruciais da segurança continental. Mas a diversidade de crimes e problemas relacionados ao controle da fronteira Brasil, Paraguai e Argentina não deve ser reduzida a agenda antiterrorista americana. $^{164}$ Se de um lado, os problemas dessa área se enquadram num

\footnotetext{
162 O neoconservadorismo perde força na política externa norte-americana em dois momentos. O primeiro ocorre a partir de $2005 \mathrm{com}$ a escolha de Condoleezza Rice para o Departamento de Estado. Portanto no início do segundo mandato do presidente George W. Bush. Como lembra Antonio Patriota (2008, p. 100), a recusa ao diálogo com governos tidos como hostis e a tomada de decisão sem preocupação com a aceitabilidade internacional foram substituídos por um "renovado realismo" com a chegada de Condoleezza Rice. O neoconservadorismo começa a ser substituído por uma visão mais pragmática "ou realista" das relações internacionais. Para Patriota (Op. Cit.), exemplo dessa tendência é a aposta diplomática em 2005 no tocante ao processo de desnuclearização da Coréia do Norte. Washington manteve diálogos com China, Rússia, Japão e as Coréias. Também sobre o Irã, os Estados Unidos passaram a apoiar negociações lideradas pelo Reino Unido, França e Alemanha em 2005. O segundo momento teve início em 2008, quando o hiper-realismo perde ainda mais espaço com a eleição de um governo democrata e a crise econômica deflagrada em solo americano. Esta crise redireciona as prioridades diplomáticas do país.

${ }_{163}$ Em escala local, a Tríplice Fronteira conecta o Oeste Paranaense ao Nordeste Argentino e ao Leste Paraguaio. A mesorregião paranaense - que se desenvolveu com o avanço da sojicultura nos anos 1960 (IPARDES, 2003b) e consolidou posteriormente um sistema produtivo baseado na indústria agropecuária em torno da soja e do abate de suínos, bovinos e outras reses (PERIS, 2002; PERIS \& BRAGA, 2002; IPARDES, 2003a) - possui uma das mais densas redes de municípios da fronteira brasileira. O sistema logístico da região, apesar da deficiência em transporte sobre trilhos (MARTINS, 2001), é bastante integrado ao restante do território brasileiro e aos demais países do Mercosul. Além da característica produtiva que aproxima está área do Nordeste Argentino e do Leste Paraguaio (LIMA, 2002), a malha territorial local permite a fluidez continental de atividades relacionadas ao crime e ao contrabando. Devido ao fato de o Oeste Paranaense, o Nordeste Argentino e o Leste Paraguaio comporem um corredor logístico continental, a circulação de mercadorias contrabandeadas, o tráfico de drogas, além de toda sorte de atividades ilegais na fronteira, têm grande força de disseminação pelo espaço sulamericano.

${ }^{164}$ A temática da criminalidade na Tríplice Fronteira não deve ser tratada exclusivamente pela defesa dos limites territoriais. É estarrecedor que num cenário de integração, grande parte das atividades ilegais - e justamente aquelas que mais envolvem o esforco de coibição das instituicões estatais - é composta por um comércio popular que sustenta parcela significativa da população que vive na informalidade nas grandes cidades brasileiras. Se uma parcela desse comércio envolve o contrabando de produtos pirateados, uma parte considerável é de mercadorias cuja circulação está atrelada à baixa (ou nula) carga tributária paraguaia e às variações cambiais. Esse é uma tema a ser tratado por uma agenda de integração fronteiriça no
} 
cenário de expansão imperial dos Estados Unidos, servindo de justificativa a militarização da relação do país com a América do Sul, de outro, as limitações no controle fronteiriço remetem a uma situação regional relacionada às relações econômicas e sociais.

No campo econômico, consolidou-se um circuito comercial que envolve desde áreas adjacentes a região até bairros ou áreas de comércio popular em pequenas, médias e grandes cidades brasileiras. No que tange a criminalidade, o contrabando de drogas, armas e carros roubados, canalizados pela Tríplice Fronteira afeta todas as regiões sul-americanas, com destaque as zonas tecnoindustriais.

A fronteira possui um "efeito radiação" através dos fluxos materiais e informacionais, que por meio das linhas de força, alcançam as áreas de concentração do vetor tecno-industrial. Os efeitos da dinâmica fronteiriça sobre o restante do território variam conforme sua nervura, sendo mais intensos quanto maior a densidade dos sistemas logísticos. A fronteira-faixa é alargada por uma fronteira-rede. A Tríplice Fronteira, um dos casos mais emblemáticos do mundo, demonstra o efeito radiação com os fluxos materiais alcançando a escala continental.

No Brasil, na geopolítica clássica de Rodrigues (1947), Golbery do Couto e Silva (1967) e Meira Mattos (1975), a fronteira é pensada exclusivamente a partir da relação interestatal. Hoje, os interesses em torno da Tríplice Fronteira, tanto sob o hiper-realismo americano, quanto sob a agenda regional, passa por uma perspectiva multidimensional. Embora esta região seja a maior síntese sulamericana dessa tendência, áreas de fronteira em todo continente são zonas de fragilidade.

É o caso das zonas de fronteira na rede Setentrional, cuja imensidão da Amazônia e a presença do cultivo e contrabando de drogas se tornou central à

interior do Mercosul, que passe pela criação de um regime específico para o comércio nessas áreas fundamentais à cooperação. 
agenda internacional, conforme discutido previamente. Enquanto na rede Meridional a problemática fronteiriça está relacionada à maior fluidez da ilegalidade, na rede Setentrional o fator preponderante está na baixa densidade da nervura territorial e na conseqüente deficiência da capilaridade territorial do Estado.

Mas os problemas políticos e econômicos relacionados à fronteiriça são maiores conforme o nível de (in) governabilidade. ${ }^{165}$ Lembramos com Raffestin (1993) que a fronteira é um subconjunto do limite territorial, que por sua vez revela de um modelo social historicamente desenvolvido. ${ }^{166}$ A fronteira (e o limite territorial) não funciona isoladamente do restante da sociedade. Assim, o tema da segurança suscitado pelas fronteiras sul-americanas leva necessariamente a uma discussão sobre um modelo político, econômico e social no continente. Os desafios fronteiriços das redes Meridional e Setentrional não passam somente pela definição de uma agenda pontual. Estão atrelados a amplas transformações regionais.

As instabilidades políticas, econômicas e sociais, os grandes fatores de vulnerabilidade da região como salienta Rojas Aravena (2005), aprofundam os problemas relacionados à criminalidade e à ilegalidade, fortalecendo interesses externos. Dessa forma, as instabilidades regionais, sejam elas referentes as fronteiras, aos recursos naturais ou ao meio-ambiente, estão necessariamente atreladas a discursos geopolíticos que fundamentam a hegemonia globalista norteamericana.

\footnotetext{
165 Usamos (in) governabilidade a partir de Francisco Rojas Aravena (2005) que faz referência às inúmeras crises que fragilizaram a governabilidade na região nas últimas décadas. Rojas Aravena (Op. Cit.) destaca as grandes crises financeiras, o desemprego, e os problemas de baixo crescimento econômico entre os principais fatores de vulnerabilidade interna e externa da região.

166 "O limite, a fronteira a fortiori, seria assim a expressão de uma interface bissocial, que não escapa à historicidade e que pode, por conseqüência, ser modificada ou até mesmo ultrapassada. De fado, desde que o homem surgiu, as noções de limite e de fronteira evoluíram consideravelmente, sem, no entanto nunca desaparecerem. É evidente que os significados do limite variaram muito no decorrer da História. Não há por que se admirar, pois o limite é um sinal ou, mais exatamente, um sistema sêmico utilizado pelas coletividades para marcar o território: o da ação imediata ou da ação diferenciada. Toda propriedade ou apropriação é marcada por limites visíveis ou não, assinalados no próprio território ou numa representação do território: plano cadastral ou carta topográfica. Toda função é também marcada por limites frouxos ou rígidos que determinam sua área de extensão ou de ação. Nesse caso, os limites estão em estreita relação com o trabalho, portanto com o poder. Limites de propriedade e limites funcionais podem coincidir, superpondo-se, ou, ao contrário, se recortarem. Mas vê-se logo que na qualidade de sistema sêmico, os limites são utilizados para manifestar os modos de produção, isto é, para torná-los espetaculares. O limite cristalizado se torna ideológico, pois justifica territorialmente as relações de poder." Claude Raffestin, 1993, pp. 164-165.
} 
Não é por outro motivo que os problemas fronteiriços da rede Setentrional se misturam com desafios geopolíticos maiores da Amazônia. Se sob o multilateralismo a Amazônia é considerada uma área de ingovernabilidade a partir dos direitos humanos e da destruição ambiental, para a linha coercitiva predominante nos anos 2000, a região é também um risco à segurança internacional. São tendências opostas que levam a mesma situação de subordinação.

Os discursos geopolíticos envolvem o emprego de representações do espaço, que por sua vez guia as praticas espaciais centrais de uma ordem geopolítica (AGNEW \& CORBRIDGE, 1995, p. 47). É necessário aos países que compõem uma determinada ordem regional superar as imposições de discursos sobre o território e o poder gestados pelos hegemons globais. Mas afora uma situação de caos sistêmico na ordem mundial, a superação de limitações à soberania na América do Sul é apenas possível com desenvolvimento econômico e social.

Paralelamente a estas duas dimensões e considerando o fortalecimento da via coercitiva na atual ordem geopolítica, a expansão do uso da força é uma necessidade incontornável às principais lideranças sul-americanas. De fato, num primeiro momento a corrida armamentista reflete o aumento de tensões regionais. Mas essa tendência também acompanha (como previamente analisado) a expansão dos gastos com armamento em todos os continentes. Ainda que a "corrida armamentista global" seja resultado de uma conjuntura maior, os interesses mundiais relacionados à exploração de recursos são uma das causas centrais.

A América do Sul, com grande concentração e diversidade de recursos naturais, desperta grandes interesses internacionais envolvendo petróleo, gás natural e diversos minérios. Como chama atenção Philippe Le Billon (2001; 2005), a abundância de recursos naturais em regiões pobres (com Estados fracos ou 
falidos) é também uma poderosa fonte de instabilidades internas. Em muitos casos, fomenta a espoliação, os conflitos civis e a subordinação a uma economia geopolítica global que tende a trazer pobreza no lugar de desenvolvimento. Há uma economia política da guerra com participação decisiva dos recursos naturais. ${ }^{167}$

As disputas por recursos naturais não resultou em guerras internas ou graves conflitos regionais na atual ordem sul-americana. Mas os recursos naturais foram uma fonte de espoliação com a falência de muitos países e as subseqüentes privatizações. Nos últimos anos, privatizações de setores mineralógicos significaram a espoliação de recursos da região por grandes corporações globais. Isso é problemático num continente onde o controle estatal de recursos energéticos é um símbolo de soberania (LINKOHR, 2007, p. 55). Este é um dos temas sensíveis à regionalização sul-americana, na qual a integração no setor dos recursos energéticos tem se caracterizado como um dos vetores (SIMÕES, 2007, p. 25).

Como mostram Edmilson Moutinho dos Santos (2003) e Michael Klare (2004), as disputas por recursos energéticos são historicamente caracterizadas por uma ação sinérgica entre o Estado e o capital. A Segunda Guerra do Iraque é considerada a primeira por petróleo no século XXI (MOUTINHO DOS SANTOS, 2003).

A política em torno do petróleo tem sido responsável por guerras, dominação colonial e várias doutrinas de política externa (AMIRAHMADI, 1996, p. 445). Há uma confluência entre os interesses energéticos de corporações

\footnotetext{
167 Conflitos internos por recursos naturais têm sido comuns nas últimas décadas, com destaque para os países africanos. Commodities primárias são facilmente (e pesadamente) taxadas, constituindo-se em atrativos tanto para a elite no comando de um país, quanto para seus competidores (LE BILLON, 2001). Atualmente, os conflitos por recursos são motivados pelo prêmio de controle do Estado ou territórios, enquanto proporciona aos grupos armados a pilhagem necessária para compra de equipamentos militares (Op. Cit.). Esse tipo de conflito tende a ser comercializado, isto é, caracterizado pela integração do comércio de recursos naturais em sua economia, e pela mudança de uma agenda política para uma agenda de interesses econômicos privados (Op. Cit.). Mas os recursos são fontes de conflitos políticos internos também em regiões mais desenvolvidas que o continente africano, como a América do Sul. Ainda que os recursos não tenham a mesma influência em conflitos internos como demonstrado no caso da África, o controle sobre gás, petróleo, minérios e água, ocupa lugar central nas disputas políticas em muitas nações sul-americanas. Especialmente naqueles países com menor economia, como Paraguai e Bolívia, a discussão envolvendo a soberania sobre os seus recursos tem ocupado lugar privilegiado nas últimas eleições. No caso boliviano, as recentes guerras do gás e da água tiveram importante influência nos novos rumos políticos do país.
} 
nacionais e o governo norte-americano. O fato de a guerra no Iraque não ter sido definida exclusivamente por recursos naturais não impediu que corporações americanas fossem as mais privilegiadas pelos novos contratos de exploração petrolífera. $^{168}$

Evidentemente, não é possível fazer uma comparação direta entre o Oriente Médio e a América do Sul no que se refere a conflitos internacionais por recursos naturais. Ao contrário daquela região, na atual ordem geopolítica a América do Sul não esteve no centro de um conflito internacional envolvendo petróleo, gás ou outro recurso. Mas nem por isso, a reativação da IV Frota em 2009 foi ignorada pelas lideranças da região. O presidente Lula relacionou a reativação às recentes descobertas brasileiras de petróleo (BATTAGLINO, 2009, p. 38).

A ativação da IV Frota faz parte de reestruturação global da presença militar americana. Até recentemente, o Atlântico Sul era o único oceano em que as forças militares do país não estavam institucionalmente presentes. O novo pressuposto de organização militar através de forças móveis se soma a estratégia da presença americana na região por meio da ampliação das funções do Comando Sul. ${ }^{169}$

Os Estados Unidos defendem a ativação da IV Frota como um modo de “... demonstrar o compromisso com seus sócios regionais, melhorar a efetividade

\footnotetext{
${ }^{168}$ Esse não é apenas um aspecto da política do Governo Bush, e remete à "parceria público-privada" (KLARE, 2004) que domina a agenda americana sobre recursos energéticos desde o início do século XX; uma tendência ilustrada pelo célebre acordo entre o presidente Roosevelt e o rei saudita Ibn Saud em 1945, à bordo do USS Quincy no Canal de Suez. As motivações da investida do Governo Bush são muito diferentes daquelas que fundamentaram o lançamento da Doutrina Carter em 1980, a mais explícita política dos Estados Unidos referente aos recursos energéticos no Oriente Médio. Essa doutrina, apesar de prever o uso da força como meio de garantir os interesses norte-americanos na região frente a qualquer ameaça a segurança energética, não demonstrou o extremismo da Doutrina Bush, que impôs a guerra e a expropriação unilateral dos recursos naturais de um país. Embora a doutrina de 2002 visasse em primeiro lugar o combate ao terrorismo global e não exatamente o uso da força como resposta à ameaças aos interesses energéticos no Oriente Médio, o petróleo e o gás natural dessa região estão irremediavelmente ligados às prioridades público-privadas que dominam a agenda energética dos Estados Unidos.

169 "Em 1990, ele [Comando Sul] incluiu entre as suas missões a defesa diante das chamadas ameaças "emergentes" e "não tradicionais", principalmente o tráfico de drogas. A Ata de Autorização de Defesa de 1990 estabeleceu que o Departamento de Defesa deveria desempenhar o papel principal na luta contra o narcotráfico. Até 1995, o Pentágono e o Poder Executivo argumentaram que o aumento da presença militar norte-americana na região era necessário para apoiar os programas antidrogas. Em 2002, o Congresso aprovou uma "expansão da missão" para as operações do Comando Sul. A ajuda e o treinamento que anteriormente estavam limitados à luta contra as drogas, agora poderiam ser utilizados para combater o narcoterrorismo e a narcoguerrilha. A Área de responsabilidade do Comando Sul expandiu-se em 1997, ao incluir o Mar do Caribe, o Golfo do México e uma parte do Oceano Atlântico, que anteriormente era responsabilidade do Comando do Atlântico. O comando conta atualmente com 17 instalações de radar (principalmente na Colômbia e Peru), três Espaços de Segurança Cooperativa (CSLs, Aruba, Curaçau e Comalapa, El Salvador) e duas Bases Militares (Guantánamo, Cuba, e Soto Cano, Honduras)." Jorge Battaglino, 2009, p. 36.
} 
das missões marítimas que permitem promover e fortalecer à construção de coalizões, fomentar relações com outras nações e dissuadir agressões." (Op. Cit.). Os questionamentos das lideranças sul-americanas à reativação estão na incongruência da via adotada pelo país. Como ironiza Battaglino (Op. Cit.) é improvável que se tente melhorar vínculos com uma região mediante a mobilização de uma frota. Com um discurso anacrônico, os Estados Unidos buscam legitimar a militarização como um meio de aproximação com a América do Sul.

O modo de interferência na política por meio de golpes militares, o enfraquecimento do hiper-realismo e a crise econômica deflagrada em 2008 tornam improvável uma ação bélica dos Estados Unidos contra países da América do Sul. Apesar dos norte-americanos não assinarem a Convenção das Nações Unidas sobre o Direito do Mar (CNUDM) $)^{170}$ - não reconhecendo oficialmente as Zonas Econômicas Exclusivas (ZEE) - o país tem respeitado áreas marítimas dos signatários.

Ainda assim, as descobertas brasileiras de gigantescas reservas de petróleo em sua ZEE reforçam as necessidades de projeção de um poder marítimo sul-americano no Atlântico Sul. Mesmo em cenários globais de cooperação, o poder militar é um dos pilares da ordem geopolítica. Não se trata de naturalizar a dissuasão como faz Colin Gray (2003, p.01), considerando-a tão antiga quanto à sociedade humana. No entanto, a dissuasão entre Estados continua uma das forças das relações internacionais após a Guerra Fria. Mas na atual ordem sulamericana, o hard power se faz necessário como empenho regional ante ameaças externas.

\footnotetext{
170 Conforme estabelecido pela CNUDM (1982), a soberania de um Estado costeiro se estende além do seu território, alcançando uma zona marítima adjacente designada como Mar Territorial. Os Estados costeiros têm o direito de fixar a largura do seu Mar Territorial em 12 milhas marítimas. Além dessa área, eles têm o direito a uma Zona Econômica Exclusiva, com direito à exploração, gestão e preservação de recursos naturais. Portanto, o Brasil possui 12 milhas de Mar Territorial e 200 milhas de ZEE. Os Estados Unidos, mesmo não sendo signatários do acordo, adotaram estas referências para suas zonas marítimas.
} 
Apesar da reorganização do Comando Sul e da ativação da IV Frota, há no Atlântico Sul um grande "vácuo geopolítico". Ao contrário do Índico ou do Pacífico, esse oceano não possui projeção maciça de um poder militar global ou regional. É nesse contexto que é pensada a Estratégia Nacional de Defesa (END) de 2008. O desafio abrange a conjuntura global de aumento dos gastos militares, a recente projeção militar americana na região, e um processo de integração continental que busca a autonomia regional sobre o território e os recursos naturais.

Ainda que os Estados Unidos tenham mantido uma política de dependência energética em relação ao Oriente Médio (KLARE, 2004), o National Energy Policy (2001), relatório do National Energy Policy Development Group que visa orientar as políticas energéticas do país, defende a diversificação de áreas de fornecimento de petróleo. A América do Sul e o Atlântico Sul estão entre as indicadas.

A END tem como objetivo preencher lacunas estratégicas (territoriais e tecnológicas) brasileiras, buscando a consolidação de temas centrais desde a ascensão da geopolítica militar. Um deles, a inserção do Brasil na vigilância do Atlântico Sul, buscada desde os anos 1970, ainda não ocorreu (ALBUQUERQUE, 2010a, p. 78). Uma das bases da END foi o lançamento da Política Nacional da Indústria de Defesa (PNID, 2005) visando o fortalecimento da Base Industrial de Defesa (BID). ${ }^{171}$ A recuperação da BID é indispensável para tornar o Brasil uma potência militar, servindo para orientar os investimentos em defesa estabelecidos pelo END. ${ }^{172}$

\footnotetext{
${ }^{171}$ Alguns dos objetivos que demonstram o alcance da PNID ao fortalecimento da BID estão postos nos seguintes artigos: "Art. 3ㅇ A PNID tem como objetivo geral o fortalecimento da BID. Art. 4 Para a consecução do objetivo geral da PNID, concorrem os seguintes objetivos específicos: I - conscientização da sociedade em geral quanto à necessidade de o País dispor de uma forte BID; II - diminuição progressiva da dependência externa de produtos estratégicos de defesa, desenvolvendo-os e produzindoos internamente; III - redução da carga tributária incidente sobre a BID, com especial atenção às distorções relativas aos produtos importados; IV - ampliação da capacidade de aquisição de produtos estratégicos de defesa da indústria nacional pelas Forças Armadas; V - melhoria da qualidade tecnológica dos produtos estratégicos de defesa; VI - aumento da competitividade da BID brasileira para expandir as exportações; e VII - melhoria da capacidade de mobilização industrial na BID."

${ }_{172}$ O ciclo de investimentos para modernização das forças armadas iniciados com a END se completará em duas décadas. Entre os principais investimentos em andamento, o Le Monde Diplomatique Brasil (2009) destaca: a aquisição para o exército brasileiro de 250 de carros de combate Leopard 1 A5 da Alemanha em 2006; a restauração do porta-aviões São Paulo entre
} 
A END resgata a questão do desenvolvimento espacial, cibernético e nuclear para a organização da Defesa (Op. Cit. 2010b, p. 48). Além disso, prega a necessidade de novas parcerias estratégicas para a modernização das forças armadas e reforma dos organismos internacionais (Op. Cit.). A disposição de estabelecer parcerias com os países que possam contribuir para o desenvolvimento de tecnologias de ponta para a defesa (BRASIL, 2008, 43) reforça a tendência inaugurada no governo Geisel de ampliação de aliados estratégicos.

Em relação às fragilidades internas, a END destaca as regiões de fronteira, a Amazônia e o Atlântico Sul, como áreas que justificam a expansão do poder militar. E esse entendimento pressupõe uma posição chave à regionalização, valorizando a integração das bases industriais de defesa. ${ }^{173}$ Dessa forma, a ampliação da capacidade de defesa que se estenderá pelas próximas décadas visa também preservar a estabilidade regional através da cooperação militar. ${ }^{174}$ Não por acaso, a EDN nasce no mesmo ano em que é criado o CDS na Unasul. Na atual ordem, não basta uma estratégia nacional fundamentada na dissuasão; uma postura pacífica e preventiva como advoga Meira Mattos (2007a). Em matéria de defesa, os países da região devem se aproximar por objetivos similares.

2005 e 2009; a incorporação em 2008 do NDCC Garcia D’Ávilado, e em 2009 do Almirante Sabóia, navios de desembarque pesado. Referente ao acordo Brasil-França, o jornal detalha um conjunto maior de investimentos para os próximos anos. Dentre eles, a construção de seis fragatas da classe Fremm (navio de 137 metros de comprimento e tripulação de 108 pessoas) nos estaleiros do Arsenal da Marinha no Rio de Janeiro, que passa por um processo de modernização. A fabricação de quatro submarinos da classe Scorpène, além de um maior do mesmo modelo para acomodar um reator nuclear desenvolvido pela Marinha do Brasil. Os Scorpène serão construídos no Brasil e o custo total do projeto é de US\$ 9 bilhões. A compra de 51 helicópteros EC 725 Cougar, com capacidade de transporte de até 29 combatentes e dois pilotos, que serão fabricados pela empresa euro-brasileira Helibrás em Itajubá, Minas Gerais, onde a Eurocopter investirá US\$ 400 milhões numa linha de montagem. O projeto ainda em aberto envolve a aquisição de 36 aviões de ataque de última geração. Em princípio, os meios de comunicação indicavam que o Brasil estava próximo de fechar a compra do modelo francês Dassault Rafale. Mas os recentes cortes de gastos do governo forçaram um adiamento da decisão sobre o modelo a ser adquirido pelo Brasil. Isso abriu caminho para outros dois concorrentes dessa fase da licitação: o Boeing F/A-18 dos Estados Unidos e o Saab Gripen da Suécia.

173 "Essa integração não somente contribuirá para a defesa do Brasil, como possibilitará fomentar a cooperação militar regional e a integração das bases industriais de defesa. Afastará a sombra de conflitos dentro da região. Com todos os países avançase rumo à construção da unidade sul-americana. O Conselho de Defesa Sul-Americano, em debate na região, criará mecanismo consultivo que permitirá prevenir conflitos e fomentar a cooperação militar regional e a integração das bases industriais de defesa, sem que dele participe país alheio à região." Brasil, 2008, p. 09.

174 "1. O Ministério da Defesa e o Ministério das Relações Exteriores promoverão o incremento das atividades destinadas à manutenção da estabilidade regional e à cooperação nas áreas de fronteira do País. 2. O Ministério da Defesa e as Forças Armadas intensificarão as parcerias estratégicas nas áreas cibernética, espacial e nuclear e o intercâmbio militar com as Forcas Armadas das nacões amigas, neste caso particularmente com as do entorno estratégico brasileiro e as da Comunidade de Países de Língua Portuguesa. 3. O Ministério da Defesa, o Ministério das Relações Exteriores e as Forças Armadas buscarão contribuir ativamente para o fortalecimento, a expansão e a consolidação da integração regional, com ênfase na pesquisa e desenvolvimento de projetos comuns de produtos de defesa." Op. Cit., pp. 55-56. 
Conforme analisado na Segunda Parte, o CDS é uma das forças de projeção continental da integração liderada pelo Cone Sul. Além de fomentar a cooperação em relação a temas internos de segurança, esse mecanismo abre caminho para que a ampliação da força militar se torne um meio de dissuasão à potências externas. Mas a maior capacidade de dissuasão não seria apenas um meio de contraposição ao hard power de potências externas. Contribuiria para enfraquecer pressões generalizadas que influem nas decisões dos Estados sobre o uso do território, um processo que Becker (2005, p. 71) denomina de coerção velada.

No que tange às relações internacionais, é possível delinear dois grandes desafios à segurança continental. O primeiro, cuja maior síntese é a Tríplice Fronteira Brasil-Paraguai-Argentina, envolve o estabelecimento de um controle sobre a fluidez transfronteiriça da criminalidade. Devido ao "efeito radiação" garantido pelos sistemas logísticos, a criminalidade que se concentra nas fronteiras das redes Meridional, Central e Setentrional, é disseminada por todo continente.

Mas a multidimensionalidade da dinâmica desses espaços remete a problemas econômicos e sociais maiores, como pobreza e exclusão social. São esses fatores que garantem a conexidade entre a criminalidade nas fronteiras das redes Meridional, Central e Setentrional e as grandes, médias e pequenas cidades em quase toda América do Sul. A superação dessas fragilidades exige mais que vigilância. Demanda acima de tudo, o desenvolvimento econômico e social do continente.

O segundo desafio refere-se à soberania sobre os recursos naturais; marítimos ou continentais. Após décadas de estabelecimento do OTCA, os países ainda não conseguiram integrar completamente a Amazônia no espaço social e econômico sul-americano. Predominam as formas predatórias de exploração dos 
recursos ambientais, a deficiente integração territorial, e o baixo desenvolvimento regional.

Para contrapor concepções de soberania compartilhada sobre a Amazônia predominantes na década de 1980 e 1990 (Op. Cit., 2005, p. 77) - ou de governança global sobre essa área, como defendida pelo ex-diretor da OMC, Pascal Lamy (MEIRA MATTOS, 2007c) - urge um amplo projeto continental para a floresta. Se por um lado continua válida a visão de consolidação da região como espaço econômico e político como defende Meira Mattos (2007b), por outro, velhas concepções de desenvolvimento foram ultrapassadas pelas novas fronteiras da ciência e tecnologia. Muito além da madeira e do solo, as grandes riquezas da Amazônia são a água e a biodiversidade; esta última com valor incalculável para a ciência. As maiores possibilidades de gerar riquezas e inclusão social preservando a natureza estão nos recursos florestais não madeireiros (BECKER, 2009a, p. 47). Estes abrangem em sua cadeia desde comunidades no âmago da floresta até centros de biotecnologia avançados e a bioindústria (Op. Cit.).

Assim, a soberania plena sobre a Amazônia depende de um projeto para o século XXI, que possa articular a integração regional, os Estados, o uso do território, e as sociedades na era da informação, da engenharia genética etc. A soberania envolve a autonomia tecnológica para a exploração sustentável dos recursos.

A nova fronteira de exploração de recursos naturais para o Brasil, o Atlântico Sul, embora signifique uma grande riqueza depositada em bilhões de barris de petróleo na camada pré-sal, também traz o desafio do desenvolvimento sustentável. Não basta a projeção de um poder marítimo como contraposição as potências hegemônicas. Além dos riscos de desindustrialização, os perigos de poluição são consideráveis num setor historicamente marcado por tragédias ambientais. 
Os temas referentes à integração e ao desenvolvimento da América do Sul pressupõem a ampliação da autoridade regional em contraposição a soberania globalista sustentada pelos Estados Unidos e seus principais aliados. Essa linha de raciocínio não significa a simples refutação às tradicionais potências ocidentais. Ao contrário, trata-se de forjar um projeto para o continente sem a tutela externa que muitas vezes se sobrepõe à necessidades internas. A legitimidade do processo de integração em andamento depende de maior autonomia regional sobre temas determinantes para a consolidação da nova ordem sul-americana. A multidimensionalidade da segurança nos leva novamente à economia geopolítica, cujas rupturas atuais sinalizam para as maiores transformações mundiais desde 1989.

\subsection{Rupturas na Economia Geopolítica: O Lugar da América do Sul no Mundo I}

Enquanto a geopolítica em torno do dólar praticada pelos Estados Unidos no decorrer dos anos 1980 tornou o cenário internacional completamente desfavorável à América do Sul, a última década assistiu transformações que inverteram esta conjuntura. A consolidação de novos espaços de desenvolvimento modificou a economia mundial, estando na base da recuperação da maioria dos países sul-americanos. A atual crise econômica dos países centrais é um importante elemento de reorganização da econômica geopolítica em escala planetária.

O crash financeiro de 2008 é mais um caos sistêmico na ordem internacional. A crise se tornou o maior desafio ao modelo de economia geopolítica mundial hegemônica desde a ascensão da reaganomics no início dos anos 1980 . Os interesses das empresas globais americanas, que começavam a se descolar da geopolítica do país já nos anos 1960, se tornaram condicionados à relações 
econômicas acentuadas cada vez mais pela ascensão do mercado como "ator geopolítico" autônomo. A política monetária americana de Nixon a Reagan, uma ação deliberada buscando manter a liderança internacional (PARBONI, 1986) produziu, num primeiro momento, importantes vantagens a setores estratégicos nacionais.

A fluidez financeira comandada pelas cidades globais contribuiu para 0 crescimento de setores de alta tecnologia. Apesar de essa tendência ter levado à criação de uma bolha tecnológica, resultando no crash da bolsa de eletrônica de Nova York (Nasdaq) em 2000, a crença na infalibilidade do mercado se mantinha inabalada. O crescimento sem paralelo do setor de alta tecnologia, fenômeno que o então presidente do FED, Alan Greenspan, chamou de "exuberância irracional" (MORRIS, 2008, p. 32), parecia corroborar uma vitória irrestrita do capitalismo. Ao ampliar os ganhos de produtividades, o desenvolvimento tecnológico seria um Deus ex machina, acabando com ciclos econômicos e perpetuando o desenvolvimento.

Alguns setores econômicos dos Estados Unidos e seus principais aliados foram os que mais lucraram com esse cenário. A desregulamentação dos anos 1980 "libertou o gênio da garrafa" (AGNEW \& CORBRIDGE, 1995). O "dinheiro em estado puro" (SANTOS, 1997; 1999), ao ser atraído para as praças financeiras das cidades globais, materializou desejos de corporações internacionais, especuladores, e setores emergentes de alta tecnologia. De tal modo, privilegiou regiões, setores e agentes concentrados na América do Norte, Europa Ocidental e Japão.

Por um lado, esse processo tornou possível a "geopolítica informacional". Mas por outro, as decisões tomadas nos anos 1980 comprometeram a competitividade da economia territorial americana (AGNEW \& CORBRIDGE, 1995). Todo setor industrial dos países centrais foi desafiado pela industrialização do Sudeste Asiático e da China. Essa região como, observou Arrighi (2008, p. 
343), tornou-se cada vez mais o centro dinâmico de acumulação de capital em escala mundial.

Mas a desindustrialização causada pela elevação do dólar nos anos 1980 (AGGLIETA, 1982; PARBONI, 1986), apesar de levar os Estados Unidos a uma situação de déficit na balança comercial com o resto do mundo, foi mitigada na década seguinte pela economia baseada na informação, ciência e tecnologia. Desde os anos 1960 o setor terciário começa concentrar a maior parte da riqueza nos países desenvolvidos (SASSEN, 2001). A desregulamentação financeira, a desindustrialização e o crescimento do setor terciário seria o cume de um modelo econômico.

Segundo Charles R. Morris (2008, p. 35), da mesma forma que a experiência dos anos 1980, o crescimento americano nos anos 1990 - liderado dentre outro fatores, pelas novas tecnologias de informação - consolidou a convicção no poder do mercado e na desregulamentação quase completa do mercado financeiro. Para os arautos do livre-mercado, as empresas "pontocom" e as companhias do vale do silício se tornaram provas da superioridade da autoregulação.

Os primeiros a tombarem frente à fé cega no mercado foram os países latino-americanos. A falência com as transformações econômicas dos anos 1970 os levou nas décadas seguintes à subordinação ao mercado financeiro, aos países centrais, e às (até então poderosas) instituições supranacionais. As seguidas crises econômicas enfrentadas por esses países nas décadas seguintes eram interpretadas pela political élite global como uma conseqüência de fenômenos endêmicos, como o pobreza, e a corrupção. A solução dessas crises estava na perseguição do "fim da história" e das benesses proporcionadas pelo mundo hiperliberal.

O enfraquecimento do Estado, a abertura do mercado nacional, e as políticas recessivas, estavam em consonância com interesses de grandes 
corporações internacionais. De fato, a subordinação da região era uma conseqüência da soberania globalista exercida pelos Estados Unidos. Todavia, os esquemas de compreensão da economia geopolítica até os anos 1980 não explicam isoladamente novas hierarquias globais. A débâcle de "economias em desenvolvimento" já demonstrava o alcance do mercado como poderoso Leviatã planetário.

A crise a recair sobre a economia internacional tem revelado que mesmo entre os países centrais, a supremacia dos interesses do mercado sobre a sociedade está associada à corrupção e à infiltração de agentes de corporações globais em instituições públicas, nacionais ou internacionais. Paralelamente a crença na superioridade e eficiência do mercado auto-regulado, há um ambiente de corrupção que subordina governos e demais instituições aos interesses corporativos.

Ironicamente, nas últimas décadas os discursos geopolíticos globais têm insistido no imbricamento entre pobreza, subdesenvolvimento e corrupção na América do Sul. Ainda que seja um dado irrefutável, esses discursos fazem parte do processo de visualização e hierarquização do espaço mundial examinado por Agnew (1998).

Nos anos 1990 e 1980, a subordinação internacional dos países sulamericanos não se resume a geopolítica interestatal. Este é um processo atrelado à economia geopolítica global conduzida por interesses corporativos cada vez mais autônomos. A crise no continente é um fenômeno associado à "soberania do mercado", onde os discursos de defesa da autonomia da esfera econômica determinaram o uso do território, e o funcionamento de instituições públicas e governos.

As mega-corporações globais foram grandes privilegiadas com as crises dos anos 1980 e 1990 na América do Sul. As aquisições feitas por firmas americanas e européias nos setores de recursos naturais, energia, comunicação, 
transporte etc., eram consideradas uma condição natural da globalização da economia.

Portanto, a globalização, entendida como uma conseqüência natural das transformações tecnológicas e econômicas é um conceito vazio. Esse fenômeno é resultado das forças geopolíticas que reorganizam a economia política internacional e as práticas espaciais dela originadas. Não se trata de considerar as mudanças espaço-temporal como mera derivação de interesses do mercado. Mas nessa ampla conjuntura de transformações, é possível traçar forças corporativas, cujos interesses são centrais na definição de hierarquias geopolíticas globais.

A multiplicação desenfreada dos ativos financeiros globais nas últimas décadas (GALL, 1998; 2008; 2010) não ratifica apenas que o mercado financeiro se descolou da economia real. Demonstra que toda gama de instituições e agendes privados, além de se transformar numa força geopolítica independente dos governos, tornou-se capaz de ameaçar o futuro da economia e do próprio mercado. $^{175}$

O mercado financeiro se tornou um colosso econômico desterritorializado e avassalador, fazendo com que os Estados não sejam mais capazes de controlálo isoladamente. Embora seja um poder difuso, a contestação de sua hegemonia passa pela formação de alianças ou grupos de países, como o representado pelo G20. Ainda que governos mantenham "relações perigosas" com coalizões de rentistas e profissionais financeiros, o desastre econômico e a falência dos Estados criam conflitos sociais e pressões que tendem a limitar a hegemonia do mercado.

\footnotetext{
${ }^{175}$ A confirmação dessa linha de argumentação está na explosão do estoque mundial dos ativos financeiros que cresceram numa velocidade muito superior à renda real e o PIB (GALL, 1998; 2008; 2010; PAULANI, 2009). No início dos anos 1980 os ativos financeiros estavam na ordem de US\$ 2 trilhões enquanto o PIB mundial era de US\$11,8 trilhões. Em 2010, os ativos somam US\$ 209 trilhões enquanto o PIB mundial é de US\$55,9 trilhões, disparando a distância entre riqueza fictícia e real (Op. Cit.).
} 
Lembramos com Polanyi (2001), que o esforço visando a desimbricação da economia em relação a sociedade é caracterizado por um duplo movimento. Se no primeiro período se destacam o laissez-faire e a auto-regulação, posteriormente há um contramovimento para impedir a autonomia do mercado. Além da classe trabalhadora, empresários e grupos econômicos passam a insistir em formas de estabilidade da economia através de políticas de regulação (BLOCK, 2001, p. xxxviii).

Por isso, o livre-mercado só existe em sentido estrito enquanto grande utopia. Os países industrializados têm papel ativo, não somente protegendo suas indústrias por meio de tarifas, mas também promovendo novas tecnologias (STIGLITZ, 2001, p. XIII). Mas ainda que o laissez-faire não seja uma realidade de todos os setores econômicos, a desregulamentação dos anos 1980 garantiu ao mercado financeiro uma autonomia em relação aos governos e a "economia real". A globalização permitiu a esse setor e às grandes corporações se tornarem poderosos atores geopolíticos. Nesse contexto, a força transnacional das multinacionais (GILPIN, 1971; WELLS, 1971) fez com que muitos interesses corporativos se tornassem conflitantes com as necessidades dos países sulamericanos.

Nos anos 1990, grande parte dos IED que se dirigiam de outros continentes à América do Sul objetivava o setor de Fusão e Aquisição ( $F \& A)$, e cada vez menos os Greenfield Investment, isto é, novas unidades produtivas (SCHERER p. 110). A desintegração vertical migrou a produção de muitas corporações para outros continentes. Ao mesmo tempo, o enfraquecimento do Estado abriu caminho para que os IED fossem voltados para a aquisição de setores estratégicos nacionais. Essa tendência subordina a região à economia geopolítica das grandes potências, das economias emergentes e das corporações globais. 
Num contexto de frágeis condições econômicas e sociais, a hegemonia da ortodoxia liberal intensificou nos países sul-americanos as crises econômicas e sociais. Em toda América Latina, os longos períodos de desemprego, desigualdade e pobreza projetaram efeitos desastrosos à coesão social (STIGLITZ, 2001, p. x). A agudização da crise forçou a retração da "soberania" do mercado.

Assim como no Pacífico Asiático após a crise deflagrada em 1997, a experiência de colapsos financeiros impôs às principais economias sul-americanas a rediscussão da relação entre Estado e sociedade. O fortalecimento do papel do Estado é um dos fatores que sustentam a recente recuperação econômica. Somada aos investimentos públicos, as políticas de inclusão social e recuperação da renda foram determinantes à ampliação do mercado interno e a retomada do crescimento do PIB. Esses fatores fizeram o presidente do FED, Bem Bernanke (2011), alegar que economias emergentes são modelos a recuperação de países centrais.

De modo geral, o atual momento da ordem internacional demonstra dois processos emblemáticos e igualmente significativos. A crise econômica e financeira mundial afeta toda economia geopolítica global. Os novos espaços de atração de recursos e investimentos forçam uma reestruturação da hierarquia do espaço mundial fundada no último quartel do século XIX, quando Japão, Estados Unidos, Itália e Alemanha romperam com a ordem geopolítica comandada pela Inglaterra.

É nesse sentido que crescem as pressões sobre o modo de regulação da economia política internacional e o monopólio do uso da força em escala global. Assim como a liderança da liquidez mundial, esses fatores definem a supremacia das potências ocidentais sobre a economia geopolítica. As discussões referentes ao monopólio da moeda internacional, a reestruturação do Conselho de 
Segurança, e a regulação econômica sinalizam uma re-hierarquização da ordem mundial.

Entre os fatores que demonstram a re-emergência da América do Sul na economia geopolítica global está a atratividade aos IED. Enquanto nos anos 1990 o crescimento no input de investimento externo esteve bastante condicionado as privatizações, nos anos 2000 esse processo foi comandado pela melhora no ambiente econômico e ampliação dos mercados internos. Nos últimos trinta anos, Argentina, Brasil Chile, Colômbia e Venezuela experimentam dois períodos de forte crescimento na entrada de IED: de 1996 a 2001 e de 2004 em diante (Gráfico 21).

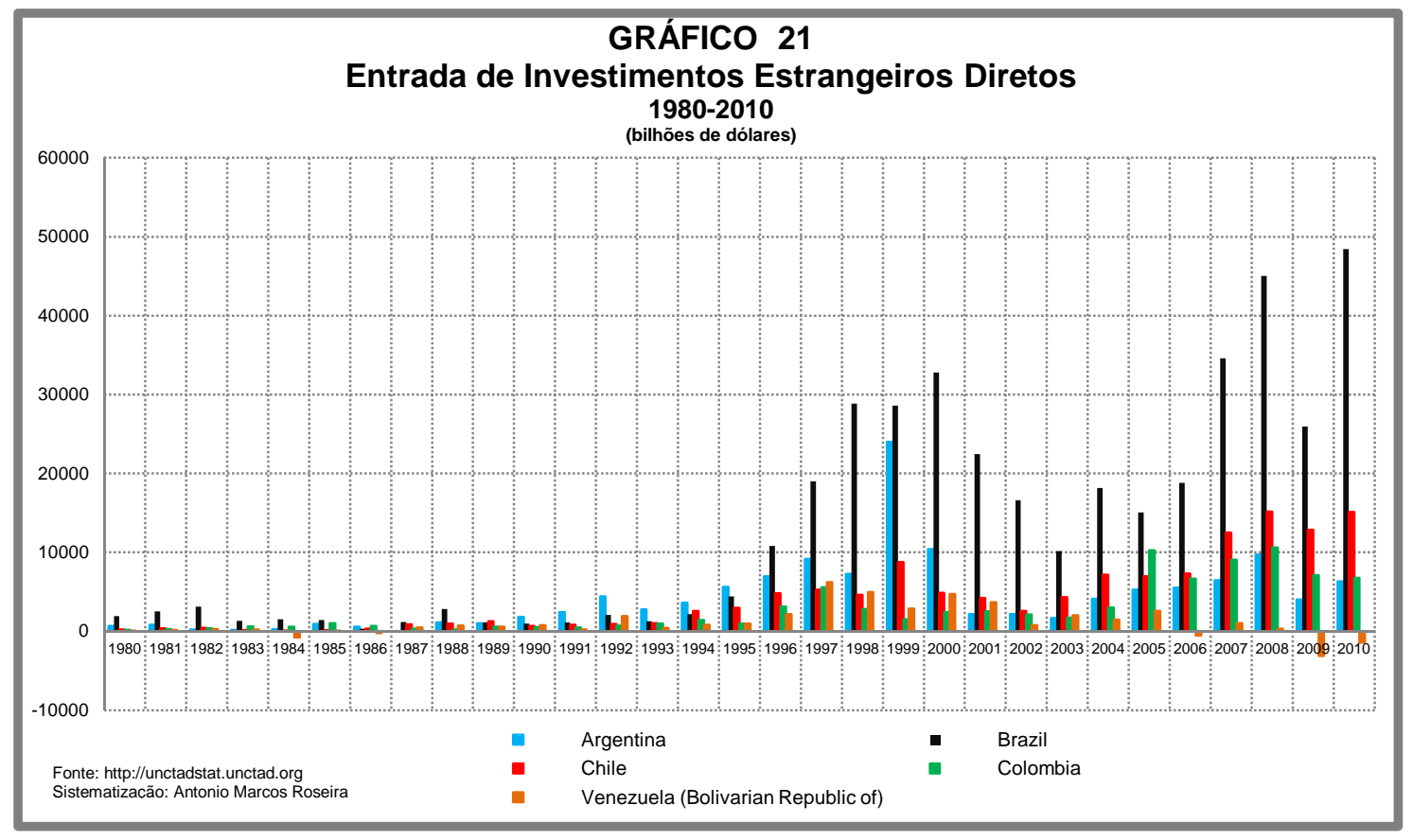

De acordo com estudo da CEPAL (2005, p.12) os processos de privatização foram decisivos para o boom de IED na América do Sul nos anos 1990. O boom iniciado em 2004 - apesar de toda América Latina experimentar uma grande inflexão em 2009 quando os investimentos foram 42\% inferior ao 
alocado em 2008 (CEPAL, 2009, p. 35) - está relacionado a um movimento mais sólido.

Delineia-se nos anos 2000 uma tendência de entradas de IED na América do Sul, marcada pelo crescimento da participação de corporações de países em desenvolvimento. Esse crescimento é explicitado especialmente pelo mercado transfronteiriço de F\&A. A média anual de aquisição realizada por corporações desses países na América Latina, que era de US\$1,3 bilhão entre 1991 e 2000, atinge US\$ 5,6 bilhões entre 2001 e 2010 (UNCTAD, 2011, p. 60). Entre os maiores inputs de IED, destacam-se aqueles oriundos da Ásia e do próprio continente.

No nível intra-regional, tanto as F\&A quanto os IED voltados para Greenfield Investment indicam o fortalecimento de firmas translatinas no contexto de recuperação econômica. Entre 1995 e 2002, essas companhias eram responsáveis por apenas 5\% das F\&A intra-regionais. Todavia, no período de 2003 a 2010 a participação sobe para 36\% (Op. Cit.). Apesar dos IED em F\&A remeterem ao poder de corporações e potências externas na década de 1990, o crescimento dos investimentos intra-regionais evidencia o fortalecimento de companhias locais, sobretudo as brasileiras, chilenas e argentinas na América do Sul.

Até 2010, as corporações transnacionais asiáticas eram investidores marginais no mercado latino-americano de F\&A. Os IED provenientes desses países concentravam-se em Greenfield Investment, com participação de 10\% do total das negociações nesse setor entre 2003 e 2010 (Op. Cit.). Mas a partir de 2010 é registrada uma onda sem precedentes de investimentos no setor latinoamericano de F\&A realizado por países asiáticos. As aquisições realizadas por companhias dessa região saltaram para US $\$ 20$ bilhões em 2010, representando $68 \%$ do total (Op. Cit.). Impressionantemente, esse valor corresponde a mais de 
três vezes o total acumulado pelas empresas asiáticas nas últimas décadas (Op. Cit.).

Na América Latina, são os países sul-americanos que lideram a entrada de IED. Vultosos investimentos vêm sendo realizados por empresas asiáticas nos setores de petróleo, gás e energia nesses países. Duas empresas chinesas (SINOPEC e CNOOC) realizaram grandes aquisições em 2010 e 2011 no Brasil e Argentina. Empresas indianas também fizeram importantes aquisições nesse período nas indústrias de gás na Venezuela e de cana-de-açúcar no Brasil (Op. Cit.).

A posição internacional da América do Sul é evidenciada pela comparação com o volume de IED em outras regiões. Apesar de muito distante da União Européia e América do Norte no volume de input e output de investimento externo, o continente tem adquirido relevância nas últimas décadas. O estoque sulamericano de IED em outros continentes saltou de US\$ 49,3 bilhões em 1990, para US $\$$ 96,0 bilhões em 2000 e US $\$ 307,4$ bilhões em 2010 (Gráfico 22, p. 284). O estoque de IED na região saltou de US\$ 74,8 bilhões em 1990 para US $\$ 309,0$ bilhões em 2000 e US\$ 899,5 bilhões em 2010 (Gráfico 23, p. 284). O volume de 2010 é pouco inferior ao do Sudeste Asiático, com estoques no valor de US\$ 938,4 bilhões.

Se o crescimento na entrada de IED na América do Sul foi marginal em comparação às regiões que comandam a economia geopolítica mundial - com América do Norte, União Européia e Ásia Oriental acumulando respectivamente US\$ 4,0 trilhões, US\$ 6,8 trilhões e US\$ 1,8 trilhão em 2010 - o continente superou o Oriente Médio e Ásia do Sul (Gráfico 23). Essas duas regiões acumularam respectivamente estoque de US $\$ 575,2$ bilhões e US $\$ 260,9$ bilhões em 2010 (Op. Cit.)

Em 2010, o volume de IED sul-americano no mundo superou os US $\$ 97,1$ bilhões da Ásia do Sul e os US\$161,0 bilhões do Oriente Médio, ficando atrás do 
Sudeste Asiático que acumulou US\$431,5 bilhões. Esta região é a que apresenta as maiores semelhanças com a América do Sul no crescimento do input e output do IED (Op. Cit.).
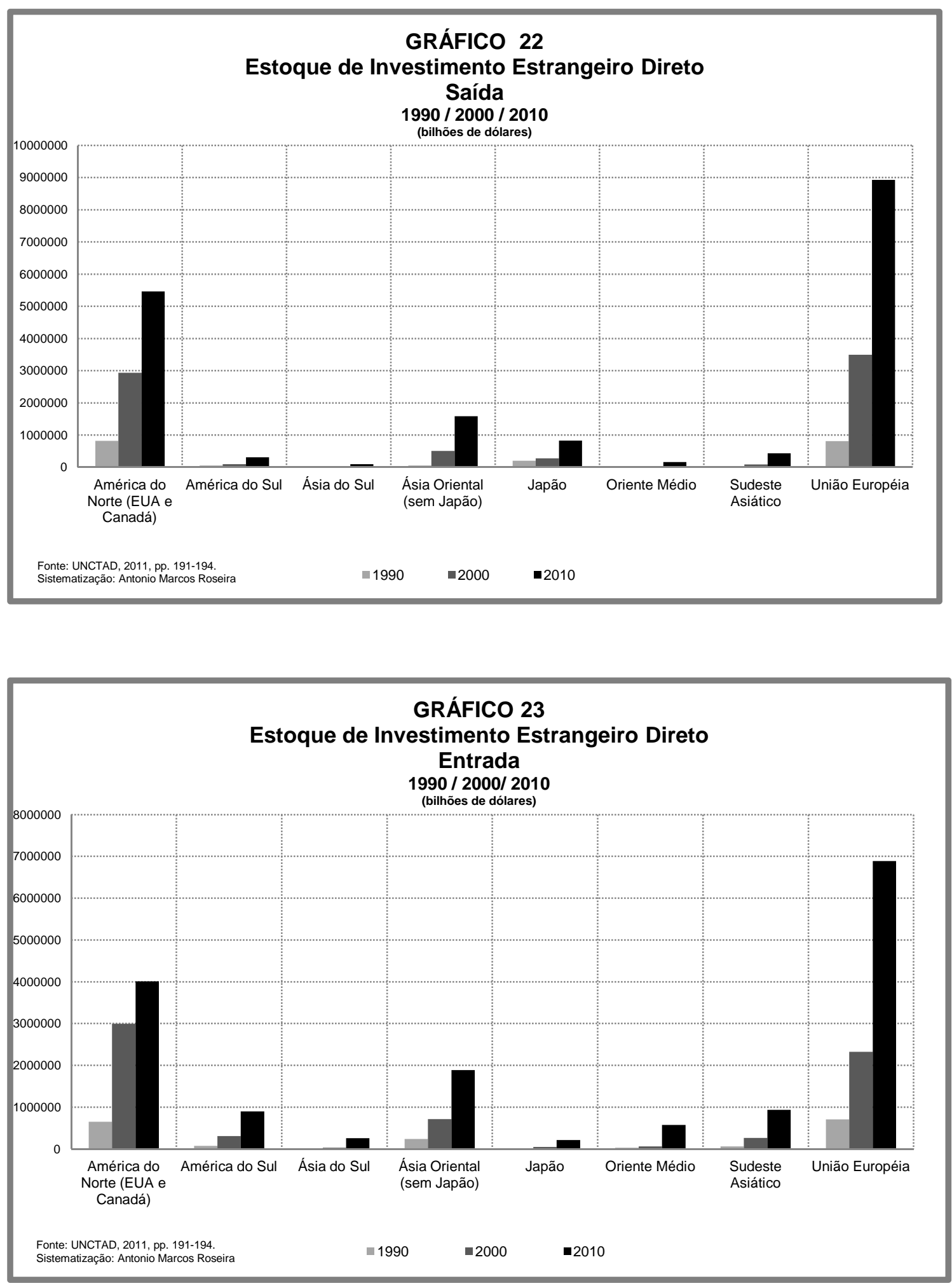
O crescimento do volume de IED, apesar de ser um importante indicador para o exame do lugar da América do Sul entre as regiões com maior poder de atração de capital e investimento, também evidencia fragilidades históricas. O atual crescimento das F\&A corrobora a tese da expansão das firmas asiáticas em detrimento das empresas e sul-americanas. Enquanto o continente foi uma área de hegemonia das corporações globais nos anos 1990, hoje é um espaço de expansão do capitalismo de corporação da China e outras potências asiáticas. À semelhança dos Estados Unidos até os anos sessenta, os interesses corporativos chineses atuais estão em consonância com a expansão geopolítica do país em regiões periféricas.

O lugar da América do Sul na economia global tem sido marcado pela emergência de uma nova dependência. Malgrado o sucesso que os países da região têm tido com as políticas de recuperação das economias com um papel mais ativo dos governos, a atual onda de crescimento é em grande parte, um fenômeno a reboque do desenvolvimento asiático. O período de retomada do crescimento econômico das principais economias sul-americanas (como mostra o Gráfico 14, p. 224) coincide com a fulminante elevação dos preços das commodities internacionais. O crescimento acompanha o forte movimento de ampliação das exportações de commodities agrícolas demonstrado pelo Gráfico 19 (p. 233).

A recuperação da economia brasileira acompanha o aumento do intercâmbio comercial com a China, como evidencia o Gráfico 24 (p. 286). Na última década, o comércio entre os dois países experimenta uma expansão sem paralelo. Em 2000, o intercâmbio de US\$ 2,3 bilhões significa apenas 2,0\% do comércio mundial do Brasil. Em 2010 o comércio alcança US\$ 56, 3 bilhões, representando $14,6 \%$.

Os dados de 2010 mostram a China como o terceiro parceiro comercial do Brasil, atrás da UE e do Nafta que representam respectivamente 21,4\% e 
15,4\% do comércio mundial do país. Um dado revelador, a China se consolida a frente do MERCOSUL no intercâmbio comercial do Brasil (Gráfico 25). Com $10,2 \%$ do comércio exterior brasileiro em 2010, o bloco é o quarto parceiro comercial.
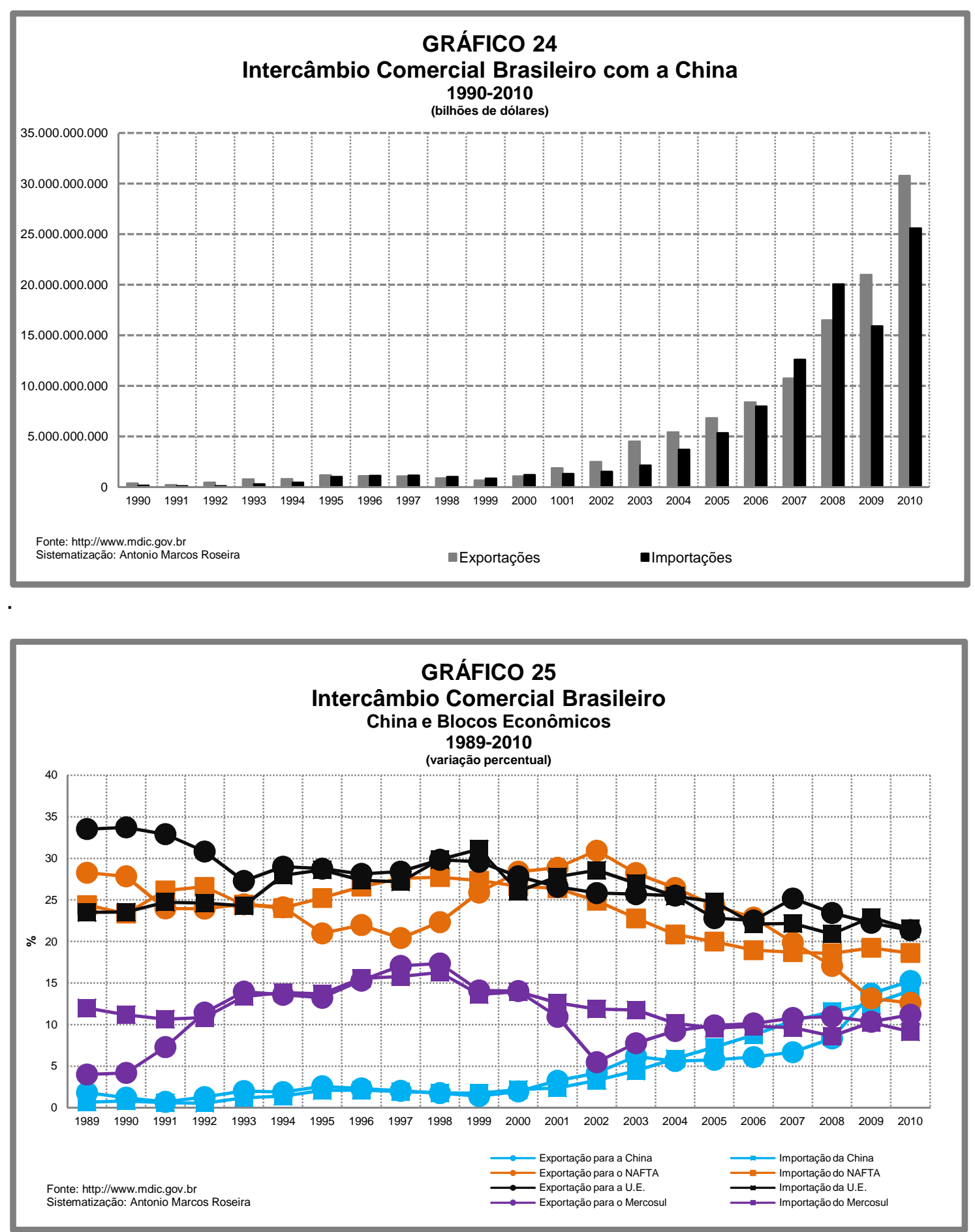
Ao mesmo tempo em que consolida as exportações de bens manufaturados, a China condicionou ao comércio internacional do Brasil uma pauta predominada por produtos primários (Gráfico 26). Entre as principais mercadorias brasileiras importadas pelo país, destacam-se principalmente grãos de soja, petróleo bruto, açúcar e minérios de ferro. Este último ocupou o primeiro lugar em 2010 entre os produtos brasileiros mais exportados para o mercado chinês.

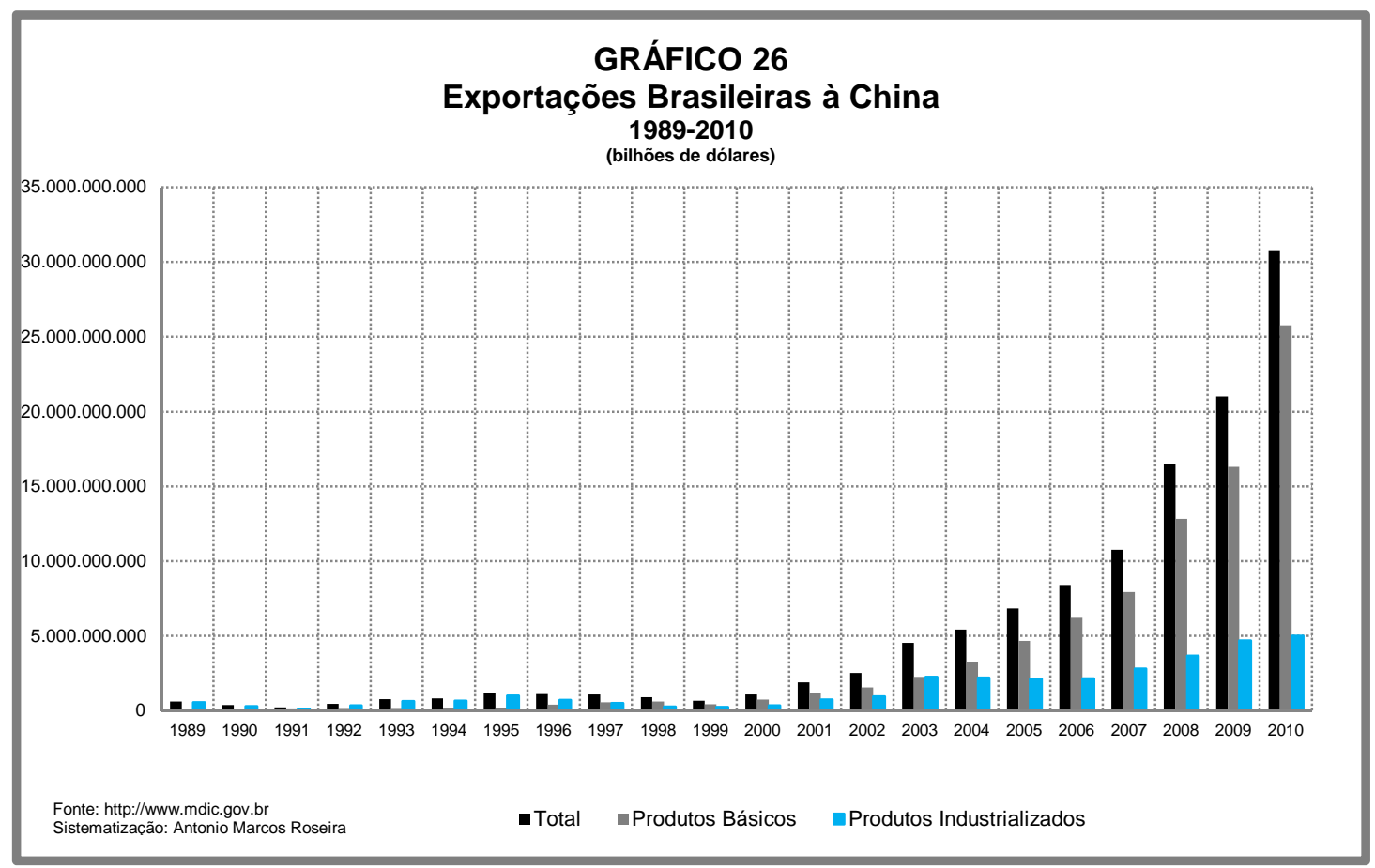

O crescimento do novo grande consumidor de commodities agrícolas e minerais não tem alavancado apenas o crescimento das principais economias sulamericanas. Bolívia, Equador, Guiana, Paraguai, Peru e Suriname são países cujo crescimento na década de 2000 está relacionado ao desenvolvimento das novas economias industrializadas da Ásia. As economias dependentes do setor mineralógico e as dependentes do setor agroexportador mantêm perspectivas de crescimento, apesar da crise mundial. A evolução do PIB desses países dá a retomada do crescimento da América do Sul um alcance realmente continental. 
Nesse contexto, destaca-se o Peru, que com o crescimento sustentado pelas commodities minerais, se aproxima das maiores economias sul-americanas. O PIB peruano de US\$ 52,7 bilhões em 2001 alcança US\$ 147,3 bilhões em 2010 (Gráfico 27).

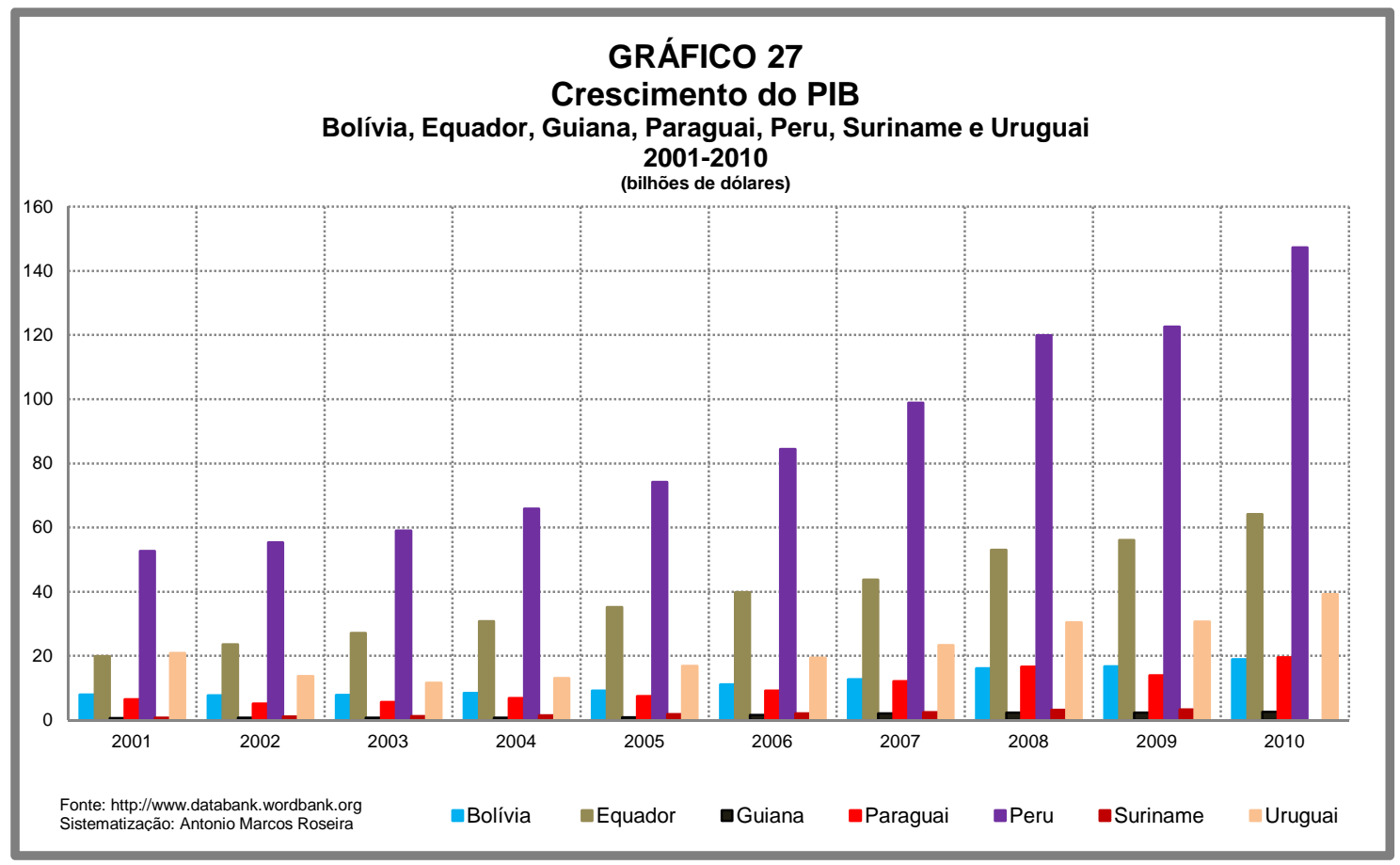

A atual tendência subordina os países sul-americanos ao avanço da industrialização no Pacífico Asiático. Todo continente tem fortalecido a condição de consumidor de manufaturas dessa região enquanto perpetua sua situação de exportador de produtos primários, um fator importante para traçar sua posição internacional.

Este é um aspecto fundamental dentro da re-hierarquização da economia geopolítica mundial. Ainda que os países desenvolvidos se mantenham no topo da inovação tecnológica, subordinando toda produção industrial das economias emergentes, o Pacífico Asiático avança a passos largos na agregação de valor em suas mercadorias industrializadas. Nesse contexto de competição, os países sulamericanos se caracterizam pelo baixo investimento em P\&D. O Brasil investe em 
média 1\% do PIB em inovação enquanto a Argentina 0,4\% (FELDMANN, 2007, p. 108). Os EUA gastam em torno de 2,7\%, Alemanha, 2,3\%, França, 2,2\%, Japão e Coréia do Sul 2,9\%. O investimento Chinês alcançou os 2,0\% do PIB em 2007 (OCDE, 2007, p. 20). Segundo estudo do Center For Strategic And International Studies e do Institute For International Economics (CSIS/IIE, 2006), em 2005 as exportações chinesas de produtos de alta tecnologia alcançaram US $\$ 220,0$ bilhões, correspondendo $1 / 3$ de suas exportações; um aumento de mais de 100 vezes em relação 1989.

A partir dos anos 1950, os países latino-americanos começaram a produzir bens de consumo duráveis e bens intermediários com maior complexidade tecnológica (FELDMANN, 2007). Os governos sul-americanos passaram a investir em P\&D, destacando-se no Brasil o Centro Tecnológico da Aeronáutica (CTA), responsável pelo sucesso da Embraer, e a Embrapa, que permitiu a revolução na produtividade agrícola (Op. Cit.). Apesar desses esforços, segundo Feldmann (Op. Cit.) a Embraer é única empresa de alta tecnologia sulamericana.

No Brasil e Argentina, os esforços visando o desenvolvimento tecnológico cessaram com o colapso do modelo geopolítico militar. As crises das últimas décadas contribuíram para a estagnação dos investimentos em ciência e tecnologia. O enfraquecimento da geopolítica brasileira de base tecno-industrial é um dos aspectos de maior fragilização não apenas do país, mas de toda América do Sul.

A inovação, ao permitir a transformação da produção, do consumo, e, portanto, dos empreendimentos e dos negócios - um processo dentro daquilo que Joseph Schumpeter (2008) denomina de destruição criativa - radicalizou o modelo de geopolítica baseado na economia destacada por Mackinder (1942). Enquanto a inflação e a dívida subordinavam toda América do Sul à economia geopolítica das potências centrais, os países asiáticos em desenvolvimento galgaram posições em 
setores estratégicos. O surgimento de novas empresas globais nos setores automotivo e eletroeletrônico na China e Sudeste Asiático indica a ampliação da dependência tecno-industrial sul-americana para além dos Estados Unidos, Europa e Japão. Estudos da Booz Allen Hamilton (2006; 2010) demonstram que esses dois setores estão entre os que mais investem em P\&D. Os países asiáticos estão sendo capazes de absorver a destruição criativa que transformou o capitalismo nas últimas décadas, ao mesmo tempo em que usam o desenvolvimento tecno-industrial como um poderoso meio de projeção internacional.

Os acordos de livre-comércio assinados por Peru, Chile e Colômbia, com países mais industrializados na Ásia-Pacífico reforçam a condição de economias primário-exportadoras. A abertura comercial, sobretudo com a China e os Estados Unidos, não funciona somente com uma força de fragmentação sul-americana. Chile e Peru são dois casos emblemáticos de países que optam por uma estratégia de liberalização do comércio a partir de vantagens comparativas baseadas na atividade primário-exportadora. Essa estratégia, ainda que seja importante para destravar o comércio exterior nos setores onde esses países são mais competitivos, subordina a América do Sul à geopolítica informacional conduzida pelas grandes potências mundiais e por economias asiáticas em ascensão.

$\mathrm{Na}$ ausência de políticas agressivas de desenvolvimento e inovação tecnológica, esse caminho pode se tornar predominante também para as economias do Brasil e Argentina. São os novos países industrializados da Ásia que mais forçam uma especialização produtiva sul-americana no setor primárioexportador. A integração comercial da América do Sul com essa região é importante para diminuir a dependência econômica em relação às potências ocidentais. Mas se por um lado a Europa e os Estados Unidos são protecionistas em relação ao setor agrícola, por outro são os principais consumidores de 
produtos industrializados dos países sul-americanos. Historicamente, a União Européia tem sido o maior destino da exportação brasileira de manufaturas. $O$ histórico do comércio com esse bloco evidencia que a exportação de produtos industrializados tem sido superior a dos setores agrícola e mineral (Gráfico 28). Os manufaturados representaram $50,2 \%$ das exportações brasileiras à União Européia em 2010.

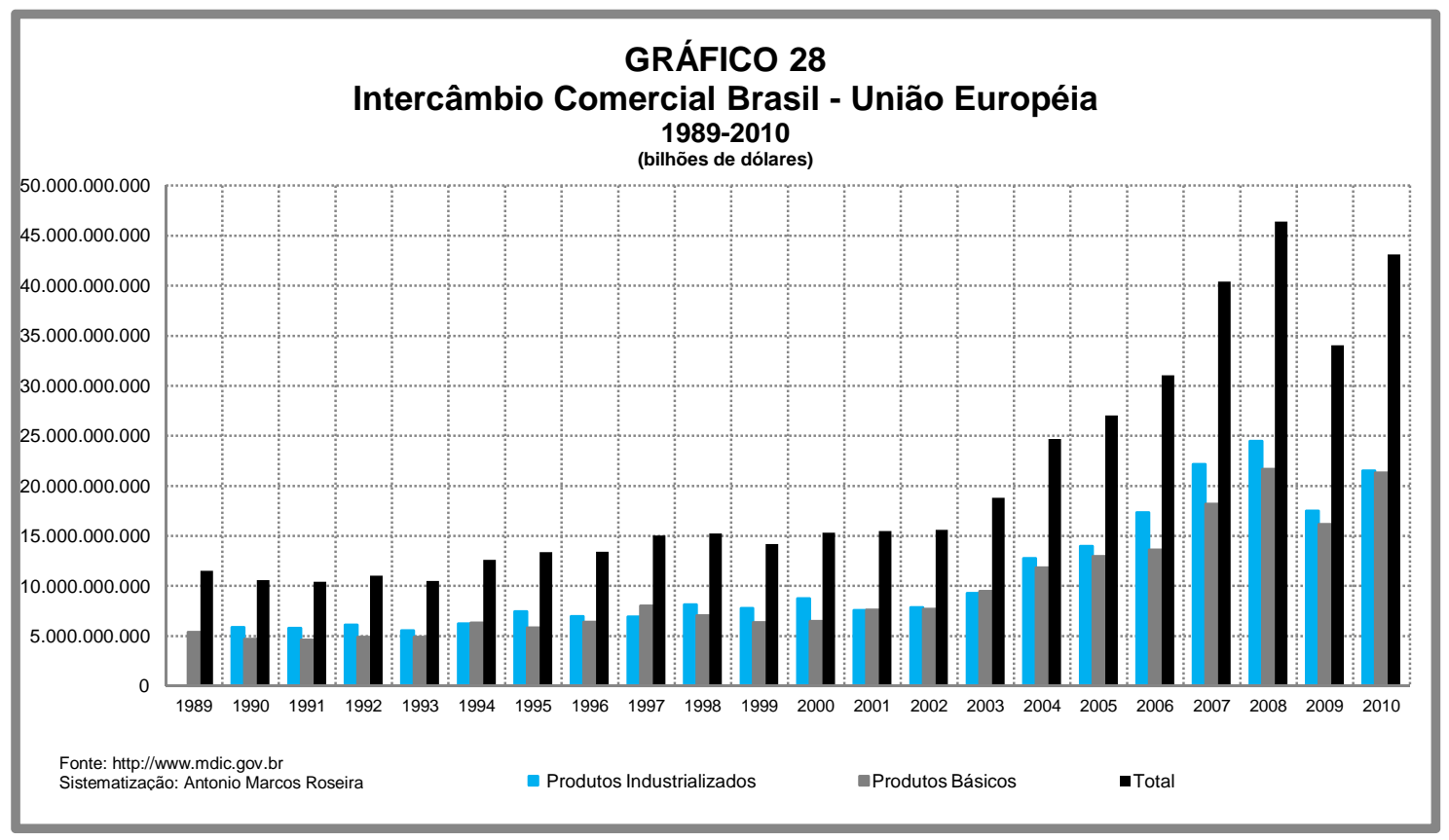

O modelo de crescimento ancorado nas commodities pode conduzir à armadilha dos anos 1970. Sem fortalecimento do vetor tecno-industrial, a desvalorização de produtos agrícolas e minerais solapa o desenvolvimento regional. Além da ampliação do mercado interno e do combate às desigualdades sociais e regionais, o grande desafio sul-americano envolve o desenvolvimento de setores ligados à inovação e ao desenvolvimento tecnológico. São esses fatores que sustentam o crescimento de outras áreas em desenvolvimento na economia mundial.

O fortalecimento da integração sul-americana exige a superação do modelo mercantilista que predomina desde o início dos anos 1990. A concentração 
dos investimentos em infra-estruturas territoriais para garantir o escoamento das exportações agrícolas e minerais precisa ser complementada por um mecanismo regional de desenvolvimento industrial e tecnológico. Caso contrário, o futuro da América do Sul não se difere do passado de subordinação às ordens geopolíticas globais.

\subsection{Reorganização do Espaço Mundial: O Lugar da América do Sul no Mundo II}

As limitações não invalidam os importantes avanços alcançados nas últimas décadas. Malgrado o grande desafio regional a respeito da agenda industrial e tecnológica, as principais forças sul-americanas jamais dispuseram de uma força econômica e financeira semelhante a que possuem na atual ordem geopolítica. Se um dos principais sustentáculos do desenvolvimento dos países da região na década de 1970 era a oferta internacional de dólar barato, a ordem sulamericana atual tem esboçado maior autonomia econômica e financeira. Ainda que continue altamente dependente do valor das commodities, o crescimento do PIB e a ampliação do mercado interno demonstram o novo caminho do desenvolvimento regional, que pela primeira vez está livre da tutela das grandes potências.

O crescente papel do BNDES, FONDPLATA e CAF, desemboca na ampliação da autonomia sobre políticas de desenvolvimento nacional e regional. Ainda assim, a soberania financeira carece de um fundo monetário continental esboçado na proposta de criação do Banco do Sul - que possa realizar aportes não apenas em infra-estruturas físicas, mas também em programas regionais de inovação tecnológica. Todavia, os bancos locais de fomento têm cumprido o papel de substituição das instituições financeiras mundiais, braços da soberania globalista. 
$\mathrm{Na}$ década de 2000, o processo de integração dá sinais concretos de rompimento com a subordinação do continente à economia geopolítica global. No entanto, um dos grandes desafios está em transformar a própria imagem geopolítica da América do Sul, uma derivação dos discursos geopolíticos conduzidos pelas grandes potências mundiais. Isso está arraigado, sobretudo numa regional élite que vê as elites dos países desenvolvidos como " ... fonte da verdade e como líderes naturais a serem seguidos" (BRESSER-PEREIRA, 2001, p. 161). A política econômica é pautada pelo que Bresser-Pereira (Op. cit.) chama de confidence building, isto é, um "internacionalismo subordinado" que abraça diretivas de Washington e Nova York para ganhar a confiança do mercado internacional.

A grandeza da América do Sul foi ofuscada pelas décadas de crise econômica. A região geopolítica pressupõe maior autonomia na condução de políticas de interesse continental. Significa não sucumbir a imposições da soberania globalista. Se toda hegemonia tem uma dimensão imperial (AGNEW, 2008b), a autonomia regional representa o maior esforço de superação do imperialismo que assolou a América do Sul durante todas as ordens geopolíticas globais. O continente não apenas se torna capaz de se opor ao poder através do consenso, mas também de superar a imposição e a coerção baseadas no hard power.

A crescente importância econômica internacional do continente sintetizada pelo aumento fluxos de IED - o torna atrativo para outros blocos regionais. A integração em andamento, ao proporcionar a ampliação da soberania regional, passa a funcionar como um meio de projeção internacional via acordos multilaterais. Enquanto em escala sul-americana o Mercosul funciona como núcleo duro, em escala global vem se caracterizando com um meio de inserção competitiva de seus membros plenos na economia geopolítica internacional. Os acordos de livre-comércio em negociação entre o Mercosul e outros países e 
blocos regionais representam uma estratégia comercial em conjunto entre seus membros, que se opõe à via de negociação bilateral adotada pelos países andinos.

Segundo Messias de Sá Pinto \& Maria Helena Guimarães (2005, p. 01), os objetivos da União Européia em estabelecer acordo de associação com o Mercosul está relacionado com a criação da ALCA e os interesses dos Estados Unidos na América Latina. Os europeus buscavam concluir as negociações antes da ALCA, para dessa forma condicionar o processo de criação da área de livre comércio continental e minimizar os constrangimentos da formação desse agrupamento à relação da UE com o Mercosul (Op. Ci., p. 02). A hegemonia comercial dos Estados Unidos na América do Sul ameaçaria a posição européia na região.

A oposição de Brasil, Paraguai, Uruguai, Argentina e Venezuela ao projeto elaborado unilateralmente pelos Estados Unidos, ao resultar no seu adiamento sine die na Cúpula de Mar del Plata em 2005, impôs a maior derrota do país na região. Com esses desdobramentos, o acordo com a União Européia se tornou a prioridade do bloco sul-americano na política de acesso a um grande mercado internacional.

A importância do Mercosul à União Européia reside na sua relevância comercial. As negociações que se arrastam desde os anos 1990 visam a criação gradual de um zona de livre-comércio entre os dois blocos, com uma abertura seletiva de setores agrícolas e industriais em 10 anos a partir da implementação. $O$ acordo objetiva abrir o mercado agrícola da União Européia ao Mercosul, e em contrapartida, ampliar o acesso de produtos manufaturados europeus ao bloco sulamericano.

Além da aproximação com a União Européia, estão em negociação os acordos de cooperação econômica com a Índia e o Conselho de Cooperação dos 
Estados Árabes do Golfo (CCG). ${ }^{176}$ Destacam-se também acordos já assinados em 2010 com Egito e Israel, que junto ao CCG ampliam a relação do Brasil com o Oriente Médio e a África Setentrional. Esses acordos dão escopo global ao Mercosul, impedindo que o bloco resulte no isolamento internacional dos seus membros.

Além dos acordos no âmbito do Mercosul, destacam-se a negociação trilateral entre Índia, Brasil e África do Sul (IBAS), que constitui um fórum de cooperação política e econômica entre os países. Também conhecido como G3, o IBAS estabelece um diálogo Sul-Sul, promovendo a cooperação científica, tecnológica e política (PECEQUILO, 2008, p. 146). O G3 obteve avanços em parcerias na área nuclear, produção de medicamentos genéricos e de combate a AIDS, e programas sociais, buscando acordos entre o fórum, o Mercosul e mecanismos de integração na Ásia do Sul e na África (Op. Cit., 2008, pp. 146147). Essas negociações são formas de fortalecimento da capacidade política de negociação na OMC frente aos partners mais desenvolvidos (OLIVEIRA, 2005, p. 07). Ao mesmo tempo busca uma reforma no Conselho de Segurança da ONU (Op. Cit.).

Como instrumentos de ampliação das alianças políticas e econômicas para além do continente, os acordos do Mercosul com outros blocos extracontinentais refletem novos interesses do Brasil. Indubitavelmente, os acordos visam ampliar o comércio dos Estados partes com regiões que possuem intercâmbio incipiente com a América do Sul. Mas, é liderando aberturas transcontinentais que a diplomacia brasileira atende a objetivos cada vez mais globais do país.

Se acordos de livre-comércio entre o Mercosul e Estados sul-americanos resultaram na Unasul e na preponderância regional do Brasil, os firmados com países e blocos extracontinentais compõem um amplo e poderoso processo global

176 Esta união política e econômica constituída em 1981, é formado por Bahrein, Arábia Saudita, Omã, Emirados Árabes Unidos, Qatar e Kuwait. 
de criação de novos eixos políticos e comerciais. As forças que comandam esses eixos são as grandes lideranças emergentes, especialmente Índia, China e Brasil. Em muitos casos, essas novas potências atrelam seus interesses com os de demais países em desenvolvimento para criar coalizões emergentes de alcance global.

Por um lado, o Brasil aposta em suas vantagens competitivas para estreitar relações comerciais com regiões em desenvolvimento como a África. Por outro, seus principais produtos têm sido ferramentas de projeção mundial. As negociações para a entrada do etanol brasileiro na União Européia através do acordo de livre-comércio não é apenas fator de interesse comercial. Os bicombustíveis, defendidos como tecnologia indispensável frente à crise ambiental, tornaram-se fonte de influência mundial e trunfo do novo discurso internacionalista do país.

Na África, o Brasil instalou escritório da Embrapa em Gana para cooperar com políticas relacionadas ao combate a fome e a pobreza, e com projetos voltados à energia alternativa (muitos financiados pelo BNDES). Em reportagem publicada na edição de 06 de agosto de 2007, o jornal espanhol El Pais declara que o etanol é a ponta-de-lança mais afiada da política externa do governo Lula. Em outra matéria, publicada e 26 de novembro de 2008, o jornal afirma que ao promover os bicombustíveis na África, o governo objetiva tanto torná-lo planetário quanto aumentar a influência do Brasil na região. A Odebrecht anunciou em 2010, investimentos na ordem de US\$ 300 milhões na produção de etanol em Gana, sendo US\$ 255 milhões financiados pelo BNDES (REVISTA EXAME, 2010). Além do continente africano, o Brasil assinou acordos de transferência de tecnologia de produção dessa matriz energética com Guatemala em 2005 (MELO PEREIRA, 2005, p.01). Esses acordos fazem parte de uma política maior, cujo intuito é promover a expansão da produção e transferência de know how à América Central. 
Em 2007, Brasil e Estados Unidos firmaram acordo de cooperação no setor de bicombustíveis, estabelecendo uma estratégia em três níveis: bilateral, terceiros países e global. Enquanto o primeiro envolve a cooperação em torno de novas tecnologias para biocombustíveis de nova geração, o segundo e o terceiro estão relacionados a uma diplomacia de internacionalização dessa nova matriz energética. $^{177}$

A estratégia de internacionalização é posta através de iniciativas de cooperação técnica para estimular a produção de bicombustíveis na América Central e Caribe. A partir desse acordo, El Salvador foi escolhido em 2007 para construção de uma usina de etanol. Para a transformação dessa matriz em commoditie mundial, o acordo adota uma política de expansão da produção para áreas viáveis em termos de solo e clima. Essa cooperação é um esforço para manter os dois países no comando da inovação e produção dessa nova matriz energética. No contexto internacional, os países latino-americanos são considerados potenciais fornecedores de bicombustíveis, enquanto que as economias asiáticas são vistas como grandes consumidoras (MASIERO \& LOPES, 2008, p. 61).

A estratégia de projeção do Brasil via energia alternativa remete à diplomacia do petróleo da China. O rápido crescimento no consumo chinês dessa matriz impulsionou o comércio sino-africano nos últimos anos (TAYLOR, 2006, p.

\footnotetext{
177 “I. Bilateral: Os Participantes pretendem avançar na pesquisa e desenvolvimento de tecnologia para biocombustíveis de nova geração, potencializando, sempre que possível, o trabalho em andamento no âmbito do Mecanismo de Consultas entre o Ministério do Desenvolvimento, Indústria e Comércio do Brasil e o Departamento de Comércio dos Estados Unidos (Diálogo Comercial Brasil-Estados Unidos); do Comitê Consultivo Agrícola (2003); do Mecanismo de Consultas sobre Cooperação na Área de Energia (2003); da Agenda Comum Brasil - Estados Unidos sobre Meio Ambiente (1995); e da Comissão Mista Brasil Estados Unidos de Cooperação Científica e Tecnológica (1984, emendada e ampliada pelo Protocolo assinado em 21 de março de 1994). II. Terceiros Países: Os Participantes tencionam trabalhar conjuntamente para levar os benefícios dos biocombustíveis a terceiros países selecionados por meio de estudos de viabilidade e assistência técnica que visem a estimular o setor privado a investir em biocombustíveis. Os países tencionam começar a trabalhar na América Central e no Caribe encorajando a produção local e o consumo de biocombustíveis, com vistas a trabalhar conjuntamente em regiões-chave do globo. III. Global: Os Participantes desejam expandir o mercado de biocombustíveis por meio da cooperação para o estabelecimento de padrões uniformes e normas. Para atingir esse objetivo, os Participantes tencionam cooperar no âmbito do Fórum Internacional de Biocombustíveis (FIB), levando em conta o trabalho realizado pelo Instituto Nacional de Metrologia, Normalização e Qualidade do Brasil (INMETRO) e o Instituto Norte-Americano de Padrões e Tecnologia (NIST), bem como coordenando posições em fóruns internacionais complementares." In: Memorando de Entendimento entre o Governo da República Federativa do Brasil e o Governo dos Estados Unidos da América para Avançar a Cooperação em Biocombustíveis, Março de 2007.
} 
944). O volume do comércio entre a China e a África, que era de apenas US $\$ 2,0$ bilhões em 1999, alcançou US\$39,7 bilhões em 2005 (Op. Cit.). Segundo o Forum on China-Africa Cooperation (2011), o intercâmbio excedeu os impressionantes US\$ 100 bilhões em 2010. Os investimentos chineses no setor de petróleo e gás na América do Sul e África são uma poderosa ponta-de-lança de sua projeção mundial.

Num contexto onde os conflitos influenciados pela escassez de recursos naturais têm sido pedras angulares nas relações internacionais, as descobertas de petróleo pelo Brasil transformam-se em grande vantagem aos seus interesses globais. Segundo dados da Agência Nacional de Petróleo (ANP, 2011, p.73), as reservas brasileiras subiram de 12,9 bilhões de barris em 2001 para 28,4 bilhões em 2010. As reservas da camada pré-sal despertam interesses dos maiores importadores mundiais em estabelecer acordos de exploração. Somado ao crescimento do PIB, ao aumento do comércio exterior e aos acordos internacionais, esses recursos aumentam o peso do Brasil na economia geopolítica.

Existem, inegavelmente, algumas similaridades entre a geopolítica contemporânea do Brasil e concepções de projeção mundial do país na década de 1970. Apesar de conduzidas por vias opostas, as prioridades de projeção na América do Sul, no Atlântico Sul e na África, assim como as alianças com novos eixos de poder, são marcas da diplomacia brasileira nas décadas de 1970 e 2000. Ecumenismo, universalização e diversificação das Parcerias, idéias-força que orientaram a diplomacia sob Geisel e Azeredo da Silveira (SPEKTOR, 2008, pp. 71-73), estão presentes na diplomacia contemporânea do Brasil. A maior diferença da abordagem da década de 2000 está na ruptura radical com o tradicional atrelamento das ambições internacionais do país aos desígnios dos Estados Unidos. O país quer ser visto como uma das forças de reestruturação da ordem mundial. 
Os últimos governos têm se posicionado de modo mais ousado no que se refere aos discursos e às iniciativas globais de reordenamento institucional. Em grande parte, esta postura reflete interesses compartilhados entre economias emergentes contra a hierarquia geopolítica comandada pelos países desenvolvidos.

Todavia, esses países possuem interesses (regionais e globais) divergentes, que não se resumem às relações da China com Índia ou Rússia. A Rodada Doha coloca Brasil no lado oposto da China e Índia sobre a liberalização do comércio mundial agrícola. Os dois países se opõem ao formato da abertura desse setor, que fortalece países com agricultura mais competitiva, como Brasil e Estados Unidos. Da mesma forma, os interesses brasileiros não têm encontrado apoio fácil em Pequim. Até a visita da presidente Dilma Rousseff em abril de 2011, a China não se posicionara em prol do Brasil na reforma no Conselho de Segurança.

Outro tema relevante é o enfraquecimento industrial de países emergentes frente a geopolítica da moeda empreendida pelo governo chinês. Malgrado a importância da China ao crescimento de nações pobres e em desenvolvimento, o país força uma especialização primário-exportadora entre economias menores, ao usar o câmbio desvalorizado como uma vantagem competitiva. A "arma Yuan" leva a um sério dilema econômico. Apesar de ser uma das bases do crescimento chinês, tornando possível o desenvolvimento no eixo meridional, provoca uma divisão internacional do trabalho vertical, que segundo Aglietta (1982), força a segmentação da economia internacional: de um lado, os países produtores de bens industrializados; de outro, aqueles especializados no setor primárioexportador.

Mas ainda que países semi-periféricos tenham interesses distintos em diversos temas - não compondo o que se poderia chamar de "movimento alinhado" - geopolíticas emergentes confluem regionalmente e globalmente, 
forçando um re-arranjo do poder em detrimento da soberania globalista. As coalizões, como as formadas pelo BRICS, IBAS ou blocos regionais, funcionam como containment à potência hegemônica e seus aliados na atual ordem geopolítica.

O primeiro resultado desse processo é a transformação do mapa dos fluxos comerciais e financeiros, que se tornam cada vez mais densos em regiões periféricas. Há de certa forma, a emergência de uma aliança Sul-Sul pautada naquilo que André Roberto Martin (2002, p. 117) denomina de meridionalismo, isto é, a utilização da meridionalidade como trunfo no contexto internacional. A falta de graves contenciosos entre as economias emergentes do eixo Sul-Sul e o baixo intercâmbio político e econômico fazem das coalizões por elas formadas um importante meio de ampliação das relações. Não é por outro motivo que o presidente Lula afirmou em outubro de 2008, na reunião de cúpula do IBAS em Nova Délhi, que Brasil e Índia não exploram $10 \%$ do potencial de intercâmbio comercial.

O Segundo resultado é a pressão sobre a estrutura político-institucional mundial. Os acordos, tratados e coalizões entre potências emergentes, apesar de ser uma condição dada pela própria soberania globalista, transcende o alcance e 0 controle das potências hegemônicas. Nesse contexto, a contraposição surge nas fimbrias da própria soberania globalista. Não é, portanto, uma oposição externa como representou o comunismo na ordem geopolítica precedente. São forças cuja pressão tende a fazer ruir o arranjo político-institucional e o modelo de economia geopolítica.

Para muitos críticos da atual política externa do Brasil, as demandas internacionais não encontram respaldo em sua condição política, econômica e social interna. Como revelaram documentos vazados pelo wikileaks, essa posição é partilhada por diplomatas chineses, para quem as ambições do país excedem seu verdadeiro peso no cenário internacional. Em certo sentido, esta é uma 
posição que revela mais sobre conflitos de interesses do que sobre concepções de política externa.

$\mathrm{Na}$ conjuntura internacional, nem sempre o poder está condicionado ao nível de desenvolvimento de um país. Se esta fosse uma "lei geral" das relações internacionais, o Japão deveria ter quase tanto peso político quanto Europa e Estados Unidos. A política externa brasileira engajada não é resultado de um partido ou de um governo, mas derivação de uma postura internacionalista com raízes na tradição de participação nos fóruns e instituições internacionais, consolidada desde a Liga das Nações. Alexandra de Mello e Silva (1998, p. 149), lembra que na Liga e na ONU, o Brasil desenvolveu aspirações a um papel internacional protagônico em momentos históricos distintos. ${ }^{178}$ Ainda que muitas críticas sejam coerentes e consistentes, uma parcela da elite brasileira padece de um isolacionismo que João Augusto de Araujo Castro, ministro das relações exteriores no governo Goulart, chamou de síndrome de Greta Garbo: I want to be let alone.

O engajamento do Brasil num projeto regional e na reformulação da ordem mundial compõe um processo mais amplo e profundo. Muito além dos blocos econômicos, as alianças políticas e militares regionais têm transformado o posicionamento de nações que haviam se desviado de investimento massivos em hard power. Isso se aplica até mesmo ao Japão, que já possui um dos maiores orçamentos militares do mundo, e que instigado pela ascensão da China, busca alterar a constituição nacional para fazer uso da força em conflitos externos (SEIGEL, 2007).

Novamente, a Ásia Oriental é a área onde se travam alguns dos maiores conflitos de interesses em relação ao destino de uma ordem geopolítica. A ascensão da China cria uma "cisão" entre os países da região. Muitos políticos conservadores do Japão, por exemplo, defendem o rearmamento como forma de

\footnotetext{
${ }^{178}$ A autora está se referindo às "... postulações brasileiras a ser membro permanente do Conselho Executivo da Liga, no período 1921/1926; à candidatura brasileira a um assento permanente no Conselho de Segurança da ONU, em 1944/45; e à renovação dessa candidatura em período recente." Alexandra de Mello e Silva, 1998, p. 149.
} 
inserção internacional ao lado dos Estados Unidos (YAMAGUCHI, 2007). Por outro lado, a participação do país em conflitos internacionais através da ONU tem aumentado ainda mais as rivalidades na região devido ao passado imperialista (SAKAMOTO, 2007). Na Ásia Oriental, a ASEAN e o crescimento da China funcionam como força magnética, atraindo investimentos intra-regionais e cooperação em volume que nenhuma superpotência é capaz de proporcionar isoladamente. Resta ao Japão, uma das "âncoras" dos Estados Unidos na região, aderir a essa tendência para não se tornar peça deslocada em seu próprio continente.

A Shanghai Cooperation, liderada por Rússia e China, contribui para o fechamento de bases militares dos Estados Unidos na Ásia Central. Junto aos arranjos regionais do Sudeste Asiático, a constituição desse acordo tem paulatinamente enfraquecido a influência do país em grande parte do continente. Mesmo que instituições regionais da Ásia Oriental também funcionem como um instrumento americano de aprisionamento da China em agrupamentos de Estados que permitem ao mesmo tempo conter e se associar a Pequim (IKENBERRY, 2008, p.98), o intenso crescimento econômico fortalece uma agenda mais autônoma.

As estreitas relações dos blocos asiáticos com os Estados Unidos não são apenas uma derivação da soberania globalista. O capitalismo praticado pela Ásia Oriental e Sudeste Asiático possui uma orientação aberta em parte por fatores geopolíticos. A maioria dos seus países não dispõe de fatores geográficos tradicionais, aspecto que os tornam dependentes dos recursos naturais, da agricultura e de mercados extracontinentais. Daí a importante força de extroversão exercida pela APEC.

Após as crises financeiras dos anos 1990, países emergentes retomaram o papel do Estado no desenvolvimento, imbricando seus interesses com o entorno regional. O crash de 2008 expôs os conflitos entre países desenvolvidos e em 
desenvolvimento. Estes últimos passaram a se opor abertamente à irracionalidade do mercado financeiro. Uma nova ordem mundial emergirá se passar a existir um sistema de prioridades compatíveis (KISSINGER, 2009). Mas antes disso, é preciso que as forças hegemônicas não sejam mais capazes de manter o monopólio sobre as instituições e o modo de regulação que sustentam a ordem atual.

Nessa conjuntura de transformações, o lugar da América do Sul é o oposto daquele que ocupou nas ordens geopolíticas precedentes. O continente começa a constituir uma nova centralidade mundial. A integração sul-americana é uma forma de coalizão continental, que tem no Brasil uma ponta-de-lança geopolítica nos conflitos de interesses que perpassam o re-arranjo da ordem mundial. O Mercosul e a Unasul têm a prerrogativa de definir institucionalmente a nova ordem regional. Ao mesmo tempo, legitimam as articulações brasileiras e argentinas na ONU, no G20, ou em qualquer outra instituição e fórum internacional.

A máxima hobbesiana de que poder atrai poder pode ser aplicado a América do Sul em duas perspectivas. Internamente, o crescimento econômico e a ampliação da importância política de suas lideranças funcionam como forças de persuasão, tornando a cooperação uma vantagem irrefutável. Externamente, atrai grandes potências, economias emergentes e países mais pobres, resultando em maior capacidade de influência na arena global. Como todo poder é relacional (RAFFESTIN, 1993), há um reposicionamento da América do Sul frente os demais continentes.

Essa transformação tem relação com o que pode ser caracterizado como expansão regional do mundo. Tal como observou Mackinder na Royal Geographical Society (1904) o ecúmeno está completo desde o fim das grandes descobertas. Todavia, a concentração da riqueza e dos sistemas técnicos em um número reduzido de países e regiões mantém o mundo bastante limitado perante 
as imensas possibilidades postas pela diversidade de lugares e culturas. $O$ crescimento de áreas historicamente alijadas do desenvolvimento material e informacional que impulsionou Estados Unidos, Europa, Japão, e uma gama reduzida de lugares, traz ao mundo uma nova escala de produção e interações espaciais.

O espaço mundial é dilatado à medida que novas regiões multinacionais se tornam forças cuja influência alcança a escala global. As configurações das redes territoriais e informacionais são transformadas, constituindo novos eixos geográficos que diversificam a concentração do poder e as possibilidades de interações políticas, econômicas, e culturais. Ao contrário de uma era pósterritorial, está se configurando um gigantesco amalgama de regiões subnacionais e multinacionais, articulado por Estados e instituições mundiais numa arena global multipolar.

A inserção na geopolítica mundial do eixo formado por países em desenvolvimento ainda padece de duas formas de subordinação. Por um lado, a soberania globalista lança mão de um poder imperial através do unilateralismo, da coerção, e do uso da força. Por outro, dispõe de um poder consensual que se manifesta no multilateralismo conduzido por coalizões de forças neoliberais (PASHA, 2007). Apesar de serem meios opostos, ambos buscam atingir seus objetivos por meio do fundamentalismo. Este se expressa em valores políticos das potências ocidentais que avançam sobre Estados soberanos, e, ao mesmo tempo, impõe-se através do mercado sobre valores fundamentais da vida humana (Op. Cit.).

A nova ordem sul-americana amalgama passado, presente e futuro. De tal modo, faz interagir tendências tradicionais que perduram no espaço e no tempo com as novas possibilidades vislumbradas a partir das iniciativas políticas e econômicas de transformação da realidade continental. O fortalecimento dessa ordem depende da interdependência entre Estados, áreas subnacionais e a escala 
continental. Não há uma substituição linear de um mundo dominado por Estados territoriais para outro definido por um espaço mundial liso e homogêneo. Tampouco é possível dizer que uma raison de système em desenvolvimento suplantará e desalojará uma "velha" e "ultrapassada" raison d'état. A América do Sul é um campo de potencialidades, cujo desenvolvimento depende da autonomia sobre seus espaços e sua diversidade cultural e natural. Da mesma forma, depende da capacidade de pensar e projetar o próprio futuro num mundo em ebulição. 


\section{CONSIDERAÇÕES FINAIS}




\section{América do Sul, um Constructo Geopolítico para o Futuro}

Civilized people seem to have early aspired to universality. But they have always partitioned the space around them carefully to set themselves apart from their neighbors.

Jean Gottmann

O ecúmeno era formado por frações separadas ou escassamente relacionadas. Somente agora a humanidade pode identificar-se com um todo e reconhecer sua unidade, quando faz sua entrada na cena histórica como um bloco. É uma entrada revolucionária, graças à interdependência das economias dos governos e dos lugares.

Milton Santos

Grande parte da agenda de discussão predominante durante os anos 1990 e 2000 foi construída em torno da crença de que a globalização em si se caracteriza na maior ameaça à soberania dos Estados nacionais. A revolução tecnológica deflagrada nas décadas de 1960 e 1970 tornou possível, no limiar do século XXI, a existência de uma arena global transnacional que desafia as concepções econômicas, políticas e sociais vigentes. Na visão polêmica de Hardt \& Negri (2005) esse império forjado a partir de um poder jurídico e institucional, absorve todas as fímbrias do globo e submete todos os lugares a uma soberania planetária.

Nos países desenvolvidos, as discussões acerca da globalização foram marcadas principalmente pelas transformações da sociedade civil. Nesse caso, 
não eram os desafios representados pela pobreza e exclusão social que orientavam a maioria dos estudos, mas as possibilidades trazidas pela revolução tecnológica e informacional. Os conflitos políticos e econômicos não estavam mais circunscritos às fronteiras nacionais. Para muitos estudiosos, a chamada "sociedade civil global" destaca-se como uma arena de potencialidades que força uma transformação "por dentro". Portanto, o embate entre comunismo e capitalismo teria dado lugar a uma modificação contínua no interior da própria sociedade.

Como escreveu Beck (1995, p. 02), não é a crise, mas a vitória do capitalismo que produz uma nova forma social. De fato, as revoluções tecnológicas e a "destruição criativa" não apenas garantiram a perenidade do capitalismo, mas permitiram sua expansão geográfica e incorporação de países e regiões. Todavia, muito da retórica em torno da sociedade civil global deriva de uma fé cega num modelo de globalização, cuja concentração da riqueza em lugares centrais é acompanhada da proliferação da fome, da miséria e da violência nas franjas do capitalismo.

Em regiões periféricas cresceram as preocupações com a subordinação dos Estados e da sociedade a atores hegemônicos globais representados pelas corporações, instituições multilaterais e supranacionais, e pelos países centrais. A globalização revoluciona os meios de exercício de poder e diversifica as formas de conflito.

A globalização entendida apenas como derivação da transnacionalização das esferas política, econômica e social a partir dos sistemas técnicos é um mito. Esses fenômenos são catalisados por um conjunto de forças hegemônicas sob a égide dos Estados Unidos, que impõem um regime capaz de comandar relações políticas, econômicas e sociais em praticamente todo mundo. A revolução tecnológica é uma das vigas mestras da soberania globalista, mas não sua origem. Os Estados nacionais não foram exatamente sujeitos à força de atores não 
estatais nos anos 1990 e 2000. O que subordina países e sociedades ao redor do mundo são atores hegemônicos cujas diretrizes não escapam da soberania globalista comandada pelos Estados Unidos e seus principais aliados na Europa e Ásia.

Por mais que corporações globais se desacoplem dos interesses da sociedade, o mercado não é capaz de se desimbricar plenamente da política. $A$ desimbricação, apesar de ser uma crença utópica como ensina Polanyi (2001), tem sido um dos pilares da defesa de uma sociedade global acima das instituições nacionais. Na América do Sul, os arautos do mercado auto-regulado se orientam por diretrizes emanadas das cidades globais e capitais políticas dos Estados Unidos e Europa. De modo geral, são os mesmos que defendem cegamente alianças com as potências ocidentais hegemônicas a qualquer custo político ou econômico.

As forças hegemônicas que comandam a ordem geopolítica global impõem três grandes limitações aos países sul-americanos. Grosso modo, estamos perante subordinações no campo das representações espaciais, da economia geopolítica e da geoestratégia. Em conjunto, essas três sujeições expõem a dominação a que as nações sul-americanas se encontram submetidas na ordem mundial. Apesar das vertentes de discussão do conceito de poder desenvolvidas na segunda metade do século $X X$, o entendimento de dominação em Weber $(1999 ; 2000)$ confere uma compreensão precisa dos desafios sulamericanos.

De um lado, ordem geopolítica mundial é hegemonia. O poder é exercido no campo dos valores, sendo a coerção um mecanismo complementar de sujeição dos inimigos e forças não aliadas. Os valores disseminados a partir dos centros mundiais, além de constituírem um ambiente geral de exercício de poder, tornam possíveis meios específicos de dominação. A ordem geopolítica, como hegemonia que configura as relações em escala global, comporta formas específicas de 
dominação. Estas equivalem à probabilidade de imposição dos interesses das principais potências em acordos, rodadas de negociações, instituições multilaterais, etc. A partir do poder consensual, a dominação resulta em subordinação quase irrestrita aos interesses políticos e econômicos da soberania globalista.

A primeira e mais arraigada forma de subordinação da América do Sul à ordem geopolítica global ocorre a partir da geografia. Pode-se dizer que as representações espaciais expressam o conjunto da subordinação no campo dos valores políticos, econômicos, sociais e culturais. Um desafio decisivo aos países sul-americanos é romper com a visualização imposta pelos principais hegemons globais.

A visualização - como meio de conceber e interpretar os diferentes espaços que compõem a totalidade do planeta - é necessariamente um processo hierarquizante. $\mathrm{O}$ aprisionamento imposto por esse processo dificulta 0 estabelecimento de uma agenda autônoma pelas regiões dominadas. O primeiro esforço visando romper com essa dominação passa por um projeto regional independente, que escape da imposição de fórmulas forjadas pela soberania globalista.

Isso não significa necessariamente o estabelecimento de uma soberania integrativa nos moldes da União Européia. Mas ainda assim, o aprofundamento institucional da integração é indispensável para maior autonomia da região. O enfrentamento das forças externas exige coesão interna. $E$ isso é somente possível através de um arranjo institucional que assegure a interdependência continental.

É fundamental a constituição de um projeto regional que contribua para superar aspectos que caracterizam o continente como um espaço de atraso na ordem mundial. O desenvolvimento político, econômico e social é o caminho para inverter visualizações globalmente impostas desde a era das geopolíticas 
civilizacionais. Num contexto de interdependência e globalização, a integração regional é o meio fundamental para a transformação da imagem geopolítica sulamericana. A nova ordem regional, como uma síntese multidimensional da conjuntura continental, contribuía para a inversão dessa imagem através de três fatores.

Primeiro, a modernização das instituições e dos governos não pressupõe apenas a democracia - e sua aceitação como valor universal. Cabe aos governos recuperarem a capacidade de planejamento, investimento e liderança, buscando transformações econômicas e sociais fundamentais ao desenvolvimento da região. Na América do Sul, a consolidação da democracia a partir dos anos 1990 abriu caminho para a participação de governos nacionais e subnacionais, da iniciativa privada e de toda sociedade em um projeto de cooperação que inaugura uma nova era na política continental. Mas a partir da década de 2000 , tornou-se premente aos governos e instituições (públicas e privadas), assim como a toda sociedade civil, a necessidade de trabalhar em busca de um projeto político autônomo que fundamente a re-inserção do continente na ordem mundial. Representações espaciais dominantes serão transformadas apenas quando os países desafiarem a lógica hegemônica que conduz as políticas nacionais, intra-regionais e interregionais.

Segundo, a interdependência econômica regional não pode encontrar seu limite na abertura comercial. É inquestionável que a criação da zona de livrecomércio foi um fator determinante para a ampliação da interdependência econômica e irradiação continental do crescimento. Mas isso não garante a superação das limitações tecno-industriais que subordinam a América do Sul na economia geopolítica global. Para além do intercâmbio comercial, as políticas de cooperação regional na área de ciência, tecnologia e inovação são bases para maior autonomia frente ao domínio tecno-industrial que marca a superioridade geopolítica dos Estados Unidos, Europa e Ásia Oriental. Se o poder de um país é 
cada vez mais dependente da geopolítica informacional, tanto a imagem da região quanto sua inserção internacional é dependente do desenvolvimento de alta tecnologia.

Terceiro, o território é dimensão onde se expressam os grandes desafios relacionados à infra-estrutura. As décadas de estagnação comprometeram a capacidade de investimentos em transporte e comunicação, ampliando a distância entre a América do Sul e os continentes mais desenvolvidos. Os gargalos nos sistemas de transporte urbano e intra-regional (em escala nacional) somam-se às deficiências em infra-estruturas de integração continental - pensadas pela primeira vez de modo multilateral com a assinatura do Tratado da Bacia do Prata. Desse modo, a paisagem cultural - no sentido como proposto por Hartshorne (1935b) reforça a visualização hegemônica da região. As deficiências em infra-estrutura criam um efeito paisagem de alcance continental, reforçando a imagem de pobreza e atraso.

A reversão das tendências de representações espaciais é somente possível a partir de um projeto no campo das relações econômicas e comerciais. $\mathrm{Na}$ Era da Informação, a economia geopolítica é a última fronteira à projeção internacional de uma região. Essa assertiva se refere ao campo das alianças internacionais e da economia política, com desdobramentos ao desenvolvimento tecnológico.

Primeiro, o Mercosul e a Unasul são pontas-de-lança num contexto dominado por blocos econômicos. Esse fator analisado no decorrer do trabalho tem adquirido mais peso com a diplomacia levada a cabo pelas potências em ascensão. O Brasil ganha terreno no continente e em outras regiões emergentes com uma diplomacia comercial agressiva. Ao mesmo tempo, acordos interblocos permitem às menores economias sul-americanas ampliarem o acesso a mercados externos. 
Apesar das divergências e conflitos de interesses entre países emergentes, a diplomacia comercial por eles empregada tem sido bem-sucedida na consolidação de novos eixos econômicos. Acordos firmados (ou em negociação) entre o Mercosul e blocos extracontinentais consolidam a América do Sul como plataforma de expansão do comércio mundial do Brasil e seus aliados regionais.

A busca promovida no âmbito do Mercosul, pelo estabelecimento de acordos com parceiros econômicos tradicionais do continente e com eixos emergentes, demonstra que os países escapam de dois equívocos. Em primeiro lugar, as novas possibilidades não significam a necessidade de substituir Estados Unidos e Europa (parceiros com os quais o Brasil e a América do Sul mantêm relações históricas) por regiões emergentes. A crise que assola os países desenvolvidos não resultará na simples substituição de um eixo econômico por outro. Ao contrário, o que se desenha para as próximas décadas é a diversificação de centros mundiais de poder político e econômico. Em segundo lugar, a projeção mundial das relações comerciais não pode ser alcançada em detrimento da cooperação regional. Iniciativas brasileiras isoladas em busca de mercados levariam a crises continentais e ao fortalecimento da influência de potências externas.

Segundo, a economia política é um campo que envolve decisões capazes de definir o escopo geopolítico de um país ou região. Desse modo, a projeção do continente envolve a intersecção entre o campo da economia e o da geopolítica. A continentalização das redes de produção e distribuição consolida o poder econômico e a autoridade dos países sul-americanos sobre o continente. De tal modo, o planejamento territorial se completa com estratégias econômicas em torno da criação de clusters e circuitos espaciais de inovação tecnológica, do aprofundamento da fluidez territorial, do desenvolvimento de regiões deprimidas, etc. 
Considerando que o soft power não elimina conjunturas mundiais de uso da força bélica, a consolidação de uma geoestratégia é base para a segurança regional perante ameaças internas e externas - estatais ou não estatais. O hard power é aspecto central à projeção internacional, sobretudo para as lideranças regionais.

A dimensão geoestratégica abrange primordialmente o campo militar e territorial. O poder bélico e o poder sobre um território são dimensões de um mesmo processo em andamento na atual ordem regional. Envolvem a soberania dos países sul-americanos sobre o território e os recursos naturais, bem como a projeção no Atlântico Sul. Em conjunto, esses fatores contribuem para a inversão do raciocínio mackinderiano que prevaleceu no século XX.

A legitimidade da expansão da força militar está assentada na necessidade de dissuasão perante potências externas. Mas na atual ordem regional, a ampliação da capacidade bélica é um fator relacionado à integração. Assim sendo, a cooperação no campo estratégico-militar permite diminuir as tensões internas, ao mesmo tempo em que estabelece um poderio bélico capaz de garantir a soberania plena sobre o território e os recursos naturais abundantes em todo continente. Ainda que as possibilidades de ameaças tenham diminuído com a atenuação do contexto mundial dominado pelo terrorismo e pela pre-emption, a soberania dos países sul-americanos passa pelo fortalecimento militar em âmbito regional.

Mesmo com a consolidação de novas escalas de poder político, a autoridade sobre o território e os recursos se mantém necessariamente ligada à soberania tradicional. Todavia, a questão militar pode ser transformada em um meio de aprofundamento da integração. Na América do Sul, a regionalização permite a confluência entre os interesses dos Estados e aqueles que envolvem o multilateralismo continental. A cooperação em temas relacionados ao controle das fronteiras e dos recursos é importante plataforma de aprofundamento da 
integração. Como evidencia a criação do CDS, é preciso inverter a lógica militar tradicional, fazendo da ampliação do poder bélico um mecanismo de estabilidade regional.

Em conjunto, as representações espaciais, a economia geopolítica e a geoestratégia formam um arcabouço que define a posição internacional da América do Sul. De modo geral, esses fatores estão correlacionados a perspectiva mackinderiana de representação do espaço mundial que predominou no século $X X$, e que vem lentamente sendo desafiada com a ascensão de novos eixos de poder.

A América do Sul enquanto região geopolítica não significa, de modo algum, uma via realista de projeção internacional num mundo dominado pela idealpolitik. A região é uma área síntese que vetoriza simultaneamente diversas tendências. Há concomitantemente em operação na região sul-americana tendências realistas e idealistas. Apesar de atuarem por meios opostos, formam uma conjuntura geográfica marcada pela multidimensionalidade dos meios de exercício de poder.

As forças realistas e idealistas estão de modos distintos, arraigadas na economia, na política e no território, isto é, nas três estruturas que conduzem à integração. Portanto, compõem a arena multidimensional que caracteriza a região geopolítica. Esta escala de poder é simultaneamente resultado das diversas iniciativas concretas em operação e das forças ideacionais que Ihe dão coesão interna.

A nova ordem regional pode ser interpretada tanto por meio de uma perspectiva empírica, quanto por uma crença utópica. Empiricamente, significa uma conjuntura marcada por um movimento de coesão política, econômica e territorial, cujos efeitos vão desde a mudança das condições internas até a transformação da inserção internacional. Sob uma perspectiva utópica, esta ordem é entendida como uma crença na realização de todas as potencialidades do 
continente através da cooperação. É somente em conjunto que as duas perspectivas são capazes de conduzir a América do Sul a uma nova condição geopolítica. 
REFERÊNCIAS BIBLIOGRÁFICAS 
ABBOTT, Philip K. A Ameaça Terrorista na Área da Tríplice Fronteira: Mito ou Realidade? Military Review, p. 18-23, Jan./Fev., 2005. Disponível em: http://www.leavenworth.army.mil/milrev/download/portuguese/JanFeb0 5/abbot.pdf.

ACCIOLY, Elisabeth. O Mercosul e a União Européia: Estrutura Jurídico Institucional. Curitiba: Juruá, 1999, 221p.

AGÊNCIA NACIONAL DE PETROLEO GÁS NATUAL E BIOCOMBUSTÍVEIS (ANP). Anuário Estatístico Brasileiro do Petróleo, Gás Natural e Biocombustíveis - 2011. Rio de Janeiro. Documento Eletrônico e Impresso, 2011, 231p.

AGLIETTA, Michel. World Capitalism in the Eighties. New Left Review, London, No. 136, p. 05-41, Nov./Dez., 1982.

AGNEW, John. A Nova Configuração do Poder Global. Caderno CRH. Salvador, Vol. 21, No 53, p. 207-219, Maio/Ago., 2008b.

Border in the Mind: Re-Framing Border Thinking. Ethics \& Global Politics. Vancouver, Vol. 01, No. 04, p. 175-191, Outubro, 2008.

. Entre la Geografía y las Relaciones internacionales. Tabula Rasa. Bogotá, No.05, p. 85-98, Jul./Dez., 2006.

. Geopolitics: Re-visioning World Politics. London: Routledge, 1998, $151 \mathrm{p}$.

Globalization and Sovereignty. New York: Rowman \& Littlefield Publishers, 2008a, 231p.

- Sovereignty Regimes: Territoriality and State Authority in Contemporary World Politics. Annals of the Association of American Geographers. Washington, Vol. 95, No 02, p. 437-461, Junho, 2005.

. The New Global Economy: Time-Space Compression, Geopolitics, and Global Uneven Development. Journal of World-Systems Research. Santa Cruz, Vol. VII, No 02, p. 133 -154, Set./Out./Nov/Dez., 2001.

. The Territorial Trap: The Geographical Assumptions of International Relations Theory. Review of International Political Economy. Londres, Vol. 01, No. 01, p. 53-80, Mar./Abr./Maio/Jun, 1994.

AGNEW, John; CORBRIDGE, Stuart. Mastering Space: Hegemony, Territory and International Political Economy. London: Routledge, 1995, 260p.

The New Geopolitics: The Dynamics of Geopolitical Disorder. In: JOHNSTON, Ronald John; Taylor, Peter James A World In Crises?: 
Geographical Perspectives. Oxford: Blackwell, 1989, p. 266-288.

ALBUQUERQUE, Edu Silvestre de. A Geopolítica da Dependência Como Estratégia Brasileira de Inserção no Sistema Internacional. OIKOS. Rio de Janeiro, Vol. 09, N0. 01, p. 67-82, Jan./Jun., 2010a.

A (Geo)Política de Defesa Brasileira. Revista Geopolítica. Ponta Grossa, Vol. 01, No. 01, p. 46-59, Jan./Jun., 2010 b.

ALMEIDA, Alessandra Juttel. Mercosul, Antecedentes Estrutura e Objetivos (2003). Disponível em: http://jus.uol.com.br/revista/texto/4513/mercosul-antecedentesestrutura-e- objetivos.

ALVES, José Augusto Lindgren. Fragmentação ou Recuperação. Política Externa. São Paulo, Vol. 13, No. 02, p. 09-19, Set./Out./Nov., 2004.

AMIRAHMADI, Hooshang. Oil at the Turn of the Twenty First Century. Futures. Londres, Vol. 28, No 05, p. 433-452, Junho, 1996.

AMOORE, Louise. Biometric Borders: Governing Mobilities in the War on Terror. Political Geography. Londres, Vol. 25, p. 336-351, Março, 2006.

AMORIM, Celso. A Integração Sul-Americana. Diplomacia, Estratégia e Política. Brasília, No 10, p. 05-26, Out./Dez., 2009.

. A Inserção Global do Brasil: OMC, Mercosul, ALCA, Zona de Livre Comércio do Brasil com a União Européia. Revista Política Externa. São Paulo, Vol. 12, No. 02, p. 121-125, Set./Out./.Nov., 2003.

ANDRADE, Manuel Correia de. Espaço, Polarização e Desenvolvimento. Uma Introdução a Economia Regional. São Paulo: Ed. Atlas, 1987, 150p.

. O Brasil e a América Latina. São Paulo: Contexto, 1989, 90p.

ARAÚJO Jr., José Tavares de. Infraestrutura e Integração Regional: o Papel da IIRSA. Política Externa. São Paulo, Vol. 18, No 03, p. 33-48, Dez./Jan./ Fev., 2009.

ARON, Raymond. Paz e Guerra Entre as Nações. São Paulo: Imprensa Oficial do Estado, 2002, 931p.

ARRIGHI, Giovanni. The Long Twentieth Century. Money, Power and the Origins of our Times. New York: Verso, 2008, 417p.

ARRIOLA, Salvador. Economia e Política Externa na América Latina. Política 
Externa e Processos de Integração. As Assimetrias e a Integração: 0 Começo de Uma Resposta. Política Externa. São Paulo, Vol. 11, p. 99-111, Set./Out./Nov., 2002.

ARROYO, Maria Mônica. A Vulnerabilidade dos Territórios Nacionais LatinoAmericanos: o Papel das Finanças. In: LEMOS, Amália Inés Geraiges de; SILVEIRA, María Laura; ARROYO, Maria Mónica. Questões Territoriais na América Latina. São Paulo: Clacso, 2006, p. 177-190.

Mercosul: Discursos de uma Nova Dimensão do Território que Encobre Antigas Falácias. In: SANTOS, Milton; SOUZA, Maria Adélia Aparecida; SILVEIRA, Maria Laura. Território, Globalização e Fragmentação. São Paulo: Hucitec, 1994, p. 308 - 314.

BANCO INTERAMERICANO DE DESARROLO (BID). Integración en el Sector Transporte en el Cono Sur. Transporte Terrestre. Buenos Aires: Documento Eletrônico e Impresso, 1997, 154p.

BANC0 MUNDIAL. World data bank. Word Development Indicators (WDI) \& Global Development Finance (GDF). Disponível em: http://databank.worldbank.org/ddp/home. Acessado em 2010.

BARNETT, THOMAS P.M. The Pentagon's New Map: It Explains Why We're Going to

War, And Why We'll Keep Going to War. (2004) Disponível em: http://www.esquire.com/ESQ0303-MAR_WARPRIMER?click=main_sr

BARTOLOMÉ, Mariano César. A Tríplice Fronteira: Principal Foco de Insegurança no Cone Sul-Americano. Military Review, p. 22-35. Abr./Maio/Jun., 2003.

BASSO, Maristela. As Fontes do Direito do Mercosul. (2000) Disponível em: http://jus.uol.com.br/revista/texto/1624/as-fontes-do-direito-domercosul.

BATTAGLINO, Jorge. A reativação da IV Frota e o Novo Paradigma de Controle Global dos Estados Unidos. Revista Política Externa. São Paulo, Vol. 17, No. 04, p. 31-44, Mar./Abr./ Maio., 2009.

BATISTA Jr., Paulo Nogueira. Brasil, Argentina e a América do Sul. Estudos Avançados. São Paulo, Vol. 19, No. 55, p. 65 -74, Set./Dez., 2005.

BAUMANN, Renato. Uma Visão Econômica da Globalização. In: BAUMANN, Renato et al. O Brasil e a Economia Global. São Paulo: Editora Campus, 1996. p. 33-51.

BEAVERSTOCK, Jonathan V.; SMITH, Richard G.; TAYLOR, Peter J. WorldCity Network: A New Metageography? Annals of the Association of 
American Geographers. Washington, Vol. 90, No 01, p. 123-134, Março, 2000.

BECK, Ulrich. Liberdade ou Capitalismo. Ulrich Beck Conversa com Johannes Willms. São Paulo: Editora UNESP, 2003, 225p.

. The Reinvention of Politics: Towards a Theory of Reflexive Modernization. In: BECK, Ulrich; GIDDENS, Anthony; LASH, Scott. Reflexive Modernization. Politics, Traditions, and Aesthetics in the Modern Social Order. Stanford: Stanford University Press, 1995, p. 01-55.

BECKER, Bertha. A Geografia e o Resgate da Geopolítica. Revista Brasileira de Geografia (RBG). Rio de Janeiro, Vol. 50, p. 99-125, 1988 (Número Especial).

A Geopolítica na Virada do Milênio: Logística e Desenvolvimento Sustentável. In: CASTRO, Iná Elias; GOMES, Paulo Cesar da Costa; CORRÊA, Roberto Lobato. Geografia: Conceitos e Temas. Rio de Janeiro: Bertrand Brasil, 1995. p. 271-307.

Geopolítica da Amazônia. Estudos Avançados. São Paulo, Vol.19, No. 53, p. 71-86, Jan./Abr., 2005.

Articulando o Complexo Urbano e o Complexo Verde na Amazônia. In: CENTRO DE GESTÃO E ESTUDOS ESTRATÉGICOS (CGEE). Um Projeto Para a Amazônia no Século 21: Desafios e Contribuições. Brasília: CGEE, 2009a, p. 39-86.

. O Uso Político do Território: Questões a Partir de uma Visão do Terceiro Mundo. In: BECKER, B.; HAESBAERT, R.; SILVEIRA, C. Abordagens Políticas da Espacialidade. Rio de Janeiro: Editora da UFRJ, 1983. p. 01-21.

. Os Eixos de Integração e Desenvolvimento e a Amazônia. Revista Território. Rio de Janeiro, No. 06, p. 29-42, Jan./Jun., 1999.

. Problematizando os Serviços Ambientais para o Desenvolvimento da Amazônia. In: CENTRO DE GESTÃO E ESTUDOS ESTRATÉGICOS (CGEE). Um Projeto Para a Amazônia no Século 21: Desafios e Contribuições. Brasília: CGEE, 2009b. p. 87-128.

- Tendências de Transformação do Território no Brasil. Vetores e Circuitos. Revista Território. Rio de Janeiro, No. 02, p. 05-17, Jan./Jun., 1997.

BECKER, Bertha. A Geografia e o Resgate da Geopolítica. Revista Brasileira de Geografia (RBG). Rio de Janeiro, Vol. 50, p. 99-125, 1988 (Número 
Especial).

BENKO, Georges. Geografia de Lugar Nenhum ou Hiperglobalização. Breve Exame do Mundo Pós-Moderno. In: SANTOS, Milton; SOUZA, Maria Adélia Aparecida; SILVEIRA, Maria Laura. Território, Globalização e Fragmentação. São Paulo: Hucitec, 1994, p. 247-250.

BERNANKE, Bem. Lessons from Emerging Market Economies on the Sources of Sustained Growth (2011). Disponível em: http://www.ibtimes.com/articles/221597/20110928/bernanke-federalreserve-fed-ben-bernanke-monetary-policy-economy.htm

BERMAN, Marshall. All That Is Solid Melts into Air: The Experience of Modernity. New York: Penguin Books, 1982, 383p.

BERNAL-MEZA, Raúl. Argentina y Brasil en la Política Internacional: Regionalismo y Mercosur (Estrategias, Cooperación y Factores de Tensión). Revista Brasileira de Política Internacional. Brasília, Vol. 51, No. 02, p. 154-178, Jul./Dez., 2008.

BINNER, Hermes. De la Ciudad a la Región. La Experiencia de Mercociudades en sus Años Formativos y su Contribución a Integración Sudamericana. In: SECRETARÍA EJECUTIVA DE MERCOCIUDADES 2009-2010 (MUNICIPALIDAD DE ROSARIO). 15 Años de Mercocidades. Rosario: Acquatint, Evolución Gráfica, 2010, p.21-23.

BISLEY, Nick. Still Anchoring an American Asia Pacific? In: CAMILLERI, Joseph A; MARSHALL, Larry; MICHAEL, Michális (Orgs.). Asia-Pacific Geopolitics: Hegemony vs. Human Security. Massachusetts: Edward Elgar, 2007, p. 43-58.

BLANCO, Luis Fernando. O novo Acordo Brasil-Paraguai e a Renegociação do Tratado de Itaipú. Enfim uma Postura de Liderança SubRegional? (2009). Disponível em: http://www.kas.de/wf/doc/kas_17309-1522-5-30.pdf?091006165817

BLOCK, Fred. Introduction. In: POLANYI, Karl. The Great Transformation: The Political and Economic Origins of Our Time. Boston: Beacon Press, 2001. p XVIII-XXXIII.

BOBBIO, Norberto. Estado, Governo e Sociedade: Por uma Teoria Geral da Política. Rio de Janeiro: Paz e Terra, 1986, 173p.

BOLÍVIA. The Blue Book: The Maritime Claim of Bolivia. La Paz: Edição Impressa, 2004, 163p. 
BOOTE, John. A Criminal Haven: The Tri-Border Area of South America. Virginia: Documento Eletrônico e Impresso, 2009, 29p.

BOUDEVILLE, Jacques. Desenvolvimento Polarizado e Planejamento Regional. Boletim Geográfico (IBGE). Rio de Janeiro, No. 239, p. 0516, Mar./Abr.,1974.

BOWMAN, Isaiah. Geography vs. Geopolitics. In: WEIGERT, Hans. Compass of the World: a Symposium on Political Geography. New York: Mc Millian Company, 1944, p. 40 - 52.

. South America. A Geography Reader. Chicago / New York: Rand MacNally \& Company, 1915, 354p.

. The Strategy of Territorial Decisions. Foreign Affairs. Washington, Vol. 24, No. 02, p. 177-194, Janeiro, 1946.

BOOZ ALLEN HAMILTON. Smart Spenders. The Global Innovation 1000. Virginia: Documento Eletrônico e Impresso, 2006, 16p.

BOOZ ALLEN HAMILTON. THE GLOBAL INNOVATION 1000 How the Top Innovators Keep Winning. Virginia: Documento Eletrônico e Impresso, 2010, 16p.

BRASIL. Estratégia Nacional de Defesa. Brasília: Documento Eletrônico e Impresso, 2008, 64p.

BRASIL. Política Nacional da Indústria de Defesa - PNID (2005). Disponível em: \%20\%C3\%ADntegra.pdf. http://www.fiesp.com.br/defesa/pdf/pnid\%20-

BRASIL \& ESTADOS UNIDOS. Memorando de Entendimento entre o Governo da República Federativa do Brasil e o Governo dos Estados Unidos da América para Avançar a Cooperação em Biocombustíveis (2007). Disponível em: http://www2.mre.gov.br/dai/b_eua_332_5915.htm

BRESSER-PEREIRA. Assalto ao Estado e ao Mercado, Neoliberalismo e Teoria Econômica. Estudos Avançados. São Paulo, Vol. 23, No. 66, p. 07-23, Maio./Ago., 2009.

. Incompetência e Confidence Building. Por Trás de 20 anos de Quase Estagnação da América Latina. Revista de Economia Política. São Paulo, Vol. 21, No. 01, p. 141-166, Jan./Mar., 2001.

BURGA, Manuel. Novos Olhares sobre a Formação Econômica Peruana. Diplomacia, Estratégia e Política. Brasília, No 10, p. 181-204, Out./Dez., 2009. 
CABRAL, Severino. Carlos de Meira Mattos e a Projeção Mundial do Brasil. In: ESCOLA SUPERIOR DE GUERRA (ESG). O General Meira Mattos e a Escola Superior de Guerra. Rio De Janeiro: ESG, 2007, p. 11-16.

CAIRO, Heriberto. A América Latina nos Modelos Geopolíticos Modernos: da Marginalização à Preocupação com sua Autonomia. Caderno CRH. Salvador, Vol. 21, No. 53, p. 221-237, Maio./Ago., 2008.

CAMAGNI, Roberto. The Economic Role and Spatial Contradictions of Global City-Regions: The Functional, Cognitive and Evolutionary Context. In: SCOTT, Allen J. (Editor). Global City-Regions: Trends, Theory, Policy. Oxford University Press: New York, 2001, p. 96-118.

CAMARGO, Pedro de. O Papel da Circulação na Integração Econômica e Territorial da América do Sul. 1999, 196p. Tese (Doutorado em Ciências. Área de Concentração: Geografia Humana) - Faculdade de Filosofia, Letras e Ciências Humanas, Universidade de São Paulo, São Paulo, 1999.

CAMILLERI, Joseph A. Between Alliance and Regional Engagement: Current Realities and Future Possibilities. In: CAMILLERI, Joseph A; MARSHALL, Larry; MICHAEL, Michális (Orgs). Asia-Pacific Geopolitics: Hegemony vs. Human Security. Massachusetts: Edward Elgar, 2007, p. 193-218.

CARTA DE MONTEVIDÉU. Boletim Informativo da Delegação do Brasil junto à ALADI e ao MERCOSUL. Montevidéu: Documento Eletrônico e Impresso, 2009, 24p.

CARVALHO, Carlos Eduardo; SENNES, Ricardo. Integração Financeira e Internacionalização de Empresas Brasileiras na América do Sul. Nueva Sociedad. Buenos Aires, Vol. 01, p. 17-32, Dezembro, 2009. (Edição Especial em Português).

CASTELLS, Manuel. A Era da Informação: Economia, Sociedade e Cultura. Vol.1. A Sociedade em Rede. São Paulo: Editora Paz e Terra, 1999a, $698 p$.

. A Era da Informação: Economia, Sociedade e Cultura. Vol.3. Fim de Milênio. São Paulo: Editora Paz e Terra, 1999c, 530p.

A Era da Informação: Economia, Sociedade e Cultura. Vol.2. 0 Poder da Identidade. São Paulo: Editora Paz e Terra, 1999b, 530p.

Para o Estado-Rede: Globalização Econômica e Instituições Políticas na Era da Informação. In: PEREIRA, L. C. Bresser; WILHEIM, Jorge; SOLA, Lourdes (Orgs). Sociedade e Estado em 
Transformação. São Paulo: Editora UNESP / Imprensa Oficial, 2001. p. 147-171.

The Network Society. In HELD, David; McGREW, Anthony; GOLDBLATT, David; PERRATON, Jonathan. The Territorial State and Global Politics. In: Global Transformations: Politics, Economics and Culture. Stanford: Stanford University Press, 1999d. p. 76-81.

CASTILHO, R. Agronegócio e Logística em Áreas de Cerrado: Expressão da Agricultura Científica Globalizada. Revista da Anpege. Vol. 03, No. 03, p. 33-43, 2007. Disponível em http://anpege.org.br/revista/ojs2.2.2/index.php/anpege08/issue/view/RA\%203

- Transporte e Logística de Graneis Sólidos Agrícolas: Componentes Estruturais do Novo Sistema de Movimento do Território Brasileiro. Investigaciones Geográficas: Boletín del Instituto de Geografía. Cidade do México, No. 55, p. 79-96, Dezembro, 2004.

CASTRO, Armando; CARDOSO, Fernando Jorge. Dinâmicas e Espaços de Integração. In: A Integração Aberta. Um Projeto da União Européia e do Mercosul. Lisboa: IEEI, 1995, 367p.

CASTRO, Iná Elias. Geografia e Política. Território, Escalas de Ação e Instituições. Rio de Janeiro: Bertrand Brasil, 2005, 299p.

. O problema da Escala. In: CASTRO, Iná Elias; GOMES, Paulo Cesar da Costa; CORRÊA, Roberto Lobato. Geografia: Conceitos e Temas. Rio de Janeiro: Bertrand Brasil, 1995. p.117-140.

CENTER FOR STRATEGIC AND INTERNATIONAL STUDIES; INSTITUTE FOR INTERNATIONAL ECONOMICS. China: The Balance Sheet. What the World Needs to Know Now About the Emerging Superpower. New York: Public Affairs, 2006, 207p.

CENTER FOR STRATEGIC AND INTERNATIONAL STUDIES; INSTITUTE FOR INTERNATIONAL ECONOMICS. Transnational Threat Update. Washington, Vol. 07, No. 07, p. 01-05, Setembro, 2009.

CENTRO DE ESTUDOS DE INTEGRAÇÃO E DESENVOLVIMENTO (CINDES). Força-Tarefa: O Brasil na América do Sul (Relatório Final). Rio de Janeiro: Documento Eletrônico e Impresso, 2007, 28p.

CICCOLELLA, Pablo José. Desconstrução / Reconstrução do Território no Âmbito dos Processos de Globalização e Integração. In: Santos, Milton; SOUZA, Maria Adélia Aparecida; SILVEIRA, Maria Laura. Território, Globalização e Fragmentação. São Paulo: Hucitec, 1994, p. 296-307. 
CLINTON, W. Inaugural Address. (1993) Disponível em: http://www.whitehouse.gov

Remarks by the President to the 52을 session of the U.N. General Assembly. (1997) Disponível em: http://www.whitehouse.gov

CORRÊA, Roberto Lobato. Espaço: um Conceito-Chave da Geografia. In: CASTRO, Iná Elias; GOMES, Paulo Cesar da Costa; CORRÊA, Roberto Lobato. Geografia: Conceitos e Temas. Rio de Janeiro: Bertrand Brasil, 1995, p. 15-47.

. Região e Organização Espacial. São Paulo: Editora Ática, 1987.

Territorialidade e Corporação: um Exemplo. In: SANTOS, Milton; SOUZA, Maria Adélia Aparecida; SILVEIRA, Maria Laura. Território, Globalização e Fragmentação. São Paulo: Hucitec, 1994, p. 251-256.

CHANDLER, David. New Rights For Old? Cosmopolitan Citizenship and the Critique of State Sovereignty. Political Studies. Sheffield, Vol. 51, No. 02, p. 332-349, Junho, 2003.

CHESNAIS, François. A Emergência de um Regime de Acumulação Mundial Predominantemente Financeiro, Praga - Revista de Estudos Marxistas. São Paulo, No. 03, p. 19-46, 1997.

CHIELD, John. Geopolitical Thinking in America Latina. Latin America Research Review. São Francisco, Vol. 14, No. 02, p. 89-111, Jan./Fev./Mar./Abr., 1979.

COHEN, S. B. Geopolitical Realities and United States Foreign Policy. Political Geography. Londres, Vol. 22, No. 01, p. 01-33, Janeiro, 2003.

COMISSÃO ECONÔMICA PARA A AMÉRICA LATINA E CARIBE. (CEPAL). La Inversión Extranjera en América Latina y el Caribe. Documento Eletrônico e Impresso. Santiago, 2009, 232p.

COMISSÃO ECONÔMICA PARA A AMÉRICA LATINA E CARIBE. (CEPAL). La Inversión Extranjera en América Latina y el Caribe. Documento Eletrônico e Impresso. Santiago, 2010, 296p.

COMISSÃO ECONÔMICA PARA A AMÉRICA LATINA E CARIBE. (CEPAL). Investimento Estrangeiro na América Latina. Documento Eletrônico e Impresso. Santiago, 2005, 190p.

CONFEDERAÇÃO NACIONAL INDÚSTRIA (CNI). Os Interesses Empresariais Brasileiros na América do Sul. Investimentos Diretos no Exterior. Documento Eletrônico e Impresso. Brasília, 2007, 56p. 
COSTA, Darc; PADULA, Raphael. Uma Proposta de Infra-Estrutura de Transportes para o Brasil - 2011-2014. (Com Base na Proposta 2007-2010). Nota Técnica Elaborada para a Federação Nacional dos Engenheiros (FNE). In: Federação Nacional dos Engenheiros (FNE). Nota Técnica Produzida para o Projeto Cresce Brasil. Documento Eletrônico e Impresso. Rio de Janeiro, 2009, 24p.

COSTA, Rayssa Alexandre; VALENTE Jr, Airton Saboya. Investimentos em Infraestruturas no Nordeste, $2^{\mathrm{a}}$ Edição. Informe Etene. (Banco do Nordeste). Fortaleza, No. 08, Ano V, p. 01-05, Maio, 2011.

COSTA, Wanderley Messias da. Geografia Política e Geopolítica. Discursos sobre o Território e o Poder. São Paulo: Edusp, 1992, 374p.

- O Brasil e a América do Sul: Cenários Geopolíticos e os Desafios da Integração. Confins, Revista Franco-Brasileira de Geografia. Paris, No. 07, p. 1-23, 2009.

Política e Território em Tempos de Mudanças Globais. 2005, 97p. Livre Docência (Livre Docência em Geografia) - Faculdade de Filosofia, Letras e Ciências Humanas, Universidade de São Paulo, São Paulo, 2005.

- Políticas Territoriais Brasileiras no Contexto da Integração SulAmericana. Revista Território. Rio de Janeiro, No. 07. p. 25-41. Jul./Dez., 1999.

Subsídios para uma Política Nacional de Ordenamento. In: MINISTÉRIO DA INTEGRAÇÃO NACIONAL (Brasília, DF). Para Pensar uma Política Nacional de Ordenamento Territorial. Documento Eletrônico e Impresso, Brasília, 2005, p. 55-59.

COUTO E SILVA, Golbery. Geopolítica do Brasil. São Paulo: Olympio, 1967, $581 \mathrm{p}$.

COX, Robert. Civil Society at the Turn of the Millennium: Prospects for an Alternative. Review of International Studies. Aberystwyth, Vol. 25, No. 01, p. 03-28, Novembro, 1999.

DANESE, Sérgio F. O Brasil e a América do Sul: Apontamentos para a História de Uma Convergência. Política Externa. São Paulo, Vol. 09, p. 49-71, Mar./Abr./Maio, 2001.

DELEUZE, Gilles. Mil Platôs. Capitalismo e Esquizofrenia. Vol. 05. São Paulo: Editora 34, 1996, 234p.

DIAS, Leila Christina. Redes: Emergência e Organização. In: CASTRO, Iná 
Elias de; GOMES, Paulo Cesar da Costa; CORRÊA, Roberto Lobato. Geografia: Conceitos e Temas. Rio de Janeiro: Bertrand Brasil, 1995, p. $141-162$.

DIETZ, Circe Inês. Cenários Contemporâneos da Fronteira BrasilArgentina: infra-estruturas Estratégicas e o Papel dos Atores no Processo de Cooperação/Integração Fronteiriça. 2008, 238p. Dissertação (Mestrado em Geografia. Área de Concentração: Geografia) - Instituto de Geociências, Universidade Federal do Rio Grande do Sul, Porto Alegre, 2008.

DINIZ, Bernardo Palhares Campolina. O Grande Cerrado do Brasil Central. 2006, 231p. Tese (Doutorado em Ciência. Área de Concentração: Geografia Humana) - Faculdade de Filosofia, Letras e Ciências Humanas, Universidade de São Paulo, São Paulo, 2006.

DINIZ, Clélio Campolina; SANTOS, Fabiana; CROCCO, Marco. Conhecimento, Inovação e Desenvolvimento Regional/Local. In: DINIZ, Clélio Campolina; CROCCO, Marco (Org.). Economia Regional e Urbana: Contribuições Teóricas Recentes. Belo Horizonte: Editora UFMG, 2006, p.88-122.

DOUGLASS, Michael. Intercity Competition and the Question of Economic Resilience. Globalization and Crisis in Asia. In: SCOTT, Allen J. (Editor). Global City-Regions: Trends, Theory, Policy. Oxford University Press: New York, 2001, p. 236-262.

DREGER, Fabrício Brugali. A Integração na América do Sul: A Unasul e o Conselho de Defesa Sul-Americano. 2009, 102p. Monografia. (Bacharelado em Relações Internacionais) - Faculdade de Ciências Econômicas, Universidade Federal do Rio Grande do Sul, Porto Alegre, 2009.

DUARTE, Bernardo Pestana Mello C; SARAIVA, Thiago Carvalho; BONÉ, Rosemarie Bröker. Impacto na relação Brasil-Bolívia, com a nacionalização dos hidrocarbonetos bolivianos, em 2006. Indicadores Econômicos FEE. Porto Alegre, Vol. 36, No. 01, p. 87-98, Jan./Fev./Mar., 2008.

EGLER, Cláudio. Questão Regional e Gestão do Território no Brasil. In: CASTRO, Iná Elias; GOMES, Paulo Cesar da Costa; CORRÊA, Roberto Lobato. Geografia: Conceitos e Temas. Rio de Janeiro: Bertrand Brasil, 1995, p. 207-238.

FAGUNDES, Pedro Ernesto. O Uruguai e o Mercosul: Novos Desafios de José Mujica. Boletim Meridiano 47. Brasília, No. 114, p. 51-53, Janeiro, 2010. 
FAINSTEIN, Susan S. Inequality in Global City-Regions. In: SCOTT, Allen J. (Editor). Global City-Regions: Trends, Theory, Policy. Oxford University Press: New York, 2001, p. 285-298.

FARINELLI, Franco. Friedrich Ratzel and the Nature of (Political) Geography. Political Geography. Londres, Vol. 19, No. 08, p. 943-955, Novembro, 2000.

FEDERAL BUREAU OF INVESTIGATION. Major Executive Speeches. (2003). Disponível em: http://www.fbi.gov/pressrel/speeches/speech090803.htm.

FELDMANN, Paulo Roberto. A Relação entre Espaço Geográfico e o Surgimento de Inovações Tecnológicas: O Caso das Empresas LatinoAmericanas de Grande Porte. Geousp - Espaço e Tempo. São Paulo, No. 21, p. 103-118, Maio, 2007.

FERRER, Aldo. A Relação Argentina - Brasil no Contexto do Mercosul e a Integração Sul-Americana. Política Externa. São Paulo, Vol. 09, p. 0517, Set./Out./Nov., 2000.FOLHA DE SÃO PAULO. Presidente de El Salvador Destaca Importância do Etanol para o País (2007). Disponível em: http://www1.folha.uol.com.br/folha/mundo/ult94u106283.shtml

FONSECA JR. Gelson. Aspectos da Teoria das Relações Internacionais: Notas Didáticas. Política Externa. São Paulo, Vol. 03, p. 72-100, Dezembro,

FORBES. The Global 2000. (2010) Disponível em: http://www.forbes.com/lists/2010/18/global-2000-10_The-Global2000_Rank.html

FORUM ON CHINA-AFRICA COOPERATION (2011). Disponível em: http://www.focac.org/eng/zfgx/t758818.htm

FOUCHER, Michel. The Geopolitics of Front Lines and Borderlines. Geopolitics. London, Vol. 05. No. 02, p.159-170, Setembro, 2000.

FOUCAULT, Michel. A Verdade e o Poder. In: Microfísica do Poder. Rio de Janeiro: Edições Graal, 2000, p. 01 -14.

FRIEDMAN, John. Intercity Networks in a Globalizing Era. In: SCOTT, Allen J. (Editor). Global City-Regions: Trends, Theory, Policy. New York: Oxford University Press, 2001, p. 119-137.

FUKUYAMA, Francis. The End of History? The National Interest. Washington, No. 16, p. 03-18, Jul./Ago./Set., 1989.

FURTADO, Fabrina. Integração Financeira da América do Sul. Banco do Sul: 
Mais do Mesmo ou Oportunidade Histórica? Oikos. Rio de Janeiro, Vol. 07, No. 01, p. 173-190, Jan./Jun., 2008.

GADDIS, John Lewis. Grand Strategy in the Second Term. Foreign Affairs. Washington, Vol. 84, No. 01, p. 02-15, Jan./ Fev., 2005a.

Strategies of Containment: a Critical Appraisal of American National Security Policy During the Cold War. Nova York: Oxford University Press, 2005b, 484p.

GALL, Norman. A festa do Crédito e a Economia Mundial. Dinheiro, Ganância, Tecnologia. Braudel Papers. São Paulo, No. 43, p.01-19, 2008.

. O Brasil e a Crise Asiática. Dinheiro, Ganância e Tecnologia. Braudel Papers. São Paulo, No. 20, p. 01 e 04-12, 1998.

. O Terremoto Financeiro. A Primeira Crise Global do Século XXI. São Paulo: Editora Campus, 2010, 167p.

GALVÃO, Thiago Gehre. América do Sul: Construção pela Reinvenção (20002008). Revista Brasileira de Política Internacional. Brasília, Vol. 52. No. 02, p. 63-80, Jul./Dez., 2009.

GEIGER, P. Des-territorialização e Espacialização. In: SANTOS, Milton; SOUZA, Maria Adélia Aparecida; SILVEIRA, Maria Laura. Território, Globalização e Fragmentação. São Paulo: Hucitec, 1994, p. 233-246.

GILPIN, Robert. The Politics of Transnational Economic Relations. International Organization. Cambridge, Vol. 25, No. 03, p. 398-419, Jul./Ago./Set., 1971. (Edição Especial - Transnational Relations and World Politics).

GOMES, Paulo Cesar da Costa. O Conceito de Região e sua Discussão. In: CASTRO, Iná Elias; GOMES, Paulo Cesar da Costa; CORRÊA, Roberto Lobato. Geografia: Conceitos e Temas. Rio de Janeiro: Bertrand Brasil, 1995, p. 49 - 76.

GOTTMANN, Jean. Megalopolis. The Urbanized Northeastern Seaboard of the United States. New York: Twentieth Century Fund, 1961, 810p.

. The Evolution of the Concept of Territory. Social Science Information. Londres, Vol. 14, No. 03, p. 29-47, Setembro, 1972.

. The Significance of Territory. Charlottesville: The University Press of Virginia, 1973, 170p.

GRAY, Colin. Maintaining Effective Deterrence. Carlisle: Documento Eletrônico e Impresso, 2003, 69p. 
GRIGG, David. Regiões, Modelos e Classes. Boletim Geográfico (IBGE). Rio de Janeiro, No. 234, p. 03-46, Maio./Jun.,1973.

HAESBAERT, Rogério. O Mito da Desterritorialização: do "Fim dos Territórios" a Multiterritorialidade. Rio de Janeiro: Bertrand Brasil, 2004, 396p.

HALL, Bruce Rodney. Moral Authority as a Power Resource. International Organization, Toronto, Vol. 51, No. 04, p. 591-622, Agosto, 2003.

HALL, Peter. Global City-Regions in the Twenty-first Century. In: SCOTT, Allen J. (Editor). Global City-Regions: Trends, Theory, Policy. Oxford University Press: New York, 2001, p. 59-77.

HAMEL-GREEN, Michael. Japan, Australia and the UN Disarmament Agenda. In: CAMILLERI, Joseph A; MARSHALL, Larry; MICHAEL, Michális (Orgs). Asia-Pacific Geopolitics: Hegemony vs. Human Security. Massachusetts: Edward Elgar, 2007, p. 123-144.

HARDT, Michael \& NEGRI, Antonio. Commonwealth. London: Harvard University Press, 2009, 435p.

. Império. São Paulo: Editora Record, 2005, 501p.

HARRIS, Chauncy; ULLMAN, Edward. The Nature of the Cities. Annals of the American Academy of Political and Social Science. Philadelphia, Vol. 242, p. 07-77, Novembro, 1945.

HARTSHORNE, Richard. Geographic and Political Boundaries in Upper Silesia. Annals of the Association of American Geographers. Washington, Vol. XXIII, No 04, p. 195-228, Dezembro, 1933.

. Perspective on the Nature of Geography. Chicago: Rand Mcnally, 1960, 201p.

Recent Developments in Political Geography I. The American Political Science Review. Washington, Vol. 29, No. 05, p. 785-804, Outubro, 1935a.

. Recent Developments in Political Geography II. The American Political Science Review. Washington, Vol. 29, No 06, p. 943-966, Dezembro, 1935b.

. The Functional Approach in Political Geography. Annals of the Association of American Geographers. Washington, Vol. 40, No. 02, p. 95 - 130, Junho, 1950. 
. The Nature of Geography: A Critical Survey of Current Thought in the Light of the Past. Lancaster: The Science Press Printing Company, 1939, 482p.

HARVEY, David. The Condition of Postmodernity. An Enquiry into the Origins of Cultural Changes. Oxford: Blackwell, 1989, 379p.

HELD, David; McGREW, Anthony; GOLDBLATT, David; PERRATON, Jonathan. The Territorial State and Global Politics. In: Global Transformations: Politics, Economics and Culture. Stanford: Stanford University Press, 1999, p. $32-86$.

HEPPLE, Leslie. South American Heartland: The Charcas, Latin American Geopolitics and Global Strategies. The Geographical Journal. Londres, Vol. 170, No. 04, p.359-367, Dezembro, 2004.

HERZ, Monica. Política de Segurança dos EUA para a América Latina Após o Final da Guerra Fria. Estudos Avançados. São Paulo, Vol. 16, No. 46, p. 85-104, Set./Dez., 2002

HOBBES, Thomas. Leviatã ou Matéria, Forma e Poder de Uma República Eclesiástica e Civil. São Paulo: Martins Fontes, 2003, 616p.

HOBSBOWM, Eric. A Era dos Impérios, 1875-1914. Rio de Janeiro: Paz e Terra, 1988, 547p.

HOFFMANN, Andrea Ribeiro; COUTINHO, Marcelo; KFURI, Regina. Indicadores e Análise Multidimensional do Processo de Integração do Cone Sul. Revista Brasileira de Política Internacional. Brasília, Vol. 51, No. 02, p. 98-116, Jul./Dez., 2008.

HOLZSCHEITER, Anna. Discourse as Capability: Non-state Actors Capital in Global Governance. Millennium, Journal of International Studies. Londres, Vol. 33, No. 03, p.723-746, Junho, 2005.

HUDSON, Rex. Terrorist and Organized Crime Groups in the Tri-Border Area (TBA) of South America. Washington: Documento Eletrônico e Impresso, 2003, 87p.

HUNTINGTON, S. The Clash of Civilizations. Foreign Affairs. Nova York, Vol. 72, No. 03, p. 22-49. Jul./Ago./Set., 1993.

. The Clash of Civilizations and the Remaking of World Order. New York: Simon \& Schuster Paperbacks, 1996, 368p.

HURREL, Andrew. Hegemony, Liberalism and Global Order: What Space for Would Be Great Powers? International Affairs. Londres, Vol. 82, No. 01, p. 01-19, Janeiro, 2006. 
O Ressurgimento do Regionalismo na Política Mundial. Contexto Internacional. Rio de Janeiro, Vol. 17, No. 01, p. 23-59, Jan./Jun., 1995.

IANNI, Otávio. Nação: Província da Sociedade Global? In: SANTOS, Milton; SOUZA, Maria Adélia Aparecida; SILVEIRA, Maria Laura. Território, Globalização e Fragmentação. São Paulo: Hucitec, 1994, p. 77-84.

IKENBERRY, G. John. Asian Regionalism and the Future of U.S. Strategic Engagement with China. In: DENMARK, Abraham (et alli). China's Arrival: A Strategic Framework for a Global Relationship. Washington, 2009, p. 95-108.

INICIATIVA PARA A INTEGRAÇÃO DA INFRAESTRUTURA REGIONAL SULAMERICANA - IIRSA. Cartera de Proyectos 2010: Planificación Territorial Indicativa. Buenos Aires, Edição Impressa 2010a, 288p.

INICIATIVA PARA A INTEGRAÇÃO DA INFRAESTRUTURA REGIONAL SULAMERICANA - IIRSA. Agenda de Implementação Consensuada, 2005-2010. Relatório de Avaliação (31 Projetos de Integração em América do Sul. Buenos Aires, Edição Impressa, 2010b, 157p.

INSTITUTO PARANAENSE DE DESENVOLVIMENTO ECONÔMICO E SOCIAL. (Curitiba, PR). Arranjos Produtivos Locais e o Novo Padrão de Especialização Regional da Indústria Paranaense na Década de 90. Curitiba, 2003b. 95p.

INSTITUTO PARANAENSE DE DESENVOLVIMENTO ECONÔMICO E SOCIAL. (Curitiba, PR). Leituras Regionais - Mesorregião Geográfica Oeste Paranaense. Curitiba, 2003a. 119p.

JAMES, Preston. A Estrutura Conceitual da Geografia. Boletim Geográfico (IBGE). Rio de Janeiro, No. 199, p. 03-23, Jul./Ago.,1967.

JAGUARIBE, Hélio. Aliança Argentino-Brasileira. Diplomacia, Estratégia e Política. Brasília, No. 02, p. 42-52, Jan./Mar., 2005.

JORDAN, Lisa; VAN TUIJL, Peter. Political Responsibility in Transnational NGO Advocacy. World Development. Oxford, Vol. 28, No. 12, p. 2051-2065, Dezembro, 2000

JORNAL DO SENADO. Reajuste do Valor da Energia Cedida pelo Paraguai Divide Senadores. Brasília, 13 de maio de 2011, p.08.

JUILLARD, Étienne. A Região: Tentativa de Definição. Boletim Geográfico (IBGE). Rio de Janeiro, No. 185, p. 224-236, Mar./Abr., 1965.

KALDOR, Mary. The Idea of Global Civil Society. International Affairs. Londres, Vol. 79, No. 03, p. 583-593, Maio, 2003. 
KEANE, John. Global Civil Society? Cambridge: Cambridge University Press, 2003, 236p.

KELLY, Philip. Checkerboards and Shatterbelts: The Geopolitics of South America. Austin: University of Texas Press, 1997, 241p.

. O Pensamento Geopolítico do General Meira Mattos. In: ESCOLA SUPERIOR DE GUERRA (ESG). O General Meira Mattos e a Escola Superior de Guerra. Rio De Janeiro: ESG, 2007, p. 17-37.

KENNAN, George. The Long Telegram. (1945) Disponível em: http://www.gwu.edu/ nsarchiv/coldwar/documents/episode-

1/kennan.htm

KENNEDY, Paul. The Rise and Fall of the Great Powers: Economic Change and Military Conflict from 1500 to 2000. New York: Vintage Books, 1989, 677p.

KISSINGER, Henry. Diplomacy. New York, London, Toronto and Sydney: Simon \& Schuster Paperbacks, 1994, 913p.

. The Chance for a New World Order. International Herald Tribune. São Paulo, 13 Jan. 2009. International, Editorials \& Commentary, p. 06.

KLARE, Michael. Blood and Oil: The Dangers and Consequences of America's Growing Petroleum Dependency. New York: Penguin Books, 2004, 265p.

KLEIMAN, Alberto. Processo de institucionalização de Mercocidades. Da REMI ao FCCR. In: SECRETARÍA EJECUTIVA DE MERCOCIUDADES 2009-2010 (MUNICIPALIDAD DE ROSARIO). 15 Años de Mercocidades. Rosario: Acquatint, Evolución Gráfica, 2010, p. 61-64.

KPMG. Multinacionais Brasileiras. A Rota dos Investimentos Brasileiros no Exterior. São Paulo: Documento Eletrônico e Impresso, 2008, 18p.

KRASNER, Stephan D. Power Politics, Institution, and Transnational Relation. In: RISSE-KAPPEN, Thomas. Bringing Transnational Actor Back In. Cambridge: Cambridge University Press, 1995, p. 257-279.

KRAUER, Juan Carlos Herken. Paraguai: Os Desafios de uma Economia Mediterrânea. Diplomacia, Estratégia e Política. Brasília, No. 10, p.162-180, Out./Dez., 2009.

KRUGMAN, Paul. Scale Economies, Product Differentiation and Pattern of Trade. The American Economic Review. Nashville, Vol. 70, No. 05, p. 950-959, Dezembro, 1980. 
KUME, Honório (et alli). Acordo de Livre Comércio Mercosul - União Européia: Uma Estimativa dos Impactos no Comércio Brasileiro. In: XXXII Encontro Nacional de Economia, 2004, Paraíba. Disponível em: http://www.anpec.org.br/encontro2004/artigos/A04A082.pdf

KUWAHARA, Mônica Yukie. Mercosul: Além da Problemática Comercial. 1999, 207p. Dissertação (Mestrado em Programa de Integração da América Latina) - Programa de Integração da América Latina (PROLAM), Universidade de São Paulo, São Paulo, 1999.

LA BLACHE, Paul Vidal de. La Géographie Politique à Propos des Écrits de M. Frédéric Ratzel. Annales de Géographie. Vol. 07, No. 32, p. 97-11, Março, 1898.

LACOSTE, Yves. A Geografia - Isso Serve, em Primeiro Lugar, Para Fazer a Guerra. Campinas: Papirus, 1988, 264p.

LAFER, Celso. O Cenário Mundial e o Relacionamento União Européia/Mercosul. Política Externa. São Paulo, Vol. 09, No. 01, p. 8891, Jun./Jul./Ago., 2000.

LAFER, Celso \& FONSECA JR, Gelson. Questões para a Diplomacia no Contexto Internacional das Polaridades Indefinidas (Notas Analíticas e Algumas Sugestões). In: FONSECA JR, Gelson; NABUCO DE CASTRO, S. H. Temas de Política Externa Brasileira II. Rio de Janeiro: Ed. Paz e Terra, 1994, p. 49-77.

LE MONDE DIPLOMATIQUE BRASIL. O PAC das Forças Armadas (2009). Disponível em: http://diplomatique.uol.com.br/artigo.php?id=371

LE BILLON, Philippe. The Geopolitics of Resource Wars: Resource Dependence, Governance and Violence. London and New York: Routledge, 2005, 278p.

. The Political Ecology of War: Natural Resources and Armed Conflicts. Political Geography. Londres, Vol. 20, No. 05, p. 561-584, Junho, 2001.

LENCIONI, Sandra. Reestruturação Urbano-Industrial no Estado de São Paulo: a região da metrópole desconcentrada. In: SANTOS, Milton; SOUZA, Maria Adélia Aparecida; SILVEIRA, Maria Laura. Território, Globalização e Fragmentação. São Paulo: Hucitec, 1994, p. 198-210.

. Região e Geografia. São Paulo: Edusp, 1999, 220p.

LÉVY, Jacques. Beyond Geopolitics: A French Connection. Geopolitics. Londres, Vol. 05, No. 02, p. 561-584, Setembro, 2000. 
. Entre a Sociedade Civil e a Sociedade Política. In: SANTOS, Milton; SOUZA, Maria Adélia Aparecida; SILVEIRA, Maria Laura. Território, Globalização e Fragmentação. São Paulo: Hucitec, 1994, p. 221- 232.

LIMA, Jandir Ferreira. Integração Regional: Paraná, Brasil e Mercosul. In: ITAIPU BINACIONAL / UNIVERSIDADE DO OESTE DO PARANÁ Mesorregião Oeste do Paraná: Diagnóstico e Perspectivas, 2001, $527 p$.

LIMA, Marcos Costa. Capitalismo Financeiro, Inovação Tecnológica e Aquecimento Global: as Relações Complementares. Teoria e Pesquisa: Revista de Ciências Sociais. São Carlos, Vol. 17, No. 01, p. 35-48, Jan./Jun., 2008.

LINKOHR, Rolf. A Política Energética Latino-Americana: Entre o Estado e o Mercado. Política Externa. São Paulo, Vol. 15, No. 03, p. 55-63, Dez./Jan./Fev., 2006/2007.

LIPSCHUTZ, Ronnie D. Power, Politics and Global Civil Society. Millennium: Journal of International Studies. Londres, Vol.33, No.3, p. 747-769, Junho, 2005

LÓPEZ-SUÁREZ, L. P.; GUERRA, S. M. G.; UDAETA, M. E. M. A Indústria de Gás Natural e a Integração Energética da América do Sul. Política Externa. São Paulo, Vol. 18, No. 03, p. 49-60, Dez./Jan./Fev., 2009/2010.

LUKE, Timothy W. Running Flat Out on the Road Ahead: Nationality, Sovereignty, and Territoriality in the World of the Information Superhighway. In: Ó TUATHAIL, Gearóid; DALBY, Simon. Rethinking Geopolitics. New York: Routledge, 1998, p. 274-294.

MACHADO, João Bosco M.; RIBEIRO, Fernando J. Conflitos Comerciais no Mercosul. Revista Brasileira de Comércio Exterior (RBCE). Rio de Janeiro, Vol. 01, No. 61, p. 01-09, Abr./ Jun., 1999.

MACHADO, Lia Osório. Limites e Fronteiras: da Alta Diplomacia aos Circuitos da llegalidade. Revista Território. Rio de Janeiro, No. 08, p. 7-23, Jan./Jun., 2000.

MACKINDER, Halford. Democratic Ideals and Reality. New York: Henry Holt and Company, 1942, 220p.

. Geography as a Pivotal Subject in Education. The Geographical Journal. Londres, Vol. 57, No. 05, p. 376-384, Maio, 1921.

. On The Scope and Methods of Geography. Proceedings of the Royal 
Geographical Society and Monthly Record of Geography (New Monthly Series). Londres, Vol. 9, No. 03, p. 141-174, Março, 1887.

. Progress of Geography in the Field and in the Study During the Reign of his Majesty King George The Fifth. The Geographical Journal. Londres, Vol. 86, No. 01, p. 01-12, Julho, 1935.

. The Geographical Pivot of History. The Geographical Journal. Londres, Vol. 23, No. 04, p. 421-437, Abril, 1904.

. The Round World and the Winning of Peace. Foreign Affairs. Washington, Vol. 21, No. 04, p. 595-605, Julho, 1943.

MAHAN, A. T. The Influence of Sea Power Upon History, 1660-1783. New York: Dover, 1987, 557p.

MANTEGA, Guido. A Integração da Infra-Estrutura na América do Sul. Primeira Rodada de Consultas para Construção da Visão Estratégica Sul-Americana no Brasil. 23 de Novembro de 2005. Apresentação em Data Show. 16 Slides.

MARTIN, André Roberto. Qual é o Nosso Bloco?: O Brasil Procura o seu Lugar no Mundo. In: SCARLATO, Francisco C. (Org.). O Novo Mapa do Mundo: Globalização e Espaço Latino-Americano. São Paulo: Hucitec/Annablume, 2002, p. $105-121$.

MARTINS, Élvio Rodrigues. Geografia e Ontologia: O Fundamento Geográfico do Ser. Geousp - Espaço e Tempo. São Paulo, No. 21, p. 33-51, Maio, 2007.

MARTINS, Ricardo Silveira. Caracterização da Infra-Estrutura de Transporte. In: ITAIPU BINACIONAL / UNIVERSIDADE DO OESTE DO PARANÁ. Mesorregião Oeste do Paraná: Diagnóstico e Perspectivas, 2001, 527p.

MAYHEW, R. Halford Mackinder's "New" Political Geography and the Geographical Tradition. Political Geography. Londres, Vol. 19, No. 06, p. 771-791, Agosto, 2000.

MASIERO, Gilmar; LOPES, Heloisa. Etanol e Biodiesel como Recursos Energéticos Alternativos: Perspectivas da América Latina e da Ásia. Revista Brasileira de Política Internacional. Brasília, Vol. 51, No. 02, p. 60-79, Jul./Dez., 2008.

MEIRA MATTOS, Carlos de. A Estratégia - Origens, Fundamentos, Desdobramentos no Espaço e no Tempo. Revista da Escola Superior de Guerra. Rio de Janeiro, No. 43, p. 05-09, Jan./Dez., 2004. 
A Importância Geopolítica da Amazônia Brasileira. In: In: O General Meira Mattos e a Escola Superior de Guerra. Rio de Janeiro: ESG, 2007b. p. $91-121 .$.

- A Tese da Internacionalização da Amazônia. In: O General Meira Mattos e a Escola Superior de Guerra. Rio de Janeiro: ESG, 2007c p. 121-128.

. Brasil, Geopolítica e Destino. Rio de Janeiro: Biblioteca do Exército, 1975, 110p.

. O Brasil e sua Estratégia. Revista da Escola Superior de Guerra, Rio de Janeiro, No. 40, p. 48-55, Jan./Dez., 2001.

- Reflexões Sobre uma Estratégia Militar para o Brasil. In: O General Meira Mattos e a Escola Superior de Guerra. Rio de Janeiro: ESG, 2007a, p. 55-58.

MELO PEREIRA, Rafaella Arruda. Brasil e Guatemala Assinam Acordos de Cooperação. PUC Minas: Conjuntura Internacional. Belo Horizonte: Documento Eletrônico e Impresso, 2005, 4p.

MELLO, Leonel Itaussu Almeida. A Geopolítica do Brasil e a Bacia do Prata. Manaus: EDUA, 1997, 300p.

MELLO E SILVA, Alexandra de. Idéias e Política Externa: a Atuação Brasileira na Liga das Nações e na ONU. Revista Brasileira de Política Internacional. Brasília, Vol. 41, No. 02, p. 139-158, Jul./Dez., 1998.

MICHAEL, Michális S; MARSHALL, Larry. Hegemony and Human Security: Competing Principles of Regional Order. In: CAMILLERI, Joseph A; MARSHALL, Larry; MICHAEL, Michális (Orgs). Asia-Pacific Geopolitics: Hegemony vs. Human Security. Massachusetts: Edward Elgar, 2007, p. 03-21.

MILTON SANTOS. Roda Viva. São Paulo: TV Cultura, 30 de março de 1997. Programa de TV.

MINISTÉRIO DO DESENVOLVIMENTO, INDÚSTRIA E COMÉRCIO EXTERIOR.

http://www.mdic.gov.br//sitio/interna/interna.php?area=5\&menu=576

MITRE, Antonio. Ligações Perigosas: Estado e Guerra na América Latina (2010). http://www.plataformademocratica.org/Arquivos/Ligacoes\%20Perigosas .pdf

MONIZ BANDEIRA, Luiz Alberto. Formação do Império Americano: Da 
Guerra Contra a Espanha à Guerra no Iraque. Rio de Janeiro: Civilização Brasileira, 2006, 851p.

. Estado Nacional e Política Internacional na América Latina. O Continente nas Relações Argentina - Brasil (1930 - 1992). São Paulo: Editora Ensaio, 1993, 337p.

MONTE-MÓR, Roberto Luís. As Teorias Urbanas e o Planejamento Urbano no Brasil. In: DINIZ, Célio Campolina; CROCCO, Marco. Economia Regional e Urbana: Contribuições Teóricas Recentes. Belo Horizonte: Editora UFMG, 2006, p. 61-85.

MORAES, Antonio Carlos Robert (Org.) Ratzel. São Paulo: Ática, 1990, 200p.

MORGENTHAU, Hans J. Politics Among Nations: The Struggle for Power and Peace. Boston: McGraw-Hill Higher Education, 1948, 703p.

MORRIS, Charles R. The Two Trillion Dollar Meltdown. Easy Money, High Rollers, and the Great Credit Crash. New York: Public Affairs, 2008, p. 210p.

MOUTINHO DOS SANTOS, Edmilson. Petróleo - Quadro Estratégico-Global no Início do Século XXI. Política Externa. São Paulo, Vol. 12, No. 01, 95115. Jun./Jul./Ago., 2003.

Mr. X. The Sources of Soviet Conduct. Foreign Affairs. Washington, Vol. 25, No. 04, p. 566-582, Julho, 1947.

MÜLLER, Martin. Reconsidering the Concept of Discourse for the Field of Critical Geopolitics: Towards Discourse as Language and Practice. Political Geography. Londres, Vol. 27, No. 03, p. 322-338, Março, 2008.

MÜLLER, Vivian Cristina. Direito comunitário: a função judicial no Mercosul. (2003) Disponível em: http://jus.uol.com.br/revista/texto/4873/direito-comunitario-a-funcaojudicial-no-mercosul

MUZAFFAR, Chandra. Containing China: A flawed Agenda. In: CAMILLERI, Joseph A; MARSHALL, Larry; MICHAEL, Michális (Orgs). Asia-Pacific Geopolitics: Hegemony vs. Human Security. Massachusetts: Edward Elgar, 2007, p. 59-72.

NYE Jr. Joseph S. The Powers to Lead. New York: Oxford University Press, 2008, 226p.

NYE Jr., Joseph; KEOHANE, Robert. Transnational Relations and World Politics: An Introduction. International Organization. Cambridge, Vol. 
25, No. 03, p. 329-349, Jul./Ago./Set., 1971a. (Edição Especial Transnational Relations and World Politics)

Transnational Relation and World Politics: A Conclusion. International Organization. Cambridge, Vol. 25, No. 03, p. 721-748, Jul./Ago./Set., 1971b. (Edição Especial - Transnational Relations and World Politics)

ODDONE, Nahuel Potencialidades del Mercosur desde los Gobiernos Locales. In: SECRETARÍA EJECUTIVA DE MERCOCIUDADES 2009-2010 (MUNICIPALIDAD DE ROSARIO). 15 Años de Mercocidades. Rosario: Acquatint, Evolución Gráfica, 2010, p.76-80.

O'LOUGHLIN, John. Geography as Space and Geography as Place: The Divide Between Political Science and Political Geography Continues. Geopolitics. Londres, Vol. 05, No. 03, p. 126-137, Setembro, 2000.

Ó THUATHAIL, Gearóid. Critical Geopolitics: The Politics of Writing Global Space. Minneapolis: Minnesota Press, 1996, 314p.

Postmodern Geopolitics? The Modern Geopolitical Imagination and Beyond. In: Ó THUATHAIL, Gearóid; DALBY, Salmon. Rethinking Geopolitics. New York: Routledge, 1998, p.16-38.

. Putting Mackinder in His Place: Material Transformations and Myth. Political Geography. Londres, Vol. 11, No. 01, p. 100-118, Janeiro, 1992.

. The Postmodern Geopolitical Condition. State, Statecraft, and Security at the Millennium. Annals of the Association of American Geographers. Washington, Vol. 90, No.01, p. 166-178, Março, 1997.

Ó THUATHAIL, Gearóid; AGNEW, John. Geopolitics and Discourse. Practical Geopolitical Reasoning in American Foreign Policy. Political Geography. Londres, Vol. 11, No. 02, p. 127-230, Março, 1992.

Ó THUATHAIL, Gearóid; DALBY, Simon. Introduction: Rethinking Geopolitics. In: Ó THUATHAIL, Gearóid; DALBY, Salmon. Rethinking Geopolitics. New York: Routledge, 1998, p. 01-15.

OFFE, Claus. A Atual Transição da História e Algumas Opções Básicas para as Instituições da Sociedade. In: PEREIRA, Luiz Carlos Bresser Pereira; WILHEIM, Jorge; SOLA, Lourdes (Orgs). Sociedade e Estado em Transformação. São Paulo: Unesp / Enap / Imprensa Oficial, 2001, p. 119-145.

OHMAE, Kenichi. How to Invite Prosperity from the Global Economy into a Region. In: SCOTT, Allen J. (Editor). Global City-Regions: Trends, Theory, Policy. Oxford University Press: New York, 2001, p. 33-43. 
OLIVEIRA, Marcelo Fernandes de. Alianças e Coalizões Internacionais do Governo Lula: o Ibas e o G-20. Revista Brasileira de Política Internacional. Brasília, Vol. 48, No. 02, p. 55-69, Jul./Dez., 2005

OLIVERA, Eliézer Rizzo de. A Estratégia Nacional de Defesa e a Reorganização e Transformação das Forças Armadas. Interesse Nacional. São Paulo, No. 05, p. 71-83, Abr./Jun., 2009.

ORGANIZAÇÃO DAS NAÇÕES UNIDAS (ONU). Convenção das Nações Unidos Sobre o Direito ao Mar (1982). Disponível em: http://www2.mre.gov.br/dai/m_1530_1995.htm

ORGANISATION FOR ECONOMIC CO-OPERATION AND DEVELOPMENT (OCDE) \& THE MINISTRY OF SCIENCE AND TECHNOLOGY, CHINA. Reviews of Innovation Policy CHINA Synthesis Report. Paris: Documento Eletrônico e Impresso, 2007, 68p.

PARBONI, R. The Dollar Weapon: From Nixon to Reagan. New Left Review. Londres, No.158, p. 05-18, Jul./Ago., 1986.

PASHA, Mustapha Kamal. Hegemony, Perilous Empire and Human Security. In: CAMILLERI, Joseph A; MARSHALL, Larry; MICHAEL, Michális (Orgs). Asia-Pacific Geopolitics: Hegemony vs. Human Security. Massachusetts: Edward Elgar, 2007, p. 23-41.

PATIENCE, Allan. Japan, Australia and Niche Diplomacy in the South Pacific. In: CAMILLERI, Joseph A; MARSHALL, Larry; MICHAEL, Michális (Orgs). Asia-Pacific Geopolitics: Hegemony vs. Human Security. Massachusetts: Edward Elgar, 2007, p. 145-162.

PATRIOTA, Antonio de Aguiar. O Brasil e a Política Externa dos EUA. Revista Política Externa. São Paulo, Vol. 17, No. 01, Jun./Jul./Ago., 2008.

PAULANI, Leda Maria. A Crise do Regime de Acumulação com Dominância da Valorização Financeira e a Situação do Brasil. Estudos Avançados (Dossiê Crise Internacional II). São Paulo, Vol. 23, No. 66, p. 25-39. Maio/ Ago., 2009.

PECEQUILO, Cristina Soreano. A Política Externa do Brasil no Século XXI. Os Eixos Combinados de Cooperação Horizontal e Vertical. Revista Brasileira de Política Internacional. Brasília, Vol. 51, No. 02, p. 136156, Jul./Dez., 2008.

PEET, R. From Eurocentrism to Americentrism. Antipode. Worcester, Vol.38, No. 02, p. 336-343, Março, 2006.

PEÑA, Felix. Mercosul: Análise de uma Década e Tendências para o Futuro. 
Política Externa. São Paulo, Vol. 10, No. 01, p. 07-23, Jun./Jul./Ago., 2001.

PERIS, Alfredo Fonseca. Trilhas, Rodovias e Eixos: um Estudo Sobre o Desenvolvimento Regional. Cascavel: Edunioeste, 2002, 174p.

PERIS, Alfredo Fonseca; BRAGA, Eliézio Goulart. Eixos de Desenvolvimento Intra-Regionais. In: ITAIPU BINACIONAL / UNIVERSIDADE DO OESTE DO PARANÁ. Mesorregião Oeste do Paraná: Diagnóstico e Perspectivas, 2001, 527p.

PFRIMER, Matheus Hoffmann. Heartland Sul-americano? Dos Discursos Geopolíticos à Territorialização de um Novo Triângulo Estratégico Boliviano. Geousp - Espaço e Tempo. São Paulo, No. 29, p. 131-144, 2011.

PFRIMER, Matheus Hoffmann; ROSEIRA, Antonio Marcos. Transformações Territoriais na Bolívia: Um Novo "Triangulo Estratégico"? In: $12^{\circ}$ Encuentro de Geografos da América Latina, 2009, Montevidéu. Disponível em: egal2009.easyplanners.info/area01/1062_Hoffmann_Pfrimer_Matheus. doc

PORTER, Michael E. A Vantagem Competitiva das Nações. Rio de Janeiro: Editora Campus, 1993, 897p

. Regions and the New Economics of Competition. In: SCOTT, Allen J. (Editor). Global City-Regions: Trends, Theory, Policy. New York: Oxford University Press, 2001, p. 139-157.

PRADO JR. Caio. História Econômica do Brasil. São Paulo: Editora Brasiliense, 1970, 310p.

POLANYI, Karl. The Great Transformation: The Political and Economic Origins of Our Time. Boston: Beacon Press, 2001, 318p.

PORTO, Edgard. As Políticas de Desenvolvimento Regional do Brasil e seus Reflexos sobre a Região Nordeste. In: ELIAS, Denise; PEQUENO, Renato. Difusão do Agronegócio e Novas Dinâmicas Socioespaciais. Fortaleza: Banco do Nordeste do Brasil, 2006. p. 83113.

PUNTIGLIANO, Andrés Rivarola. 'Going Global': An Organizational Study of Brazilian Foreign Policy. Revista Brasileira de Política Internacional. Brasília, Vol. 51, No. 01, p. 28-52, Jan./Jun., 2008.

RAFFESTIN, Claude. Por Uma Geografia do Poder. São Paulo: Editora Ática, 1993, 269p. 
RAMANZINI Jr., Haroldo; VIGEVANI, Tullo. Autonomia e Integração Regional no Contexto do Mercosul: Uma Análise Considerando a Posição do

Brasil. OSAL. Buenos Aires, No. 27, p. 45-63, Abril, 2010.

RANGEL, Alfredo. Progressos e Desafios na Colômbia de Hoje. Diplomacia, Estratégia e Política (DEP). Brasília, No. 10, p. 117-128, Out./Dez., 2009.

RAPOPORT, Mário. Argentina: Economia e Política Internacional. Os Processos Históricos. Diplomacia, Estratégia e Política (DEP). Brasilia, No. 10, p. 27-51, Out./Dez., 2009.

RAPOPORT, Mario; SPIGUEL, Claudio. La Argentina y el Plan Marshall: Promesas y Realidad. Revista Brasileira de Política Internacional. Brasília, Vol. 52, No. 01, p. 05-28, Jan./Jun., 2009.

RATZEL, Friedrich. La Géographie Politique: les Concepts Foundamentaux. Paris: Fayard, 1987, 220p.

REAGAN, Ronald. National Security Strategy of the United States. Washington: Brassey's Inc, 1988, 128p.

REDE DE SEGURIDAD Y DEFENSA DE AMÉRICA LATINA (RESDAL). Atlas Comparativo de la Defensa en América Latina. Buenos Aires: Documento Eletrônico e Impresso, 2008, 312p.

REIS, Marcos Aurélio B. Dos; LEANDRO, Ismael Voigt. A Recepção dos Refugiados Colombianos nos Países Fronteiriços com Exceção do Brasil. Consilium - Revista Eletrônica de Direito. Brasília, Vol. 01, No. 04, p. 01-12, Maio/Ago., 2010.

RETAILLÉ, Denis. Geopolitics in History. Geopolitics. Londres, Vol. 05, No. 02, p. 35-51, Setembro, 2000.

REVISTA EXAME. Odebrecht fará etanol na África (2010). Disponível em: http://exame.abril.com.br/blogs/primeiro-lugar/2010/04/28/odebrechtfara-etanol-na-africa/

RIBEIRO, Fernando J; LIMA, Raquel Casado. Investimentos Brasileiros na América do Sul: Desempenho, Estratégias e Políticas. Relatório Final. Rio de Janeiro: SDC/FUNCEX, 2008, 52p.

RIBEIRO, Letícia Parente. As Cidades Gêmeas Foz do Iguaçu e Ciudad Del Este: Interações Espaciais na Fronteira Brasil-Paraguai. 2001. 98p. 
Dissertação (Mestrado em Geografia) - Instituto de Geociências, Universidade Federal do Rio de Janeiro, Rio de Janeiro, 2001.

RISSE-KAPPEN, Thomas. Bringing Transnational Actors Back. An introduction. In: Bringing Transnational Actor Back In. Cambridge University Press, 1995, p. 3-33.

ROCHEFORT, Michel. Um Método de Pesquisa das Funções Características de uma Metrópole Regional. Boletim Geográfico (IBGE). Rio de Janeiro, No. 198, p. 11-15, Maio/Jun., 1967.

RODRIGUES, Lysias A. Geopolítica do Brasil. Rio de Janeiro: Biblioteca Militar, 1947, 144p.

ROJAS ARAVENA, F. Panorama da Segurança na América do Sul. Revista Brasileira de Diplomacia. Brasília, No 01, p. 53-77, Jan./Mar., 2005.

ROSEIRA, Antonio Marcos. Foz do Iguaçu: Cidade Rede Sul-Americana. 2006, 170p. Dissertação (Mestrado em Ciência. Área de Concentração: Geografia Humana) - Faculdade de Filosofia, Letras e Ciências Humanas, Universidade de São Paulo, São Paulo, 2006.

ROSENAU, James N. Governança, Ordem e Transformação na Política Mundial. In: ROSENAU, James; CZEMPIEL, Ernest-Otto. Governança Sem Governo: Ordem e Transformação na Política Mundial. Brasília: Editora UNB, 2000, p. 11-41.

RUCKERT, Aldomar Arnaldo. O Processo de Reforma do Estado e a Política Nacional de Ordenamento Territorial. In: MINISTÉRIO DA INTEGRAÇÃO NACIONAL (Brasília, DF). Para Pensar uma Política Nacional de Ordenamento Territorial. Documento Eletrônico e Impresso, Brasília, 2005, p. 31-40.

- Usos do Território e Políticas Territoriais Contemporâneas: Alguns Cenários no Brasil, União Européia e Mercosul. Revista de Geopolítica. Ponta Grossa, Vol. 01, No 01, p. 17-32, Jan./Jun., 2010.

RUGGIE, John Gerard. Reconstituting The Global Public Domain - issues, actors and practices. European Journal of International Relations. Vol. 10, No. 04, p. 499-531, 2004.

RUIZ, José Briceño. O Mercosul: Reflexões sobre a Crise de seu Modelo de Integração e seus Relançamento. Cadernos PROLAM/USP. São Paulo. Vol. 01, No. 10, p. 187-209, 2007.

SÁ PINTO, Messias de; GUIMARÃES, Maria Helena. O Mercosul e a Alca: Os Interesses (Irre)Conciliáveis da União Européia e dos EUA. Revista 
Brasileira de Política Internacional. Brasília, Vol. 48, No. 01, p. 129150, Jan./Jun., 2005.

SAKAMOTO, Yoshikazy. Beyond the Japanese Constitutional Dilemmas. In: CAMILLERI, Joseph A; MARSHALL, Larry; MICHAEL, Michális (Orgs). Asia-Pacific Geopolitics: Hegemony vs. Human Security. Massachusetts: Edward Elgar, 2007, p. 105-121.

SANGUIN, André-Louis. A Evolução e Renovação da Geografia Política. Boletim de Geografia. Rio de Janeiro, Vol. 35, No. 252, p. 05-23, Jan./Mar., 1977.

SANTOS, Luís Cláudio Villafañe G. A América do Sul no Discurso Diplomático Brasileiro. Revista Brasileira de Política Internacional. Brasília, Vol. 48, No. 02, p. 185-204, Jul./Dez., 2005.

SANTOS, Marcelo. O México Como Aliado dos EUA no Projeto de Integração das Américas. Revista Brasileira de Política Internacional. Brasília, Vol. 50, No. 02, p.146-161, Jul./Dez., 2007.

SANTOS, Marlene Xavier. BR-277 - A Vivificação da Fronteira. 1995. 251p. Dissertação (Mestrado em Geografia) - Faculdade de Filosofia, Letras e Ciências Humanas, Universidade de São Paulo, São Paulo, 1995.

SANTOS, Milton. Da Política dos Estados a Política das Empresas. Cadernos da Escola do Legislativo. Belo Horizonte, Vol. 03, No. 06, p. 9-23, Jul./Dez.,1997.

O Chão e o Cifrão (1999). Disponível em: http://www1.folha.uol.com.br/fol/brasil500/dc_3_8.htm

O Retorno do Território. In: SANTOS, Milton; SOUZA, Maria Adélia Aparecida; SILVEIRA, Maria Laura. Território: Globalização e Fragmentação. São Paulo: Hucitec, 1993, p. 15-20.

. Por Uma Outra Globalização: Do Pensamento Único a Consciência Universal. São Paulo: Editora Record, 2000, 174p.

SANTOS, Milton; SILVEIRA, Maria Laura. O Brasil: Território e Sociedade no Início do Século XXI. São Paulo: Editora Record, 2001, 474p.

SASSEN, Saskia. The Global City: New York, London, Tokyo. New Jersey: Princeton University Press, 2001, 448p.

. Global Cities and Global City-Regions. a Comparison. In: SCOTT, Allen J. (Editor). Global City-Regions: Trends, Theory, Policy. New York: Oxford University Press, 2001, p. 78-95. 
SARAIVA, Miriam Gomes; RUíZ, José Briceño. Argentina, Brasil e Venezuela: as Diferentes Percepções sobre a Construção do Mercosul. Revista Brasileira de Política Internacional. Brasília, Vol. 52, No. 01, p. 149166, Jan./Jun., 2009.

SCHAEFFER, Fred K. Exceptionalism in Geography: A Methodological Examination. Annals of the Association of American Geographers. Washington, Vol. 43, No. 03, p. 226-249, Setembro, 1953.

SCHERER, André Luís Forti. Investimento direto estrangeiro, fusões e aquisições e desnacionalização da economia brasileira: um balanço da década do Plano Real. Indic. Econ. FEE. Porto Alegre, Vol. 32, No. 02, p. 107-128, Agosto, 2004

SCHILLING, Paulo. Expansionismo Brasileiro (A Geopolítica do General Golbery e a Diplomacia Brasileira). São Paulo: Global, 1981, 288p.

SCHUMPETER, Joseph A. Capitalism, Socialism and Democracy. New York: Harper Perenial Modern Thought, 2008, 432p.

SCOTT, Allen J. Regional Motors of the Global Economy. Futures. Londres, Vol. 28, No. 05, p. 391-411, Junho, 1996.

SCOTT, Allen J.; AGNEW, John; SOJA, Edward; STORPER, Michael. Global City-Regions. In: SCOTT, Allen J. (Editor). Global City-Regions: Trends, Theory, Policy. New York: Oxford University Press, 2001, 468p.

SEABRA, Odete; CARVALHO, Mônica; LEITE, José Corrêa. (Org.). Território e Sociedade: Entrevista com Milton Santos. São Paulo: Fundação Perseu Abramo, 2000, 127p.

SECRETARÍA EJECUTIVA DE MERCOCIUDADES 2009-2010 (MUNICIPALIDAD DE ROSARIO): 15 Años de Mercocidades. Rosario: Acquatint, Evolución Gráfica, 2010. 113p.

SEIGEL, Michael T. Questioning the Rationale for Changing Japan's Peace Constitution. In: CAMILLERI, Joseph A; MARSHALL, Larry; MICHAEL, Michális (Orgs). Asia-Pacific Geopolitics: Hegemony vs. Human Security. Massachusetts: Edward Elgar, 2007, p. 75-92.

SEMPLE, Ellen Churchill. Influences of the Environment. On the Basis of Ratzel's System of Anthropo-Geography. New York: Henry Holt and Company, 1911, 683p.

SIKKINK, K. A Emergência, Evolução e Efetividade da Rede de Direitos Humanos da América Latina. In: JELIN, Elizabeth; HERSHBERG, Eric. 
Construindo a Democracia: Direitos Humanos, Cidadania e Sociedade na América Latina. São Paulo, Edusp, 2006, p 97-132.

SILVA, Armando Corrêa da. O Território da Consciência e a Consciência do Território. In: SANTOS, Milton; SOUZA, Maria Adélia Aparecida; SILVEIRA, Maria Laura. Território, Globalização e Fragmentação. São Paulo: Hucitec, 1994. p. 257-260.

SILVA, Carlos Alberto Borges da. Região do Rio Essequibo: Atualidade de uma Reivindicação Territorial Venezuelana. Ambiente: Gestão e Desenvolvimento. (2006) Disponível em: http://www.uerr.edu.br/revistas/remgads/uploads/c881 ba82-22d764fe.pdf

SILVEIRA, Maria Laura. Globalização na Rede Urbana Argentina e Nordpatagônica. In: SANTOS, Milton; SOUZA, Maria Adélia Aparecida; SILVEIRA, Maria Laura. Território, Globalização e Fragmentação. São Paulo: Hucitec, 1994, p. 125-140.

SIMÕES, Antonio José Ferreira. Petróleo, Gás Natural e Biocombustíveis: Desafios Estratégicos no Mundo e no Brasil. Revista Política Externa. São Paulo, Vol. 15, No. 03, p. 21-32, Dez./Jan./Fev., 2006/2007.

SLATER, David. Repensando a Espacialidade dos Movimentos Sociais. Questões de fronteira, cultura e política em tempos globais. In: ALVAREZ, Sonia; DAGNINO, Evelina; ESCOBAR, Arturo. Cultura e Política nos Movimentos Sociais Latino-Americanos. Novas Leituras. Ed. UFMG, Belo Horizonte, 2000, p. 503-533.

SOARES DE LIMA, Maria Regina; HIRST, Mônica. Brazil as an Intermediate State and Regional Power: Action, Choice and Responsibilities. International Affairs. Londres, Vol. 82, No. 01, p. 21-40, Janeiro, 2006.

SOSA, Sebastián. The Influence of "Big Brothers:" How Important are Regional Factors for Uruguay? In: International Monetary Fund Working Paper. Washington: Edição Impressa, 2010, 27p.

SOUCHAUD, Sylvain; CARMO, Roberto Luis do. Migração e Mobilidade no Mercosul: A Fronteira do Brasil com Bolívia e Paraguai. In: XV Encontro Nacional de Estudos Populacionais, 2006, Caxambu. Disponível em: http://www.abep.nepo.unicamp.br/encontro2006/docspdf/ABEP2006_7 02.pdf.

SOUTO MAIOR, Luis A. P. O Brasil e o Regionalismo Continental Frente a uma Ordem Mundial em Transição. Revista Brasileira de Política Internacional. Brasília, Vol. 49, No. 02, p. 42-59, Jul./Dez., 2006. 
SOUZA, Ana Tereza Lopes Marra. A Presença de Empresas Multinacionais Brasileiras na América do Sul: uma Visão a Partir das Políticas Brasileiras para a Integração Regional. In: Anais do II Seminário de Sociologia e Política. Curitiba, Vol. 10, 2010, p.03-19.

SOUZA, Marcelo José Lopes. O Território: Sobre Espaço e Poder, Autonomia e Desenvolvimento. In: CASTRO, Iná Elias; GOMES, Paulo Cesar da Costa; CORRÊA, Roberto Lobato. Geografia: Conceitos e Temas. $7^{\circ}$ Edição. Rio de Janeiro: Bertrand Brasil, 1995, p. 77-116.

SOUZA, Maria Adélia Aparecida de. Geografia da Desigualdade: Globalização e Fragmentação. In: SANTOS, Milton; SOUZA, Maria Adélia Aparecida; SILVEIRA, Maria Laura. Território: Globalização e Fragmentação. São Paulo: Hucitec, 1993, p. 21-41.

SPEKTOR, Matias. Kissinger e o Brasil. Rio de Janeiro: Jorge Zahar Editor, 2009, 236p.

. O Brasil e a Argentina entre a Cordialidade Oficial e o Projeto de Integração: a Política Externa do Governo de Ernesto Geisel (19741979). Revista Brasileira de Política Internacional. Brasília, Vol. 45, No. 01, p. 117-145, Jan./Jun., 2010.

SPYKMAN, Nicholas. America's Strategy in World Politics: The United States and the Balance of Power. New York: Transaction, 2007, 525p.

. Geography and Foreign Policy I. The American Political Science Review. Vol. 32, No.01, p. 28-50, Fevereiro, 1938a.

. Geography and Foreign Policy II. The American Political Science Review. Vol. 32, No. 02, p. 213-136, Abril, 1938b.

STIGLITZ, Joseph E. Foreword. In: POLANYI, Karl. The Great Transformation: The Political and Economic Origins of Our Time. Boston: Beacon Press, 2001, p. VII-XVII.

STIGLITZ, Joseph; BILMES, Linda J. The Three Trillion Dollar War. The True Cost of the Iraq Conflict. Nova York: W. W. Norton \& Company, 2008, 312p.

STOCKHOLM INTERNATIONAL PEACE RESEARCH INSTITUTE (SIPRI). Military Expenditure. In: Yearbook 2009: Armaments, Disarmament and International Security. Estocolmo: Documento Eletrônico e Impresso, 2009, p. 179-211. 
STORPER, Michael. The Regional World. Territorial Development in a Global Economy. New York: The Guilford Press, 1997, 339p.

STORPER, Michael; SCOTT, Allen J. The Wealth of Regions. Market Forces and Policy Imperatives in Local and Global Context. Futures. Londres, Vol. 27, No.05, p. 505-526, Junho, 1995.

TARROW, Sidney. The New Transnational Activism. New York: Cambridge University Press, 2005, 258p.

TAMBS, Lewis. Factores Geopoliticos en America Latina. In: Antologia Geopolitica de Bolivia. La Paz: Ediciones los Amigos del Libro, 1978, p. 229-244.

TAYLOR, lan. China's Oil Diplomacy in Africa. International Affairs. Londres, Vol. 82, No. 05, p. 937-959, Outubro, 2006.

TAYLOR, Peter J. World City Network: A Global Urban Analysis. London: Routledge, 2004.

THE WHITE HOUSE. The National Security Strategy of the United States of America. Washington: Documento Eletrônico e Impresso, 2002, 35p.

THÉRY, Hervé; MELLO, Neli Aparecida de. Atlas do Brasil. Disparidades e Dinâmicas do Território. São Paulo: Edusp, 2005, 310p.

TOMASSINI, Luciano. Economia e Sociedade no Chile. Um processo Histórico. Diplomacia, Estratégia e Política (DEP). Brasília, No.10, p. 88-116, Out./Dez., 2009.

TRATADO DE ASSUNÇÃO (1991) Disponível em: http://www.mercosul.gov.br/tratados-e-protocolos/tratado-de-assuncao1 Acessado em fevereiro de 2010.

TRATADO DE LIMA (1929). Disponível em: http://www.congreso.gob.pe/comisiones/2008/seguimientodemandaperuana/documentos/TratadodeLimayProtocoloComplementar io1929.pdf

TRAVASSOS, Mário. Projeção Continental do Brasil. São Paulo: Companhia Editora Nacional, 1935, 206p.

UNITED NATIONS CONFERENCE ON TRADE AND DEVELOPMENT (UNCTAD) (2011). http://unctadstat.unctad.org/TableViewer/tableView.aspx?Reportld=106

UNITED NATIONS CONFERENCE ON TRADE AND DEVELOPMENT (UNCTAD). World Investment Report. Transnational Corporations, 
Agricultural Production and Development. Documento Eletrônico e Impresso. Nova York / Genebra, 2009, 278p.

UNITED NATIONS CONFERENCE ON TRADE AND DEVELOPMENT (UNCTAD). World Investment Report. Investing in a Low-Carbon Economy. Documento Eletrônico e Impresso. Nova York / Genebra, 2010, 184p.

UNITED NATIONS CONFERENCE ON TRADE AND DEVELOPMENT (UNCTAD). World Investment Report. Non-Equity Modes of International Production and Development Documento Eletrônico e Impresso. Nova York / Genebra, 2011, 226p.

UNITED NATIONS HIGH COMMISSIONER FOR REFUGEES (UNHCR). http://www.unhcr.org/cgi-bin/texis/vtx/page?page=49e492ad6

UNITED STATES OF AMERICA (USA). National Energy Policy. Documento Eletrônico e Impresso. Washington, 2001. 170p.

UNIVERSIDADE DE SÃO PAULO (São Paulo, SP). Diretrizes para Apresentação de Dissertações e Teses da USP. Documento Eletrônico e Impresso. São Paulo, 2004. 110p.

VALÉRY, Paul. Introdução ao Método de Leonardo da Vince. São Paulo: Editora 34, 1998, 256p.

VELUT, Sébastien. Argentine - Chili: Une si longue frontière. Confins, Revista Franco-Brasileira de Geografia. Paris, No. 07, p. 1-20, 2009.

VENIER, Pascal. The Geographical Pivot of History and Early Twentieth Century Geopolitical Culture. The Geographical Journal. Londres, Vol. 170, No. 04, p. 330-336, Dezembro, 2004.

VENCOVSKY, Vitor Pires; CASTILLO, Ricardo. Sistema Ferroviário PósPrivatização e Fluidez Corporativa: O Movimento de Produtos Agrícolas no Território Brasileiro. Geousp - Espaço e Tempo. São Paulo. No. 21, p. 119-134, Maio, 2007.

VILLA, Rafael Duarte; OSTOS, Maria del Pilar. As Relações Colômbia, Países Vizinhos e Estados Unidos: Visões em Torno da Agenda de Segurança. Revista Brasileira de Política Internacional. Brasília, Vol. 48, No. 02, p. 86-110, Jul./Dez., 2005.

VIRILIO, Paul. Espaço Crítico e as Perspectivas do Tempo Real. São Paulo: Editora 34, 1993, 119p. . Velocidade e Política. São Paulo: Estação Liberdade, 1996, 137p. 
WALTON, C. Dale. The Geography of Universal Empire: A Revolution in Strategic Perspective and Its Lessons. Comparative Strategy. Reading, Vol. 24, No. 03, p. 223-235, Jul./Set., 2005.

WANDERLEY, Luiz Eduardo W. Mercosul e Sociedade Civil. São Paulo em Perspectiva. São Paulo, Vol. 16, No. 01, p. 63-73, Jan./Mar., 2002.

WEBER, Max. A Instituição Estatal Racional e os Modernos Partidos Políticos e Parlamentos (Sociologia do Estado). In: Economia e Sociedade. Vol. 2. Fundamentos da Sociologia Compreensiva. Brasília: Editora UNB, 1999, p. 517-580.

Os Tipos de Dominação. In: Economia e Sociedade. Vol. 1. Fundamentos da Sociologia Compreensiva. Brasília: Editora UNB. 2000, p. 139-198.

WELLS Jr, Louis T. The Multinational Business Enterprise: What Kind of International Organization? International Organization. Cambridge, Vol. 25, No. 03, p. 447-464, Jul./Ago./Set., 1971. (Edição Especial Transnational Relations and World Politics).

WHITTLESEY, Derwent. O Conceito Regional e o Método Regional. Boletim Geográfico. Rio de Janeiro, No. 154, p. 05-36, Jan. / Fev., 1960.

WROBEL, Andrzej. Teorias e Modelos de Desenvolvimento Regional: Um Exame Crítico. Boletim Geográfico (IBGE). Rio de Janeiro, No. 239, Ano 33, p. 01-16, Mar./Abr., 1974.

YAMADA, Tetsuya. The Role of the United Nations in the Twenty-First Century. In: CAMILLERI, Joseph A; MARSHALL, Larry; MICHAEL, Michális (Orgs). Asia-Pacific Geopolitics: Hegemony vs. Human Security. Massachusetts: Edward Elgar, 2007, p. 163-174.

YAMAGUCHI, Jiro. Can Japan Create a Basis for its Internationality? In: CAMILLERI, Joseph A; MARSHALL, Larry; MICHAEL, Michális (Orgs). Asia-Pacific Geopolitics: Hegemony vs. Human Security. Massachusetts: Edward Elgar, 2007, p. 93-104. 